Historic, Archive Document

Do not assume content reflects current scientific knowledge, policies, or practices. 



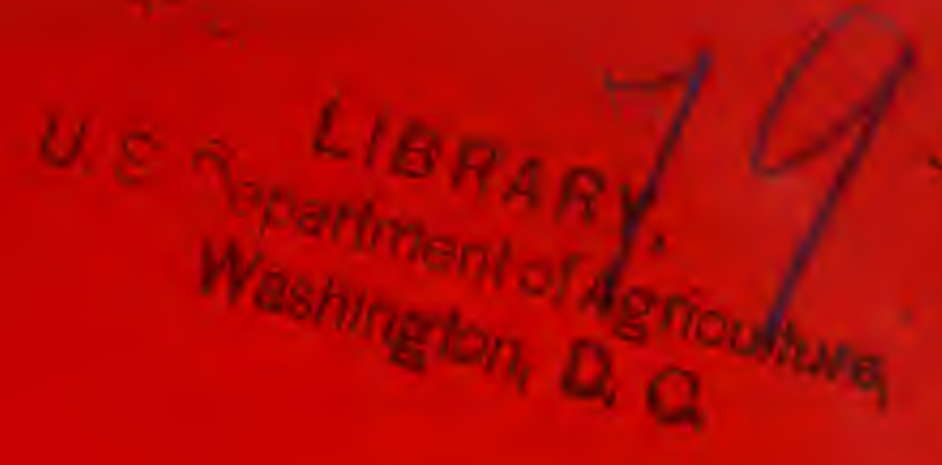

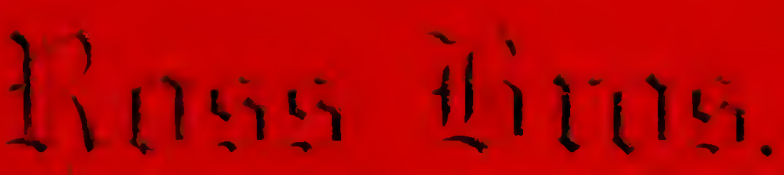

Ammil Smon

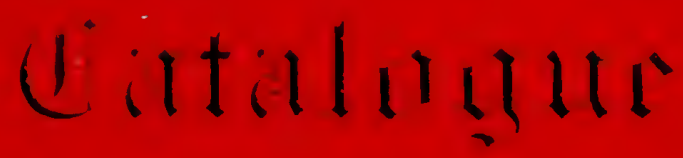

9O-92 FRONT STREET

WORCESITER MIASS 


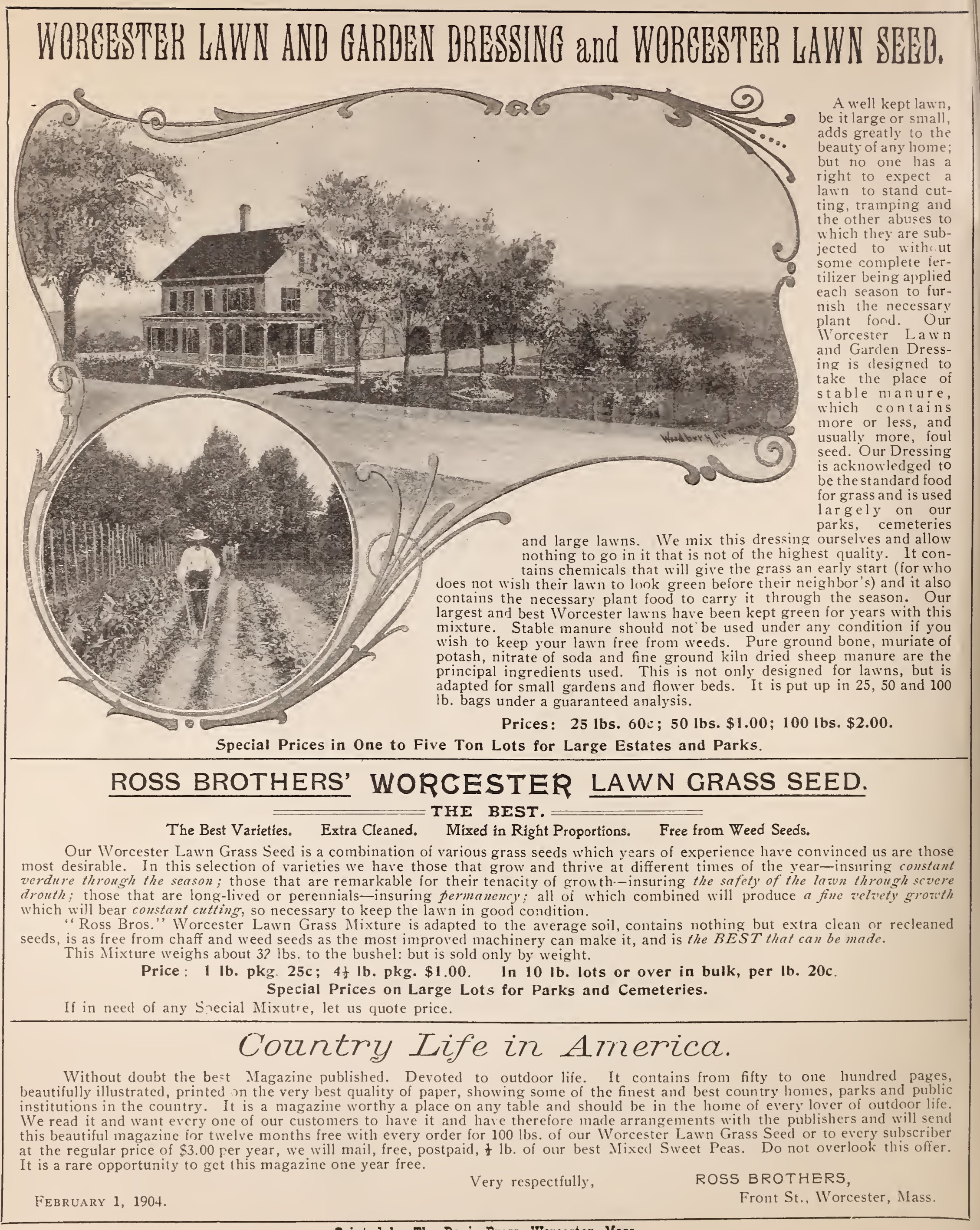

Printed by The Davis Press, Worcester, Mass. 


\title{
ROSS BROTHERS,
}

\section{Wholesale and Retail Dealers in All Kinds of Farm and Garden Supplies,}

\section{0 and 92 Front Street, WORCESTER, MASS.}

\begin{abstract}
N or about the first of February of each year, it is our custom to mail to each of our customers a copy of our Annual Seed and Implement Catalogue. Our reason for doing this is to enable them to better select from our large stock of agricultural requisites, the supplies that they will need during the coming year. Our business is the selling, at both wholesale and retail, all kinds of agricultural tools and seeds of every description, as well as special lines pertaining to agriculture, such as poultry and dairy supplies, woodenware, hardware, fertilizing materials, etc.

It is now fifteen years since we started in this business and referring to the first year when we started, we find that we are doing in one month more business than we did in that entire year. Several causes have contributed to this very satisfactory showing. First, the quality of the goods that we sell. They must have been right or our customers would not stay with us. Second, our prices are as low as other houses are selling an inferior article for. Third, we always endeavor to satisfy each and every customer no matter how small the sale. We should always consider it a favor if our customers called our attention to anything that was not satisfactory, rather than let it go unnoticed. We want to know that you are satisfed and we will promptly refund the money on any purchase that is not as represented. We have customers' names on our books that send to us several hundred miles each year for their supplies. Our trade has increased from fifteen to twenty-five thousand dollars each year since we first started in business.

The advantages of purchasing goods by mail is becoming better known each year and with our catalogue to refer to, you can select in your own home anything needed on the largest farm or the smallest garden and with our guarantee of fair dealing backed by fifteen years of business, you take no chances whatever in sending your order to us. Buying as we do, direct from the largest manufacturers and growers, we are in a position to sell at considerably lower prices, but we always look for quality first and then to the price. Our conveniences for the prompt and economical handling of goods is unsurpassed by any house in New England. We occupy ten floors, each one hundred feet deep and all connected so that any order, no matter whether it be for a package of seed or a carload of machinery or fertilizer, can be shipped promptly. We make no charge for boxing or carting only in extreme cases where the profit is so small that it is absolutely necessary for us to do so, and we deliver free all goods to any freight or express office in the city and within the city limits. Freight rates from Worcester are as low and we have as good freight and express service as any city in New England and far superior to most of them. All things considered, we think you will find it to your advantage to place your order with us. We guarantee prompt shipment and satisfaction in every way.
\end{abstract}

Very respectfully,

ROSS BROTHERS.

OUR CATALOGUE COVER IS
IN THE INTEREST OF ECONOMY RATHER THAN BEAUTY.
We have many letters received last year with no name or address signed. Don't forget to give name and address.

\section{A Few Things of Importance that We Wish Our Customers to Read.}

WE WARRANT OUR SEEDS just as far as it is possible for us to

WHAT WE GUARANTEE. That all seeds sold by us shall be as represented; should they prove otherwise, we will refill the order gratis, but we cannot guarantee the crop further, as there are so many causes over which we have no control, that let seeds be ever so fresh, weather greatest care to have all seeds pure and reliable, we do not give any warrant, expressed or implied. If the purchaser does not accept the seed on will be refunded.

C. O. D. ORDERS. Parties ordering goods to be sent C. O. D. must enclose with the order one-third of the amount, as a guarantee that they express, as railroad companies will not do any collecting.

EXTRA PARTS. Parties sending us broken castings for patterns on repair orders nilust prepay express charges, as we cannot afford to pay express on old castings.

BAGS USED IN SHIPPING SEED. Two bushel bags, I5 cents; al1 other sizes, unless otherwise noted, o cents, which may be returned, provided they are in good condition and return express charges pre-
paid. Returned bags must always liave the nanle of the sender on the tag.
HOW TO ORDER. Give your name, town, state and county, and do not forget the post-office, as that is the most important of all.

TERMS. As there are no means of our ascertaining the financial standing of farmers at a distance, we 11ust have cash with the order or some satisfactory bank reference, but the liberal discount we offer for cash will more than pay the customer for sending the money wheu they order the goods.

HOW TO SEND MONEY. There are a number of safe ways to send money by mail. Either by an Express or Post Office Money Order, of send check on your bank. We are not particular how it cones, as long on small orders. Wrap them in oiled paper to prevent sticking.

ORDER EARLY. You may think it is because we are in a hurry to get your nioney that we advise ordering early. Not so; but early orders always get the hest of attention, the best of stock. and the best of everything. As a great many varieties of vegetable seed are short on account of the wet weather last year, late buyers will get left, for the reason that there is not enough seed to supply the de mand.

MARKET GARDENERS. Parties wanting ten or more dollars worth of bulk seed will do well to write us for market gardeners' prices for on such orders, if received early, we can nilake lower prices than are quoted.

Do not forget to read our instructions in regard to seeds by mail. We explain it fully, and if you will follow our advice it will save you a great many delays. 


\section{ROSS BROS.' \\ RELIABLE \\ SEEDS

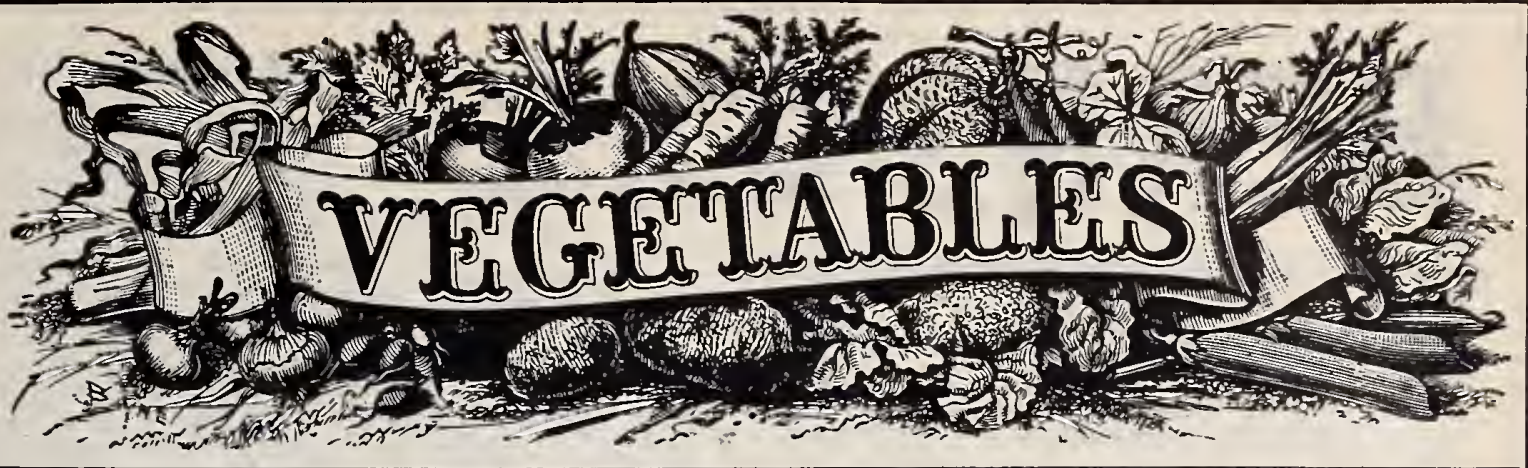

SEEDS BY MAIL.

WE PAY POSTAGE on all Seeds by the Packet, Ounce and Quarter-Pound, but, except pound require an additional amount for postage at the rate of 8 cents per pound, and those sold by measure-Beans, Peas and Cornrequire additional amounts as follows: Beans and Peas-Quart, 15 cents; Pint, 8 cents; Half-Pint, 4 cents. Corn-Quart, 10 cents; Pint, 5 cents; Half-Pint, 3 cents.

A CHANGE. Customers will note that we have discontinued the custom yet largely prevailing among seedsmen of must always be an indefinite one to the buyer and probably is often a disappointing one. We adopted our present method two years ago and are sure that it has met, and will continue to meet, the approval of our customers.

\section{Special Offer of Seeds by the} Packet Ounce Only.
Purchasers of Seeds by the Packet or Ounce where the price quoted is not over rocents per Packet or Ounce may select such seeds as follows:

For 25c. seeds may be selected a mounting to 35c. For 50c. seeds may be selected amounting to $\mathbf{7 5 c}$.

For $\$ 1.00$ seeds may be selected a mounting to $\$ 1.60$.

Please bear in mind that this offer applies only to seeds by the Pucket and Ounce and only to those of which the price is not over ro cents per Packet or Ounce, and does not apply to seeds by the Quart or Pound. Customers therefore sending us mixed orders, that is for Packets and Ounces and Seeds in Bulk, either by the Quart or Pound, with an insufficient remittance, will only receive of the latter the quantity covered by the remittance after allowance has been made on the order for Packets and Ounces.

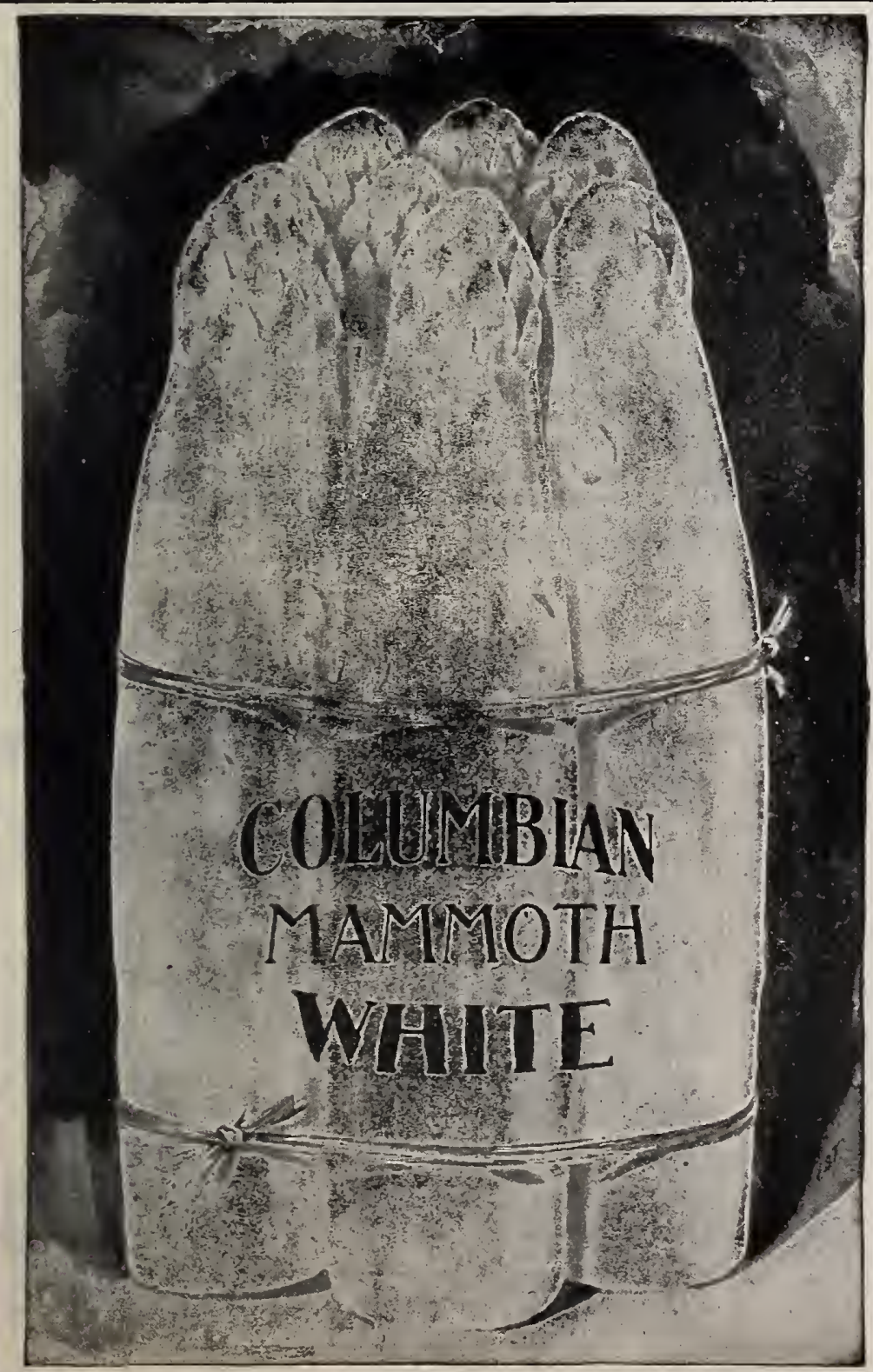

\section{Asparagus}

Barr's Mammoth. Originated in Philadelphia and very popular in that market. Claimed to grow twice as large and to be more productive than Conover's Colossal.

Columbian Mammoth White. A distinct and valuable variety. Stalks are very large and clear white until three or four inches high.

Conover's Colossal. An old standard variety, largely grown.

Donald's Elmira. A new and popular sort; originated in Elmira, N. Y., by Mr. Donald. Claimed by some to be the largest and of the best quality of all varieties.

The Palmetto. Claimed by the introducers to be much earlier and a better yielder than the Colossal, and more even and regular in growth.

Each variety-Pkt. 5c., o.. 10c., 2 ozs. 15c., 表-1b. 25c., 1b. 75c.

\section{Asparagus Roots.}

All varieties, by mail or express prepaid, per 50,65 cents. By express or freight not prepaid, per 100,80 cents; per $1000, \$ 5.50$.

Before Ordering Asparagus Roots, kindly read the following:

As it sometimes happens that the crop of some varieties of As paragus Roots is very short, but which we are not always able to determine at the time of writing our catalogue, and also that toward the last of the season our stock of some is liable to be exhausted, we reserve the right to make substitutions of varieties without further notice. Customers, therefore, desiring that their orders shall be filled only as ordered will please so state distinctly in their orders, and we suggest that it would be well, especially when the season is considerably advanced, for customers to indicate what their preference would be in case our stock of the variety ordered was exhausted.

Before Ordering, if you will Carefully Read what we say above regarding our Special Offer and Postage, - IT MAY SAVE YOU A DISAPPOINTMENT OR DELAY. 


\section{BEANS}

Early Red Valentine. An old well-known, extra-early variety, deserving its popularity as a snap or string bean. Pods round, meaty and tender, and of the finest texture and quality. Very productive. $1 / 2 \mathrm{pt}$. Ioc., pt. $15 \mathrm{c}$.', qt. $25 \mathrm{c} ., 2$ qts. $45 \mathrm{c}$., $1 / 2 \mathrm{pk}$. $80 \mathrm{c}$,, $\mathrm{pk}$. $\$ 1.50$.

Mammoth Green Pod, Stringless. A valuable addition to the list of greenpodded string beans. The vine is of vigorous habit, healthy and productive. Pods are considerably larger than those of the Valentine. Not quite as fine in texture, fully as meaty, and remain tender and crisp

Early Long Yellow Six Weeks. An old standard variety, used both as a string and shell sort. $1 / 2$ pt. 8 c., pt. I2c., qt. $20 \mathrm{c}$., 2 qts. $40 \mathrm{c}$., $1 / 2 \mathrm{pk} .70 \mathrm{c}$. pk. $\$ 1.25$.

Early China Red Eye. Also an old and well-known variety. $1 / 2$ pt. $8 \mathrm{c}$.

Low's Champion. One of the best varietios for shelling. Beans when ready for use in their green state bright red, becoming darker when dry.
Plant vigorous in its growth; less liable to blivht or mildew than most Plant vigorous in its growth; less liable to blight or mildew than most
other varieties; very productive. Several years ago we catalogued this other varieties; very productive. Several years ago we catalogued this
variety, but the trade in New England demauding the colored or striped podded Horticultural type, the call for this was solinited we were obllged to drop it from our list, which we greatly regretted, as we believed it to be, and still think it is, one of the best, if not the best, variety for the private garden for shelling. As the public has, in a measure, learned its it on our list. $1 / 2$ pt. Ioc., pt. 15c., qt. 25 c., 2 qts. 45 c., $1 / 2$ pk. $75 \mathrm{c} .$, pk. $\$ 1.40$.

Dwarf Horticultural or Speckled Cranberry. The standard green shell bean throughout New England. Beans ova1, large, yellowish brown, considerably splashed with red and of excellent quality. Pods yellowish green splashed with carmine, and, when free from rust and blight, very showy. 1/2 pt. 10c., pt. 15c., qt. 25c., 2 qts. 45 c., I/2 pk. 80c., pk. \$1.50.

Best of All. An early variety of the Horticultural type. Beans kidneyshaped and similar in color to the Dwarf Horticultural. Pods long, straight and more slender than of that variety; they are, when fit for use as a string bean, of a peculiar deep green, becoming lighter, with splashes of red, when at the stage suitable for shelling. Although the coloring on the pods is not so bright and distinct as on those of the Dwarf Horticultural, the pods are yet very attractive, and the earliness, hardi. ness, vigor and productiveness of the vine make this variety valuable ness, for the market and home garden, either as a string bean or for shelling. $1 / 2$ pt. IOc. pt. I5c., qt. $25 \mathrm{c} ., 2$ qts. $45 \mathrm{c}$., 1/2 pk. $75 \mathrm{c}$., pk. $\$ 1.40$.

Goddard or Boston Favorite. Beans large and long, similar in color to all Horticultural varieties. Pods long, yellowish green, splashed with crimson. Very attractive and equal in size to those of many pole beans.
Vines large, of strong, vigorous brauching habit, inclined to run, and very productive. L, ter than preceding varieties. $1 / 2 \mathrm{pt}$. 1oc., pt. I5c., qt. $25 \mathrm{c}, 2$ qts. $45 \mathrm{c}$., $1 / 2$ pk. $80 \mathrm{c}$, , pk. $\$ \mathrm{r} .5 \mathrm{O}$.

Improved Goddard. Has all the desirable qualities of the regular strain. But is entirely free from runners. Since its introduction the Goddard has and long, straight, handsome, bright-colored pods makiug it so; but it and long, straight, handsome, bright-colored pods makiug it so; but it vented its use by suine. In the Improved Goddard we have a variety ved in in which this tendency has been overcome, making it a great inprovepods. $1 / 2$ pt. IOc., pt. I5c., qt. $30 c ., 2$ qts. 50c., 1/2 pk. 9oc., pk. $\$ 1.65$.

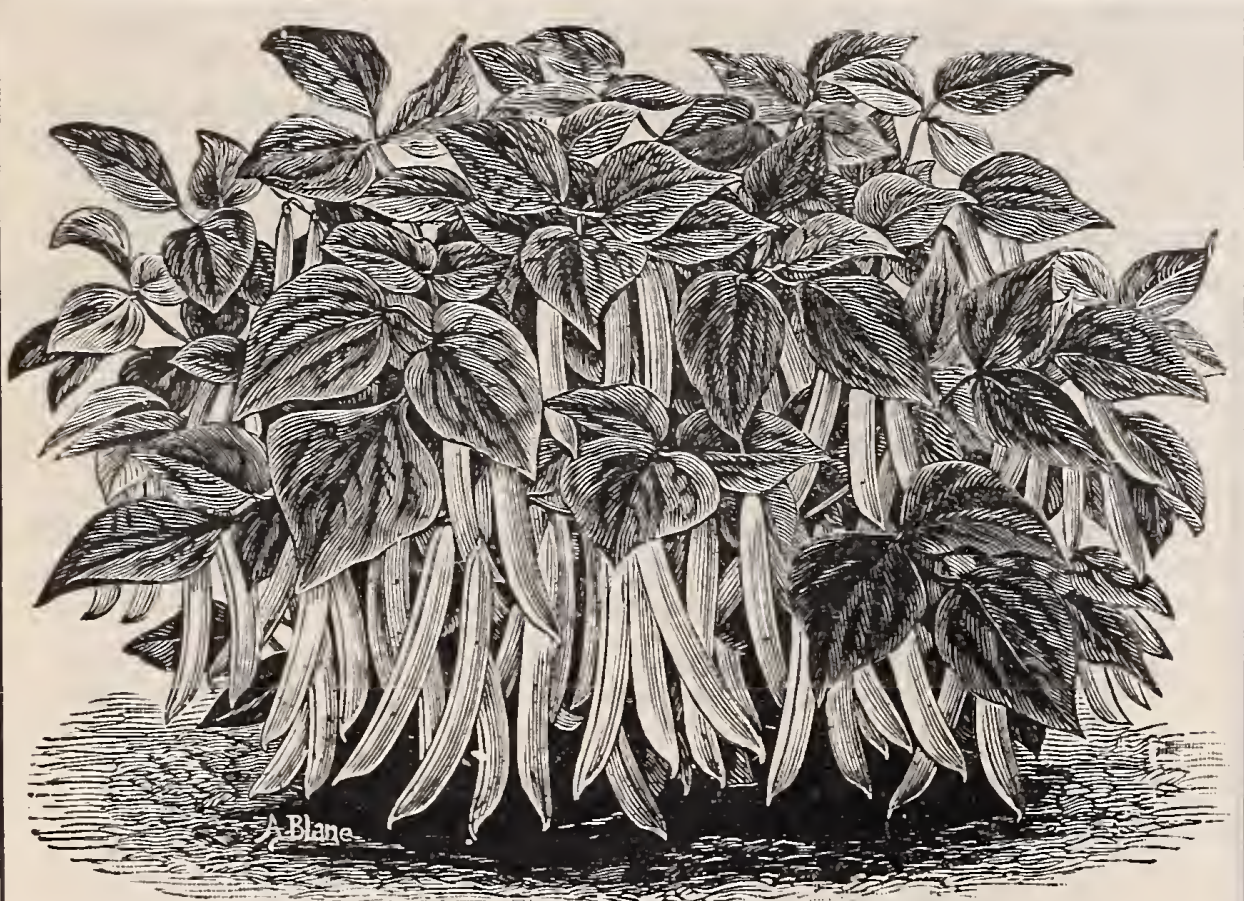

Golden Eyed Wax.

\section{DWARF WAX OR BUTTER BEANS.}

Black or German Wax. One of the oldest wax sorts. Pods round, meaty, tender and of finest flavor, but small. More liable to rust than other good varieties, but when free from rust and blight Currie's Rust Proof Black Wex. Beans brownish black; pods flat, of good length, showy and of fine quality. Well merits the name of rust-proof.

Davis' White Kidney Wax. Claimed by the introducers to be "earlier, hardier, more prolific, handsomer and a better seller than any of all the wax varieties," a claim which the opinion of many who have grown it, to a considerable extent, verifies.

Detroit Wax. An excellent variety. Plant hardy and productive; pods straight, flat. but broader than the Golden Wax, of beautiful wax color, when grown to a size suitable for use; keep crisp and bright long after picking, very seldoin rust, and a re of good in shape to the White Marrow, and equally as good for baking.

Golden Wax. For a long time the standard wax bean and still a great favorite. Pods long, nearly straight, flat, golden yellow with short green points, stringless, fleshy and tender. Beans
medium sized, ovals, ground white, covered more or less with purplish red, different crops varying considerably in appearance, owing probably to soil or location in which they were grown. Plant vigorous and productive.

Golden-Eyed Wax. One of the best wax beans for the marketgardener. Although not equal in quality to some others, its hardiness, entire freedom from
make it a profitable variety.

Wardwell's Kidney Wax. Although not quite as early as some of the preceding varieties, it is one of the best. The vine is of very strong, vigorous growth, healthy and productive. especially good quality. "This variety has in recent years been growing in popularity with All of the preceding Wax varieties at uniform prices. $1 / 2$ pt. roc., pt. $20 c$., qt. $35 \mathrm{c} ., 2$ qts. $65 \mathrm{c}$. If desired by mail, see page I for rates of postage.

Two Varieties of recent origin worthy a place in all gardens. The first is desirable for both the market and home garden, and the second especially for Jones' Stringless Wax. A new white-seeded variety of great beauty and unsurpassed good qualities while its faults of shy bearing and ill-formed pods are elinininated. The pods of the Jones Stringless Wax are long, round, fleshy, entirely stringless and uniformly well some pods very early. Another feature of this and other white-seeded varieties worthy of

Golden Crown Wax.

作 def ets of either. The pods are beautiful golden yellow, as large as those of the Yoselinite, and very productive. The seeds of this are also wlite. Those who have hitherto planted the Yosemite will find in this a variety equal in size and superior in quality.
$1 / 2$ pt. 15 c., pt. $25 \mathrm{c}$., qt. $40 \mathrm{oc}$., 2 qts. $75 \mathrm{c}$., $1 / 2 \mathrm{pk}$. $\$ 1.25, \mathrm{pk} . \$ 2.25$.

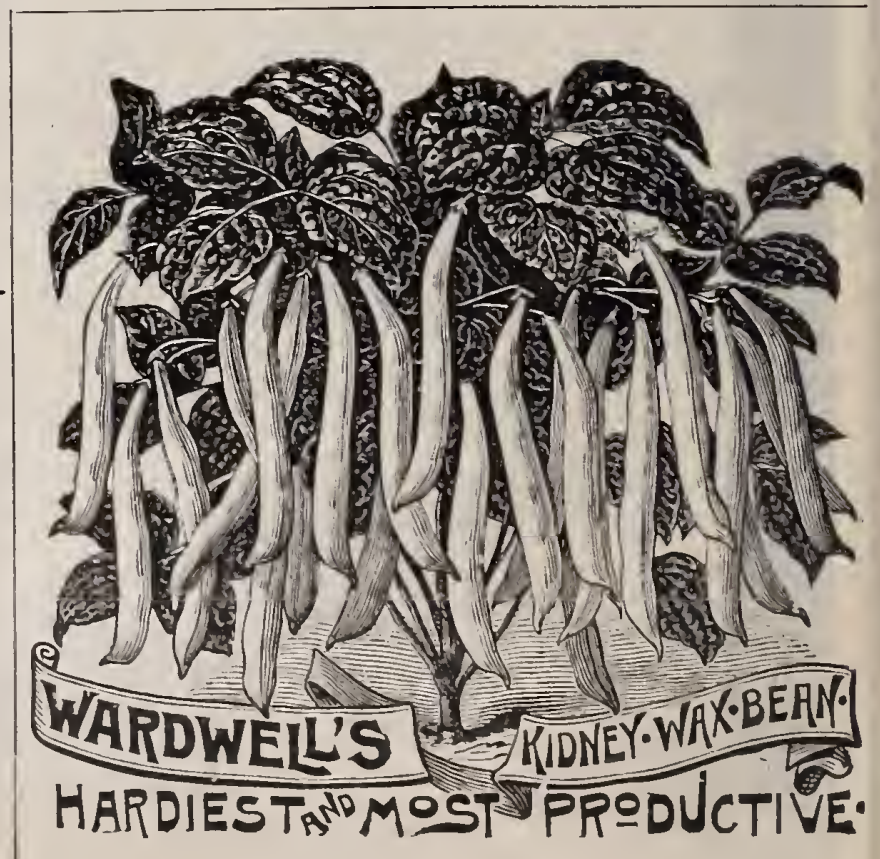




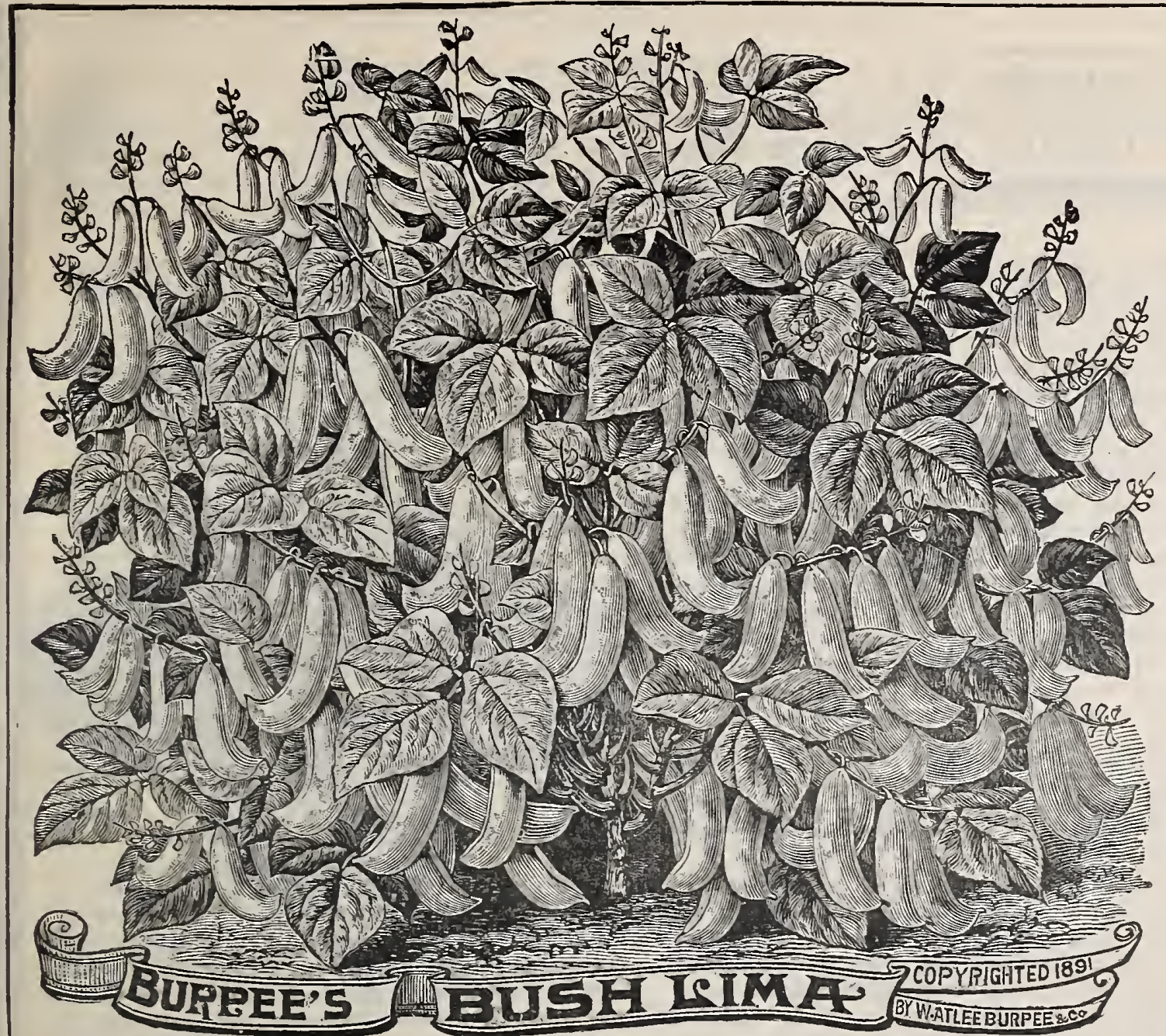

\section{BEANS}

Henderson's Bush Lima. This variety is

especially valuable on account of 1 ts earli-

ness; a bush form of the Early Sieva Lima and has the small beans of that variety. pk. 90c., pk. $\$ 1.65$.

Burpee's Bush Lima. A bush form of the large Lima. Grows uniformly dwarf. Beans are equal in size and quality to the large Lima. By far the most popular of
this class. qts. $60 \mathrm{c} ., \frac{1}{2} \mathrm{pk} . \$ 1.00$, pk. $\$ 1.85$.

Dreer's Bush Lima. A bush form of the Dreer's Improved Pole Lima, which is Limas. $\frac{1}{2}$ pt. 10c., pt. 20c., qt. $35 \mathrm{c} ., 2$ qts. 60c., $\frac{1}{2} \mathrm{pk} . \$ 1.00, \mathrm{pk} . \$ 1.85$.

LIMA BEANS * Pole or Running.

The Seibert's Lima was developed by a market gardener who selected the largest green beans from the thinnest and most easily opened pods. The vine is very productive and exceptionally hardy and vigorous. It produces pods very early and the beans are of fine quality. The green shelled beans are of immense size, but so drying to about the size of the Large White Lima. In earliness, ease of shelling, size, beauty and quality of the green beans, this new variety is in advance of all other sorts.

King of the Garden Lima. Vine vigorous and productive. Pods very large and well filled with large, white beans, succulent and fine flavored. On account of its large pods a general favorite with market gardeners.

Large White Lima. The old standard sort, yet largely grown, but being to a considerable extent displaced by the newer varieties.

Challenger, or Dreer's Improved Lima. A distinct variety; both pods and beans are shorter but much thicker than other sorts. The pods are borne in clusters, rarely have over four beans, often but three, in a pod, but are always well filled, so that a quantity of them will usually produce more beans than an equal quantity of any other variety. The beans are easily shelled, are of excellent flavor, slightly more mealy than other thinner sorts. The vine is of vigorous growth and very productive, does not produce pods quite as early as the flat pod sorts, but does not differ greatly in this respect from the preceding two varieties. A decided favorite with those who are acquainted with it.

All varieties at uniform prices. $-\frac{1}{2}$ pt.10c., pt. 15c., qt. 30c., 2 qts. $55 \mathrm{c} ., \frac{1}{2}$ pk. $\$ 1.00$, pk. $\$ 1.75$.

WORCESTER MAMIMOTH POLE HORTICULTURAL.

The Largest and Handsomest Beans and Pods. Most productive and thrifty vine. Sells easier and for Higher Price than any other. Best for the Market Garden. Best for the Home Garden.

This variety, while similar in general character to the Horticultural Pole, is much superior in several ways. The beans though closely resembling those of the commun strain are so much larger that, if that were the only point of excellence it would be alone sufficient to recommend it for general use, but its strikingly handsome pod combined with its great size are both features of excellence which still further recommend it. Added to these excellent qualities, are those of thrifty, vigorous growth of vine and great productiveness, all making it a variety especially desirable to the market gardener. It easily brings a higher price in the market than any other, and is not excelled by any other sort for the home garden.

We have an unusually large and fine stock of this bean and are enabled to considerably reduce the price from what it has generally been

$$
\begin{gathered}
\frac{1}{2} \text { pt. } 10 \text { c., pt. } 20 \text { c., qt. } 40 \text { c., } 2 \text { qts. } 75 \text { c., } \\
\text { 专 pk. } \$ 1.25 \text {, pk. } \$ 2.25 \text {. }
\end{gathered}
$$
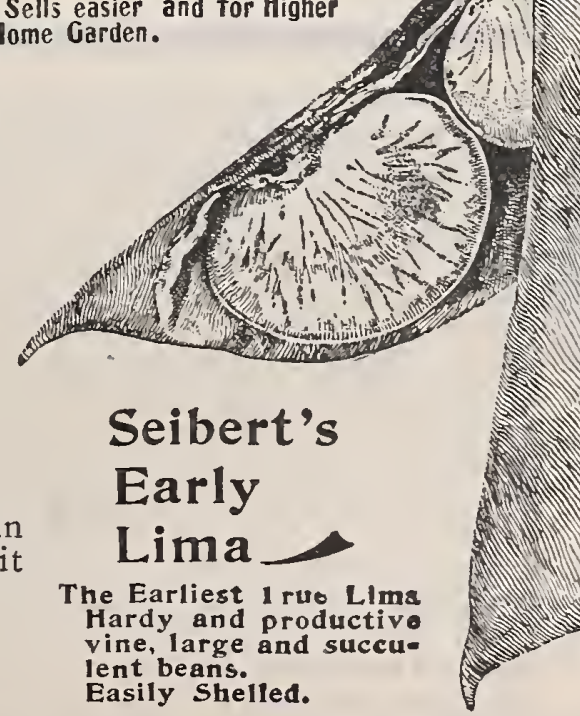
tender and succulent that they shrink in

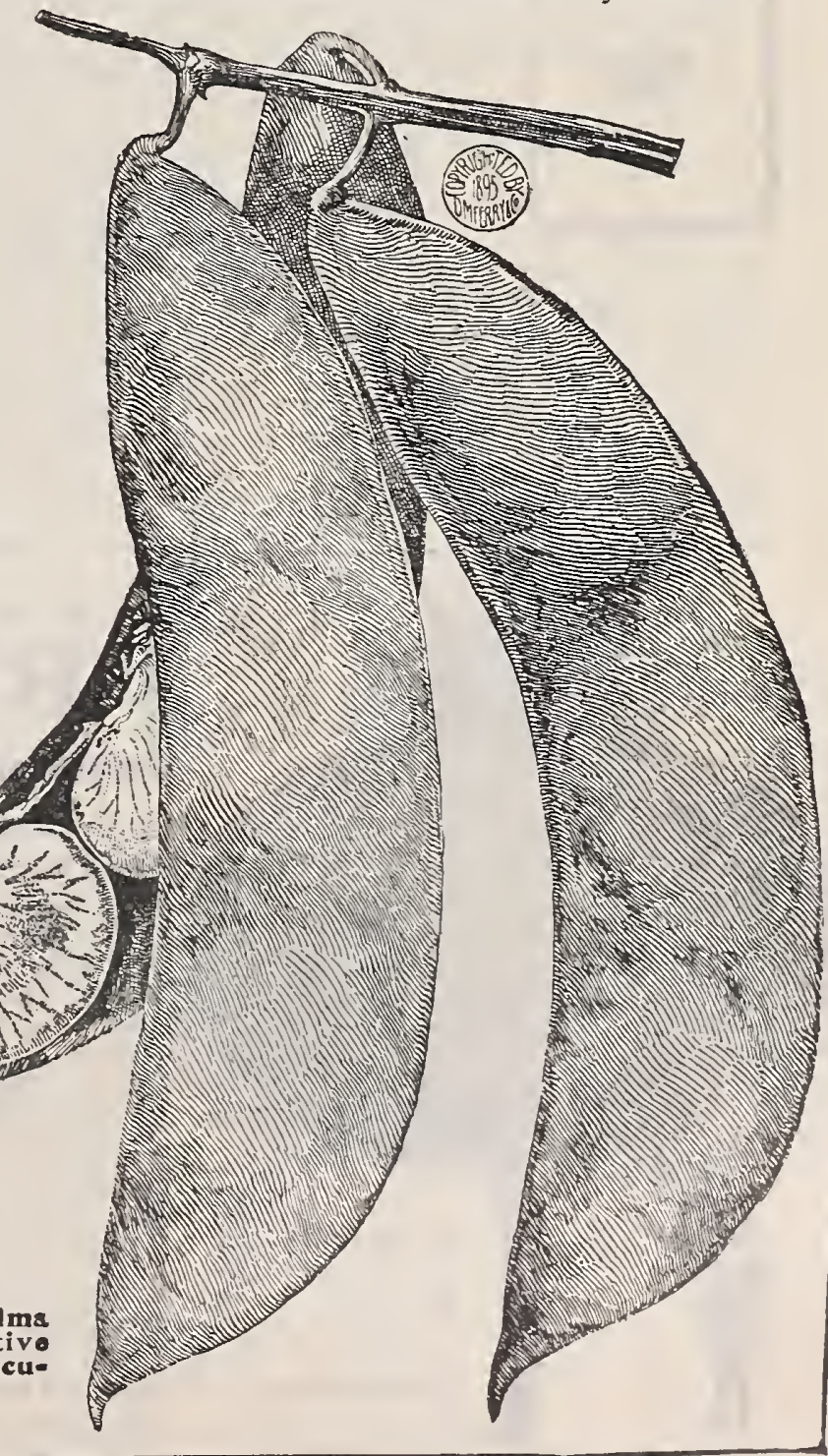

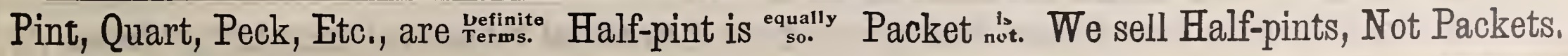




\section{BEANS Pole or Running \\ STANDARD \\ VARIETIES}

Horticultural, or Speckled Cranberry. A well-known standard variety. Beans similar to Dwarf Horticultural. $\frac{1}{2}$ pt. 10c., pt. 15c., qt. $25 \mathrm{c} ., 2$ qts. $45 \mathrm{c} ., \frac{1}{2}$ pk. $80 \mathrm{c}$., pk. $\$ 1.50$.

Brockton Horticultural. This variety bears the same relation to the Pole Horticultural that the Goddard does to the Dwarf Horticultural. Beans and pods are both similar in shape and color to the Goddard. It is a vigorous, thrifty grower, productive, and well worthy a place in every garden. $\frac{1}{2}$ pt. 10c., pt. $15 \mathrm{c}$., qt. $25 \mathrm{c} ., 2$ qts. $45 \mathrm{c}$, $\frac{1}{2}$ pk. $80 \mathrm{c}$., pk. $\$ 1.50$.

Concord Pole. An old variety, which, years ago, was a popular one, especially in the eastern part of this state but which, probably owing to the great demand for varieties with colored pods, has been largely displaced by them. Beans large, white with large blotch of yellowish brown around eye. Pod when fit for picking yellowish green. A productive and especially desirable variety for home use. $\frac{1}{2}$ pt. 10c., pt. 15c., qt. $25 \mathrm{c} ., 2$ qts. $45 \mathrm{c} ., \frac{1}{2}$ pk. $80 \mathrm{c}$., pk. $\$ 1.50$.

Dutch Caseknife. An old, well-known variety. Beans white, flat, kidney-shaped; pods very long. $\frac{1}{2}$ pt. 10c., pt. 15c., qt. 30c., 2 qts. 50c., $\frac{1}{2}$ pk. 90c., pk. $\$ 1.65$.

Indian Chief, or Black Wax. One of the best wax pole sorts. Remains in bearing longer than the Dwarf Wax. Beans large, round, black. Pods of waxy yellow, remaining in good condition longer than most varieties. $\frac{1}{2} \mathrm{pt} .10 \mathrm{c} ., \mathrm{pt}$. 15c., qt. 30c., 2 qts. 50c., 考 pk. 90c., pk. $\$ 1.65$.

old Homestead, or Kentucky Wonder. The earliest pole bean. The pod is very long, of a silvery green; entirely stringless, of good quality, and makes one of the best snap beans. It is enormously productive, the pods hanging in clusters from top to bottom of the pole. The beans are of a yellowish dun, of medium size, but, owing to the length and number of pods, the yield of beans is laige. A very satisfactory variety for home use. $\frac{1}{2}$ pt. 10c., pt. 15c., qt. 30c., 2 qts. 50c., $\frac{1}{2}$ pk. 90c., pk. $\$ 1.65$.

Scarlet Runner. Largely grown as an ornamental climber; its rapid grow th and early production of dazzling scarlet flowers make it a favorite for covering screens, walls, etc. It is also of excellent edible qualities but rarely grown for that purpose.

White Dutch Runner. Quite similar in general appearance to the preceding, differing only in color of flowers and beans, which are white; used both for ornamental and table use; early, productive and of excellent quality. Each variety, $\frac{1}{2}$ pt. 10c., pt. 20c., qt. 35c., 2 qts. 60c., $\frac{1}{2}$ pk. $\$ 1.00$.

\section{EXTRA EARLY POLE HORTICULTURAL * A New Variety.}

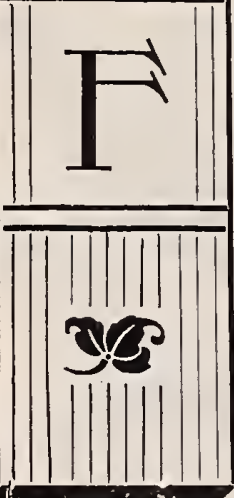

O R SEVERA L YEARS a few market gardeners in the vicinity of Worcester have been growing a very early strain of the Pole Horticultural type with the result of being able to bring into market "Pole Beans," at least two weeks earlier than their competitors growing the ordinary strain. Like many other varieties which have been cultivated for some time by different persons before seed was offered for sale, is difficult to determine its origin. It is locally known both as Little Gem and Little Wonder. Our attention was called, a number of years ago while visiting a seed-grower, to a variety quite similar to this, if not entirely identical with it, but as it was so late in the season that we had no opportunity to see it growing or to see the pods in the condition that they are usually brought to market, or to learn its earliness, etc., as we since have, we were at the time so little impressed with it that it nearly passed from mind. We have, however, for several years, had opportunity to see growing crops, and therefore learn its merits, and were fortunate in securing, last spring, from a leading gardener of this city, a limited quantity of seed which we placed with a reliable grower who succeeded in obtaining a fair crop, which we now offer. We are satisfied that whether or not it is a new variety, that but few are familiar with it, and because of its merit we are warranted in introducing it as a new and valuable one.

The vine, while thrifty does not grow nearly as tall as the common Pole Horticultural, therefore, requires only a short pole, which, of course, is not as liable to be blown over as a taller one. It is immensely productive, and we think less liable to blight than the old strain. The pods have the characteristic bright coloring of all the Horticultural varieties but to a greater degree, are a trifle shorter than the common strain, but a little broader and always well filled. The beans are fully equal in size and quality and identical in appearance with the common type. While these features are all desirable and serve to recommend it, that on which we lay the most stress is its earliness; believing that a variety so much earlier than any other of its class should receive the attention of both the market and home gardener, not only because it will afford profit to the smaller number of market gardeners who will probably first use it, but because, eventually, if generally used, it will considerably extend the season of Pole Horticultural Beans of which so many are extremely fond. $\frac{1}{2}$ pt. 12 c., pt. 20c., qt. 35 c., 2 qts. 60c., $\frac{1}{2}$ pk. $\$ 1.00$, pk. $\$ 1.85$.

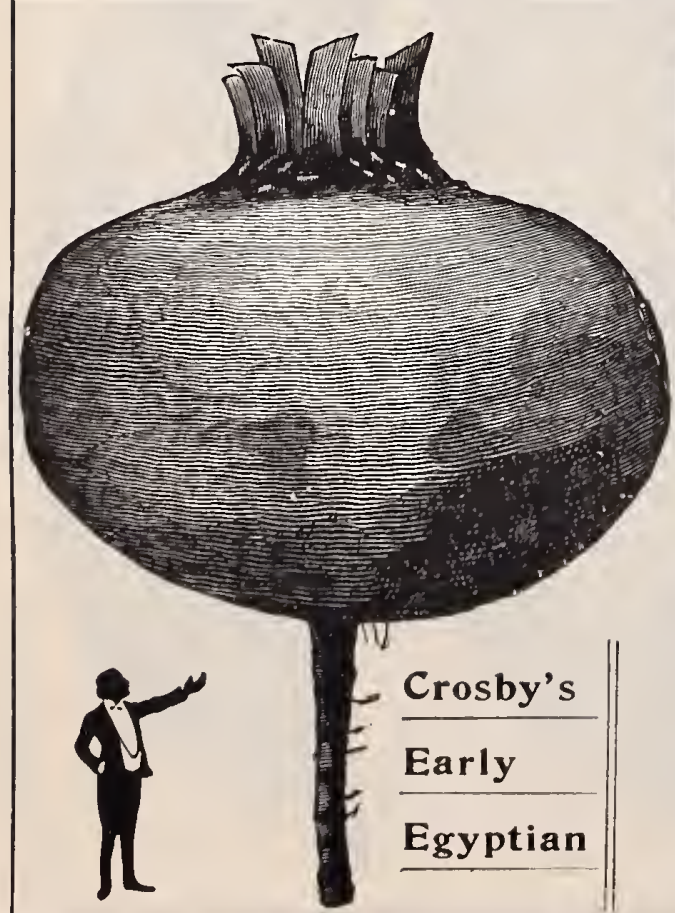

Had only the name Crosby been given this variety it would, in our opinion, have been much more appropriate and not misleacing as now callerl, for in only one respect does it much resemble the Egyptian, that is color, and even that is a little lighter. It is more nearly round than the Egyptian with none of its tendencies towards irregularity in form. It makes a much better appearance when bunched for market, and is decidedly of better quality. While it is a well known fact that flat roots are as a rule earlier than deep, round ones, there are some exceptions which are without doubt made and kept so by careful selections. This variety being essentially one for the market gardener, more attention. has been given it by the seed growers, than to the Egyjtian, and we have in this variety of nearly spherical form, one as early as that flat variety, and which in every other way excels it. Owing to its quick growth and good quality it is now being used to some extent for the last sowing for winter use, seed sown as late as the middle of July on rich soil often producing roots of good marketable size. Its great popularity has, however, been gained as an extra early, and we have yet to see a variety which equals it for that purpose. We have yearly grown this beet and have often made comparative trials of other so-called fancy strains, but have yet to find one which in anywise excelled ours while we have found some which were inferior in various respects. While seed of this strain is very scarce this year we have not considered it necessary to greatly increase our price, and offer it at only a slight advance from the low price which for several years we have sold it. Pkt. 5c., oz. 10c., 2 oz. 15c., t lb. 20c., 卉 lb. 35c., 1b. 65c. 


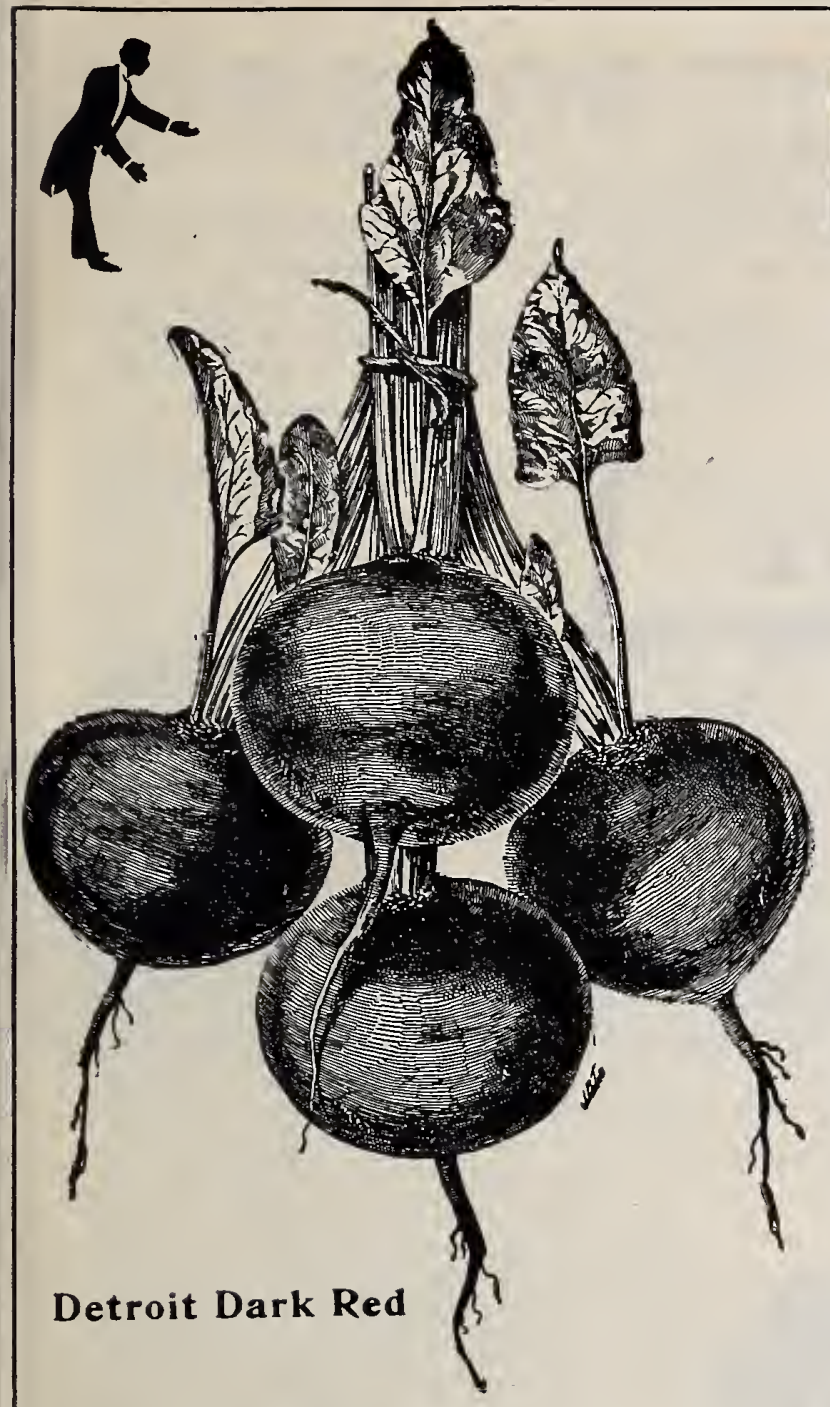

Detroit Dark Red. So nearly in accord are we with the introducers' claims and description of this valuable variety that we quote what they say of it as follows : "Long experience has shown this variety of our own introduction to be the best deep red turnip beet, not only for market gardeners, but for the home garden. Its small upright-growing tops, early maturing, and the splendid shape and color of the roots, make it popular with every one who plants it. Tops small, uprightgrowing, so that the rows may be close together; leaf-stems and veins dark red, blade green, roots globular or ovoid, peculiarly smooth; color of skin, dark bloodred; flesh bright red, zoned with a lighter shade, very crisp, tender and sweet, and remaining so for a long time.

The only possible objection to this variety would be that it has a tendency to the ovoid form rather than the globular, a feature which, perhaps is a sectional objection rather than a general one. A large part of our trade demands a beet as nearly round as possible and which we supposed was general, although aware that the longer types were used to some extent in other sections. How be it, this, if an objection, is so slight an one that it has not prevented us from having a constantly increasing trade since we began to sell it, its rich deep color more than off-setting any possible objection to its shape.

Crimson Globe. A new comer, claimed to be the best of the Early Round Deep Crimson Varieties. As early and far superior to the Egyptian. In reply to our inquiry regarding the merit of this beet, and especially whether it would be desirable for fall planting as well as early, a prominent seed grower has this to say of it: "The Crimson Globe Beet is really an early variety, but also a very good one for general crop. It is of good shape and deep color, and is just what is needed for fall planting. The Egyptian planted in the fall does not grow smooth, while this grows very smooth and is perfectly round or globular. The flesh is dark, if anything, darker than the Eclipse, while the skin is, although a shade lighter, of a crimson, resembling that of the Mangel Wurzel. It grows to a fair marketable size, of course not as arge as the old Dewing, and I do not think you would care to have it. Everyone with whom I have come in contact, who have seen the Crimson Globe, like it, and in my opinion it will fill the bill for what you are seeking-a deep-colored, medium-sized variety, good for late as well as early planting."

Each of above, pkt. 5c., oz. 10c., 2 oz. 15c., 表 lb. 20c. 1b. 60c.

\section{\# BEET * STANDARD VARIETIES.}

Early Egyptian. One of the earliest, roots flat, of a deep crimsön, tops small, permitting it to be planted closer than other varieties, therefore especially desirable for forcing as well as for first open ground planting.

Eclipse. One of the earliest globe-shaped varieties, with rather small tops and small tap root, blood-red; of excellent quality.

Bastian's Early. A very quick-growing sort, of superior flavor, very tender and sweet, tops of medium size, leaves green, stem pink, roots red, flesh purplish-pink zoned with white; on account of its light color not as popular as its quality would otherwise make it.

Faust's Early Crimson. This is also known as Mitchell's. A first early of good quality and form, and as its name indicates, of deep color.

Arlington Favorite. An excellent variety of globular form and deep color, especially desirable to follow the first earlies.

Edmand's Early Blood Turnip. Somewhat similar in general character to the Dewings, both being a great improvement on the old Blood Turnip. This has smaller tops than either, is of fine globular form, deep color and superior quality. Used largely for main crop and winter use.

Dewing's Improved Blood Turnip. A decided improvement of the old Blood Turnip, has smaller tops and is of better color.

Swiss Chard. Used for Greens only, like Spinach, at first entire, later the leaf stalks are sometimes used separately, cooked like Asparagus.

All varieties at uniform prices except where noted. Pkt. 5c, oz, 10c, 2 oz. 15c, 交 1b. 20c, 1b. 50c.

\section{BRUSSELS SPROUTS.}

A very hardy plant of the Cabbage family, growing from two to three feet high, producing at the axils of the leaves the whole length of the stem small heads about two inches in diameter, resembling a cabbage and considered by some to be of finer flavor.

Best Imported. Pkt. 5c, $\frac{1}{2}$ oz. 10c, oz. 15c, 2 oz. 25c, $\frac{1}{4}$ lb. $40 \mathrm{c}$.

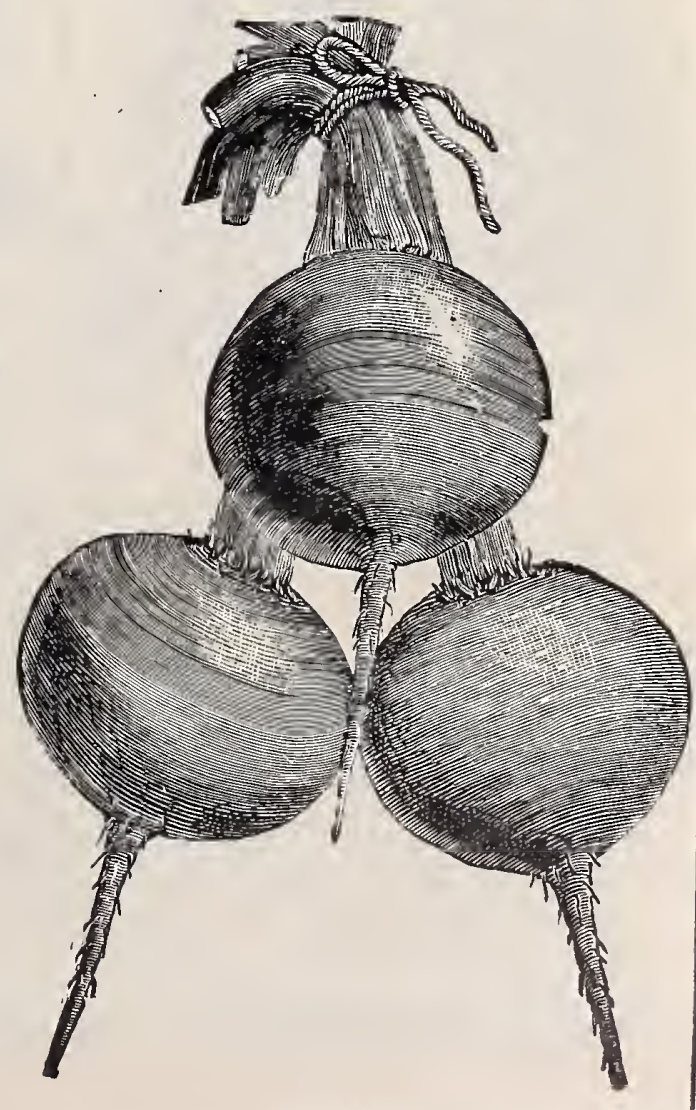

ECLIPSE. 
Lane's Sugar. An improvement on the old white French, recommended as hardier and as containing a larger percentage of sugar.

Mammoth Long Red Mangel. A variety of mammoth size; skin light red, flesh white and rose. Grows well out of ground; extensively used in all sections.

Norbiton Giant Long Red. Similar to the preceding; has smaller top and neck; flesh scarlet.

Golden Tankard. Top and neck very small; root ovoid, large; flesh yellow, zoned with

Orange Globe. One of the best, top small, root medium size, skin deep orange yellow, flesh white. Grows almost entirely out of the ground; good for shallow ground; easy to harvest. Prices uniform on all: $\frac{1}{4} 1 \mathrm{~b} .15 \mathrm{c} ., \frac{1}{2} 1 \mathrm{~b} .20 \mathrm{c} ., 1 \mathrm{~b} .35 \mathrm{c} ., 5 \mathrm{lb}$. 1ots per lb. $30 \mathrm{c}$.

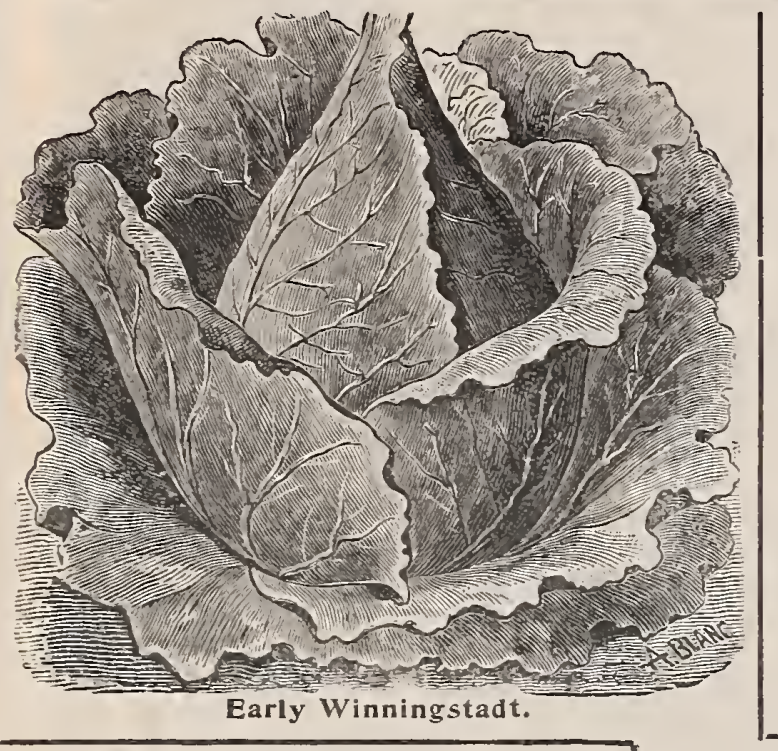

Premium Flat Dutch. An old popular. Heads flat, large and solid. Very reliable in heading. Pkt. 5c., $\frac{1}{2}$ Oz. 10c., oz. $15 \mathrm{c},, 2$ oz. 25c., $\frac{1}{4}$ lb. 40c., 1b. $\$ 1.40$.

Warren Stone Mason. An improvement on the Stone Míason which for years was one of the most popular varieties in New England. This is earlier, more nearly roind and more solid; one of the very best for winter use. The seed we offer was grown by one of the most reliable growers in New England, who originally obtained his stock from headquarters and who has exercised the greatest care in selection and keeping it true to type. $\mathrm{Pkt}$ 5c., $\frac{1}{2}$ oz. 12c., Oz. 20c., 2 oz. , 1 b. $60 \mathrm{c} ., 1 \mathrm{~b} . \$ 2.00$.

Autumn King. Claimed by the introducers to be the best late cabbage in the country. They say of it: "The Autumn King is an entirely distinct variety and the best keeper we have ever seen; it produces enormous solid heads with such small outer leaves that it can be planted much closer than the ordinary late sorts, and will produce a greater weight of crop per acre than any
other variety, from the fact of its producing so few outer leaves and going all to head. A distinct feature of the Autumn King is the peculiarly crimped leaves." Pkt. 5c., $\frac{1}{2}$ oz. 15c., oz. 25c., 2 oz. 40c., 吕 1b. 70c., 1b. $\$ 2.50$.

Marblehead Mammoth. A late variety, the largest of all cabbages; heads have been grown weighing

Danish Ball Head. A variety grown almost exclusively in Denmark for winter use; extremely hardy and

well-enriched land. The stumps

than

heavy, averagin

and excell $\$ 2.50$.

American Improved Savoy. An improvement on the Green Globe Savoy: very reliable for heading. Pkt. 5c., $\frac{1}{2}$ oz 12c., oz. 20c., 2 oz. 35c., 孝 1b. 60c., 1b. $\$ 2.00$
Charleston Early Wakefield. A selection of the Jersey Wakefield, a fer days late:

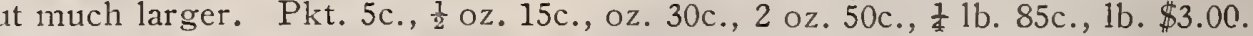

An Early Summer. An early large heading sort. Heads flat, sometimes slightly conical with large outer leaves; very popular with market gardeners, Plor the home garden. in existence." Very similar to that excellent variety the All the finest cabbage Pkt. 5c., $\frac{1}{2}$ oz. 15c., oz.

$25 \mathrm{c}, 2$ oz. $40 \mathrm{c}$,,$\frac{7}{4}$ 1b. $70 \mathrm{c}, 1 \mathrm{~b} . \$ 2.50$. All Seasons. A variety which for reliability in heading is not exceeded by any other, if indeed equaled. Its rapid growth and good size make it desirable for either

arly Jersey Wakeficld. Heads conical, very compact and solid. Can be set closer than most varieties. Pkt. 5c, 考 oz. 15c, oz. 25c, 2 oz. 40 c, $\frac{1}{4}$ lb. 70 c, 1b. $\$ 2.50$. early or late planting, and for the latter purpose it has become very popular. Heads are large and solid, round, flattened on the top, and when mature will remain longer in the field without buisting than most other varieties. Pkt. $5 \mathrm{c}$., $\frac{1}{2}$ oz. $12 \mathrm{c}$, oz. $20 \mathrm{c} ., 2$ oz. $35 \mathrm{c}$, , $\frac{1}{4}$ lb. 60c., lb. $\$ 2.00$.

Early Winningstadt. Heads large, cone-shaped and solid; one of the best for all soils. Pkt. 5c., 考 oz. 10c., oz. 15c., 2 oz. 25c., $\frac{1}{4}$ lb. 40c., 1b. $\$ 1.40$.

Fottler's Improved Brun s= wick. The earliest of the large heading Drumlheads; in great favor with market gardeners in all sections. Pkt. 5c., $\frac{1}{2} \mathrm{oz}$. 12c., oz. $20 \mathrm{c}$, 2 oz. $35 \mathrm{c}$., $\frac{1}{4} \mathrm{lb}$. 60c., 1b. $\$ 2.00$.

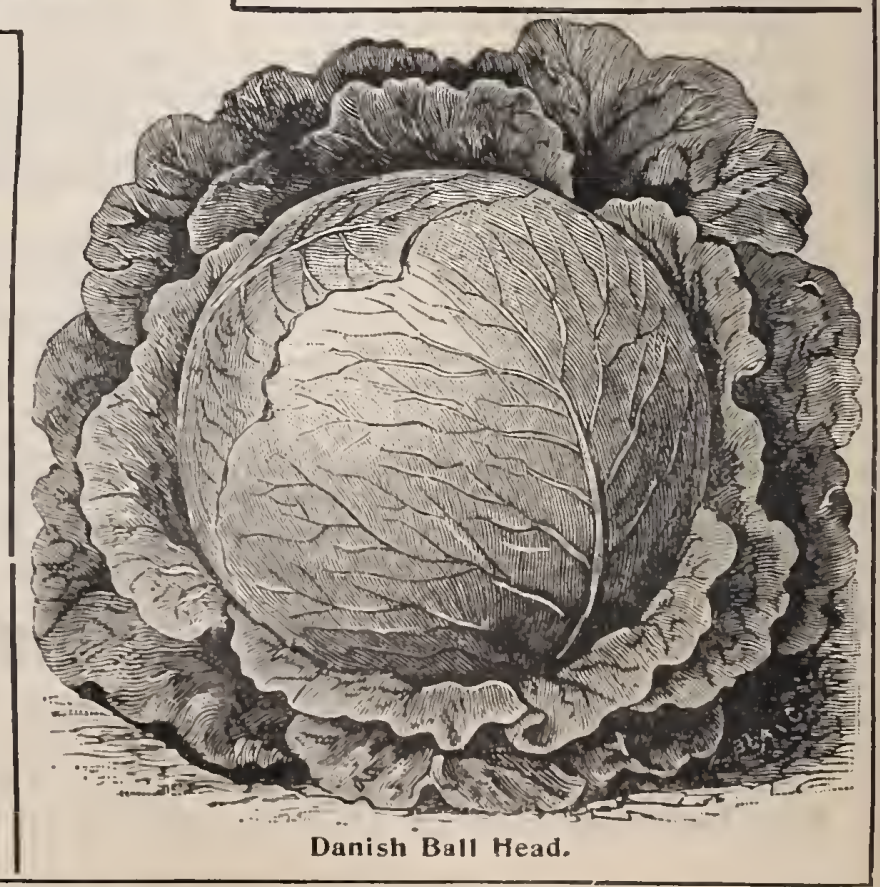




\section{CABBAGE \\ (Continued)}

Hollander, or German Export. This is also an imported variety with similar characteristics to the preceding, some claiming that it is even hardier than the Danish Ball Head, and that it will endure frost and drought that would destroy any other cabbage. It is late in maturing, an excellent keeper and of the best quality. For best results both this and the preceding should be sown at least two weeks earlier than other winter varieties. Pkt. $5 \mathrm{c} ., \frac{1}{3} \mathrm{Oz} .15 \mathrm{c} ., \mathrm{oz}$. 25c., 2 oz. 40c., $\frac{1}{4}$ lb. 70c., 1b. $\$ 2.50$.

Luxemburg, or Hard Heading. Heads medium size, nearly round and of good quality; outer leaves slightly tinged with red. Excellent as the two preceding varieties are, the Lux- emburg is thought by some to exceed them in hardiness and solidity and especially in keeping. An old and very reliable seed firm say:-"This is the king of all cabbages for late spring selling, and those who raise it will have the markets of late spring entirely to themselves." Like the Danish Ball Head and Hollander, it should be planted earlier and soil should be richer than for most other varieties. Pkt. 5c., $\frac{1}{2}$ oz. 12c., oz. 20c., 2 oz. 35c., 考 1b. 60c., 1b. $\$ 2.00$.

Mammoth Rock Red. The best, largest and surest heading Red Cabbage. Pkt. 5c., $\frac{1}{8}$ oz. 12c., oz. 20c., 2 oz. 35c., lb. 60c., 1b. $\$ 2.25$.

Red Dutch. An old well-known variety; heads not large but very solid. 6 c., 1 b. $\$ 2.00$.

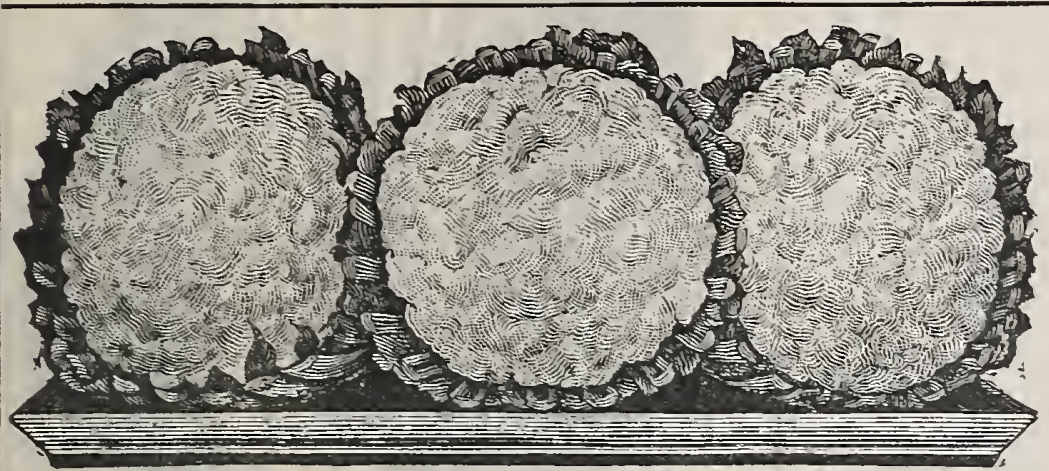

field than others. Were there no other variety in existence we should all be fully as well off, and probably better It wrould be difficult to imagine a better one, unless one could be originated that would head under the unfavorable conditions that sometimes prevail when no variety succeeds. We offer a strain of seed, which, in spite of the claims put forth by some that they have the only pure and reliable seed, we yet claim to be true and reliable; a claim which we could easily substantiate, and in a convincing manner to any who are open to conviction, by the results obtained by those who have used it. While good seeds cannot, as a rule, be sold at extremely low prices it is, nevertheless, a fact that an exorbitant price does not necessarily make any article good or better. Neither our claims nor those of others are of value unless they can be proven to be true,-results only can prove them. These our customers have found entirely satisfactory and equal in all respects to those obtained from seed claimed to be the only retiable and for which they formerly paid nearly twice what ours cost them. Pkt. 20c., $\frac{1}{4}$ oz. 65c., $\frac{1}{2}$ oz. $\$ 1.25$, oz. $\$ 2.25$.

Extra Early Paris. Heads large, white, compact and solid, of excellent flavor; a favorite with market gardeners. 10c., 支 Oz. 40c., Oz, 75c.

Half Early Paris. Not as early as the preceding variety. Heads large and compact, of good quality. Pkt. 10c., $\frac{1}{2} \mathrm{oz} .35 \mathrm{c} ., \mathrm{oz} .60 \mathrm{c}$.

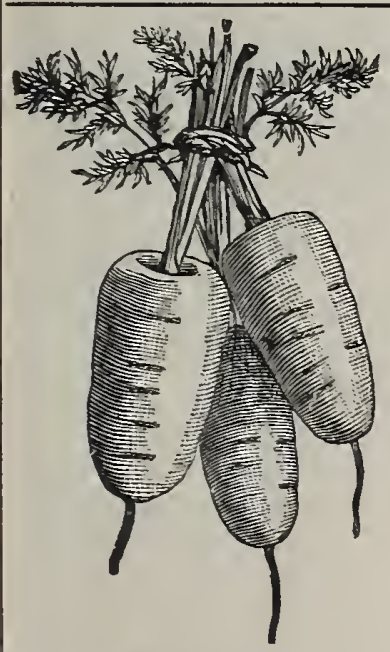

Early Horn.

\section{CARROT}

Early Scarlet Horn. A popular early variety, grown only for table use. The roots are about three inches long and one-half inch in diameter at top, tapering slightly and terminating abruptiy like the larger stumprooted varieties. They make an attractive bunch, are of excellent quality and have small tops. Pkt. 5c.. Oz. Ioc., 2 oz. I5c., 1/4 1b. $25 \mathrm{c} ., 1 \mathrm{~b} .90 \mathrm{c}$.

Chantenay. This is an excellent variety for bunching. The roots are five inches long, three inches in diameter at the top, tapering gradually, but uniformly stump-rooted. The flesh is tender and crisp, color deep orange. The tops are of medium size, and necks small. Pkt. 5c., oz. Ioc., 2 oz. 15c., $1 / 4$ 1b. $25 \mathrm{c}$., $1 \mathrm{~b} .90 \mathrm{c}$.

Oxheart, or Guerande. Roots very thick, often over five inches in diameter at shoulder, tapering to not less than two inches at the stump-root, and about five or six inches in height. The flesh is very fine-grained, free from core, tender and sweet. Color, bright orange. An excellent rariety for either table use or for stock, and especially suited for hard, stiff soil, where longer growing varieties seldom thrive. Plat. 5c., oz. Ioc. 2 oz. 15c., 1/4 1b. $25 \mathrm{c} ., 1 \mathrm{~b} .85 \mathrm{c}$.

Danvers. This for a long time has been, and is yet, the most popular variety. It is used for bunching for market early in the season, and later for packing in boxes or crates. It is also exteusively grown for stock. While the yield per acre would probably not be as large as from the Rubicon or L,ong Orange, it, like the first, succeeds better on

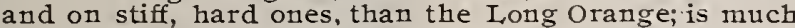
easier harvested than the latter, and of much better form and more attractire in appearance than the former. This latter feature, of course, nakes it more desirable for market, although of no 1nore value for feeding, and its popularity for feeding is perhaps largely due to a want of acquaintance with the Rubicon. The roots are about two inches in di- ameter at the shoulder and five to six inches 1oug. The flesh is finegrained, te nde $t$ and
sweet. The tops are of sweet. The tops are of neck sma11. Our strain is one which we have sold for a long time; has the rich, dark color so trade, and runs very uniform and true to name. Pkt. 5c., Oz. IOc.

Rubicon. This new vatieity is sinilar in form to the Ox Heart, but longer. It is also earlier, larger and, therefore, heavier than the Danvers, and, while we are uot disposed to in any way disparage the excellence of the Danvers, we consider the Rubicon the superior variety for growing for stock, because of its greater weight the yield per acre mould belarger, and as the roots, like the Dauvers, are short it is as equally desirable for sha low, or stiff, hard, soils. It has fewer and finer leaves than the Danvers has no neck, growing hollow-crowned, and is very uniform in growth market variety, lacking attractive form. Plot market variety,

Long Orange. An old well-known and popular variety, and on soits a ed for it-that is deep, mellow ones-tive heaviest crovper of all. It is largely grown for stock, but to solue extent

very long, smooth and handsome, holding thei

tapering gradually to a point. The

shortening of the root, with perhaps a deeper

the desired color and true to narne,

years, and we have vet to find one which in a

Large White Belgian. Grown only for stock feeding,

white and grows one-third above the ground, th

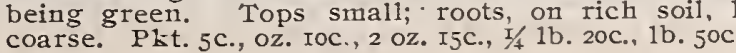




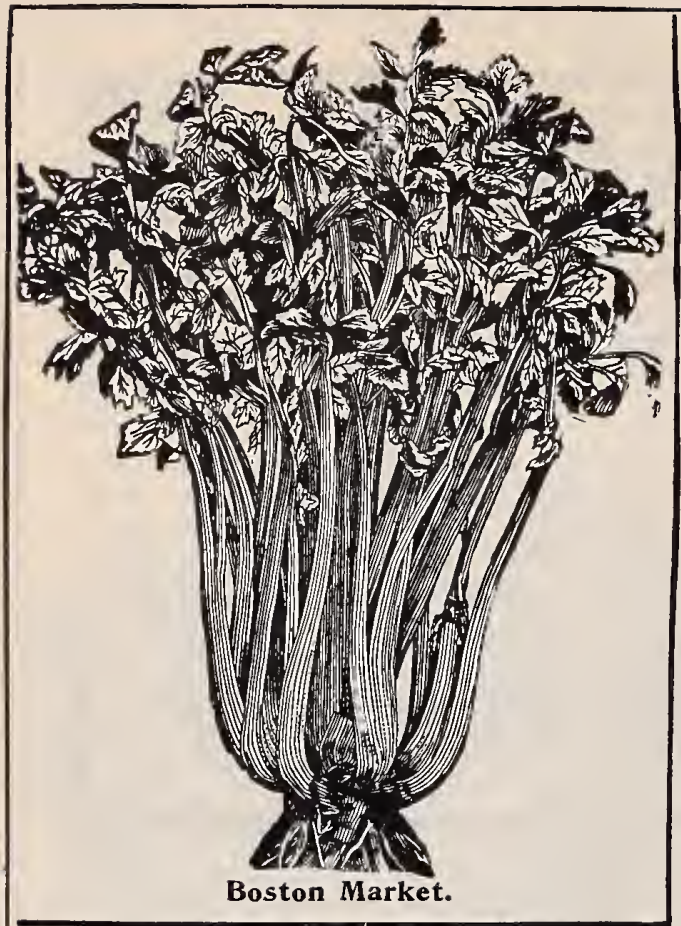

\section{CELERY}

White Plume. The earliest and most easily blanched of all varieties; requires little banking-up to make it fit for market, belonging to the self-blanching class; but, in our opinion, it, like all celeries, is of much better flavor when blanched with earth. A desirable variety for early fall use, but does not keep well; very showy and beautiful, but not more so than the Golden Self-Blanching, and not equal to that in several other respects. Pkt. 5c., $\frac{1}{2}$ oz. 12c., oz. 20c., 2 oz. 35c., $\frac{1}{4}$ lb. 60c.

Pink Plume. Nearly identical with the White Plume, except the tinge of red on the leaf stalks, which fades to faint pink when blanched. Like the White Plume it is easily blanched and is of better quality. Pkt. 5c., $\frac{1}{2}$ oz. 12c., oz. 20c., 2 oz. $35 \mathrm{c}, \frac{1}{4} \mathrm{lb}, 60 \mathrm{c}$

Golden Self-Blanching. The most popular variety in cultivation. It is nearly as early as the White Plume, is generally considered to be of better quality and flavor, and has to a considerable extent displaced it. It is of dwarf, compact habit, and, when grown in rich, moist soil and under favorable conditions, produces more large, thick stalks than other varieties, in such cases requiring but two plants to make a bunch, whereas it usually requires three or more of other varieties. It is self-blanching to a remarkable degree. When young the plant is of a yellowishgreen, blanching to a deep, golden-yellow, and the inner stalks to nearly white. It is, when ready for market or the table, a thing of beauty as well, as utility, and a most decided ornament to any table. We offer a proven strain of seed. Pkt. 10c., $\frac{1}{2}$ oz. 20c., oz. 35c., 2 oz. 65c., t lb. $\$ 1.20$.

Rose Ribbed Paris. This variety in general character resembles the Golden Self-Blanching, differing, however, in a few features. It is even more compact in growth, and the stalks are a little larger. The color is a beautiful goldenyellow, slightly deeper than the Golden Self-Blanching, especially the upper portions of the inner stalk; but that which makes it the most distinct and more beautiful is the tint of red on the stalks. At the base, this is more nearly a pink, but deepens into a carmine line on the ribs. The outer leaves are green, shading into deep yellow at the center. It is practically stringless, is crisp, tender and fine flavored. It is nearly as early as the preceding and as easily blanched. Its attractive appearance, large size and superior quality entitles it to first place in the list of self-blanching varieties and warrants a more general cultivation. Pkt. 10c., $\frac{1}{2} \mathrm{Oz} .20 \mathrm{c}$, oz. 35c., 2 oz. 60c., 表 lb. $\$ 1.00$.

Boston Market. An old standard variety, for many years grown more extensively for Boston market than any other. It is noted for its tenderness and flavor. It is peculiar in its growth, forming a cluster of heads instead of a single large one. Pkt. 5c., 专 oz. 12c., oz. 20c., 2 oz. 35c., 孝 1b. 60c.

Boston Market. Selected stock, Arlington grown. Pkt 10c., $\frac{1}{2}$ oz. $25 \mathrm{c}$., Oz. 40c., 2 oz. $75 \mathrm{c}$., 迹 lb. $\$ 1.25$.

Giant Pascal. This is a green leaved variety, which was developed from the Golden Self-Blanching. It is much larger, a better keeper and of superior flavor. It grows about two feet high, has very broad and thick stalks, which are stringless. It has a peculiarly sweet and nutty flavor, entirely free from any bitter taste. It blanches quickly after banking-up. Pkt. 5c., $\frac{1}{2}$ oz. 12., oz. 20c., 2 oz. 35c., $\frac{1}{4} 1 \mathrm{~b} .60 \mathrm{c}$.

Celeriac, or Turnip-rooted Celery. The roots only of this are used, either boiled or sliced for salads, or for flavoring soups.

Erfurt Giant. Pkt. 5c., $\frac{1}{2}$ oz. 10c., oz. 15c., 2 oz. 25c., $\frac{1}{4} 1 \mathrm{~b} .40 \mathrm{c}$.

\section{SWEET CORN}

A New Variety. THE UETROPOLITAN.

\section{CRESS, OR PEPPER GRASS.}

Curled. Pkt. 5c., oz. 10c., 2 oz. 15c., 1b. 20c. numerous, narrow and very dark green in color. whe the to the plant. They are uniformly 9 inches long, 10 to 12 rowed, well filled to the tip with large deep grains, which are very tender. It is not merely sweet, but possesses in a remarkable degree that exquisite richness so well-known in the larger and later sorts. We should add that an ample husk fully insures its value as a shipping variety; indeed, the combination of good qualities possessed by it makes it the most desirable of all for early trucking.

While the above claims and descriptions are in general correct, we take exception to the statement that it is only two days later than the Cory. All those who are at all familiar with the Champion and Kendel's know that they are from a week to ten days later. $\mathrm{W}^{\top}$ e have found that the Metropolitan ripens with them. That this is correct is verified by the statement made by the Everett $\mathrm{B}$. Clark Co. of Connecticut, the largest growers of sweet corn in New England, who in reply to an inquiry of ours as to the general characteristics of the Metropolitan said: "We find the Metropolitan and Kendel's ripening the same day with the Champion, perhaps one or two days later. The Metropolitan is perhaps a little more slim and longer eared and a trifle more dwarf in habit of stalk." This, while undoubtedly the truth, does not greatly detract from its value and should not prevent any from a just consideration of its many good qualities or from a general use of it. $\frac{1}{2}$ pt. 10c., pt. 15c., qt. 30c., 2 qts. 50c., $\frac{1}{2}$ pk. $90 \mathrm{c} .$, pk. $\$ 1.75$, bush, $\$ 6.50$. 


\section{Sweet Corn}

TABLE VARIETIES 000000

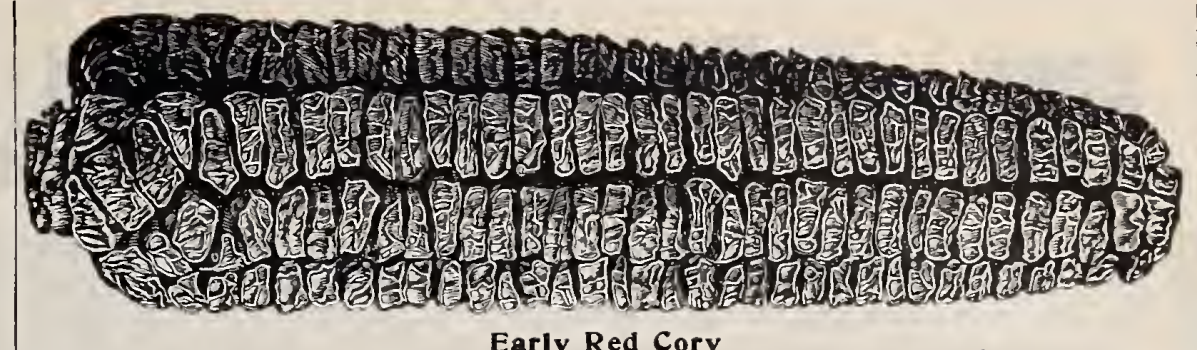

Early Red Cory

A NOTHER unfavorable season has resulted in a great scarcity of seed 1 sweet corn. Not only was the past season unfavorable for the production, but especially so for curing sweet corn, so at this writing no dealer is certain how much or (what perhaps would be a better way to state it) how little he may have to offer. All are, however, certain that the crop will be far short of an average one. Prices, therefore, rule high, and even those here quoted are necessarily subject to change if by any good fortune we might be able to secure more seed when our supply is exhausted. We do not, however, judging from the present outlook, deem this possible, and there will therefore probably be no change in the prices here quoted. Customers should bear in mind that this of all years is the time when "the early bird catches the worm"; that is, the early customer will secure the corn. Those, however, who defer ordering until the season is well advanced will do well to state in their order a second choice, so tinat if our supply is exhausted of the variety desired we may fill the order with the second named one. In case, however, the first named variety is the only one desired, we will at once return the amount remitted. We believe it better and only fair to customers to state that we do not anticipate that sweet corn will be at best of more than average germination, and therefore advise a liberal planting, as even at the high prices the slight additional cost will be of but little account compared with the greater certainty of securing a good stand if more seed is used. We hope none will infer that we are expecting to send out corn that will be inferior in quality to that which might be purchased of other dealers, for such is not the case. On the contrary our stocks will be (as they always have been) fully equal to any to be obtained from any other source, and we only men. tion the probable or possible condition of seed to put customers on their guard and thereby prevent their possible disap pointment.

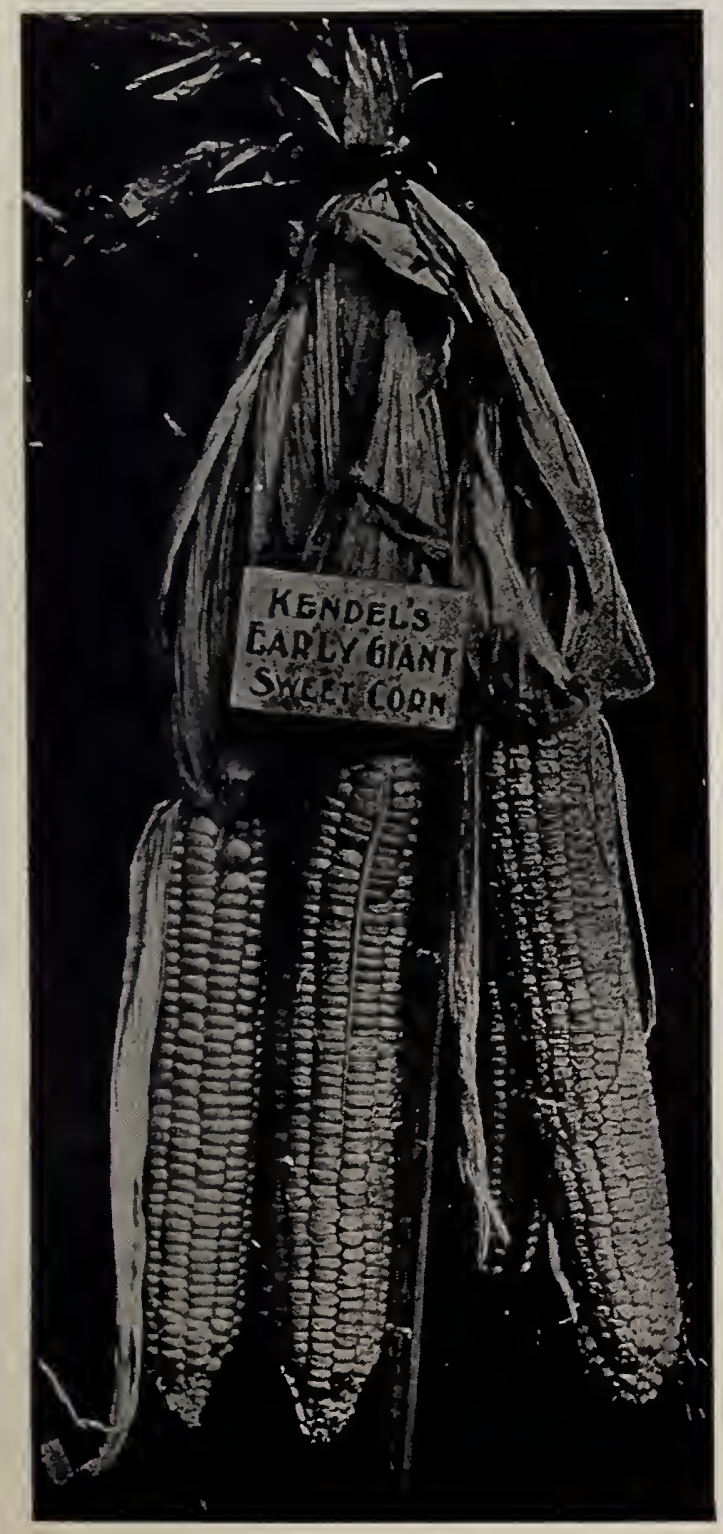

First of All. One of, if not the earliest of all varieties. selection from the Red Cory, identical in appearance and having the same general characteristics, varying, however, slightly in size of ear, which is a very little smaller, and sometimes having ten or twelve rows. We note a tendency of all seed-growers to select too large ears for seed-stock of this and other extra-early varieties, thereby getting stock which will produce green ears of larger size, but at the sacrifice of earliness. We have endeav ored in this strain to maintain its original earliness rather than to increase the size of ear. $\frac{1}{2}$ pt. 10c., pt. 15c., qt. 30c., 2 qts. 50c., $\frac{1}{2}$ pk. 90c., pk. $\$ 1.75$, bush. $\$ 650$.

Early Minnesota. An old well-known variety which, although it has to a considerable extent been displaced by the many new varieties, is yet a favorite with some on account of its good quality. Kernels broad, ears of medium size, eight-rowed. $\frac{1}{2}$ pt. 10c. pt. 15 c., qt. 30c., 2 qts. 50c., $\frac{1}{2}$ pk. 90c., pk. $\$ 1.75$, bush. $\$ 6.00$.

Early Red Cory. The most popular early variety; cobs mostly red, kernels from deep pinkish cast to white, ears eight-rowed and of fair size; of medium quality and a good yielder. $\frac{1}{2} \mathrm{pt}$. 10c., pt. 15 c., qt. 30c., 2 qts. 50 c., $\frac{1}{2}$ pk. 90c., pk. $\$ 1.75$, bush, $\$ 6.50$.

Early White Cory. A selection from the Red Cory, having only white kernels and cobs. Ears are a little larger. It is nearly if not quite as early, and is considered by some of better quality. Eight-rowed. $\frac{1}{2}$ pt. 10c., pt. 15c., qt. 30c., 2 qts. 50c., t $\frac{1}{2}$ pk. 90c., pk. $\$ 1.75$, bush. $\$ 6.50$.

Mammoth White Cory. This, while the stalks are no larger than the White Cory, has larger ears and is claimed to be more productive. The ears are twelverowed, very symmetrical and handsome, with no space between the rows at the base. The kernels are large, broad, very white, and of good quality for an early variety. $\frac{1}{2}$ pt. 10c.; pt. 15c., qt. 3oc., 2 qts. 50c., $\frac{1}{2}$ pk. 90c., pk. $\$ 1.75$, bush. $\$ 6.50$.

Kendel's Eariy Giant. This, the Champion and Metropolitan, are close rivals for first place in the class of second early sorts. Ears of this are from eight to ten inches long and usually have twelve or more rows. Kernels white, sweet and tender. $\frac{1}{2}$ pt. 10c., pt. 15c., qt. 30c., 2 qts. 50c., $\frac{1}{2}$ pk. 90c., pk. $\$ 1.75$, bush. $\$ 6.50$.

Early Crosby. New England Strain. The Crosby has for years been one of the most popular varieties. The strain we offer differs from the original in being of much larger growth and having much larger ears. These, with the exception of size, closely resemble those of the original, and are usually twelve-rowed, sometimes more. $\frac{1}{2}$ pt. 10c., pt. 20c., qt. 40c., 2 qts. 75 c., 卉 pk. $\$ 1.25$, pk. $\$ 2.25$, bush. $\$ 8.00$.

Early Champion. The ears are fit for use with or before the Crosby and are much larger. From ten to twelve-rowed. Kernels are deep, pure white, and of good quality. $\frac{1}{2}$ pt. 10c., pt. 15c., qt. 30c., 2 qts. 50c., $\frac{1}{2}$ pk. 90c., pk. $\$ 1.75$, bush. $\$ 6.50$.

Moore's Concord. An old well-known variety which was for many years the most popular of the second early class. Ears are large, twelve to sixteen-rowed, and fit for use soon after the Champion. Of excellent quality. $\frac{1}{2}$ pt. 10c., pt. 15c., qt. 30c., 2 qts. 50c., t pk. 90c., pk. $\$ 1.75$, bush. $\$ 6.00$.

Black Mexican. A variety when ripe with bluish-black kernels, but when in suitable condition for eating cooks white. But few varieties equal it in tenderness and sweetness. Ears of medium size. It is ready for use about with the Concord. $\frac{1}{2}$ pt. 10c., pt. 15c., qt. 25c., 2 qts. 45c., $\frac{1}{2}$ pk. 80c., pk. $\$ 1.50$, bush. $\$ 5.00$.

Potter's Excelsior or Squantum. Known by the first name for years in Boston market, where it was very popular. Used extensively in Rhode Island, where it was named Squantum. Ears of medium size. A standard of excellence in tenderness and sweetness. $\frac{1}{2}$ pt. 10c., pt. 20c., qt. 35c., 2 qts. 60c., t pk. $\$ 1.00$, pk. $\$ 1.90$, bush. $\$ 7.00$.

Country Gentleman. A medium late variety, having irregular rows. Has a very small cob and deep kernel; is tender and sweet; very desirable for the home garden. $\frac{1}{2}$ pt. 15c., pt. 25c., qt. 50c., 2 qts. 90 c., $\frac{1}{2}$ pk. $\$ 1.50$, pk. $\$ 2.75$, bush. $\$ 10.00$.

Marblehead Mammoth. The earliest, sweetest and largest of all the Mammoth sweet varieties. $\frac{1}{2}$ pt. 10c., pt. 15c., qt. 30c., 2 qts. 50c., $\frac{1}{2}$ pk. 90 c., pk. $\$ 1.75$, bush. $\$ 6.50$.

Ferry's Early Evergreen. A selection from the well-known Stowell's Evergreen; identical in appearance, equal in quality, and is claimed by the introducers to be from one to two weeks earlier and to remain in condition for use longer. $\frac{1}{2}$ pt. 10c., pt.15c., qt. 30c., 2 qts. 50c., $\frac{1}{2}$ pk. 90c., pk. $\$ 1.75$, bush. $\$ 6.50$.

Stowell's Evergreen. More largely used than any other late variety. Ears large, kernels very deep and shriveled. $\frac{1}{2}$ pt. 10c., pt. 15c., qt. 30c., 2 qts. 50c., $\frac{1}{2}$ pk. 90 c., pk. $\$ 1.75$, bush. $\$ 6.50$. 


\section{CORN \& Field, Fodder and Ensilage o CORN Is KING}

WE DOUBT if the magnitude of our agricultural interests in the United States is fully realized by many, especially of our corn
crop. The following, taken from Green's Fruit Grower, may interest our readers, and shows what part of the enormous

Wonderful Figures for Farmers. - With a few figures, Secretary Wilson brings out in a striking manner the magnitude of the agricultural interests of the country, says Post Express. In 1900, the fixed capital of that industry was $\$ 20,000,000,000$, or four times that devoted to manufacturing. The 5,000,740 farms covered 841,000,000 acres, of which 415,000,000 acres were improved land. On these farms resided $40,000,000$ of people, or more than half of the population. Of the 29,000,000 of people engaged in gainful occupations, 10,000,000 were engaged in agriculture. The agricultural products of 1899 amounted to nearly $\$ 5,000,000,000$. Corn came first with a value of $\$ 828,000,000$, hay and forage second with a value of $\$ 484,000,000$; wheat third with a value of $\$ 370,000,000$; cotton fourth with a value of $\$ 324,000,000$, and oats fifth with a value of $\$ 270,000,000$. The animals sold and slaughtered were worth $\$ 900,000,000$, the products of the dairy $\$ 472,000,000$, and poultry and eggs $\$ 281,000,000$.

It is evident to us that there has been a change of opinion in New England regarding the advisability of raising corn for grain. veral years ago it was held by many New England farmers that they could buy corn cheaper than they could raise it. The rapidly increasing demand for sevcral years for seed of such varieties as are grown mainly for grain indicates to us a greatly increased acre-

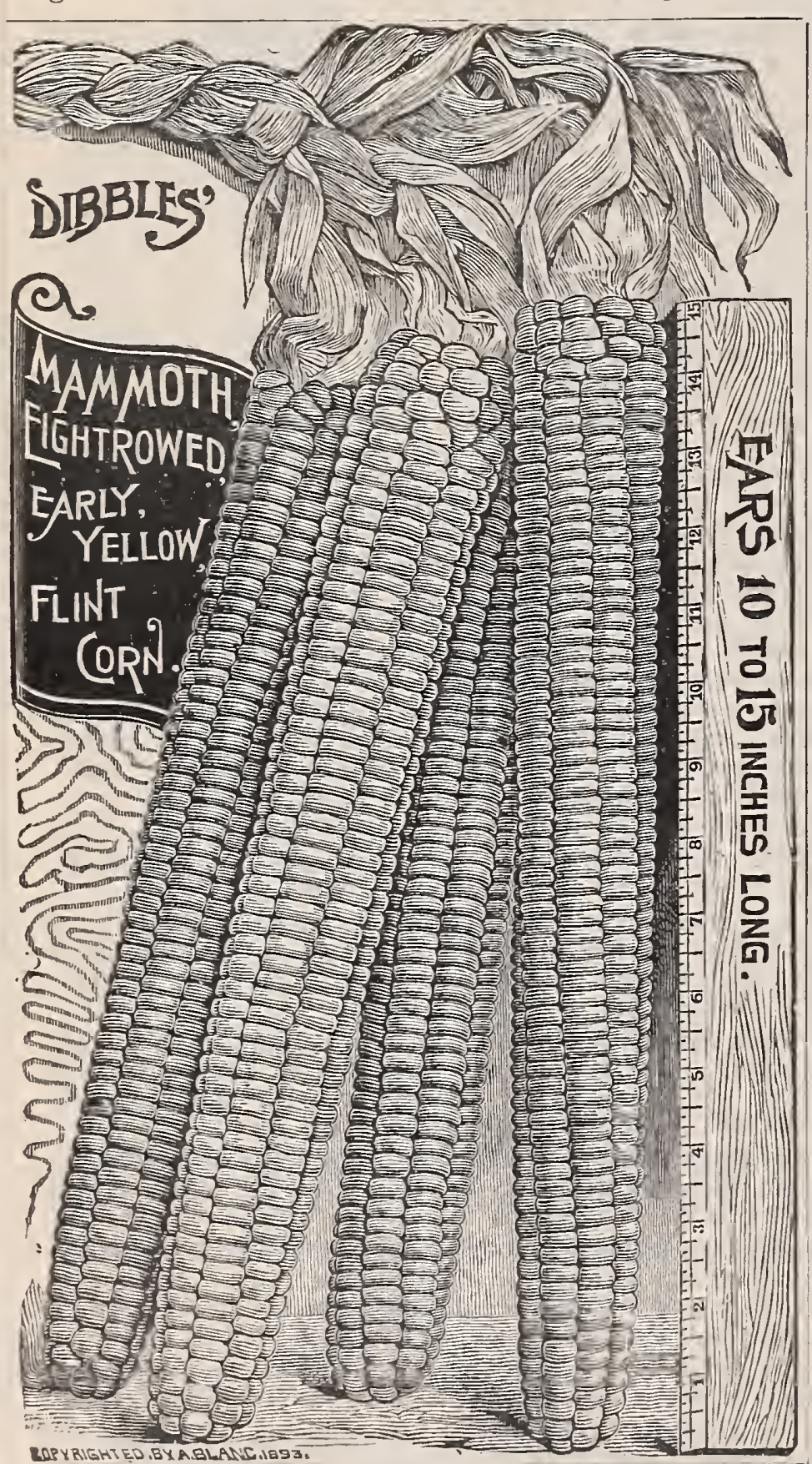
permitted to call attention to it, and to suggest a thoughtful consideration of it. We have to say regarding our supply of seed that in spite of another unfarorable season and a consequent shortage, we expect, owing to our largely increased contracts for growing seed, a larger amount of such arieties as Improved Canada, Longfellow, etc., than we have ever before had. Upon its arrival we should be pleased to send samples to any who may choose to apply.

Improved Canada. Known also as the Farly Demond, Deerfield, Greenfield, or Con necticut ralley. This differs from the common Canada, or Canada Cap, in that the ear is about two inches longer. Like that, it is eight-rowed, and early enough to
mature a crop in any section where corn can be profitably grown. Pk. 50c., bush. \$r.75.

Longfellow. This popular variety is said to be the result of careful selection in the Longfellow family for over fifty years. The ears are very long, sometimes reach. It yields well, often having two good ears on a stalk. It is safe for planting in the latitude of Massachusetts, and is in this state extensively grown. Pk. 50c., bush.

Sanford White. A white flint variety, used considerably in Rhode Island for grinding both for stock and culinary purposes, and very extensively used in Vermont for ensilage. Pk. 35c., bush. \$1.25. Extra selected seed, pk. 40c., bush. \$I.50.

Dibble's Mammoth Eight=Rowed Yellow Flint. The introducer of this excellent variety, Mr. Dibble, in reply to an inquiry of ours concerning its origin, earliness, etc., has in substance this to say of it: Its origin is without question, the Canadian Yellow Flint, but having been kept in one family for something like 75 years, the original type has been improved by selection by using only the long ears, with eight rows, until now the ears will average ten to fifteen inches. The stalks also have been increased in height fully two feet, and now average eight to ten feet. The illustration here shown is from an engraving Mr. Dibble had made, of which was one eighteen inches long, but which was not as perfect as the four shown in the cut. In regard to its time of maturing, he say

King of the Earliest. This Dent variety was a selection from the Pride of the North made by the originator of that variety and is from ten days to two weeks earlier, which we think makes it safe for planting in this latitude for the purpose of matur ing grain. The cob is small and although the ears are not long the kernels are very deep and the yield large. We may say here that more attention is being given in the localite much larger yield from the Dent. Pk. 4Oc., bush. \$1.50.

Pride of the North. A Dent variety. We have always considered this sufficiently early to advocate its planting in this latitude for grain, but we find that there are other varieties which are earlier and have had some complaint the last two seasons that this did not mature early enough to warrant its planting here or in this latitude for this purpose. Doubtless the unfarorable seasons had some bearing in regard to its this purpose. Doubtiess the unfavorable seasons had some bearing in regard to its this when ripened prain is desired This however, is popular with some for ensilage this when ripened grain is desired. This. however, is popular with some for ensilage although it does not grow as tall is preferable to them on cold clayey soils on account of its earliness. Pk. 40 .

White Cap Yellow Dent. Nearly as early as the Pride of the North; with large ears. The grower and introducer of this wonderful corn says he will guarantee this corn to mature in ninety to ninety-five days from planting, and to grow a larger crop on poor soil than any other corn in the world. Stalks are eight to tell feet high, with to ten inches long, well filled out and have from sixteen to eighteeu rows. Kernels are of the true Dent type, sweet and nutritious, the outer end white and the balance Early Mastodon Dent. and grain. Iu the Amercan Agriculturalist corn contest, inl ISS9, it outyielded all others, making the wonderful record of 213 bushe
Used extensively for ensilage. Pk. $40 c$., bush. \$r.5o.

by many seedsmen is the variety having a pointed kernel, which is not as leafy, nor is it generally grown by those engaged in growing corn for seed; is, therefore, not as well cured, and usually does not germinate nearly s

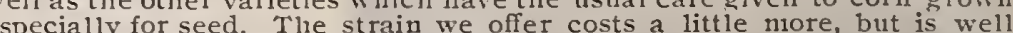
worth the difference. Pk. 30c., bush. \$1.15, 2 bush. $\$ 2.20$.

Sweet Fodder, Evergreen, and other large varieties, Pk. 5oc., buslı. $\$$ r. 75 . 


\section{The Eureka Ensilage Corn \& The Best}

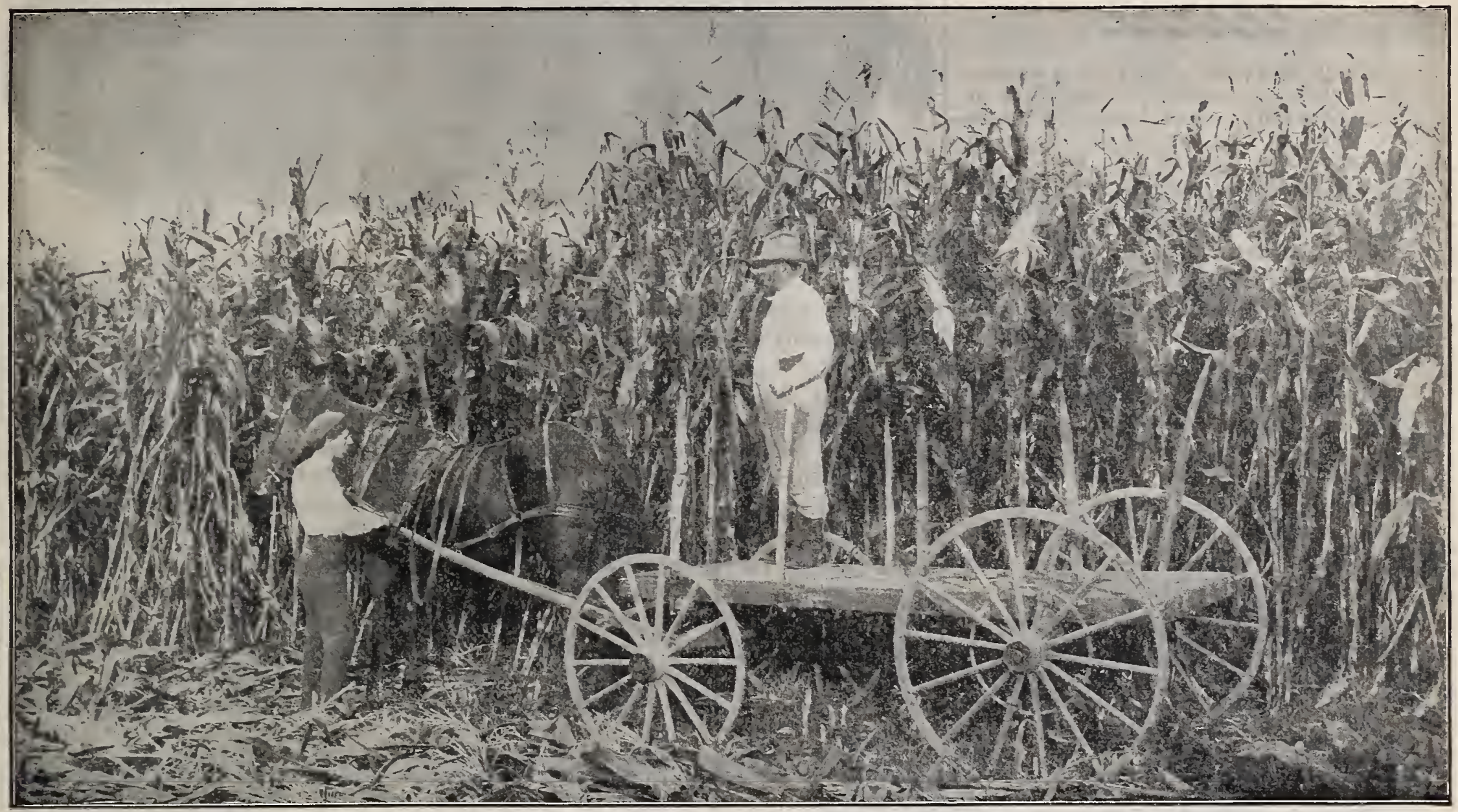

The above illustration is from a photograph of a field of the Eureka grown by W. C. Jewett of this city, who has for many years been one of our customers.

\section{)$_{0}(3$ \\ The EUREKA will produce more Tons of Ensilage
Than Any Other Variety. \\ per Acre}

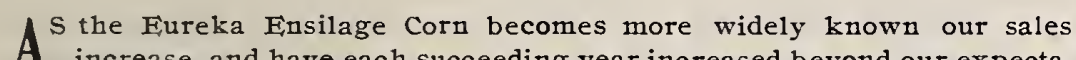
A increase, and have each succeeding year increased beyond our expectation. Each year, when placing our order for growing of seed for use the following season, we have increased the amount sufficiently, we thought, to meet all demands, but with one or two exceptions since its introduction we have sold all seed before the season ended, and in several years our supply was exhausted considerably in advance of that time. That which still further indicates its merit and growing popularity is that where the Eureka is best known our sales are the largest. That is in our immediate ricinity. This fact has been particularly noticeable and of interest to us because of the strong hold another variety had in this section. We refer to the Leaming, an excellent variety, and of which we formerly sold seed largely in excess of all other varieties combined, including the Eureka, and while as our business has increased, our sales of seed of the Leaming have also, uutil in the past season we sold a much larger amount than ever before; they were but slightly in excess of the Eureka, although seed of the former was sold at only a little more than half the price of the latter.

We think we are not exaggerating when we say that the best farmers in Worcester County, one of the leading dairy counties in the Union, are planting largely or entirely the Eureka Corn for ensilage.

The Eureka originated in Virginia, where particular attention has always been paid to growing corn that produced the most leaves. Since its introduction there has been evident improvement made in it in earliness, and it now not only excels in leafiness, but is at least as heavily eared and ears as early as any other variety that at all approaches it in size of growth.
The originator has never grown any seed of the Fureka for any other seedsman, nor have we ever had any grown by any other grower. We therefore control the seed, and it is a!ways the same. It is put in one and two-bushel bags, always plainly marked "Ross Bros.' Eureka Ensilage Corn," and when sold in smaller quantities a slip is enclosed in bag printed in the same manner. The seed is nearly identical in appearance with that of the Southern White; customers, therefore, should exercise care when seed is not purchased directly of us that it is the genuine, which is always indicated by the manner to which we have referred.

We have further to say regarding the seed of this variety that in all of our years of experience with seed-corn, we have never found seed of any variety from any grower that equaled seed of the Eureka in high per cent of germination. This is because especial care is given to the selection and treatment of seed of Eureka by our grower, and also because the seed is never shipped to us until thoroughly cured beyond any possibility of heating from dampness. Seed of the Eureka costs more to grow and handle, sells for a higher price, but is well worth it, considering only its superior and certain germination, regardless of the fact that it is also a superior variety.

While the delay in shipping seed to us by our grower has in the past sometimes prevented us from filling orders as early as we would prefer, and has at times made some of our customers impatient, we are convinced that it is altogether the better plan, and we wish here to call attention to the fact that while we desire early orders, none can be filled until new seed is received. Seed will, however, be sent in ample time for planting.

Price. Pk., 6oc.; bushel, $\$ 2.00$; three bushels, $\$ 500$. No charge for bags. 


\section{Cucumber ssssso}

Early Russian. The earliest variety and probably the hardiest. Fruit three to four inches long, one and one-half inch to two inches in diameter, oval, pointed at both ends and covered with fine, small spines. Vines of vigorous growth and productive. Pkt. 5c., oz. $15 \mathrm{c} ., 2 \mathrm{oz} .25 \mathrm{c}$., t lb. $40 \mathrm{c}$., lb. $\$ 1.40$.

Early Cluster. An early and very

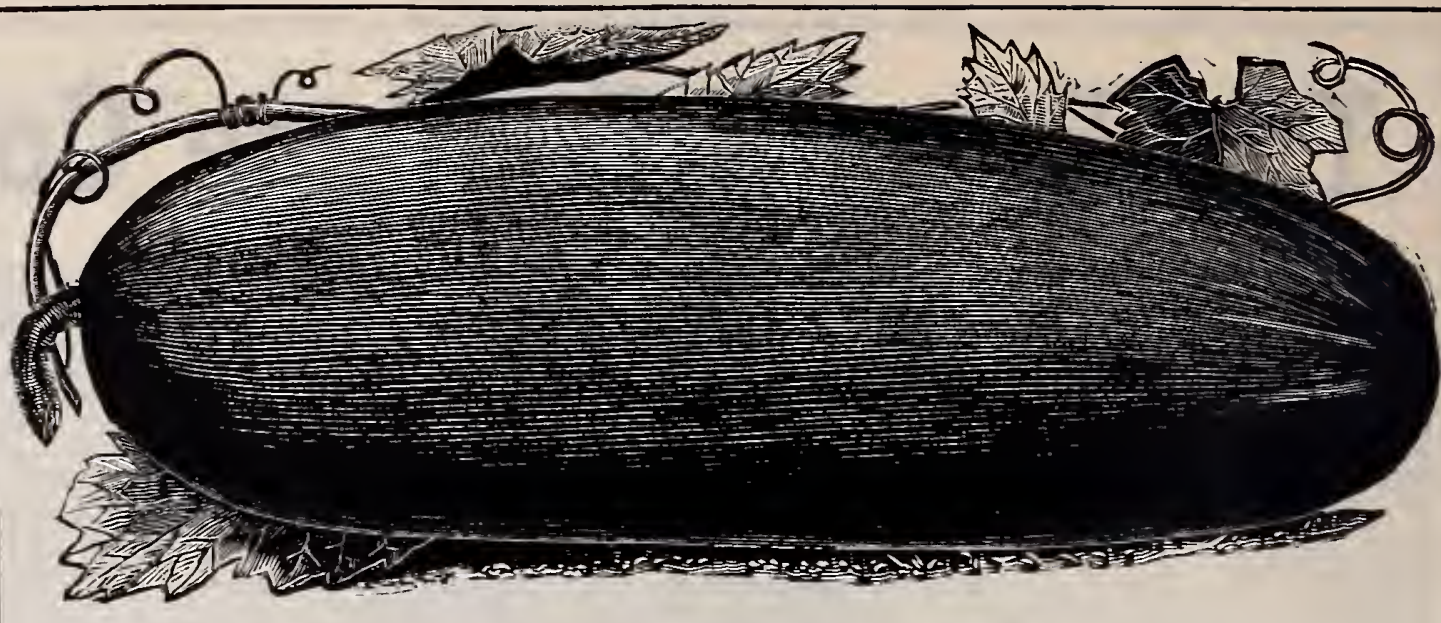
productive variety. Fruit small, thick at the end, dark green, but lighter at blossom end, borne in pairs or clusters and largely near the root. Used to some extent for pickles. Pkt. 5c., oz. 15c., 2 oz. 25c., t 1b. $\$ 1.40$.

Early Frame or Short Green. Fruit short, straight, small at each end, bright green, lighter at blossom end, and although small is an attractive variety and of excellent quality. Used both for slicing and pickling. Vine vigorous and productive and produces fruit of suitable size for slicing soon after the Cluster. Pkt. 5c., oz. 15c., 2 oz. 25c., $\frac{1}{6}$ lb. 45c., lb. $\$ 1.75$.

Improved White Spine. The most popular variety for slicing. Fruit uniformly straight and handsome, dark green, with white lines at blossom end, and has but few spines. Flesh is tender and crisp, and the variety well deserves its popularity. Nearly all the varieties used for forcing in this country sprang from this. They doubtless are more desirable for that purpose, but for growing in the usual way we have found none that surpasses this. Pkt. 5c., oz. 15c., 2 oz. 25c., $\frac{1}{4} \mathrm{lb}$. 50c., lb. $\$ 1.90$.

Evergreen White Spine. An extra long and distinct strain of this popular type. It is beautiful in shape and color and of the finest quality. Fruit long, cylindrical, dark green, crisp and tender; vine productive and comes into bearing soon after the preceding variety. A favorite with some for forcing. Pkt. 5c., oz. 15c., 2 oz. 25c., $\frac{1}{2}$ lb. 50c., 1b. $\$ 1.90$.

Emerald. The originators describe this as follows: "It is strictly an evergreen, retaining its color until quite ripe, making it an attractive variety. The fruit sets early, and its vigorous vines abound in long, straight, handsome fruits of the most desirable qualities. As a slicer the flesh is peculiarly crisp and tender, and the flavor most pleasing. The young fruit being deep green, straight and slender, makes an excellent pickle, and

\section{DANDELION,}

American Improved. Thick leaved. Pkt. 10c., $\frac{1}{2}$ oz. 25c., 40c., 2 oz. 70c., 古 1b. $\$ 1.25$, lb. $\$ 4.50$.

French, or Common. Pkt. 5c., 孝 oz. 15c., oz. 25c., 2 oz. 40 c. 釆 lb. 75 c., lb. $\$ 2.50$.

Arlington. Leaves finer than the American Improved; very popular in Boston market. Pkt. 10c., $\frac{1}{2}$ oz. 25c., oz. 40c. 2 oz. 70 c. , $\frac{1}{4}$ lb. $\$ 1.25,1 b . \$ 4.50$.

\section{EGG PLANT.}

New York Improved. The standard variety in all sections of the country. Pkt. 10c., $\frac{1}{2}$ oz. $20 \mathrm{c}$, oz. 35c., $2 \mathrm{oz} .60 \mathrm{c} ., \frac{1}{\mathrm{lb}}$. $\$ 1.00$.

when ripe none excels it for making sweet pickles. For those who grow under glass, or for long-distance shipping, it will prove a boon on account of holding its deep green color so long, and it is not excelled for beauty in color and form, even by the best English Frame varieties; almost spineless. As an all-purpose table or market variety it cannot be surpassed." Pkt. 5c., oz. 20 c., 2 oz. 35 c., $\frac{1}{4}$ lb. 60 c., lb. $\$ 2.25$.

Improved Long Green. This probably stands next to the White Spine in popular favor. Fruit from ten to twelve inches long, dark green, and very firm and crisp. It is used largely for slicing, but on account of its firmness and crispness is popular with some for pickling, and is especially desirable when mature for sweet pickles. Vine of strong, vigorous growth and productive. Pkt. 5c., oz. 15c., 2 oz. 25c., $\frac{1}{4}$ lb. 50c., lb. $\$ 1.90$.

Nichols Medium Green. Fruit thicker than the White Spine and full at both ends. Skin light green and very smooth. An attractive variety and of fine quality. Used by some for early forcing. Pkt. 5c., oz. 15c., 2 oz. 25c., t lb. 50c., lb. $\$ 1.90$.

Cumberland. This new variety originated with a wellknown firm of seed growers, who say of it: "We honestly believe this to be the best pickling cucumber ever produced. The variety is of the hardy, white spine type, is a rapid, strong and vigorous grower and very prolific in fruit. The pickles differ from all other hardy sorts in being thickly set with fine spines; the form is exceptionally straight and symmetrical, thus being as choice a variety for slicing as it is for pickling." Pkt. 5c., oz. 15c., 2 oz. 25c., + 1b. 50c., 1b. $\$ 1.90$.

Boston Pickling. Probably more widely known and more extensively grown for both private and commercial purposes than any other variety. Pkt. $5 \mathrm{c} .$, oz. $15 \mathrm{c},, 2 \mathrm{oz} .25 \mathrm{c}, \frac{1}{4} \mathrm{lb} .50 \mathrm{c} ., 1 \mathrm{~b}$. $\$ 1.90$.

\section{Moss Curled.}

\section{ENDIVE}

Large Green Curled. A large, coarse, strong-growing variety, which by tying up can be made to form finely blanched centers of good quality; outer leaves well cut, and bright, deep green. Each, Pkt. 5c., oz. 10c., oz. 15c., 2 oz. 25c., 支 lb. 40c.

\section{KALE (Borecole.)}

Green Curled Scotch. Of dwarf and compact growth, leaves curled and crimped, the whole plant resembling a bunch of moss. The best variety for general use. Pkt. 5c., oz. 10c., 2 oz. $15 \mathrm{c} .,+\mathrm{lb} .25 \mathrm{c}$.

\section{KOHL RABI.}

Early White Vienna. Pkt. 5c., $\frac{1}{2}$ oz. 10c., oz. 15c., 2 Early Purple Vienna. $\quad$ oz. 30c., $1 \mathrm{~b} .50 \mathrm{c}$. 

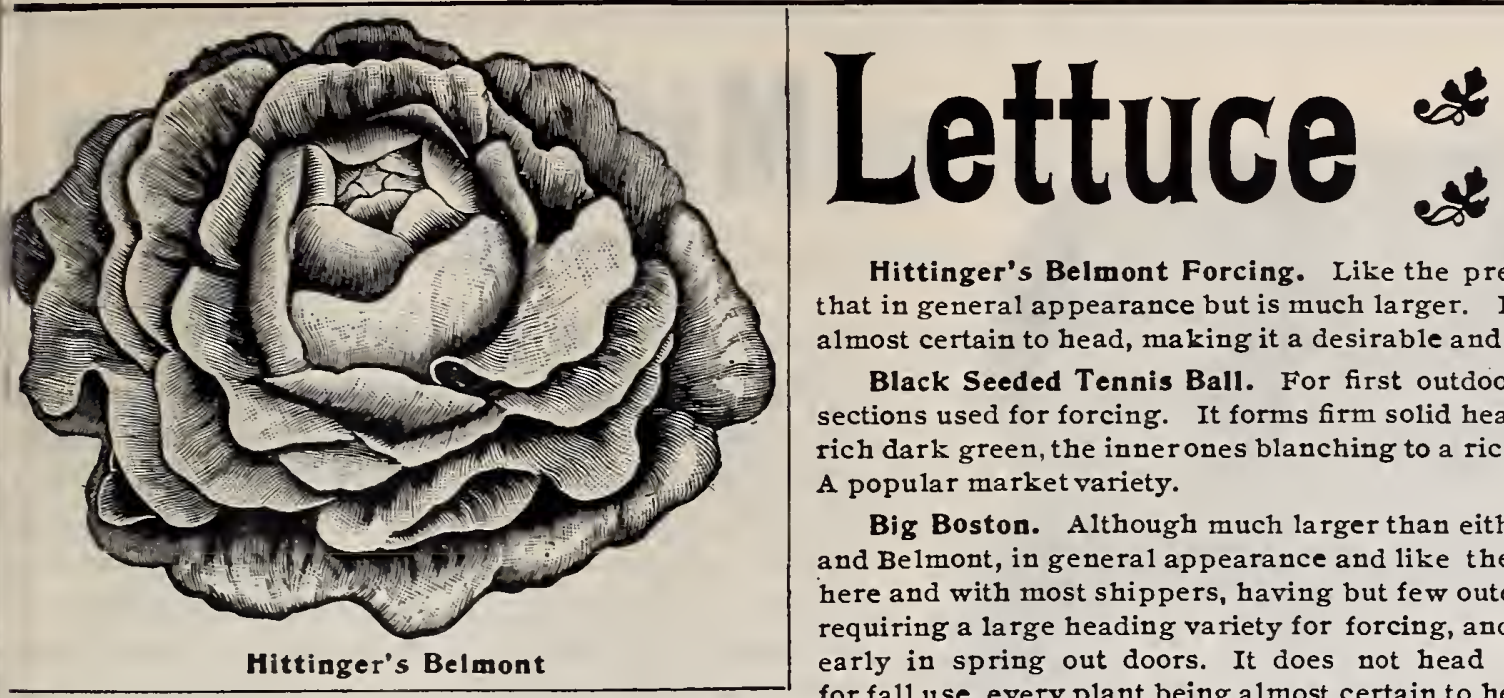

White Seeded Tennis Ball, or Boston Market. This has been more largely used in this section for forcing than any other. It has,

however, in recent years been, to a considerable extent, displaced by the Belmont Forcing.

Hittinger's Belmont Forcing. Like the preceding this is a plain leaved variety, resembles that in general ap pearance but is much larger. It forms a compact head and is, like the Tennis Ball, almost certain to head, making it a desirable and profitable variety for forcing.

Black Seeded Tennis Ball. For first outdoor crop nothing surpasses this. It also is in some sections used for forcing. It forms firm solid heads of medium size. The leaves are plain, thick, rich dark green, the innerones blanching to a rich creamy white and are then crisp and of fine flavor. A popular market variety.

Big Boston. Although much larger than either, this resembles the white Seeded Tennis Ball and Belmont, in general appearance and like them is of the type popular with market gardeners here and with most shippers, having but few outer leaves. It is very desirable for those gardeners requiring a large heading variety for forcing, and for growing in cold frames, and heads well very early in spring out doors. It does not head well in midsummer but is especially valuable for fall use, every plant being almost certain to head in the cool months of that season. The heads a re large, but having only a few outer leaves, the plants may be set more closely than other large varieties. The leaves are broad, comparatively smooth, thin and very hard, the outer leaves are light green; a large proportion of the inner ones or head blanching to a beautiful creamy white. When well grown, of the finest quality, crisp and tender.

Early Curled Simpson. (White Seed.) An old variety with broad, often frilled, very curly light green leaves; sweet, tender, and of fine flavor.

Black Seeded Simpson. Much larger than the preceding, but not as much curled. Forms a large loose cluster of leaves rather than a head, leaves light yellowish green; a good variety and extensively grown.

Early Curled Silesia. An old standard sort, very popular for home gardens.

Boston Fine Curled. Beautifully curled, excellent for garnishing but of rather poor quality.

Deacon. One of the most popular summer varieties, forming heads a little above medium size which although not as large as some of this class are nevertheless very solid, of excellent quality and flavor and which remain fit for use a long time. The outer leaves are few and are of a deep green, the inner portion blanching to a beautiful cream yellow.

Prize Head. This variety has no superior where a thin, terder, crisp and sweet lettuce is wanted for the home garden or local market. Being so thin leaved and tender it, of course, wilts very quickly after cutting, and is not suitable for distant markets. Plant large, deep green, so washed with red as to appear more red than green, forming a head of a dense mass of leaves, rather than one like a cabbage, and very slow to run to seed.

Hanson. An old variety of great merit. It forms a large, flat, cabbage-like head very slow to run to seed. The outer leaves a re bright green with veins of lighter shade, inner leaves white usually curved and twisted at the base. A very attractive variety of excellent quality and extensively grown for home use.

New York Market. One of the largest varieties in cultivation. The heads are very solid with but little tendency to run to seed. It blanches itself naturally, is crisp, tender and of excellent flavor, and is always free from bitterness. It is not a forcing variety bit is one of the best for summer use.

\section{Preceding varieties at uniform prices.}

Pkt. 5c., $\frac{1}{2}$ oz. 10c., oz. 15c., 2 oz. 25c., $\frac{1}{4}$ lb. 40c., 1b. $\$ 1.25$.

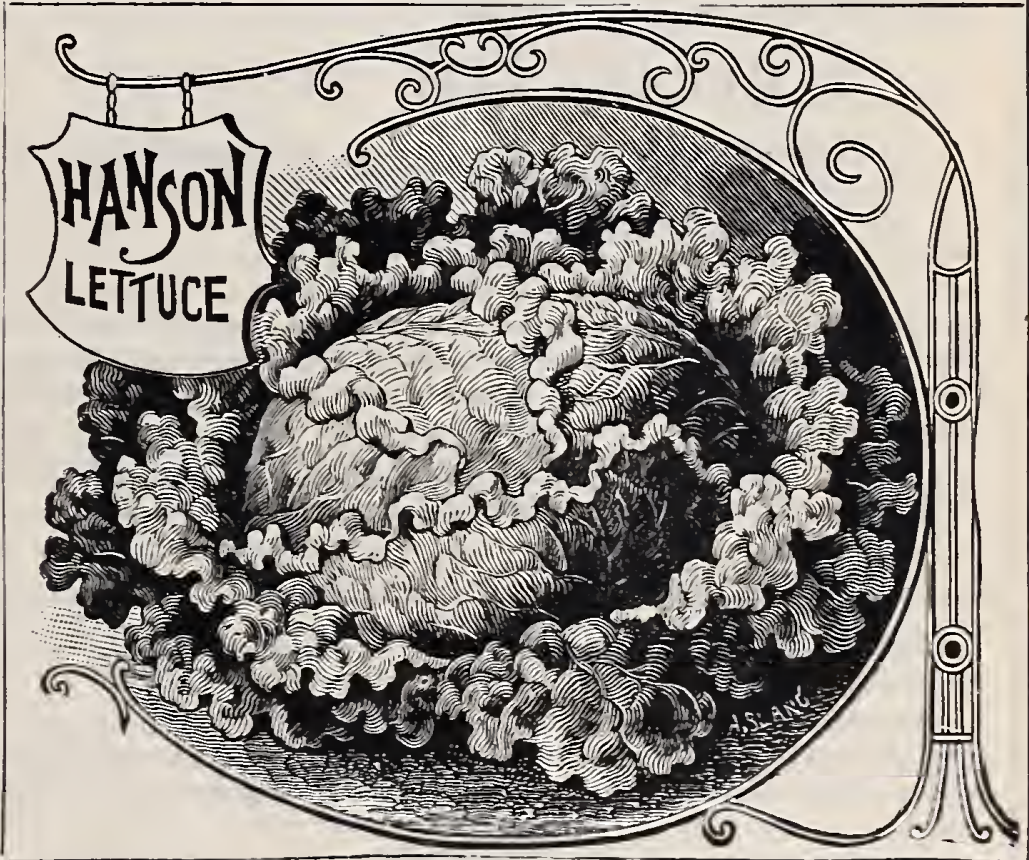

\section{A New Lettuce - “GIANT GLACIER." withstands heat and DRought}

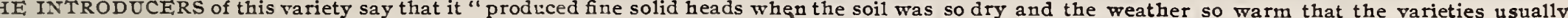

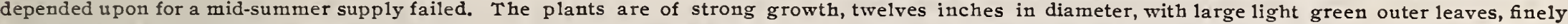

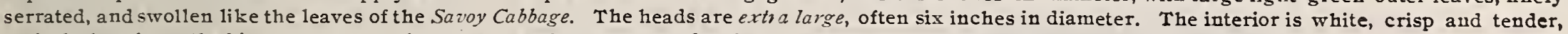
entirely free from the bitter pungency of many sorts when grown under the hot summer sun

Prices. Pkt. 5c., 1/2 oz. Ioc., oz, 20c., 2 oz. 30c., $1 / 4$ 1b. 50c., 1b. \$I.75.

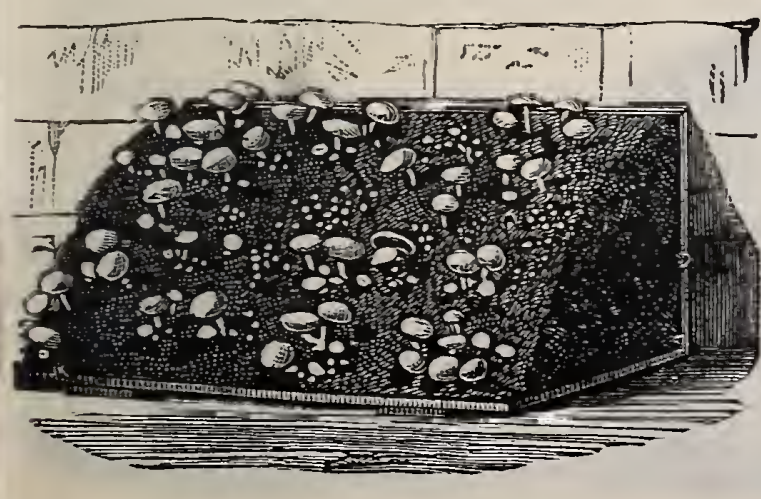

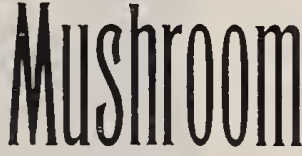

Spawn

Lb. 15 c.

8 lbs. $\$ 1.00$.

If desired by mail add 8 cents per pound.
LEEK.

American Broad Flag. The standard variety. $\frac{1}{2}$ oz. 10c., oz. 15c., 2 oz. 25c., $\frac{1}{4}$ lb. 40c., 1b. $\$ 1.25$

\section{MARTYNIA,}

The seed pods when young and tender make excellent pickles, but should be gathered when less than half grown. $\mathrm{Pkt} . \frac{1}{2} \mathrm{Oz}$. 20c., oz. 35c., 2 oz. 60 c., 孝 lb. $\$ 1.00$. 

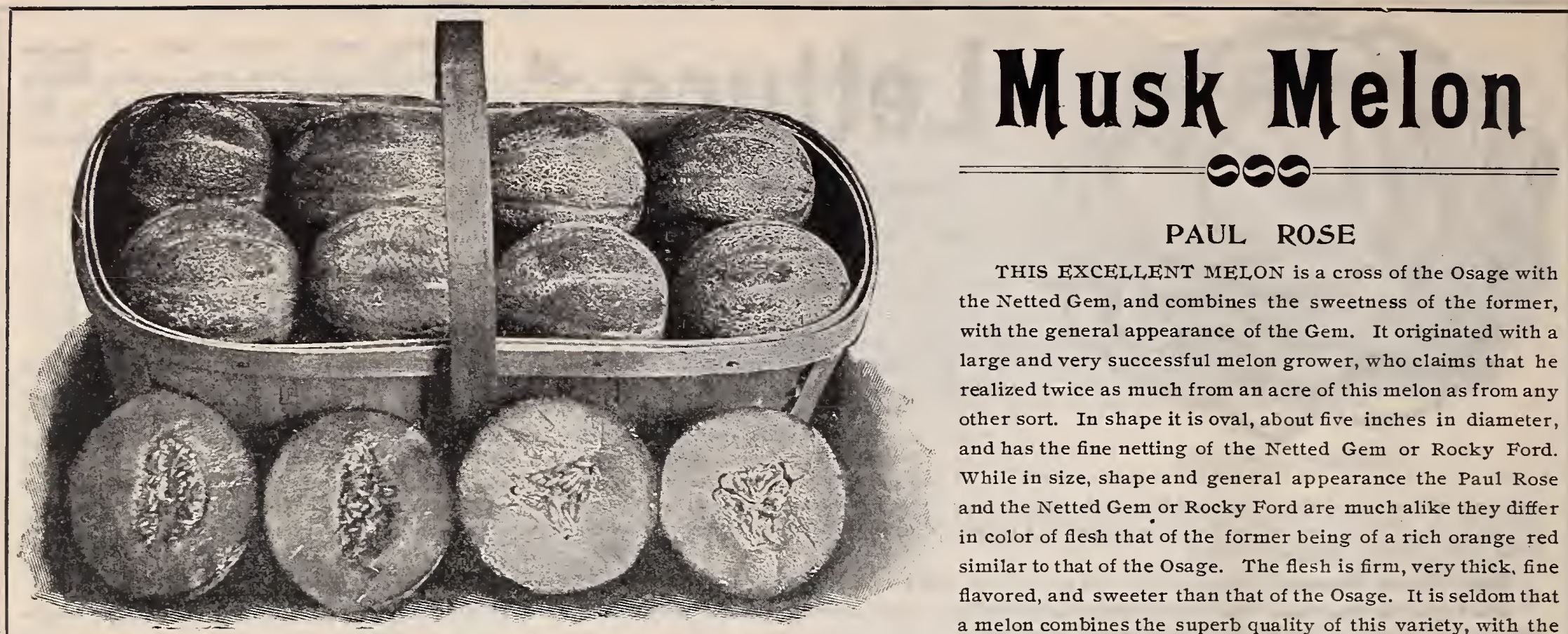

PAUL ROSE

THIS EXCELIENT MELON is a cross of the Osage with the Netted Gem, and combines the sweetness of the former, with the general appearance of the Gem. It originated with a large and very successful melon grower, who claims that he realized twice as much from an acre of this melon as from any other sort. In shape it is oval, about five inches in diameter, and has the fine netting of the Netted Gem or Rocky Ford. While in size, shape and general appearance the Paul Rose and the Netted Gem or Rocky Ford a re much alike they differ in color of flesh that of the former being of a rich orange red similar to that of the Osage. The flesh is firm, very thick, fine flavored, and sweeter than that of the Osage. It is seldom that a melon combines the superb quality of this variety, with the necessary features for shipping. The Paul Rose, however, is especially adapted for shipping, remaining in good condition longer than most other varieties.

Price. Pkt. 5c., oz. 15c., 2 oz. 25c., $\frac{1}{4}$ 1b. 35c., 1b. $\$ 1.25$.

\section{EMERALD GEM $\frac{\text { UNIFORMLY GOOD }}{\rho \odot \odot}$}

Notwithstanding the excellence of the many new varieties, this ranks with them in delicious and peculiar flavor, and we are somewhat in doubt if any other variety equals it in certainty and uniformity of excellence. The flesh is thicker than that of any other melon of equal size, and ripens clear to the thin rind. It is very sweet and melting and of an especially pleasing flavor; in color a beautiful salmon. The melons are small-about the same size as the Netted Gem. The skin, while ribbed, is generally smooth, sometimes slightly netted and in color deep green. Its general appearance is not attractive, which undoubtedly prevents it from being grown for market as extensively as it otherwise would, but in sections where its excellence and
uniformity have been recognized it is largely used. The vine is of vigorous healthy growth, productive, and matures fruit extremely early.

Price. Pkt. 5c., oz 15c., 2 Oz. 25c., I/4 1b. 35c., 1b. $\$ 1.25$.

\section{COSMOPOLITAN THE MOST BEAUTIFUL}

The introducers said of this at its introduction that it was truly cosmopolitan in character, combining the firm sweet flesh of the French Cantaloupe with the delicious flavor of the American Musk Melon. It is the most beautiful of the green fleshed varieties; of medium size, nearly round, slightly oval, without ribs. Color light green but becoming covered when ripe with dense, silver-grey netting. Flesh green, firm, sweet, and of fine flavor. Vine hardy and vary productive. The very handsome a ppearance of this melon, combined with its excellent quality and great productiveness, should make it popular with all those engaged in growing melons for market; while its quality well entitles it to a place in the home garden.

Price. Pkt. 5c., oz. Ioc., 2 oz. 15c., 1/41b. 25c., 1b. 9oc.
Prolific Nutmeg. Fruit of medium size, round, slightly flattened, ribbed and heavily netted. Flesh pale-green, thick, and well flavored.

Surprise. A popular variety, although of but medium quality. Fruit slightly oval and of medium size; slightly ribbed, seldom netted. Skin cream yellow, flesh deep salmon, vine hardy and productive, and matures fruit early.

Extra Early Hackensack. Fruit of good size, round, flattened, heavily ribbed and netted. Flesh green, thick, and of fine flavor.

Osage, or Improved Miller's Cream. Although much larger the fruit resembles the Emerald Gem, having the same dark green skin with lighter

The preceding seven varieties at uniform prices. bands between the ribs. Flesh is very thick and firm, of fine quality; color orange. Keeps well and is a favorite with shippers.

improved Orange Christiana. A favorite in the Boston market. Known also as Black Japan. Fruit above medium size, round, generally smooth; dark green. Flesh yellow, very thick, and of finest flavor and quality.

Montreal Market. One of the largest of this type. Fruit round, slightly flattened, with broad heavy ribs and heavily netted. Flesh light green, very thick, and when melon is well grown of finest flavor and quality.

Bay View. One of the largest, most productive and best flavored melons grown. Shape oblong, flesh green.

Pkt. 5c., oz. 10c., 2 oz. 15c., $\frac{1}{4}$ lb. 25c., lb. 85 c.

\section{A Very Popular Variety - NETTED GEM, or ROCKY FORD}

THIS EXCELLENT VARIETY was introduced as the Netted Gem in I88r and has always been a popular melon. It has, however, attained greater popularity under the name Rocky Ford. It has been very extensively grown in Colorado, there having been shipped from there in season of 1900,780 cars, representing the product of 2,500 acres, and doubtless the acreage has since been increased. It acquired its later name from the town Rocky Ford, which led in the production and shipping of this variety. It is claimed by many to be the finest small-fruited melon in cultivation. Fruits are of uniform size, nearly globular, sometimes slightly ova1, always finely netted, and of a grayish golden yellow when ripe. The flesh is light green, ripens to the rind, melting, and of fine flavor. The vine is of strong, healthy growth, very productive, and fruits ripen early. It is undoubtedly one of the best for shipping, and its ruiformly excellent quality makes it equally desirable for the home garden. Price. Pkt. 5c., oz. I5C., 2 oz.25c., 1/4 1b. 35c., 1b. \$1.25.

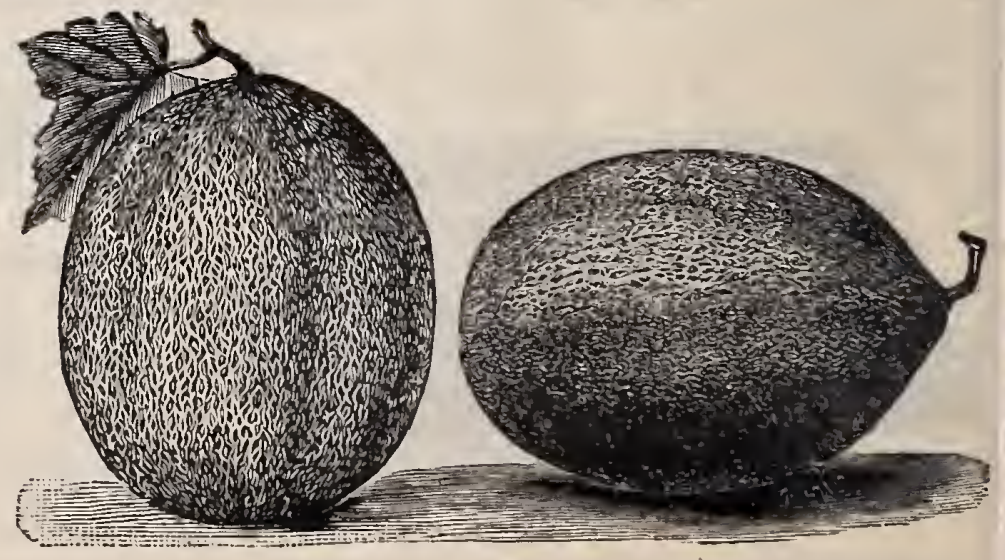




\section{+ Water Melon : 9090}

Sweetheart. One of the best for shipping. This melon introduced several years ago, has become very popular with shippers in the south. It not only excels as a shipping variety, but is of more than average good quality. Fruit is large, oval, and very heavy. It is uniformly mottled light and very light green, and has a very thin but firm rind. The flesh is bright red, firm and solid, but very tender, melting and sweet. The fruit retains its good quality for a long time after ripening. The vine is rigorous and productive and ripens fruit early. Pkt. 5c., oz. IOC., 2 Oz. 15c., 1/4 1b. 25 c., 1b. 75 c.

Kleckley's Sweet, or Monte Cristo. The Sweetest of All. Since its introduction until now this has been known as the "sweetest of all" watermelons. The fruit is large, oblong, averaging eighteen to twenty inches in length by ten to twelve inches in diameter, with a dark green skin and having a very thin brittle rind. The beautiful bright scarlet flesh with its very large solid heart, the white seeds being placed close to the rind, is crisp, sugary and melting to a remarkable degree, and is entirely free from any stringiness. Although its thin brittle rind unfits it for shipping to distant markets, its uniformly superior quality guarantees its ready sale in any markets to which it can besent in good condition, while for the home garden but few if any equal it. Pkt. 5c., oz. Ioc., 2 oz. I5c., 1/4 1b. 25 c., 1b. 90.

Cole's Early. A small but very early variety, of fine quality, and sure to mature in any latitude where melons can be grown. Rind thin, skin green with white stripes, flesh dark red. Pkt. 5c., oz. roc., 2 oz. I5c., 1/4 1b. $25 \mathrm{c}$, , 1b. $75 \mathrm{c}$.

Phinney's Early. A standard early variety; of medium size, ova1; marbled with two shades of green; rind thin; flesh pink, sweet, tender and crisp. $\mathrm{Pkt}$ $5 \mathrm{c}$, oz. 10c., 2 Oz. I5C., I/4 1b. $25 \mathrm{c}$., 1b. $75 \mathrm{c}$.

\section{FORDHOOK EARLY The Earliest Large-Fruited Melon.}

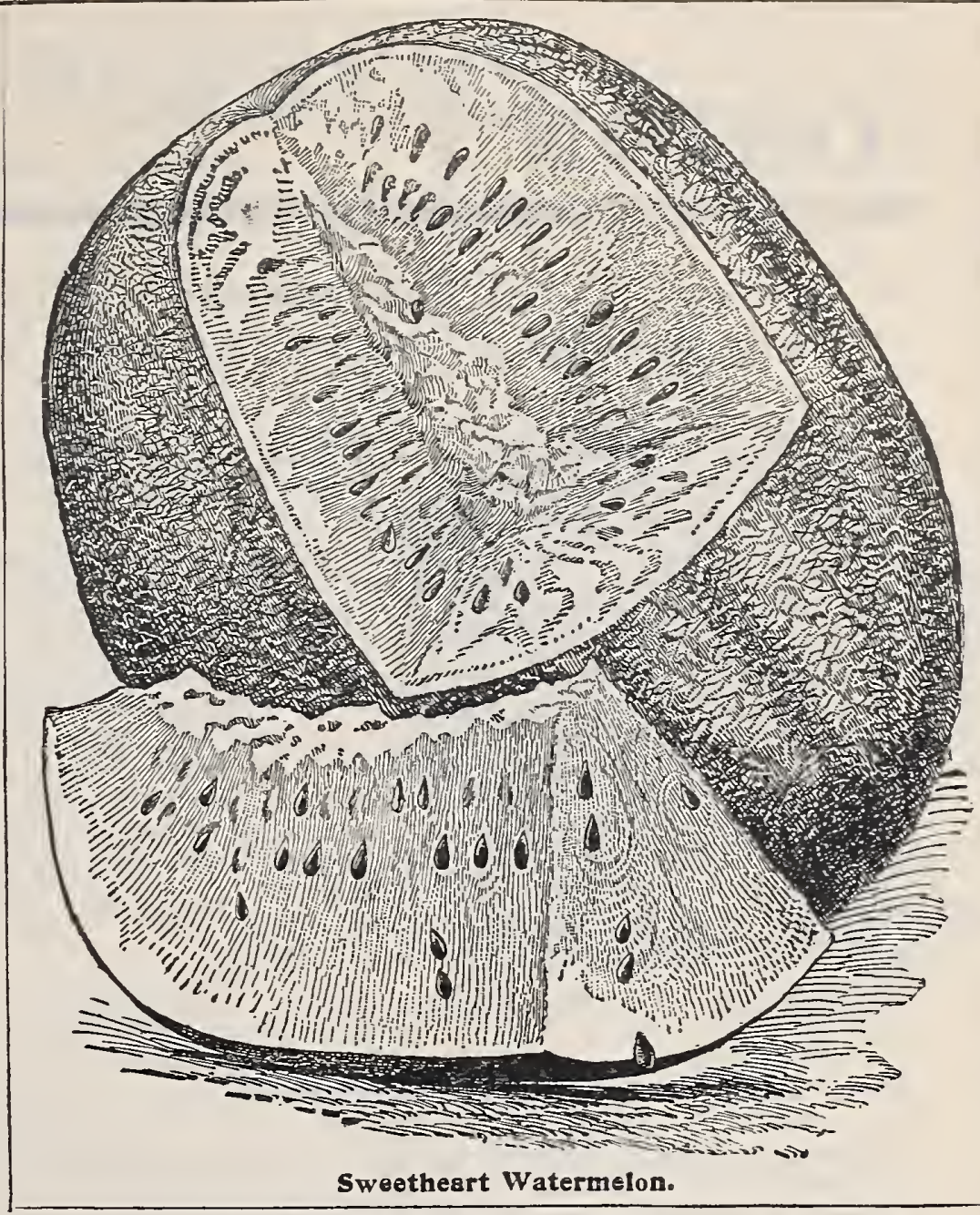

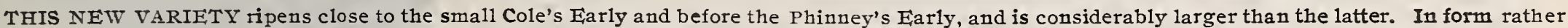

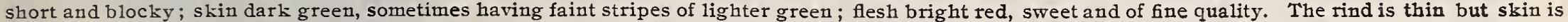
tough, making it an excellent variety for shipping.

Price. Pkt. 5c., Oz. I5c., 2 oz. 25 c., I/4 1b. 35c., 1b. $\$ 1.25$

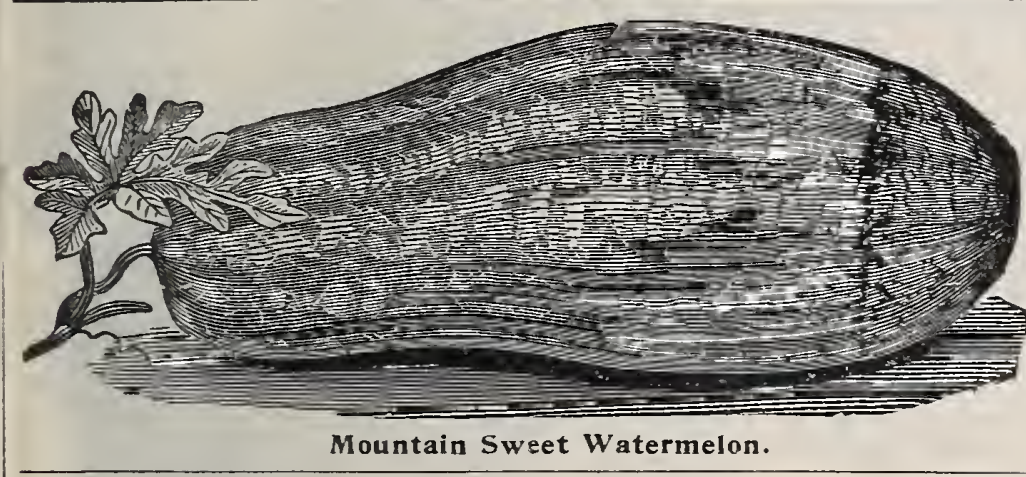

Citron. For preserving only. Pkt. 5c., oz. roc., 2 oz. $15 \mathrm{c}, 1 / 41 \mathrm{~b} .25 \mathrm{c}, 1 \mathrm{~b}$
Peerless, or Ice Cream. Fruitoblong, of medium size; skin dark green, flesh scarlet, very sweet. Pkt. 5c., oz. 10c., 2 oz. 15c., 1/4 1b. 25 c., 1b. 75c.

Mountain Sweet. An old and popular variety, especially in New England. Rind green and rather thick; flesh scarlet, solid, very sweet, and of excellen quality. Pkt. 5c., oz. Ioc., 2 oz. I5c., I/4 Ib. 25c., 1b. 75 c.

Kolb's Gem. Fruit round or slightly oval and very large. Skin marked with irregular stripes of dark and light green; flesh bright red and rather coarse, rind very tough and hard, making it especially desirable for shipping; and it is largely grown in the south for that purpose. Pkt. 5c., oz. Ioc., 2 oz. I5c., I/4 1b. 25c., 1b. $75 \mathrm{c}$

Cuban Queen. Fruit large, globular or oval; skin beautifully striped light and dark green; rind thin but stands shipping well; flesh bright red, very solid, crisp and sweet. Pkt. 5c., oz. roc., 2 oz. I5c., $1 / 4$ ib. 25 c., 1b. 75 c.

Eight Varieties Mixed. Pkt. $5 c$.

\section{A NEW WATERMELON - Halbert Honey} THE BEST FOR THE HOME GARDEN.

The new Halbert Honey is a rival of the Kleckley Sweet in sweetness, is fully equal in flavor, more regular in form and much more productive. The melons average eighteen to twenty inches in length by six to eight inches in diameter and a re blunt at both stem and blossom end. In color they are deep glossy green. The flesh is a beautiful crimson-lake and extends to with in less than half an inch of the rind; is entirely free from any fibrous substance, and is rich, sugary and melting, with a delicious flavor peculiar to itself. The vine is hardy and wonderfully productive and matures its fruit sufficiently early to permit it being grown throughout the Northern States, where frost does not appear before September Ist. The thin rind, like the flesh, is so tender that it will not stand shipping to any great distance, but for the nearby market and the home garden no other variety in all respects equals it.

Price. Pkt. roc., 0z. 20c., $207.30 \mathrm{c}$, I// 1b. 50c., 1b. \$1.65

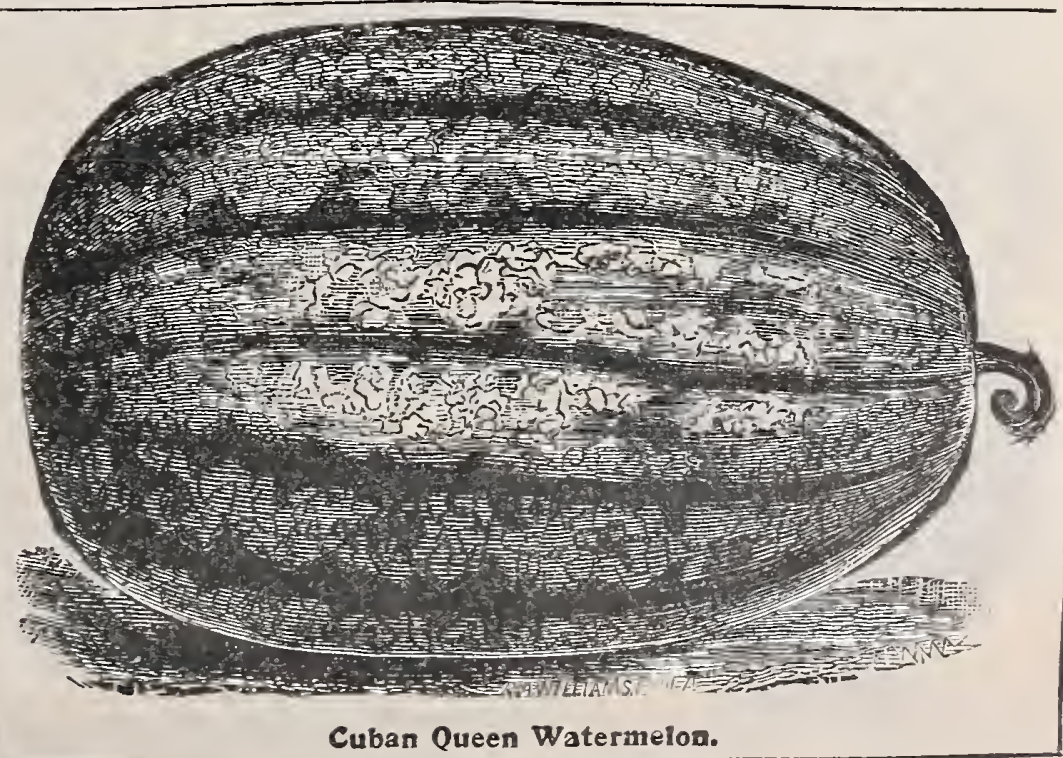




\section{ONION

\section{The Heaviest - The Best Keepers * The Handsomest The Quickest to Sell The Money Makers.}

TO NO other branch of our business do we give more attention than to the growvarieties which are globe-shaped, personally selecting our stock in the field, and have to offer THE BEST THAT GROWS.

It must be obvious to all that a globe-shaped onion occupies no more room when growing than a flat one of equal diameter, and equally obvious that the first would be the heavier when mature; therefore the yield per acre must be much larger. The globe-shaped onions all have thicker outer skins than the flat, bear handling better, and consequently are much better keepers. They are also of more attractive form, selling easier and usually at higher prices. The globe-shaped varieties are the ones to grow for profit. To grow them the right seed is necessary.

That there is a vast difference between the results obtained from the use of eastern and western grown stocks all careful and candid observers will admit, and, while we are not prepared to say here that seed which will produce crops of uniformly globe-shaped onions cannot be grown in California, we can truthfully say, after years of careful nhservation, that we have yet to see a crop grown from western seed that could at all compare in this respect, nor for that matter in any other, with the many grown from our Selected Eastern Grown Seed.

Yellow Globe Danvers. Eastern Grown. This variety is more largely grown than any other, and in Massachusetts the demand for seed of it by far exceeds that for all other varieties combined. The strain which we offer is much different from the old type, that being a flat bottomed onion while the upper half somewhat resembled this. This more nearly resembles the Southport type, is of true spherical form, only differing from the Southport in that it is a very little flattened at the top and bottom. We have for sereral years been selecting in the field such bulbs as were strictly true to the type and have developed a very superior strain. Our onions when selected for seed and spread upon the storage floors excite the admiration of all who see them. As we have said above, this type is the one to grow for profit.

Southport Yellow Globe. Very similar to our Yellow Globe Danvers, a little more elongated and possibly a little later in maturing but not differing nearly as much in that respect as commonly supposed.

Southport Red Globe. Identical in form with the preceding. The handsomest of all onions and is being grown to greater extent at present than ever before.

The preceding varieties each, pkt. 5 c., $\frac{1}{2}$ oz. 12c., oz. 20 c., 2 oz. 35 c., $\frac{1}{4} 1$ b. 50 c., lb. $\$ 1.50$.

Southport White Globe. Of true globe shape. Not largely grown but brings the highest prices in market of any variety. A much better keeper than any other white variety. Pkt. 5c., $\frac{1}{2}$ oz. 15c., oz. 25c., 2 oz. 40c., $\frac{1}{3} 1 \mathrm{~b} .75 \mathrm{c} ., 1 \mathrm{~b} . \$ 2.60$.

Extra Early Red Flat. The earliest red variety. Pkt. 5c., $\frac{1}{2}$ oz. 10c., oz., 15c., 2 oz. 25 c., $\frac{1}{4} 1$ b. 35 c., 1b. $\$ 1.15$

Early Yellow Cracker. The earliest yellow variety; very flat, mild; needs care in handling to insure keeping; rery desirable for home markets. Pkt. 5c., $\frac{1}{2} \mathrm{oz} .12 \mathrm{c}$., oz. 20c., 2 oz. 35c., $\frac{1}{4}$ lb. 50c., 1b. $\$ 1.50$.

Early Red Globe Danvers. While not all of a crop of this has as yet been as per-

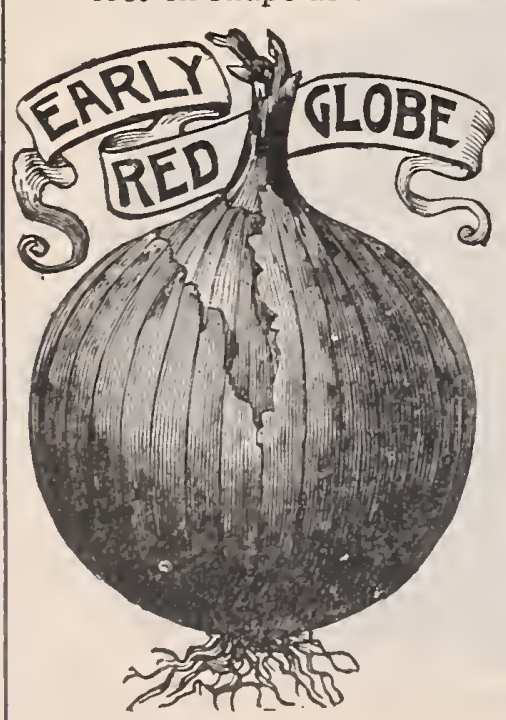
what approaching it. It might perhaps be better described as a very thick onion rather than globe-shaped. It is nearly as early as the Early Red Flat, has a firm skin, is of fair size and good color. It is remarkably free from the tendency to produce stiff necks or scallions. It is growing in favor, to which its earliness and other good qualities well entitle it. Pkt. 5c., $\frac{1}{2}$ oz. 12c., oz. 20c., 2 oz. 35c., $\frac{1}{4} 1$ b. 50c., 1b. $\$ 1.50$.

White Portugal or Silver Skin. A white, thin skinned variety, of especially mild flavor and very tender. It grows to a good size and is early. Desirable for the market gardener for early use and for the home garden because of its tenderness and mild flavor. Pkt. 5c., $\frac{1}{2}$ oz. 15c., oz. 25c., 2 oz, 40c., $\frac{1}{4} 1 \mathrm{~b}$. $75 \mathrm{c} ., 1 \mathrm{~b} . \$ 2.50$

Yellow Globe Danvers. Best Western Stock. Offered by many leading seedsmen as their best.

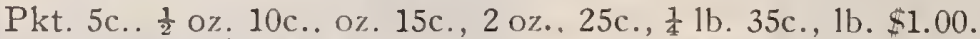

Red Wethersfield. A variety which has been extensively grown but which in most of the oniongrowing districts of New England is now but little used, and while the demand for red onions seems to be increasing, that for seed is largely for the globe-shaped varieties, planters having learned the superiority of this class. We offer, however, a choice strain of seed grown from selected bulbs. Pkt. 5c., t oz. 10c., Oz. 15c., 2 oz. 25c., $\frac{1}{4}$ lb. 35c., 1b. \$1.00.

Prize Taker. One of the largest varieties in cultivation. Skin thin, light straw color, flesh pure white and is extremely mild and sweet flarored. It is quite sure to bottom, but is late and is not a good keeper. It is largely used for sowing early in the hotbed for transplanting, and for that purpose is an excellent sort. Pkt. 5c., $\frac{1}{2}$ oz. 10c., Oz. 20c., 2 oz., 35c., 1 b. 50c., 1b. $\$ 1.50$. 


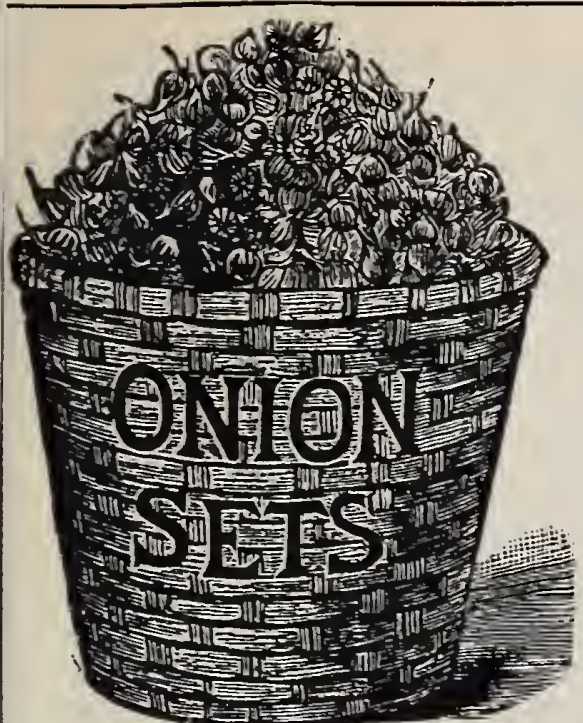

\section{Onion Sets.}

Prices Variable.

If by mail add to cents per quart to price.

White. Qt. 20c., $\frac{1}{2} \mathrm{pk} .65 \mathrm{c}$, pk. $\$ 1.25$.

Yellow. Qt. 20c., $\frac{1}{2}$ pk. 65c., pk. $\$ 1.25$.

Top or Button. These are the best for the home garden, especially for growing to full sized matured onions. The sets are obtained by planting large or matured onions which bear the sets at the top of the seed stalk.

We have been unable to secure these for many years and consider ourselves fortunate in being able now to offer them.

Qt. 25c., 考 pk. 75c., pk. $\$ 1.35$.

Potato Onions. Qt. 15c., $\frac{1}{2}$ pk. 50c., pk. 90c.

Shallots. Qt. 20c., 考 pk. 65c., pk. $\$ 1.25$.

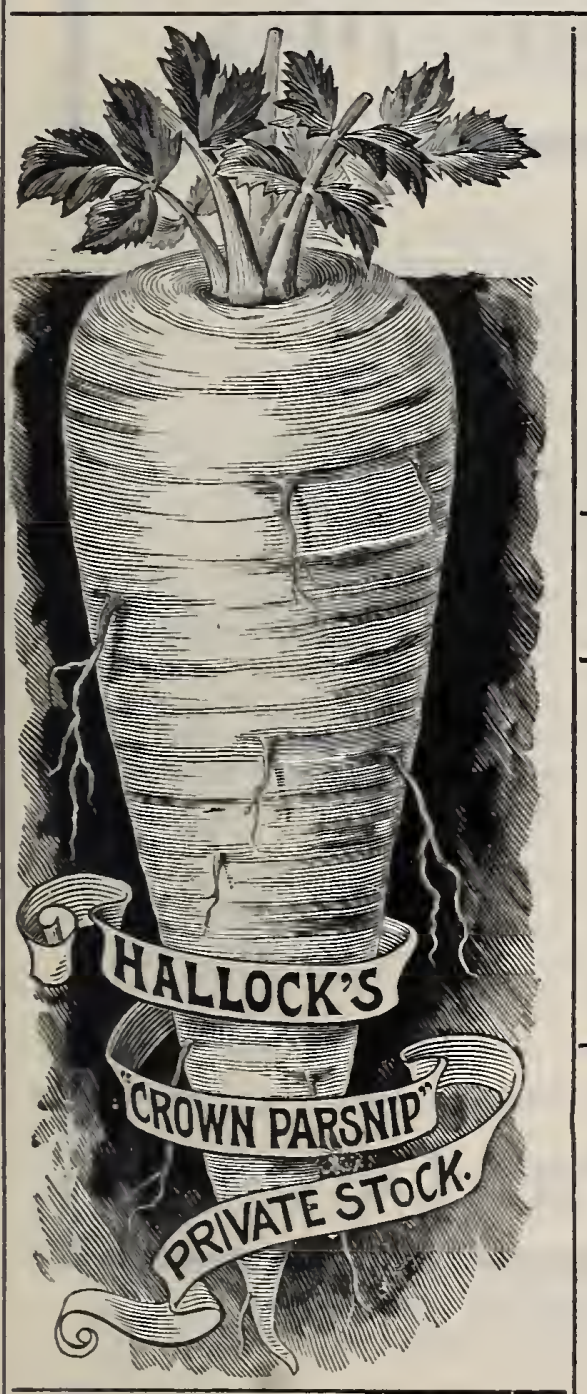

Arlington Long Smooth.

A selected strain; roots extra on shallower soils. and which cannot be surpassed.
PEPPERS.

Large Bell. Large, bell - shaped, th i c $\mathrm{k}$ gent than some other sorts. Good for filling.

Sweet Mountain. Fruit very large, often eight inches long by two in diameter. Flesh thick, sweet and mild.

Ruby King. The handsomest of the large sorts, mild and

Squash or Tomato Shaped. Fruit flat or tomato shaped, and somewhat ribbed, flesh thick and slightly more pungent than other large sorts, early and sure to mature.

Cayenne. Best for sea

soning pickles; very hot.

Red Chili. Used for

making pepper sauce.

Pods bright red, slen-

der, about two inches

Requires a long season;
seed should be sown

early in hot bed.

Each of above, pkt. $5 \mathrm{c}$

$\frac{1}{2}$ Oz. $15 \mathrm{c}_{1}, \mathrm{Oz}, 25 \mathrm{c}$

oz. $40 \mathrm{c} ., \frac{1}{2} \mathrm{lb} .75 \mathrm{c}$.
Coral Gem Bouquet.

Coral Gem Bouquet.

sorts. Its small red pods are so thickly set

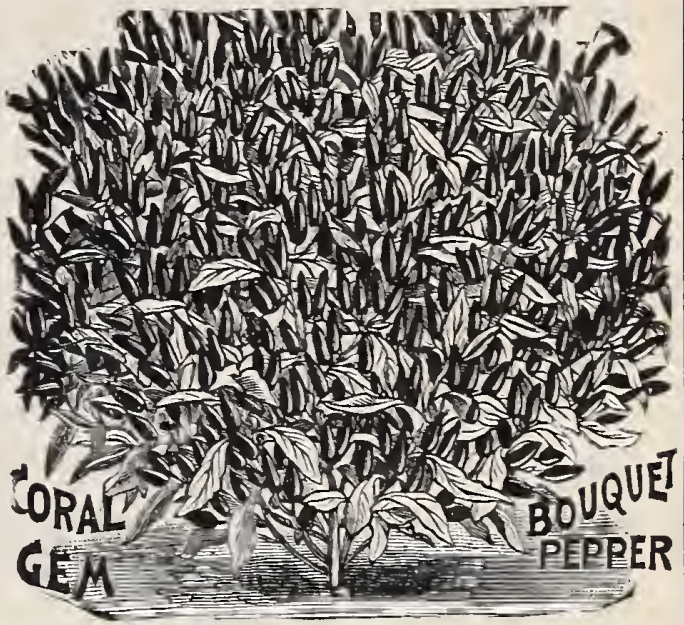

ance of a bouquet. Very ornamental, as well as useful.

Pkt. 10c., $\frac{1}{2}$ oz. 20c., oz. 40c.

long; desirable for deep mellow soil.

Hollow Crown. Roots shorter than the preceding; succeeds where that would not, that is

Of both rarieties we have to offer choice strains of seed which we have for many years sold Each, pkt. 5c., oz. 10c., 2 ozs. 15c., 表 lb. 20c., 1b. 50c.

Small Sugar. The popular variety in New England for pies;

Large Cheese or Kentucky Field. Shape flat, skin of a rich cream color when ripe, flesh tender and of fine quality. Pkt. 5c., oz. 10c., 2 ozs. 15c., $\frac{1}{4} 1 \mathrm{~b} .25 \mathrm{c} .$, lb. $75 \mathrm{c}$.

Mammoth Tours. One of the largest in cultivation; good for feeding stock. Pkt. 5c., oz. 10c.. 2 ozs. 15c., $\frac{1}{4}$ lb. 25 c., 1b. 75 c.

Connecticut Field. The standard variety for feeding stock. Pkt. 5c., 1 lb. 15c., 1b. 50c.

\section{PEAS. Smooth Varieties.} Nearly the whole crop can be gathered at one picking. Vines grow about $2 \frac{1}{2}$ feet in height, bearing abundantly pods which, although small, are always well filled. Peas are small, bluish green.

$$
\frac{1}{2} \text { pt. 10c.; pt. 15c.; qt. 25c.; } 2 \text { qts. 40c.; } \frac{1}{2} \text { pk. 75c.; pk. \$1.25.; bush. } \$ 4.50 \text {. }
$$

Ross Bros.' Best Extra Early. So nearly identical are all of the first early smooth white peas offered under a multitude of names, that in view of the great decrease in demand for such peas, we no longer consider it necessary to offer but one variety. In offering this stock under this name, we are confident that it is equal to any of this type offered elsewhere, regardless of what name others may choose to attach to what they offer. Others may have as good, none have better. IVe do not claim that it differs greatly in type, if at all, from others of this class, but do claim that by years of careful selection by one of the most reliable growers, there has been some improvement in size of peas and pod, and uniformity of ripening, on some stocks of Daniel names.

$$
\frac{1}{2} \text { pt. 10c.; pt. 15c.; qt. 25c.; } 2 \text { qts. } 40 \text { c.; } \frac{1}{2} \text { pk. } 75 \text { c.; pk. } \$ 1.25 ; \text { bush. } \$ 4.50 \text {. }
$$

Note that we ofier Peas by the Definite 0uantity 


\section{THE GRADUS PEA}

(2)

the varieties of vegetable that have been introduced for many years nothing has sprung into popularity deserving of it. Both the pods and peas are nearly as large as the Telephone, and it ripens with or very closely to the Alaska and other extra earlies. Its quality is of the best, nearly equal to the Champion of England, which has always in this respect been the standard with which all varieties have been compared. That it will eventually supplant the small early varieties is very probable if not certain. While the great value of it has, as yet, been apparent to only comparatively a few of the many who cultivate peas, the demand for seed has been far in excess of the supply, and when all have recognized its merit will probably be greater than it has ever been for any other variety. In its habit of growth t!ie vine is strong and vigorous, about two and one-half feet in height, foliage large, closely resembling the Telephone in general appearance, although much dwarfer. The pods are nearly as large as those of that variety and are well filled with peas of enormous size, which are ready for the table so soon after the Alaska that the difference in time is harly worth noting, their quality, however, being so superior that it can hardly be compared with that of the Alaska. The combination of earliness, large size and superior quality places it far in advance of any other. While great productiveness is generally claimed for it, reports regarding this are somewhat conflicting. Our own observation has led us to the conclusion that in order to have the vine productive the soil must be in a richer condition than is generally considered necessary for growing peas, and that if it is will be found to be a fairly productive variety. Owing to the very high price at which seed of the Gradus has thus far sold, growers have only retained barely enough for stock seed for growing contract orders, so that in no year since its introduction have they been able to accumulate a surplus. Unfortunately the conditions for securing a crop last season were worse than the previous two unfavorable ones, so that there is less seed in the hands of the dealers this season than for two years. Those who wish to secure seed must order early. The variety called Prosperity is identical with this, and for a continuation of that name there seems to be no good reason. $\frac{1}{2}$ pt. $15 \mathrm{c}$., pt. 30c,, qt. 50c., 2 qts. 90 c., $\frac{1}{2}$ pk. $\$ 1.50$, pk. $\$ 2.75$.

\section{GREGORY'S EARLY SURPRISE PEA}

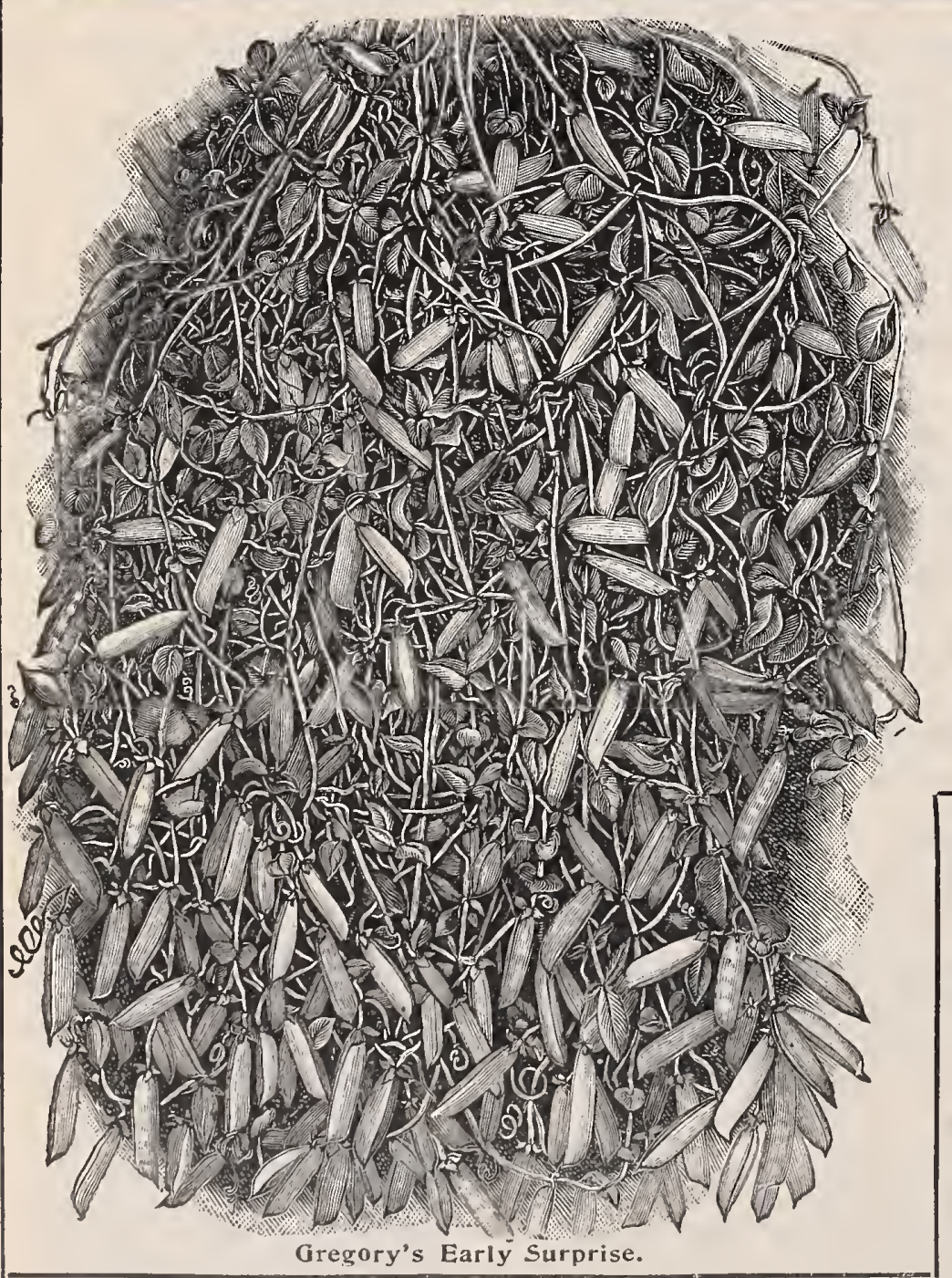

CHIS pea was introduced by the veteran seedsmen, Jas. J. H. 6. Gregory \& Son, who at the time of its introduction said of it :1 "It is the very earliest of the Wrinkled varieties, - the Station, Compared with the early hard sorts it will be found to be decidedly earlier than many of them, including the well-known Alpha and Maud S., while it is as early as the very earliest of them. Vines grow 24 inches high and need no bushing; pods well filled, containing six or seven peas; not as large as the American Wonder, but is a far better cropper and ready for the markct days before it.

"Gregory's Surprise is one of Mr. Horsford's creations, he having obtained it by crossing 'Earliest of All' on the 'A merican Wonder,' and the result is a wrinkled pea as early as the 'Earliest of All' with the quality of the 'Wonder.' If it has the hardiness of its parent, 'Earliest of All,' the knell of the early class of hard peas has struck; for the public well know that they are inferior in quality, and will cease buying them as soon as they can find a wrinkled pea in the market". Had it not been that the Gradus was introduced at about the same time as the Surprise this would, undoubtedly, have become very popular. As it is, it is a desirable variety on account of its earliness and superior quality, and will with the Gradus, without doubt, displace the hard early sorts, which to some extent they have already done. $\frac{1}{2}$ pt. $10 \mathrm{c}$., pt. $20 \mathrm{c}$., qt. $35 \mathrm{c} ., 2$ qts. 60 c., $\frac{1}{2}$ pk. $\$ 1.00$, pk. $\$ 1.75$.

\section{$\frac{N E W}{P E A}$ Admiral Dewey}

CLAIIIED BY THE INTRODUCERS TO BE THE

LARGEST PODDED PEA EVER OFFERED.

61 HIS variety is from one of the oldest firms of pea-growers in the country, whose description is as follows:-- "During the season of 1894 , while watching the growth of a small sample of a new and most desirable pea sent us from Carlisle, England, we found a few vines entirely different from the main crop, and entirely distinct from any pea we had ever seen. These few vines were carefully removed, and succeeding crops have shown them to be remarkbly uniform and distinct. This is without exception the largest podded pea of which we have any knowledge, and when to this is added the heavy cropping and highest quality, it can readily be seen that it stands at the head of its class. Height three and one-half vigorous, producing in abundance pods of largest size, frequently

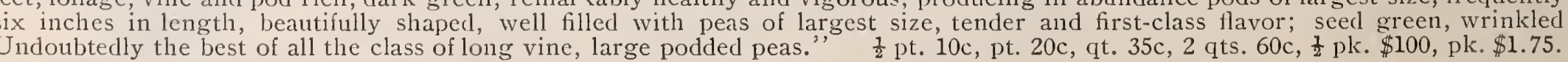




\section{PEAS 柰 $\begin{gathered}\text { Duart Extra } \\ \text { Early varietices. }\end{gathered}$}

but not equal to the Nott's Excelsior for the market garden. bush. $\$ 6.50$

Nott's Excelsior. This is similar to the American Wonder but superior in nearly all respects. The vine grows about 14 inches high, is of vigorous habit, exceptionally uniform in growth and wonderfully productive. The pods are larger than those of the Wonder and well filled. The peas are of fine flavor. $\frac{1}{2}$ pt. 10c., pt. 15c., qt. 30c., 2 qts. 55c., $\frac{1}{2}$ pk. $\$ 1.00$, pk. $\$ 1.90$, bush. $\$ 7.00$.

Premium Gem. A popular variety, growing about 15 inches high. Pods are a little larger than those of the IVonder, and though not generally so closely packed with peas are yet well filled. The peas are wrinkled, of good size and flavor. Considered by many to be superior to the Little Gem. $\frac{1}{3}$ pt. 10c., pt. 15c., qt. 30c., 2 qts. 50c., $\frac{1}{3}$ pk. 90c., pk. $\$ 1.60$, bush. $\$ 6.00$.

McLean's Little Gem. An old favorite and yet largely grown. Height about 18 inches. Pods are well filled. Peas of good size, green, wrinkled, and of excellent quality. A productive and desirable variety. A little later than the preceding varieties. $\frac{1}{3}$ pt. 10c., pt. 15c., qt. 30c., 2 qts. 50c., $\frac{1}{2}$ pk. 90c., pk. $\$ 1.60$, bush. $\$ 6.00$.

\section{Second Early, Medium and Late Sorts.}

McLean's Advancer. A green, wrinkled marrow of extra quality. The standard second early in .Boston market, and grown extensively everywhere. Height, $2 \frac{1}{2}$ feet. $\frac{1}{2}$ pt. 10c., pt. 15c., qt. $25 \mathrm{c}$., 2 qts. $45 \mathrm{c}$., $\frac{1}{2}$ pk. $75 \mathrm{c}$., pk. $\$ 1.35$, bush. $\$ 5.00$.

Hosford's Market Garden. A wrinkled variety; ripens closely to Advancer; of branching habit, very stocky. Peas medium size, of good quality. Height, 2 feet. $\frac{1}{2}$ pt. 10c., pt. 15c., qt. $25 \mathrm{c} ., 2$ qts. $45 \mathrm{c}$., $\frac{1}{2}$ pk. $75 \mathrm{c}$., pk. $\$ 1.35$, bush. $\$ 5.00$.

Bliss' Abundance. Similar in general appearance to the Hosford's

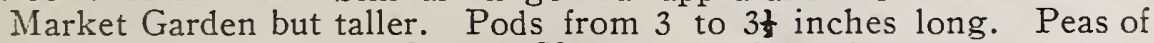
good size and excellent flavor. Very productive. $\frac{1}{2}$ pt. 10c., pt. 15c., qt. 25c., 2 qts. 40c., $\frac{1}{2}$ pk. 70c., pk. $\$ 1.25$, bush. $\$ 4.50$.

Heroine. A distinct and valuable variety. Foliage even and luxuriant, pods long, handsome and well filled with large peas of fine flavor. Remarkably true and fixed in its habit of growth. Height, $2 \frac{1}{2}$ feet. $\frac{1}{2}$ pt. 10c., pt. 15c., qt. 25c., 2 qts. 45c., $\frac{1}{2}$ pk. 75c., pk. \$1.35, bush. $\$ 5.00$.

Yorkshire Hero, or Dwarf Champion. An old wrinkled sort, peas large and of delicious flavor, vines of a robust branching habit. Notwithstanding the many excellent new varieties, this old favorite still continues to be in great demand. Height, $2 \frac{1}{2}$ feet. $\frac{1}{2}$ pt. 10c., pt. 15c., qt. 25 c., 2 qts. 40c., $\frac{1}{2}$ pk. 70c., pk. $\$ 1.25$, bush. $\$ 4.50$.

Shropshire Hero. A strong, robust grower and very prolific. Pods are long and handsome; remarkably well filled with large peas. We know of no other variety which will shell out so many peas from a given quantity of pods. The peas are of delicious flavor: One of the best of its class and should be more generally used. Height, about $2 \frac{1}{2}$ feet. $\frac{1}{2}$ pt. 10c., pt. 15c., qt. 25 c., 2 qts. 40 c., $\frac{1}{2}$ pk. 70c., pk. $\$ 1.25$, bush. $\$ 4.50$.

Improved Stratagem. An improvement on the old Stratagem, the tendency to sport being almost entirely removed. Vines are stocky, of vigorous habit and luxuriant foliage, and very productive. Height about $2 \frac{1}{2}$ feet. Pods and peas are of the largest size; quality unsurpassed. $\frac{1}{2}$ pt. $10 \mathrm{c}$, pt. $15 \mathrm{c}$., qt. $25 \mathrm{c} ., 2$ qts. $45 \mathrm{c}$., $\frac{1}{2}$ pk. $75 \mathrm{c} .$, pk. $\$ 1.35$, bush. $\$ 5.00$.

Everbearing. Vigorous and branching in habit of growth. Remains in bearing longer than most varieties. Pods medium in size. Peas are very large and of best quality. Height about $2 \frac{1}{2}$ feet. $\frac{1}{2}$ pt. 10c., pt. 15c., qt. 25c., 2 qts. 40c., $\frac{1}{2}$ pk. 70c., pk. $\$ 1.25$, bush. $\$ 4.50$.

Telephone. The most popular late variety with market gardeners. Vines large and vigorous, growing about 4 feet high. Foliage light colored and large. Pods large. Peas large and sweet. We offer a carefully selected stock. $\frac{1}{2}$ pt. 10c., pt. 15c., qt. 25c., 2 qts. 45 c., $\frac{1}{2}$ pk. $75 \mathrm{c}$., pk. $\$ 1.35$, bush. $\$ 5.00$.

Champion of England. The most popular late sort for the home garden. It is unsurpassed in richness and flavor by any of the newer varieties, if indeed equalled. Pods medium size. Peas of medium size and much shriveled. Vines fairly productive. Height, 4 to 5 feet. $\frac{1}{2}$ pt. 10c., pt. 15c., qt., 25c., 2 qts. 40c., 妾 pk., 70c., pk. $\$ 1.25$, bush. $\$ 4.50$.

Large Black=Eyed Marrowfat. A well-known variety, growing about five feet high. Pods large and well filled. Peas large, round and smooth, but much inferior in quality to the wrinkled sorts. $\frac{1}{2}$ pt. $6 \mathrm{c}$., pt. 10c., qt. 15c., 2 qts. 25c., $\frac{1}{2}$ pk. 45 c., pk. 75c., bush. $\$ 2.60$.

White Marrow. Similar to the preceding. Prices the same.

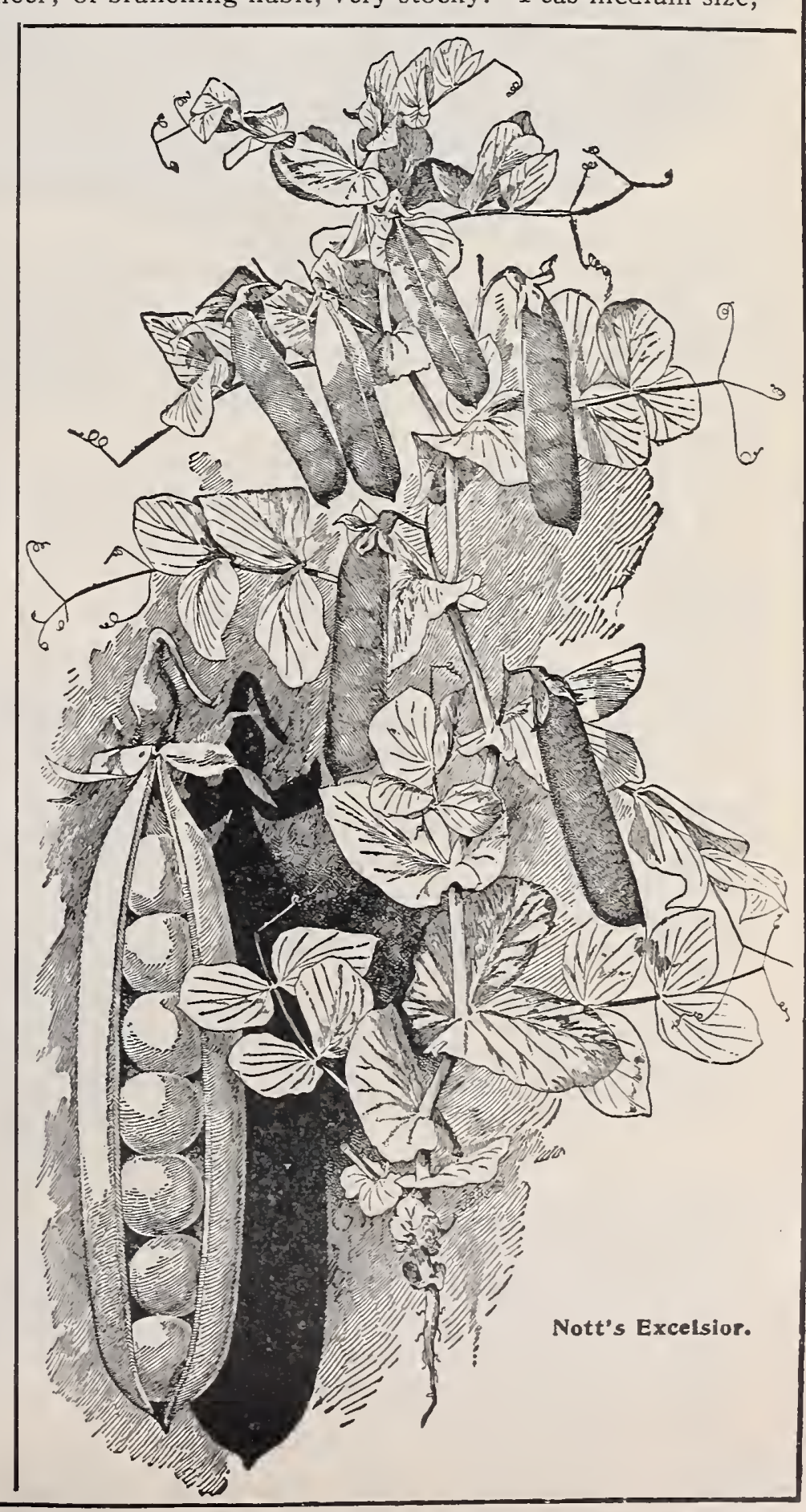




\section{POTATOES ciober latitien Gion seat.}

Progressive Farmers Change Seed Often BECAUSE IT PAYS.

THE stocks which we offer of the following varieties an experienced and reliable grower, and especially for seed. In 110 part of the country the past season could the crop of potatoes at all compare with that in Maine, and we feel sure that customers will be pleased with the appearance of our stocks. They are of good size, healthy, and true to name.

The varieties offered a re such as our experience and that of others has led us to think the most desired or desirable. That a change of seed is profitable and that it should be that which was grown as far north as possible, is a question almost beyond discussion, as it is almost universally admitted to be a fact. While we would lead none to infer that we thought there was no choice in the several early varieties which are in general somewhat similar, we wish to say that we believe that that which is often of more importance than the choice of a variety is in getting a change of seed and good seed-that is, of good size, healthy and pure. If we are correct in our sending orders after the season is well advanced when we are liable to be sold out of some varieties, what they mention a second choice or even a third with which we might fill the order, if out of the first with which we might fill the order, if out of the first
named sort. This of ten would save customers much annoyance, delay and disappointment and enable them to get seed much sooner than would otherwise be possible.

A11 varieties are put up in sacks, guaranteed to contain 165 pounds (a barre1), plainly marked with name of variety.

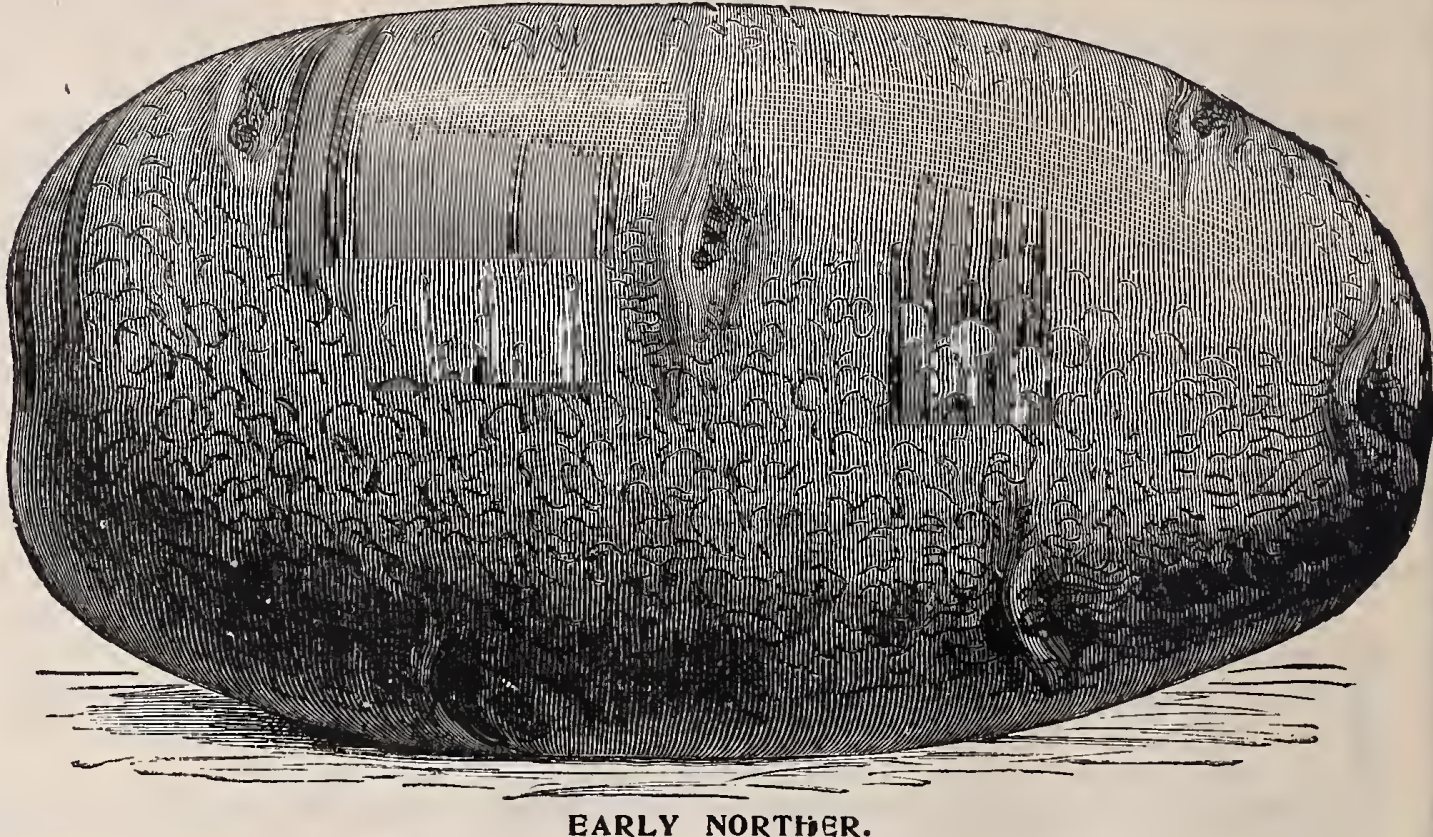

\section{EXTRA EARLY VARIETIES.}

Early Six Weeks. An extra early variety, of good quality, cooking well as soon as it attains marketable size. In size medium to large, color light red or rose, form round oblong, resembling the Ohio, and having the specks peculiar to the Ohio type. Keeps well. A good yielder. Our grower says of it: "I consider it the best all around potato ever introduced." Pk. 50c., bush. $\$ 1.65$, bbl. $\$ 4.00$.

Early Bovee. An extra early variety, claimed by the introducers to have outyielded all other sorts. Closely resembles the Queen in shape and color; of good size, producing but few small tubers, and of best quality. All reports seem to bear out the introducers' claim of large yieldings when planted on strong soil. Pk. 50c., bush. $\$ 1.65$, bbl. $\$ 4.00$.

Early Fortune. Recommended as one of the best for early market, as it stands shipping well. A heavy cropper. In form and color it resembles the Rose, in quality surpasses it. The introducer says: "It is the earliest potato in the world, and I have tested everything. The quality, shape and color is of the best. It is going to lead everything." $\mathrm{Pk} .50 \mathrm{c}$, bush. $\$ 1.65$, bbl. $\$ 4.00$.

Early Harvest. An early white skinned variety of finest quality. A vigorous grower and great yielder. Said to bear shipping better in hot weather than most kinds. Pk. 50c., bush. $\$ 1.65$, bbl. $\$ 4.00$.

Irish Cobbler. Our grower says of this: "The biggest potato and greatest producer I have ever known among the first early varieties. It will outyield all other early kinds and equal most of the later varieties. Quality the best. Color a pure creamy white. Shape round to oblong, smooth. Vines very stocky, foliage dark green. Withstands drouth remark-, ably well for an early variety. It is a wonderful potato.' Pk. 55c., bush. $\$ 1.85$, bbl. $\$ 4.50$.

\section{SECOND EARLY,}

Prolific Rose. This is neither a selection nor sport of the Early Rose but a NEW SEEDLING of merit. Vines more stocky. One of the heaviest yielders of all the Rose seedlings, A little later than the Early Rose. We therefore place it with the second earliers, although we note that our grower places it this year with the first early sorts, while in his list of last year it was with the second early. Shape similar to the Early Rose. Color the same, except that the seed end is nearer red. Pk. 50c., bush. $\$ 1.75$, bbl. $\$ 4.25$.
Early Norther. In general appearance closely resembles its parent, the Early Rose. Since its introduction it has always been a favorite. Matures about with the Rose, perhaps a little earlier, is equal to that in quality and more even and regular in form. Pk. 50c., bush. $\$ 1.65$, bbl. $\$ 4.00$.

Early Essex. A seedling of the Early Rose, which it resembles. The rine, however, is of a ranker growth and more productive. It originated years ago in Massachusetts, and while it has never been a leading sort it has been, in portions of New England, a popular one. Pk. 50c., bush. $\$ 1.75$, bbl. $\$ 4.25$.

New Queen. A very popular sort. Closely resembles the Beauty of Hebron but is considerably earlier. A heavy yielder and of excellent quality. Pk. 50c., bush. $\$ 1.65$, bbl. $\$ 4.00$.

Clark's No. 1. An old favorite and still one with some growers; claimed by them to be earlier and more productive than the Rose, to which it is similar in general appearance. Of excellent quality. Pk. 50c., bush. $\$ 1.65$, bbl. $\$ 4.00$.

Early Rose. This standard variety needs no description; it is sufficient to say that most new early varieties are compared with this in earliness and quality. $\mathrm{Pk} .45 \mathrm{c}$., bush. $\$ 1.50$, bbl. $\$ 3.75$.

Beauty of Hebron. One of the most popular varieties. Probably more extensively grown than any other. Productive, early and of the best quality. Pk. 45c., bush. $\$ 1.50$, bbl. $\$ 3.75$.

Early Thoroughbred. A productive early variety. Matures with the Rose, in appearance resembles it; produces but few small tubers; is of extra quality. Vines are exceptionally hardy. Pk. 50c., bush. $\$ 1.65$, bbl. $\$ 4.00$.
Aroostook Beauty. Our grower says of it: "The rankest grower of nearly fifty varieties. Large, very smooth, about the shape of Carman No. 1. Rose colored. Never has rotted with us. Has no weak spots; of fine quality; no blossoms. $\$ 1.85$, bb1. $\$ 4.50$.

Delaware. Succeeds well in all soils. A valuable combination of size, yield and quality. White throughout. Shape oblong. Pk. 50c., bush. $\$ 1.65$, bbl. $\$ 4.00$. 


\section{POTATOES - Continued}

\section{Late or Main-Crop Varieties.}

Cambridge Russet. In shape round to oblong, skin a beautiful light russet-brown covered with fine veinings. Uniform in size-none overgrown, few small ones. Never hollow. Of finest quality. Has a rich growth of vines which resist blight and drouth remarkably. Very productive. $\mathrm{Pk}$. 50c., bush. $\$ 1.65$, bbl. $\$ 4.00$.

Green Mountain. A white skinned variety of flat oval form, smooth and attractive. Ripens slowly and is a good keeper. Quality excellent when well grown. $\mathrm{Pk}$. 50c., bush. $\$ 1.65$, bbl. $\$ 4.00$.

Carman No. 1. Originated by Mr. Elbert S. Carman, late editor of the Rural New Yorker. Has been very popular wherever grown. Shape round or globular, skin white, shallow eyes; not inclined to rot in field or cellar; of excellent quality. Late in ripenirg, but yields large crops of fine marketable potatoes. $\mathrm{Pk}$. 50c., bush. $\$ 1.65$, bbl. $\$ 4.00$.

Carman No. 3. Also originated by Mr. Carman, who said of it: "First, it is the handsomest round white potato ever produced; second, it will

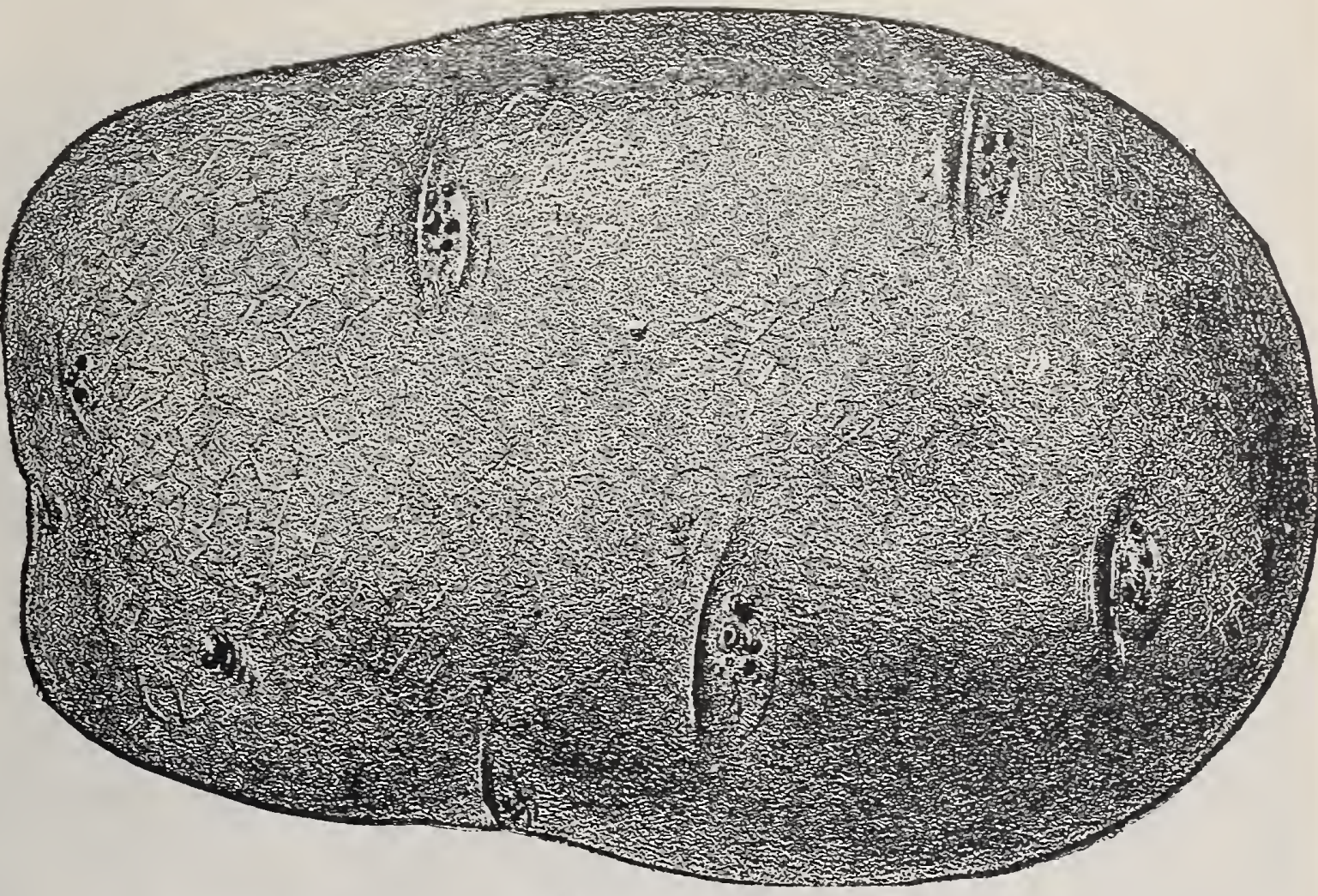
outyield any potato of its class; third,

CAMBRIDGE RUSSET.

practically every potato is of merchantable size; fourth, its table qualities are up to the highest standard." It has yielded over six hundred bushels per acre, and in one instance twenty-two acres have produced 7,600 bushels. The vines grow very large and vigorous, rich dark green in color, and are not troubled by blight or bugs as much as many varieties are. Pk. 50c., bush. \$1.65, bbl. $\$ 4.00$.

Rural New Yorker No. 2. This was one of the first varieties originated on the experimental grounds of the Rural New: Yorker. Very large and smooth, in form oblong inclined to round; skin and flesh white. Of superior quality. A large cropper. Pk. 50c., bush. $\$ 1.65$, bbl. $\$ 4.00$.

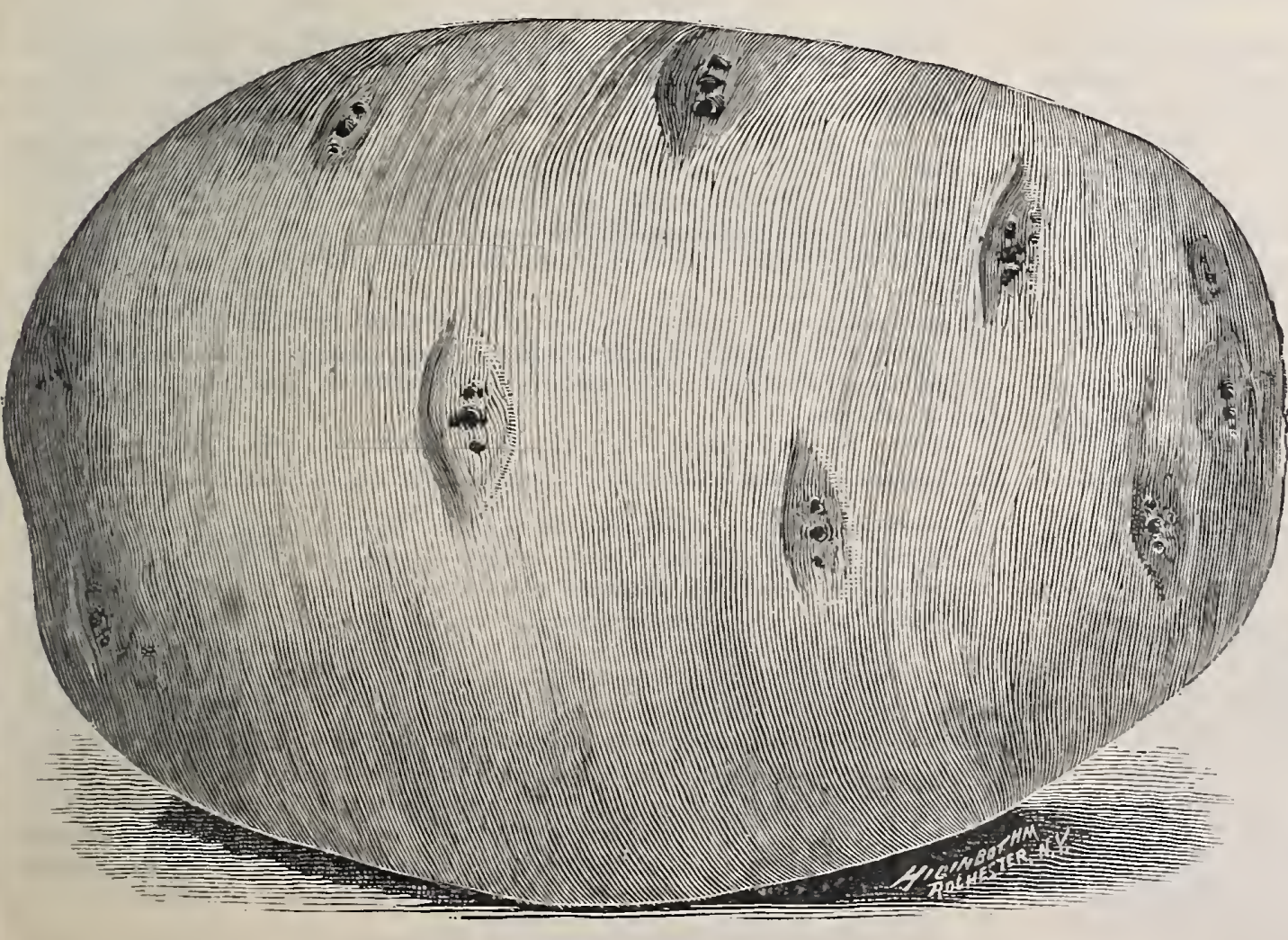

CARMAN NO. 3

Enormous. As its name implies, a very large variety and also an enormous yielder. Skin very white, smooth, eyes of medium depth. A large percentage of crop marketable, few small ones. Late. Vines healthy and very stout and tall. Like all very large varieties, is more liable to be unsymmetrical in form than average sorts. $\mathrm{Pk} .50 \mathrm{c}$, bush. $\$ 1.75$, bbl. $\$ 4.25$.

Maggie Murphy. Another larga variety though not equal in size to the preceding. Like that, nearly all are of marketable size. In shape flatish oblong, with shallow eyes. Oi fine quality. A desirable sort. Pk. 50c. bush. $\$ 1.75$, bbl. $\$ 4.25$.

White Elephant. Identical in appearance with the Beauty of Hebron but ten or twelve days later, of stronger growth and a heavier yielder. $\mathrm{Pk} .45 \mathrm{c}$., bush. $\$ 1.50$, bbl. $\$ 3.75$.

W liability of the potato market to fluctuate rese1ve the right to change without notice. shall not, however, advance prices unless solutely necessary, and if there should be any material falling off in prices we shall endeavor to meet them. 


\section{POTATO A Comparatively NEW Variety}

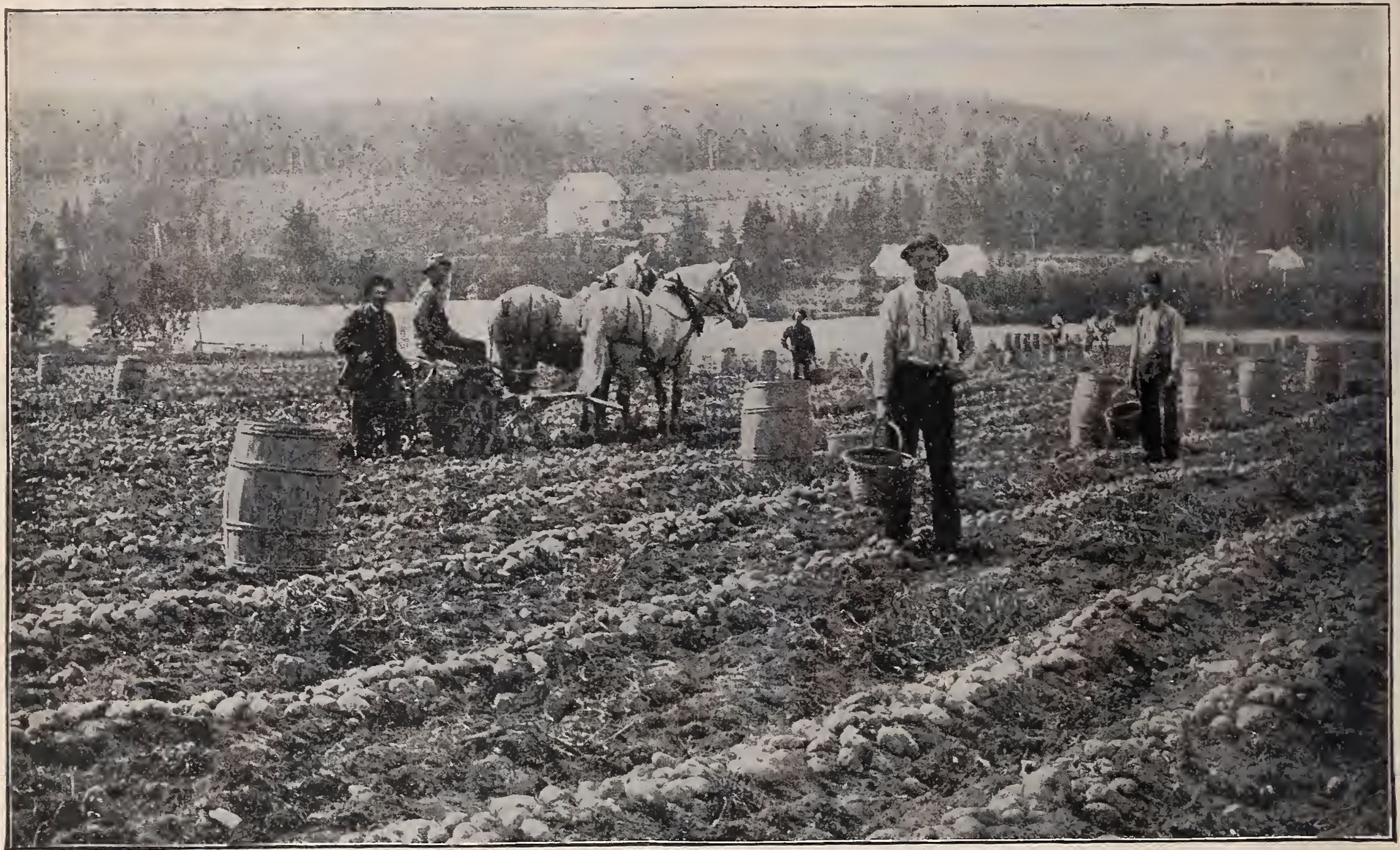

\section{Spaulding's Number Four}
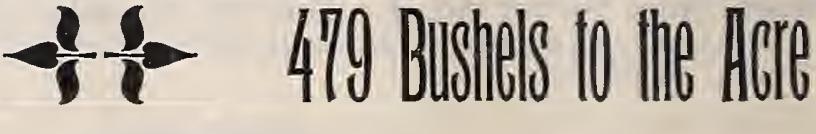

$W^{E}$ do not recollect of ever having had brought to our notice as favorable

a report of any potato as we have had of this. A reliable firm-growers of seed potatoes in Maine, say of it: "We planted this variety in Maine this year-the result has been astounding. None of the fields have yielded less than 280 bushels, a large number 400 bushels, and one field yielded 479 bushels to the acre. The potato is medium early, and was practically free from blight and rot. It yields well in all climates, and is in one section of Florida being planted almost exclusively. It is in all respects a wonderful potato." In color it resembles the Early Rose, perhaps a trifle lighter. In shape it is somewhat similar, but inclines to the oblong and is thicker. It is an attractive variety and of good quality.

Although largely used in the locality to which twe have referred, and in a more limited way in others, sufficiently, however, to determine its adaptability to a variety of climates, it has not been generally disseminated, and

is therefore comparatively a new variety to the public. We have fortunately secured a large stock of it, and at a price which enables us to offer it at the same price as those of the older varieties. We honestly believe that none who buy seed potatoes can afford to let this opportunity pass to secure new seed of such a superior variety as we feel sure this is. Aside from the merit of this variety, the seed we offer is remarkably uniform in size-not over large nor small, healthy and pure. The opportunity is therefore an exceptional one, not only because of the great productiveness of the variety, but also because of the uniformity of size, purity, and healthy condition of the tubers, and the low price at which we offer it. Even if not superior to the older varieties (and we firmly believe it is, especially in productiveness), these other features well entitle it to a trial by all who plant potatoes.

Price. Pk., 50c.; bush., $\$ 1.65 ;$ bbl., $\$ 4.00$; 1o bbls. or over, $\$ 3.75$ per bb1

We wish to again call attention to the advisability or necessity of a change of seed. The following article sent to us by the growers in Maine from whom we secured our supply of the Spaulding's Number Four, and some other varieties, is to the point and well worthy of consideration:

\section{Potatoes and Science}

\section{Change Your Seed}

There is a hint from a leading daily paper for sociologists and statesmen in the immense profit that the scientifically minded German farmer has found in heeding the warning that Darwin gave against the unfavorable results of inbreeding. Both plants and animals, if reproduced generation after generation from the same stock and under identical conditions, lose vigor and fecundity. Germany now beats the world in potato culture, largely because a German farmer rarely plants seed potatoes from his own fields. If he cannot get fresh varieties from a government experiment station, or from some remote district or foreign country, he does the next best thing by exchanging with his neighbors as far away from his own farm as possible. The difference between the soil of the hills and that of the valleys aids him, and if his fields lie in low, wet ground, he sends to the dry, sandy hill slopes for his seed, while the dwellers on the uplands plant potatoes grown iu the heavy soil or the river bottoms. Human beings are not exempt from this law of nature. In the frequent interlinking by marriage of Eastern culture with Western strength, Southern beauty with Northern vigor, lies one of the surest pledges of the continued progress of the American race, and the consequent per petuation of American institutions."

Our seed is grown several hundred miles north of New York, which makes a perfect change. 


\section{RADISH}

forcing and out-door planting Deep scarlet.

Early Scarlet Turnip, White Tipped. Roots round, bright scarlet, the lower part white. A rapid grower, well adapted for forcing and used largely for out-door planting, although more liable to be pithy than the Scarlet Globe.

Rosy Gem. Identi-

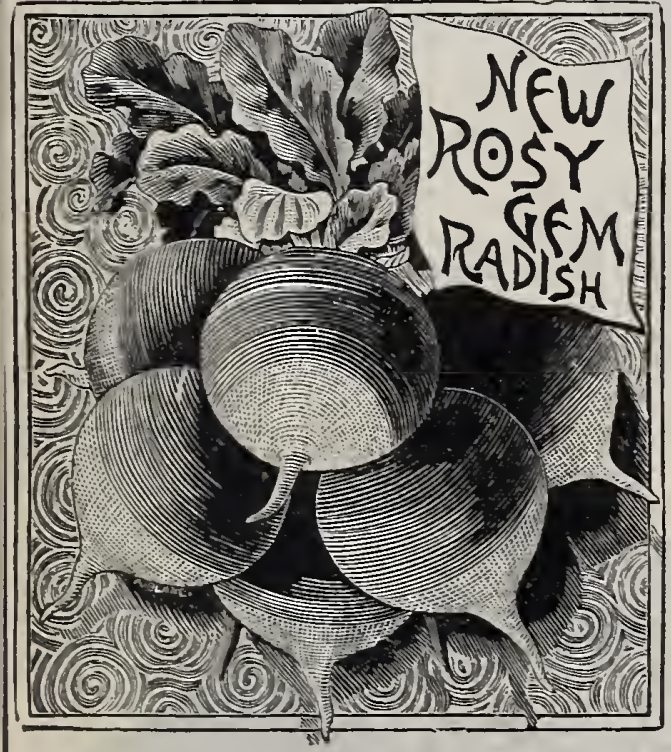
cal with the preceding. Our first trial of it led us to think that it was a selected strain less liable to grow pithy than the White Tipped; subsequent ones, however, have convinced us that there is no dif ference, but from its popularity with some we feel obliged to catalogue it under this name.

Non Plus Ultra, or Deep Scarlet. One of the earliest; tops very small, especially suited for for c in g. Color deep, rich red; form, globular.

Scarlet Globe. The shape of this when large enough for use at first is oval, in later stages of growth is more nearly globular. Brilliant red, which it holds long after pulling. Tops are a little larger than those of some varieties, but it is, nevertheless, largely used for forcing because it is seldom pithy, excelling in this respect any other variety either when planted under glass or out of doors. By far the best of its class for all purposes.

New Early Scarlet Olive Shaped, or Leafless. This differs greatly from the old Olive Shaped, in fact the name is hardly appropriate. It more closely resembles the French Breakfast (though much smaller), having an abrupt termination of the root. It is deeper in color than the Olive Shaped; it has much smaller tops than other varieties, and is, therefore, admirably adapted for forcing, as it can be grown more closely. We cannot recommend it for out-door planting, as with us it has become pithy before attaining a size suitable for pulling.

French Breakfast. A stump-rooted variety; longer than the preceding varieties, often slightly larger at bottom of root than at the top. Bright scarlet, white tipped. An old favorite yet popular for the home garden, but little used by market gardeners.

Early Long Scarlet Short Top. Once the most popular radish, but has been largely displaced in most sections by the round varieties. Grows from six to eight inches long; is ready to pull in twenty-five to thirty days from sowing.

Woods Early Frame. Similar to Long Scarlet, but shorter, of more brilliant color and slightly thicker at top, matures quicker and is more largely used for forcing.

Chartier, or Shepherd. A long variety, distinct, and one of the handsomest. Color, red at the top, shading through pink in the middle to white at the tip. Attains a very large size before being unfit for use. Of too strong growth to be used for forcing, but a desirable variety for out-door growing.

White Strasburg. A fine summer variety, growing about four inches long and two inches thick. Pure white.

Long Black Spanish Winter. One of the hardiest and best - for winter use.

Chinese Rose Winter. A popular winter variety, roots cylindrical, slightly larger at the bottom, terminating abruptly. Grows about one-half above ground. Color of upper part scarlet, shading to rose in lower portion; 6 to 8 inches long.

EACH OP ABOVE VARIETIES: Pkt. $5 \mathrm{c}$. $0 \mathrm{oz}$. 10c., $2 \mathrm{oz} .15 \mathrm{c}$.

\section{SALISFY \& Or Oyster Plant.}

Sandwich Island Mammoth. A new and larger growing . 5c., oz. 10c., 2 oz. 20c., $\frac{1}{4}$ lb. 30c., lb. $\$ 1.00$

\section{SPINACH}

Round Thick Leaved. The popular variety. Good for either fall or spring planting.

Long Standing. Remains for a longer time than other varieties without running to seed; leaves thick and fleshy. A
valuable variety.

Savoy Leaved. The earliest variety; leaves curled and crinkled like the Savoy Cabbage. Should be sown in the fall only, as it runs quickly to seed if sown in the spring

Each of above, pkt. 5c., oz. 8c., $\frac{1}{4}$ lb. 15c., $\frac{1}{2}$ lb. 20c., 1b. 35c.

\section{SQUASH}

Mammoth White Bush Scallop. An improvement on the old variety, larger,pure white and superior in quality. The Scallop varieties, while popular in the South, are but little used in the north.

Early Summer Crookneck. For early planting the Crookneck type is used in New England to almost the exclusion of any other. This, while much smaller than the Mammoth Crookneck, is yet largely grown, many considering it of better flavor.

Mammoth Summer Crookneck. This, like the preceding varieties, is of true bush form. The squashes are nearly twice as large as the ordinary Summer Crookneck and more warty. It is generally considered earlier than that. This opinion is held because the fruit attains more quickly a size equal to the ordinary strain when that is mature or fit to eat. If fruit of this were left on the vine until really in condition to eat, instead of being, taken when half ripe, it would not then be held that it was much earlier, if indeed any. It is because it has been so largely used before reaching a proper size that it is thought by some to be inferior in quality and flavor to the old Crookneck, while it really is fully equal to that.

Fordhook. An early running variety, suited for either summer or winter use. Fruit small, oblong, eight to ten inches in length, with smooth, thin skin, bright yellow; flesh straw yellow, dry, sweet and of fine flavor. Excellent for baking or for pies; a remarkable keeper.

The Faxon. A very desirable variety for the home garden. It is very productive, of medium size (five or six pounds), fine grained, dry, sweet, a good keeper, uniform in shape, but varied in color. This variation in color is a distinct feature of the squash. While some of the ripe squashes are pale yellow, with still paler yellow stripes, others are green, mottled and faintly striped with a light green.

Price of each of preceding varieties: Pkt. $5 c_{1}$, oz. $10 c_{,}, 2$ oz. $15 \mathrm{c}$.,

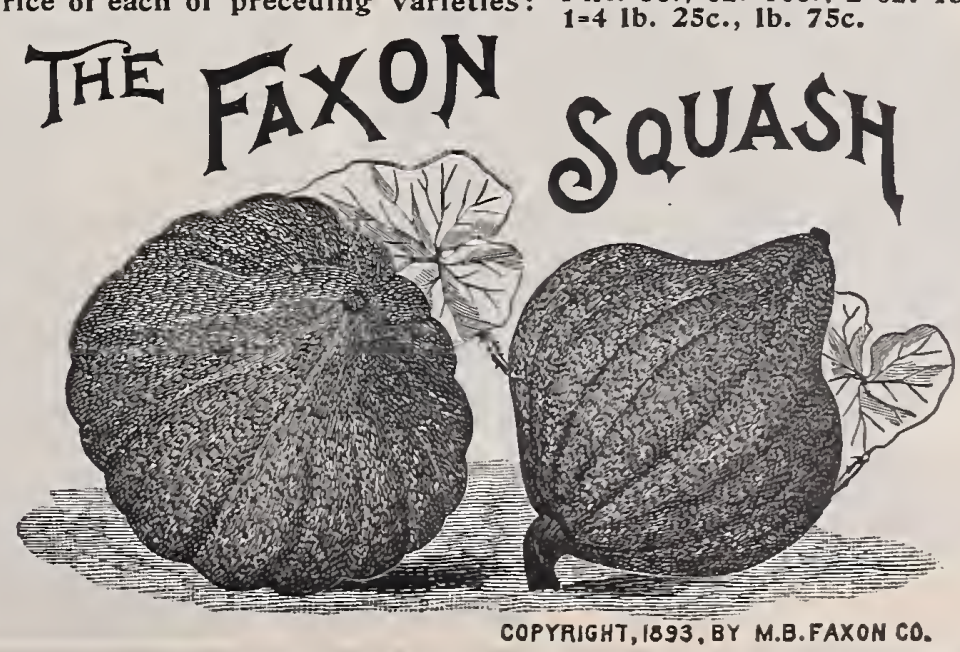




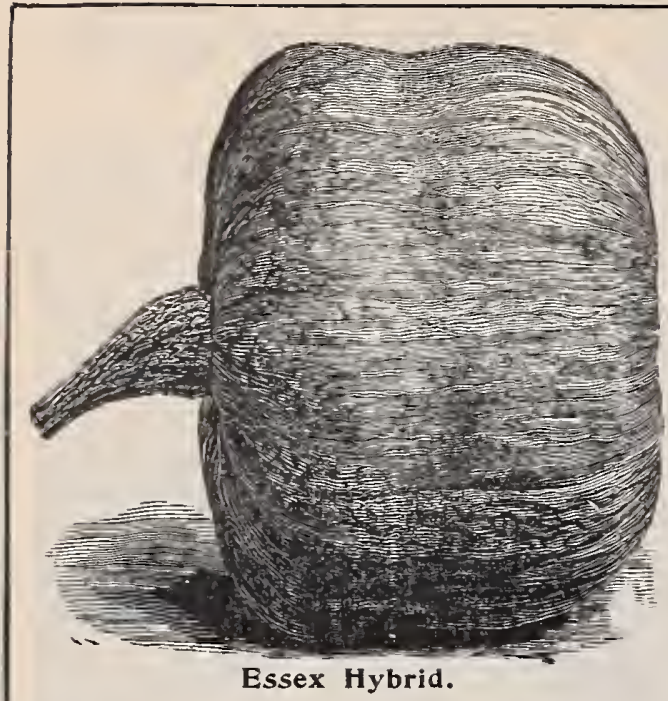

\section{SQUASH=-CONTINUED.}

Prolific Marrow. (Dunlap's.) The earliest fail variety; from a week to ten days earlier than any other Marrow. Color deep orange. Skin considerably pitted. Not as thick meated as the Orange Marrow nor quite equal in quality, but especially desirable on account of its earliness and also because it is very prolific. Pkt. 5c., oz. 10c., 2 ozs. 15c., $\frac{1}{4} 1$ b. 25c., 1b. 85c.

Orange Marrow. Also an early variety, generally considered identical with the Prolific Marrow, but differs sufficiently to be catalogued as a variety. It is identical in color and pitting but is more nearly round, later, much thicker meated and of better quality. Pkt. $5 \mathrm{c}$., oz. 10c., 2 ozs. 15c., $\frac{1}{4}$ lb. 25c., 1b. 75c.

Boston Marrow. This grows larger than either of the preceding but is not of so deep color. Skin thin, yellow with pinkish tint. Desirable for pies but not as dry as the Hubbard. Pkt. 5c., oz. 10c., 2 ozs. 15c., 这 lb. 25c., 1b. 75c.

Essex Hybrid. A cross between the Hubbard and old Turban, partaking somewhat of the features of both. Like the Hubbard, it is hard shelled. In color it is like the Turban and in form somewhat resembles it, but an improvement. Of fine flavor and quality and an excellent keeper. (See cut.) Pkt. 5c., oz. 10c., 2 ozs. 20c., $\frac{1}{4} 1$ b. 30c., 1b. $\$ 1.00$.

Bay State. Similar in shape to the Essex Hybrid; shell slate color and harder, and flesh is dryer than of that variety. Of excellent flavor and very solid. Pkt. 5c., oz. 10c., 2 ozs. 20c., lb. 30c., lb. $\$ 1.00$.

Warren. Similar in shape to the Essex Hybrid, but of richer color, a very deep orange. Shells also are thicker and are rough and warty. Claimed to be of better quality. Crop failed.

\section{Golden HubBard.}

This has now become a standard variety, and as extensive as our list of varieties now is this is yet a decided acquisition.

It is a distinct sort, of the shape and general character of the Hubbard, but a little smaller, earlier to mature, and a rich orange red instead of the dark olive green of the old Hubbard, while the flesh, which is thick, is a little deeper colored, of fully as good quality, fine grained and dry. Pkt. 5c., oz. 15c., 2 ozs. 25c., $\frac{1}{4}$ lb. 35c., 1b. $\$ 1.25$.

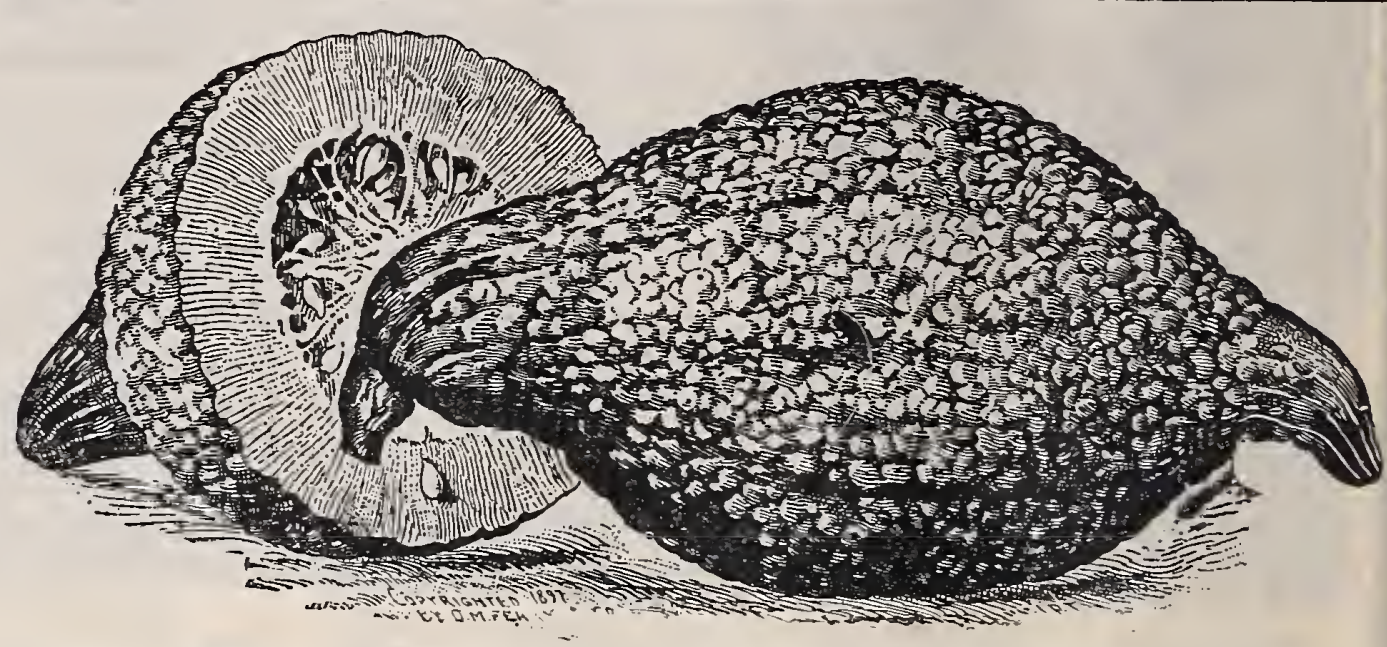

Hubbard. A well-known and favorite winter variety, more largely grown than any other. Very hard shelled, skin dark green, flesh yellow, fine grained, sweet, dry, and of the best flavor. We offer a choice strain, considered by some of our customers to be superior to the popular Chicago Hubbard Pkt. 5c., Oz. 10c., 2 ozs. 20c., 道 lb. 30c., 1b. $\$ 1.15$.
Chicago, or Warted Hubbard. A selection of the Hubbard with thickly warted shell. Equal in quality to that and generally considered to be of more attractive appearance. Of this also we offer a carefully selected strain, unsurpassed by any we have ever seen. Pkt. 5c., oz. 10c., 2 ozs. 20c., $\frac{1}{4} 1 \mathrm{~b}$. 30 c., lb. $\$ 1.00$.

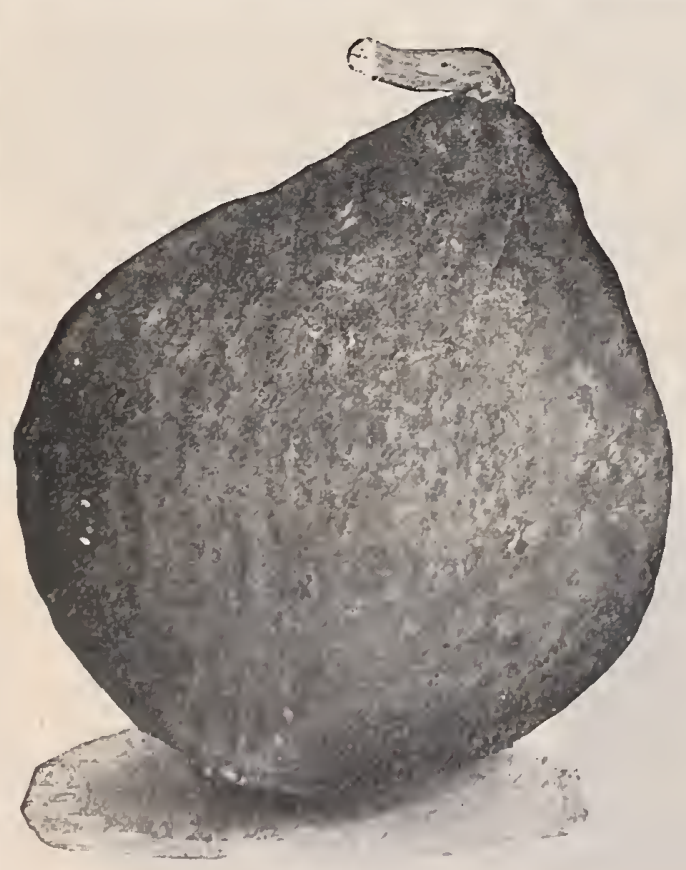

Golden Bronze.

\section{GOLDEN BRONZE.}

A NEW VARIETY.

The introducers say of it: "A cross, some four years ago, of the Bay State and Boston Marrow. In form the same as the last named, with stem and blossom end precisely like that variety; also'having that peculiar wrinkled appearance of the skin like the Boston Marrow. Size averaging from eight to ten pounds; color a dark greyish green, with bronze on upper surface when ripe; flesh an exceedingly bright golden yellow. Fine grained, very sweet and of delicious flavor. Early in maturing, a good keeper and yielder. Squashes are of very uniform size and appearance. As a squash, combining the qualities desired for the table and pies, this has no superior. Specimens grown in 1897 were kept until June, 1898." Pkt. 5c., Oz. 10c., 2 ozs. 20c., $\frac{1}{4}$ lb. 30c., lb. $\$ 1.00$.

Marblehead. A popular variety in Massachusetts but not so extensively grown elsewhere, as its superior quality warrants it to be. No other variety exceeds it in delicious flavor or dryness, and it is witha! productive. Form oval, shell hard, color slate. A good keeper. Pkt. 5c., oz. 10c., 2 ozs. 20c., $\frac{1}{4}$ lb. 30c., 1b. $\$ 1.00$.

Green Mountain. Fruit uniformly round, symmetrical and larger than the Hubbard, and has a beautiful netting of darker green instead of the wartiness of that variety. Rind thin but hard, flesh very deep, orange red, without any of the objectional green tinge near the rind so common in the best winter sorts. Cooks very quickly and evenly, and is the best of all squashes for pies. Vine hardy, early and certain to mature the large crop it produces. Pkt. 5c., oz. 10c., 2 oz. 15c., $\frac{1}{4} 1 \mathrm{~b} .25 \mathrm{c}$, , ib. $75 \mathrm{c}$.

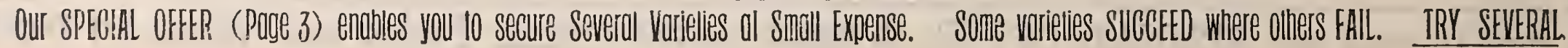




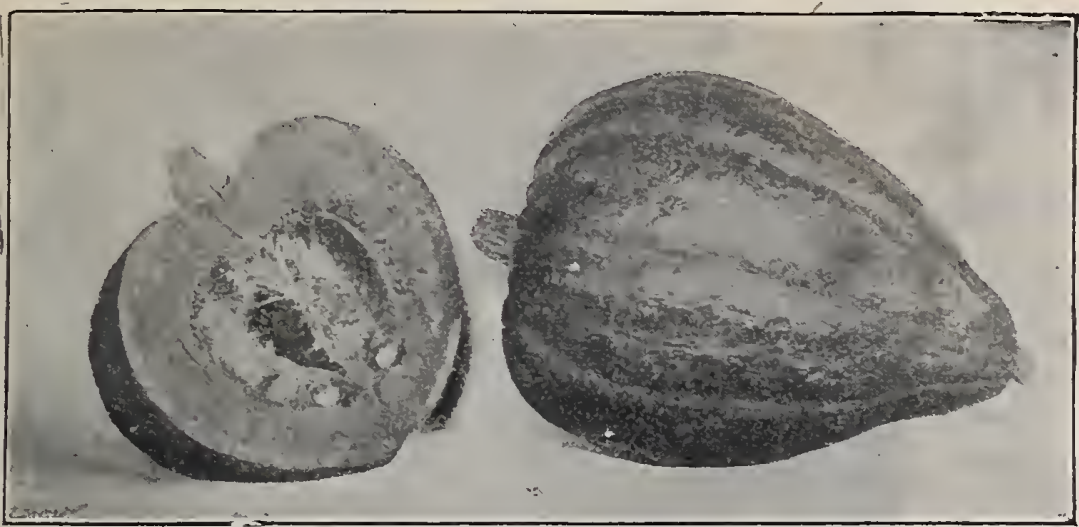

\section{SQUASH-CONTINUED.}

\section{The Delícious ฐquash.}

\section{zA inew Wariety.}

Originated by Mr. Jas. J. H. Gregory, who in the past has originated and introduced to the public more of the good varieties of squashes than any one else, and whose claims are, therefore, entitled to greater consideration. What he claims for this is shown in the following:

"If any one asks why we have given the above name to our new squash (it is the eighth variety we have introduced) our answer would be, because this is the one adjective most frequently used to express opinions of its quality. The Delicious is the product of the work of years in careful selection, crossing and isolating. The Faxon was our starting point. About every variety we ever knew enters into its composition, among the least desirable of which were several kinds of yellow and the large Brazilian blue varieties. We have been for years engaged in weeding these out, at the same time selecting by the test of cooking the richest among the class bearing a green color, and these we crossed on the Hubbard. From the resulting cross we have been selecting each season for our seed stock the thickest meated specimens and the very best for quality. The final result is a squash that by the universal agreement of those who have tested it, in quality surpasses every one of the fine varieties I have from time to time introduced (these include the Hubbard. Marblehead, Butman, Chestnut, Warren. Victor and Golden Bronze) not even excepting the Hubbard itself as it was a quarter of a century ago when at its best. In form the Delicious ranges between the two examples given above. Its color is almost uniformly of a green shade, with occasionally a blue specimen, it being just about as pure in this respect as was the original Hubbard. In size it also closely follows the original Hubbard, which weighed between five and ten pounds. In thickness of flesh it surpasses nearly every variety, the color being a dark orange. For table use no squash compares with it in its remarkable combination of fineness and compactness of grain, dryness, sweetness and exceeding richness of flavor. It is a fall and winter squash, being excellent at all seasons, but like the old Hubbard, though at any time excellent, does not acquire its best quality until winter. When but half grown it will be found to surpass in quality most varieties when fully ripe."

$$
\text { Pkt. 10c.; Oz. 25c.; } 2 \text { oz. 45c.; } 1 \text { lb. 85c. }
$$

Sibley, or Pike's Peak. The shell is pale in color, very hard and flinty, being at the same time thin and smooth, flesh is solid, thick, vivid, brilliant orange, and is possessed of rare edible qualities, being dry, and really wonderful for fineness of grain and the rich and delicate flavor peculiarly its own. The weight ranges from eight to eleven pounds. Will keep to the last of March. Pkt. 5c., oz. 10c., 2 oz. 15c., $\frac{1}{4}$ lb. 25 c., 1b. 85 c.

Large Winter Crookneck. Vines resemble those of the pumpkin; seldom troubled by borers; very productive; of fair quality. Pkt. 5c., oz. 10c., 2 ozs. 15c., 妾 $\mathrm{lb}$. 25c., 1b. $75 \mathrm{c}$.

Mammoth Chili. The largest variety in cultivation, a squash having been grown in Nova Scotia that reached the enormous weight of 292 pounds. Pkt, 10c., oz. 25c.
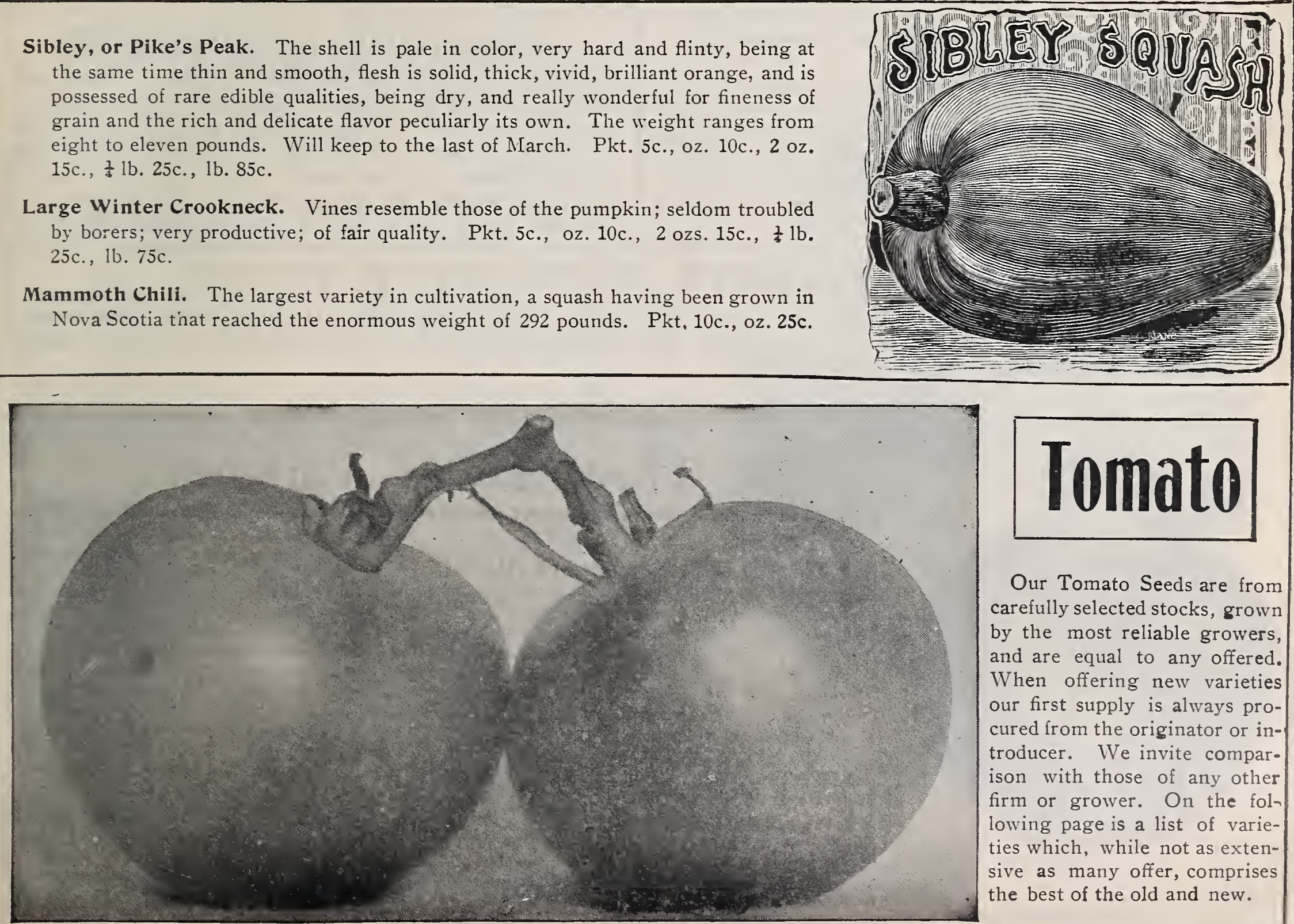

\section{Iomato}

Our Tomato Seeds are from carefully selected stocks, grown by the most reliable growers, and are equal to any offered. When offering new varieties our first supply is always procured from the originator or introducer. We invite comparison with those of any other firm or grower. On the following page is a list of varieties which, while not as extensive as many offer, comprises the best of the old and new. 


\section{th TOMATO Ht ossese}

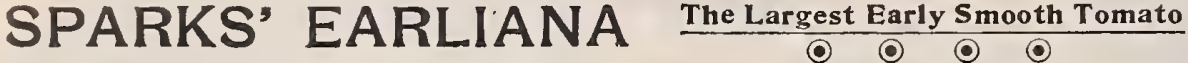

This new extra early variety is exactly what many gardeners have for a long time desired - an extra early which would, if not equal the later varieties, more nearly approach them in size, smoothness and quality than any of those of previous introduction. In the Earliana we have one that at the very least compares favorably with later varieties in size and smooth, regular form, and surpasses many of them in solidity, having a smaller seed cavity and fewer seeds than almost any other variety, while in quality it ranks with the best. It has also the merit of ripening a good proportion of its fruit early, and on this account alone is a profitable variety for the market gardener. The vine is of rather slender habit, hardy and productive, and produces its handsome deep red fruit in clusters of five to eight.

Price. Pkt. 10c., 古 oz. 25c., $\frac{1}{2}$ oz. 40c., oz. 75c.

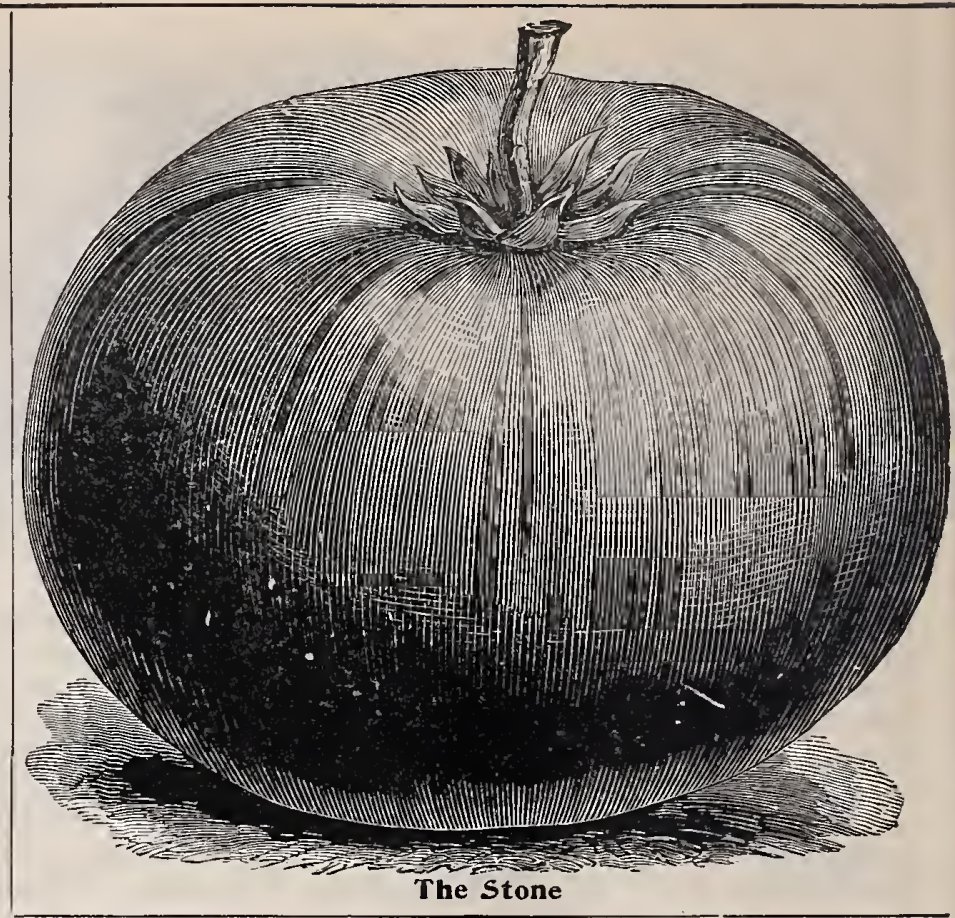

Atlantic Prize. An extremely early variety of medium size; bright red.

Acme. An old, yet still popular variety. Fruit of good size; bright pink.

Livingston's Perfection. One of the most popular large red

tomatoes. Fruit is very solid with not a large amount of seed. Vine hardy and productive.

Livingston's Favorite. Very similar to Perfection.

Livingston's Beauty. Fruit large, solid, and smooth; purplish pink.

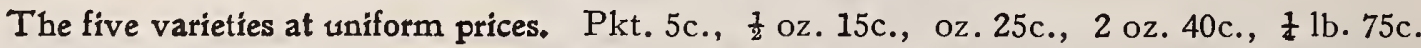

\section{IMPERIAL ONE OF THE MOST PRODUCTIVE}

The Imperial was originated by a market gardener, a large grower of tomatoes, who said of it at its introduction: "My experience with it is that it is the earliest, most solid, and most productive, perfectly smooth tomato on the market. It ripens evenly, is the best flavored, and more than twice as productive as any other known variety. It is the handsomest tomato grown I always get first premium at the fairs." Color purplish crimson.

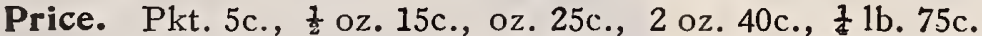

\section{THE STONE A PAVORITE FOR MARKET}

Since its introduction this has steadily increased in favor with market gardeners on account of its exceptional firmness and great productiveness. Its solidity and carrying qualities are remarkable. Its color is a desirable red; in shape, thicker from stem to blossom end than most varieties; perfectly smooth, making it very handsome and salable.

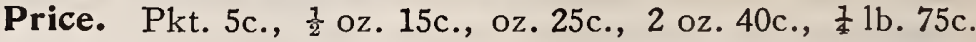

\section{TRUCKER'S FAVORITE THE FINEST LARGE-FRUITED PURPLE TOMATO}

This new variety is very uniform in size, thick meated and very solid. Although very large it is always smooth, ripens evenly, and is of the finest flavor. The vine is of strong, vigorous growth, not subject to rust or blight, and produces enormous crops, yielding well throughout the season until killed by frost.

Price. Pkt. 10c., $\frac{1}{2}$ oz. 20c., oz. 30c., 2 oz. 50c., $\frac{1}{4}$ lb. $85 \mathrm{c}$.

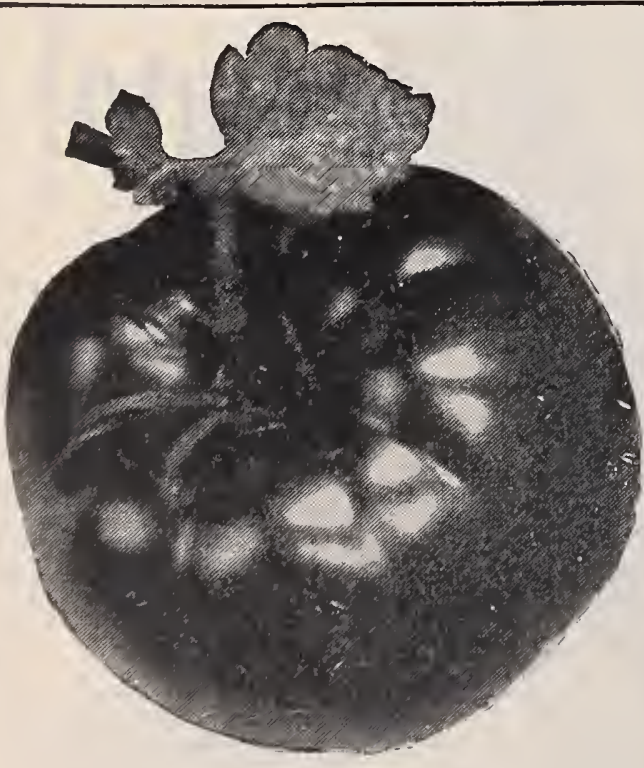

\section{Three Dwarf Varieties}

Which on account of their dwarf habit and compact form may be set much closer than the ordinary type

Livingston's Dwarf Stone Livingston's Stone in color, shape, and what is more remarkable for an erect sort, it is practically of the same size. Ten fruits picked from one vine at same time weighed five pounds, three ounces. Five fruits selected by eye for average size weighed two pounds, nine ounces. This was under field cultivation on farm land, with no fertilizer. Specimens weighing one pound each are quite common. The New Dwarf Stone is fully double the size of Dwarf Champion, and yet equally as early. It is fully as prolific, and consequently vastly more productive. We consider this one of our best productions, one that will meet with general favor; especially will this be true with the class of growers whose gardening is limited to a few acres, and where economy in saving land must be taken into account. Price. Pkt. 10c., $\frac{1}{2}$ oz. 30c., oz. 50c., 孝 lb. $\$ 1.50$.

Dwarf Champion. Vine dwarf and compact, early and productive. Fruit of medium size, in color deep purplish red. Pkt. 5c., 孝 oz. 15c., Oz. 25c., 孝 lb. 90c.

Dwarf Aristocrat. Of similar habit to Dwarf Champion. Preferred by some on account of its color, which is bright red. Prices same as for Dwarf Champion. 

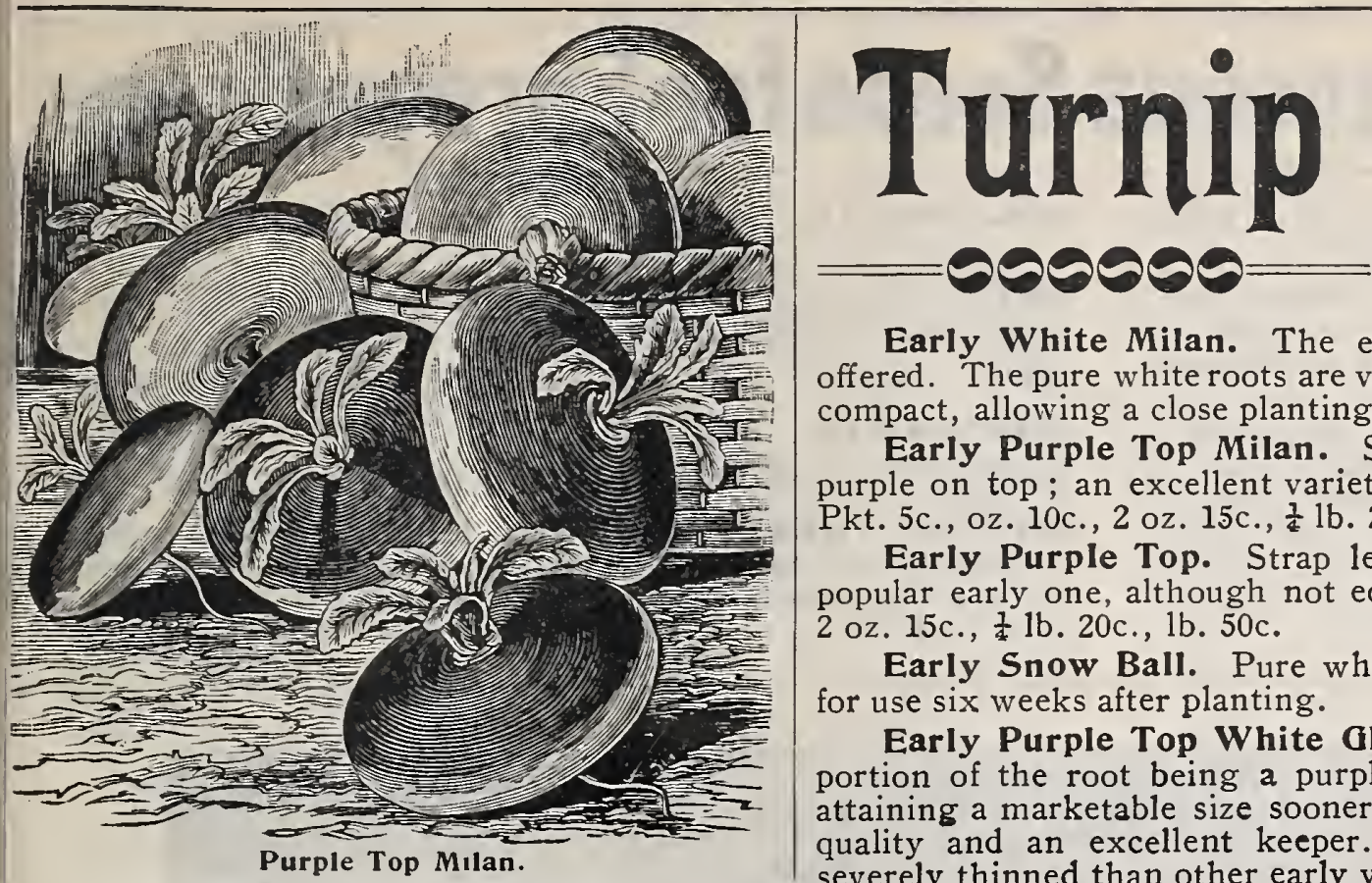

The following list comprises the best varieties in cultivation and all the good ones that are to any extent distinct. TVe see no reason for including several varieties generally catalogued which are either similar or inferior to those offered. Our Turnip seed is the bestt he world

Early White Milan. The earliest, showiest and best early white turnip ever offered. The pure white roots are very smooth and handsome, tops small, upright and compact, allowing a close planting. Pkt. 5c., oz. 10c., 2 oz. 15c., 亩 1b. 25c., 1b. 75c.

Early Purple Top Milan. Similar to the White Milan, but a little flatter and purple on top ; an excellent variety. Superior to the well-known Purple Top Flat. Pkt. 5c., oz. 10c., 2 oz. 15c., 妾 1b. 25c., 1b. 75c.

Early Purple Top. Strap leaved. This well-known variety is yet the most popular early one, although not equal to the Early Top Milan. Pkt.5c., oz. 10c. 2 oz. 15c., 孝 lb. 20c., 1b. 50c.

Early Snow Ball. Pure white, round, of medium size and fine quality. Fit for use six weeks after planting.

Early Purple Top White Globe. One of the handsomest varieties, the upper portion of the root being a purplish red, the lower pure white. A rapid grower attaining a marketable size sooner than other large globular varieties. Of the best quality and an excellent keeper. Owing to its strong growth should be more severely thinned than other early varieties. Pkt. 5c., oz. 10c., 2 oz. $15 \mathrm{c} ., \frac{1}{4} 1 \mathrm{~b} .20 \mathrm{c}$., 1b. $60 \mathrm{c}$.

White Egg. Also a very attractive variety and of superior quality. Egg-shaped, pure white. Grown to some extent for early use, and is a very popular winter variety. A fine keeper. Pkt. 5c., oz. 10c., 2 oz. 15c., $\frac{1}{4} 1 \mathrm{~b} .20 \mathrm{c} ., 1 \mathrm{~b} .50 \mathrm{c}$.

Yellow Globe. The standard yellow variety. Round, slightly flattened. Largely grown for stock and to some extent for inarket. An excellent keeper. Pkt. 5c., oz. 10c., 2 oz. 15c., 壬 1b. 20c., 1b. 60c.

Golden Ball, or Orange Jelly. The handsomest yellow variety. Of perfectly globular form and of rich orange color, superior in both shape and color to the Yellow Globe. The flesh is pale amber, fine grained, mild and sweet. It is equal as a keeper to any other variety. Pkt. 5c., oz. 10., 2 oz. 15c., $\frac{1}{4}$ lb. 20c., 1b. 50c.

\section{SWEDISH, RUSSIAN OR RUTA BAGA}

White French, or Rock. A very delicate flavored variety; an excellent keeper; fine for table. Pkt. 5c., oz. 10c., 2 oz. 15c., $\frac{1}{6} 1 \mathrm{~b}$. 20c., 1b. 50c.

Sweet German. A white globe-shaped sort. Superior for table use. Of excellent quality; good keeper. Pkt. 5c., oz. 10c., 2 oz. 15c., t lb. 20c., 1b. 50c.

Breadstone. A medium sized quick growing variety; white, faintly colored at top; exceptionally tender and sweet. One of the best table varieties. Pkt. 5c., oz. 10c., 2 oz. $15 \mathrm{c} ., \frac{1}{4}$ lb. $25 \mathrm{c} ., 1 \mathrm{~b}, 75 \mathrm{c}$.

Budlong. Originated in Rhode Island by Mr. Budlong, a very extensive grower of Ruta Bagas. Earlier and more nearly round than other white varieties of this class. An excellent strain. Pkt. 5c., oz. 10c., 2 oz. 15c., $\frac{1}{4}$ lb. 20c., 1b. 50 c.

Shamrock. A popular English Yellow Swede. A decided favorite with our local trade. Has short neck, shape oblong. Pkt. 5c., oz. 10c., 2 oz. 15 c., $\frac{1}{4}$ lb. 20c. , 1b. 50 c.

Long Island Improved. This is undoubtedly the finest variety of Purple Top Ruta Baga, and is of American origin. It grows much larger than other American varieties, is therefore desirable for stock, but equally desirable for the table and market as it is tender and sweet and of very attractive appearance. Pkt. 5c., oz. 10c., 2 oz. 15c., $\frac{1}{4}$ lb. 20c., lb. $50 \mathrm{c}$.

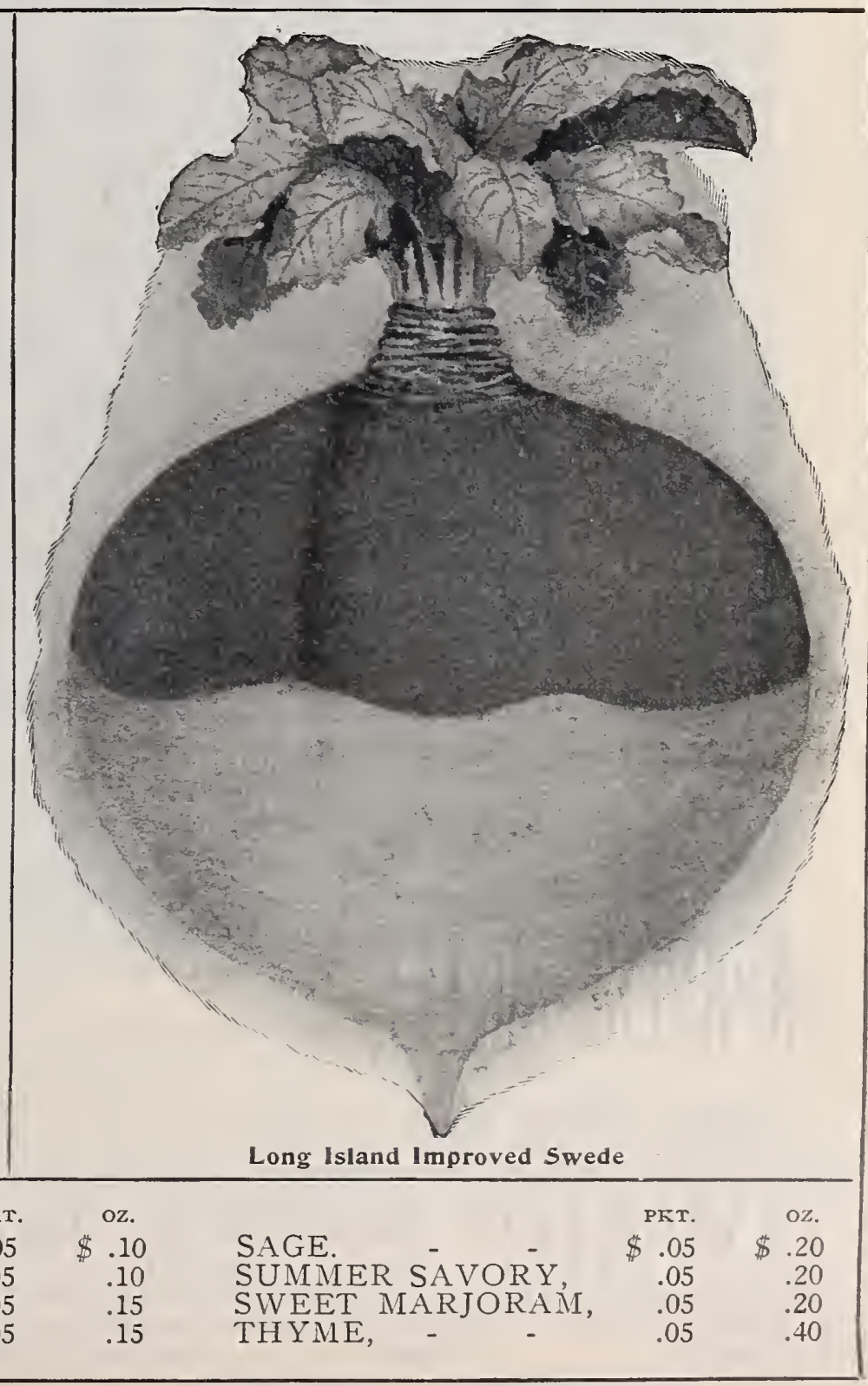




\section{Grain and Miscellaneous Seeds for Forage Crops}

BARLEY. Very largely used in New England as a forage plant. For this purpose sow $2 \frac{1}{2}$ to 3 bush. per acre.

Mansury 6 Rowed. Bush. $\$ 1.00 .2$ Rowed. Bush. $\$ 1.15$.

Beardless. Considered by many much more desirable for green fodder and especially so for hay, in that it is free from beards, which are thought to often injure cattle.

We were umable to secure last season any stock of this which we considered suitable for seed and have not at this writing received from growers any samples of the required quality. We are therefore unable at this time to quote price or even to say definitely that we shall have seed. We however hope to secure a stock and shall probably be able to quote price by the time catalogues reach customers. We solicit inquiries concerning this.
BUCKWHEAT, Japanese. Earlier, yields better and grain is larger than other varieties. Bush. $\$ 1.25$.

OATS. Used extensively for soiling. We offer the heaviest and cleanest seed obtainable. Bush. 65c.

RYE. (Spring.) Also largely used for soiling. Bush. \$1.25.

WINTER RYE. Bush. $\$ 1.00$.

WHEAT. (Spring.) Choice selected seed. Pk. 50c. Bush. $\$ 1.75$.

WINTER WHEAT. This is now being considerably used in the East for early green feed in the spring, and is considered by some to be greatly superior to rye for this purpose. $\mathrm{Pk}$. 50c. Bush. $\$ 1.75$.

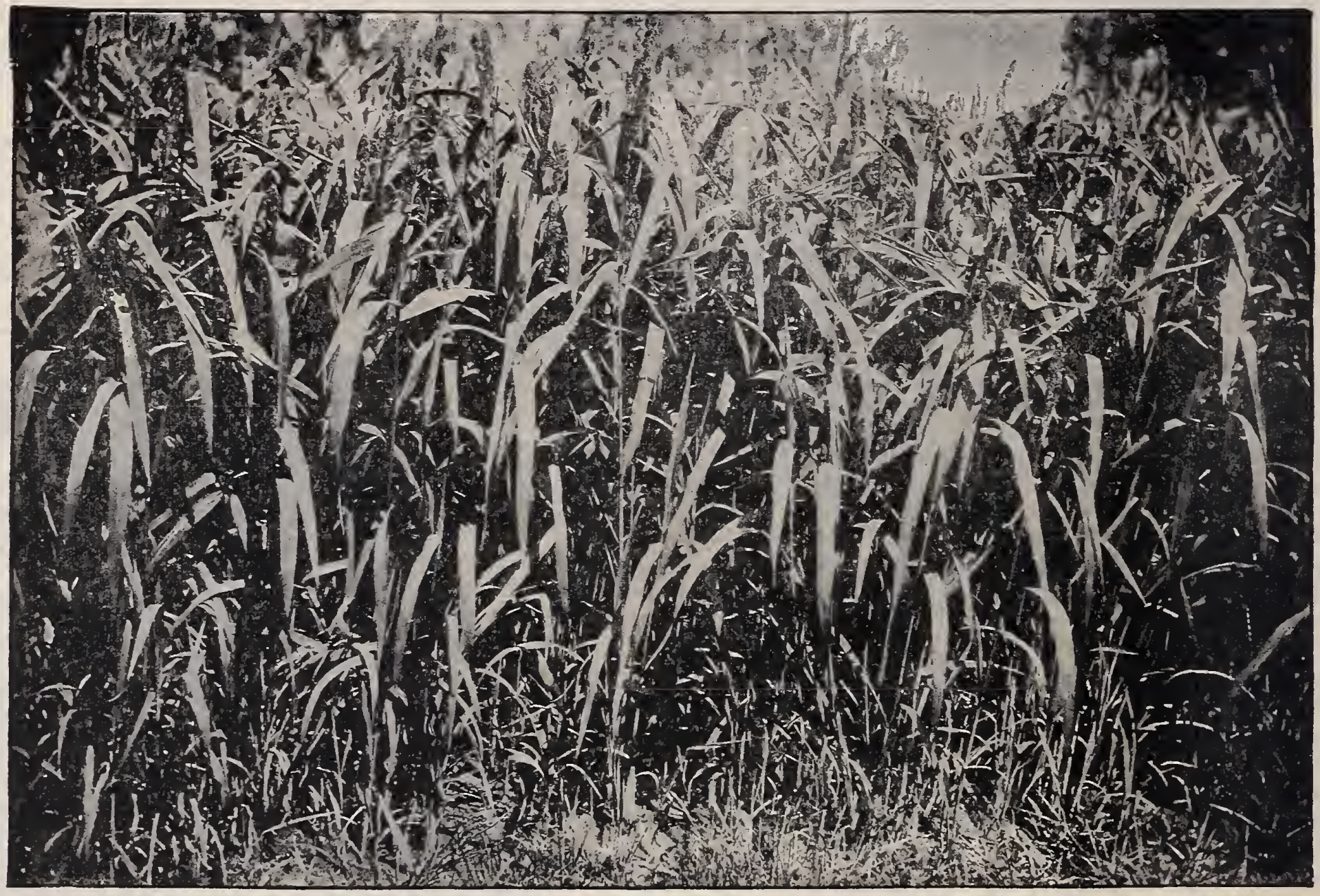

Japanese or Barnyard Millet.

We are enabled to publish this photographic illustration of a field of Japanese Millet through the kindness of the Hatch Experiment Station of the Massachusetts Agricultural College.

JPPANESE MULLET, -ORJAPANESE BARNYARD GRASS
(Panicum Crus Galli.) The most popular forage plant ever introduced. Readily eaten by cattle either green or dry.

GOOD FOR SOILING, FOR ENSILAGE, FOR HAY

Will produce more tons per acre of either green or dry fodder than any other plant of similiar nature.

For further description see one of following pages under head of Millets.

Lb. 12c. Lb. by mail 20c. 15 lbs. or over, 10c. per lb.

\section{DWARE ESSEX PAPE $\begin{gathered}\text { Used both for green manuring and for pasturing sheep } \\ \text { and hogs, and is considered by many to be the clieapest }\end{gathered}$ feed for these animals and to leave the land in an im-} proved condition after the crop has been eaten by them. Sow as soon as frost is out of ground, the crop will be ready for pasturing in about six weeks. Sown in drills, two and one-half feet apart, it will require about three pounds per acre, broadcast about double that quantity. Price. Lb. 12c. Lb. by mail 25c. $10 \mathrm{lbs} .75 \mathrm{c}$. $25 \mathrm{lbs}$ or over $6 \mathrm{c}$. per pound. 


\section{Go Seeds for Forage Crops Comtimued}

VETCH. Spring. (Vicia Sativa.) Known also as Spring Tare. Used the same as the Canada Pea, as a green forage plant. May be sown alone, but is generally sown with oats, and requires then from $\$$ to 1 bush. per acre. Bush. $\$ 2.75$.

Winter, Sand or Hairy. (Vicia Vilosa.) This thrives on poor, sandy soil, and will produce heavy crops of hay or green forage. It is perfectly hardy, may be sown either in spring or fall, and will remain green through the winter. It is claimed to be more satisfactory than Crimson Clover, as it may be sown later and produces a larger crop of green foliage earlier in the spring. It makes an excellent cover crop, preventing washing by winter storms. It may be sown with rye, the latter making a support for the vine. Alone, 1 bush. per acre; with rye, $\frac{1}{2}$ bush. (60 lbs. to the bush.) Lb. $15 \mathrm{c} ., 10 \mathrm{lbs} . \$ 1.35,100 \mathrm{lbs} . \$ 13.00$.

Kafir Corn. This is especially valuable for dry and comparatively poor soils, withstanding long periods of drought, and producing a fair crop of good fodder under conditions that would ruin common corn. It is distinct from the latter in habit of growth, does not stool from the roots, but branches from upper joints. The stalks are tender and juicy, are used entire as well as the blades and are readily eaten by horses or cattle either green or dry. Usually sown in drills about $2 \frac{1}{2} \mathrm{ft}$. apart, with plants from 5 to 9 inches apart, according to the nature and condition of soil. About 10 lbs. to the acre. For further information we advise a reading of Farmers Bulletin No. 37, which may be obtained of the Secretary of Agriculture at Washington, D. C., on application. Lb. 10c.; 1b. by mail, 20c.; $10 \mathrm{lbs}$. or over by express or freight, $5 \mathrm{c}$. per $1 \mathrm{~b}$.

Early Amber Sugar Cane. Sorghum is more and more becoming to be regarded of value as an addition to the list of fodder and ensilage plants. The Early Amber Sugar Cane is considered the most desirable variety of this class for these purposes. It withstands extreme drought and hot dry winds, remaining fresh and green through a dry period that would ruin corn. It is recommended for pasturing, especially for sheep and hogs. It will mature a crop of grain wherever Indian corn will ripen. This, while not quite equal in value for general feeding purposes to corn, is, however, considered very desirable for poultry in that it is greedily eaten by them, affords a desired change, and is said to greatly stimulate egg production. Further information may be gained by a reading of Farmers' Bulletin No. 50, which may be obtained free on application to the Secretary of Agriculture at Washington, D. C. Seed may be sown either broadcast or in drills with the rows sufficiently apart to admit of cultivation, the latter method being the more popular in the East. 75 to $100 \mathrm{lbs}$. to the acre. Lb. 12c.; 1b. by mail, 20c.; by express or freight, 10 lbs. $75 \mathrm{c}$.; 25 lbs. or over, 6c. per lb.

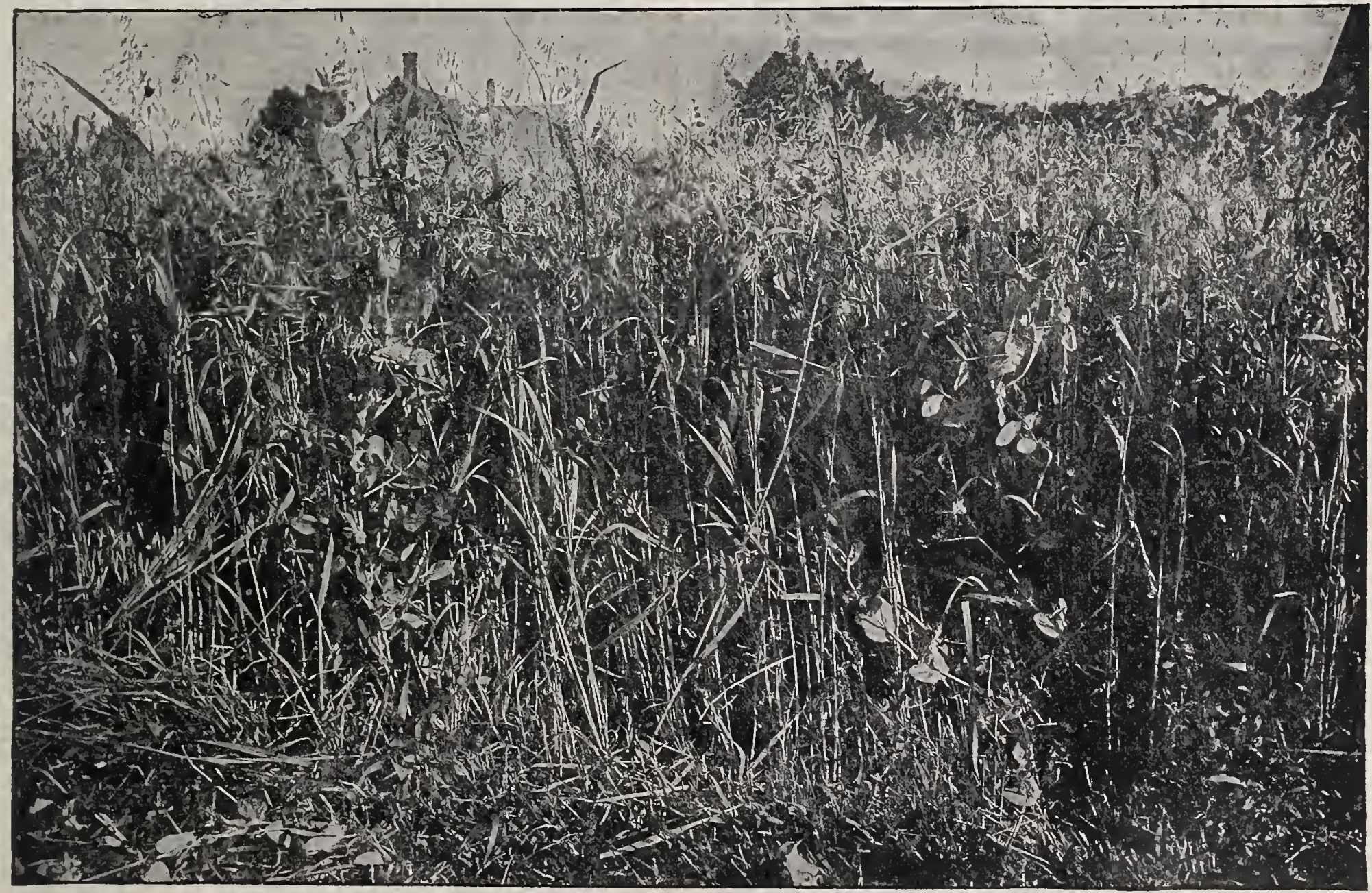

A Field of Peas and Oats

The above photographic ullustration is from a cut loaned us by the Hatch Experiment Station.

In the Station's Bulletin No. 72 - Summer Forage Crops, we find the following regarding this combination.

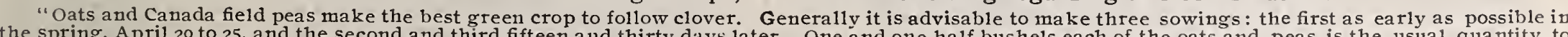

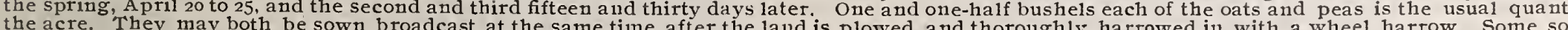
the acre. They may both be sown broadcast at the same time after the land is plowed, and thoroughly harrowed in with a wheel hatrow. Sone

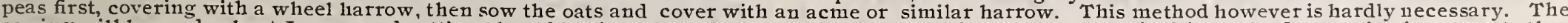

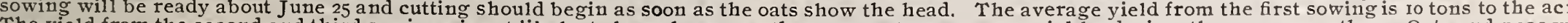

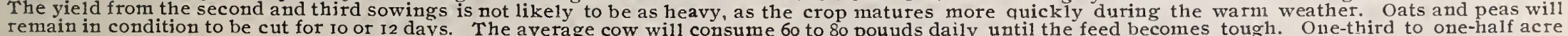
will furnish sufficient fodder for lo cows twelve days."

CANADA PEAS. These may also be sown with other grains as well as with oats, and are sometimes sown in August with Barley. They are also sometimes sown alone. Pkt. 50c., bush. $\$ 1.75$. 
COW PEA. This is not only an excellent forage plant, but a great soil in common with all leguminous plants, it increases the fertility of the soil upon which it grows. While this fact has been recognized for a long time it was not until recently known how this was accomplished, but within a few years it has been discovered by scientists that minute bacteria which
within the roots of leguminous plants take np free nitrogen from the ga in the soil. Nitrogen, as nearly all know, is a necessary element of plant food. This is usually furnished by the use of nitrate of soda or some form of animal wastes. The first is expensive and other forms more or less so, therefore any suggestion as to a cheaper way to obtain this indispensable element is certaialy worth considering by all engaged in agriculture. Scientists atmosphat on every acre of land there rests over three thousand tons of a vailabie plant food every time a crop of Cow Peas, Red clover or Alfalfa is grown upon it. The Cow Pea has for years been grown in the South, and iu The rapidly increasing demand for seed here shows that at least some have learned the value of this plant. It is unfortunate that it bears the name pea, as it is really a bean. The misnomer has evidently led some to plant too early, and probably many of the failures in the North may be rightly with Oats appears to us an nnwise one, as in this latitude the latter succeeds with corn, but are here generally sown alone and used for forage, ensilage are sometimes made into hay, and to a small extent for plowing into the soil. The latter practice is, however, not as prevalent as once, it being considered now more profitable to feed the crop to stock and return the stable mannre to the soil. Seed may be planted in drills or broadeast; the amount varying
from 8 quarts to 2 bushels per acre, less of course being required if sown in drills 8 to 30 inches a part than when broadcast. It may be covered to the depth of 2 or 3 inches. While there are a number of varieties, we have not
thought it necessary to offer but two. Of these the Whippoorwil is here used
much in excess of the other.

Whippoorwill. Clay. Each, pk. 85c., bush. $\$ 3.00$.

SOY, or Soja Pea. This is another valuable legume, yearly growing in popularity as a forage and ensilage plant. From the Farmers' Bulletin, found to thrive best on soils of medium texture that are well supplied with potash, phosphoric acid, and lime. It succeeds very well, however, on comparatively light soils, often giving an abundant crop on soils too poor to grow clover. As a general thing the Soy Bean is not so easily injured by frost as the common fleld bean, a nd hence can be planted earlier. Wuile possessed of excellent drought-resisting qualities, it at the same time seems to be able to survive a period of excess of moisture better than the Cow Pea or even as would be given to the ordinary field bean." One of the most important uses of the Soy Bean is for green forage- wherever tried it has proved a most valuable forage for milk production. A number of State experiment stations have conducted experiments in making and feeding Soy Bean ensi作

Early Yellow. Succeeds on any soil but especially well on light sandy or gravelly soil. Can be grown to the Northern limit of bean culture.

MEDIUM EARLY GREEN. Of very branching habit, and produces a dense, rank growth of foliage. Considered one of the best for soiling or ensilage and especially poptrar in the Eiast. Pk. \$I.15; bush. $\$ 4.00$.

\section{G rass Seed}

T would seem unnecessary for us to make an extended comment on the great importance of a knowledge of $\mathrm{g}$ rasses to the farmer. That he 1 should have at least a greneral knowledge of the many species and varieties, the adaptability of each to certain soils or situations, their
and comparative value regarding nutrition, production, duration, etc., ought

Custom is not always wisdom; on the contrary is often but another name for ignorance. Knowledge often leads to a departure from custom ject would, we feel sure, at least greatly modify the present custom, if not general use of many varieties of grasses of which now but little is generally known.

What we think should determine the grasses to be used on a given soil should be, first, the nature of the soil and situation, and perhaps next, whether to be mown or

For the many varying natures and conditions of soils, situations, climate, etc., there seem to be grasses especially suitable. Some thrive in one place or soil and and fail utterly in others some lelight in cool moist land and others in dry hot places, and still others seem to have a general adaptability to a11 soils. Some start very early in the spring, some grow grow till late in the season. Some are very productive at once but die out grow till late in the season. Some are very productive at once but die out lished, are then productive and continue to be so for many years. It is lished, are then productive and continue to be so for many years. It is tion of grass or hay, ought to be as well informed as possible of the nature
or characteristies of the different grasses to obtain the most profitable result in his occupation.

The descriptions in the following list have been compiled from various writers interested in the subject either in a scientific way or commercially, modified by the opinions of those engaged in growing grasses as a farm crop. That they may not be entirely correct is probable, but we ction of vatieties for the many different soils, conditions, purposes, etc. Of the grass seeds which we offer we have only to say that we aim to have the best obtainable. We do not claim to have better than any other We do however, claim to have as good as any and better than some, and offer them at prices compatible with their quality.

As the market price of the leading varieties of grass seeds is very liable to fluctuate, we are not always able to maintain quoted prices are, therefore, subject to change rvithout notice.

Many of the grasses in the following list are not suitable for sowing alone. We have, however, with each given the quantity required per acre if sown in that manner, which will perhaps aid in determining the amount of each necessa applied to grass seeds, and in fact to nearly all other seeds, is an indefinite and misleading one, as the bushel is determined by weight without regard to bulk, We have, therefore, to a great
extent, discontinued its use here (as it ought to be entirely in regard to
everything), only using it where custom unwisely necessitates it.

25 lbs. will be sent at the 100-lb. rate.

A wnless Brome Grass. (Bromus Inermis.) An extremely hardy grass, enduring a wider range of temperature than a yy other and standing well
long droughts. Will produce large crops of hay where most other grasses
would perish. While not equal in nutritive quality to that of our standatd
sorts, it, because of its drought-resisting ability and great hardiness, is attempt to grow the more nutritious grasses. Owing to the rapid spreading of its creeping root-stocks and quick formation of new plants, it is
difficuit to eradicate when once established, and is therefore rather undesirable for temporary meadows. Height, 3 to 5 feet. 35 to $401 \mathrm{bs}$. per acre. I,b. 20c., Io $1 \mathrm{bs}$. $\$ \mathrm{I} .75$, I00 1bs. $\$ 15.00$.

Canada Blue Grass. (Poa Compressa.) This thrives on a variety of soils and is very hardy. It forms by means of its creeping root-stocks a compact and durable turf of fne texture. It thrives on the poorest and dryest soils, and also on hard clayey ground as well, and grows well in and will endure severe frost, remaining green later in the season than and will endure severe frost, remaining green later in the season than most other grasses. It is said to be nutritious, and is considered by some
to be one of the most valuable for pastures, they claiming that cows feeding on it yield richer milk and also keep in better condition than on other sorts. It differs from the Kentucky Blue Grass in that the stems are flattened, decumbent and wiry. and also in its color, which more nearly approaches blue. It is not as valuable as that variety on good land but is desirable for light soils where many of the more productive grasses would not thrive, and is especially desirable for pasture mixtures designed for
poor soils or shady situations. Height, $1 / 2$ to $I \frac{1}{2}$ feet. $401 \mathrm{bs}$. per acre. L.b. I5 c., Io $1 \mathrm{bs}$. \$I.25, I00 1bs. \$10.00.

Creeping Bent Grass. (Agrostis Stolonifera.) This is of rapid growth, fine texture, and of creeping, spreading habit. Its growth is low and compact and its stoloniferous roots form an extremely close sod which endures rema rkably constant trampling, if, indeed, it is not thereby improved. It is therefore one of the most valuable grasses for the lawn, Ib. $30 \mathrm{co}$., Io $1 \mathrm{bs}$. $\$ 2.50$, I00 1bs. $\$ 23.00$.

Crested Dogs=tail. (Cynosurus Cristatus.) While thriving best on moist rich land, this seems to accommodate itself to nearly all soils. As its roots penetrate the ground deeply it is enabled to withstand severe droughts, making it of value for hilly situations. It also thrives in the shade. It forms a compact, smooth and durable turf, and because of its adaptability to a variety of soils and conditions should form a part of all mixtures for permanent pastures. It is as well a valuable grass for the lawn, and shouid especially be included in those mixtures designed for shady places. It is very nutritious and tender if cut at time of flowering and is then greedily eaten by cattle, but refused by them if allowed to ripen seed, when it becomes hard and wiry. Recommended to be used to a limited extent in mixtures for permanent mowing as well as for mixtures previously mentioned, but not generally for sowing alone. Would, however, require for that purpose $30 \mathrm{lbs}$. per acre. Height, I to 2 feet. Ib. $40 \mathrm{cc}$., Io $1 \mathrm{bs} . \$ 3.50$, $1001 \mathrm{bs}$. $\$ 33.00$.
I

English or Perennial Rye Grass. (Lolium Perenne.) While not a misnomer, the term perennial as a pplied to this is nevertheless misleading, in that it seems to imply permanency, while under favorable conditions it seldom lasts more than three or four years. Ir is, however, a very valuable grass. owing to its quick growth, great productiveness and nutritious quality. In Great Britain it is considered the most valuable grass, and holds there the relative position that Timothy does here. While the cool and moist climate of England is especially conducive to its growth it, nevertheless, thrives well in our eastern and middle states and growth it, nevertheless, thrives wellin our eastern and middle states and in a great diversity of soils. It makes a strong growth in four or five tious, and while the hay is somewhat hard, it is greatly relished by both tious, and while the hay is somewhat hard, it is greatly relished by both pasturing, both temporary and permanent. The objection to it by some for the permanent mixture is not, in our opinion, entirely well founded. We consider it desirable in such mixtures, for the reason that it furnishes at once a large crop of hay or very early feed, as the case may be, and in either occupies the ground at once, and as it dies out its place is filled by those sorts which require a longer time to become established. Its use is ered as good as the following variety. Height, $I \frac{1}{2}$ to 2 feet. $601 \mathrm{bs}$. per acre. Ib. I2c., Io 1 bs. $\$ 1.00$, I00 1bs. $\$ 8.00$.

Pacey's Perennial Rye Grass. A selected strain of dwarf habit, deirable for lawns for quick effect, making a fine green turf in a few weeks. Ib. I5c., 10 1bs. $\$ 1.25$, 1001 bs. $\$ 12.00$. 


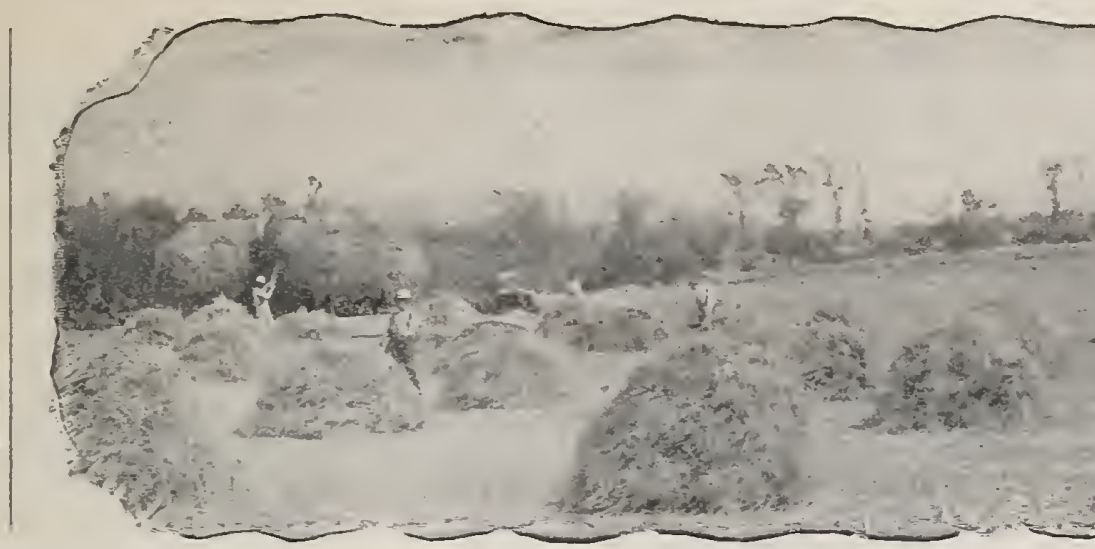

Fine Leaved Sheep's Fescue or Slender Fescue. (Festuca Ovina Tenuifolia.) A variety of $F$. O vina or Sheep's Fescue, having much fiuer leaves. It thrives on dry and poor soil, bears grazing well, is very hardy and lastiug, and is therefore desirable for mixtures designed for permafineness of leaf, makes it of value for dry slopes on the lawn. Height, to 2 feet. 35 lbs. per acre. L b. $40 \mathrm{c}$, , Io $1 \mathrm{bs}$. $\$ 3.50$, I00 $1 \mathrm{bs}$. $\$ 33.00$

Fowl Meadow. (Poa Serotina.) This grass grows abundantly in almost every sectiun of New England, and in portions of the Middle and Western States, especially where it has been introduced and cultivated in suitable ground, such as the borders of rivers and places occasionally flooded. It never grows so coarse or hard but that the stalk is sweet and tender, and eaten without waste. It is easily made into hay, and is a nutritive and valuable grass. It does best used in mixtures.

Hard Fescue. (Festuca Ovina Duriscula.) This also is a variety of Sheep's Fescue, of dwarfer habit and not as vigorous in its growth. It is especially desirable for dry, shallow soils, and is, like all varieties of Sheep's Fescue, very hardy, withstanding extremes of heat and cold and long periods of drought. It is probably of most value as a pasture grass on sandy soils, though it may often be used to adrantage in meadow mixtures for well-entiched clavey lands and will there often yield a good crop of hay and a heary aftermath. Recommended by some for lawns. An objection to it, horrever, for that purpose is found in its stooling habit. Heiglit, I to 2 feet. $301 \mathrm{bs}$. per acre. L, b. 20c., Io $1 \mathrm{bs}$. $\$ \mathrm{r} .75$, I00 $1 \mathrm{bs}$. $\$ 15.00$.

Italian Rye Grass. (Lolium Perenne Italicum.). This, like the Perennial Rre Grass, is of very rapid growth. With this in its favor that better withstands extremes of temperature and long drought. It is at its best on moist fertile soils of medium consistency, rielding a large crop in four or five weeks from sowing. and after that at intervals of six weeks unti1 late in the fall. It is largely treated as an annual, that is, used for soiling, but is of value in mixtures for temporary meadows but shoild not enter to any great extent, if at a11, mixtures for permanent purposes on

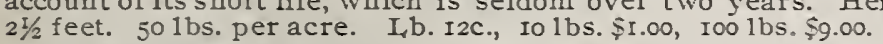

Kentucky Blue Grass. (Poa Pratensis.) This well-known grass is one of our most valuable, probably combining more points of excellence than any other. It takes two or three years to become established but will then last almost indefinitely. It succeeds in nearly all soils, starts early in the spring and lasts until frost. It is productive and nutritious and may be used to great advantage in all mixtures for perinanent meadows or pastures. Its smooth even growth, fine soft texture and pleas stalks, makes it one of our most raluable lawn grasses. Height, 3 to to foot. 40 to $501 \mathrm{bs}$. per acre. Lb. I6c., Io $1 \mathrm{bs}$. \$1.40, I0o $1 \mathrm{bs}$. $\$ 13.00$.

Meadow Fescue or English Blue Grass. (Festuca Pratensis.) This also, like the preceding, is one of our very valuable grasses, and is probably nearly as largely used as any in the various mixtures, both for permanent and temporary meadows and pastures. It succeeds best in cool moist, light soils, and no attempt should be made to grow it in warm, dry 1and. When fully established, which takes two or three years, it much exceeds most other grasses both in the quantity and quality of its product. It is very nutritious, and cattle are very fond of it if cut at the proper Height, 2 feet. $401 \mathrm{bs}$. per acre. Lb. 25c., Io $1 \mathrm{bs}$. $\$ 2.25$, $1001 \mathrm{bs} . \$ 20.00$.

Meadow Brome Grass. (Bromus Pratensis.) This, like the Awnles Brome Grass, is very hardy, withstanding extremes of cold and drought. It is recommended for mixtures both for pasture and mowing, but is not recommended for sowing alone except on pooor lands or dry, gravelly hillsides, where grasses of more value will not thrive. It makes good hay it cut before flowering, but later becomes woody and tough. Hoight, $2 \frac{1}{2}$ to $3^{1 / 2}$ feet. $301 \mathrm{bs}$. per acre. L, L. $25 \mathrm{c}$., Io $1 \mathrm{bs}$. $\$ 2.25$, I00 $1 \mathrm{bs}$. $\$ 20.00$.

Meadow Foxtail. (Alopecurus Pratensis.) An extremely early species, succeeding best on low, moist ground, but adapting itself to higher and dry siluations, and withstanding remarkably the burnin cerst pariet requiring a long time to derelop, should never be sown alone. Height, 2 to 3 feet. Lb. 3oc., 1o $1 \mathrm{bs}$. $\$ 2.75$. I00 $1 \mathrm{bs} . \$ 25.00$.

Orchard Grass. (Dactylis Glomerata.) One of our most popular grasses, which should, in the opinion of those seemingly best fitted to judge, form the base of most mixtures, both for permanent meadows and pastures. Next to Meadow Foxtail it is the earliest grass, grows in a diversity of soils, succeeding best on those containing some clay and not holding too much water, bears frequent cutting and close cropping, and is rery productive and nutritious. It thrives in the shade, hence its name exceeding in this respect any other grass except the Rough Stalk Meadow (Poa Trivialis). Blossoming with Red Clover it forms with that an excellent combination tor tem porary mowings. Stock of all kinds eat it readily when young. Cut at the proper stage it makes a much better hay than Timothy, is greatly preferred by animals, is more nutritious, and will greatly outyield it in a season, as it grows verr quickly after cutting and yields a much heavier aftermath, exceeding in this respect

most other grasses. The only objection urged against it is its tende to grow in bunches or tussocks, which upon the ground and the filling up of great1y improves the quality of it by rest it more delicate. Its tendency to grow in bunches entirely unfits it for
the lawn. Height, 2 feet. 40 to 50 bs. per acre. Lb. I6c, To 1bs. \$s. 1 , 100 $1 \mathrm{bs}$.

Red ol Creeping Fescue. (Festuca Rubra.) A valuable grass for exposed banks growing in light sandy or gravelly soils and resisting it of value for lawns and golf grounds, and it may'be used to advantage in mixtures for shady port
Io $1 \mathrm{bs}$. $\$ 1.85$, 100 $1 \mathrm{bs}$. $\$ 17.00$.

Red Top. (Agrostis Vulgaris.) This well-known grass, succeeding best on moist lands, accommodates itself to a variety of soils, often grov being in the eastern states at least next to Timothy, the most popular grass. It is, however often used like Tiruothy, to a n extent not warranted and in situations where other grasses rrould probably be more profitable because better adapted to them. It stands well our hot climate. is a per-
manent grass is not greatly affected by trampling, and enters largely manent grass is not greatly affected by trampling, and enters largely It is of fine growth and forms a close turf which, with its permanency, makes it valuable in lawn mixtures. Height, I to 2 feet.

Extra Clean or Fancy Seed-entirely free from chaff. $201 \mathrm{bs}$. per acre. I, b. I3c., Io $1 \mathrm{bs}$. \$1.25, I00 1bs. \$I.00.

Common or Chaff. 50 to $601 \mathrm{bs}$. per acre. Lb. 7c., Io $1 \mathrm{bs}$. 6oc., sack of 50 1bs. $\$ 2.50$.

Rhode Island Bent. (Agrostis Canina.) This resembles the preceding but has shorter and narrower leaves, is dwarfer in its habit, and thrives in a wider range of soils. It is one of the most valuable grasses finest growth. Height, I to 2 feet. 401 bs. per acre. Lb. 25 c., Io 1 bs., $\$ 2.25$, 1bs. $\$ 20.00$

Rough Stalk Meadow Grass. (Poa Trivialis.) Of spreading habit and very stoloniferous. It thrives on moist rich soils and is valuable in all other grasses except, perhaps, Orchard Grass, in growing iu the

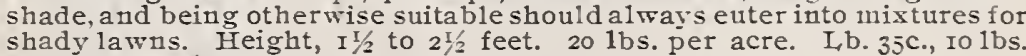
$\$ 3.25$, 100 1bs. $\$ 30.00$.

Sheep's Fescue. (Festuca Orina.) This, like its varieties previously mentioned, thrives in dry, shallow, poor soils, and is very hardy. It is of very nutritious and of which sheep are extremely fond. It is valuable in pasture mixtures for high and dry situations and is often used in lawn mixtures, for such places, though somewhat inclined to grow in bunches. Height, I to II/2 feet. 351 bs. per acre. L, b. 20c., Io lbs. $\$$ I. 75 , I00 1 bs. $\$ 15.00$ Sweet Vernal Grass. (Anthoxanthum Odoratum.) Valuable for its fall. Of but little value as hay, being of scanty growth and not nutritious. Desirable in meadow mixtures on account of its pleasing odor, sweetening hay, and acting in the nature of a condiment for cattle. Height, I to $I \frac{1}{2}$ Tall Fescue. (Festuca Elatior.) This thrives best on strong, moist. clayey soils, is very productive and permanent. It is very nutritious, and is readily eaten by all kinds of stock. On suitable soil it yields large
crops of hay, and should enter into all mixtures for permanent meadows crops of hay, and should enter into all mixtures for permanent meadows acre. Ib. 30 c., Io 1 bs. $\$ 2.75$, $1001 \mathrm{bs}$. $\$ 25.00$.

Tal1 Meadow Oat Grass. (Avena Elatior.) A rery hardy species, withstanding extremes of heat and cold, making a very early and luxurisouth the best winter grass. It succeeds best on deep sandy soils. When used for soiling it may be often cut, four or five times in favorable seasons, and twice for hay and should be cut for that purpose as soon as it comes into bloom. Cattle are then fond of it. It is especially valuable feet. $501 \mathrm{bs}$. per acre. Lb. 25 c., Io $1 \mathrm{bs}$. $\$ 2.00$, 100 $1 \mathrm{l}$

Timothy. (Phleum Pratense.) cription is really needed. It thrive
but is largely used on others and would succeed better. Its extensive use is probably in a measure due to our city markets as pure Timothy. It undoubtedly is, for temporary meadows on favorable soils, one of our most valuable grasses, but for per acre ( 45 1 bs. to the bushe1). Lb. $8 c$., Ioo $1 \mathrm{bs}$. $\$ 6.00$. 
Various Leaved Fescue. (Festuca Heterophylla.) An early and rery hardy grass, thriving best in cool, moist soils, and is very productive on such when they contain sufficient humus and potash. It produces a large amount of root leaves, making it an excellent bottom grass. It is said to be very nutritious, and is desirable in mixtures for both permaneut growth is especially desirable in mixtures for shaded lawns and parks. Height, 2 to 3 feet. $401 \mathrm{lbs}$. per acre. L b. $30 \mathrm{c}$., $10 \mathrm{lbs}$. $\$ 2.75$, 100 lbs. $\$ 25.00$.
Wood Meadow Grass. (Poa Nemoralis.) A very early and permanent grass, especially valuable for shaded lawns and parks rery hardy,
withstanding extremes of temperature; ronts creeping, forming a close turf. Desirable for permanent pastures and in good soil for hay. $30 \mathrm{lbs}$. per acre. Lb. 40 c., I0 $1 \mathrm{bs}$. $\$ 3.75$, I00 $1 \mathrm{bs}$. $\$ 35.00$.

Add 8 cents per $1 \mathrm{~b}$. to all prices given in the foregoing list when same is desired sent by mail.

\section{MILIETS.}

Hungarian Grass. (Panicum Germanicum.) Used extensively in New England for forage and to some extent for hay. It withstands drought well, succeeds on any ordinary soil, and on rich land two crops may be grown the same season. 4r lbs. to the bushel. One bushel per acre. Bush. \$1.65.

Common Millet. (Panicum Miliaceum.) Of somewhat ranker growth than Hungarian and with a more open or loose head. Seed very closely resembles that of German Millet. 50 lbs. per bush., $x$ bush. per acre.

German or Golden Millet. (Setaria Italica.) Of stronger, ranker growth than either of the preceding and requires richer land. It has an abundant foliage; is, therefore, an excellent forage crop and makes a coatse tather harsh hay but which is readily eaten by all kinds of stock if cut at the proper time. 5o $1 \mathrm{bs}$. to the bushel, $3 / 4$ to $x$ bushel per acre,

Siberian or Russian Millet. Of this comparatively new Millet the largest dealer in grass seeds in this country says: "Siberian, sometimes country and has largely taken the place of German and Common Millet, as well is Hungarian. We have made extensive inquiries and the general reports are that the plant grows larger than Common Millet, with beard and chaff similar to Hungarian; the plant inaking a ranker- growth, produces more leaves than either Common Millet, German Millet or Hungarian, leaves starting close to the ground and continuing nearly to top of stem; leaves wide and tender, making it preferable to other irillets for hay, Yields a hay reported $1 / 3$ to $I / 2$ more per acre, besides hay softer hay. Yields a hay reported $1 / 3$ to $1 / 2$ more per acre, besides hay softer millets. It matures about the same time as Common Millet and Hungamillets. It matures about same sillet; it is claimed that it will stand drought better than other varieties of Millet. It has been a success in drought better thano is too short to mature a corn crop." $3 / 4$ bush. per acre. 50 lbs. to the bush. Bush. \$1.25.

Japanese Millet. (Panicum Crus Galli.) This comparatively new yet popular forage plant is of very rank growth, from six to seren feet coarse growing plants it needs abundant plant food, and when givent this on good soil the yield is inmense. While its use has been largely confined to soling purposes, it may be used for ensilage, and is, when cut at the proper stage and made into hay, readily eaten by both catte and
horses. Probably no other forage plant ever sprang so quickly into popuhorses. Probably no other forage plant erer sprang so quick y into popular tavor, and that it will continue to occupy a prominent place among our
forage plants is without doubt. It may be sowu from May I 5 th to July. 1bs. per acre. I, 12 .; 1b. by mail, 20c.; I5 lbs. or over, xoc. per lb.

Pearl or Egyptian Millet. (Pencillaria Spicata.) A very rankgrowing grass, attaining a height of six or more feet. Popular in the has for many years been offered under various names. Whether it would be of value for ensilage we are not a ware. L b. I 2c., ro $1 \mathrm{bs}$. $\$$ r.oo.

\section{CIUIERS.}

Medium Red. (Trifolium Pratense.) This well-known plant, one of the most valuable, especially in the eastern states, needs no description. It is sufficient to say that its great value either for soiling, hay pasturing or for turning under for green manure, and the improved condition of the land on which it has been grown, gives it its deserved popularity. L, b. I4c., I00 1bs. \$I 3.00 .

Mammoth or Pea Vine. ('Trifolium Pratense var.) A variety of the preceding growing taller and lasting longer. Very valuable for plow100 lbs. $\$ 24.00$

Alsike or Swedish. (Trifolium Hybridum.) A very hardy variety, succeeding best iu stiff, cold soils, and in those too wet for the other species. Itis continually growing in popularity and should enter into al pasture mixtures for moist or wet lands. L b. I8c., Ioo 1 bs. \$17.00.

White Clover. (Trifolium Repens.) This thrives in nearly all soils and situations, withstandirg extremes of heat and cold, dryness and humidity. It is of low growth and spreads rapidly, the stems creeping and rooting at the joints. It well bears trampling and is valuable for both pasture and lawn mixtures. L, b. $25 \mathrm{c}$.

Crimson Clover. (Trifolium Incarnatum.) An annual which has been largely grown in the south for plowing under, and to some exteut in the north for the same purpose. Pn the norti.. treated as an for soiling and perhaps for hay, sown in the spring either alone or with Italian Rye Grass it no do»bt is of great value, but in this section and as far as we can learn all attempts to winter it north of New Jersey have largely resulted in failure. $20 \mathrm{lbs}$. per acre. Lb. 8c., roo $1 \mathrm{bs} . \$ 7.50$.

Alfalfa or Lucern. (Medicago Sativa.) There having been more or less contention among those seemingly fitted to be authorities on the sub ject as to whether Alfalfa can be profitably grown in the northern and eastern states. We are somewhat in doubt as to the advisability of recommending it for this section. We, however, quote from a Farmers' Bulletin (No. 3I. Alfalfa or Lucern) issued by the Department of Agriculture at Washington, D. C., whose op portunity for general observation certainly is not exceeded by any others. "Alfalfa has been grown with more or less success in every State and Territory in the Union, from Maiue to Washington and from California to Florida. There is not a State from which the report has 1 -t gone out that Alfalfa will, when properly treated, become one of the best fodder plants. It is the best hay and soiling crop in the West. In the South it has been widely recominended as a very valuable addition to the list of forage grasses and clovers. In the Middle and Fastern States it promises to become a rival of the better known and more widely grown Red clover." Its roots often reach the depth of to to 15 feet. It, therefore, requires a deep, rich, well-drained soil, and on such is capable of resistnin long droughts. It should be sown alone ( 15 to $25 \mathrm{lbs}$, per acre) and cut as it begins to bloom. Height, sown alone (I5 to 25 lbs. per acre) a
I to 3 feet. L, b. I 8 c., Ioo $1 \mathrm{bs}$. \$17.00.

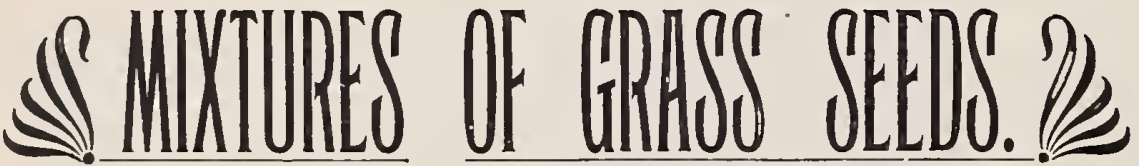

FOR MEADOWS PASTUPRE $\infty$ (2) Our Special Mixture for Permanent Mowing for Dry Soils.

\section{Our Regular Mixture for Perma- nent Mowing for Average Soil.}

In view of what we have previousiy said concerning a combination of several grasses we would say further that it seems to us to be beyond dispute that a thicker growth, therefore larger yield, nay be obtained by sowing a mixture of many varieties than by the use of one or a few. Many the grasses of fine growth are rich in nutritive quality and of heavy bottom growth, but their scanty top growtl makes thew ursuitable for Combined; however, with those of coarser aud taller latter, waking them thereby more tender and greatly increase the total ield, the whole producing not only a larger yield and much heavier This mixorities, assisted the experience of theser fring wing (which may sometines be profitably increased) of 40 pounds per ins included (but in separate
them unless it be in the fall,
This is prepared from varieties which are especially adapted to high and dry soils and, while probably it will not prove as productive as the preceding would if sown on good average soil, it will, we feel sure, prore greatly superior in results to those obtained from the use of the few generally sown, which are not only inadequate but also unsuited to the purpose. 40 pounds per acre, including 4 pounds of Mrixed Clovers. L, b. I4c., IOo $1 \mathrm{bs} . \$ 13.50$.

\section{Our Special Nixture for} Permanent Mowing for W Wet Soils.

This, like the precediug, is a special mixture, but designed for soils of an opposite nature. If sown ou land not too wet, that is, not swampy (it is of course understood there is a limit both as to wetness and dryness as to where grasses will thrive), this will produce large crops of excellent hay for many years. $40 \mathrm{lbs}$. per acre, including $3 \mathrm{lbs}$. of Mixed Clovers. I.b. I 4 c., $1001 \mathrm{bs} . \$ 13.50$. 
MIXTURES OF GRASS SEEDS-CONTINUED.

\section{Our Regular Mixture for Permanent Pastures.}

As fully important is it, and perhaps more, when laying down a pasA sired to have it permanent. We have before referred to the different characteristics of the different grasses, which also a re shown in the descriplions. We a ain call attention to some of them. Some grasses start early in the spring some much later, others in the intervening time. Some of these are at their best early in the season, others at midsumer, while others continue to grow until the ground freezes. Some bear, seem to be at all injured by close and constant cropping. It would seem obvious then, that if a number of these grasses having these different characteristics were combined that a pasture might be established from which early and continuous feed might :easonably be expected, and a1so that if the right ones were selected a permanent production might also be secured. This mixture was, therefore, devised to secure just these desirable results - continual feed from early to late in the season and permanence. It is designed for the average soil. We adrise a minimum sowing of 40 pounds per acre, which includes 6 pounds of Mixed
Clovers, and which for reasons previously stated (see Regular Mixture for Mowing) are put up in separate package. I, b. I4C., I00 Ibs. $\$$ I 3.00 .

\section{Our Special Mixture for Permenant Pastures for Wet Soils.}

This, like our Specia1 Mowing Mixture for Dry Soils, is composed of varieties especially adapted to such soils, and with this as with all other our object has been to make a mixture not only continuously productive for the season but for as many years as possible. 40 pound
including 4 pounds of Mixed Clovers. Ib. I4c., Ioo $1 \mathrm{bs}$. \$I 3.50 .

\section{Our Special Mixture for \\ Permanent Pastures for Dry Soils.}

This, while containing some of the grasses which are in our Regular Mixture (in different proportions, however), also contains others which thrive on wet or very moist land. For this we claim the same probably
superior results to those obtained by the present custom of using but two or three varieties. 40 pounds per acre, including 3 pounds of Mixed Clovers. Ib. I4c., Ioo $1 \mathrm{bs}$. $\$ 13.5$
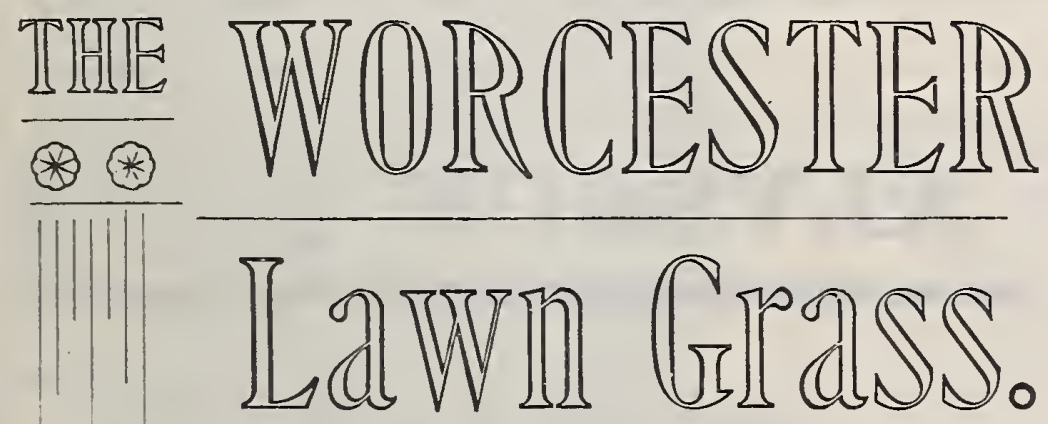

- THE BEST.

Probably above all Mixtures of grass seeds that for the lawn is one that is desired to be permanent in its results. Other considerations are, that not only shall the effect be permanent $b$ ut it is also desirable that it shall be secured as soon as possible; therefore the mixtire should contain some varieties which are of early and rapid growth. It is obvious that al1 the grasses should be of fine, soft growth, and also that they must be capable of bearing constant trampling and frequent. cutting. Simply stated, the WORCESTER LAWN GRASS MIXTURE is a combination of such varieties as years of experience and observation have shown us are those best suited to meet the requirements. In this selection of varieties we have those that grow and thrive at different times of the year-insuring early and constant verdure through the season, those that are remarkable for their enduring and tenacious qualities-insuring a degree of safet $y$ through severe drought, those that not quly bear constant trampling a nd frequent cuting but which actually im. prove by it, and those which are long-lived or perennial-insuring perma. nency. This mixture is desioned for the average soil and on such soil, properly prepared and entiched, will produce a fine, velvety growth the first season, and for years if properly treated. It contains nothing but extra clean or recleaned seeds, is as free from weed seeds as it is possible to make it with improved machinery, and is exactly what we claimto make it with improved machinery, and is exactly what we claimprice per pound it is actualiy much cheaper than that offered by many price per pound it is actually much cheaper than that offered by many 75 to 85 lbs. per acre. A I 1 b. pkg. Will therefore be required for a bout 500 75 to 85 lbs. per acre. A I lb. pkg. will therefore be required for a bout 500
square feet. I 1b. pkg. $25 \mathrm{c}$; $4 \frac{1}{2} \mathrm{lb}$. pkg. $\$$ I.00; Io $1 \mathrm{bs}$. or over in bulk, $20 \mathrm{c}$. per $1 \mathrm{~b}$.

\section{THE PARK IAA WN GRASS.}

GOOD. There being some demand for a cheaper mixture than the preceding suitable for large areas, parks, etc., as well as for smaller plots like the back door yard, we offer this mixture. We claim higher prices than our price for this. While of course not equal to the preceding, it is by no means a poor or worthless mixture. Simply stated this is good: the worcester ture we have as far as possible, that is considering the price, conformed to the ideas previously expressed as to what grasses should enter into to mixture for the lawn. Although opposed to the term g uart and bushe1 because they are indefinite when opposed to the term quart and bushe1 fact that all dealers have to determine the bushel by weight, we feel, however, to meet competition, compelled to conform to the custoln to some extent, and so offer this mixture by the quart, etc. Sow from $3^{1 / 2}$ to 4 bushels per acre. A quart package is sufficient for about 300 square feet. I qt. pkg. I5c.; 4 1/2 qt. pkg. 60c.; bush., cf 201 bs., $\$ 2.50$.

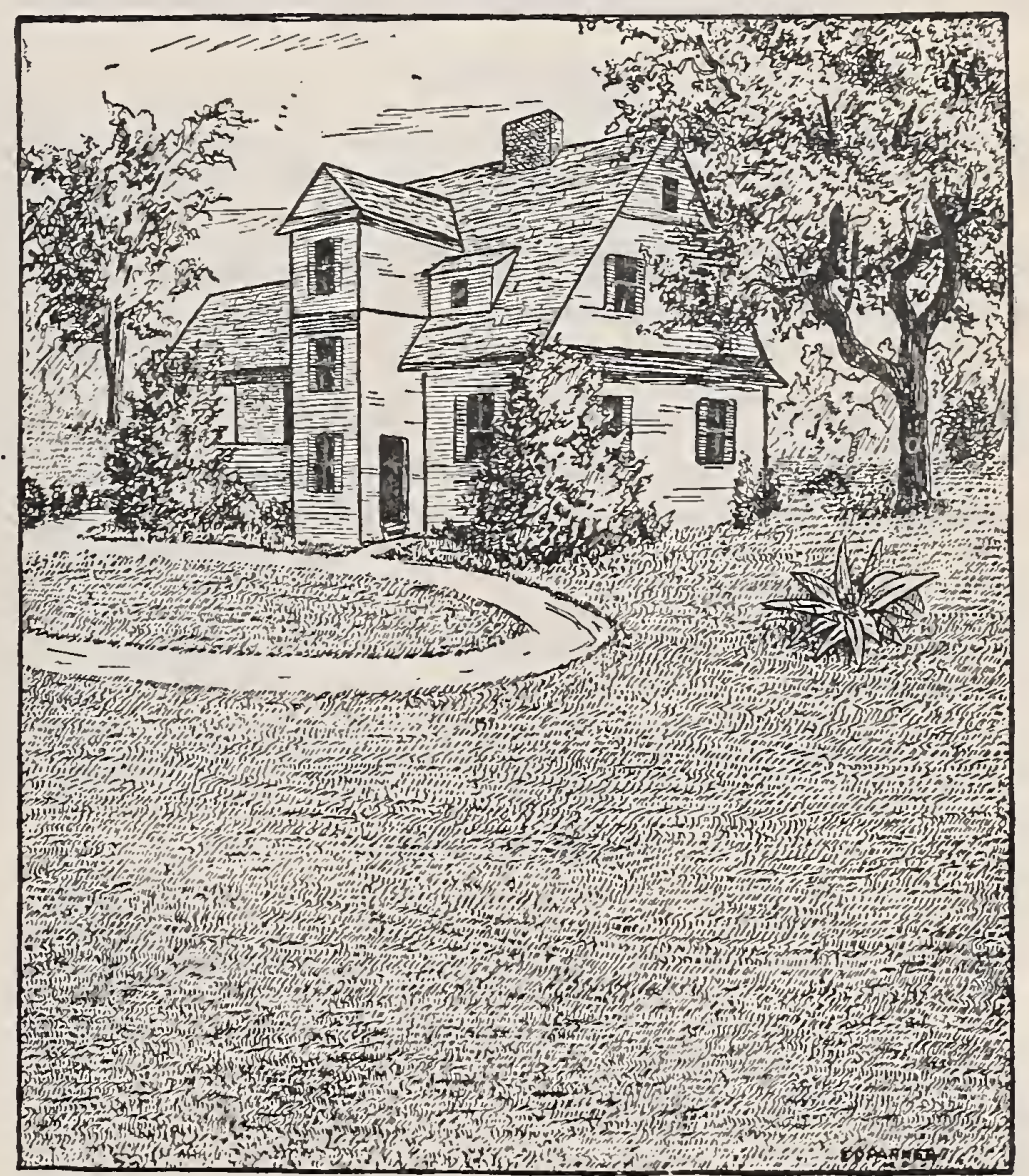

\section{Special Hawn Mixture for Shady Places.}

It certainly is displeasing, to say the least, when the larger part of the lawn presents an attractive appearance that its effect marred by bare, unsightl to an extent be obviaced by sowing grasses whic
This inixture is composed of such varieties and

extent euter into the ordinar

that where the shade

the case. If so the moss should be

over and entiched, and an application of slaked linie one bushel to
30c. Der $1 \mathrm{~b}$. 

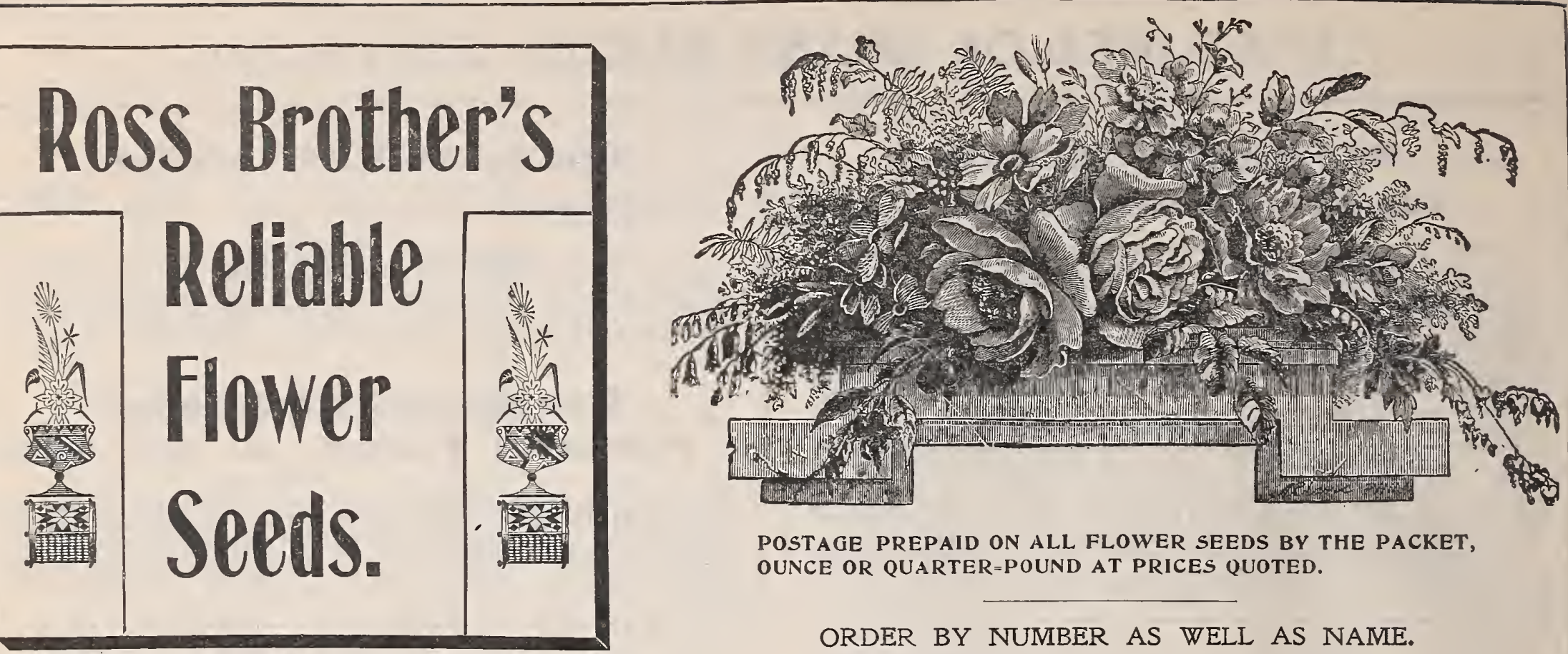

POSTAGE PREPAID ON ALL FLOWER SEEDS BY THE PACKET, OUNCE OR QUARTER=POUND AT PRICES QUOTED.

ORDER BY NUMBER AS WELL AS NAME.

\section{ABRONIA.}

1-Umbellata. A beautiful little trailer suitable for vases, rock-work, etc. Flowers fragrant, rosy pink, borne in large trusses. Half hardy annual; $\frac{3}{4 t} \ldots \ldots \ldots \ldots \ldots \ldots \ldots . . .6 \mathrm{c}$.

\section{ACROCLINIUIM * Everlastíng Flower.}

A free-flowering plant, suitable for garden culture. Flowers when d:y are largely used for winter bouquets. Half hardy annual; $1 \mathrm{ft}$.

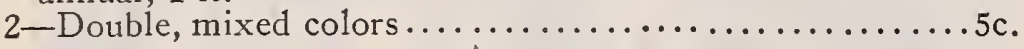
ADLUMIA * Mountain Fringe-Allegheny Vine.

3-Cirrhosa. A beautiful climber with graceful, feathery foliage, bearing freely all summer small rose colored flowers. Hardy biennial; $15 \mathrm{ft} . \ldots \ldots \ldots \ldots \ldots \ldots \ldots \ldots \ldots \ldots \ldots . .$.

\section{ADONIS * Pheasant's Eye-Flos Adonis.}

4-Autumnalis. A free-flowering garden plant with finely cut dark green foliage, bearing blood-red flowers. A popular and desirable plant, remaining in bloom for a long time; of easy culture. Hardy annual; $1 \mathrm{ft} . \ldots \ldots \ldots \ldots \ldots \ldots . . . .6 \mathrm{c}$.

\section{AGERATUM}

Favorite annual plants, profuse and continual bloomers, growing from six inches to two feet in height. The tall varieties are very suitable for planting in clumps or masses, producing a striking effect and furnishing an abundance of cut flowers. The dwarf varieties are very desirable for edgings, and both make excellent pot plants.

5-Mexicanum. Lavender blue; $2 \mathrm{ft} \ldots \ldots \ldots \ldots \ldots \ldots . \ldots . .$.

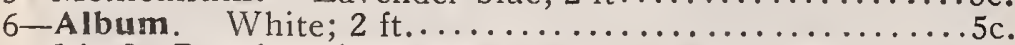
7-Little Dorrit. Azure blue, very compact; $\frac{1}{2} \mathrm{ft} \ldots \ldots \ldots . . . .5 \mathrm{c}$.

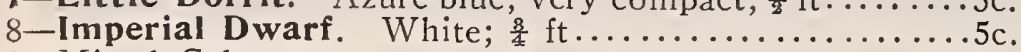
9-Mixed Colors..............................

\section{AGROSTEMA.}

Pretty, free-blooming plant, useful both for cutting and bedding.

10-Cali=rosa (Rose of Heaven) rose, white center. Hardy

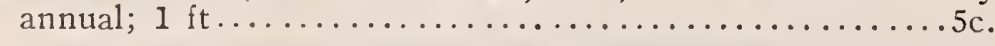

\section{AQUILEGIA * (Columbine).}

Hardy herbaceous perennials, deserving a place in every collection of perennials. Flowers curiously and gracefully formed and beautifully colored; of easy culture; $1 \frac{1}{2}$ to $3 \mathrm{ft}$.

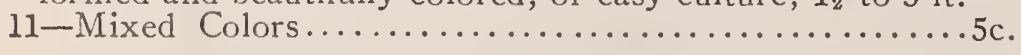

\section{ASPERULA * Swee Woodruff.}

12-Odorata. A free-blooming plant, bearing fragrant blue flowers which remain a long time in bloom. Hardy

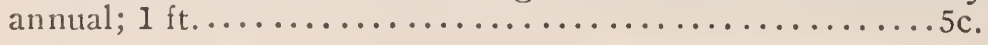

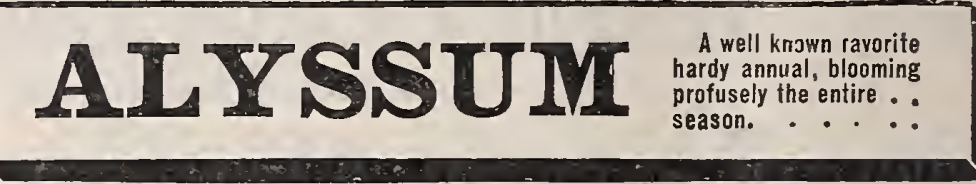

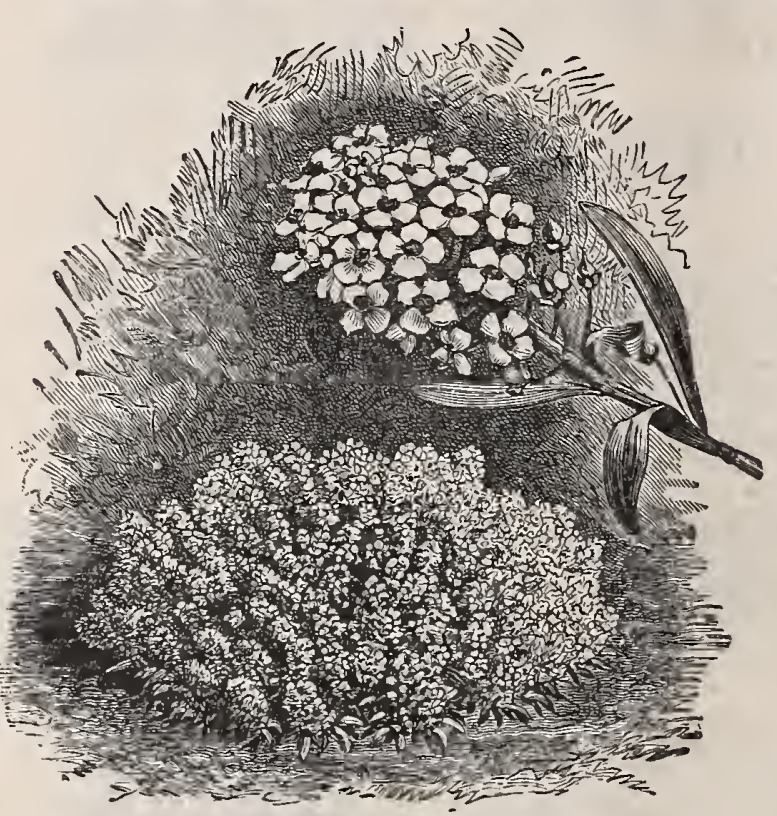

Sweet Alyssum.
$13-5$ weet Alyssum. Fragrant white; 1 ft. Oz. 25c., $\frac{1}{2}$ oz. $15 \mathrm{c} . \ldots$. c... 14 - Little Gem. Dwarf, growing but a few inches high, of spreading or trailing hubit, forming compact masses of bloom often a foot or more in diameter; very useful for edgings. Oz. 40c., $\frac{1}{2}$ Oz. $25 \mathrm{c} \ldots 5 \mathrm{c}$. AMARANTHUS.

Ornamental foliage and flowering plants; very showy and interesting, of rapid growth and easy culture; color of foliage will be better if planted on rather poor soil; half hardy annuals.

15-Caudatus. (Love-lies-bleeding.) Long, drooping flower, spikes dark red .............................. 16-Tricolor. (Joseph's Coat. Red, yellow and green foli-

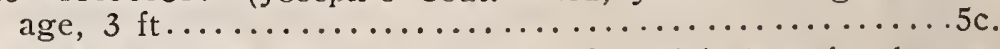
17-Salicifolius. (Fountain Plant.) Graceful, drooping leaves, varying from green to bronze, banded and tipped with

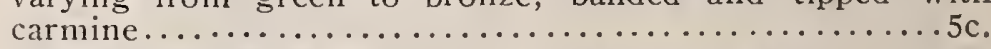

18-Mixed Varieties, including above and others.......5c.

\section{ANTIRRHINUTM * Snap Dragon.}

Well known favorite border plants, half hardy perennials, flowering first year from seed sown in spring.

19-Tall Varieties. Mixed Colors $; 2 \mathrm{ft} . \ldots \ldots \ldots \ldots \ldots . \ldots$. 20-Dwarî or Tom Thumb Varieties. Mixed Colors....5c. 


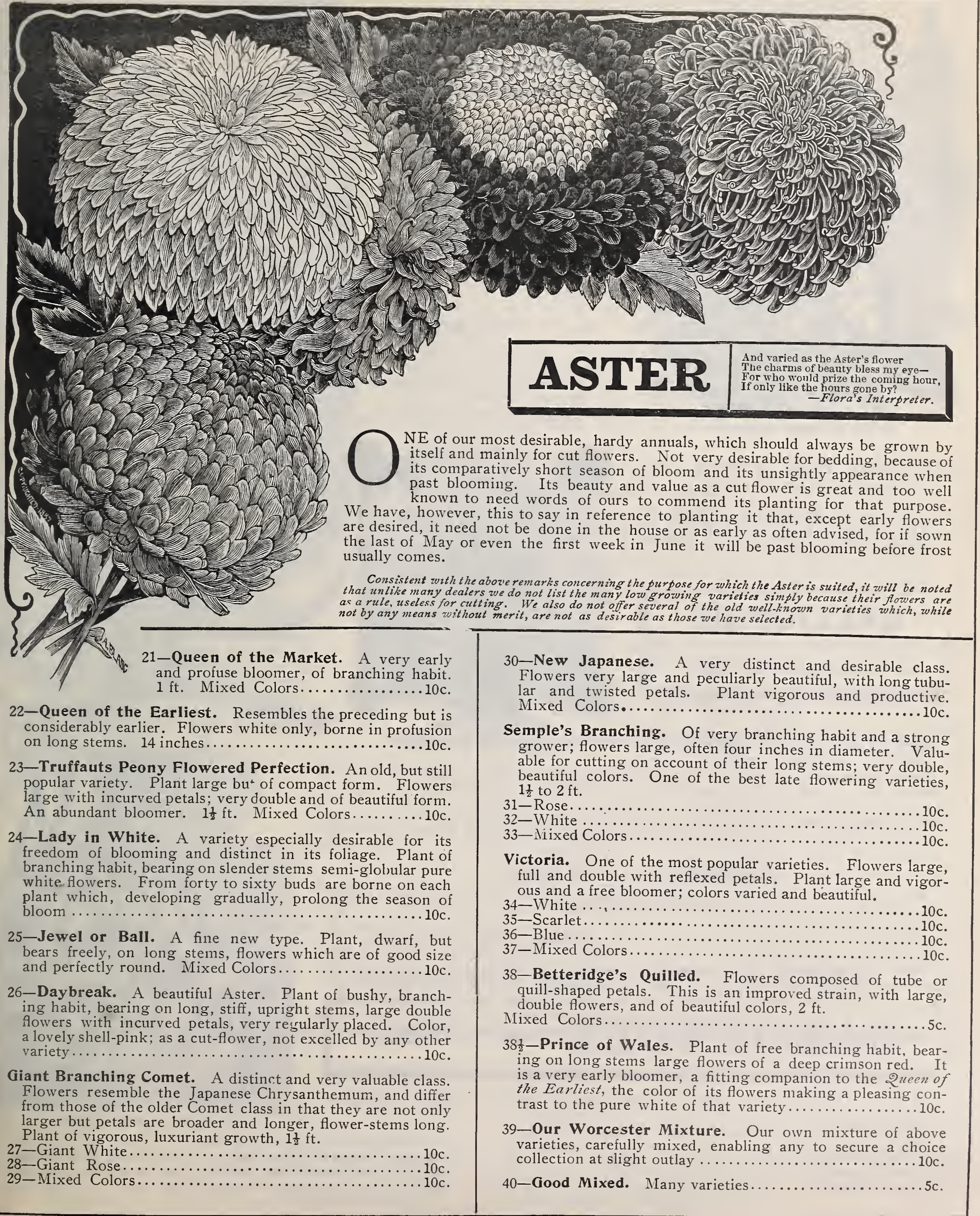




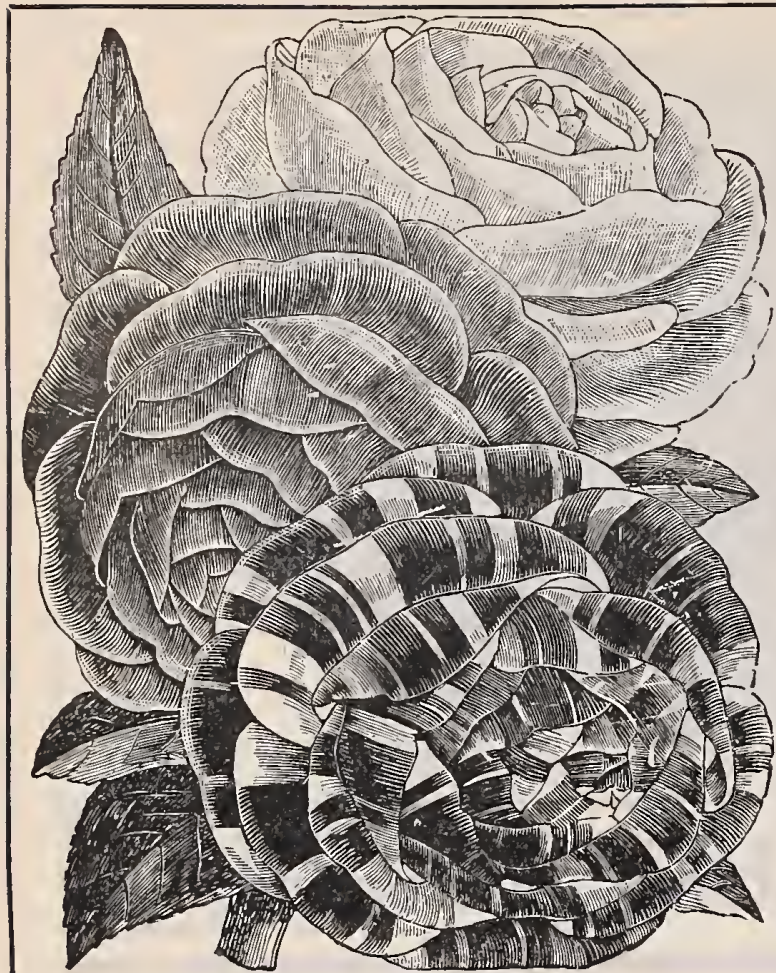

Improved Double Balsams.

BALLOOIN VINE * Love in a Puff. (Cardiospermum Halicacabum.)

47-A tender annual climber of rapid growth, bearing small white flowers, followed by curious inflated seed vessels, somewhat resembling a balloon; 10 to $15 \mathrm{ft} \ldots \ldots . .5 \mathrm{c}$

\section{CALLIOPSIS}

For Perennial Varieties See Coreopsis.

One of the most graceful and satisfactory hardy annuals, profuse and continuous bloomer, sometimes called "Bright Eyes." Flowers brilliant yellow, orange, crimson, red and brown, spotted or margined with different shades, and having long stems are excellent for cutting.

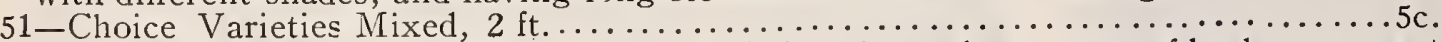
52-Golden Wave. (Drummondi.) Plant distinct from above sorts, of bushy, compact and dwarf habit. Flowers large, often 2 inches across; beautiful golden yellow with

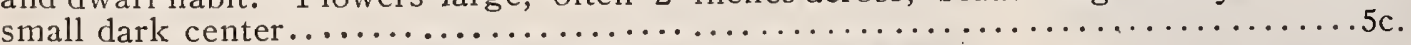

\section{CALENDULA * Pot Marigold.}

A free and continuous blooming plant of dwarf, bushy habit; of the easiest culture, growing freely in nearly all soils. Desirable both for garden decoration and pot culture. Hardy annual; $1 \mathrm{ft}$.

53-Meteor. Light yellow, striped with deep orange; very popular..........5c. 54 -Prince of Orange. Bright orange, striped with light yellow
55-Trianon, the Royal Marigold. Very large, sulphur-yellow, striped with deep, rich brown ................... 56-Pongei. White Marigold........5c ual ; 2 to $3 \mathrm{ft}$

\section{CANDYTUFT * IEERIS}

Well known, popular hardy annual, of easiest culture; useful for bedding, edgings or

57-White Rocket. (Empress.) Large trusses, $1 \mathrm{ft}$. $\frac{1}{2} \mathrm{oz}$.

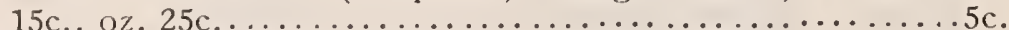

$58-$ White Fragrant. $1 \mathrm{ft} . \frac{1}{2} \mathrm{oz} .15 \mathrm{c}, \mathrm{oz} .25 \mathrm{c} \ldots \ldots \ldots \ldots .5 \mathrm{c}$.

59-Tom Thumb. Very dwarf, mixed colors.........5c.

60 -New Carmine.
A distinct shade $\ldots \ldots \ldots \ldots \ldots \ldots \ldots \ldots \ldots$.
LADY SLIPPER TOUCH $=$ ME-NOT

An old favorite garden flower which has been greatly improved in recent years. The Camellia llowered varieties are especially fine, and if planted on

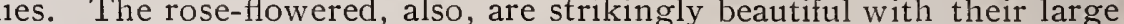

41-Double Camellia FIowered. Mixed " 43-Double Pure White.........10c. 44-Double Dark Red............10c.

45 -Good Mixed................ 5c

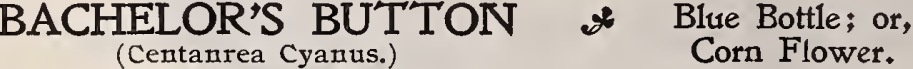

A well known and very popular plant, blooming early and continuously until autumn if flowers are not allowed to go to seed. White, blue and pink. Hardy

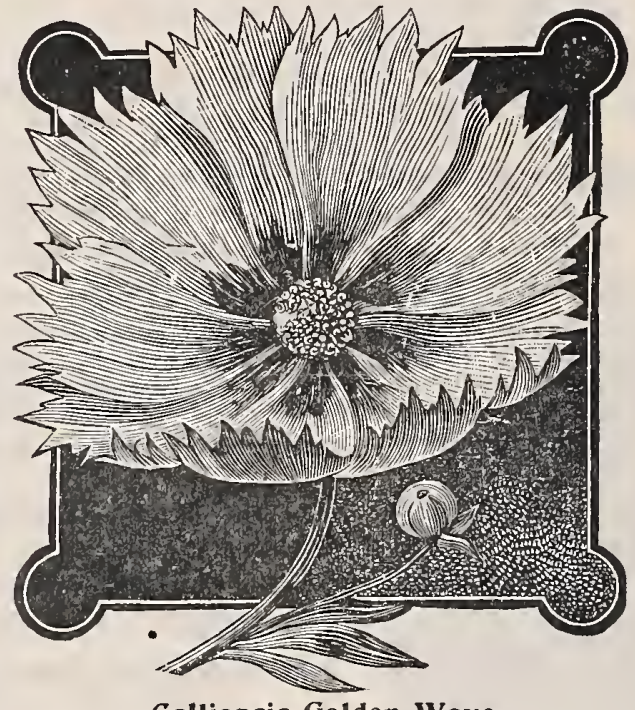

BRACHYCOME * Swan River Daisy.

A free flowering plant of dwarf compact growth, bearing in great profusion beautiful single blue or white flowers. Effective as edgings or in beds, and suitable for rustic baskets or pot culture. Half hardy annual.

48-Mixed Colors..................

BROWALLIA * Amethyst.

Strikingly beautiful plants and p rof use bloomers, succeeding best when started in the house or hot-bed, but can be sown in the open ground. When successfully grown the plants are completely studded with the rich, beautiful blue and white flowers. Half hardy annual.

49-Roezii. Blue and white mixed....10c. 50-Elata. Mixed................

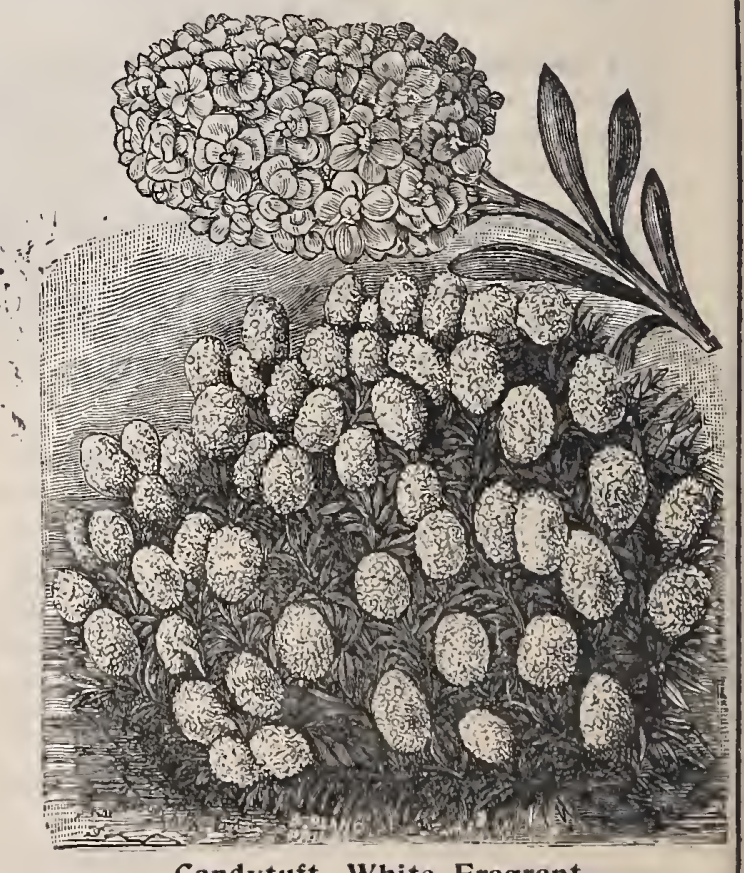

Candytuft-White Fragrant.

6l-Fine Mixed. $\frac{1}{2} \mathrm{oz} \cdot 15 \mathrm{c}$, oz. $^{2} \mathrm{c} \mathrm{c} \ldots \ldots \ldots \ldots \ldots \ldots \ldots \ldots$ 62-Semper virens. (Perennial.) A hardy dwarf, early flowering plant, well adapted for rockeries, etc., or for front rows of perennial borders; about ten inches high.............5c. 


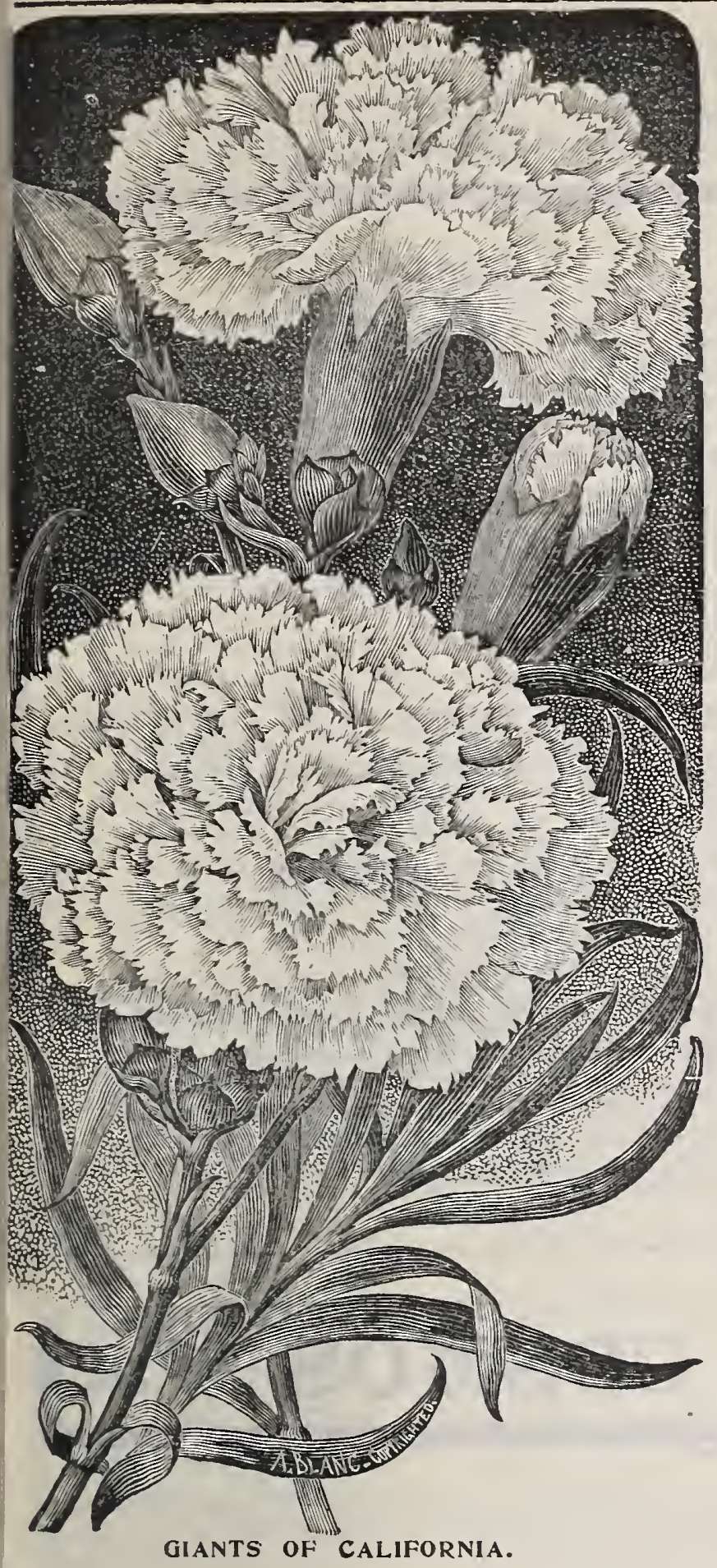

GIANTS OF CALIFORNIA.

\section{CARNATION men}

A beautiful, well-known and extremely popular flower; half hardy perennial the Marguerite class, however, flowering the first year from seed and in a comparatively short time.

63-Choice Double Mixed.

Marguerite. One of the greatest acquisitions to the flowers which the aniateur can conveniently grow, enabling all lovers of this beautiful flower to secure very satisfactory and immediate results without the usual care and time necessary to succeed with the Carnation of the older types. Flowers may be had from August until severe frost comes from seed sown in the spring, which have the characteristic form atıd fragrance of the Carnation proper, borne in greater profusion and on plants of more bushy and vigorous growth. Too much could not be said in praise of this, nor could it be too highly commended for the amateur's use.

64-Choicest Mixed. Complete assortment of colors................

\section{MARGUERITE CARNATIONS * Giants of California。}

An improved, extra large flowered strain from California, of vigorous, robust habit but having the same dwarf compact form of above, blooming also as early and produeing larger flowers, many of which are as fine and more freely produced than those grown by florists in the greenhouse. A very shy seeder.

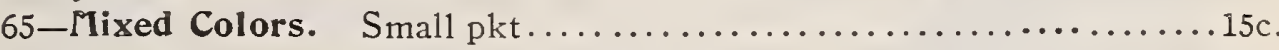

\section{HARDY GARDEN CARNATIONS \& For Open Ground.}

Plants of low, bushy, tufted form, producing on long stems the beautiful fringed flowers with their delightful clove fragrance, known as "Clove

Pinks," so highly valued in the "old fashioned garden" and which merit a. place in the perennial bed and border of today.

66-Plumarius Double Mixed. Double fringed, fragrant flower, white, crimson or purple shades, beautifully shaded and spotted.............

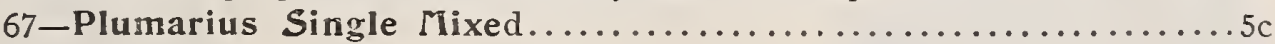

\section{CASTOR BEAN Ricinus}

$\mathrm{W}^{\top}$ ell known tender annuals; tall, stately, majestic plants of very rapid growth. with palm-like leaves of glossy green, brown or bronze hue; very effective for lawns, planted singly or in groups; 6 to $15 \mathrm{ft}$;

70-Sanguineus. (Tricolor.) Stalks blood-red, foliage reddish bronze with scarlet seed pods; $6 \mathrm{ft}$. $\frac{1}{2} \mathrm{oz} .12 \mathrm{c}$., oz. $20 \mathrm{c} . .5 \mathrm{c}$. 71-Zanzibarensis. A comparatively new class, with gigantic leaves ranging in color from light green to bronzy maroon; 10 to $15 \mathrm{ft}$. Mixed varieties. $\frac{1}{2}$ oz. 12c., oz. $20 \mathrm{c} . \ldots . . .5 \mathrm{c}$. 72-All Varieties Mixed. $\frac{1}{2}$ oz. 10c., oz. 15c..........

\section{ANNUAL CHRYSANTHEIMUIS}

-FRENCH MARGUERITES OR PAINTED DAISIES.

Free-flowering plants of branching habit, with rich, finely cut and very ornamental dark green foliage, bearing on long stems daisy-like flowers of bright and varied colorings. These colorings on the single varieties are usually in distinct rings and look on the flat petals as though they were painted on. The double varieties withstand the heat of summer, blooming more freely than the single, the latter requiring cooler weather to bloom freely but are much more beautiful than the double. Both grow freely from seed, are of easy culture, very desirable for cutting, and are effective bedding plants.
They should be given plenty of room, from two to two and one-half feet, and will bloom more freely on soil of medium fertility. 1 to $1 \frac{1}{2} \mathrm{ft}$.

73-The Sultan. (Atro-Coccineum.) Large velvety single flowers, crimson maroon with golden ring............

74-Eclipse. Large single flowers, golden yellow with scarlet

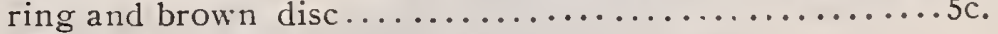

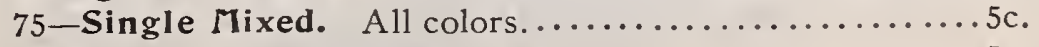
76 -Corinarium Double Mixed................. 


\section{CANTERBURY BELI \\ Tu me there's a toue from the Blue-bell flower A As ste thanked the sun for his beams the while, That flower has taught me to repay

Beautiful hardy biennial plant, of easy culture, a profuse bloomer, succeeding best in a light, rich soil; bearing flowers of rich and exquisite colorings. Like most biennials, it can be sown after mid-summer where it is to remain, or in the spring for transplanting. Plants should stand about two feet apart. $2 \frac{1}{2} \mathrm{ft}$.

77-Double. Mixed colors....................

78 -Single. Mixed colors......................

\section{CUP AND SAUCER CAN'TERBURY BELL. (Companula Calycanthema.)}

Flowers of this class are of peculiar form and strikingly beautiful, that part resembling a cup is about three inches in length or depth and the saucer from three to four inches in diameter. This plant is a very free bloomer, often bearing during its season of several weeks in early summer a hundred or more of its exquisite blossoms, and is, when in full bloom, a pyramid of beauty.

79-Mixed Colors.

\section{CANARY BIRD FLOWER * Tropaeolum Peregrinum.}

80-A favorite half hardy annual climber of rapid growth, bearing curiously formed yellow flowers having a fancied resemblance to a canary bird; blooms from July until frost;

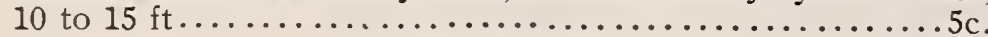

\section{CLARKIA.}

Favorite hardy annuals, bearing beautiful, delicate, rose-colored, purple and white flowers; profuse bloomers; of easiest culture; $1 \frac{1}{2} \mathrm{ft}$.

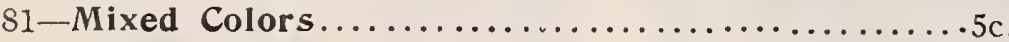

\section{COBEA.}

82-Scandens. A rapid growing perennial climber, flowering the first year from seed, bearing flowers which are at first green, changing soon to deep violet or purple. It should not be sown in open ground until soil has become quite warm, and will germinate most readily if seed is pushed into soil edgewise and barely covered; 20 to $30 \mathrm{ft} . \ldots \ldots \ldots \ldots 10 \mathrm{c}$.

\section{COCKSCOMB * Celosía Cristata.}

Popular annuals, producing flowers which somewhat resemble a cock's comb; of various colors, rose or crimson the most striking; of easy culture.

83-Glasgow Prize. Immense crimson combs; $1 \mathrm{ft} . \ldots \ldots 5 \mathrm{c}$. 84 - Mixed Colors........................... COCKSCOMB FEATHERED * Celosia Plumosa.

Of branching habit, producing large, graceful, plume-like flowers; beautiful and effective; 2 to $3 \mathrm{ft}$.

85-Ostrich Plume. Crimson................... 86-Ostrich Plume. Golden.................. 87-Mixed Colors. Crimson, orange, yellow, rose, etc....5c. Columbine. (See Aquilegia.)

Convolvulus. (See Morning Glory.)

COREOPSIS For Annual Varieties See Calliopsis.

88-Lanceolata. A beautiful hardy perennial, flowering the first year from seed sown early; forming large clumps, growing from two three feet high, bearing on long stems large rich, yellow flowers in great profusion; very desirable for cutting; of the easiest culture, growing anywhere, and should

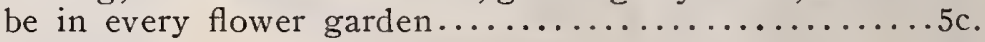

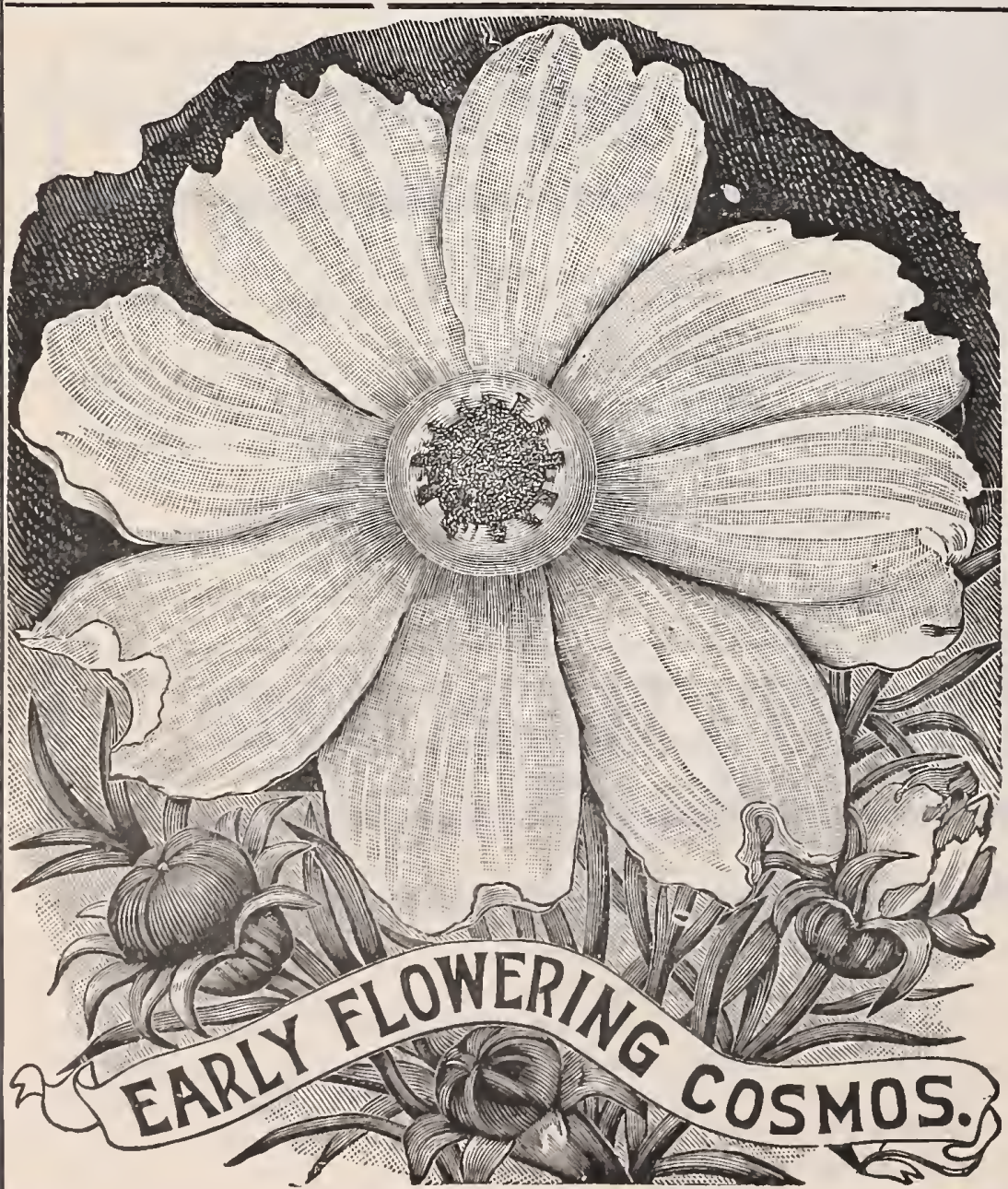

\section{* $*$ COSMOS}

A rapid growing, graceful plant, with beautiful feathery foliage, bearing flowers which resemble the Single Dahlia; a very hardy annual of strong, vigorous habit, growing about five feet high in ordinary soil, and often eight feet in very rich. It is seldom given room enough; plants should stand not closer than two and one-half feet apart, and in rich soil a greater distance. The Cosmos makes a most desirable background for many other plants, its beautiful, finely cut foliage alone making it well worth the growing for this purpose; its value, however, is greatly increased by its lovely flowers, white, pink, crimson or rosy purple, borne in great profusion on long stems, rising above the foliage in an especially graceful manner, equally graceful in appearance when arranged in a vase with sufficient foliage; for this purpose but few other flowers are as desirable and none can be had so late in the season, as, owing to the great hardiness of the plant, it bears fine flowers even after the first light frosts have come.

89-Mammoth Perfection. Flowers of mammoth size, rather late in flowering and, as the plant is quite hardy, seed should be planted as early as possible and will then, in most seasons, produce a profusion of flowers before frost..............

90-New Early Flowering. This, while flowers are not as large as those of the Mammoth, is growing in favor because of its earliness. If seed is sown in open ground in early spring, plants will begin to bloom the last of July and continue until November, making it, therefore, especially desirable in northern

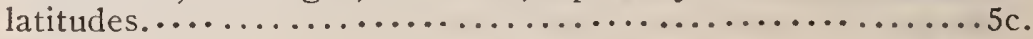




\section{CYPRESS VINE \& Ipomoea Quamoclit.}

A very popular climber, with delicate, feathery foliage, bearing small, star-shaped rose, scarlet and white flowers, presenting a very pleasing contrast with the beautiful dark-green foliage. Tender annual; 12 to $15 \mathrm{ft}$.

91--Mixed Colors.

\section{DAISY * Bellis Perennis.}

A hardy perennial plant, of dwarf, compact growth, blooming freely during the cool months of spring and fall; flowers very double, about one inch in diameter, borne singly on a stem about five inches high. A beautiful little plant well adapted for edgings, and should be more generally cultivated. It bears transplanting well, even when in flower, and thrives best on richly manured soil and in a cool, partially shaded location.

92-Mixed Colors

Dianthus. (See Pink.)

Digitalis. (See Foxglove.)

\section{DATURA.}

93-Strong, vigorous plants, of branching habit, bearing large trumpet-shaped flowers six to eight inches long and very fragrant. Tender annuals; $3 \mathrm{ft}$. Finest Mixed.......5c.

\section{DUTCHMAN'S PIPE \& Aristolochia Sipho.}

94-A beautiful, rapid growing climber, bearing curiously formed, purplish brown flowers, thought to resemble in shape a pipe. Hardy perennial; 15 to $30 \mathrm{ft} . .$.

\section{ESCHSCHOLTZIA * California Poppy •}

Very showy hardy annual, with beautiful, delicately cut foliage, bearing bright yellow and scarlet flowers; one of our most attractive annual plants, blooning early and continuously. Succeeds best in light, rich soil, and should be sown where designed to grow, as it does not bear transplanting; $1 \mathrm{ft}$.

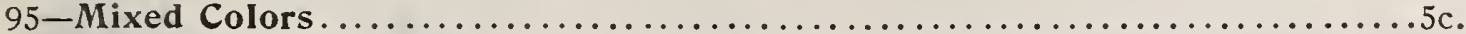

96-Douglasii. Plant very dwarf and compact, only six inches high; blooms very early, profusely, and when quite small; flowers small, clear lemon-yellow. Excellent for bed-

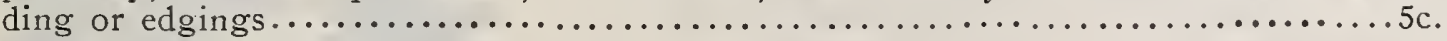

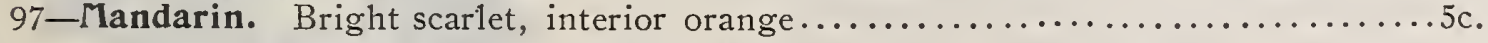

\section{EUPHORBIA VARIEGATA \& Snow-on-the-Mountain.}

98-A showy, hardy annual plant, grown for its striking foliage. Leaves, dark green, veined and margined with white. Very effective in the garden or on the lawn.....5c. EUPHORBIA HETEROPHYLLA * Mexican Fire Plant, or Annual Poinsetta.

99-This is somewhat similar to the brilliant Puinsetta, grown in pots in the greenhouse during winter and which is a very popular decorative plant. This, however, can be easily grown from seed in the open ground, which should be sown when trees are starting into leaf. It produces large bracts of fiery scarlet which, in contrast with the dark green foli-

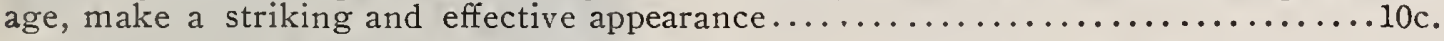

\section{FORGET-ME-NOT * Myosotis.}

An old, well-known and favorite garden plant; hardy perennial, flowering the first year from seed sown early in the spring, succeeding best in cool, moist soil and thriving well in partial shade.

100-Alpestris. Plant dwarf and compact, about six inches in height; flowers star-

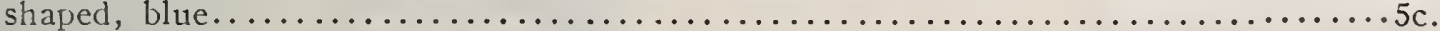

101-Alpestris Alba. Similar in habit of growth, but the florets are pure white....5c. FOUR O'CLOCK \& Marvel of Peru. (Mirabilis.)

A well-known and favorite plant, bearing freely funnel-shaped white, red and striped flowers, which open about four o'clock in the afternoon and perish before noon the next day; of easy culture, will grow anywhere, but should be given plenty of room-at least three feet each way.

102-Mixed Colors.

\section{FOXGLOVE * Digitalis.}

Favorite perennial plants, of easy culture. Flowers borne on long spikes; 3 to $5 \mathrm{ft}$. 103-Mixed Colors.

\section{GALLIARDIA * Blanket Flower.}

A very free-flowering class of plants, entirely hardy, blooming the entire summer, of easiest culture and succeeding well in the poorest soils. Flowers brilliant and beautiful, 2 to 3 inches in diameter, borne singly on long stems; exceptionally fine for cutting.

104-Choice Mixed. Comprising a wide range of colors in both single and double varieties; hardy annuals, some of which become perennial by protection of the roots in

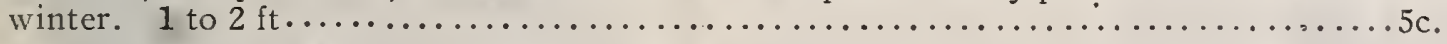

105-Picta Lorenziana. (Double.) Large, round heads composed of many individual florets, richly colored in shades of bronze, brown, maroon, etc., brightly tipped with shades of yellow and creamy white; hardy annual. Mixed colors.......... $.5 \mathrm{c}$.

\section{GODETIA.}

Attractive hardy annuals of compact growth, bearing profusely large flowers beautifully colored; fine bedding plants of easy culture; 1 to $1 \frac{1}{2} \mathrm{ft}$.

106-Mixed Colors

GOURDS.

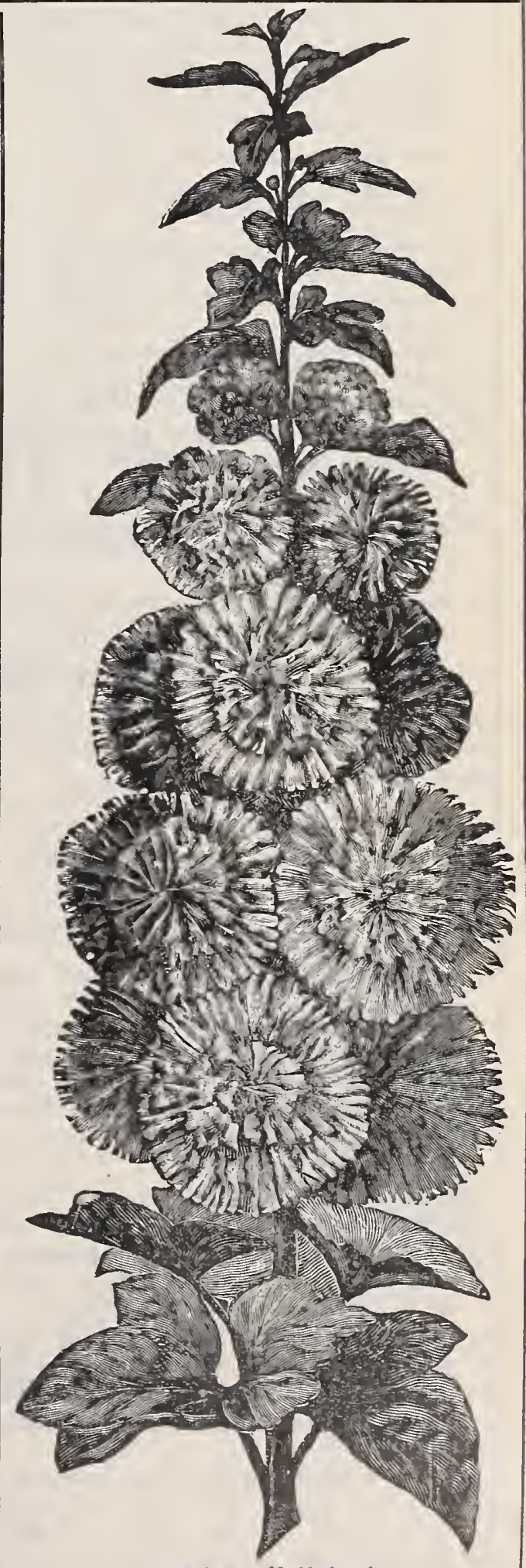

Allegheny Hollyhock

Ornamental, tender annual climbers, bearing curiously formed and colored fruit. Of very rapid growth; useful for covering fences, stumps, etc.; 10 to $20 \mathrm{ft}$. 107 -All Varieties Mixed. 


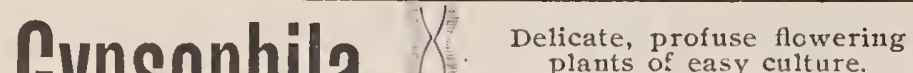

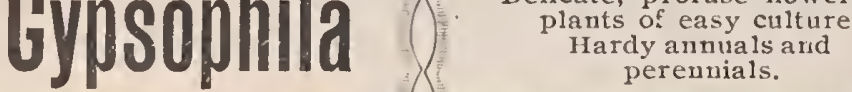

108-Muralis.

A beautiful little annual plant, with fine, feathery, grayish-blue foliage and very small, pink flowers. Grows only about six inches high, and because of that and the distinctive color of its foliage it is excellent and effective for ellgings.

109-Elegans. Hardy annual, about one foot in height, sprays well branched and thickly set with small, white flowers.

110-Paniculata. (Commonly known as Baby's Breath.) Hardy perennial, bearing white flowers; of more branching habit and sprays are longer stemmed than the preceding; very desirable for combining with other flowers in bouquets or vases, especially Sweet Peas; and in our opinion is the only flower or foliage at all suitable for combining with those delicate, lovely flowers.......................

\section{HELIOTROPE.}

A favorite perennial plant, highly prized for its delicious fragrance. We think it is not generally known that it can be had in bloom the first season from seed: but fine flowering plants can be easily grown from seed sown in the house in March. Soil should be light and rich, and young plants kept in a warm, sunny location. Sow seed in shallow boxes and transplant before plants become crowded into small pots. If desired for bedding, wait until nights are warm. Make the soil rich and give it an abundance of water.

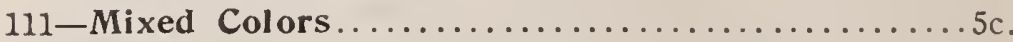

\section{HELICHRYSUM $\nsim$ Or Everlasting Flower.}

Free-blooming, hardy annual plant, of easy culture. The flowers are large, full and double, of various colors, white, scarlet, yellow, etc., and are often used when dry for winter bouquets.

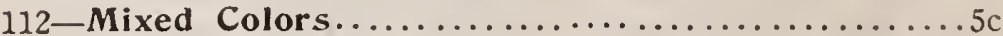

\section{HOLLYHOCK \& "Queen Hollyhock, with Butterflies for Crowns."}

This well-known plant has always been a great favorite, and is perhaps today more popular than ever. Stately and majestic in its growth, it is especially suited for a background to the perennial border. Although a biennial it becomes perennial by proper treatment, continuing to grow and bloom for several years if the flower spike is cut off as soon as through blooming. Seed may be sown at any time from spring until midsummer and will produce plants which will bloom the following season. The soil should be light, and rich, and well drained.

113-Chater's Choicest Double Mixed. This well-known, superb strain will produce a large percentage of double flowers in a wide range of colors, and has, as

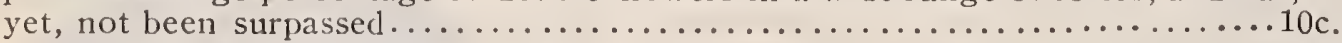

114-Allegheny. (New.) The flowers are not as double as those of the older form, but are distinctly beautiful. They differ both in form and in the manner in which they are disposed on the stem; every bud to the top of the plant develops, making the blooming season a long one. They are enormous in size, often six inches in diameter, of silky texture and beautifully fringed and colored.......10c.

\section{HYACINTH BEAN \& Dolichos Lablab.}

115-Mixed. A tender annual climbing plant, with purple or white flowers, which are followed by very ornamental seed pods. 10 to $15 \mathrm{ft} . \ldots \ldots \ldots \ldots \ldots \ldots . . .$.

\section{ICE PLANT. * (Mesembryanthemum.)}

116-A trailing plant, with succulent stems and leaves, which have the appearance of being covered with ice crystals; excellent for hanging baskets and rock work.

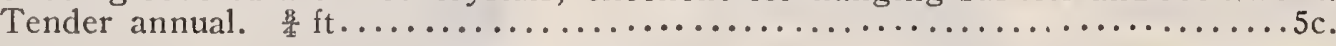

\section{IPOMEA.}

Rapid growing, annual climbing vines, with very luxuriant foliage, producing an abundance of showy flowers, white, pink, blue and purple. While both the flowers and foliage closely resemble that of the Morning Glory of most varieties, both are larger, al though the flower of one of the following (Coccinea) is smaller and of different form, more nearly resembling that of the Cypress Vine. All should be more generally cultivated. 10 to $20 \mathrm{ft}$.

117-Bona Nox. (Evening Glory.) Beautiful, large, violet-blue flowers, which

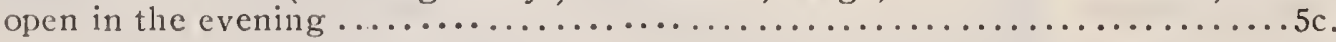

118-Coccinea. (Star Ipomea.) Plant similar to the Morning Glory; flowers small,

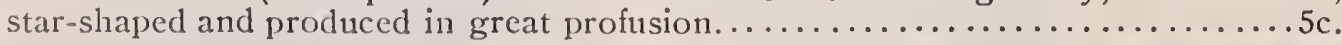

119-Grandiflora, Striped-Leaved. The leaves of this are dark green, mottled with white; the flowers intense ultra-marine blue, edged with sky-blue and shaded

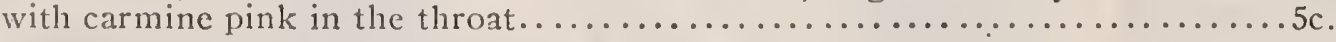

120-Setosa. A beautiful variety, of very luxuriant growth. The leaves are from eight to twelve inches across, the under sides being thickly set with small, reddish hairs, as is also the vine. The flowers are about three inches in diameter, produced in clusters, but one or two in each cluster opening at once; of a lovely

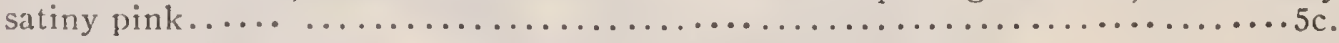

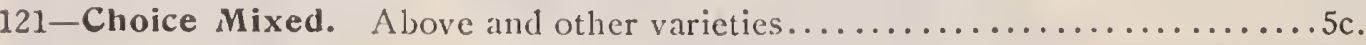

\section{LANTANA.}

Favorite, rapid growing plants, forming small shrulss; profuse and constant bloomers, well adlapted for pot culture, and are very effective planted singly in the garden. Tender perennials, flowering first year from seed if sown early; 1 to $3 \mathrm{ft}$.

122-Mixed Colors.

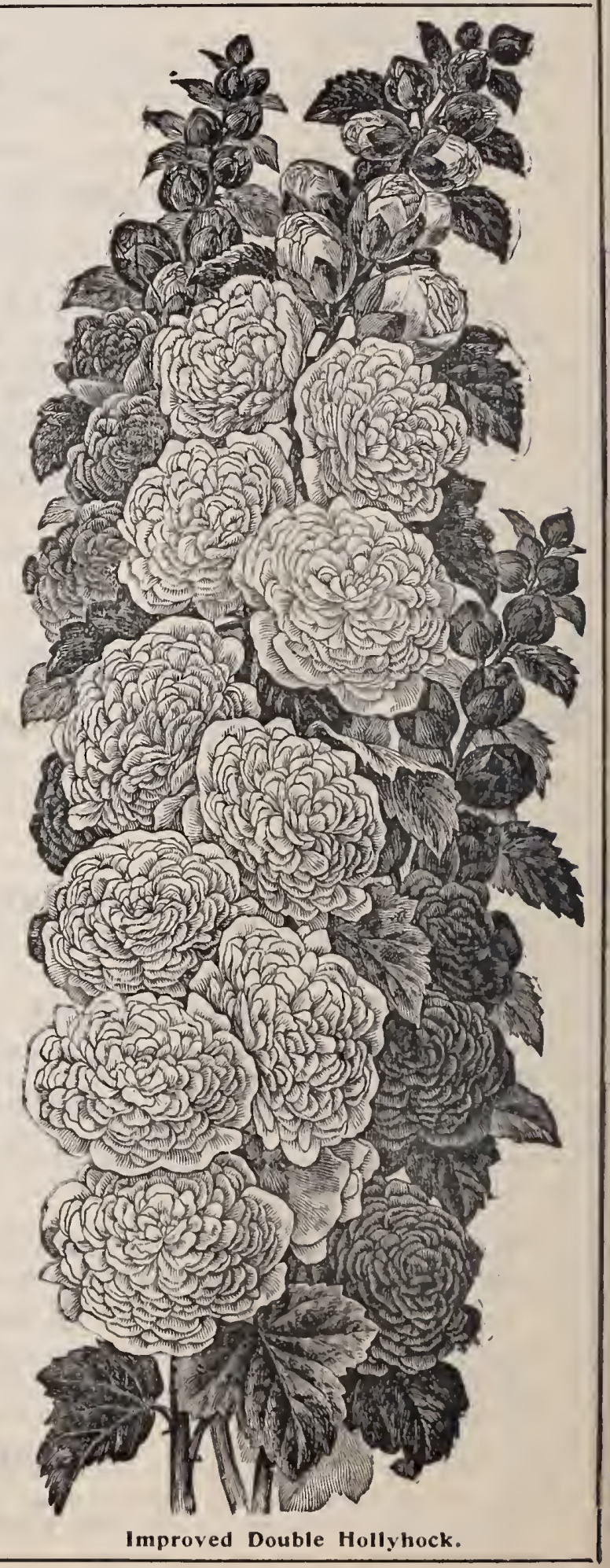




\section{LARKSPUR}

DELPHINIUM

\section{THE MISSION OF FLOWERS.}

Violet, why are your eyes of blue

Wet with tears of the morning dew?

Rosebud, why do you blusli and start,

And lide the crystal gem at your lieart?

,ily, what are you doing there,

with your bells a-swing in the balmy air?

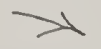

Popular annual, biennial and perennial plants, with finely cut leaves and beautiful flowers, which are either white, scarlet, pink, blue or purple, but never yellow; of easy culture, succeeding best in a location open to the sun.

123-Double D warf Rocket. Hardy annual ; $1 \mathrm{ft}$. ; mixed colors..................

124-Double Tall Rocket. Hardy annual; $2 \frac{1}{2} \mathrm{ft}$.; mixed colors..5c.

125-Elatum. (Bee Larkspur.) Hardy perennial; flowers have curiously folded, hairy petals
A light breene born of the norning lours Softly stole o'er the banks of flowers: And, list'ning closely, I seemed to hear,

Chined in silvery voices clear-

$$
\rightarrow
$$

"We are blessing the earth with our weallh of bloom; We are lading the air with a rare perfume: All things have their 111ission, and God gives us ours, And this is a part of the ninssion of flowers: To give life to the weary and lope to the sad, Fresh faith to the faithless. new joys to the glad; io cheer the desponding, give strength to the weak; 'To bring health's bright bloom to the invalid's cheek ro blush on the brow of the beautiful bride; 1'o cheer homes of mourning where sorrows betide; To rob dreaded Deatli of a part of his glooni, By decking the dear one arrayed for the tomb; 10 furnish the home with a lasting delight. With our perfumes so lovely, our blossoms so bright To hallow the homestead, embellish the lawn, Reflecting the tints of the roseate dawn. In low, voiceless la nguage, we're striving to tell How God, in His wisdom, dotl1 everything well." -Dart Fairthorne. in the center, giving them a fancied resemblance to a bee. Intense blue, plant five feet ligh

126-New Compact Blue. Harly perennial, flowering freely the first year from seed, if sown early. Rich flowers, large, lark blue. Plant about one foot high, growing a little taller the second year, and blooming even more profusely.

$10 \mathrm{c}$.

127-LA VENDER. Hardy perennial plant, bearing long spikes of blue flowers; chiefly grown on account of its delicious fragrance, which the plant, when dried, retains for years...........5c

128-LINUM. (Scarlet Flax.) A very showy and beautiful hardy annual, bearing profusely bright, scarlet flowers; $1 \mathrm{ft} . . . . . .5 \mathrm{c}$.

\section{LOBELIA.}

Pretty, graceful, little plants; those of trailing habit being used for hanging pots and rockeries, and those of divarf, compact habit for edgings and bedding.

129-Gracilis. Light blue, slender trailer, half hardy annual;

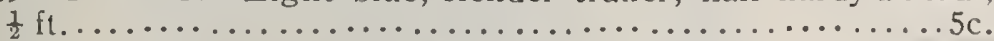

130-Crystal Palace, Compacta. Of dwarf, compact growth, excellent for edgings; blue. Half hardy annual; $\frac{1}{2} \mathrm{ft} . . .5 \mathrm{c}$.

131-White Gem. Plant of similar habit to the preceding variety; flowers pure white......................

132-Cardinalis. (Cardinal Flower.) This is a native species, of greatly different habit from the others, growing about two feet high. Though usually found when growing wild in moist places, it succeeds well in the common border and is one of the best perennials for the shady side of the house. Its spikes of intensely brilliant, cardinal red flowers make it one of the most effective plants..................

\section{LOVE-IN-A-MIST * Nigella Damascena.}

A favorite annual, bearing blue and white flowers half hidden by the fine, feathery foliage. Known also as Lady-in-theGreen and Devil-in-the-Bush; $1 \mathrm{ft}$.

133-Mixed

\section{LUPIN.}

Very showy plant, bearing spikes of pea-shaped blossoms of rich and varied colors; a free bloomer and easily grown. Hardy annual; $1 \frac{1}{2}$ to $3 \mathrm{ft}$.

134-Mixed Colors.

\section{LYCHNIS * London Pride-Burning Star.}

Hardy perennials, some of which will flower the first year from seed, and but few plants produce more brilliant blossoms. The plant blooms freely and continuously, bearing its clusters of scarlet flowers through the entire summer.

135-Chalcedonica. (London Pride.) Bright scarlet; $2 \mathrm{ft} . .5 \mathrm{c}$.

136-Haageana. Bright scarlet flowers, larger than those of the preceding. Plant about one foot high and will bloom

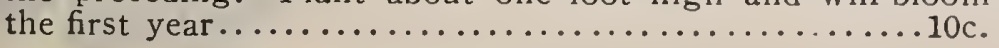

\section{MIGNONETTE

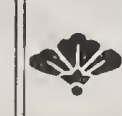 \\ Resada odorato}

A well-known and popular hardy annual, highly prized for its delightiul fragrance. While blooming freely at all times, much larger and finer spikes are produced during the cool, moist weather of early spring and late fall. Seed sown in autumn will bloom in early spring, and when sown the last of July will come into flower in a few weeks and continue until cut down by frost.

137-Sweet Mignonette. Large flowered; $\frac{1}{2} \mathrm{Oz} .10 \mathrm{c}$, , Oz. 15c...5c.

138-Parson's White. Nearly white; fragrant...........

139-Golden Queen. Flowers golden yellow. Growth dwarf but dense................... 140-New Quaker City. Flowers a handsome gold red, rich and fragrant; foliage very dark

141-New Giant Flowered Red. Form pyramidal, quite distinct, very striking and handsome...5c. 142-Choice Mixed. Our own mixture of the above and other varieties. $\frac{1}{2} \mathrm{Oz}, 15 \mathrm{c}, 0 \mathrm{Oz} .25 \mathrm{c} \ldots 5 \mathrm{c}$

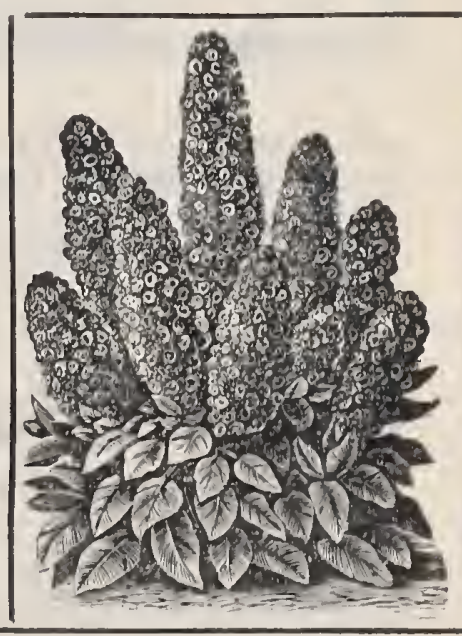

\section{DWARF Morning Clory cowowus

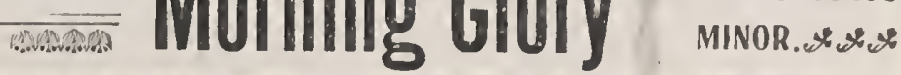

Plant of trailing, branching habit, growing about one foot high and in diameter about two feet, and bearing in great abundance small, bell-shaped fowers similar to the tall varieties. These remain open much later in the day than do those of the tall sorts, often in clear weather till evening. Half hardy annual.

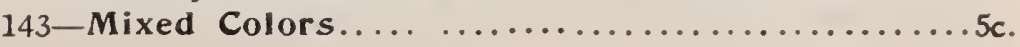




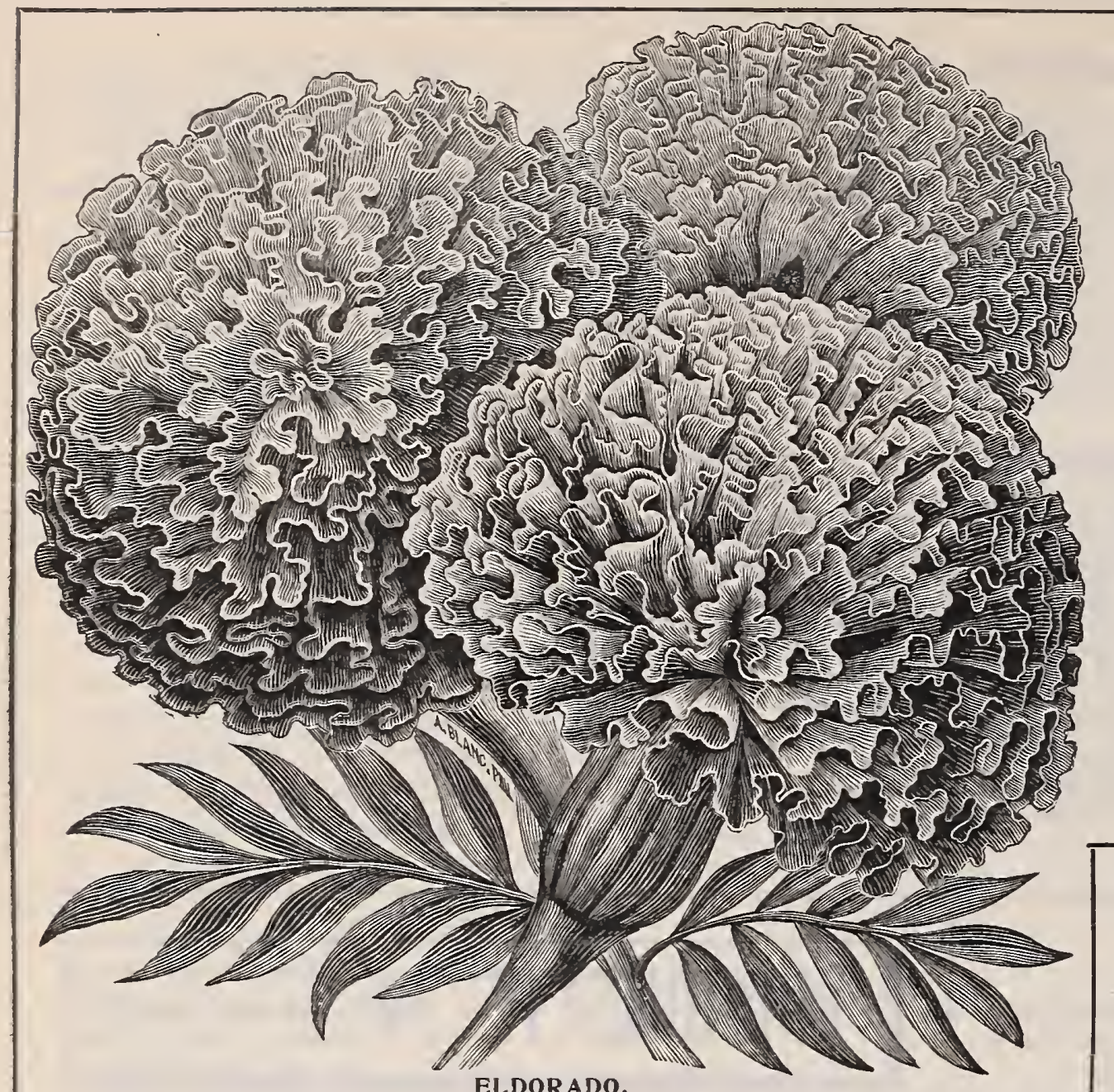

\section{MARIGOLD}

Open afresh your round of starry folds, Ye ardent Marigolds!

Dry up the moisture of your golden lids

For great A pollo bids

That in these days your praises shall be sung

On many harps, which he has lately strung.

Well-known plants, blooming freely and constantly. The African varieties are usually tall, the French more dwarf. Both are great favorites. Hardy annuals. 1 to 3 feet.

144-African Double. Mixed...............

145-African, Eldorado. Flowers very large and extremely double; quilled like a Dahlia; various shades of yellow and orange. $3 \mathrm{ft} . \ldots . \ldots . .5 \mathrm{c}$.

146-French Double. Mixed..............

147-French Double Dwarf, Gold Striped. Golden yellow striped with velvety brown.........5c.

148-French Legion of Honor. A beautiful single variety of dwarf and bushy habit, rich golden yellow, with garnet blotch in center of petal. $1 \mathrm{ft} . .5 \mathrm{c}$.

MOON FLOWER. 148 $\frac{1}{2}$. A rapid growing climber, often attaining a height of $3 n$ feet in a season. Especially adapted to shading porches, etc. To secure flowers in northern latitudes seed should be started early in the house and then be planted out in rather poor soil, else it will run too much to vine. The thick outer shell of the seed should be cut through or a portion chipped off to assist germination....10 c.

\section{IRornins Glory $\bullet$ convolvyturs}

斗

$$
\begin{aligned}
& \text { Flowers, shrinking from the chilly night, } \\
& \text { Droop and shut up; but with fair morning's touch } \\
& \text { Rise on their stems, all open and upright. } \\
& \text {-MONTAGUE. }
\end{aligned}
$$

149-Mixed. All colors. $\frac{1}{2}$ oz. 10c., oz. 15c

150-Double White Tassel. A new, very distinct and beautiful variety. The plant is of rapid growth, blooms early and as profusely as the common Morning Glory. The flowers are double and of snowy whiteness. The seed we offer will produce a much larger proportion of double flowers than any seed of double varieties yet imported from Japan................

\section{IImperíal Fapanese SIDorníng Glorp.}

Every Season Increases the Popularity of this Beautiful Flower.

Among the many wonderful novelties in the floral line introduced into this country from Japan, there is perhaps nothing which better attests the great skill of the Japanese florist or gardener than this superb strain of Morning Glory. Not only are the flowers of an almost endless variety of coloring, but the foliage, as well, is greatly varied and very attractive. The flowers are much larger than those of the old strain and fully as freely produced. Some are brilliant red and some clear blue; others are equal in brilliancy, margined or bordered with clear white. Some are striped or blotched with red or blue on white or yellow ground, and others clouded with blue and red. In fact the morning some new combinations of colorings. The large leaves are of varied form; some are plain green and some green mottled with white, while others are yellow or yellowish-green. So beautiful and effective is this plant and so simple is its culture that it would seem that none who once learned its merit could possibly fail to cultivate it.

151-Choicest Mixed. Comprising seed from several noted growers, both American and foreign, insuring the greatest possible diversity in color of

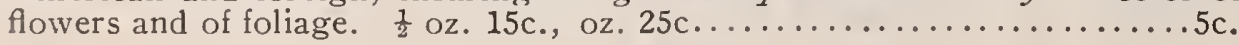

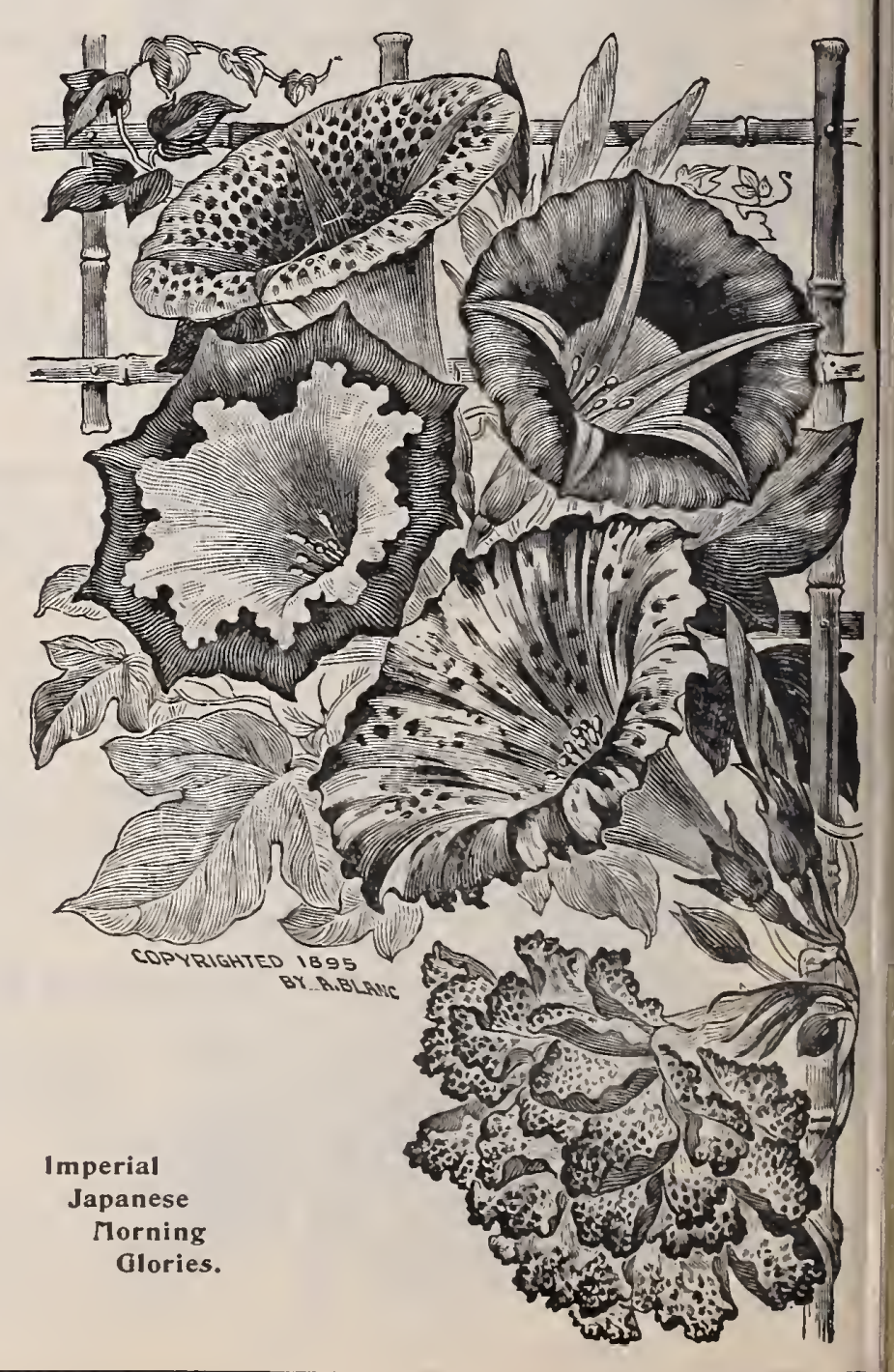




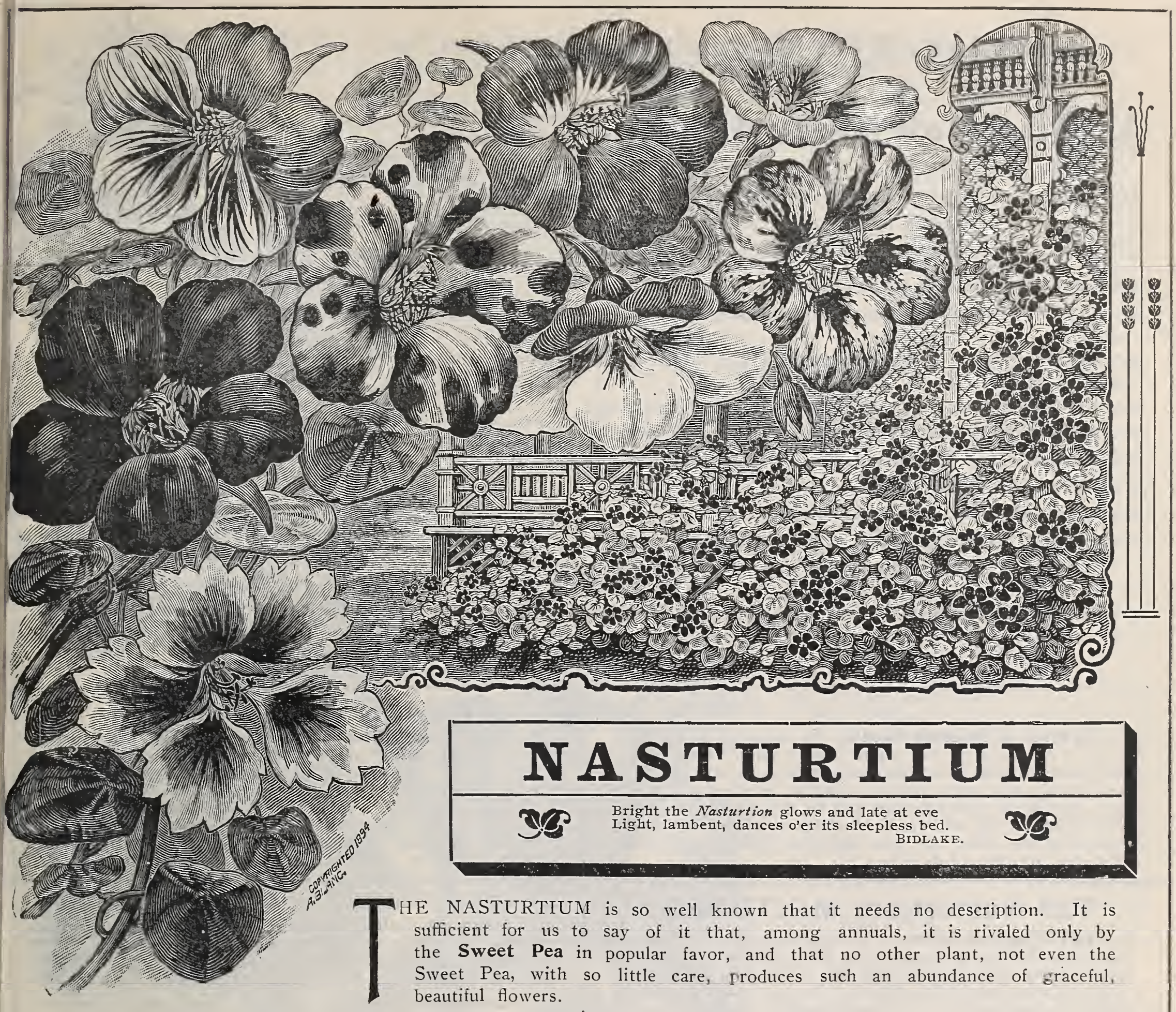

TALL NASTURTIUM * Tropaeolum Majus.

152-Atropurpureum. Rich, dark crimson. Oz. 15c...5c. 153-Dunnett's Orange. Bright orange, blotched red. Oz.

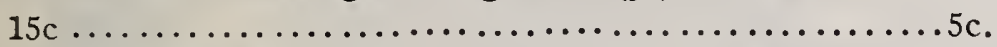
154-Edward 0tto. Light brown with yellow calyx and

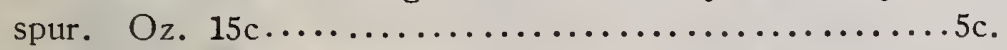
155-Golden Leaved Scarlet. Deep scarlet, with light

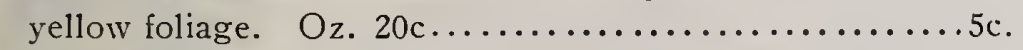
156-Heinmanni. Chocolate Brown. Oz. 20c.........5c. 157-Luteum. Clear light yellow; large. Oz. 20c......5c. 158-Pearl. Very pale yellow, nearest approach to white.

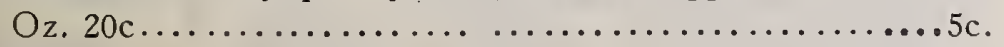
159-Prince Henry. Yellow, marbled scarlet. Oz. 15c...5c. 160-Regelianum. Deep purple violet. Oz. $15 \mathrm{c} \ldots \ldots .5 \mathrm{c}$. 161-Scarlet. Very intense scarlet. Oz. $15 \mathrm{c} \ldots \ldots \ldots \ldots 5 \mathrm{c}$.

\section{THREE GIANT-FLOWERED TALL VARIETIES.} 162-Sunlight. This beautiful variety is of strong, vigorous growth and blooms profusely. The flowers are of the largest size, often nearly three inches across; a clear golden yellow. The petals are large, of rounded form, daintily crinkled. The two upper ones have fine, brown lines at the base; the three lower are more distinctly bearded or fringed at the throat than other varieties:

163--Moonlight. This is nearly the counterpart of the "Sunlight," differing only in color, which is a lovely pale yellow or straw color. It is equal in size and has the same crinkly or crepe-like petals. It is a worthy companion of the preceding rather than a rival, and when grown side by side both show how aptly they are named.

164-Salmon Queen. A beautiful variety, with dark green foliage, bearing flowers of the largest size and beautifully
colored. Of a rich but soft, velvety shade of salmon, the two upper petals heavily veined with crimson in the throat. A fitting companion to Sunlight and Moon
variety with which none can but be pleased. Each variety, pkt. 5c., oz. 15c., $\frac{1}{4}$ lb. 40c. 


\section{LOBB'S Tall Nasturtium; (Troppolum}

This class differs from the common or Majus in being of a more free flowering habit and in the greater brillancy of its flowers. Both foliage and flowers are slightly smaller and it is not as rank in growth as the common. The greater profusion of bloom and brilliancy of color makes it the more desirable to many.

165-Cardinal. Cardinal red; purplish-green foliage.

166-Crown Prince of Prussia. Rich brownish-crimson with veinings of a deeper shade.

167-Crystal Palace. Bright orange-yellow with bronzy-crimson markings at base of each petal.

168-Giant of Battles. Sulphur-yellow with carmine markings.

169-King of the Blacks. Very dark red, foliage dark green.

170-Lucifer. Deep crimson-red, dark foliage.

171-Mercier Lacombe. Purplish-violet.

172-Queen Victoria. Rich orange-scarlet.

173-Spitfire. Brightest scarlet; very free bloomer.

Each variety, pkt. 5c., oz. $15 \mathrm{c} ., 2$ oz. $25 \mathrm{c} ., \frac{1}{4}$ lb. $40 \mathrm{c}$.

174-Lobbianum Choicest Mixed. A mixture of above and other varieties. Pkt. 5c., oz. 10c., $\frac{1}{4}$ lb. 30c.

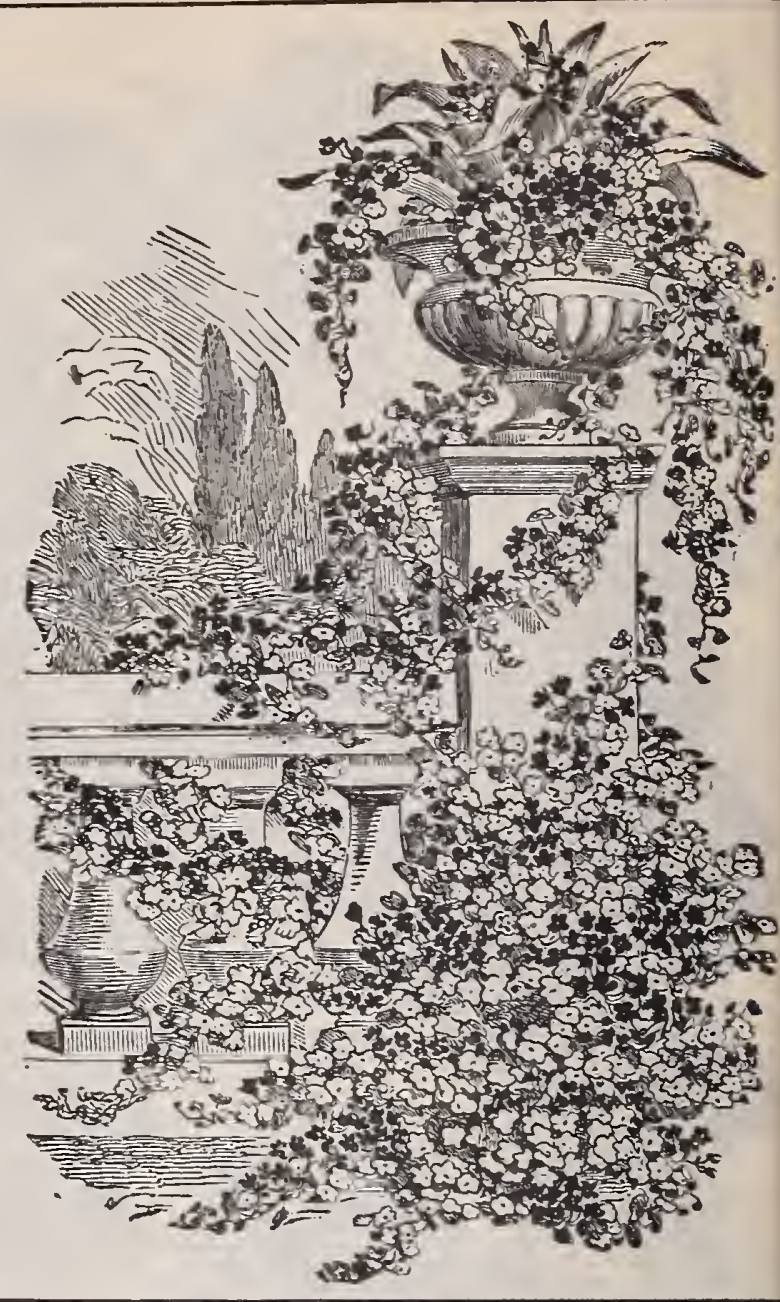

TALL NASTURTIUM.

175-Hybrids of Madame Gunter. A beautiful strain, having a wide range of distinct colorings, salmon tints striped and blotched with different shades of red predominating, but embracing pink, rose, crimson, maroon, purple, light yellow and orange in self-colors as well as striped and blotched. For richness and variety of colorings this class is not surpassed by any other nor does any other bloom more freely. Pkt. 5c., oz. 15c., $\frac{1}{4}$ lb. 40c.

\section{Tall Nasturtium MIXTURES.}

177-Tall Mixed, all Colors. A choice mixture, of which we have sold in the past few years large quantities. It comprises many distinct colorings and is fully equal to most of the mixtures generally offered. Being, however, mostly grown in mixture, it is not guaranteed to contain all of the most desirable varieties, but will, nevertheless, afford an effective display, surpassed only by the Worcester Tall Mixed. Pkt. 5c., Oz. 10c., 支 1b. 25c., 1b. 90c.

178-Worcester Tall Mixed. In this mixture we have one which cannot be surpassed. It embraces many named varieties, including such as the Giant-Flowered Sunlight, Moonlight and Salmon queen, The IJybrids of Madame Gunter, New Freuch Chameleon, and all of the best of the Majus anc Lobbiamum classes. This mixture is made by ourselves and we therefore know just what it is, and can confidently recommend it as the best that ran be made. Pkt. 5c., oz. 15c. 2 oz. 25c., t 1b. 40c., lb. $\$ 1.25$.

\section{Nasturtium \& DWARF, OR TOM THUML.}

This class blooms as freely as the Tall, and, being as well-known, requires 110 description or commendation. The following list of varieties comprises all of the best and most clistmet. parkage of Vusturtium contaius from thirty to forty serts. 179-Aurora. Bright chrome-yellow, veined with carmine. 180-Beauty. Orange, with bright scarlet markings 181-Brilliant Yellow. Clear, briglit, glossy yellow beautiful variety. Pkt. 10c., oz. 25c.
176-New French Chameleon. A wonderful new variety, having the peculiar property of producing flowers of many distinct colorings upon the same plant. The flowers are not only of different colors but are variously blotched, striped and bordered with contrasting shades. On the same plant appear at once clear self-colored flowers, others stained or flushed on a clear ground, and still others edged or banded with lighter or darker shades. Pkt. 5c., oz. 15c., $\frac{1}{4} \mathrm{lb} .40^{\circ} \mathrm{c}$.

182-Bronze Colored. A very distinct and peculiar shade.

183-Cloth of Gold. Brilliant scarlet. Foliage golden yellow, distinct and pleasing; excellent for edge of bed of Nasturtiums, or foliage plants, or for combining with dark leaved varieties like Eupress of India, King Theodore, etc.

184-Cœruleum Roseum. Bright cherry-red. A distinct shade.

185-Crystal Palace Gem. Rich sulphur-yellow, spotted with carmine.

186-Empress of India. Dark rich scarlet. Foliage bronzy purplish-green. Plant dwarf and compact; fine for edgings.

187-General Jacqueminot. Crimson scarlet, like Jack Roses. Foliage beautiful, dark green.

188-Golden King. Rich orange. Dark purplish foliage.

189-King Theodore. Rich velvety crimson. Dark foliage. Very desirable.

190-King of Tom Thumbs. Brilliant orange-scarlet. Foliage dark green.

191-Pearl. Pale primrose, often described as white.

192-Prince Henry. Pale yellow, heavily suffused with rose. A distinct aud desirable variety.

193-Rose. Bright rose. A small flowered but charming variety.

All varieties at uniform prices cxcept where noted.

Pkt. 5c., Oz. 15c., 2 oz. 25c., 表 lb. 40c. 


\section{NASTURTIUM-Continued.}

\section{DWARF * Nasturtium.}

194-New French Chameleon. This is identical with the New Tall Chameleon in the feature of producing flowers of greatly diversified colorings and markings on the same plant, the plant, however, being of the true divarf type, and is perhaps even more striking than the Tall Chameleon. A pleasing novelty, which all growers of the Nasturtium should try. Pkt. 5c., oz. 15c., 2 oz. 25c., 六 1b. 40c.

195-Liliput. A new, distinct and charming strain, of very dwarf, compact habit, which originated from the tall Troprolum Lobbianum. It has the same desirable features of great brilliancy of coloring and free-flowering habit. The plant is smaller than the common strain of Dwarf Nasturtium, as are the light green leaves. The flowers also are smaller, but so profusely borne that they appear above the foliage in clusters and embrace many new and beautiful colorings. Very desirable for edgings. Pkt. 5c., oz. 15c., 2 oz. 25 c., $\frac{1}{4}$ lb. 40 c.

\section{Dwarf Nasturtium MIXTURES.}

Two-One Good, the other Better.

196-Dwarf Mixed, all colors. For so many years have we sold this mixture that we unhesitatingly say it is a good one, despite the fact that we offer another-a better one-which we advise planting in preference to this. Although this, like the Tall Mixed is largely grown in mixture, it, like that, embraces a wide range of colors and, also like that, has given great satisfaction to our many customers who have used it. Pkt. 5c., oz. 10c., $\frac{1}{4}$ lb. 25c., lb. 90c.
197-Worcester Dwarf Mixed. In addition to all of the preceding named sorts, including the new Chameleon, we have selected other choice varieties of the large flowered type, all of which combined make a mixture which for pleasing variations cannot be surpassed. We advise its use in preference to the regular mixture, believing that the wider range of color will much more than offset the slight difference in price. Pkt. 5c., oz. 15c., 2 oz. 25c., 毒 1b. 40c., lb. $\$ 1.25$

\section{Collections of Nasturtiums.}

So popular have our collections of Sweet Peas always been that we now offer Nasturtiums in collections, enabling those who prefer to know just what varieties they are to receive to secure a large number, distinct and varied in color, at a greatly reduced price.

198-Our Special Collection of Dwarf Nasturtiums. Ten named varieties, our selection, but including the $N$ erv French Chameleon and Liliput...

199-Our Special Collection of Tall Nasturtiums. Ten named varieties, our selection, but including Sunlight, Moonlight and Tall Chameleon.

200-Our Favorite Collection. One packet each of Tall Nasturtiums-Sunlight, Moonlight, Salmon Queen, New Tall Chameleon, Golden-Leaved Scarlet, Prince Henry, Pearl, Rose, and one each of Dwarf-Bronze Color, Cloth of Gold, Coruleum Roseum, Empress of India, King Theodore, Rose, New Chameleon and Liliput-16 varieties for 40 cents.

The packets in these collections are not specially prepared for this-that is, having but few seeds-but are just what we sell at our counters for 5 cents each-full size, containing from 30 to 40 seeds. Our Special Offer does not apply on collections, nor can there be any further discount, regardless of number purchased.

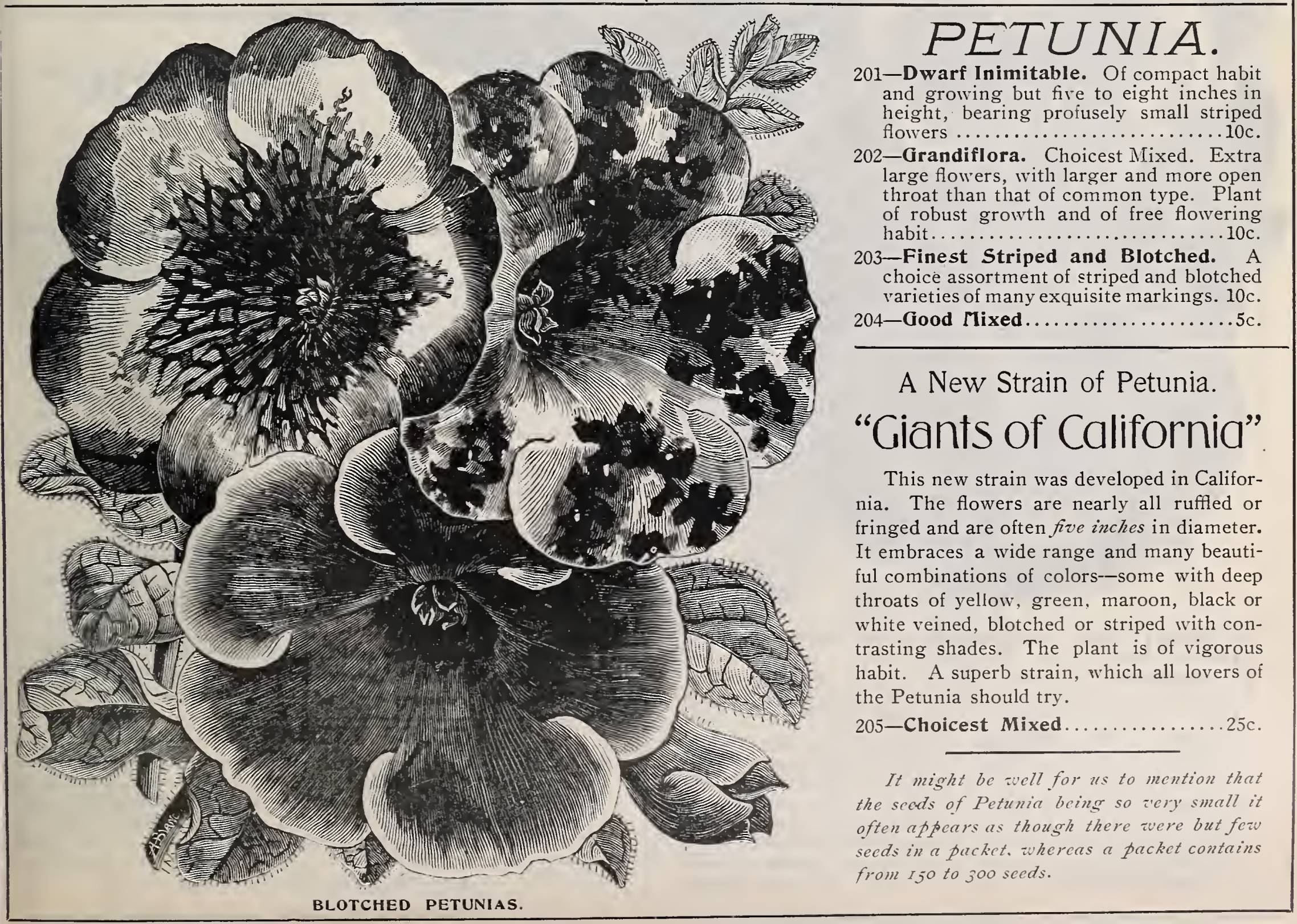



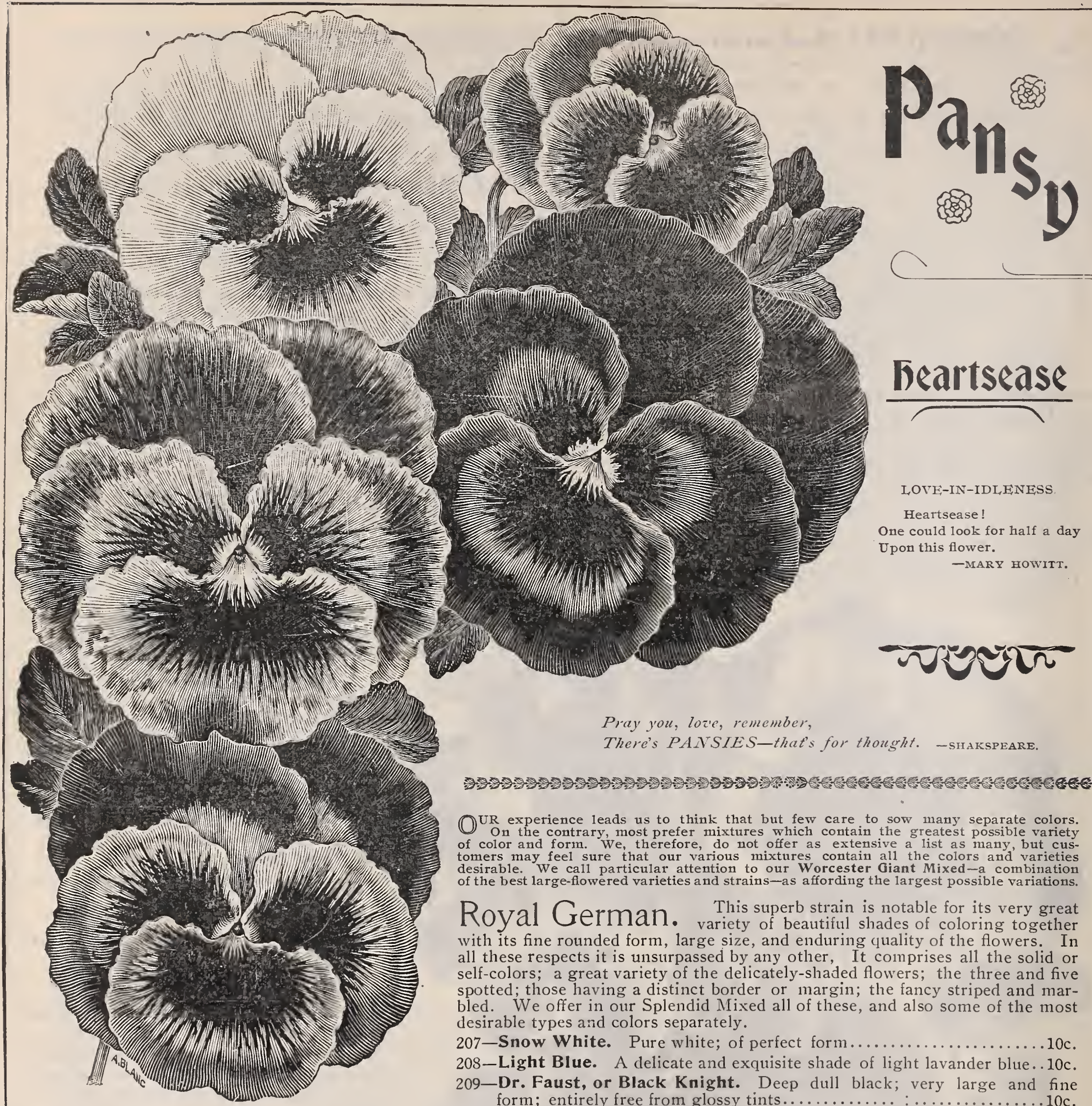

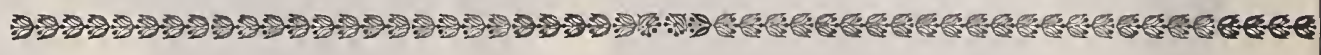

UR experience leads us to think that but few care to sow many separate colors. On the contrary, most prefer mixtures which contain the greatest possible variety of color and form. We, therefore, do not offer as extensive a list as many, but customers may feel sure that our various mixtures contain all the colors and varieties desirable. We call particular attention to our Worcester Giant Mixed-a combination of the best large-flowered varieties and strains-as affording the largest possible variations.

Royal German This superb strain is notable for its very great Pelman. variety of beautiful shades of coloring together with its fine rounded form, large size, and enduring quality of the flowers. In all these respects it is unsurpassed by any other, It comprises all the solid or self-colors; a great variety of the delicately-shaded flowers; the three and five spotted; those having a distinct border or margin; the fancy striped and marbled. We offer in our Splendid Mixed all of these, and also some of the most desirable types and colors separately.

207-Snow White. Pure white; of perfect form.................... 208-Light Blue. A delicate and exquisite shade of light lavander blue..10c. 209-Dr. Faust, or Black Knight. Deep dull black; very large and fine form; entirely free from glossy tints......................

210-Deep Yellow. Fine large flower; self-colored; of a rich

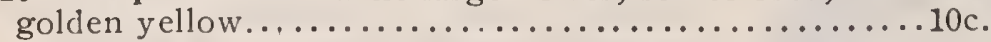

211-Rainbow. So called from its bright, glowing colors; flowers reddish-lavender, shaded with white, pink and car-

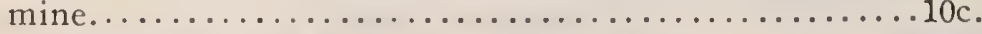
212-Odier, or Five=Spotted. Flowers large, of great beauty and of varied coloring. Each petal has a large spot or blotch of darker color and a distinct border of different shade.10c. 213-Fancy Varieties. Choicest Mixed. This mixture contains all of the best types of striped, blotched, mottled and edged flowers; of large size and rounded form, peculiar to the

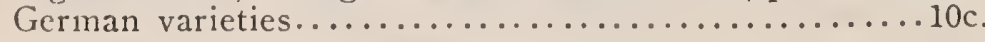
214-Show Varieties. Choicest Mixed. A choice assort- ment of solid or self-colored varieties only, having the usual characteristics of the Royal German Pansies...........10c. 215-Royal German. Splendid Mixed............. Over fifty varieties, $\frac{1}{8}$ oz. 60c., $\frac{1}{4}$ oz. $\$ 1.00$, oz. $\$ 3.50$.

\section{GIANT TRIMARDEAU.}

216-Mixed. A distinct class, with enormous flowers of rich and varied shades distinctly marked with large blotches on three lower petals. A cliarming and clesirable strain of French origin, lacking somewhat the broad round form of the German varieties, but which, on account of its size and

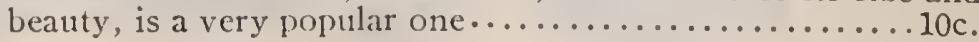
t oz. $40 \mathrm{c}, \frac{1}{4}$ oz. $65 \mathrm{c}$, oz. $\$ 2.25$. 


\section{PANSY -- eontinued.}

\section{EXTRA LARGE FLOWERED.}

217-Choice Mixed. A selection of extra large-flowered varieties containing a large proportion of the separate colors of German Pansies, with the usual characteristics of these flowers. On account of their substance, especially desirable for cutting. While not as desirable as the following for bedding, yet for early spring blooming this will be very satisfactory, especially to those who prefer large flowers rather than a greater profusion of smaller ones............... $\frac{1}{3}$ oz. 30c., $\frac{1}{\$}$ oz. 50c., oz. $\$ 1.50$.

\section{SPECIAL MIXTURE-For Bedding.}

218-This mixture is made of such varieties as experience has shown are best adapted for bedding; that is, those that will give the greatest freedom of bloom in the summer, and which, while not as large flowered as some, are yet by no means small. It comprises a large range of colors, and owing to the free blooming habit of the varieties selected is especially desirable for bedding, producing a bright effect, even in the hot weather, so trying to the Pansy.........10c. $\frac{1}{3}$ oz. 30c., 表 oz. 50c., oz. $\$ 1.50$.
ENGLISH PRIZE, or English Face.

219-Choicest Mixed. The peculiar characteristic of this strain is the bold face-like markings of the flowers, which, combined with their delicate texture and velvety appearance makes it a pleasing variation....................

$$
\frac{1}{8} \text { oz. } 25 \text { c., } \frac{1}{4} \text { oz. 40c., oz. } \$ 1.25 \text {. }
$$

\section{WORCESTER GIAN'T MIXED.}

220-This mixture is made by us, from the choicest large-flowered varieties and mixtures, including the best of those here offered, and many other German and French Prize strains, which we do not consider necessary to list separately. It affords the greatest possible diversity of color, with almost innumerable shadings and markings, and like all mixtures to which we attach the name Worcester, is the best we know

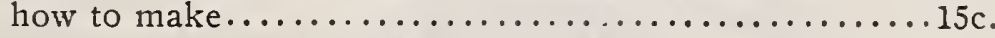

$$
\frac{1}{8} \text { oz. } \$ 1.00, \frac{1}{4} \text { oz. } \$ 1.75 \text {. }
$$

221-Good Quality. Mixed. A good assortment of colors. A strain which, being grown in mixture, does not require the care in growing. or selection, of named varieties, and can therefore be sold at less price. It will give more pleasing results than might be supposed from the price at which we offer it. $\frac{1}{8}$ oz. 20c., $\frac{1}{4}$ oz. 35c., oz. $\$ 1.00$.

\section{Pblox Drummondi}

One of most popular annuals; hardy and of the easiest culture. Remarkably free flowering and brilliant and varied in coloring. It is very desirable for bedding, the brighter colors especially producing a striking effect; the red, when grown in masses, verifying the correctness of the name Phlox-signifying fame.

Seed may be sown in the open ground in the fall or early spring and will produce plants that will commence to bloom about the first of July, and continue in bloom until cut down by severe frosts. The dwarf varieties may be allowed to grow from four to six inches apart, but the tall varieties should stand about one foot apart, for if closer they are liable to mildew.

\section{GRANDIFLORA.}

A large-flowered strain; a great improvement on the old type both in size and form of flower.

222-Choicest Varieties. Mixed, all colors. $\frac{1}{4}$ oz. 25c., oz.

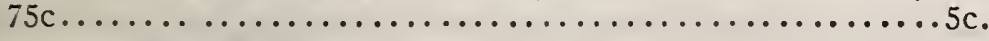

\section{NANA COMPACTA. (Dwarf Phlox.)}

This dwarf type grows only from six to eight inches high, and is especially desirable for ribbon beds and edgings.

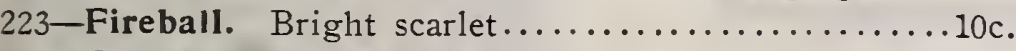
224-Snowball. Pure white..................... 225-Mixed Colors. All the choice varieties. $\frac{1}{8}$ oz. 30c.,

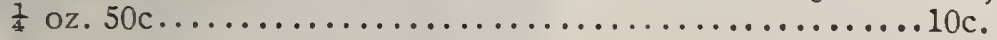

Star, or Fringed Phlox. Star of Quedlinburg.

226-A distinct class, having petals partly fringed, partly toothed, instead of the entire round form of other Phloxes, and some of which being longer than others and regularly placed give the flowers a star-like appearance.

Mixed Colors. $\frac{1}{4}$ oz. 25c., oz. 90c...................

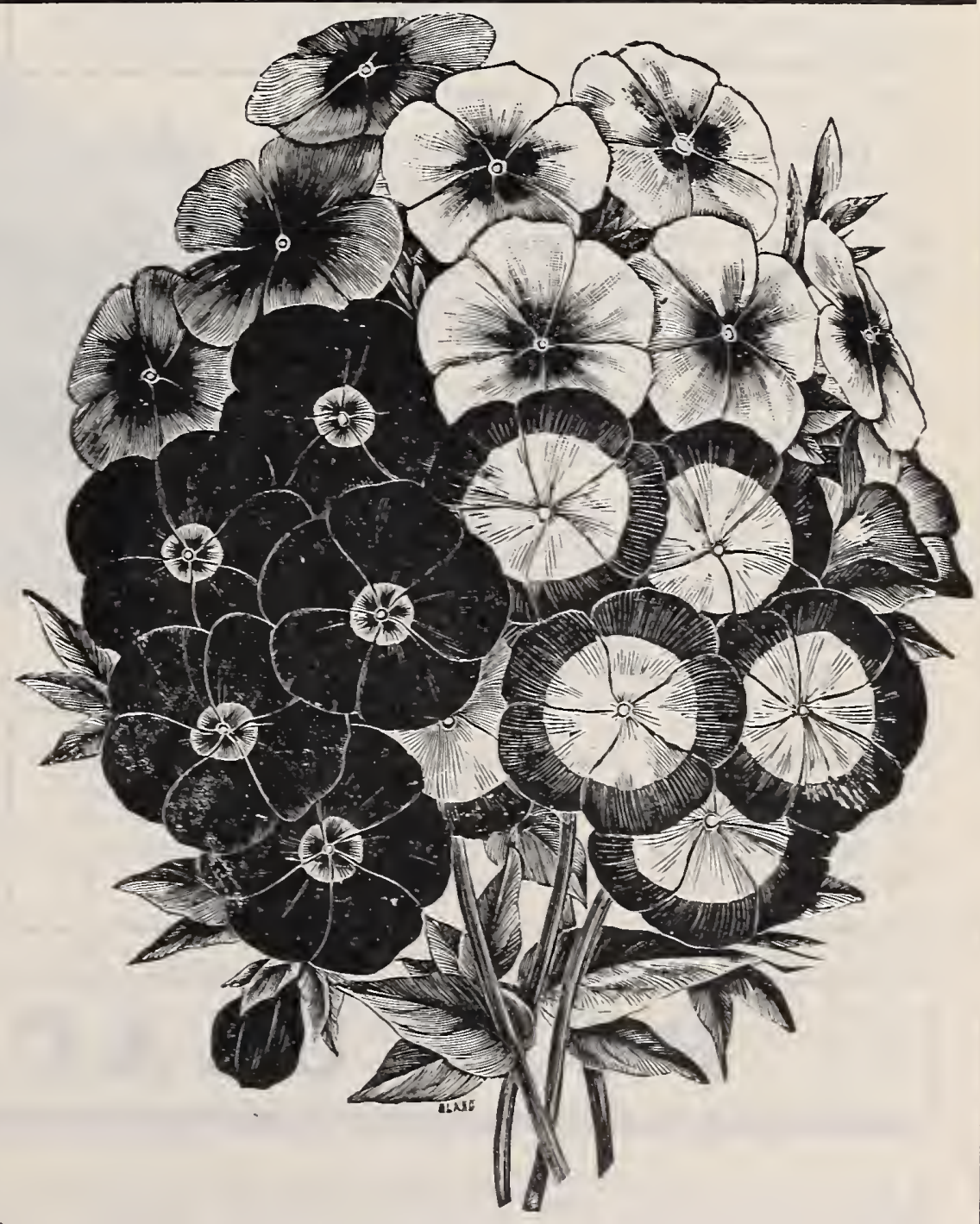

PERENNIAL PHLOX.

An old, well-known and very popular herbaceous plant, and growing in favor yearly. While propagation is usually accom-
plished by the amateur by division and by the florist with cuttings, our choice new varieties are seedlings and the field is epen to all to easily increase their stock in this way, and is,
say the least, an interesting one, with but little expense. say the least, an interesting one, with but little expense.
227 -Tall Varieties. Nixed colors. Seed sared from choicest

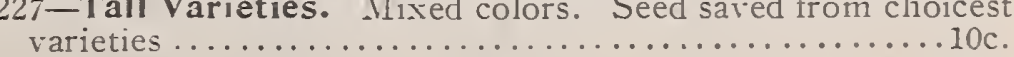



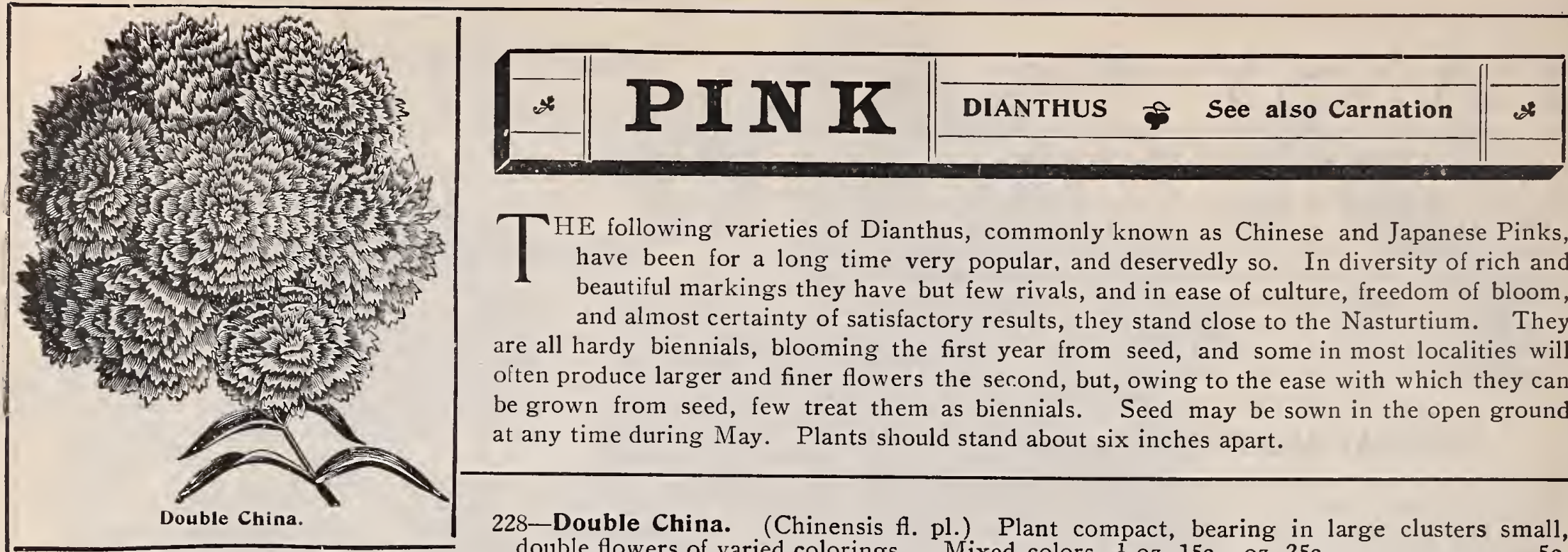

THE following varieties of Dianthus, commonly known as Chinese and Japanese Pinks, have been for a long time very popular, and deservedly so. In diversity of rich and beautiful markings they have but few rivals, and in ease of culture, freedom of bloom, and almost certainty of satisfactory results, they stand close to the Nasturtium. They are all hardy biennials, blooming the first year from seed, and some in most localities will often produce larger and finer flowers the serond, but, owing to the ease with which they can be grown from seed, few treat them as biennials. Seed may be sown in the open ground at any time during May. Plants should stand about six inches apart.

229-Double White. (Chinensis dalba fl. pl.) Double

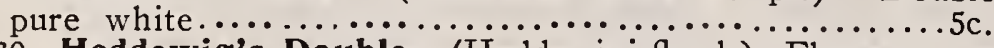
230-Heddewig's Double. (Heddewigi fl. pl.) Flowers very large and double, with finely fringed petals. A very fine strain, embracing a wide range of colors, - pink, rose, purple, maroon, white, and occasionally black and white. All colors

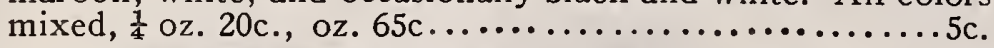

231-Crimson Belle.(Heddewig's.) Large single flowers, beautifully fringed; deep crimson.......................

232-Eastern Queen. (Heddewig's.) Flowers single, often two to four inches across; silvery white ground, with rich shadings and crimson center........5c.

233-Mourning Cloak. (Heddewig's.) Large double flowers, with deep mahogany, almost black ground, and finely fringed edge of white............

234-Heddewig's Single Mixed. Fine large flowers, of brilliant colors, deeply fringed or feathered..............

235-Double Diadem. (Diadematus fl. pl.) Flowers large, double and finely marked. Beautiful and varied in color, running from crimson-purple to black purple. Choice mixed............5c.

236-Double Imperial. (Imperialis $\mathrm{fl}$. pl.) Bright, showy flowers, very double, finely variegated in a wide range of colors. $\frac{1}{\mathrm{oz}}$. $15 \mathrm{c} ., \mathrm{oz} .50 \mathrm{c} . . . . . . .5 \mathrm{c}$.

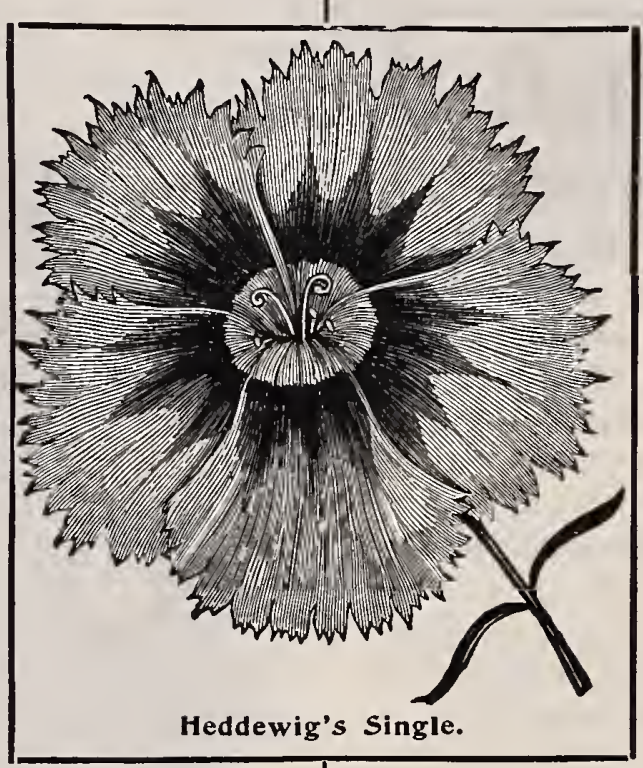
effective for either garden or house decoration. Perennial; easily attaining a fruiting size the first year............10c.

237-Double Japan. (Laciniatus fl. pl.) Large double fringed flowers, of peculiarly rich and varied colorings. A choice

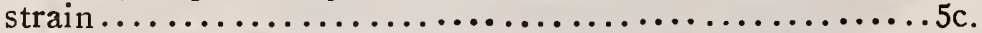

238-WORCESTER MIXED. Our own unsurpassed mixture of above and other choice varieties. $\frac{1}{4}$ oz, 20c., oz. 60c...5c.

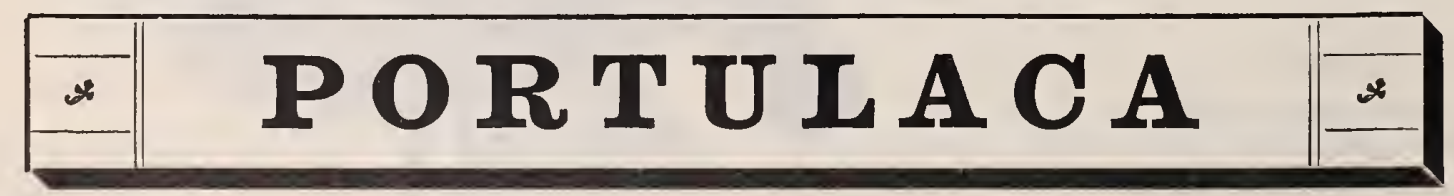
VILL-KNOWN tender annuals, blooming profusely soon after seed is sown
until cut down by frost. They thrive in nearly all soils and locations, but succeed best in a light, sandy soil and sunny spot, enduring any amount of dry weather. They are of but little value for cutting, but for a dazzling display, when sown in masses, nothing equals them.

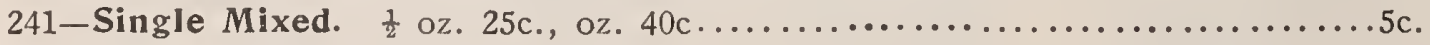
242-Double, Choice Mixed. Usually from fifty to sixty per cent of the flowers will come double, attaining to the highest proportion and largest size the latter

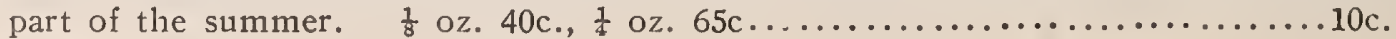

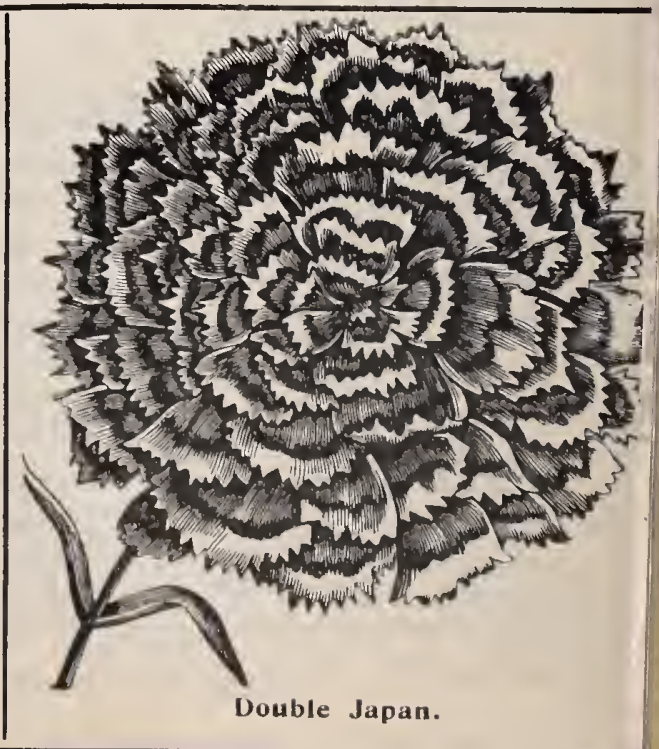




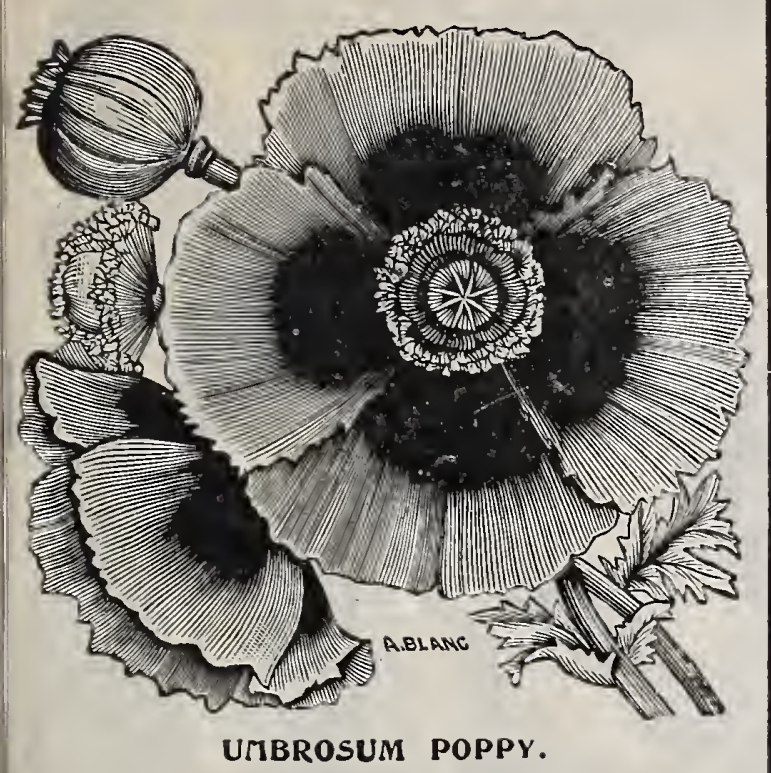

UMBROSUM POPPY.
POPPY

But pleasures are like Poppies spread You seize the flower, its bloom is shed. -BURNS.

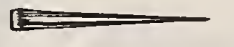

This well-known plant is of the easiest culture, only requiring to be sown where designed to remain as it is very difficult to transplant. Although not generally adapted for cutting, some of the recent additions have flowers of more lasting quality than the older type, of which the poet writes.

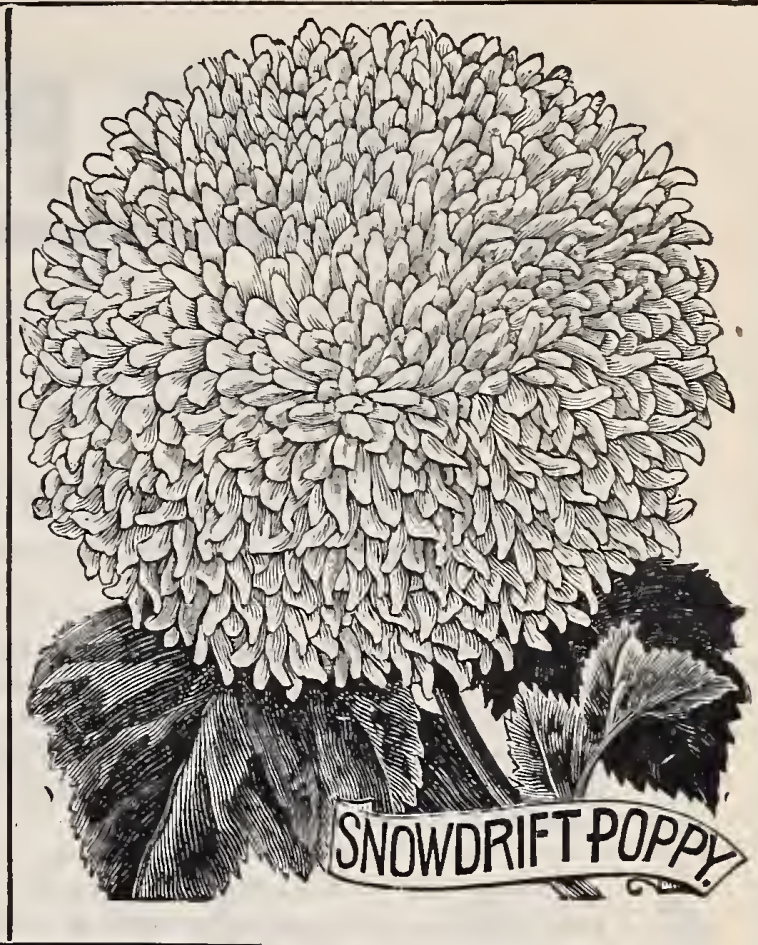

243-Umbrosum. Scarlet, with black spot on each petal. A very showy variety, of dwarf habit................ 244-Snowdrift. Large, pure white flower, very double and finely fringed. A grand variety...................

245-Cardinal. Large, double flower, bright cardinal red; as finely fringed as the Snowdrift. A worthy companion for that beautiful variety.............................

246-Tulip-Flowered. Splendid large flower, borne well above the foliage, cup-shaped, bright scarlet, sometimes having a black spot at base of each petal. Very beautiful, and when grown in mass resemble a bed of scarlet Tulips. $1 \frac{1}{4} \mathrm{ft}$.

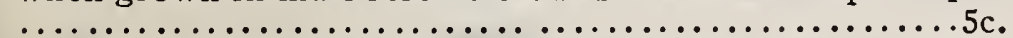

247-Shirley. Flowers large, generally single or semi-double. Of a wide range of color, running from blush-white through shades of pink-rose and carmine to deep crimson, occasionally blotched or streaked with white. A very graceful and elegant variety, especially fine for cutting............

248-Double Carnation-Flowered, Mixed. An old but desirable strain, embracing many distinct shadings and colors. Flowers very large and double, with beautifully fringed petals.......................................

249-Danebrog. A single-flowered variety; bright scarlet with white spot at base of each petal. Very showy and distinct. 5c.
250-Scarlet Single. Flowers very large, often four inches in diameter...............................5c

\section{PERENINIAL VARIETIES. ICELAND POPPIES.}

These bloom the first year from seed. Large satiny flowers, borne on long stems; somewhat fragrant; excellent for cutting, remaining in good condition several days if cut when first open. The plant is perfectly hardy and blooms from June to October.

$251-$ White, Yellow and Orange, mixed.............

\section{ORIENTAL POPPIES.}

These are also perfectly hardy and may be used to advantage in the perennial border. Seed may be sown in the open ground late in fall or early in the spring. They bloom early the second spring from sowing. All are single-flowered and of some shade of red, the following variety being much the best of the class.

252-Orientale. Flowers of immense size, six inches in diam-

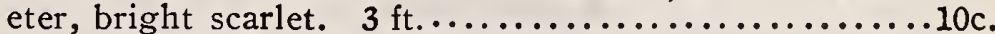

\section{ROCKET. '(Hesperis Matronalis.)}

In rival pomp, see either Rocket blow,

Bright as the sun, or as the new fallen snow. -EVANS.

Hardy perennial plant of easy culture, bearing clusters of purple or white fragrant flowers. The fragrance is much more powerful in the evening. $1 \frac{1}{2} \mathrm{ft}$.

253-Mixed.

\section{RICINUS. (See Castor Bean.)}

RHODANTHE. One of the finest everlasting flowers and an excellent plant for garden decoration. If flowers are gathered before they are fully expanded and dried in the shade, they will retain their color for years. Tender annual. $1 \mathrm{ft}$.

254-Mixed Colors. Various shades of pink, rose, crimson

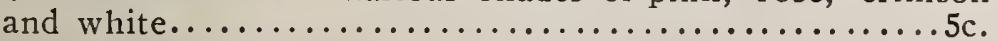

SALVIA. (Flowering Sage.) Well-known perennials, blooming the first year from seed sown early in heat. They grow well in any light, rich soil, and will bloom until after frost. The Splendens (Scarlet) is one of our best and most effective plants for lawn decoration.

255-Splendens. The well-known variety; bright scarlet. 10c.

\section{SCABIOSA, or Sweet Scabious. Mourning Bride.}

The Scabious blooms in sad array,

A mourver in her spring. -Flora's Interpreter.

A popular hardy annual, blooming freely in cool locations or during the late summer and fall. The flowers of the Tall varieties are borne on slender but stiff stems and are excellent for cutting. The foliage is of compact, rounded form, about ten inches in height. The $D$ warf varieties are similar in form but only one-half the height.

256-Dwarf Double. Mixed, all colors. Includes the new

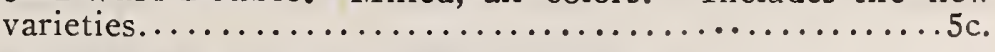

257-New Tall Large=Flowering Double. Mixed. Large double flowers in a remarkably wide range of colorings, shading from white to pink, crimson to deep red, and from lilac

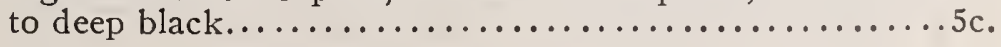

\section{SENSITIVE PLANT. (Mimosa Pudica.)}

$$
\begin{aligned}
& \text { Weak with nice sense the chaste Mimosa stands, } \\
& \text { And from each touch withdraws her timid hands. }
\end{aligned}
$$

And from each touch withdraws her timid hands. -DARWIN.

Very curious and interesting plant, the leaves closing if touched or shaken. Half-hardy annual.

258-Sensitive Plant. Pinkish white; $1 \frac{1}{4} \mathrm{ft}$. 


\section{* SWEET PEAS.}

Here are Sweet Peas, cn tiptoe for a flight; With wings of gentle flush o'er delicate white, And taper fingers catching at all things, To bind them a11 about with tiny rings

-KEATS.

A selection aimed to contain only the best or most desirable varieties, classified as to color or shade.

Descriptions of flowers, especially of those of a class as varied as the Sweet Pea, are at their best but meager and unsatisfactory, but as it is not always easy to determine in which class some varieties should be placed, the brief description with each variety may aid in distinguishing the difference between those in the same class.

Nearly all of the following varieties are of large size and excellent form, and generally superior to those of similar color or shade. We however carry in stock nearly all of the named varieties, and should any desire some of them they may safely include thern in order.

Uniform price on all varieties. Pkt. 5 c., oz. roc.,

2 oz. 15 c., $1 / 4$ 1b. 25 c.

\section{e}

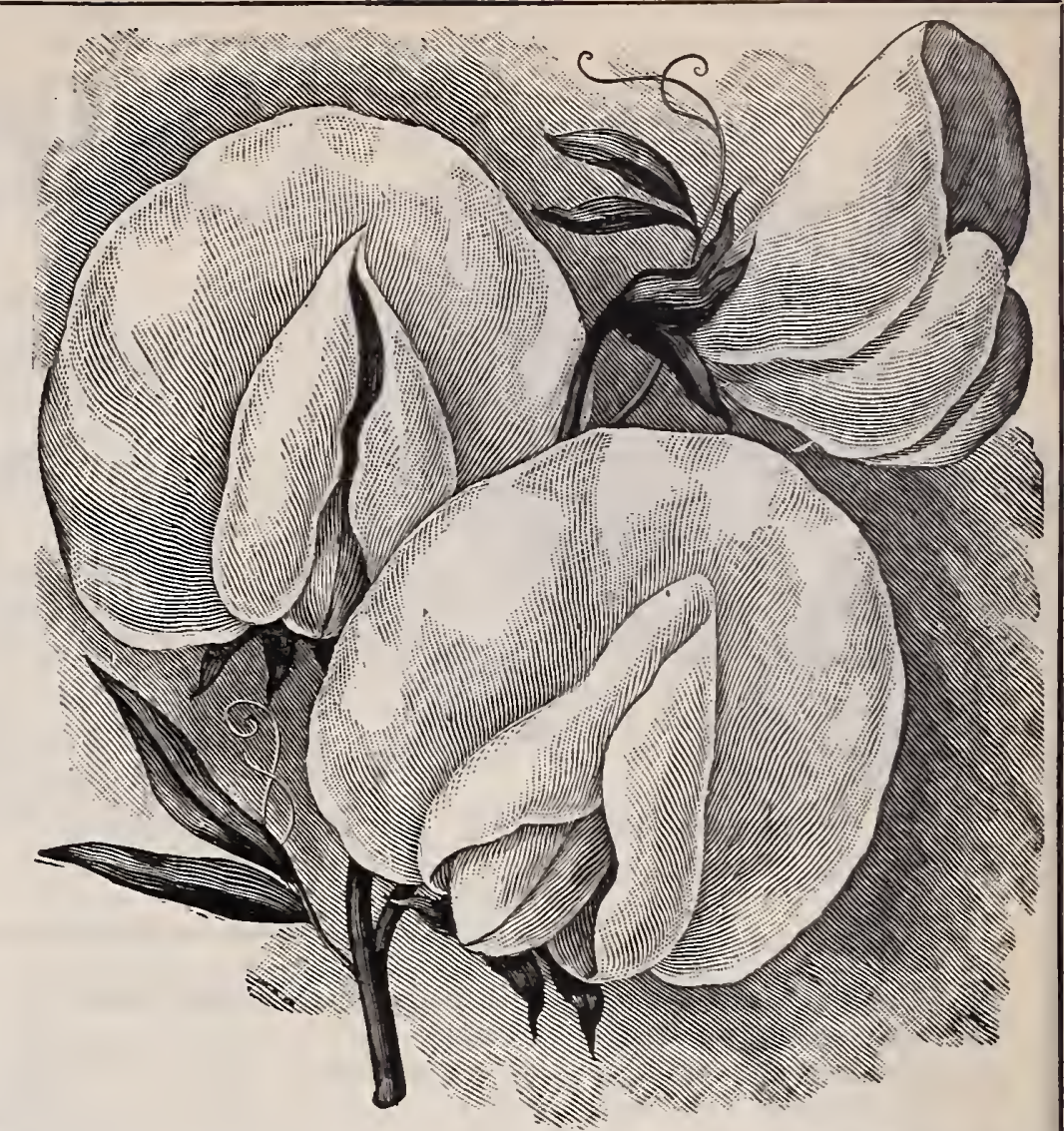

\section{White.}

1. Blanche Burpee-Large and of fine form and lasting substance, stems long and stiff; of ten three-flowered.

2. Emily Henderson-The earliest pure white variety.

3. Sadie Burpee-Claimed to be of improved form, but otherwise similar to Blanche Burpee.

\section{Pale Yellow or Cream.}

4. Coquette-Deep primrose, standard shaded with lavender, of fine form and good size.

5. Duchess of Westminster-Standard creamy white, shaded with coppery rose: wings suffused with salmon-pink.

6. Mrs. Eckford-Light primrose yellow, large

7. Queen Victoria-Primrose yellow faintly suffused with purple, the nearest a pproach to yellow excepting Stella Morse.

8. Stella Morse-I arge and of fine form, a combination of creamy yellow and salmon-pink, producing a beautiful apricot shade.

\section{Light Blush.}

9. Modesty-Silvery white faintly suffused with pink.

10. Mrs. Sankey-Often described as white, but is perhaps more appropriately classed here owing toits tinge of pink, becoming white only as it fades.

II. Sensation-Fine large flowers often three, sometimes four, on a stem, faint blush pink.

\section{Pink and White.}

12. Blanche Ferry-Standard bright pink; wings nearly white, very popular.

13. Extra Early Blanche Ferry-An extra early strain of the preceding, flowering at least a week earlier.

14. Earliest of All-Still earlier than the Extra Early Blanche Ferry, similar in color. Does not grow as tall as others.

15. Little Dorrit-Standard clear rosy pink: wings creamy white flushed with faint rose. Of desirable form.

\section{Light Pink.}

I6. Crown Jewel-Standard flushed with rosy violet, wings creamy white, slightly tinted with rose.

I7. Katherine Tracy-Both standard and wings of soft but brilliant

pink. Large and of desirable form, plant vigorous and free fowering

Lovely-Delicate shell-pink faintly tinged with yellow, a truly variety.

19. Mrs. Gladstone-Brilliant but soft rose pink on white ground.

\section{Deeper Pink.}

20. Apple Blossom-Standard heavily shaded and edged with soft

rose; cy white ground; wiugs white with rose in center. pink.
22. Prima Donna-Beautiful blush-pink. Large and of finest form, often four-flowered.

23. Royal Robe-standard rich pink, wings soft rose. Iarge and of beautiful form.

24. Triumph-Standard creany white flushed with salmon * wings shaded with carmine.

\section{Rose.}

25. Colonist-Rich rose pink, deeper in the wings.

26. Her Majesty-Beautiful, soft but deep rose, large and finely hooded,

7. Mrs. Dugdale-Both standard and wings, carmine-rose faintly marked with primrose. One of the largest flowers of all; uniformly three on a stem.

28. Ovid-Deep rose-pink veined with deeper shade ; wings still deeper. Of good size and the desired hooded form.

29. Prince of Wales-Self-colored deep rose. Large, beautifully hooded, frequently four-fiowered.

30. Royal Rose-Standard deep rose-pink; wings a lighter shade. Of largest size and fine form.

\section{Scarlet and Crimson.}

31. Brilliant-Rich brilliant red. Of good size and substance, and fine form.

32. Firefly-Bright scarlet, of medium size.

33. Mars-Intense scarlet; wings suffused with rose.

34. Prince Edward of York-Standard, a shade between scarlet and salmon; wings deep rose.

35. Princess Victoria-Standard bright scarlet; wings reddish mauve. Of good size and form.

36. Salopian-(Improved Sunproof.) The finest scarlet variety. Of the largest size and finest form, uniformly three-flowered.

\section{Salmon and Orange.}

37. Chancellor-Soft rosy-pink heavily shaded in center with salmon.

38. Countess of Powis-Light salmon-pink suff used with orange.

39. Gorgeous-Standard deep salmon-orange, wings suffused with deeper shade.

40. Hon. F. Bouverie-Soft salmon-pink, shadiug to lighter salmon buff at edges of staudard aud wings.

41. Lady Mary Currie-Of rich orauge effect, standard veined with salmol-pink and shaded at base with carmiue; wings rose-pink veined with deeper shade.

42. Oriental-Bright orange-salmou veiued with deeper shade. Large aud fiuely formed.

43. Venus-One of the loveliest of this class. Beautiful salucu-buff shaded with rose-pink.

\section{Mauve and Lavender.}

Admiration-Self-colored rosy manve. A fine large flower freely produced.

45. Celestial-I,ight lavender with faint reddish tinge. 


\section{SWEET PEAS - CONTINUED.}

46. Countess of Radnor-I,ight lavender, often witl faint purplish shade, especially in later stage of blooll.

47. Dorothy Tennant-A rich self-colored reddish mauve, which the

flower retains when fully expanded.

48. Fascination-An extra large flower, rich reddish mauve

49. Golden Gate-Pinkish mauve and lavender blended

50. Lady Grisel Hamilton-Light lavender standard with bluish wings. $5 \mathrm{I}$. Lady Nina Balfour-Delicate light lavender approaching mouse color.

52. New Countess-An improved Countess of Radnor more nearly free from reddish cast in standard.

\section{Bluish-Purple with White.}

53. Butterfly-Flowers small, but a popular variety from its peculiar form and color, creamy white with lavender shadings and purple edges.

54. Lottie Eckford-Silvery-white shaded and edged with lavender.

55. Maid of Honor-White ground shaded with light bluish-purple, and narrowly edged with violet.

\section{Approaching Blue and Purple.}

56. Captain of the Blues-Standard bluish-purple; wings purplish
57. Navy Blue-Perhaps as nearly approaching a True $B$ lue as can be reasonably expected in a sweet pea.

58 . Indigo

\section{Claret and Maroon.}

59. Black Knight-The darkest variety, standard rich dark claret wings shaded with brownish purple.

6o. Captivation-Bright claret.

6I. Duke of Clarence-Rosy claret approaching purplish maroon.

62. Duke of Sutherland-Rich claret with reddish tinge, shading to

63. Othello-Deep maroon, self-colored; very large.

64. Shahzada-Very dark maroon, with a tinge of purple.

65. Stanley-Self-colored dark maroon.

\section{Striped and Variegated.}

66. America-White, striped with bright red.

67. Aurura-Creamy white, striped or flaked with orange-salmon

extra large.

68. Gray Friar-Creamy white, marbled with light purple.

69. Juanita-(Striped Celestia1.) Light lavender narkings on cream

white ground. Large and of fine form.

70. Lotrie Hutchins-Creamy-while, striped or flaked with light pink Large, of fine form, and very attractive.

7 I. Mrs. Jos. Chamberlain-Ground clear white, striped with pink extra large and of good form, very popular.

72. Princess of Wales-White, striped with mauve.

73. Ramona-Rich cream, with broad splashes of pink.

74. Senator-White, heavily striped with chocolate maroon.

lavender.

\section{MIXTURES OF SWEET PEAS.}

OUR CHOICE MIXTURE.

This Choice Mixture is made by us, and contains about sixty named varieties, including both old and new, mixed in right proportions of color, and with the exception of some of the latest highest priced varieties contains all that is desirable for a choice mixture.

Pkt. 5c., oz. IOc., 2 oz. I5c., I/4 1b. 25c., 1b. 65 c.

\section{OUR BEST MIXTURE.}

This is made of the large flowering varieties only. It contains most of the above desirable varieties and many of the higher priced more recent introductions not therein contained. Special attention is given that it shall be rightly proportioned as to color as well as to size, form and substance of the flowers. Nearly all have long stems, many of them passed three and sometines four fowers. Thice that may be attached to it It is the Best. $\quad$ Pkt. 5c.. Oz. I5c., 2 oz. 25c., I/4 1b. 35c., 1b. $\$ 1.00$.

\section{$\sim$ COLLECTIONS}

These collections are made of our regular full size packets and, while of our selection, are guaranteed to contain only desirable varieties. They are NOT included in our Special Offer.

OUR SPECIAL COLLECTION. 10 Named Varieties, 25 cents.

OUR FAVORITE COLLECTION. 15 Named Varieties, 35 cents.

Of Our Favorite Collection we have to say that special attention is given that the varieties shall be as distinctive as possible and also those most desirable.

BUSH SWEET PEAS.

This class, an intermediate one between the Ta11 and Dwarf, growing about 18 inches high, is desirable for planting in rows, and presents a pleasing effect in the flower garden when thus planted. As the name indicates, the Bush Sweet Peas are of bushy habit, and are to a considerable extent self-supporting when allowed to stand about six inches a part, requiring then but little if any support. The flowers are not over twothirds the size of those of the Tall varieties, and are therefore of but little value for cutting. Nearly all the colors and shades of the Ta11 varieties are now found in this class, and a number of named varieties have been introduced, but as its chref value $1 i \cdot s$ in its use for garden decoration, and for that purpose the effect would be more pleasing when planted in mixture, we os s seed only in this way:

Mixture of about Fifty Varieties or Colors. Contains the named varieties and many colors not yet separately introduced. Large pkt. Ioc., oz. 20c., 1/4 1b. 50c.

\section{SWEET PEAS.}

DWARF, OR CUPID SWEET PEAS.

Plants of this class seldom grow over six inches high, but are of spreadin habit. The dense mat-like mass of rich green foliage thickly set ing habit. The dense mat-like mass of rich green foliage thickly set with flowers of varied colors is very attractive and makes this class de sirable for bedding purposes. The flowers are much larger than are Tall varieties, but unfortunately are short stemmed, which makes them like those of the Bush class - of but little or no value for cutting. There is, those of the bus clas and thrives during periods of dry, hot weather, which would greatly and thrives during periods of dry, hot weather, which would greatly the plants should not stand loo closely, as owing to the very dense growth they do not so quickly dry after heavy rains, and are, if too close, mole to rot. There have been introduced a nuniber of named valieties; most of these bear the name of some of the Tall sorts, and are identical in color with the variety which name they bear. In addition there are a large number of varieties or colors which have not yet been given a name, and nearly all of the colors of the Tall varieties a re now found in this class. We offer some of the most distinctive and desirable varieties and a mixture containing most of the named sorts and a much larger number of unnamed colors.

Mixture of over Fifty Varieties or Colors. Pkt. 5c., 1/2 oz. Ioc. Oz. I5c., 2 Oz. $25 \mathrm{c}$., $1 / 4$ 1b. $40 \mathrm{c}$.

\section{EVERLASTING, OR PERENNIAL SWEET PEA.}

\section{(Lathryus Iatifolius.)}

This is very hardy, having long roots which penetrate the soil to a great depth. It is slow in starting, does not produce many flowers the second year, but when fully establiched blooms profusely and is one of the most satisfactory perennials. The flowers are borne in clusters on stout stems, only lacking fragrance to make them more popular; but they
are, nevertheless, especially valuable for cutting, and the plant should be are, nevertheless, especially valuable for cutting, and the plant shoul
more generally cultivated. The colors are white, purple and red.

26I-Mixed Colors.

SWEET WILLIAM. (Dianthus Barbatus.)

This well-known, free flowering perennial is very desirable for an effective display in the border, is of the easiest culture, and should be more generally, cultivated. Seeds may be sown at any time from early spring to the middle of August and will make fine blooming plants for the following spring.

262-Choice Single, Mixed....5c.

263-Choice Double, Mixed....55.

SWEET SULTAN. (Centaurea Moschata.)

An annual of easy culture, bearing fragrant flowers.

264-Mixed, White and Purple.
STOCK.

One of our most popular and easily grown annuals, only needing a good, rich soil, good seed and ordinary culture to furnish a profusion of beautiful and fragrant flowers. The seed now offered is a great improve ment over the old strains of Gilliflowers, and will produce as large a pro portion of double flowers as plants of the named sorts grown from cuttings.

265-Largest Flowering Globe Py ramidal, Mixed. This new strain produces flowers of the largest size and perfectly double. Individua

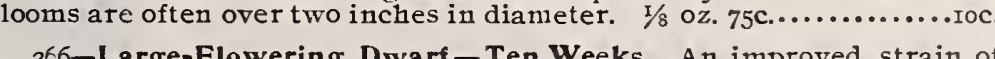

266-Large-Flowering Dwarf-Ten Weeks. An improved strain o dwarf habit, blooms profusely, and is excellent for bedding. Mixed

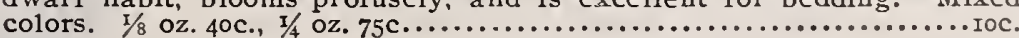

267-Double German Ten Weeks. Fine mixed.

I/8 Oz. $25 \mathrm{C}$., $1 / 4$ Oz. 4 OC., Oz. \$I.50......

268-Giant Perfection. One of the finest large-flowered varieties, with large spikes of double flowers. Plant of vigorous habit, growing about two and one-half feet in height. Jixed colors..................... Ioc.

269-Cut-and-Come-Again. (Princess Alice.) Plant of branching habit, producing from spring to fall a profusion of pure white double 


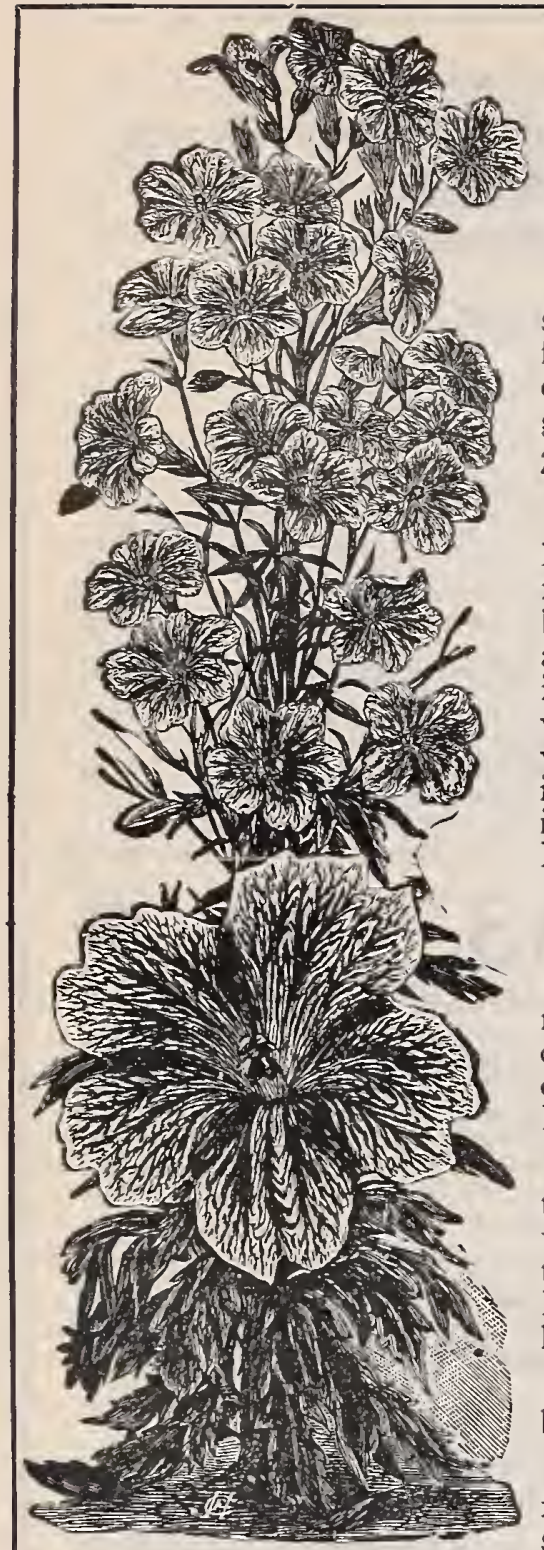

\section{SALPIGLOSSIS -}

A lovely class of half-hardy annuals which should be more generally cultivated. Flowers tunnel-shaped, of beautiful and varied colors, exquisitely marbled and veined; in bloom from August to October. $1 \frac{1}{2}$ to $2 \mathrm{ft}$.

270-Choice Mixed.

271-NEW EMPEROR. This forms only one learling stem, which often grows as thick as one's finger and bears on its end a bouquet of the most beautiful flowers. These are richly veined with gold and much larger than those of the old type. There is as much difference between the "Emperor" variety and the old type as between the improved varieties of Petunias and the common. The throat is wide open and short, and the edge of the flower is not so deeply incurved as with the old type. Mixed colors............................

\section{VERBENA.}

A well-known favorite flower, which should be more generally grown from seed. If sown in the open ground in May it will bloom in August, and, of course, somewhat earlier if sown in the house in March. Half-hardy perennial trailer. $1 \mathrm{ft}$.

272-MAMMOTH, Mixed. Not only are the trusses of extra size, but the individual florets as well are much larger than in any of the old varieties, often greater in diameter than a silver quarter. It embraces all the colors with the markings peculiar to the Verbena. $\frac{1}{4}$ oz. $40 \mathrm{c} .$, oz. $\$ 1.50 \ldots . .10 \mathrm{c}$.

273-SCARLET DEFIANCE. Large trusses; bright glowing scarlet ..................

274-MAMMOTH WHITE. Both truss and florets are of the largest size. Flowers are of good substance and of delightful fragrance..........
275-ITALIAN STRIPED. The trusses of this are large, but florets are smaller than are those of preceding varieties. Each floret is distinctly striped in bright colorings embracing a wide range of

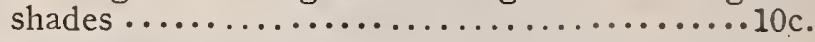

276-FINE MIXED. All colors, $\frac{1}{4}$ oz. 25c., oz. $75 \mathrm{c} . \ldots \ldots \ldots \ldots \ldots \ldots \ldots \ldots \ldots \ldots \ldots \ldots \ldots \ldots \ldots$ c.

277-HYBRIDA COMPACTA. Mixed. A distinct strain, of dwarf habit. The plant forms a compact bush about five inches in height and blooms profusely throughout the season. Trusses large; colors white, scarlet and violet.........10c.

\section{WALL FLOWER.}

The flowers of the Wall Flower are deliciously fragrant and greatly prized. The large, massive, conspicuous spikes of the Double German varieties have a charming effect, while the more bushy, compact growth and profuse blooming single ones render them exceedingly attractive. Tender perennials. $1 \frac{1}{2} \mathrm{ft}$.

278-SINGLE, Fine Mixed.............

279-DOUBLE, Choice Mixed ............10c.

\section{WILD CUCUMBER. Echinocystis Lobata.}

280-A very rảpid growing annual climber, reaching a height of 20 feet. Seeds germinate more freely if soaked a few hours in warm water

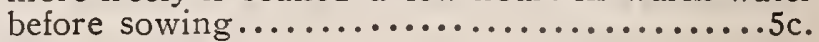

\section{WILD FLOWER GARDEN MIXTURE.}

281--This mixture is made from a large number of the best free-flowering annuals, and will be found very useful to sow in various places where there is quite an area to be filled up without much expense or labor. If properly cared for and weeds are kept out, this mixture will furnish flowers continually through the season. $0 z .25 \mathrm{c} ., \frac{1}{4} 1 \mathrm{~b} .75 \mathrm{c} \cdot .5 \mathrm{c}$.

Lower Flower 1-2 Actual Size.

EMPEROR SALPIGLOSSIS.

\section{ZINNIA. Youth and Old Age.}

The Zinnia has always been a popular plant on account of its freedom of bloom, bright, showy flowers, and the ease with which it could be grown. Although not a graceful plant, it is, when grown in masses or as the background to other lower-growing plants, striking and effective. Hardy annual. 1 to $3 \mathrm{ft}$.

282-MAMMOTH, Mixed. This plant is of unusually vigorous growth, often reaching a height of three feet. The very double flowers are of immense size, about four inches in diameter, and of rich and varied color. $\frac{1}{4}$ oz. 25c., oz. $75 \mathrm{c} . . . . . . . . . .10 \mathrm{c}$.

283-CHOICE MIXED. Not equal in size of flower to the Mammoth, but, nevertheless, a fine strain of double flowers with many brilliant colors.

284-STRIPED, or Zebra. The flowers of this are striped or mottled with contrasting colors.

285-LILlIPUT, Mixed. Plant grows about one foot high and bears in profusion small, very double and globular flowers about one inch in diameter of very brilliant colors...............10c.

286-HAAGEANA. Plant of distinct growth, more slender than others, flowers $\Rightarrow$ little over an inch in diameter, semi-double and single. Color deep orange. The plant is of very free-flowering habit, and the flowers are excellent for cutting.

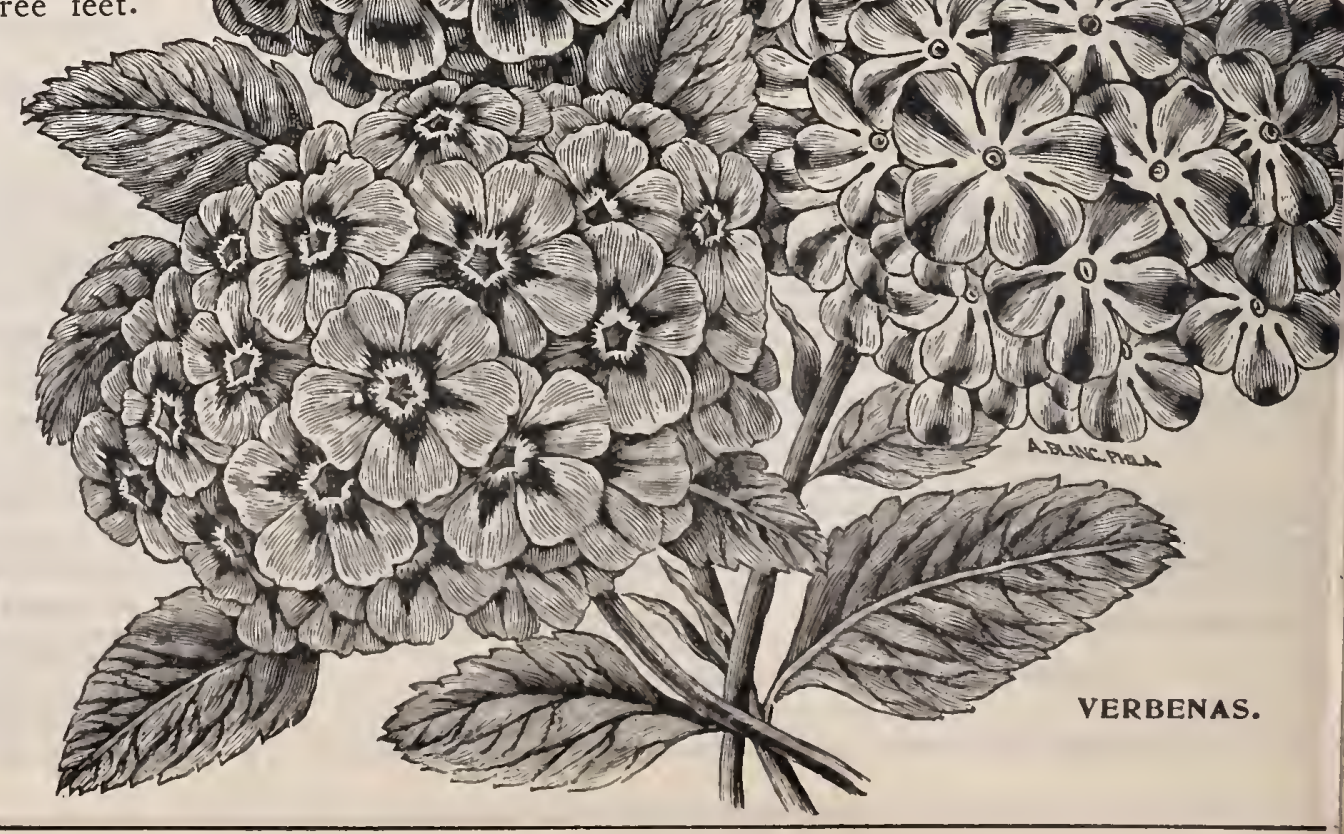




\section{* BULBS AND TUBERS For Spring Planting.}

To no class of plants can the term interesting be more truthfully applied than to bulbs and tubers. The following list contains only those which are easily within the scope of the amateur, and of some it may be said that in a production of magnificently beautiful flowers with comparatively little care, they are unequaled.

\section{BEGONIAS. Tuberous Rooted.}

These are among our finest bedding plants. They, however, seem yet to be appreciated but by only a portion of those who cultivate flowers. For some unknown reason the idea seems prevalent that their cultivation is difficult. We do not so consider it. They require a well enriched soil, a location partially shaded, and protection from severe winds. The soil should be moist but never soggy. Given these conditions, their culture is simple and easy. For best results, tubers should be started early in the house and then be planted out only when danger of frost is past. They will come into flower very soon and bloom profusely and continuously until frost. The tubers can then be taken up and stored in dry sand in a moderately warm place.

The flowers are marvels of beauty-delicate yet brilliant, of beautiful form and very large, often measuring, when conditions are favorable, over four inches in diameter. In color they are extremely varied, ranging from pure white through many shades of pink and rose to scarlet and deep crimson, and from pale yellow to deep orange. The foliage is remarkably clean and healthy, varying in form, deep green, presenting a very pleasing contrast with the bright flowers.

Single Varieties. White, Pink or Rose, Red and Yellow. Each, 10c. Doz. \$1.00. Postpaid.

Double Varieties. Same colors. Each, 15c.; 3 for $40 \mathrm{c}$. Doz. $\$ 1.50$. Postpaid.

\section{CALADIUM ESCULENTUM. Elephant's Ears.}

A very large-leaved tropical plant of rapid growth. In warm, rich, moist soil a single bulb will send up from three to ten stalks four to five feet in height, each having a leaf three to four feet long and nearly as wide. Very ornamental, planted either singly or in groups.

Extra Large Bulbs. Each, 20c.; 3 for 50c. Postpaid. Second Size Bulbs. Each, 15c.; 3 for 40c. Postpaid. Per Dozen, by Express. $\quad\left\{\begin{array}{l}\text { Extra Large, } \$ 1.50 \\ \text { Second Size, } \$ 1.25\end{array}\right.$

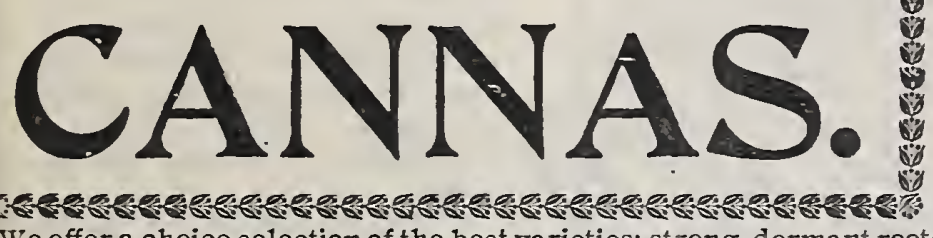

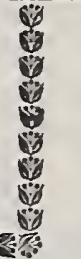

Each, 10c., 3 for 25 c.

For peculiarly beautiful flowers, with rich, brilliant and diverse colors and stately foliage, no plant exceeds the Canna. Planted in masses on the lawn, no othe plant is its equal in striking decorative a ppearance, and it is at present probably the most popular of all bedding plants, even exceeding in popularity the old-time favorite. the Geranium; a thing of interest from the time the first leaves begin to unfold, and brooming continuously until cut down by frost. It is a1so an exceptionally fine pot plant in tne garden or bed, and before danger of frost can be lifted and potted with but a little check to the plant, and will continue to grow and blooin through the winter.

We offer a choice selection of the best varieties: strong, dormant roots, with two or three eyes. (Late in the season we a re sometimes obliged to send growing plants.

A. Bouvier. Brilliant crimson, of deeper hue when fully expanded; foliage bright green; 6 feet.

Alsace. Delicate sulphur yellow, changing soon to creamywhite; the nearest approach to pure white; foliage green; $4 \frac{1}{2}$ feet.

Austria. A fine variety of the orchid-flowered or Italian type. Canary-yellow; foliage green, large and handsome; $5 \frac{1}{2}$ feet.

Burbank. Also of the Italian type; similar in color of flower and foliage to the Austria; 5 feet.

Chas. Henderson. Deep but brilliant crimson; foliage broad, a rich deep green with narrow margin of bronze; 4 feet.

Flamingo. Clear intense crimson, large flowers borne in immense trusses and in great profusion.

Florence Vaughan. Yellow, spotted with red; foliage green; a popular variety; 4 feet

Grand Rouge. A gigantic dark-leaved variety, often attaining a height or over 8 feet. Very desirable for massing. It also bears freely bright scarlet flowers of fair size which adds to its value.

Itaiia. A beautiful large orchid-like flower, brilliant red in center with $a$ wide irregular margin of yellow; foliage green; $5 \mathrm{ft}$.

\section{Fairy Lilies or Zephyr Flowers. (Zephryanthes.)}

These are a section of the large and beautiful Amaryllis family. Only one or two varieties are generally known or to any exten cultivated, and none to the extent to which their beauty warrants. They are desirable both for garden and pot culture and are amon our most easily grown plants. They are easily kept over winter. treated in the same manner as the Gladiolus.

Rosea. Beautiful rose-pink; one of the oldest and best; blooms all summer. Each, 5c.; 3 for $10 c$

Floribunda. A new variety, bearing flowers usually in pairs, nearly as large as some varieties of Amaryllis. These are rich golden yellow, and of a very peculicr fragrance. A pleasing novelty. Each, 8c.; 3 for 20c.; doz. 60c.

Candida; Pure white flowers, which are smaller but more freely produced than those of the other varieties. Each, 5c.; 3 for 10c.; doz. 35c.

\section{dozen, \$1.00. Postpaid.}

Madame Crozy. A very popular variety; crimson-scarlet, bordered with golden-yellow; foliage bright green, broad and massive. Although of vigorous growth, the plant seldom exceeds 4 feet in height, and often commences to bloom when about a foot high.

Morning Star. Yellow, spotted with maroon; somewhat similar to Florence Vaughan but does not grow as tall.

Paul Marquant. Rich salmon shaded with rosy carmine; foliage dark green; a distinct and pleasing variety; 4 feet.

Peachblow Pinkish-white, changing to rose, with a distinct blotch of deeper shade at neck; foliage green; of dwarf habit.

Queen Charlotte. Bright orange-scarlet, widely edged with golden-yellow; a popular variety; of dwarf habit.

Robusta. A tall variety with ornamental dark foliage; 7 to $8 \mathrm{ft}$.

Shenandoah. A splendid red or bronze leaved variety, beautifully veined and tinted. It bears fine large trusses of waxy-pink flowers and, unlike other dark leaved sorts, blooms early and abundantly.

Mixed. All varieties, doz. 75c., postpaid; hundred by express, $\$ 5.00$

Montbretia. When grown in masses this makes a very effecto deep orange, tive display. The flowers run from orange scarlet of the summer. It succeeds everywhere, requires little care, and propogates rapidly. Each, 5 c.; 3 for $10 \mathrm{c} . ;$ doz. $30 \mathrm{c}$;

\section{Summer-Flowering Oxalis. We know of no plant more} borders, beds, walks, etc. It is also very desirable for massing, making an attractive and effective display. It blooms quickly after planting, and continuously and profusely through the season, and were there no flowers the beautiful clover-like foliage would alone entitle it to a place in the garden.

Dieppi. Pure white with violet shading

Lasiandra. Rose-pink; foliage beautifully cut and distinct from the preceding.

Each of above, large bulbs, doz. 10c., 25 for 15c., 100 for 40c. Smaller bulbs (which we find are nearly as satisfactory), pkg. of $100 \mathrm{cr}$ more, $15 \mathrm{c}$. 


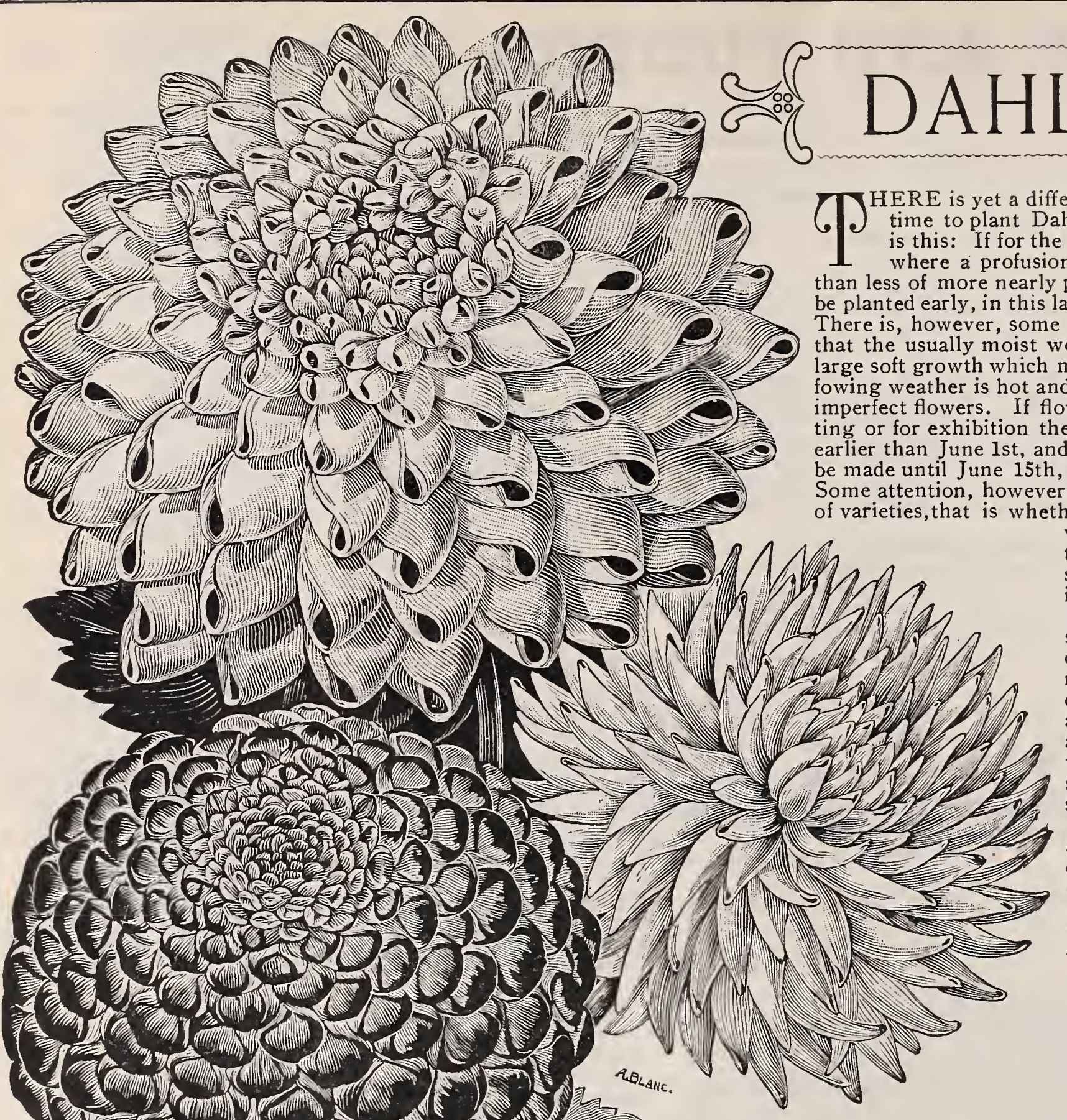
ions for late planting.

Plant in full exposure to the sun in soil thoroughly and deeply worked and well enriched, six to eight inches deep, in rows four feet apart and from two to three feet apart in the rows, but always the latter distance if finest pecimens of bloom are deCultivate often and deeply at first, but stir the soil to the depth of one or two inches only when plants commence to bloom. Stir it often, however, and never allow the surface to become hard.

During a very dry period it may be beneficial to give the plants water; but we believe that it is more often the case that artificial watering of this and other plants is harmful rather than helpful, in that it is generally so insufficiently

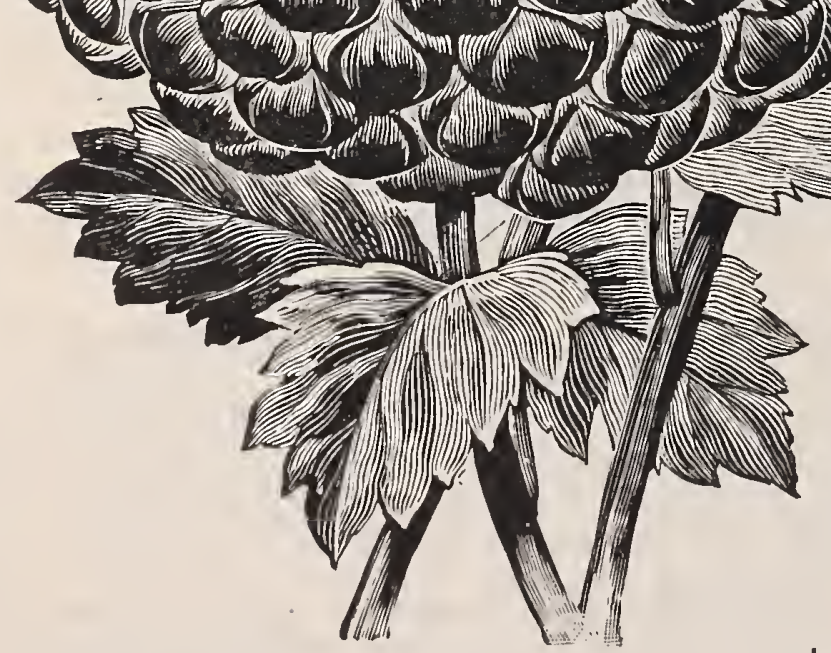

NOTE. - Early orders will probably be filled entirely, and the larger portion of later ones, with roots; but in case our stock of roots of any variety is exhausted we

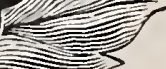

done. Water thoroughly or not at all. Constant stiring of the surface soil will go a long way toward supplying the necessary moisture, in that it will prevent the escape of what is already there.

As soon as the shoots appear remove all but the strongest one and pinch off that, which will cause it to branch at the surface of the ground. This not only concenrattes the strength of the root in this $\Rightarrow$ shoot but removes all of those first growth, thereby obviating to some extent the necessity of staking.

For further information concerning culture read "The Dahlia"

NEW BOOK "THE DAHLIA" Third and revised edition, of the chapters rewritten. Entirely revised list of varieties, which is brought right down the new types and varieties. Everyone interested in Dahlias should have a copy. Price 30 Cents, Postpaid.

CACTUS DAHLIAS. The flowers of the cactus type are all U U US DAther loosely arranged, have long pointed revolute petals, often curved and twisted like those of the Japanese Chrysanthemum and many of the latest introductions would be more appropriately termed Chrysanthemum Flowered. Although loosely built, they are perfectly double; are large, many have long stems and such are among our most desirable flowers for house decoration. The latest introductions especially are very artistic and graceful; unique and beautiful beyond description. To those acquainted only with the older unique and beautiful a revelation when seeing for the first time a collection of ball type it seems a reve Dahlias. Many of the varieties are extremely profuse in bloom and are threfore desirable for garden decoration. 


\section{CACTUS DAHLIAS \\ GNEW VARIETIES O \\ Price, Each 20 Cents, Dozen $\$ 2.00$, Postpaid.}

Arachne. This derives its name, meaning spider, from the peculiar curled and twisted petals and is of very unique form. The petals are creamy and is of very unique form. The petalsare creamy color however varies as much as the form; rarely color howev

Bridesmaid. Pale primrose, shading to delicate rose toward the outer petals; beautiful form ate blooins freely.

Britannia. Deep shaded salmon flesh, stems stout; blooms early and freely.

Capstan. Sof brick-red shaded apricot; with the exception of Countess of Lonsdale the most free-flowering variety.

Chas. Woodbridge. A magnificent flower; rich crimson purple.

Countess of Lonsdale. One of the best.exceeding in free blooning habit any other variety of this class. Large to very large, salmon-red.

Earl of Pembroke. Also one of the best, large petals long pointed and regularly arranged; bright plum, deeper and more velvety toward the center. Blooms profusely.
Exquisite. Rightly named. Flowers large, of perfect form; pure orange scarlet with salmon shadings; very free.

Firebrand. Flowers of fine form. Rich deep d, approaching crimson.

Furst Bismarck. Distinct and striking. blooms profuselv, large; rosy crimson with beautiful bluish sheen.

Harmony. A lovely combination of harmonious shades from old-gold to orange red.

Hunold. Flowers of ideal Cactus form; large, always full to the center. Blooms early and profusely.

Kingfisher. Bloons very early and profusely. Flowers have long stems and keep much longer than other cactu i varieties. Of elegant and artistic form, petals curved in a strikingly irreg ulat manner, color purplish-crimson.

Konigen Wilhemina. Deep crimson, richly shaded, of fine form. Blooms freely and con tinuously.

Lady Edmund Talbot. Terra-cotta, shaded salmon; of perfect form.

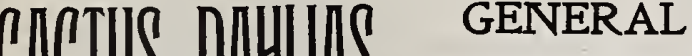 UHUlUO JHIHO COLLECTION}

Price, Each 15c., Doz. \$1.50, Postpaid Blanche Keith. Beautiful pure yellow; of largest size.

Countess of Radnor. Delicate salmon-rose.

Cycle. Bright rosy crimson; early and pro-

Delicata. A beautiful true Cactus variety. Light salmon at base of petals, shading to a delicate pink.

Ernest Cannell. Large, soft red; fine form.

Geo. Marlowe. Primrose-yellow, shaded amber.
Gloriosa. Large; long, pointed, îwisted petals; id carmine-scarlet. Very striking.

Henry Stredwick. Rich velvety maroon

Henry Stredwick. Rich velvety maroor

Henry F. Michell. Of inmense size and irregular form; petals long, broad and twist d.
In color ranging from soft yellow to deep orange. Hohenzollern. Rich, bronzy orange-red with Hohenzollern. Rich,

lona. A rich terra-cotta, shading to orange. Iong stems, profuse.

John 4. Roach. Beautiful light-yellow. Of erfect orm. John Welch. Rich glowing crimson. Of largest size with long-pointed petals. Bloom

riatchless. A grand variety. Of hranching habit, dwarf but strong; blooms extremely early
Mrs. Chas. Turner, of immense size, pure yellow. Bloonis freely.

Miss Webster. White, slightly tinted with of fine form. Very profuse.

Mr. Moore. Deep claret, shaded ma sometimes maroon with claret stripe throngh conter of petal. Always of early and prof usely. One of the best.

Mrs. Barnes. Long twisted narrow petals pink.

Porcupine. A favorite with us. Of unique and beautiful form. Deep crimson; very profuse

Ruby. Deep vermillion center, shading to a purplish tinge at tip of petals. Rich and showy nd perfect in form.

Strahlein Krone. Intense cardinal-red ver rich. Petals long and twisted. Bloons very early and prof usely.

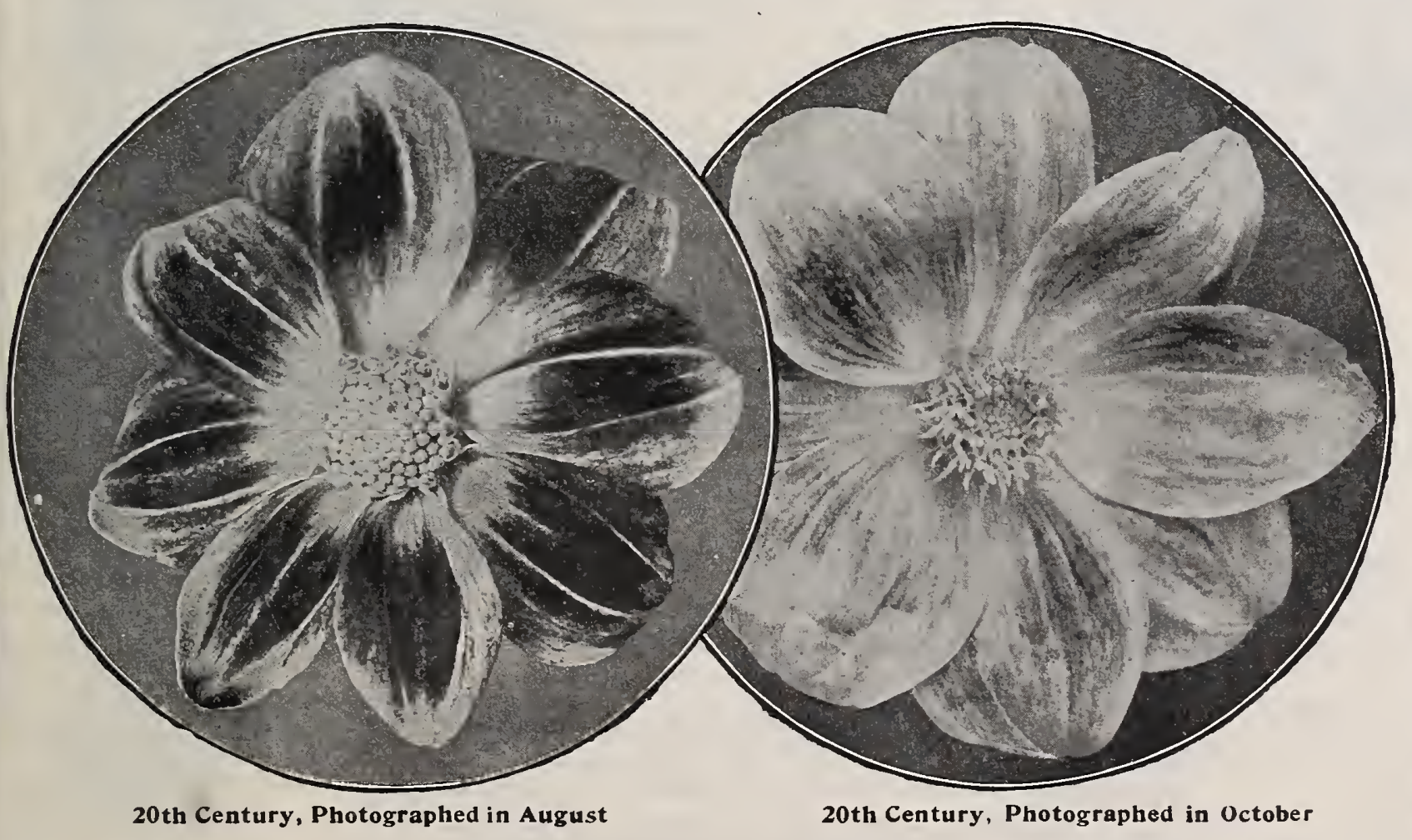

\section{New Orchid-flowered Single Dahlia}

20th CENTURY.

A unique variety. Entirely distinct from all other single Dahlias. The color is intense rosy crimson with yellow center. yellow center. As the season adlighter and the color contrast exquisitely lovely. The color does not fade or change like many other fowers but each succeeding flower opens lighter andlighter until in September tiful pure pink; toward October this zone becomes delicate pink and in October the flower is pure white delicately suffusedblush pink as shown in the photograph. It will be readily in the photograph. It will be readil variety is that practically there is every week a new fower. It blooms very early and continuously unti very early and continuously until and are from $4 t / 2$ to 6 inches in diamand are rom $4 \frac{1}{2}$ to 6 inches in diamshould be in every collection. Each Should be in every collect
$30 \mathrm{c} ., 4$ for $\$$ I.oo, postpaid.

Other Single Flowered Vari eties. Including 2oth. Century Seedlings and many others; our selection. 3 for 40 c., doz. $\$$ I.5o, postpaid.

\section{Decorative Dahlias}

These are sometimes termed Decorative Cactus, and the class includes all large loose-flowering varieties which do not properly belong to the Cactus class. They are of very free-blooming habit rivaling if not excelling the Cactus varieties in this respect, and flowers are usually of the largest size.

\section{THREE NEW DECORATIVE DAHLIAS}

Mrs. Roosevelt. A giant, six to seveninches in diameter, delicate blush-pink. Resembles Grand Duke Alexis, but is much superior. Plants only. Ready in April. Each 40c., 3 for $\$ 1.00$.
Frank L. Basset. The nearest approach to a Blue Dahlia; bright royal purple with bluish-shading. Large and of fine form. Plant always a mass of bloom. Each, $25 \mathrm{c} ., 3$ for 6oc.
Eureka. Blooms very early and profusely Large and of fine form. Long stems. Beautiful every collection. Each, 3 oc., 3 for $75 \mathrm{c}$ 


\section{DECORATIYE DAHLIAS GeNERAL COLLECTION \\ Price, Each, 15 cents, Dozen \$1,50, Postpaid.}

Admiral Dewey. Brilliant imperial purple. Antietam. Large, perfect form. Intense red.

Asia. White suffused lavender.

Black Prince. I,arge, of perfect form. Inse velvety maroon, almost black.

Bronze Beauty. Golden yellow overlaid with

Clifford W. Bruton. The best yellow.

Claribel. An exquisite variety. Very large;

Countess of Pembroke. Soft rosylake; pro-
Cyclops. Rosy crimson, richly shaded; large. Dr. Masters. A fine delicate pink; distinct. Evadne. Soft, rich, primrose-yellow, tipped creamy white, sometimes delicately edged and tinged soft pink. Constantly in bloom.

Grand Duke Alexis. A magnificent flower of largest size and distinct form.

Henry Patrick. Pure white; large, good

Lemon Giant. Of immense size; pure lemon. looins freely.

Lucile. Rich in color and beautiful in form. old gold shading to orange, reflex shaded amber. Profuse.

Lyndhurst. One of the best bright scarlets; large full center. Long stems.

Miss Barry. Large; beautuful color, deep roselake.

Nymphæa. The Waterlily Dahlia. Clear, distinct, light shrimp-pink; lighter toward the center.

Oban. Very large; distinct, rosy lavender, overlaid with delicate, silvery fawi.

Perle d'Or. The best white Decorative Dahlia. Very large; of beautiful and peculiar form.

William Agnew. One of the finest reds. Large and of perfect form. Always a mass of bloom.

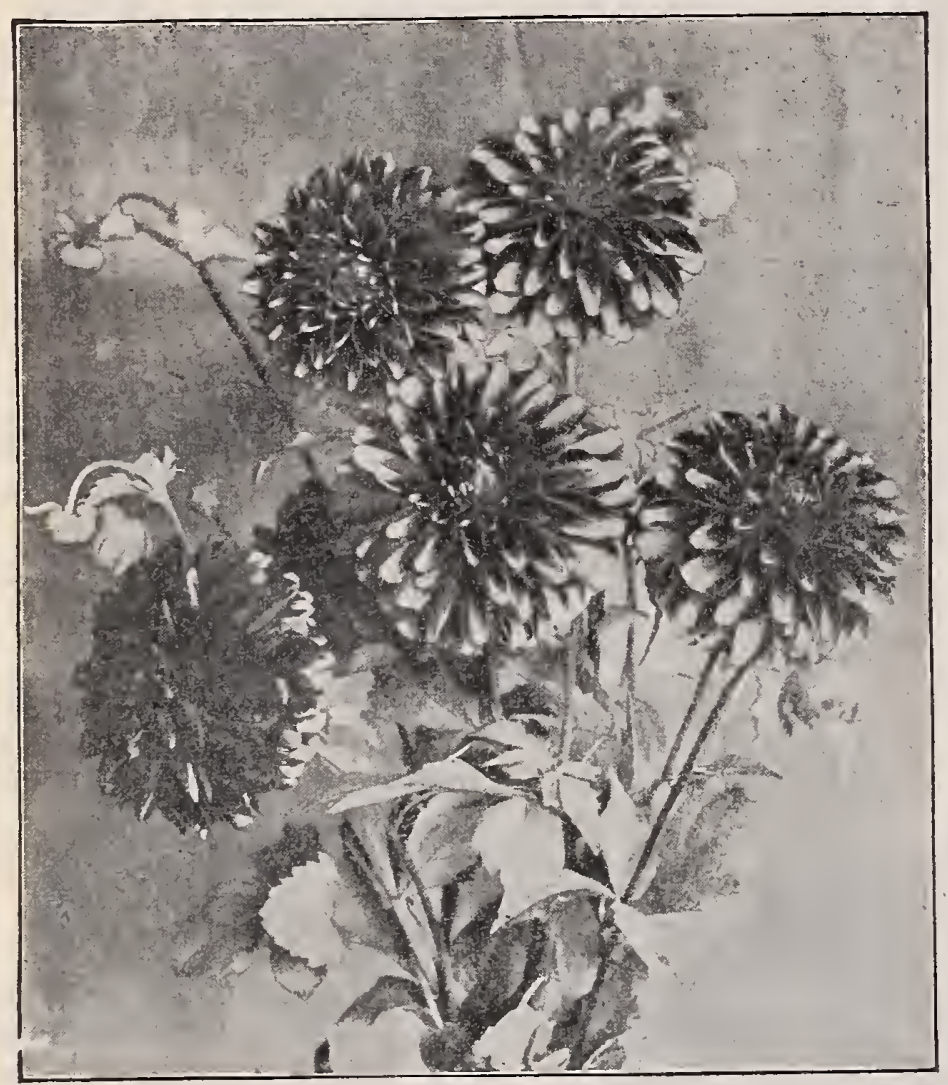

ADNIIRAL SCHLEY.
FANCY DAHLLAS

\section{Three New Fancy Dahlias}

Admiral Schley. A seedling of Ameri- | sometimes solid crimson. All these types can Flag and a great improvenient on that often appear on the same plant. Each, popular variety. It is of same color and marking-bright crimson with a broad white stripe through the center of each petal-but
much larger and blooms as freely. Each, 30c., 3 for 75 c., postpaid.

Judah. Distinct and very pleasing. Sometimes solid primrose-yellow, often gold or penciled snd striped crimson and ${ }_{5}$ c., 4 for $50 \mathrm{c}$., post paid.

Olympia. One of the grandest Fancy Dahlias to date. Of immense size, measuring 6 to 7 inches across, and, owing to the great length of the petals when opening, there is never a green center, even when the buds are first expanding. Color, deep rose-pink, striped and penciled with rich crimson. Each, $25 \mathrm{c}$., 3 for $60 \mathrm{c}$., postpaid.

\section{FANCY DAHLIAS. General Collection.}

\section{Each, 15 cents, Dozen $\$ 1.50$, Postpaid.}

Ben Butler. Rich maroon, tipped white, ways perfect.

Chang. Very large; salmon buff, striped Decorator. White, suffused pink, spotted and penciled with crimson.

Elegans. Rosy purple, tipped and banded hite.

Frank Goodman. Dark, rich purple, tipped white. Distinct.

Frank Smith. A supurb variety. Rich, purplish maroon, tipped blush white.

Gen. Grant. Very large; yellow suffused amber, striped crimson.

Gilt Edge. Pure white, margined with deep guld.
Grand Sultan. Very large; salmon

buff, penciled and spotted crimson.

Harlequin. Brilliant crimson, shaded arker, striped and tipped pure white.

Jarkosky. A beautifu1 mottled variety; crimsun, yellow and white.

Mrs. Stancombe. Straw-yellow, suf fused amber, striped red, mottled and tipped blush white.

Penelope. White, flaked lavender. A lovely variety.

Rudolph Kahl. Dark, velvety maroon, tipped whitc; very profuse.

Silver Tip. Pure canary yellow, tipped white.
SHOV DHYLIAS $\begin{aligned} & \text { Show Dahlias are identical in form } \\ & \text { with the Fancy, are often included in } \\ & \text { the same class aind }\end{aligned}$ only varieties of a single color, and those of which ground color is lighter than varies.

\section{Three New Show Dahlias.}

\section{Each, 25c., the 3 for 60 c.} Aleta. This is not only one of the earliest to bloom, but the most profuse
continuous. Although the flowers a re rather small they are of pertect and continuous. Although the flowers are good substance.

\section{Ethel Britton Large, beautiful form; white, Geo. Smith. Large and of perfect form, crim-
uffused and overlaid with soft lavender-pink.}

son. Golden Ball. Very large pale golden yellow. Hero. Deep crimson-maroon, large; blooms profusely.

Honest John. Brilliant purple-maroon, richly shaded, often with some petals much darker than others.

Magnificent. Pure light yellow, very delily edyed red.

rary D. Hallock A fine yellow quilled variety. Miss May Lomas. White suffused soft laven-

Mrs. Dexter. Very large, a rich shade of sal-
Its early and profuse blooming entitles it ually changing to a very dark maroon as the flower expands. Large, of fine

Red Hussar. Large flowers, of purest cardinal-red without trace of

A. D. Livoni. The best pink; blooms early and Arabella. Pale primrose, tipped and shaded Constancy. Very large; yellow edged and

Crimson Ball. Bright crimson-purple.

Eclipse. Brilliant scarlet.

Emily. Large and beautiful flower; varies

Emily Edwards.
Mrs Gladstone. One of the best, delicate blush. Mrs. Langtry. Excellent, cream-peach and

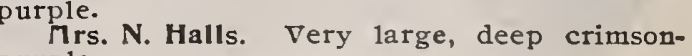
purple. Model of Perfection. Rosy lavender; long Psyche. Pale primrose, shaded rose; profuse. Psyche. Pale primrose, shaded rose; prof use. Purity. White, large and of perfect form.
Queen of the Belgians. Very delicate blushpink: early and profuse.

Ruby Queen. Ruby red, richly shaded; large, long stems; profuse.

Sir Chas. Mills. Large, pure yellow; one of Storm King. (Blizzard.) A new snow-white ariety. Extremely early; very profuse and constant.

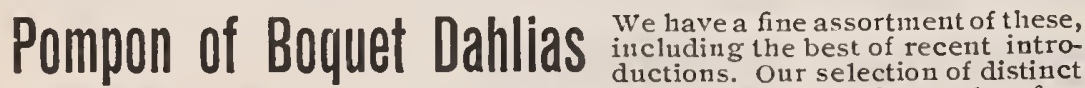
wane color when only a Each, I2c., dozen, $\$ 1.25$, postpaid.

SPECIAL OFFIR OF NAMED VARIETIES. OUI Selection. Dozen, $\$ 1.25,25$ for $\$ 2.50$, postpaid, 25 by express $\$ 2.00$.

Besides the many varieties named here we have to offer as many more which want of space prevents us offering under name. Some are new, and some are fine old varieties, Usually, some of all classes: Cactus, Decorative, Fancy, Show and Pompon will be included, but we will, as much as possible, modify the selection to suit the customer, although we cannot guarantee to a1ways conform to his choice.

\section{MIXED DAHLIAS.}

A fine range of colors and first-class roots. Dozen, $75 \mathrm{c}, 25$ for $\$ 1.50$, roo, $\$ 5.00$, by express only. 


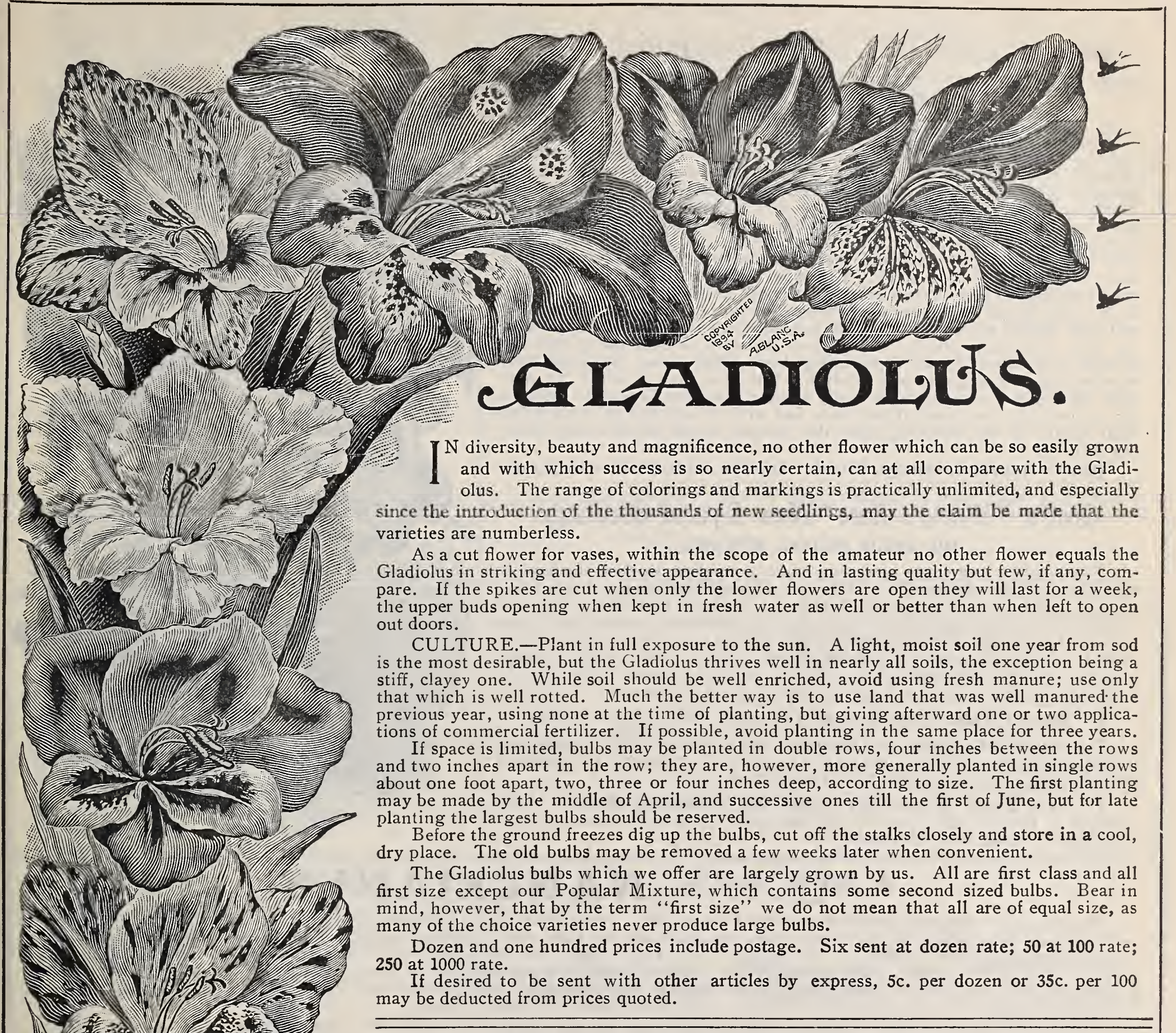

\section{THE LEMOINE HYBRIDS, Spotted or Butterfly Gladioli.}

This race, although often designated in catalogues as new, was introduced some twenty years ago by M. Victor Lemoine, of Nancy, France, with whom it originated. At its introduction it surpassed all other strains in gorgeous coloring and peculiar marking. Unfortunately a large proportion of the varieties had slender crooked flower spikes with small flowers; but many of these varieties have been discarded and from time to time better ones have been added, until now the class contains some of our most beautiful varieties.

Lemoine Hybrids, Mixed. Doz. 25c.; 100, $\$ 1.75 ; 1000, \$ 13.00$. Extra Fine Mixed Lemoine. Contains only improved and named varieties. Doz. 40c.; 100, $\$ 2.75 ; 1000, \$ 22.00$.

THE CHILDSI, or Max Leichtlin Hybrids. Giant Gladioli. This class originated in Baden Baden, Gergrower Max Leichtlin. At the time of its introduction it surpassed all other strains both in size spike and fower and was vigorous habit. The range of colors was not great, but there were many new shades of the slaty or smoky-blue type. There has been considerable improvement since its introduction, the work of the introducer in this country, and some of the new seedlings are very fine and all are very large flowered, but there is yet a lack of good white and light varieties. This should by no means prevent any from giving this strain the place it deserves nor from planting it, and we only mention the fact to prevent disappointment to those wha, ignorant of it, might plant expecting the usual proportion of such colors.

Choice Mixed Childsi. Contains many new seedlings as well as the best of the earlier introductions. Doz. 40c.; 100, $\$ 2.75 ;$ $1000, \$ 22.00$.

Gladioli and Dahlias should, if possible, have a place in every garden. As indicated by the space we devote to both, we make a specialty of these flowers. 


\section{GLADIOLUS-Continued}

\section{Groff's Hybrid Seedlings}

This new strain was originated by $\mathrm{Mr}$. H. H. Groff, of Simcoe, Canada, and although it comprises only his first introductions it surpasses the work of all other originators in great vigor of plant and equals, if not excels, all others in diversity of colors and markings, except the World's Best or Gold Medal strain and possibly the latest work of M. Lemoine. It contains colors hitherto unknown to commerce, including shades of Lilac, Lavender and Clematis, not found in any other class except the World's Best. The only fault which might be found with it is that with all its great diversity there is a dearth of light shades, especially those in which a white ground predominates. (This, however, is remedied in the later work of Mr. Groff-the World's Best strain following - section 2 containing many white and light shades of wonderful beauty and excellence, far surpassing most of the best old-named varieties.) The great diversity of dark colors and the peculiar and novel shades approaching blue, make these Seedlings well worthy a place among the best Gladioli. The low price at which we now offer them makes it possible for many to have these seedlings who hitherto did not feel that they could afford them, and with the addition of some of the light shades of the following class the mixture would afford a very pleasing diversity.

Groff's Hybrid Seedlings, Mixed. Doz. 40c.; 100, $\$ 2.75 ; 1000, \$ 22.00$.

\section{Groff's "World's Best" New Hybrid Seedlings OR GOLD MEDAL STRAIN.}

The World's Best strain represents some of the later work of the famous hybridizer and far surpasses any other of the world's commercial strains in diversity and in novel and peculiar beauty. In section 3, especially, are shades never before known to commerce, and the three sections combined afford an unequaled collection of the most desirable varieties yet offered to the public. With the exception of the Gold Medal Collection and Groff's Special Selections, not yet generally offered, the World's Best is the latest of Mr. Groff's introductions, and is without doubt the best strain in commerce.

1. Newest Reds, Scarlets, and Crimsons. Doz. 60c.; $100, \$ 4.00$.

2. New White, Light and Yellow. All shades of white, cream and yellow in many combinations, relieved by stains and blotches of rich colors in most pleasing contrasts. Doz. 70c.; 100, $\$ 5.00$.

3. Rare Blues, in Clematis, Lilac, and Heliotrope Shades. New Hybrids of Papilio Major, practically unknown. Not to be found in any other strain. Doz. 70c.; 100, $\$ 5.00$.

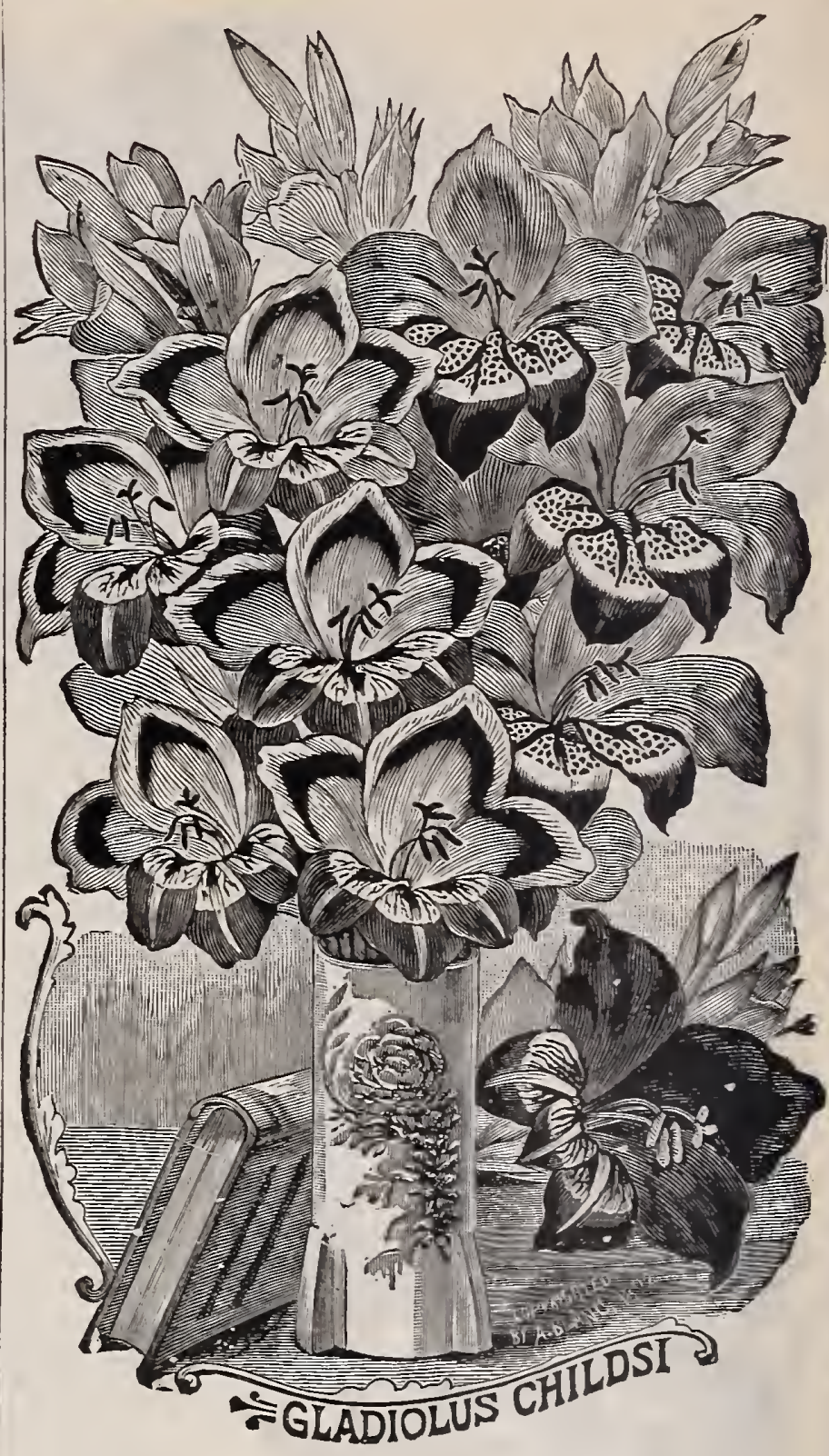

\section{A NEW RACE-NANCEIANUS}

This new race comprises the latest work of $\mathrm{M}$. Lemoine. It differs from the Lemoine Hybrid's class in having much larger and well expanded flowers with more pointed petals and spikes also are taller and of stronger growth; both flowers and spikes more closely resembling those of the Childsi. It fully equals, if not excels, the Lemoine Hybrids in diverse beautiful and unique markings and greatly surpasses the Childsi in this respect and in size and form of flower and in size of spike and habit of growth to which we have referred, is greatly superior to the Lemoine Hybrids and at least approaches the Childsi, if not equal to it, in these desirable features. The class is destined to occupy a prominent place in this large family of beautiful flowers.

Choicest mixture, of named varieties only: Doz. 70c.; 100, $\$ 5.00$.

\section{MIXTURES OF GLADIOLI}

\section{OUR WORCESTER MIXED.}

This mixture, prepared by us, comprises many named varieties, selections from all the various classes - Lemoine, Childsi, Groff's Hybrids, Extra White and Light, etc., and also selections from the strains known as Burbank's California Select and Gray's Ingleside Hybrids. It is our aim to offer a mixture at a reasonable price which shall contain the most desirable varieties possible as well as one of the greatest possible diversity, not only of color but also of form or type. In its preparation many of the best old named varieties are used and also special selections from the many new hybrids and seedlings. It will, we are sure, afford very satisfactory results, and we advise its use in preference to any other mixture here offered. Doz. 50c.; 100, $\$ 3.50 ; 1000, \$ 30.00$.
OUR CHOICE MIXED.

This is composed largely of the older type (Gandavensis) but also includes some new seedlings differing more or less from that type. The range of colors is good, the bulbs are all firstclass and first size, and our aim has been to discard all inferior varieties. It has always given satisfaction. Doz. 30c.; 100, $\$ 2.00 ; 1000, \$ 15.00$.

\section{OUR POPULAR MIXTURE.}

Bulbs all blooming size but not all first size. This mixture contains a proportion of varieties which increase rapidly, on which account as well as the size of some of the bulbs, we are enabled to offer it at such a low price. The range of colors is good, and although it is of course not equal in some respects to the preceding, it has since we first offered it been a popular mixture. Doz. 20c.; 100, $\$ 1.25 ; 1000, \$ 9.00$. 


\section{MIXED GLADIOLI IN SEPPRATE GOLORS}

White and Light Shades, Mixed. Choice Mixed. Doz. 35c. $100, \$ 2.25 ; 1000, \$ 18.00$.

Choicest Varieties, Mixed. Containing only the best of this class and including Snow White, Shakespeare and many other named varieties. Doz. 50c.; 100, $\$ 3.50 ; 1000, \$ 30.00$.

\section{Named Varieties for Special Purposes.}

It will be noted that we do not as formerly offer a large list of named varieties. Owing to the great diversity found in our mixtures and the superiority of hundreds of the new hybrids to many or most of the old named sorts we no longer consider it necessary or advisable. We offer the following mainly because of their adaptability to special purposes as indicated in descriptions.

Brenchleyensis. Vermillion-scarlet; long spike. The best variety for planting among shrubs. Doz. 25c.; 100, $\$ 1.50 ; 1000$, $\$ 10.00$

Snow White. The nearest approach to pure white having only a faint tinge of cream on lower petal. A beautiful variety;
Yellow and Orange, Mixed. Doz. 50c.; 100, $\$ 3.50$; $1000, \$ 30.00$.

Scarlet and Crimson, Mixed. Doz. 25c.; 100, $\$ 1.75$; $1000, \$ 13.00$.

Striped and Variegated Varieties, Mixed. Doz. 40c. $100, \$ 3.00 ; 1000, \$ 25.00$.

this and the following sorts are the best of their class for the florist and also for the garden. Each $15 \mathrm{c}$., doz. $\$ 1.50$.

Shakespeare. A fine old variety; white, very slightly suffused carmine-rose; spike long; blooms early. This next to Snow White is considered by many the best white sort. Each 10c. doz. $\$ 1.00 ; 100, \$ 7.50$.

Augusta. Nearly white, having only a tint of pink in throat. It is more productive than Shakespeare often having two or three spikes of bloom, many of which are branching. Each 10c., doz. $\$ 1.00,100, \$ 7.50$.

John Bull. White slightly tinted with sulphur, a beautiful variety which, although it has not a large spike, has been very largely used by florists. Each 5c.. Doz. 35c., 100, $\$ 2.50,1000$, $\$ 20.00$.

be the desired diversity or even that there shall be no duplicates. We therefore offer the following two collections which consist of some of the best old named sorts and special selections of the new

Gladioli to be fully appreciated should be grown in large quantities, but this however is not possible for all. It has been our experience that nearly all when buying a small quantity of bulbs desire to secure such as will give them the greatest diversity possible. While our mixtures will afford this when planted in quantity, it is of course impossible for us, when only a limited number is purchased to guarantee that there shall always range of colors, markings and forms possible for the number of varieties.

Collection No. 1. Twelve distinct and diverse varieties. 60c. postpaid.

Collection No. 2. Twenty-five distinct varieties permitting a wider selection. $\$ 1.00$ postpaid.

\section{* * TUBE ROSE * *}

Bulbs may be started in the house for early flowers, or they may be planted in the open border, but not earlier than June in this latitude.

Excelsior Dwarf Pearl. This is an improved strain, plant is of dwarfer habit, blooms earlier and flowers are more double than old strain. Our bulbs are sure to please.

Extra large Bulbs. Each 4c., 3 for 10c., doz. 40c., 25 for 70c. postpaid. By express, 50 for $\$ 1.00 ; \$ 1.75$ per hundred.

Medium Size. Each 3c., 4 for 10c., doz. 25c., 25 for $45 \mathrm{c}$. postpaid; 100 by express $\$ 1.35$.

MADEIRA VINE. A rapid, beautiful climber, with waxlike light green leaves and feathery, white flowers, with fragrance resembling Mignonette.- Of easiest culture, plant when danger of frost is past. Each 5c., 3 for 10c.; doz. 35c.; postpaid.

\section{* PEONIES *}

This magnificent class of plants interest in which has in the last few years revived, is well worthy a place in every garden; few plants excel it for a striking, effective appearance in the border or in clumps or singly on the lawn. Thus far there seems to be no disease or insect which affects it. It is entirely hardy, and but few plants can be so easily transplanted, either in spring or fall, with an almost certainty of living.

Named varieties, our selection, various shades of rose and pink. Each 25c.; doz. $\$ 2.50$

Named varieties, double red or double white. Each $35 \mathrm{c}$. doz. $\$ 3.50$.

If by mail add 5 cents each to price.

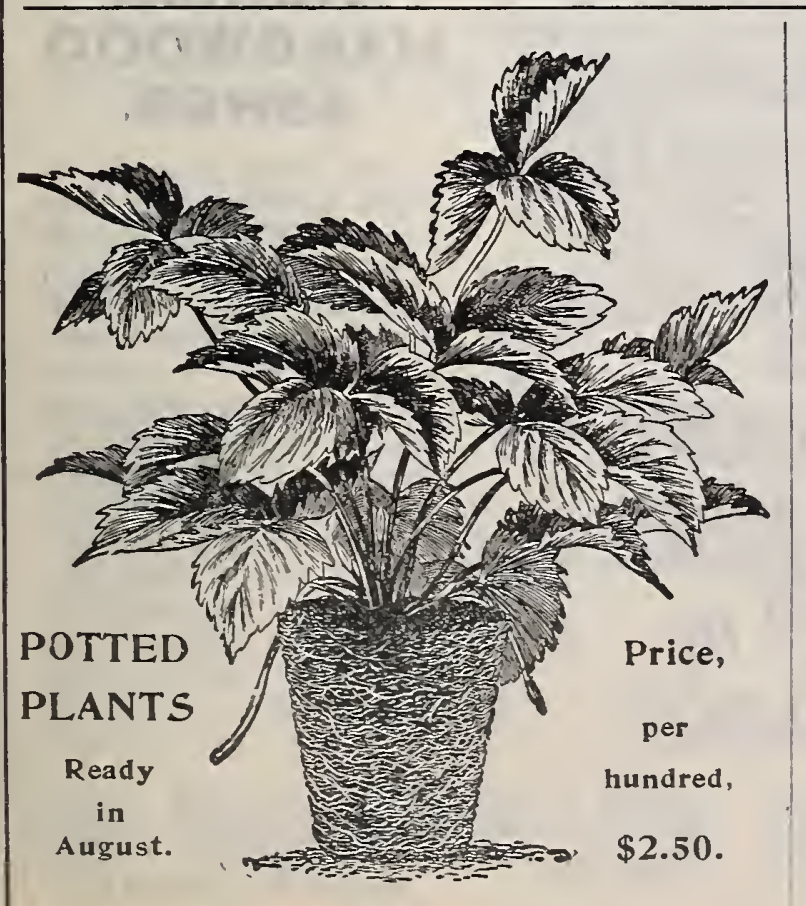

\section{Strawberry Plants} packed, insuring delivery to customer in best condition possible. Their condition will be found greatly superior generally to those received from the West or South, the latter being generally sold so cheaply that the necessary care in preparing them for shipping cannot be afforded. The probable different conditions should be consider we and see no reason for offering others inferior in various respects. Varieties marked (p) have imperfect flowers and require to be grown with them some one of the others, one row in five of the latter being ffient.

The President. This new variety is very highly recommended by those who have seen or grown it. Distinctively an all season berry, having to a remarkable degree the tendency to produce late fruit talks, the number of which is so great that they might be termed a second crop, and the product being always of largest size and perfect form. The fruit is of the finest quality and stands shipping well. The plant is not only productive but extrenely vigorous and hardy. Doz. 50c., postpaid; rooby express 50

Brandywine-A large, late and handsome berry, conical form, dark, glossy red. Plaut healthy igorous and productive.

Bubach (P.) - Of large and uniformin size, regular in furm and of good color. Plant remarkab vigorous and unsurpassed in productiveness. Probably more largely planted a

ariety.

Clyde.-Fruit large, firm and beautiful, of regular conical shape, never varying, and holds

nd of season. Color light scarlet. Considered by some good growers to be almost a perfect

Gien Mary.-A good sort for the kitchen garden. Berries conical, bright red,

Marshall.-Good to set with Talbot or other imperfect flowered varieties.

finest kinds in cultivation.

Minute Man (P.)-One of the most valuable new sorts, continuing in bearing

ong time. Fruit bright scarlet, very sweet.

Talbot (P.)-One of the best market berries in cultivation. Fruit of fine color

Fach of the abore except President by

fy the rooo. 


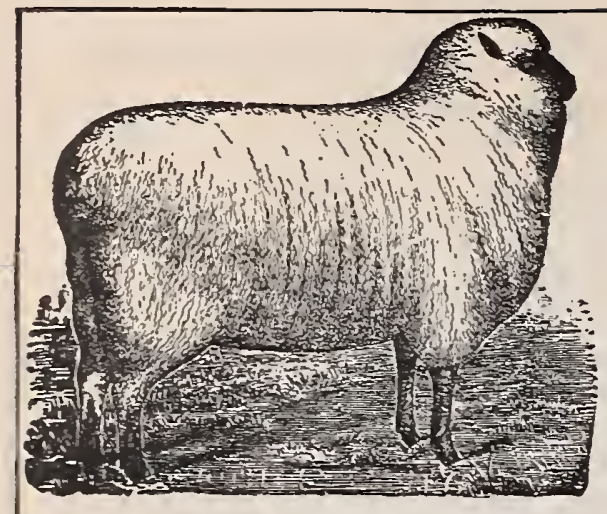

\section{PUIVERIZED SHEEP MANURE.}

This is a pure, natural manure, and the most nutritious food for plants. Its effect is immediate, much more lasting and healthy than guano or any other manure. It is the best of all manures for mixing with the soil for greenhouse plants. It makes the richest, safest and quickest liquid manure, rivaling guano, without any deleterious effect. Instead of being put up in the natural state as formerly, we have it kiln-dried and then finally pulverized, which makes it much more convenient to handle, an i it can be kept in any cellar for an indefinite length of time.

DIRECTIONS. For mixing with soil: Take one part manure to six of soil. For making a liquid: Take one pound of manure to five gallons of water. This can be used with safety every day.

Prices. Ton, $\$ 25.00$; 100 Ibs. $\$ 1.75 ; 5$ lbs. 25c. Special Price by the Car Load.

\section{Rara Materials or Fertilizing Chemicals

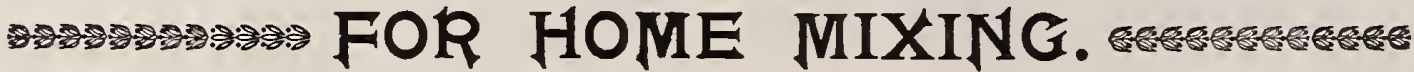

Farmers who understand compounding and mixing chemicals for different crops can no doubt save something in buying chemicals and mixing them themselves rainy days and at odd jobs, but it is a dangerous and expensive undertaking for those that do not know how, and to such we advise buying mixed goods of some reliable brand. We have for several years made a specialty of this branch of our trade and have the reputation of furnishing chemicals lower than many of the fertilizer companies who handle large quantities, but recommend mixed goods. The following prices are subject to change without notice, but in large lots we can shade the prices for cash with the order.

HIGH GRADE SULPHATE OF POTASH.

go to 95 per cent. Sulphate of Potash, 48 to 50 per cent. actual Potash.

In original bags, 224 lbs. each. DOUBLE SULPHATE OF POTASH AND MAGNESIA.

40 to 50 per cent. Sulphate of Potash, 25 to 28 per cent. actual Potash.

In original bags, 2241 bs. each. - Per 1001 bs. \$1.65; perton, $\$ 30.00$ MURIATE OF POTASH.

80 to 85 per cent. Muriate of Potash, 50 to 55 per cent. actual Potash.

In original bags, 224 lbs. each. Per I00 lbs. $\$ 2.40$; per ton, $\$ 45.00$ KAINIT.

23 to 25 per cent. Sulphate and Muriate of Potash, I2 to I3 per cent.

actual Potash. In $2001 \mathrm{~b}$. bags. $\quad$ Per $1001 \mathrm{bss}$. $90 \mathrm{c}$; per ton, $\$ 15.00$ NITRATE OF SODA.

96 per cent. purity: 9 per cent. Anmonia. In original bags about 275 lbs. each.

24-75 per cent. Ammonia. In $200 \mathrm{lb}$. bags. DISSOLVED BONE BLACK.

I5 to 18 per cent. Soluble and Available Phosphoric Acid. In $2001 \mathrm{~b}$

bags. $\quad$ Per roolbs. $\$$ I.25; per ton, $\$ 22.00$ ODORLESS SLAG PHOSPHATE.

Ig to 22 per cent. Phosphoric Acid. Nearly all available. The cheapest

form of Phosphoric Acid. Per $1001 \mathrm{bs}$. \$1.25; per ton, \$22.00
PLAIN SUPERPHOSPHATE.

I4 to I7 per cent. Soluble and Available Phosphoric Acid. In $2001 \mathrm{~b}$. bags.

DRIED BLOOD.

I2 per cent. Ammonia. In 2001 b. bags. Per Ioo 1bs. $\$ 2.35$; per ton, $\$ 43.00$ DRIED BLOOD.

I5 per cent. Ammonia. In $2001 \mathrm{~b}$. bags. Per 100 1bs. $\$ 2.75$; per ton. $\$ 50.00$ FINE GROUND TANKAGE.

6 per cent. Ammonia. 30 per cent. Bone Phosphate. In $2001 \mathrm{~b}$. bags. FINE GROUND TANKAGE.

9 per cent. Ammonia, 20 per cent. Bone Phosphate. In $2001 \mathrm{~b}$. bags.

FINE GROUND NOVA SCOTIA PLASTER.

White and fine, In $2001 \mathrm{~b}$. bags. Per roo lbs. 50c; per ton, $\$ 9.00$ FINE CROUND BONE.

3 to 4 per cent. Ammonia, 22.80 to 25.23 per cent. Phosphoric Acid. In $2001 \mathrm{~b}$. bags.

ABBATOIR BONE.

2 to 3 per cent. Ammonia, 22 per cent. Phosphoric Acid. In $200 \mathrm{lb}$. bags.
Per 100 lbs. \$1.50; per ton, $\$ 28.00$

Terms: CASH, Delivered on Board Cars, Boston or Worcester.

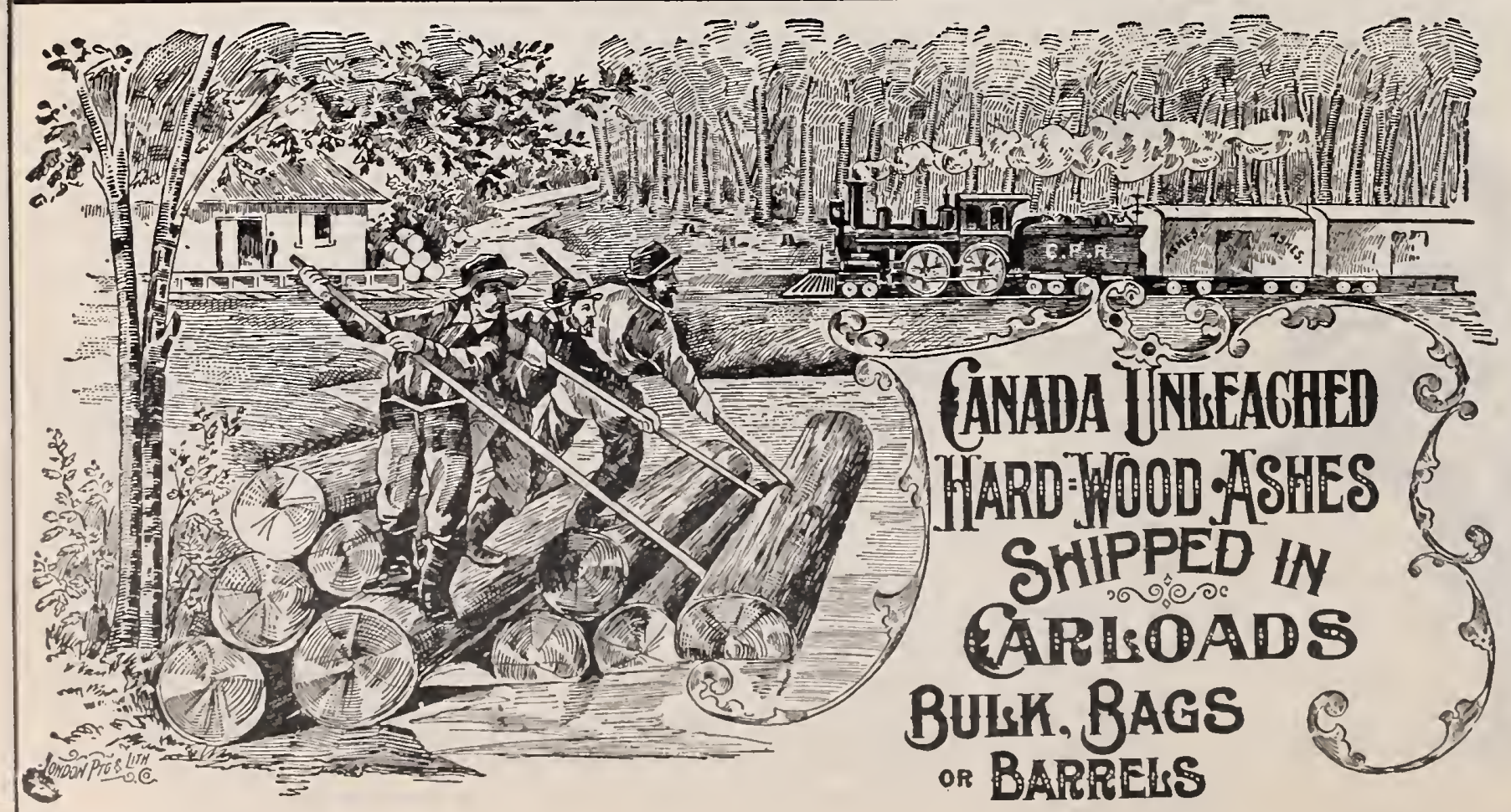

\section{CANADA HARDWOOD ASHES.}

The main features of wood ashes are that they contain Potash, Phosphoric Acid and Lime, obtained from a source which places them naturally in the most soluble, and, therefore, the most available and acceptable form necessary for the plant. Potash and phosphoric acid are two of the mineral elements of plant food which are taken up by growing plants. IVe guarantee our Ashes and can furnish any quantity

Price. Ton, $\$ 12.00$; 100 Ibs. $\$ 1.00$.

Special Price in Car Lots. 


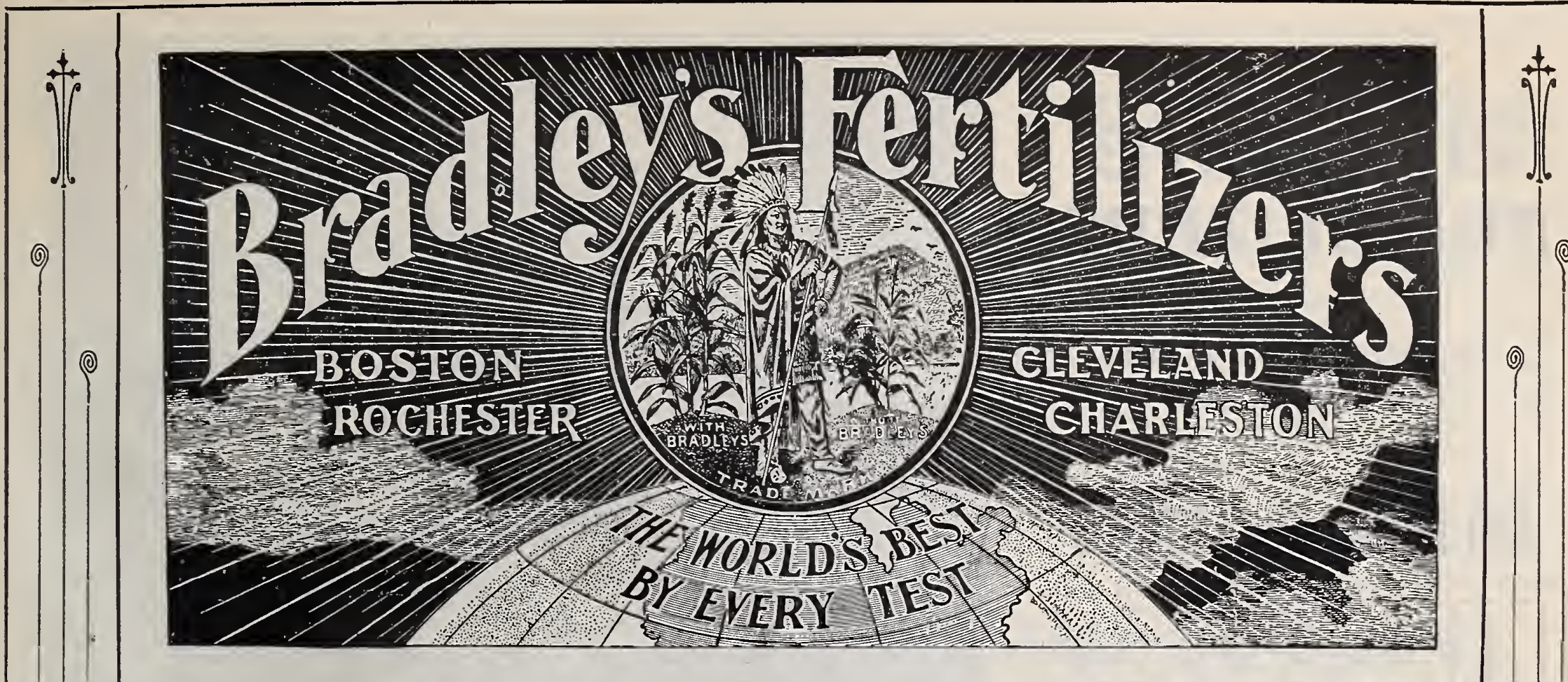

\section{THE BRADLEY}
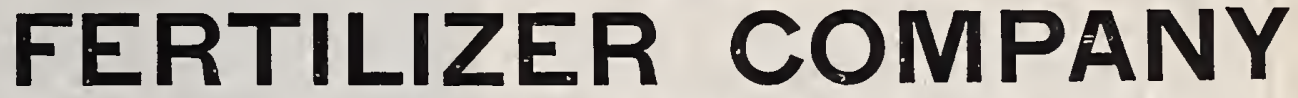

was the pioneer of the fertilizer business, and for nearly half a century has been, and still is, the leader in that line, manufacturing and selling more fertilizers yearly than any other company in this field. They have not only the largest and best equipped factories, but the prestige of longest experience and most successful career, which has rendered their products a household theme from Maine to California, and has secured to them the familiar cognomen of the "OLD RELIABLE."

BRADLEY FERTILIZERS

are to-day, as they have been for nearly half a century, the cheapest, safest, and most reliable for you to buy.

BRADLEY QUALITY

Means Best Material, Most Thorough Manufacture, Perfect Mechanical Condition, Highest Agricultural Value.

THE WORLD'S BEST BY EYERY TEST."

BRADLEY'S XL PHOSPHATE has been more extensively used than any other brand of

on all crops and under all conditions.

\section{BRADLEY'S POTATO FERTILIZER For Growing Smooth, Sound Potatoes of the Best}

It is admitted by successful potato growers that a good commercial fertilizer is indispensable in raising potatoes of the best quality and free from rot or scab. Bradley's Potato Fertilizer is in no sense a theoretical or experimental mixture. It is prepared from formulas which repeated field tests have proven to produce the largest crops of smooth, sound, and handsome potatoes. It is finely ground and very dry; it will, therefore, work perfectly in any planter.

\section{BRADLEY'S COMPLETE MANURES FOR ALL CROPS}

\section{SPECIALLY ADAPTED TO EXTENSIVE FARMING AND TARKET GARDENING.}

These manures are the richest and most effective fertilizers sold, as has been abundantly proved by results in the field. They are manufactured from the very best plant-food materials obtainable. In mechanical condition they are unequaled. They drill perfectly in any machine. They are divided into classes, based upon exhaustive field tests, and not upon theoretical experiments of the laboratory, the fault of "special crop fertilizers," in which common sense and practical experience are sacrificed for the sake of theoretical hobbies. Bradley's Complete Manures are, in the fullest sense, "complete" fertilizers, and the several grades furnish complete plant-food in the best forms for all crops grown.

Bradley's Complete Manure for Potatoes and Vegetables Is particularly rich in ammonia and potash, and has given phenomenal results in growing large crops of the best quality of potatoes, onions, beets, turnips, carrots, cabbages, squashes, melons, etc. It is the most perfectly balanced fertilizer manufactured for growing all kinds of root crops and market garden truck. It is the market gardener's favorite.

Available Phosphoric Acid,

Total Phosphoric Acid,

Potash ( $\left.\mathrm{K}_{2} \mathrm{O}\right)$

Equal to Sulphate Potash,

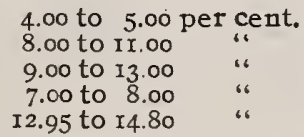

Bradley's Potato Fertilizer is one of our best known and most popproduce of lare crops of fine quality potatoes. It is finely ground and producer of large crops of fine quality potatoes. It is finely ground, and or in the potato planter.

\section{ANALYSIS.}

Nitrogen, equal to Ammonia,

Available Phosphoric A
Total Phosphoric Acid,

Potash ( $\left.\mathrm{K}_{2} \mathrm{O}\right)$

Equal to Sulphate Potash,

Bradley's XL, Phosphate, 25 1b. bag,

Bradley's XI, Phos phate, 50 1b. bag, I.00| Bradley

Bradley's Complete Manures for Potatoes and Vegetables-Cornand

will be allowed for cash. 


\section{MAPES \\ COMPLETE FERTILIZERS}

\section{The Choicest Materials Are Used in the MAPES MANURES}

\section{High Farming With Fertilizers}

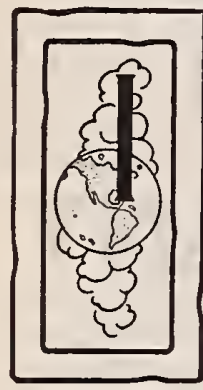

T IS AN INSPIRATION to all lovers of profitable agriculture to read the Mapes pamphlets. Professor Mapes has long exerted a powerful influence in behalf of better agriculture and more profitable farming in the Middle and New England States, and also at the South. His annual pamphlets are always full of meat, "horse sense," and the practical experience of farmers, fruitgrowers, market gardeners and others who continue to use Mapes Manures year after year because it pays them to do so.

All this is an instance of the well-known fact that the party or concern which persists in making only goods of the very highest grade will, in time, acquire a trade and reputation that nothing can break down. Acting on this plan, Professor Mapes has constantly utilized all the teachings of science and experience in the preparation and use of the Mapes Complete Manures. Their basis is genuine pure Peruvian guano and pure animal bone, made soluble and available without objectionable acidity, and all the ammoria is fixed. There is no loss from exposure or in keeping.

That the Mapes Manures are worth what they sell for is abundantly demonstrated by the experience of thousands of satisfied farmers.

Whether you use fertilizers or not, you will be benefited by reading the Mapes pamphlet, which is of genuine value as agricultural literature. It is mailed free. Ask for it.

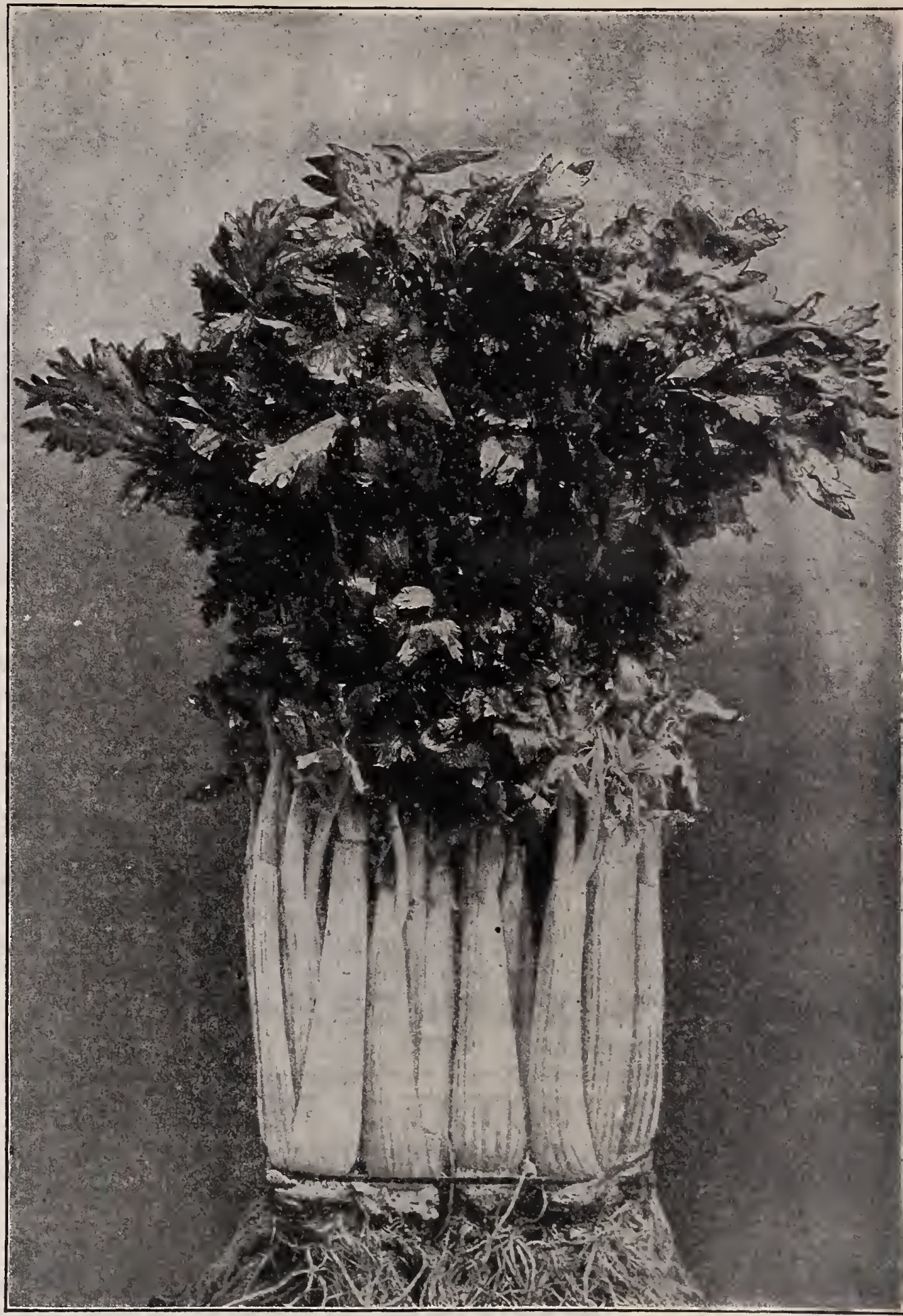

Mapes Manures are the BEST for the Market Gardener
POTATO NANIIRE Ammonia, 4.50 to 5 per cent.; Phosphoric Acid, 8 to to Pothl IMANURE. per cent. (soluble and available, 8 per cent.); Soluble Potash, actual, 6 to 8 per cent., all as high grade Sulphate, and in forms free from Muriates (or Chlorides), Magnesia, Lime, etc. For Irish and Sweet Potatoes, also Asparagus, Early Vegetables, Tomatoes, Sugar Beets, Sor-
ghum and Sugar Cane. CORN MANURE Ammonia, 3.50 to 5 per cent.; Phosphoric Acid, 12 to 13 per WORI IMAMURE. cent. (soluble and available, 8 to yo per cent.); Soluble Potash, actual, 6 to 7 per cent. For Sweet Corn, Fodder Corn, Hungarian ROU COMPLETE MANURE. phoric Acid, io to iz per cent. (soluble a nd available, 8 to Io per cent.); Soluble Potasli, a ctual, 4 to 5 per cent. A substitute for stable manure. For use onl all crops and all soils, with or without stable manure. Use broadcast; if any in hills. use sparingly. Special for Oats, Hungarian Grass, Vegetables, Melons, Tomatoes and Seeding with or with-
out grain. ECONOHICAL POTAIO MANURE. Ammonia, 4 to 5 per cent. Phosphoric able, 4 to 5 per cent.); Soluble Potash, actual, 8 to io per cent.; all as high grade Sulphate and in forms free from Muriates (or Ch1 lorides) Per ton, $\$ 37.00$ GRASS AND GRAIN SPRING TOP-DRESSING. Ammonia, 5 to 7 per cent.; cent. (soluble and available, 7 per cent.); Soluble Potash, actual, 5 to 7 per
Per ton, $\$ 42.00$
COMPIFTE MANURE ("A"Brand.) Ammonia, 3 to 4 per cent.: Phosphoric UOAd, 12 to 16 per cent. (soluble and available, Io to I2 perll on drill on all crops, particularly in connection with farm manure. Special
for Peas, Beans, Buckwheat and Turnips.

FRIIIT AND VINE MANIIRE Ammonia, 2 to 3 per cent.; Phosphoric Acid, 列 9 per cent. (soluble and available, 5 to 7 per

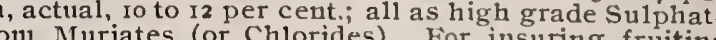
luriates (or Chlorides). For insuring fruiting ples, Plums, Strawberries, and suluall fruits. Is slow in effects, Pears, Ap-

Per ton, $\$ 42.00$

COMPIETE MANURES for Light Soils, or Vegetable Manures for All Soils. per cent. (soluble aud available, 6 to 8 per cent): Solinble Potash actual. to 8 per ceut. This is our special n11nure on all kinds of soils for Truck. Early Vcgetables, Onions. Celery, Tomnatoes; also on light soils for Oats, Hops and Barley: All vegetables require liberal supplies of soluble potash, plies of potasli are insufficieut.
Per ton, $\$ 43.00$ GEREAL BRAND Ammonia, 2 to 3 per cent.; Plosploric Acid, total, 8 to ro PotenL BRANU. A per ccnt. (soluble and available, 6 to 8 per cent.); actua

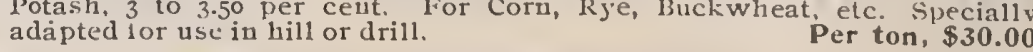




\section{Essex High Grade}

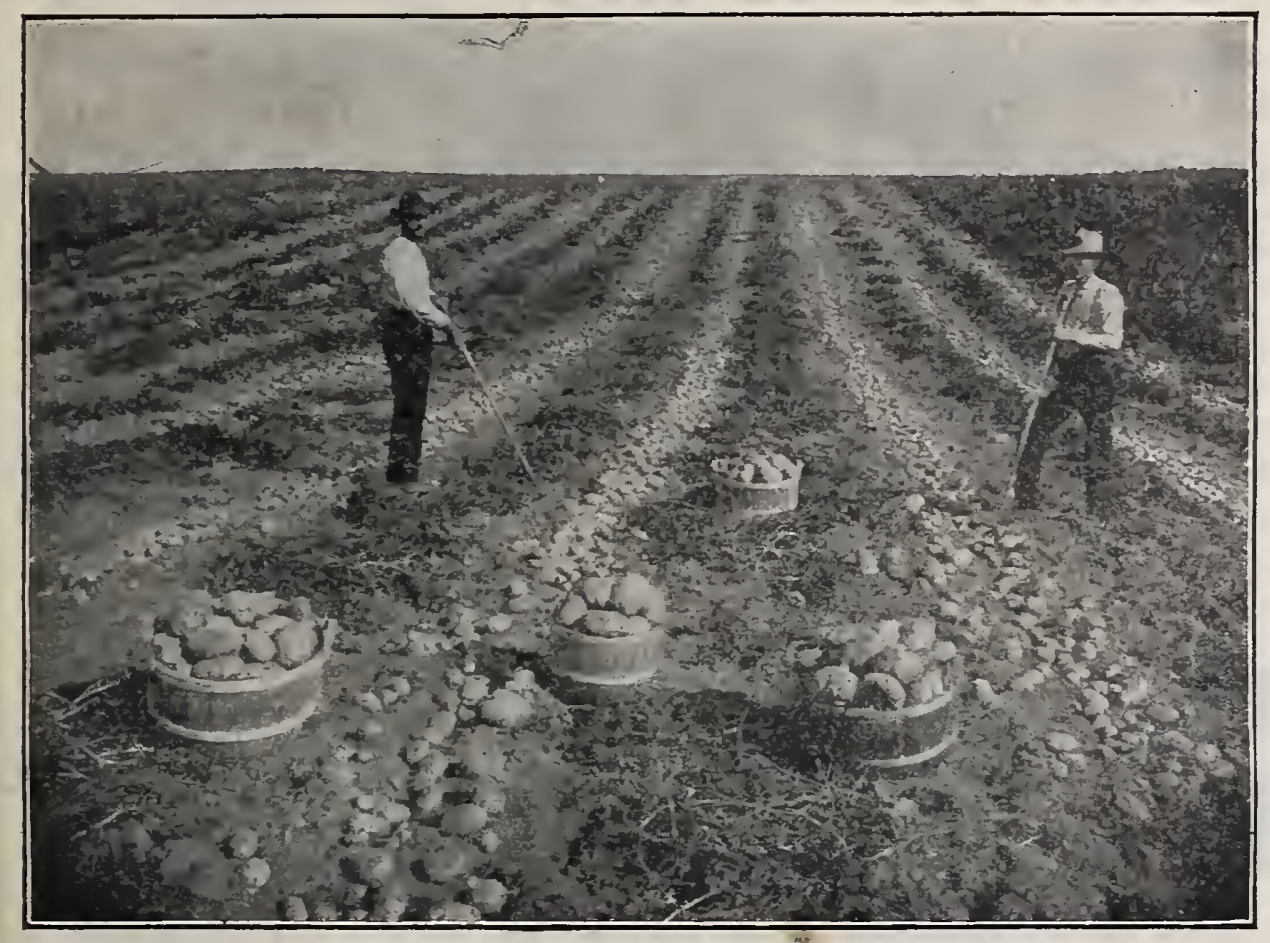

\section{RAISE GOOD CROPS}

$$
\text { 5 }
$$

$\mathrm{T}$

HE Essex Fertilizers have as a basis the Dry Fish and Fish Bone produced by the Russia Cement Co. In the process of manufacture owned by this company, and which no other manufacturer can obtain, these ingredients are manipulated in a way which renders them especially available as plant food.

This accounts for the superior availability and crop producing power of the

\section{Essex Fertilizers.}

These superior qualities have been fully demonstrated in Worcester County and vicinity, and we call your attention to the following letters from wellknown farmers and market gardeners who have tested the "Essex" in competition with the best of other leading brands.

So. Lincoln, July 17,1902 Russia Cement Co.

Valley Farm, So. Lancaster, Mass., Oct. 8, 1902.

Dear Sirs:-The "Essex Fertilizer" used here has given good satisfaction. It has been used in the garden on nearly everything (with the exception of egg plant), and the results have been quite marked, both in growth and production. As a spring dressing for strawberries, it works well. I do not hesitate in saying, it is a good thing.

I remain, dear sirs, yours truly,

A. P. MEREDITH,

Gardener to Nathaniel Thayer, Esq.

Russia Cement Co.

Dear Sirs:-I have used the Essex Fertilizer for the past two years and find it to be as represented, giving perfect satisfaction. JOS. T. CLARK,

with John E. Thayer, Esq.

Essex AI Superphosphate. Guaranteed Analysis.

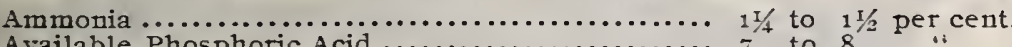
Available Phosphoric Acid..................... 7 to 8 Actual Potash..................................... 9 to II

Actual Potash........................... Price per Ton, $\$ 28.00$

Essex XXX Fish and Potash. Guaranteed Analysis.

Nitrogen ....................................... 2. to 3 per cent.

Equivalent to Anmonia...................... $2^{1 / 2}$ to 3

Soluble Phosphoric Acid...................... $4 \frac{1}{1 / 2}$ to $51 / 2$

Reverted Phosphoric Acid $\ldots \ldots \ldots \ldots \ldots \ldots \ldots \ldots \ldots, 4 \%$ to 5

Insoluble Phosphoric Acid from Bone............ 3 to 3,

Actual Potash......................................

Price per Ton, $\$ 32.00$

Essex Corn Fertilizer.

Guaranteed Analysis.

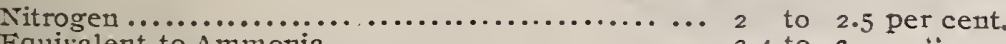

Equivalent to Ammonia....................... 2.4 to 3

Soluble Phos phoric Acid...................... 4 to 5

Reverted Phos phoric Acid .................... $4 \cdot 5$ to

Insoluble Phosphoric Acid from Bone.............. 2 to to 3

Actual Potash....................................... to to 13

Price per Ton, $\$ 35.00$
Dear Sirs:-This spring a party who bought two tons of Fertilizer of me, came to me and said it was the best fertilizer he ever used, and that this year he would buy all his fertilizer of me, provided I could use him as well as last year. At this writing, his crops look the best of any in town.

Yours truly,

F. E. COUSINS.

Russia Cement Co.

Uxbridge, Mass., Oct. 8, 1902.

Gentlemen:-I have used your Essex Fertilizer the past season on Corn, Potatoes, Grain and Hungarian, and it has given me fine results in every case. Where I used it alone without any stable manure the crops showed that there is plenty of plant food in an available form, giving to crops in a season like the past, plenty of food to produce the best results. Yours truly

E. S. FARNUM.

Essex Market Garden and Potato Manure. Guaranteed Analysis.

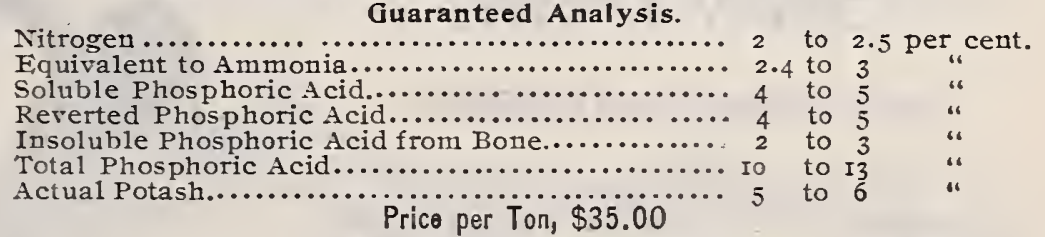

Essex Complete Manure for Corn, Grain and Grass. Guaranteed Analysis.

...................... $3 \cdot 3$ to 4 . I per cent.

Equivalent to Ammonia...................... 4 to 5

Soluble Phosphoric Acid.................... 3 to $31 / 2$

Insoluble Phosphoric A fid from Bone........... 4 to $4 / 2$

Insoluble Phos phoric Acid from Bone............. 25/2 to 3

Actual Potash................................ $91 / 2$ to II

\section{Price per Ton $\$ 40.00$}

Essex Complete Manure for Potatoes, Roots and Vagetables Guaranteed Analysis.

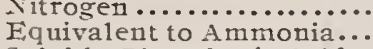

Reverted Phosphoric Aci

Insoluble Phosphoric Acid

Total Phosphoric Aci

Price per Ton, $\$ 41.00$

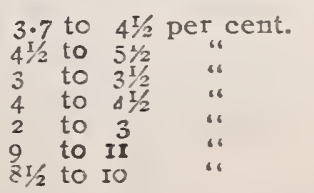

Soluble Phosphoric Acid

Actual Potash from Sulphate. 


\section{AGRICULTURAL TOOL DEPARTMENT}

2. AN THE following pages we will show you our line of IMPLEMENTS, both Horse and Hand, and we do not illustrate anything that we have not tested and know to be thoroughly reliable; and while similar tools may be bought for less money, we defy any-

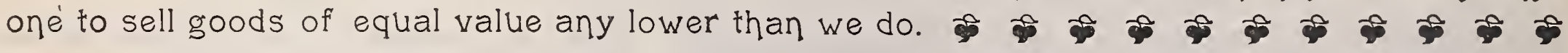
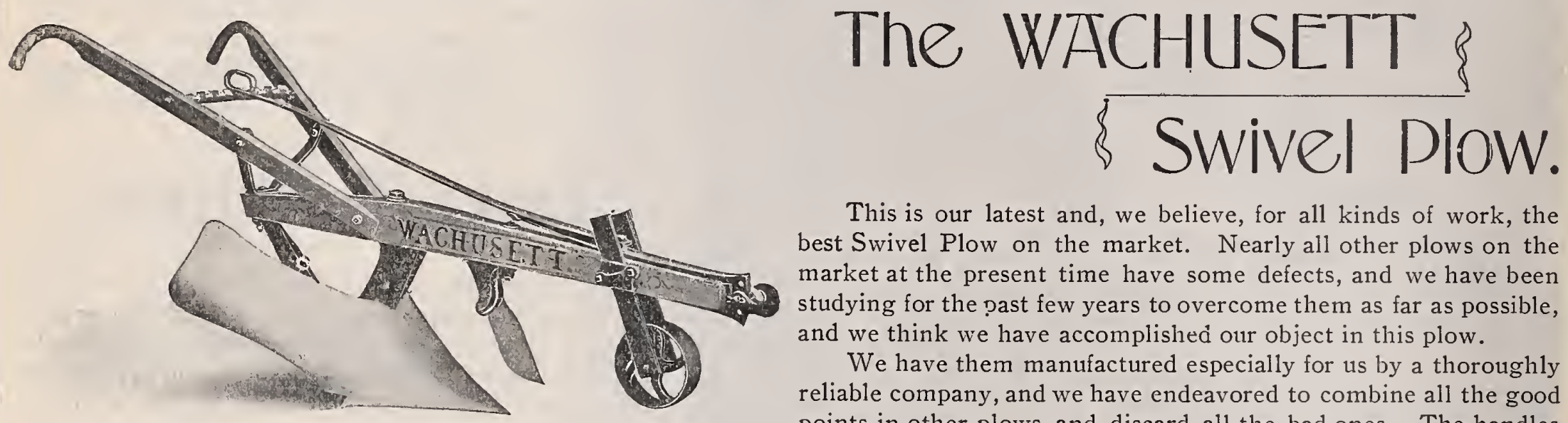

This is our latest and, we believe, for all kinds of work, the best Swivel Plow on the market. Nearly all other plows on the market at the present time have some defects, and we have been studying for the past few years to overcome them as far as possible, and we think we have accomplished our object in this plow.

We have them manufactured especially for us by a thoroughly reliable company, and we have endeavored to combine all the good points in other plows and discard all the bad ones. The handles are made adjustable, as you will see by the cut, and being attached to the beam instead of running down to the standard, they give the operator easy and perfect control over the plow. The shifting clevis is the most durable and easiest to operate of any plow that was ever put on the market. It can be shifted easy and there is no danger of pinching your fingers, as with nearly all of the other makes.

The lines on this plow are so adjusted that it stays in the ground and turns a nice furrow, and this makes it easy for both man and team The material used is the very best that we can possibly get, and we warrant every part to be free from any imperfections.

We have also made the price lower than any of the first-class plows are being sold for We have, at the present time, only two sizes, No. 2 and No. 3. The No. 2 medium, or large two-horse, and the No. 3 is a light two-horse. We can furnish either with steel or hardened moldboard, and we guarantee them to do satisfactory work and to be made of the very best material.
List price No. 2, Hardened Moldboard,
$\$ 11.00$.
Discount for cash,
$\$ 1.00$.
"No. 3 ,
11.00 .
" " "
1.00 .

For Steel Moldboard add $\$ 1.50$ extra.

\section{Syracuse Reversible} Sulky Dlow.

Steel Moldboards and Landsides.

This is the lightest draft sulky plow on the market. Will plow on sidehill or level ground and leaves no dead furrows. We believe this is the only sulky that will do satisfactory work on all kinds of soil and on hill or level farms. As shown in cut two plows are used (one only being in use at a time). Throwing the plow in and out of the ground is done by the team while the operator has control of the width of furrow with his feet, leaving both hands free to handle the team. The wheels always stand perpendicular and

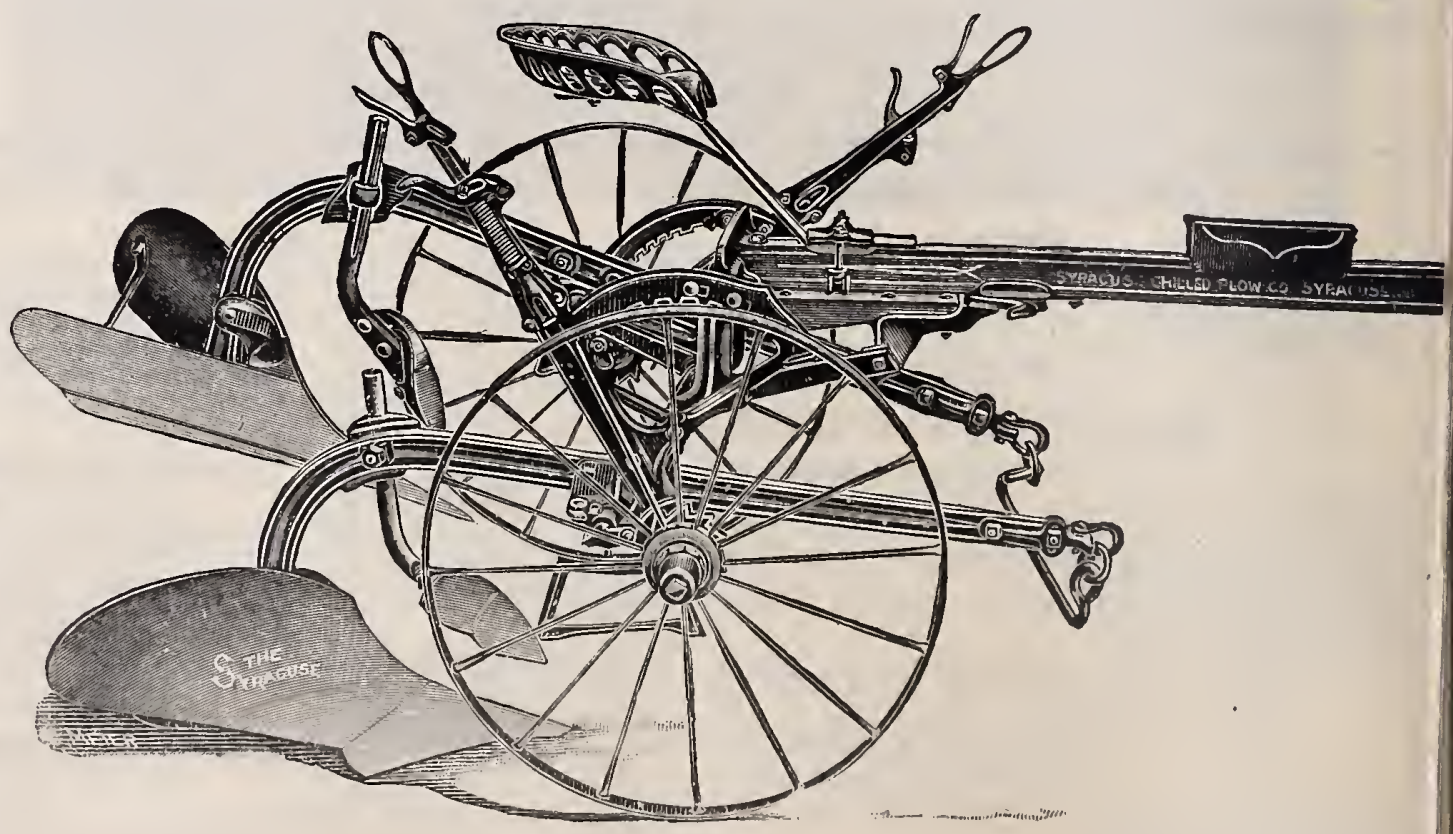
the plows level. This tool is designed for New England farmers and has stood the test for ten years. We have sold hundreds of them. Cuts 3 to $9 \mathrm{in}$. deep, 11 to $16 \mathrm{in}$. wide; weight, $556 \mathrm{lbs}$. We furnish two sets of points and two-horse hitch.

Price, \$45.00. Discount for cash, $\$ 3.00$. Three-horse hitch, $\$ 3.00$ extra. 


\section{Syracuse No. 60 Plow,}

With Steel Cutter or Jointer, Steel or Chilled Moldboard.

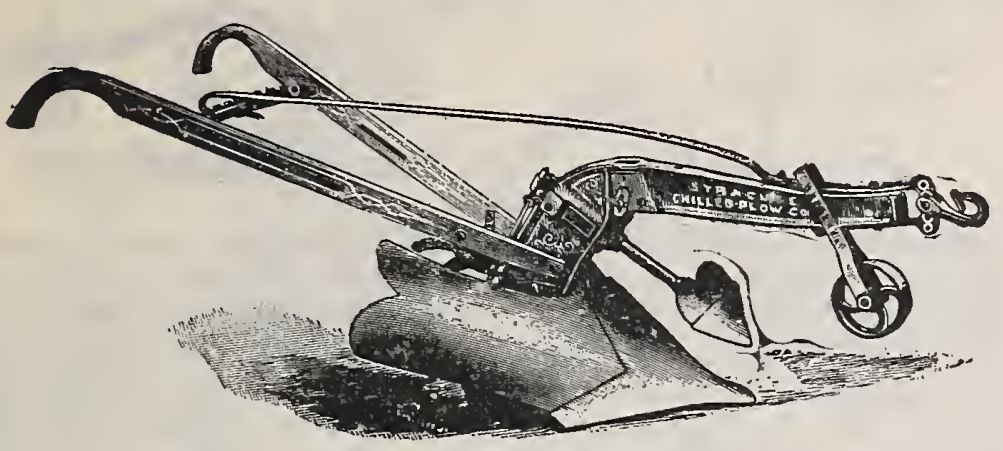

This is our leading Steel Beam swivel plow and will work on level land or sidehill. It has a steel or chilled moldboard, patent foct latch and shifting clevis. Cuts 5 to 8 in. deep, 12 to 15 in. wide; weight, 138 ibs.

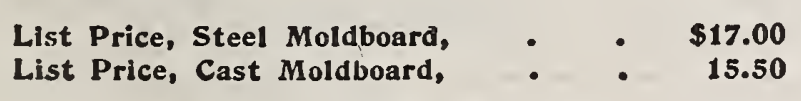

Discount for cash, $\$ 2.00$.

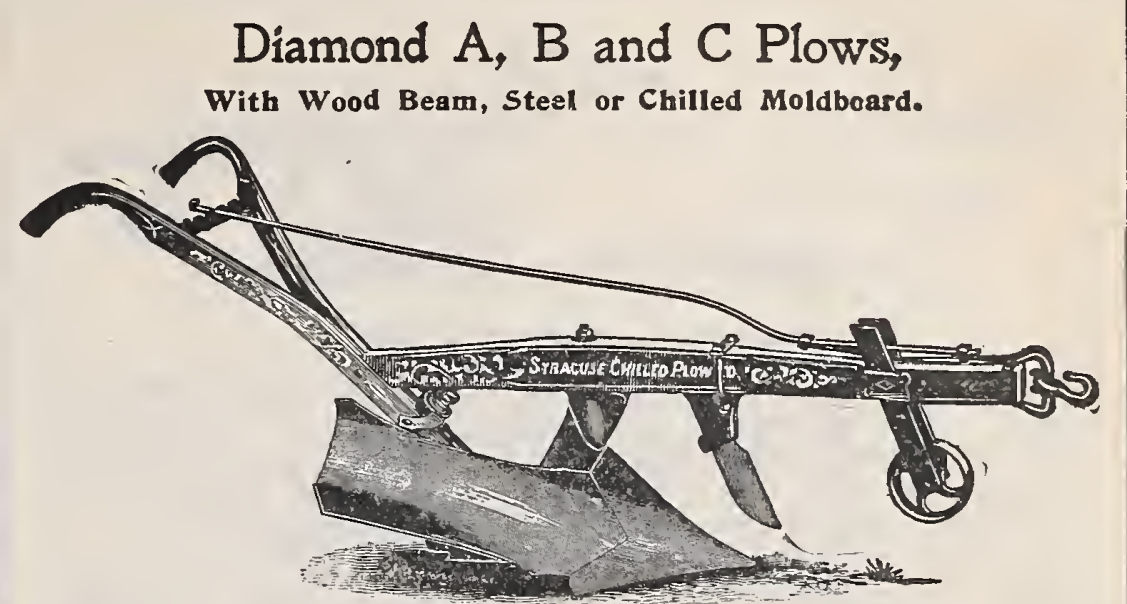

Excepting the Wachusett this is one of our best swivel plows. It is furnished with steel or chilled moldboard, patent foot latch, wheel and cutter and shitting clevis. All parts interchange with the ' 76 plow made at Castleton, Vt.

A cuts 5 to 7 in., II to I 4 in. wide; wt., IIg lbs, List price, $\$ 13.00$ $B$ cuts 4 to 6 in., 8 to 12 in. wide; wt., II4 lbs, List price, 12.00 C cuts 3 to 5 in., 7 to 8 in. wide; wt., 71 lbs. List price, 8.50 $A$ and $B$ are two-horse; $C$ one-horse. $A$ and $B$ have wheel and cutter. $C$ has wheel. Disct. for cash on A and $\mathrm{R}, \$ 2.00 ; \mathrm{C}, \$ 1.00$. Steel Moldboard, $\$$ I.50 extra.

\section{Syracuse No. 5 Vineyará Plow One-Horse.}

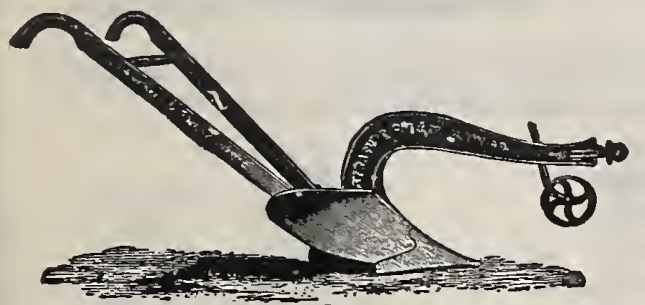

This plow is designed for plowing between rows of trees or vines. The handles are adjustable sideways or up and down. The horse can walk in the furrow or on the land. It can also be used for garden plowing. Iron beam; cuts 3 to 5 in. deep; 7 to 10 in. wide; wt., 63 lbs.

List price, with wheel, $\mathbf{\$ 7 . 5 0}$.

Discount for cash, $50 \mathrm{c}$.
The Arlington Plow has become a favorite in many sections. They are made with steel shifting lever, clevis, patent spring toot latch. Moldboards are made of patent steeled metal, and ali castings nicely polished. The beam and handles are mads from selected stock, neatly striped and varrished.

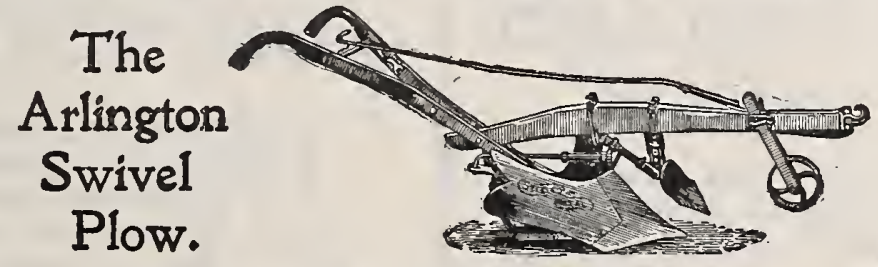

\section{DESCRIPIION OF SIZES.-}

No. 30 turns a furrow 33 to $x 6$ in. wiaje, 6 to 8 in. deep. No, 29 turns a furrow i2 to 14 in. wide, 5 to 7 eight, I35 1bs. No. 29 turns a furrow 12 to $14 \mathrm{in.}$ wide, 5 to 7 in deep.
Weight, 125 lbs. No. 27 turas a furrow 8 to II in. wide, 4 to 6 in. deep.

$\begin{array}{cccc}\text { Wo. } & \text { With } & \begin{array}{c}\text { Wheel and } \\ \text { Wheel. }\end{array} & \begin{array}{c}\text { Wheel and } \\ \text { Crtter. }\end{array} \\ \text { Joinier. } \\ 30 & \$ 13.50 & \$ 5.00 & \$ 15.50 \\ 29 & 12.50 & 14.00 & 14.50 \\ 27 & 9.00 & 10.00 & \\ 26 & 8.50 & 9.50 & \end{array}$

Discount for cash, $\$ 2.00$ on Nos. 30 and $20 ; \$ 1.00$ or Nos. 27 and 26 .

\section{Syracuse No. 52 and 53} One-horse Plow.

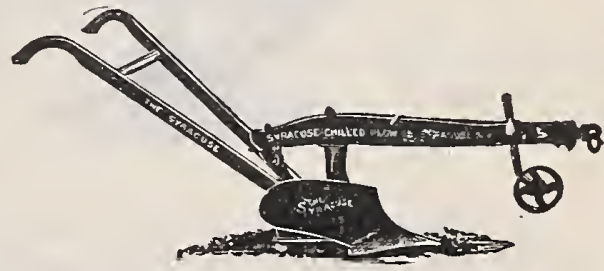

No. 52 is a medium size one-horse plow, with chilled moldboard and wheel just the size for general garden work.

No. 53 is same style of plow, only larger. Can be used as a light twohorse plow for plowing stubble land.

No. $5^{2}$ cuts 3 to $5 \frac{1}{2}$ in. deep. 9 to $\mathrm{Ir}$ in. wide; wh., 70 lbs. List price, with wheel, $\$ 8.50$. No. 53 cuts 3 to 6 in. deep, 9 to 12 in. Wride; wt., 76 lbs. List price, with wheel, $\$ 9.50$.

Discount for cash on either. 50c.

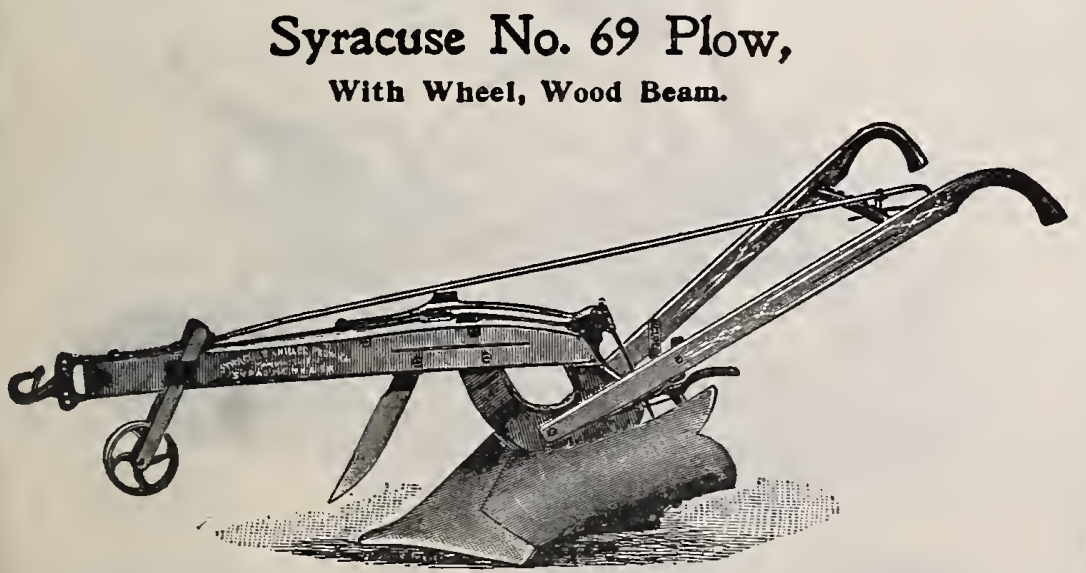

This plow is similar to the No. 60 excepting the beam, which is made of two pieces of wood, and has chilled moldboard, either cutter or jointer, wheel and shifting clevis. Cuts 4 to $u$ in. deep, 10 to 14 in. wide; wt., 130 lbs.

$$
\text { List Price, - } \$ 15.50 \text {. }
$$

Discount for cash, $\$ 2.00$.

\section{Syracuse No. 31 and No. 32 Troolhorse Plows.}

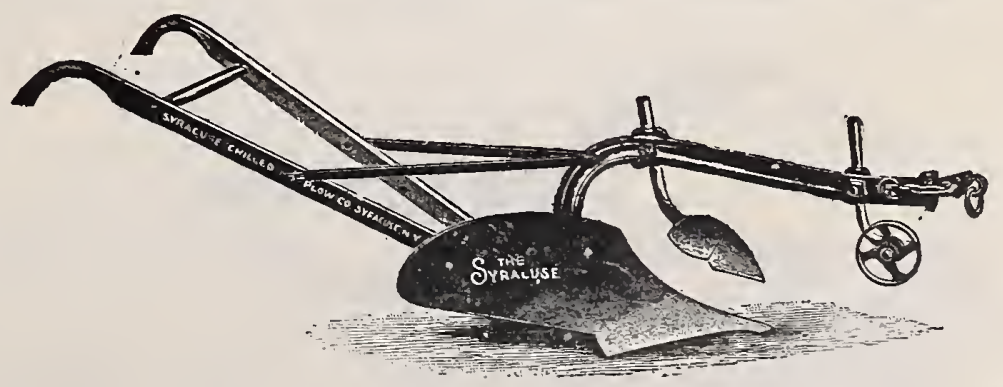

These plows have steel moldboards and wheels, straight cutters or jointers. No. 32 is the same plow used on the double sulky with the addition of a pair of handles, and no better plow was ever made.

No. 32 cuts 5 to $7 / 2$ in. deep, to to $I_{3}$ in. wide; weight, 103 lbs.

List Price, $\$ 16.00$.

No. 3 cuts 5 to 8 in. deep, I2 to I5 in. wide; weight, I08 $1 \mathrm{bs}$

List Price, $\$ 16.50$.

Discount for cash from either of the above, $\$ 3.00$. 


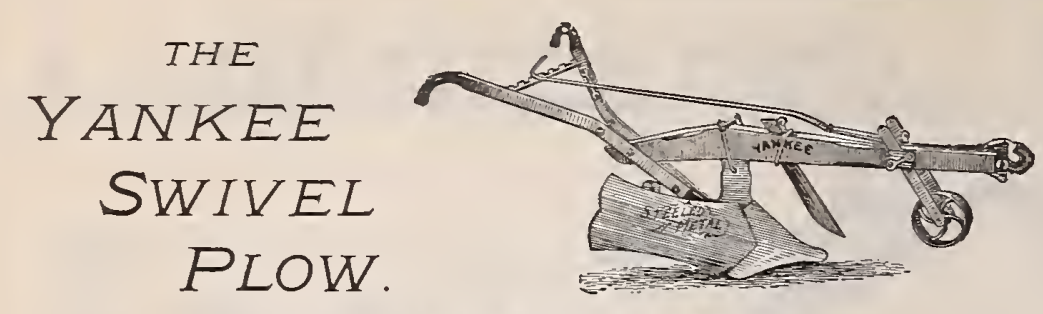

FOR ONE OR TWO HORSES.

This plow has a patent shifting clevis, foot latch, wheel and cutter. The moldboard is steeled metal, which is very hard and will polish in nearly all soils. They are painted bright vermilion and are a very nice built plow. We have two sizes for one horse, three for two horses, and one for three horses.

Number

of Plow. Description.

$00 \mathrm{H}$ Small One-Horse,

With Wheel \& Weigint

$0 \mathrm{H}$ One-Horse, . . . . . . $\quad 9.50 \quad 10.50 \quad 85$ “

$1 \mathrm{H}$ Large 1-horse or light 2 -horse, $12.00 \quad 13.50 \quad 105$ “"

$2 \mathrm{H}$ Medium 2-horse,

$3 \mathrm{H}$ Large 2-horse, . $: 0^{\circ} \quad 16.00 \quad 125$ “

Discount for cash: $\$ 2.00$ from list on two-horse; $\$ 1.00$ discount on one-horse.

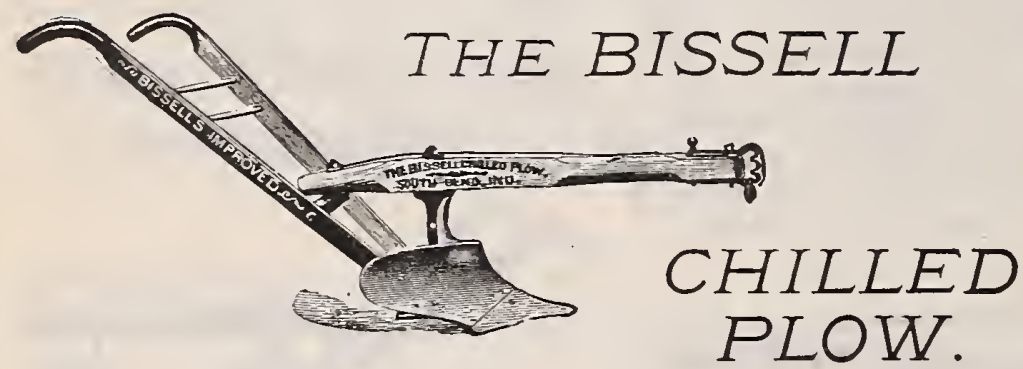

All parts interchange with the Oliver. This plow has a chilled moldboard, extra high standard, which prevents clogging in weeds or trash. It is our best one-horse landside plow.

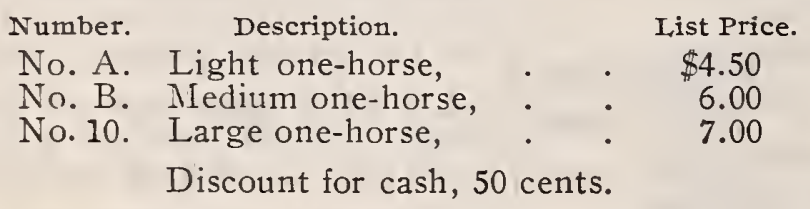

The above prices are without wheel. If wheel is wanted, add $\$ 1.00$ net to above prices.

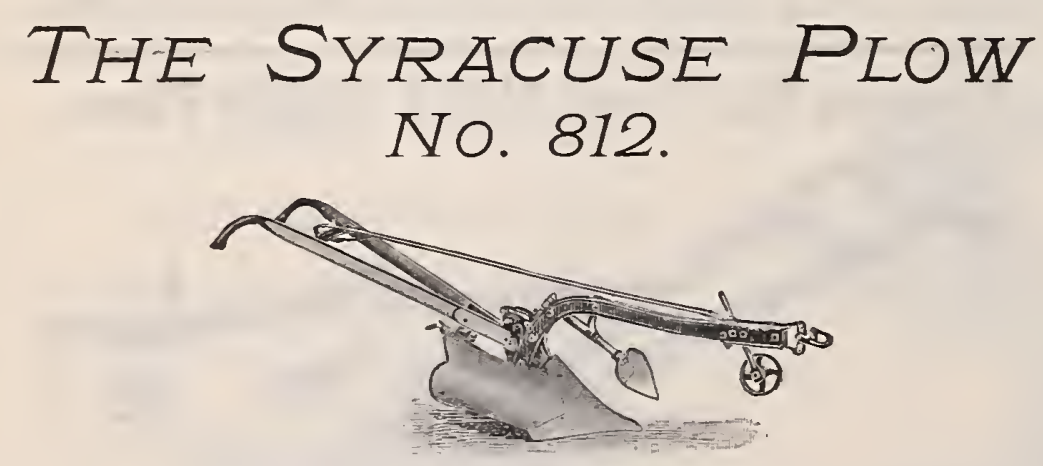

This is the latest number in the Syracuse line, and we believe the best one. The leading feature is the shifting handles, which enables the operator to walk directly behind the plow. It has a steel truss beam, automatic jointer or cutter and shifting clevis, adjustable wheel, inclining forward or back.

List price, with chilled moldboard, wheel and cutter or jointer, $\$ 16.00$. Discount for cash, $\$ 2.00$.

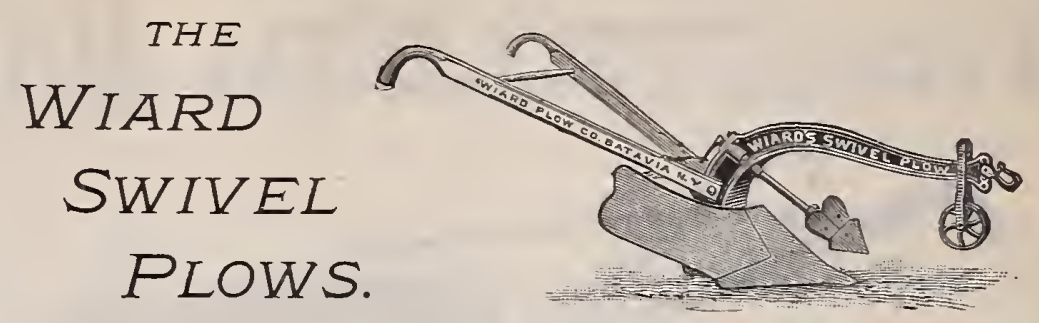

We carry a full line of these plows and they have a great many friends. Rigged either with Jointer or Straight Cutter and Wheel, steel and wood beam and shifting clevis. They are painted green.

Wheel and Weight
Cutter or ful1

Number. Description. Jointer. Rigged.

$115 \mathrm{x}$ Light 2 -horse, iron beam, cast moldboard, $\$ 15.251161 \mathrm{bs}$.

140 Medium 2-horse, wood beam, cast moldboard, . . . . $14.25133 \mathrm{lbs}$.

21 One-horse, wood beam. . . $\quad \begin{aligned} & \text { P1ain. Wheel. } \\ & \$ 8.25\end{aligned} \$ 9.25 \quad 77 \mathrm{bs}$.

Discount for cash: $\$ 2.00$ from list on two-horse; $\$ 1.00$ discount on one-horse. Steel Moldboard, $\$ 1.50$ extra.

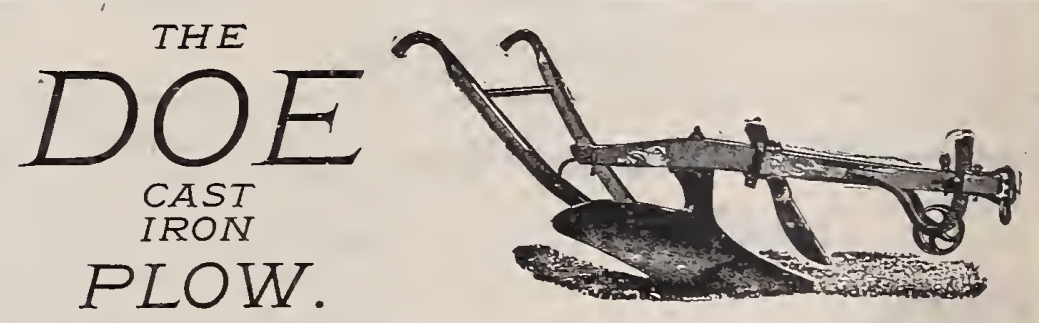

A good general purpose plow, designed for all kinds of garden work. Wood beam, cast moldboard and point.

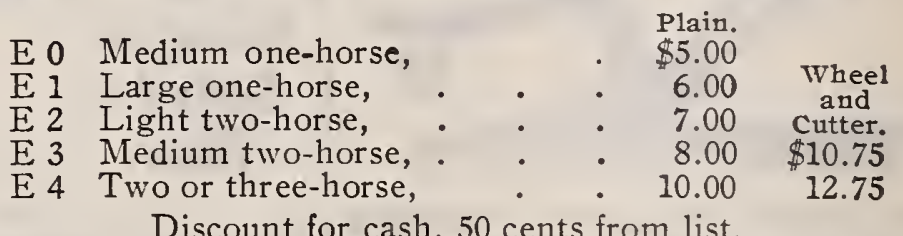
Discount for cash, 50 cents from list.

\section{THE NATIONAL REVERSIBLE SULKY PLOW.}

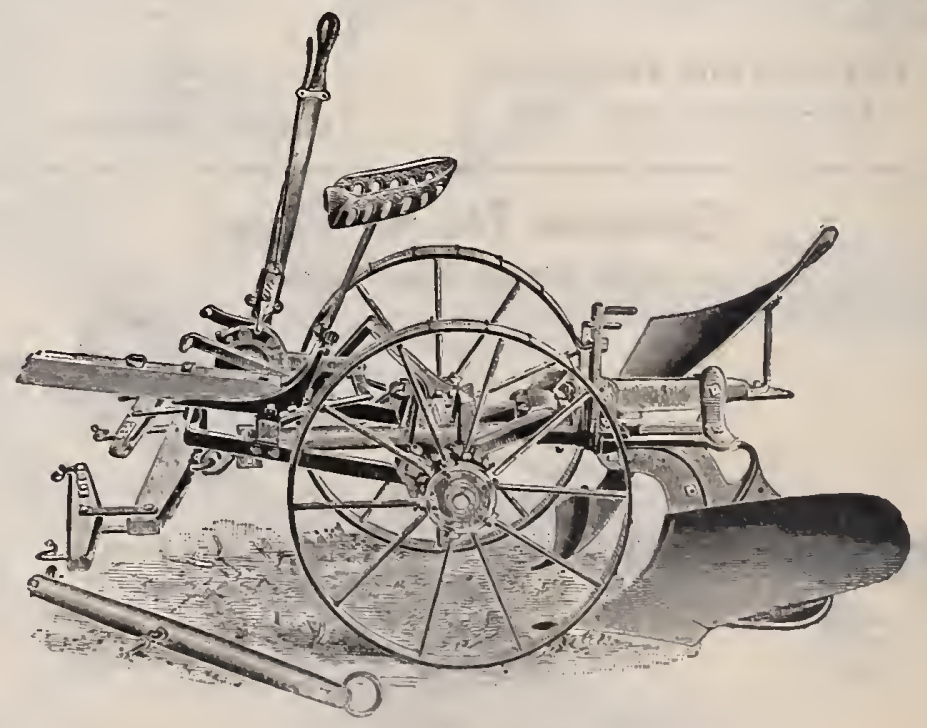

This plow works equally well on sidehill or level land. As with the Syracuse, two plows are used, both fastened to one beam. The plows are thrown in and out of the ground with the foot, making it a very easy plow to operate. A boy 12 years old can handle it easily. There are few farms in New England where a Sulky plow cannot be used to a good advantage. Price includes extra set of points, neck-yoke and evener.

List price, $\$ 45.00$. Discount for cash, $\$ 3.00$. 


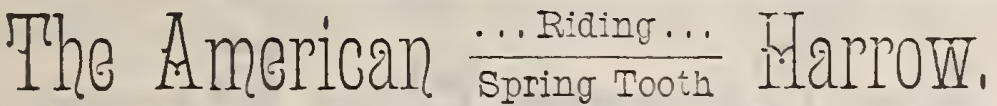

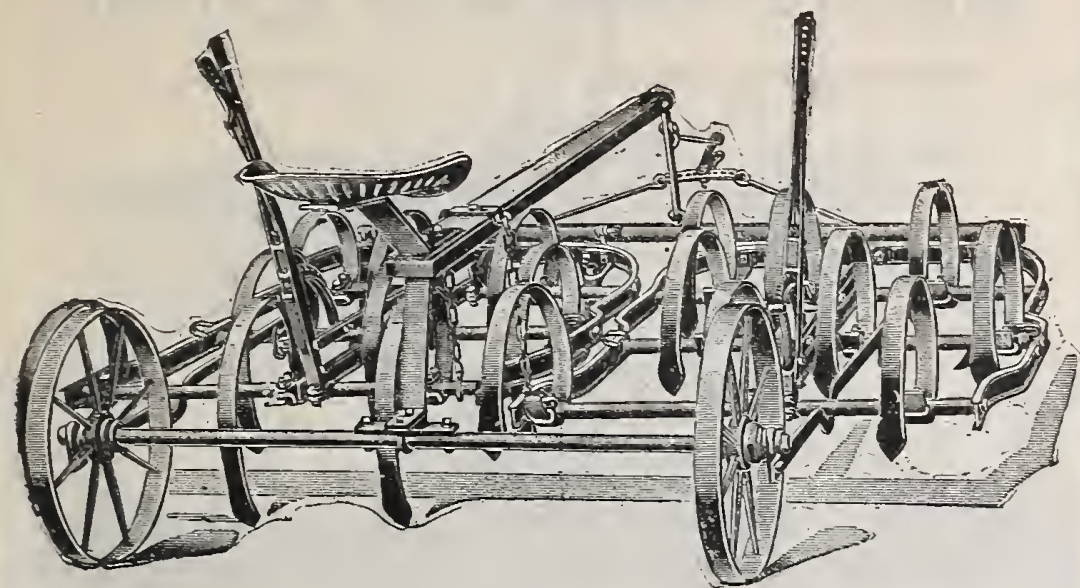

The American Spring Tooth Harrow is the latest spring harrow on the market and, we believe, the best. It is constructed on entirely different principles from other harrrowswith seat, and the driver does not get any motion of the harrow. The riding attachment is independent of the frame, the driver's weight being on the sulky attachment instead of on the frame that the teeth are attached to, as is the case with other harrows. It is as easy to ride as a buggy, and the teeth can be raised and lowered by means of a lever within easy reach of the driver. It is simple, durable, and the most practical harrow on the market.

Price, 16 teeth, complete with riding attachment, \$21.00.

Discount for cash, $\$ 1.00$.

The Bay state spring Tooth Harrow.

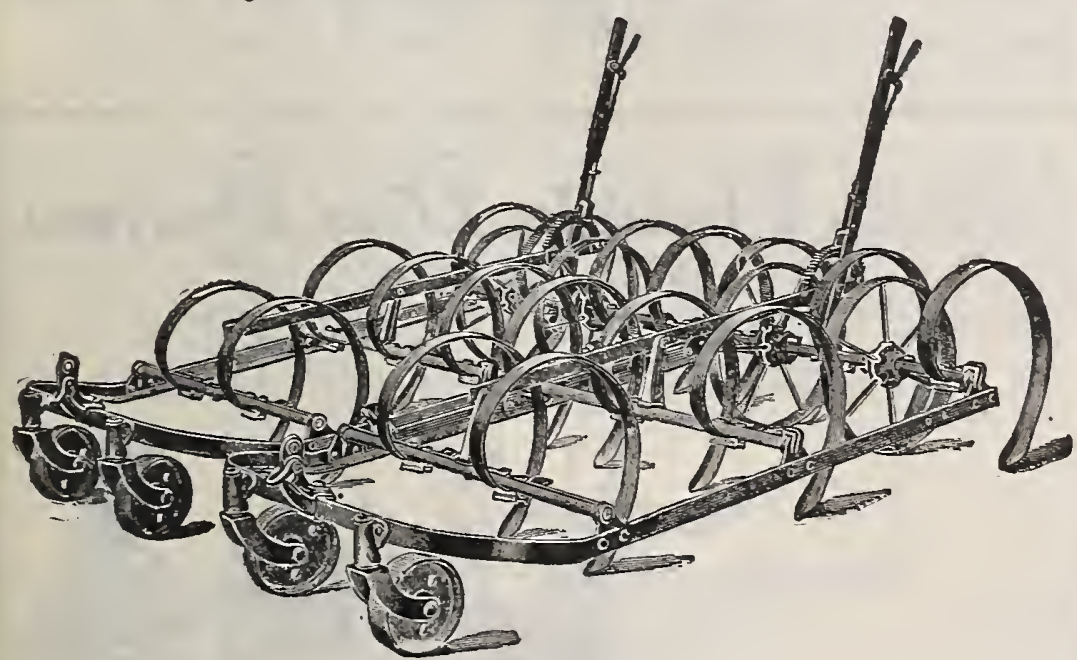

This harrow has all the good points of other low down spring harrows and a great many improvements. The frame is made of channel steel, making it very rigid. The teeth are held in place by two bolts. Excepting the American this is the best Spring Harrow on the market, being made entirely of steel.

This harrow is furnished with seat if desired.

List Price, 15 teeth, $\$ 18.00$. List Price, 17 teeth, $\$ 19.00$.

Discount for cash, $\$ 1.00$. Seat attachment, $\$ 1.50$ extra.

The Original

\section{PERRY}

spring Harrow

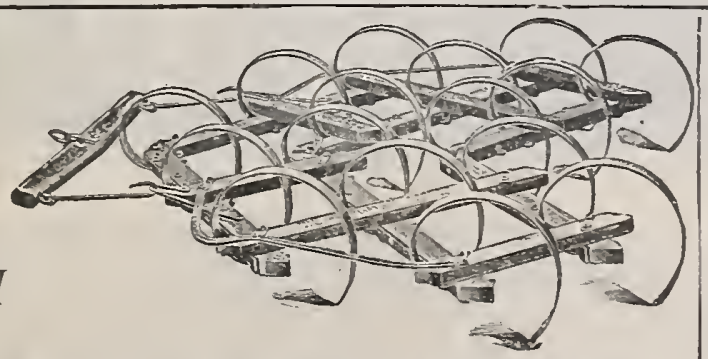

This is the first Spring Tooth Harrow ever offered for sale, and it has many friends today. For durability, it is equal to any harrow made. The wood frame is lined with carbon steel, bolt heads protected, teeth cannot get loose.

List price, 16 teeth, $\$ 11.00$. Discount for cash, $\$$ r..0.

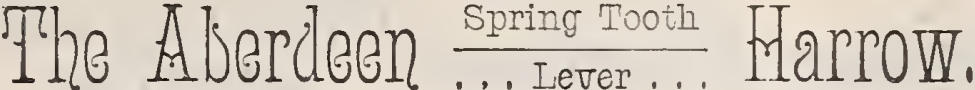

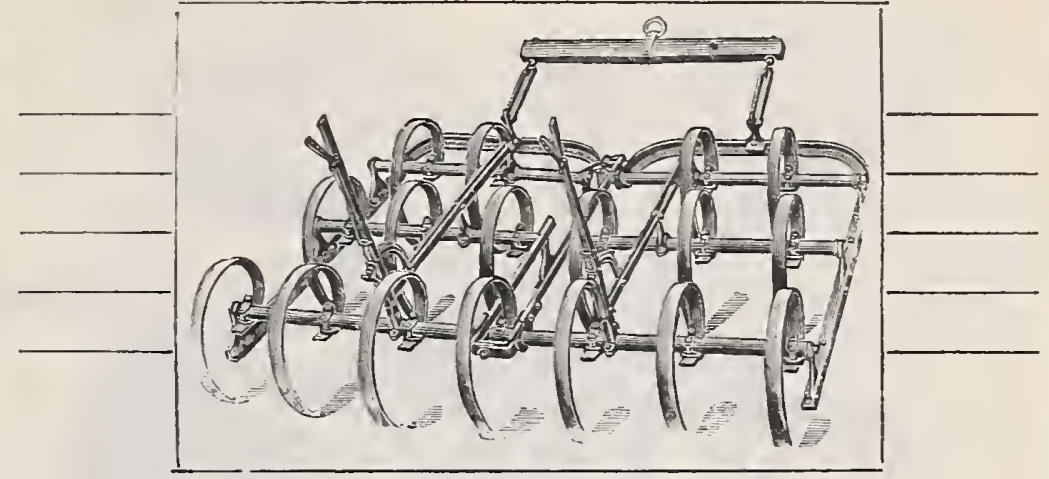

Having some calls for a spring harrow with shoes instead of wheels, we have added to our already large line of harrows this make, and while it has to be hauled to and from the field on the shoes instead of wheels, we believe it will do just as good work and is as durable as any harrow on our list.

List Price. 15 teeth, $\$ 17.00$.

17 : $\$ 18.00$.

Discount for cash, $\$ 1.00$.

Bigg 5 spike Tooth Smoothing Harrow.

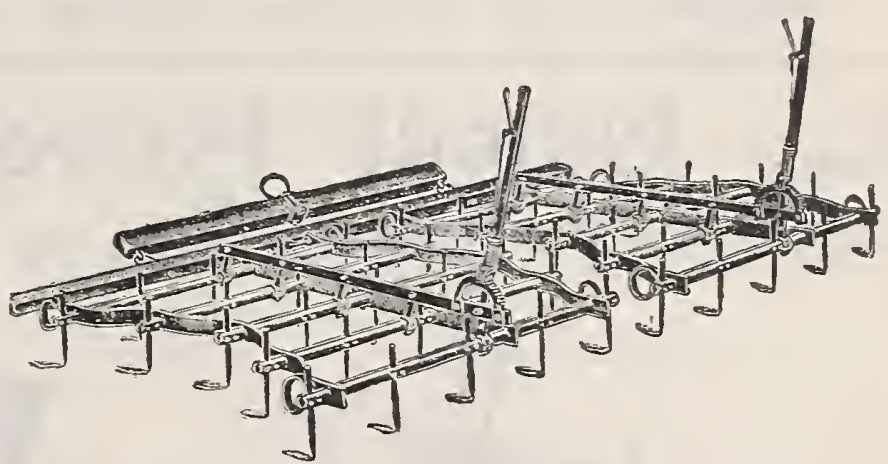

This harrow is designed as a leveling harrow, and for covering all kinds of grain and grass seed. Is also used largely for cultivating corn just after it comes up. The teeth are adjusted by means of a lever, and can also be thrown up from the ground and harrow transported to and from the field on the shoes at the end. Each tooth is held in place by two bolts (nearly all others have but one), and the entire harrow is made of steel.

List price, 60 teeth, $\$ 12.00$. Discount for cash, $\$ 1.00$. List price, 50 teeth, $\$ 11.00$. Discount for cash. $\$$. I00.

\section{Prout's}

Two-Horse Hoe.

To those unacquainted a brief description of this machine will undoubtedly prove of interest. Each Standard as shown in the cut has two Hoes attached, and in working one set of hoes work on one side of the hill and the other on the opposite side, hoeing a row at a time. The hoes operate same as a hand hoe, moving fresh earth to the plant, and crowding the old dry

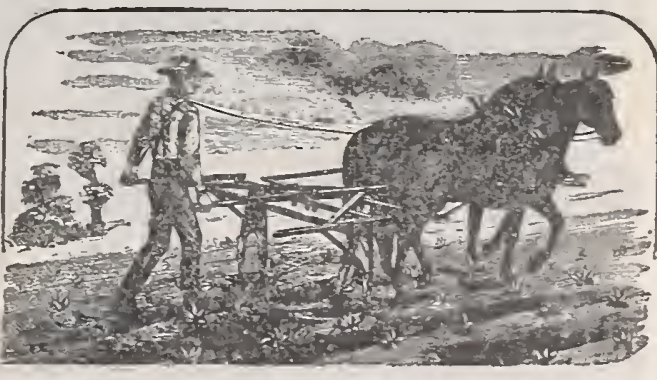

being done much more quickly and thorourbly than when hand hoes are used. Unlike the cultivators and horse hoes now 11 common use, the who'e surface for the distance of two feet, more or less, on each side of the plant is cut over, and all the weeds removed. The hoes being niade tapering permit of cutting close up to the plant without injury to corn roots which run close to the surface.

List Price, with Wheels, $\$ 25.00$; discount for cash, $\$ 3.00$ 


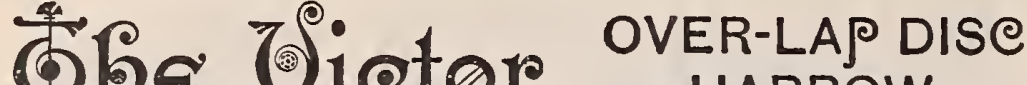 HARROW.}

With Ball-Bearings.

1316 in. Steel Discs.

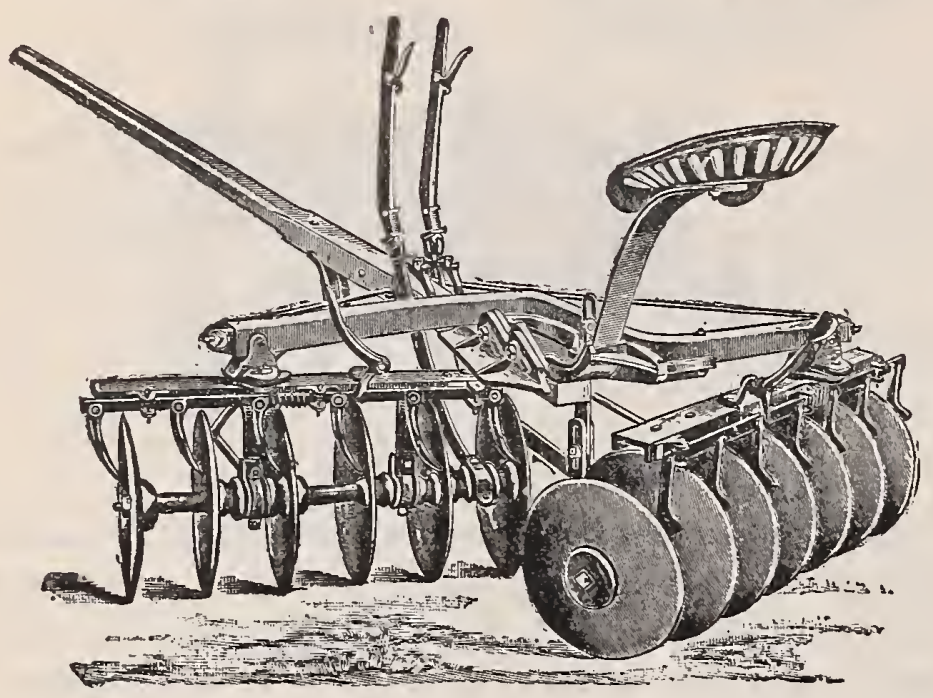

This is the latest and best thing for a Disc Harrow. As shown in the cut you will see that the right-hand gang has 7 discs instead of 6; the extra one laps over and pulverizes the centre, which all other harrows leave untouched. This has been a great disadvantage and has puzzled all manufacturers until now. It runs on ball-bearings, is made entirely of steel, and is furnished with whiffletrees, evener and yoke.

List price, $\$ 24.00$ Discount for cash, $\$ 1.00$.

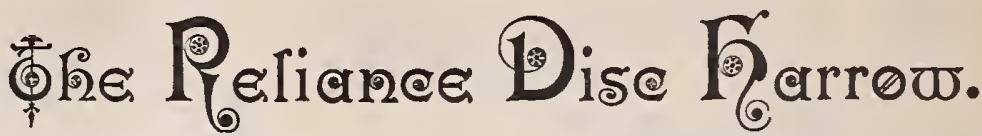

With Steel Weight Boxes.

1216 =inch Steel Discs.

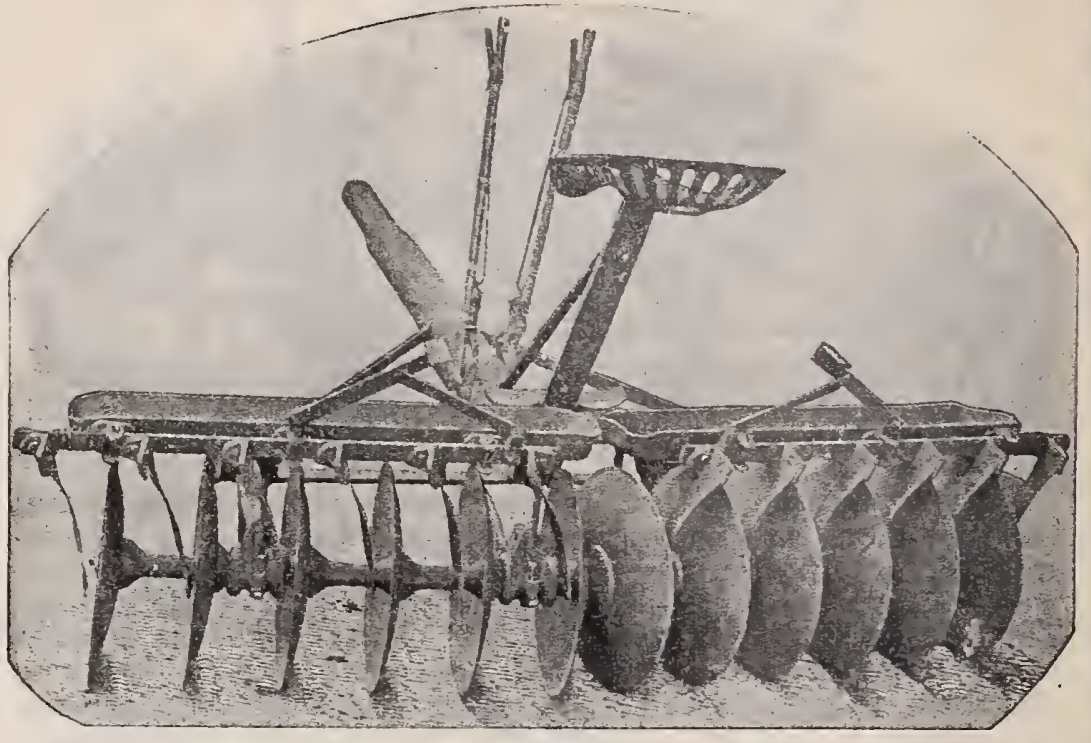

The Reliance Disc Harrow, as shown above, is made especially for us, and is designed for farmers who want a harrow with weight boxes so that it can be weighted to work on very hard soil. The boxes are also very handy to throw loose stones into while at work harrowing. It has two levers for angling the discs, a very comfortable and durable seat, and is a first-class harrow in every way. All parts except the discs are painted bright red. List price, $\$ 21.00$. Discount for cash, $\$ 1.00$.

\section{All Steol \\ नुब}

1216 in. Steel Disis.

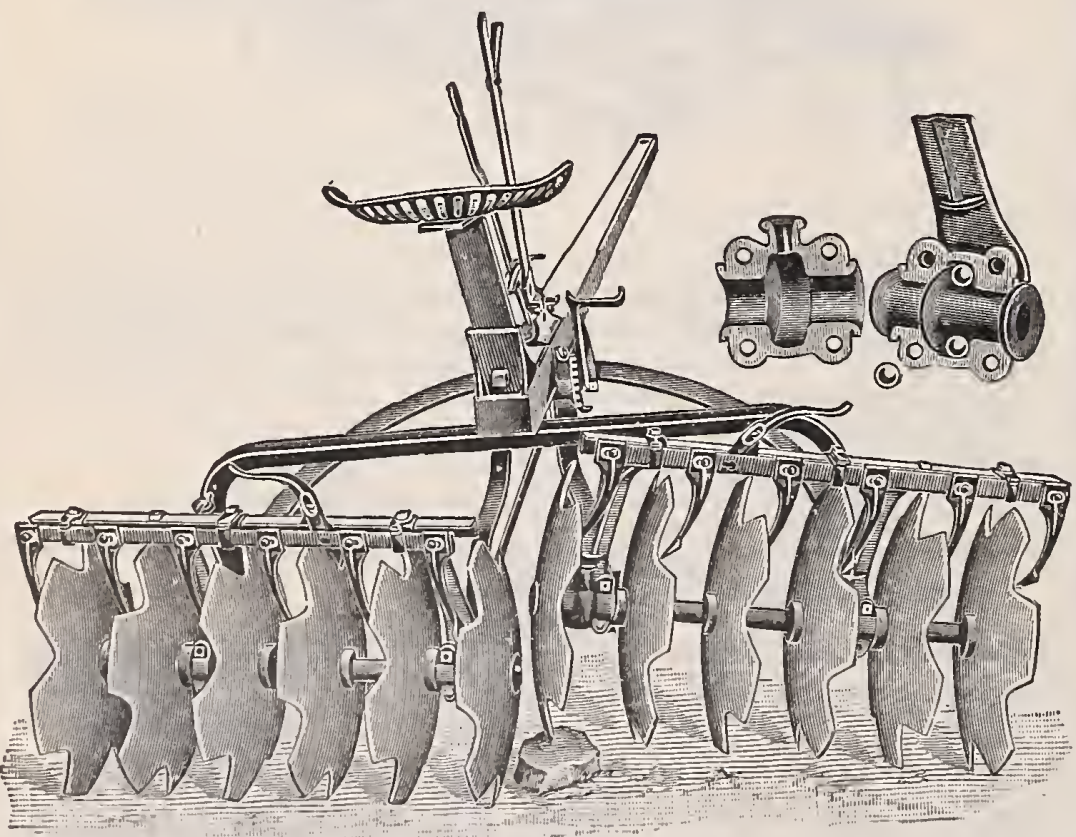

This harrow is same construction as the All Steel Flexible, but fitted with cutaway instead of round discs which, being cut in, allows them to enter the ground deeper, and is a very desirable harrow to work in bushy land. It is fitted with ball-bearings and, excepting the pole, is made entirely of steel; has the adjustable spring for putting any amount of pressure on the inside end of the discs. No other Cutaway Harrow made has this improvement. Arbors run on ball bearings.

List price, $\$ 22.00$ Discount for cash, $\$ 1.00$.

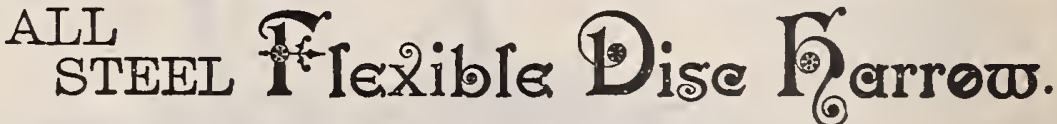

1216 in. Steel Discs.

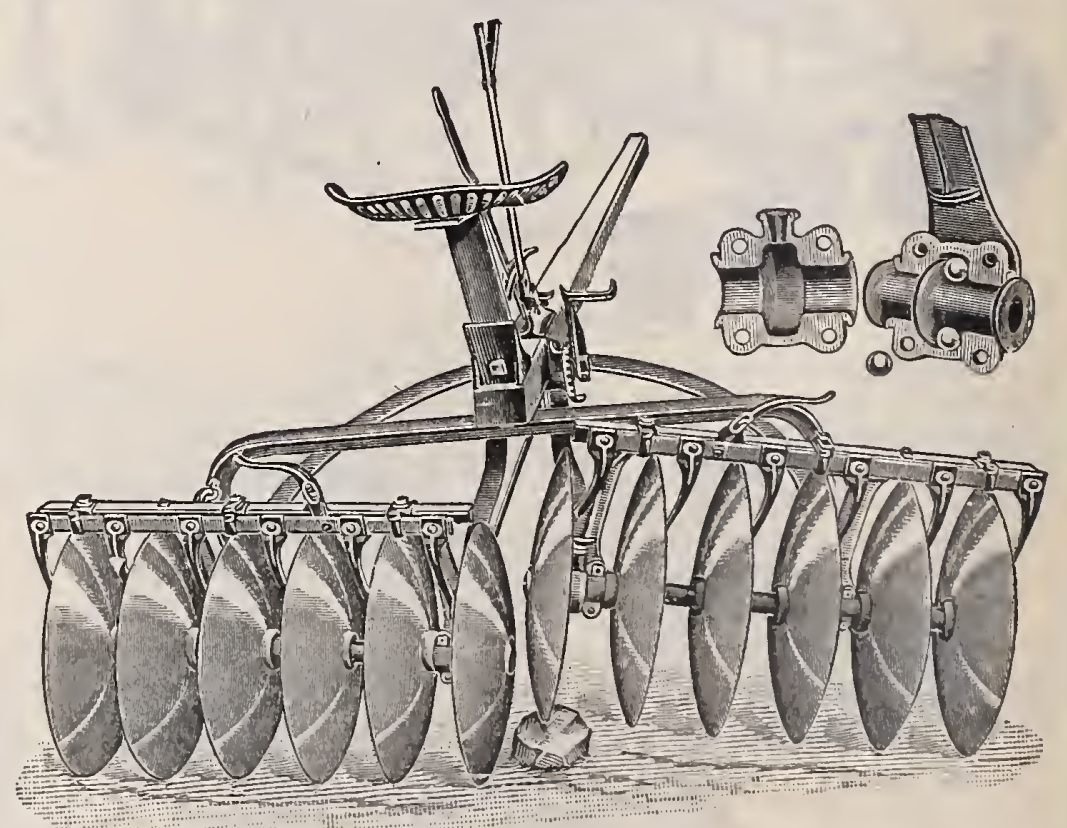

This harrow is provided with matchless new combination cone boxes and single large ball-bearings. The only Disc Harrow having independent adjustable spring pressure upon the inner end of each gang of discs, allowing any amount of pressure to be thrown upon the inner ends of the gangs by the foot of the operator. This is the simplest and easiest harrow to operate on the market. By removing two bolts it can be taken apart and handled easily by one man.

List price, $\$ 22.00$. Discount for cash, $\$ 1.00$. 
Planet Jr. No. 72, Riding Cultivator.

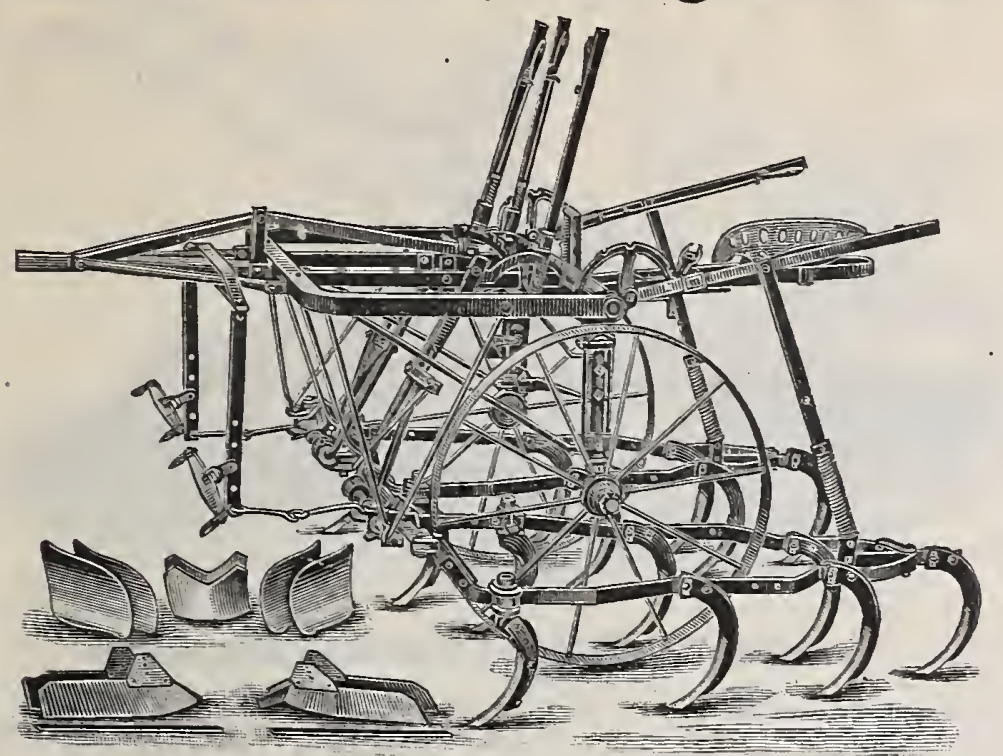

NO. 72 PLANET JR. TWO=ROW PIVOT WHEEL CULTIVATOR, PLOW, FURROWER AND RIDGER.

With Lever Adjustable Gangs, Price, $\$ 50.00$. Weight, packed 560 lbs. Liberal Discount for Cash.

Think of the saring made in cultivating perfectly two rows of potatoes, beans or corn or any crop planted in rows not over 44 inches a part, at a single passage. This means double speed at single cost, and the arrangament of the fourteen teeth is such that all the ground is well tilled and no open furrows are left next to the crop.

The center lever operates tive hinged tongue, regulating the depth of the front teeth to a nicety and levellung wp the machine to suit all heights of neck-yoke. The outside levers reguiate the depth of suit all heights of while the intermediate levers are those used in changing the width of gangs. NO. 71 PLANET JR.

IMPROVED TWO=ROW PIVOT WHEEL CULTIVATOR, PLOW, FURROWER AND RIDGER.

Price, $\$ 45.00$. Packed weight, 530 lbs.

Like No. 72 it has seven teeth on a side, and also four plows and two furrowing shovels, and the frames adjist for all rows from 28 to 48 inches. The wheels adjust from 28 to 42 inches; the wheels are also pivoted like The wheels adjust from 28 to 42 inches; the
No. 72 and steer the tool with the greatest ease.

it has adjustable seat, adjustable tongue and the front standards are adjustable, up, down and sideways; it has adjustable plant guards, and the depth of work is readily arranged by levers both front and back. The hitch is also adjustable; all like No. 72. In fact it is identical with No. 72, except that instead of the opening and closing of the frames by means of levers while and ther tightening up again. Liberal Discount for Cash. Write for large Catalogue.

\section{The Standard Pivot Axle Riding Cultivator.}

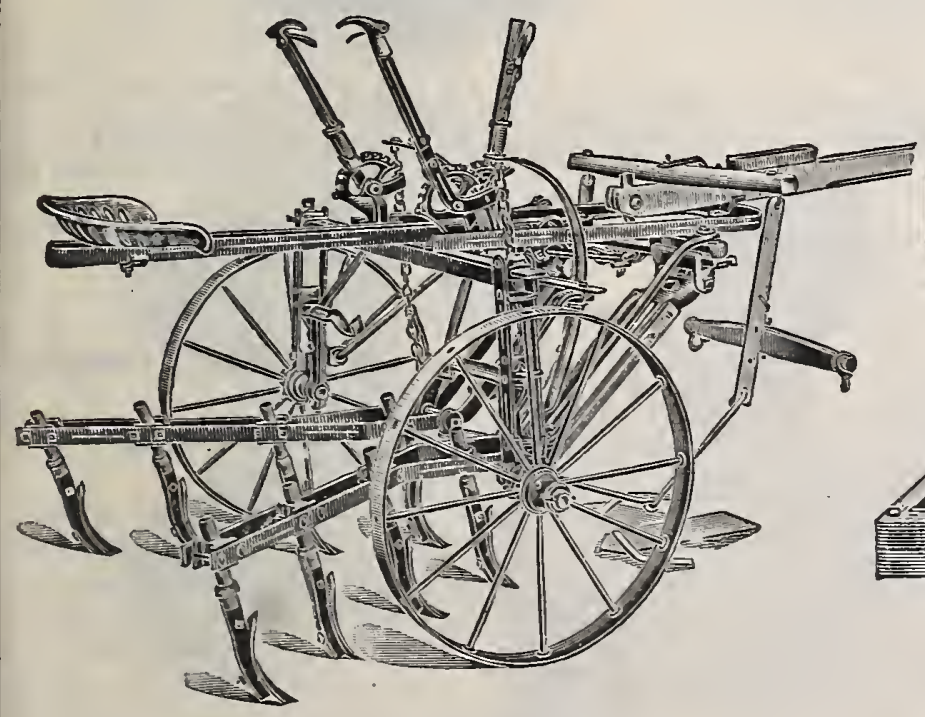

This is a powerful too! and so constructed that it is capalsle of doing a large range of work, and is very handy for cultivating all crops planted in rows. The pivot axle is very handy on side hills for holding the tool up to its place. Extra teeth may be added which makes it into a riding harrow. The wheels may be adjusted in width from 38 to 54 inches for different width rows.

List Price, $\$ 30.00$. Discount for Cash, $\$ 2.00$
The Twentieth Century .. Manure Spreader.

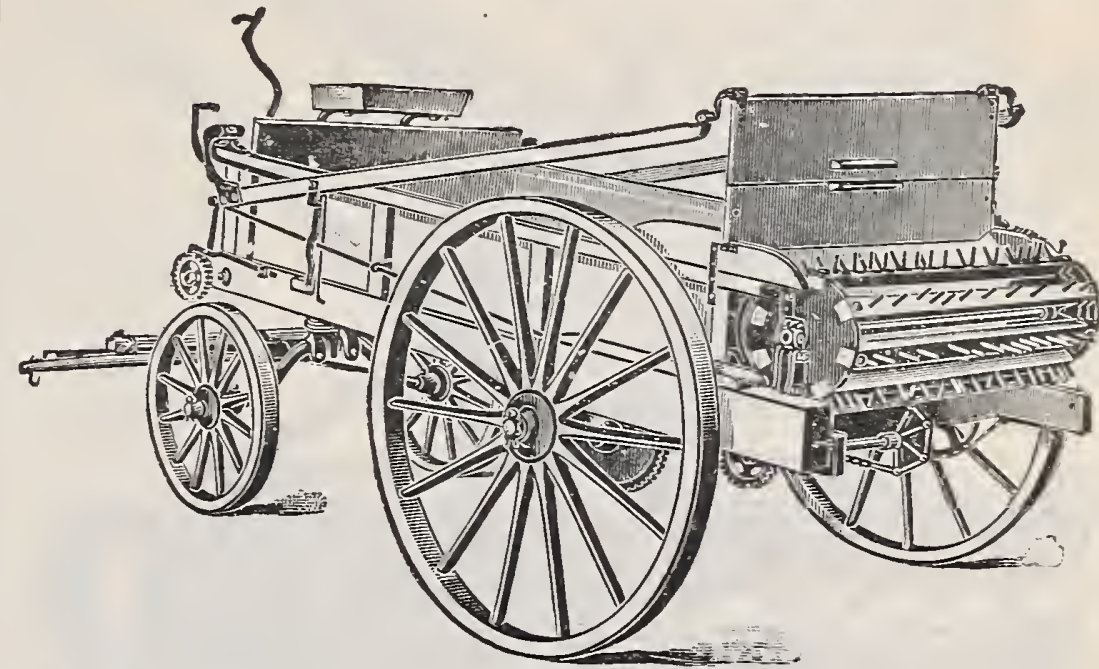

Mr. Kemp's latest invention, and the best Spreader on the market at the present time. The original tight-box Spreader, and the only machine that will sow commercial fertilizers, ashes, chemicals, lime, etc. The beater device is far ahead of other makes. Strength is placed where it is needed. Easiest to operate. Change of feed done with the foot. Not room here to mention all of its good qualities, but write for complete catalogue. It will convince you that if you are in the market for a Spreader you will buy this one.

Made in three sizes:

$$
\begin{aligned}
& \text { *A-30 Bushels, Price, \$1 } 0.00 \\
& \text { B-40 " " } \\
& \text { C-50 " " } \quad 120.00
\end{aligned}
$$

* The " $A$ " is the only size made by other manufacturers.

\section{Two Useful Articles THAT FARMERS NEED!}

The illustration below shows a simple device whereby a stone boat can be made in a few minutes by using a straight plank with the addition of the Iron fread. Anvone in need of a stone boat will readily see how easy it is done, and as one head will last for years, it is not only cheap but durable.

Illustration below shows Stone Boat Complete.

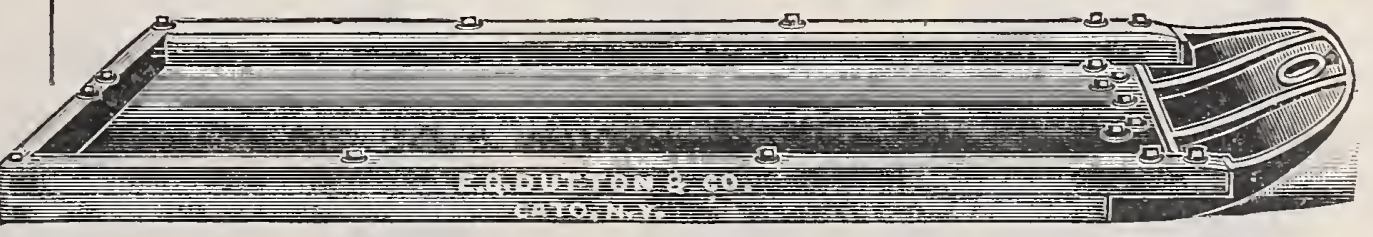

\section{PRICE, $\$ 7.50$.}

IROH STONE BOAT HEAD.

The illustration shows the Cast Iron Boat Head ready for the plank, and where they can be bad easily it is cheaper to buy simply the Head and make the boat yourself.

PRICE, \$3.50.

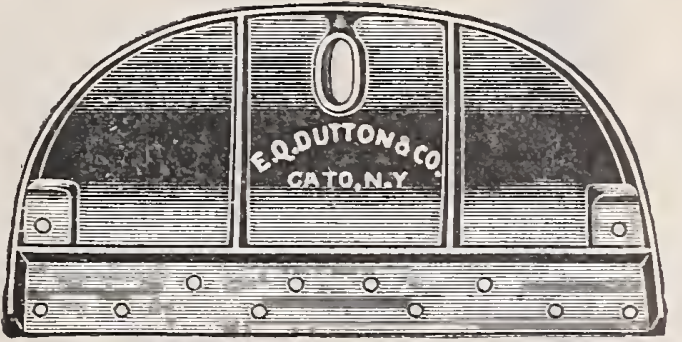




\section{THE STERLING DISO HARROW.} The Best Low Priced Disc Harrow on the Market.

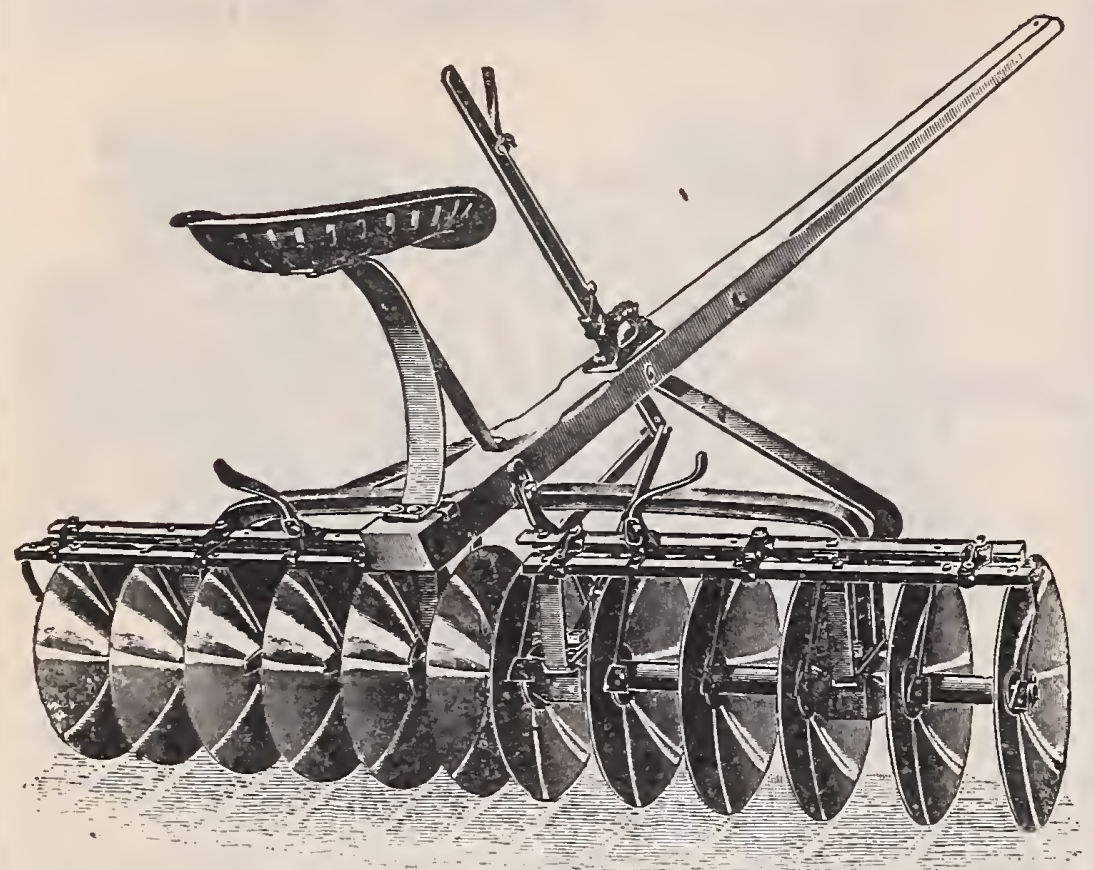

Has 12 16-in. steel discs running on ball bearings. This Harrow, as you will see, is similar to the All Steel Flexible shown on another page, the principal difference being in the flexible part. This harrow does not have the patent foot lever and long spring, but all other parts are equally as good, and we offer evener, yoke and scraper, $\$ \mathbf{2 0 . 0 0}$. Discount for cash, $\$ \mathbf{1 . 0 0}$.
The "Acme" Pulverizing Harrow, Clod Crusher and Leveller.

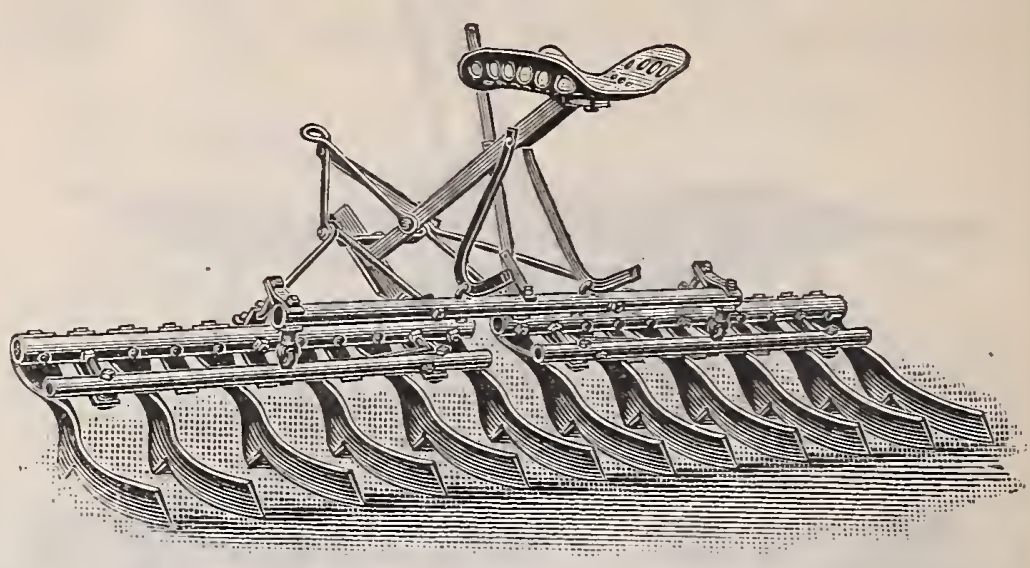

"Acme" Harrow. The Best General Purpose Harrow.

A general purpose harrow that will crush, cut, lift, turn, smooth and level the soil to perfection, all in one operation. While pre-eminently adapted for heavy, stubborn land, it can be adjusted, by means of the levers and runners, to do perfect work on the lightest soil. It cuts the entire surface without disturbing sod or trash that has been turned under by the plow. It prepares a perfect seed bed, and also covers seed in the best manner. The draft is reduced to a minimum. Being made entirely of cast steel and wrought iron, it is practically indestructibie. Nothing but the
these are readily replaced at a trifling cost.

PRICES AND SIZES:

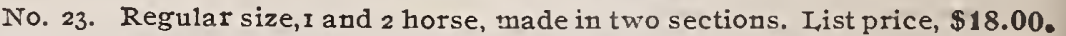
No. 25. Orchard Cultivator. I, ist price, $\$ 25.00$.

Discount for cash with order, to per cent.

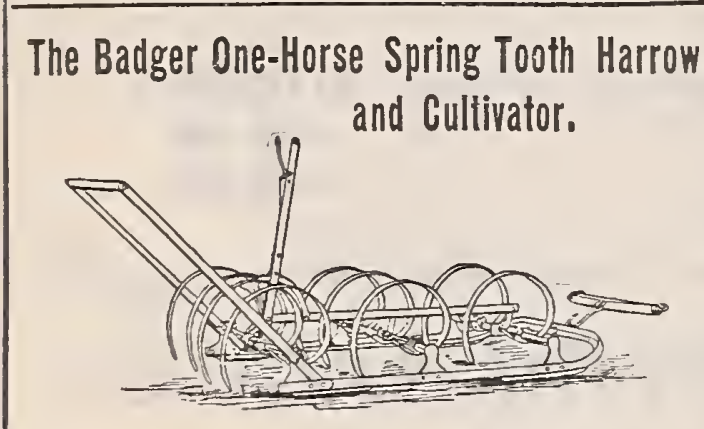

This is one of the handiest tools a farmer can have. It will do work equally as well as a twohorse harrow, having the same teeth, only a trifle smaller. We offer this harrow at a very low price.

Price, \$10.00. Discount for Cash, 50 cents.

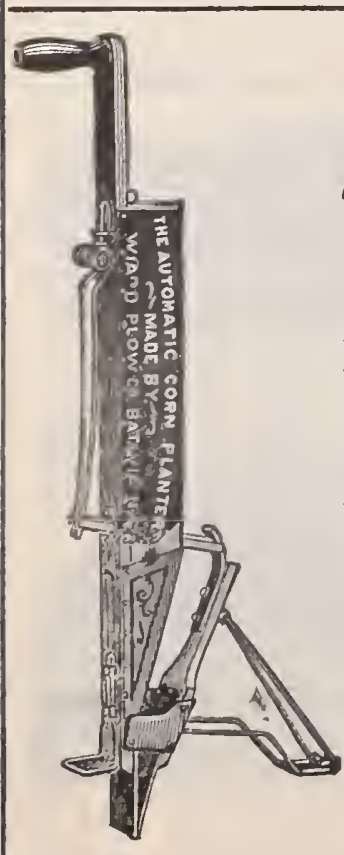

Price, \$2.00.
Discount for cash, $25 \mathrm{cts}$.

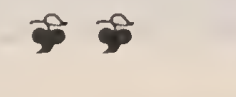

The Syracuse One Horse Spring Harrow.

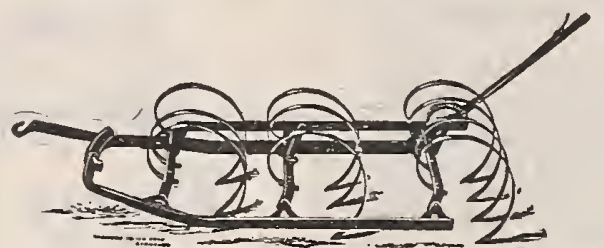

We have sold this harrow for the past four seasons and it has given perfect satisfaction. adapted for all kinds of work.

List price, $\$ \mathbf{1 0 . 0 0}$. Discount for cash, 50 cents.

The Segment One-Hand Corn and Bean Planter.

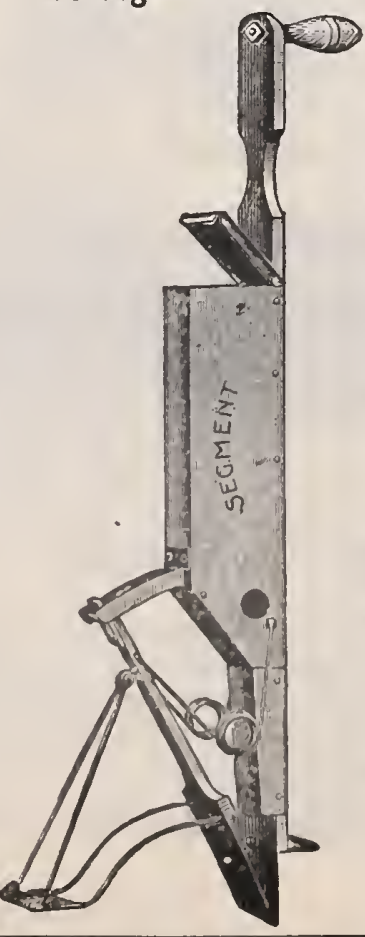

Patented Sept. II, I900.

Lightest, mostaccurate, strongest and most up-todate planter on the market. Never cracks a kernel nor skips a hill. The seed pocket can be sufficiently enlarged to perfectly adapt it for planting the largest field beans as
well as corn. The slide is a segment of a circle having its center where the jaws are pivoted together. jaws are pivoted together. in other words, the pivots on which the jaws open and shut are the hub of a is part of the rim. There is conseguently no friction or lost motion. The seed box and hopper are of galvanized iron. The brush is of genuine Chinese bristles. All of the working parts are pressed or stanped out of sheet steel, and are therefore extremely light, strong are interchangeable.

Price, \$1.75.

Discount for cash, 25 cts.

\section{"ACME" One-Horse Harrow.}

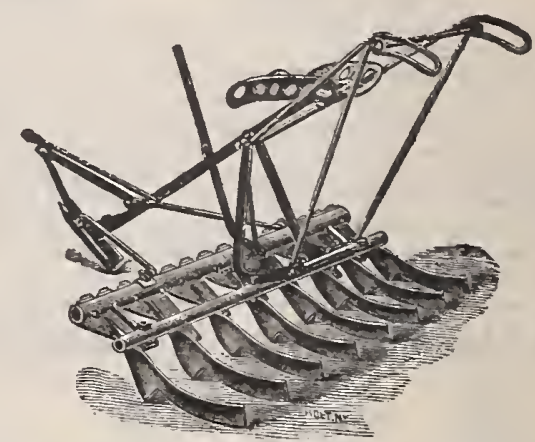

No. $\mathrm{H}$. Works $4^{\mathrm{T}} / \mathrm{f}$ feet wide, 8 coulters, Price, with seat and lever adjuster, $\$ 15.00$.

No. G. A splendid one-horse cultivator; 7 coulters. Cuts 3 feet wide. Has handles, as shown in
cut, but no seat or lever. Price, $\$ 9.00$. 


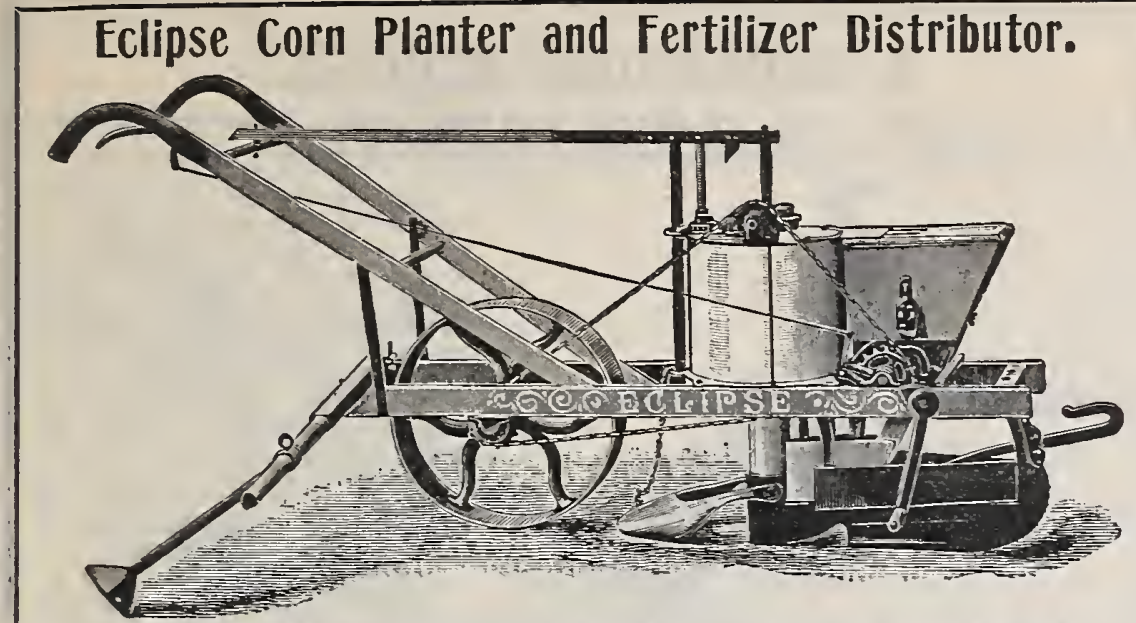

Plants field or ensilage corn, beans, peas or beet seeds in hills, drills or checks; it will drop $6,12,24$, or 36 inches a part. By scattering pumpkin seeds in with the fertilizer in flling the hopper will place seeds in hils when planting corn. It accurately distributes from 50 lo $4.501 b$. as desired, of commercial fertizer, wet or dry, in the rows of hill, hrst drawing moist earth covered to a uriform depth. Price complete, $\$ 21.00$; discount for cash, $\$ 1.00$.
"KING OF THE CORNFIELD,"

Corn, Bean and Poa Planter and Fertiizer Distributor.

\section{Eclipse Two-Row} Tw0-Horse

\section{Corn Planter.}

The Most Complete, Accurate, Durable and Easily Handled Double Row Corn Planter in the Market.

All the good points found in the well-known and popular "Eclipse Single Row Planter" are retained in this machine.

The fertilizing device is acknowledged by all to be perfect. It will distribute from 50 to 600 pounds to the acre.

Planters can be adjusted in the frame to make the

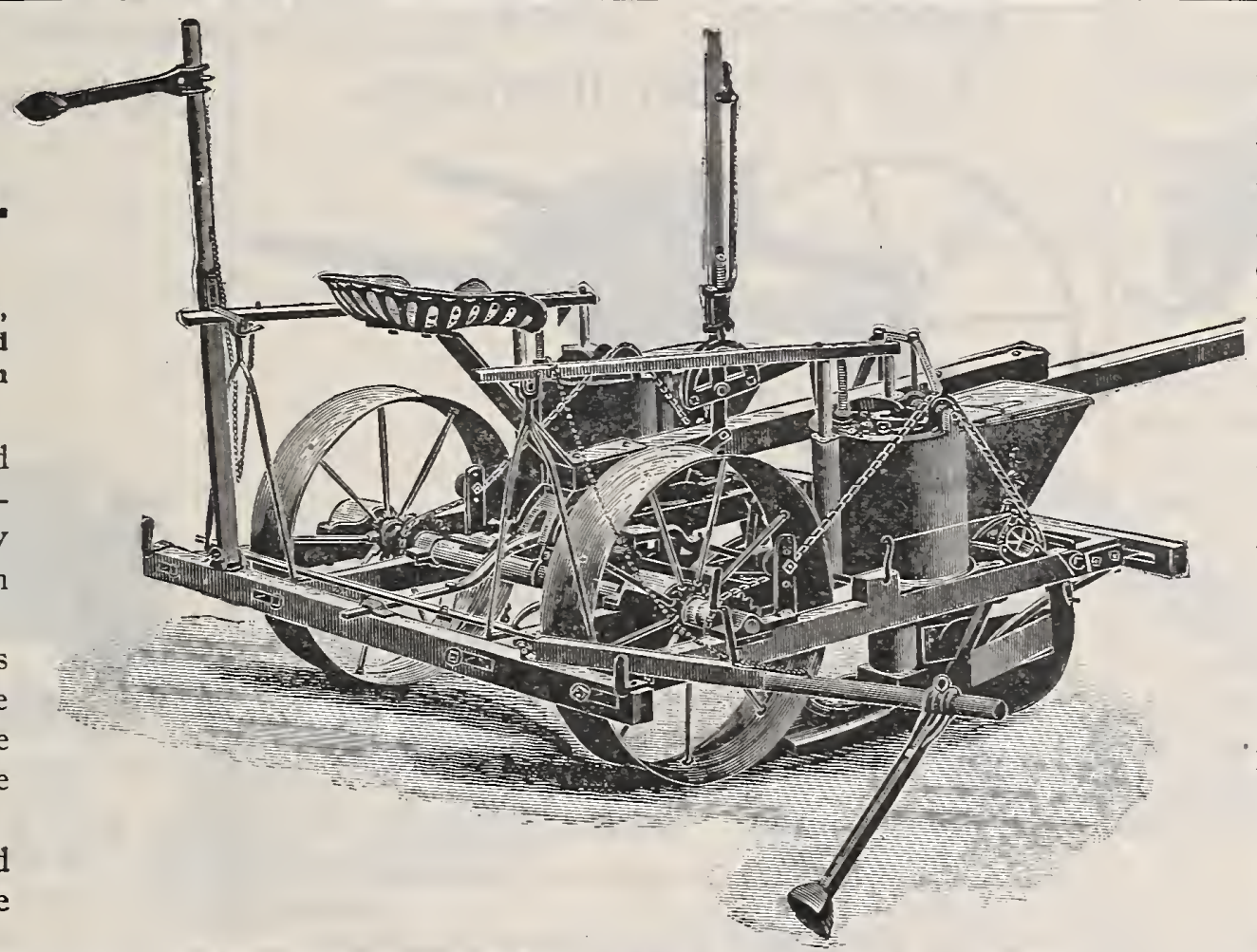

rows $36,38,40$ and 42 inches apart. The new Marker Device, used for two seasons with perfect success on the single row Eclipse, is used on this. One move of the lever throws the machine out of gear, and at the same time raises the planter and coverers ready for turning the team at end of rows.

The check is operated with the foot when found desirable to have hills in line for cross cultivation.

For those planting 10 or more acres, and farmers that plant for their neighbors, we recommend this machine.

List Price, $\$ \mathbf{5 0 . 0 0}$.

Discount for Cash, $\$ \mathbf{2 . 0 0}$.

\section{The New Aspinwall Potato Planter with Fertilizer Attachment.}

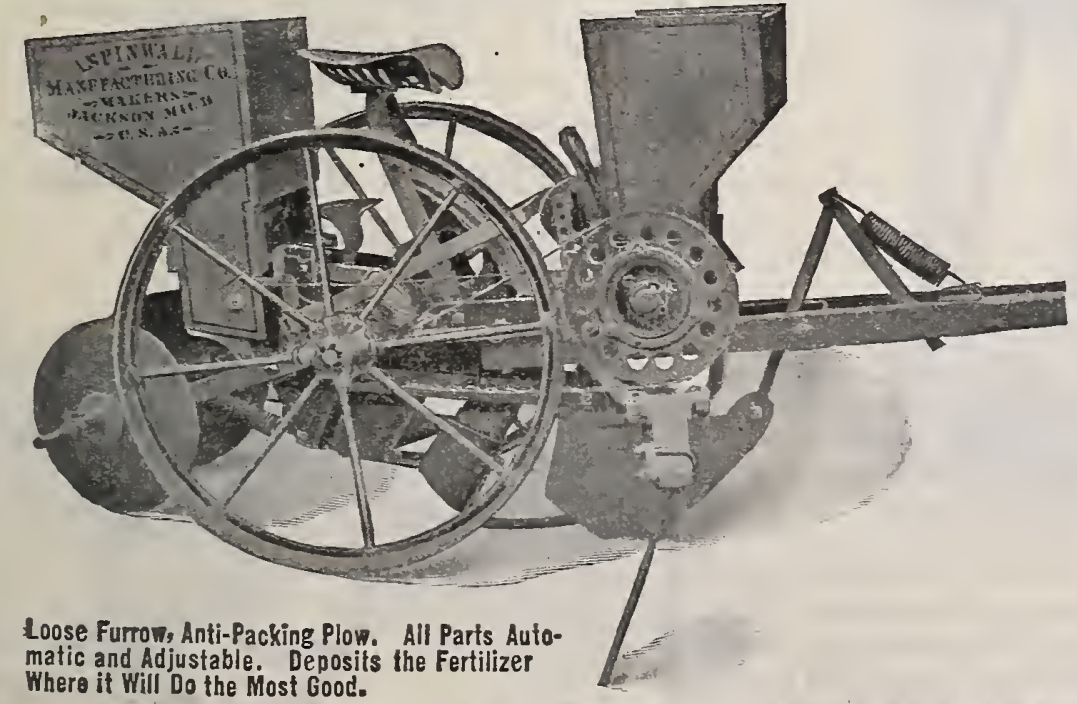

The New Aspinwall Potato Planter with Fertilizer Attachment embrace more substantial im provements and desirable features than any other make. Instead of depositing the fertilizer from the rear of the machine, partially mixing it with the earth as the furrow is being closed, they have transposed the locatior to the front and arranged the plow to open a deep furrow, wher the fertilizer is deposited, being mixed and covered with the earth, putting it underneath and in advance of dropping seed. List Price, $\$ 65.00$; discount for cash, $\$ \mathbf{5 . 0 0}$. Corn Planter attachment, $\$ \mathbf{5 . 0 0}$ extra.

\section{The Standard Corn Planter.}

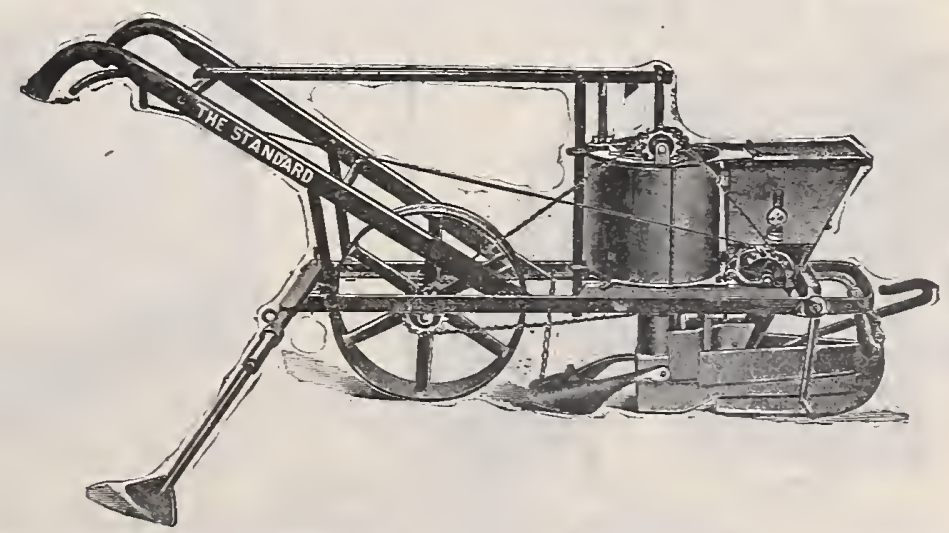

The Standard Planter shown above is in many ways the same as the Eclipse shown on the top of the page, and nearly all the parts will interchange. The principal difference is in the frame, which is made of steel instead of wood.

It will plant in hills, drills or checks, in various quantities as desired, field or ensilage corn, beans, peas or beet seeds at a variety of distances. Price, $\$ 20.00$. Discount for Cash, $\$ 1.00$. 


\section{Farmer's Friend Seed and Fertilizer Sower.}

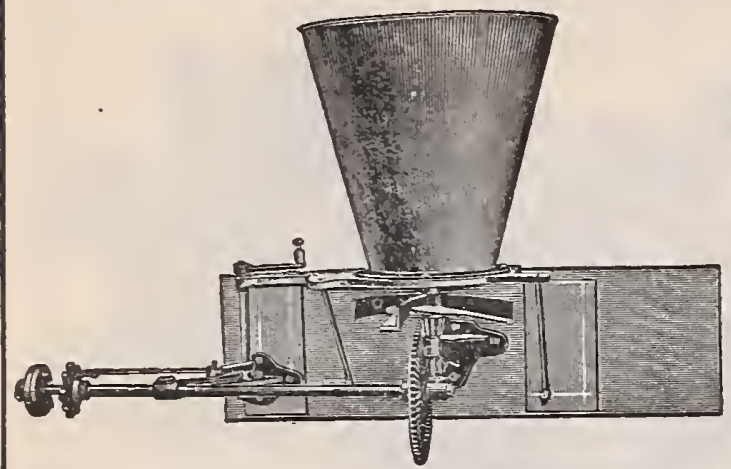

Attaches to any ordinary farm wagon, and sows to perfection grass and grain seeds of all kinds and in any desired quantity per acre, 50 to 100 acres a day. It also distributes all dry commer cial fertilizers, also ashes, land plaster, lime, etc. It has a positive force feed and an adjustment opening the holes from $1 / 4$ to I $1 / 2$ inches, which allows the sowing of seeds of any size; the flow can be shut off anywhere, either on one side or the other, or altogether, as required; it is instantly thrown in or out of gear.

Price, complete to attach to wagon, $\$ 12.00$. Discount for cash, $\$ 2.00$.

\section{The Stevens Lawn}

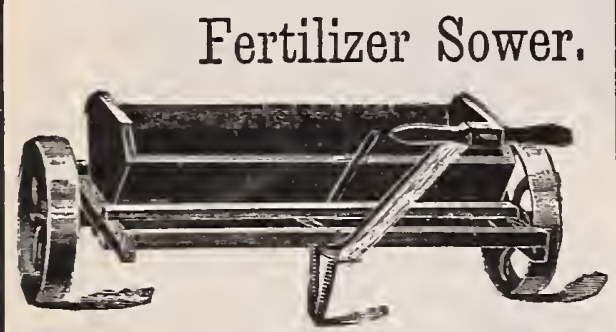

Does the work perfectly, sowing all kinds of lawn dressing and other commercial fertilizers, wood ashes, lime, etc., in large or very small quantities. It can also be successfully used for fertilizing strawberry beds and other garden and field work; is excellent for sifting wood or coal ashes. The hopper is 34 inches long and holds one and $a$ half bushels. Weight of machine, 83 pounds. It is well made and nicely painted.

Price, \$12.00.

Discount for cash, $\$ 1.00$.

Cahoon's Improved Broadcast Seed Sower.

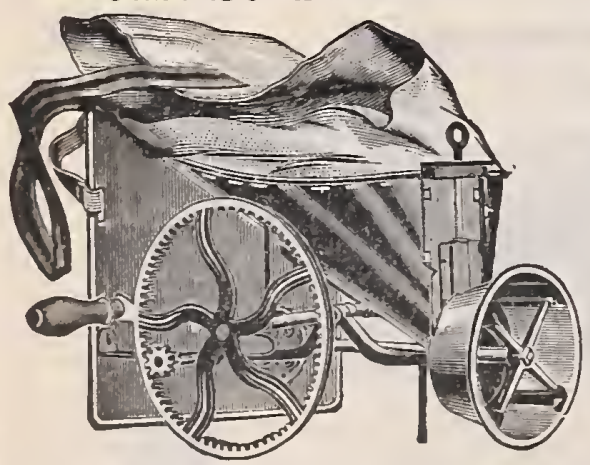

Will sow all kinds of grass and grain seeds from 4 to 8 acres per hour at a common walking gait. Heavy seeds, such as wheat, it will throw 40 feet (20 from each side of the operator); lighter seeds, of course, will not be thrown so far.

Price, $\$ 3.50$.

\section{Keystone Jr.} Hand Fertilizer Distributor.

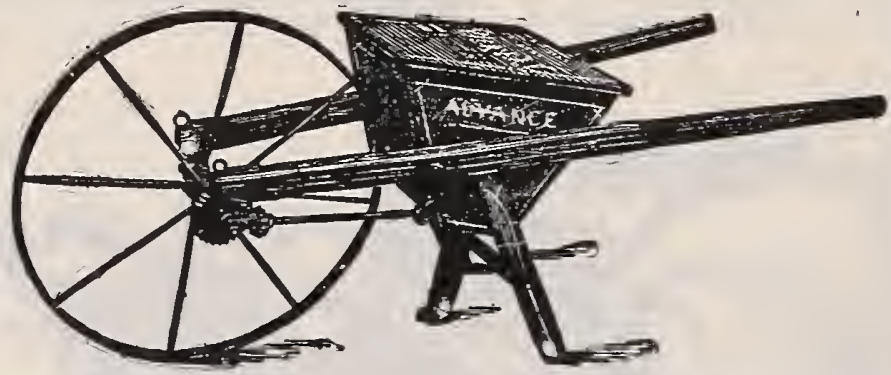

This machine is very handy for small truck farmers and gardeners for sowing all kinds of commercial fertilizers. Its distributing disc is made of galvanized iron which prevents rusting. The cutoff is operated with the foot so that it does not scatter in turning at the end. Has 24-inch wheel designed to be used by hand, but a horse may be attached if desired.

List price, \$8.50. Discount for cash, 50 cts.

\section{The Cyclone Broadcast Seeder.}

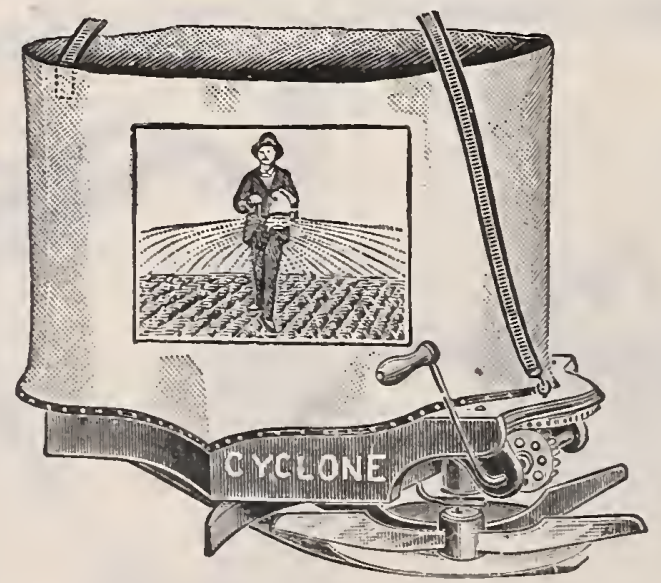

This is the cheapest and best of the hand seed sowers on the market, and every one sowing one acre or more of grass seed or grain cannot afford to be without it. Will sow Timothy, Clover, Wheat, Oats, Rye, Buckwheat, Hungarian, Red Top, Millet, and all other grains and seeds perfectly even, and any desired amount to the acre, and from 40 to 60 acres a day. The machine is first-class in every respect. We guarantee the seeder to give satisfaction, or money refunded. Net price, $\mathbf{\$ 1 . 5 0}$.

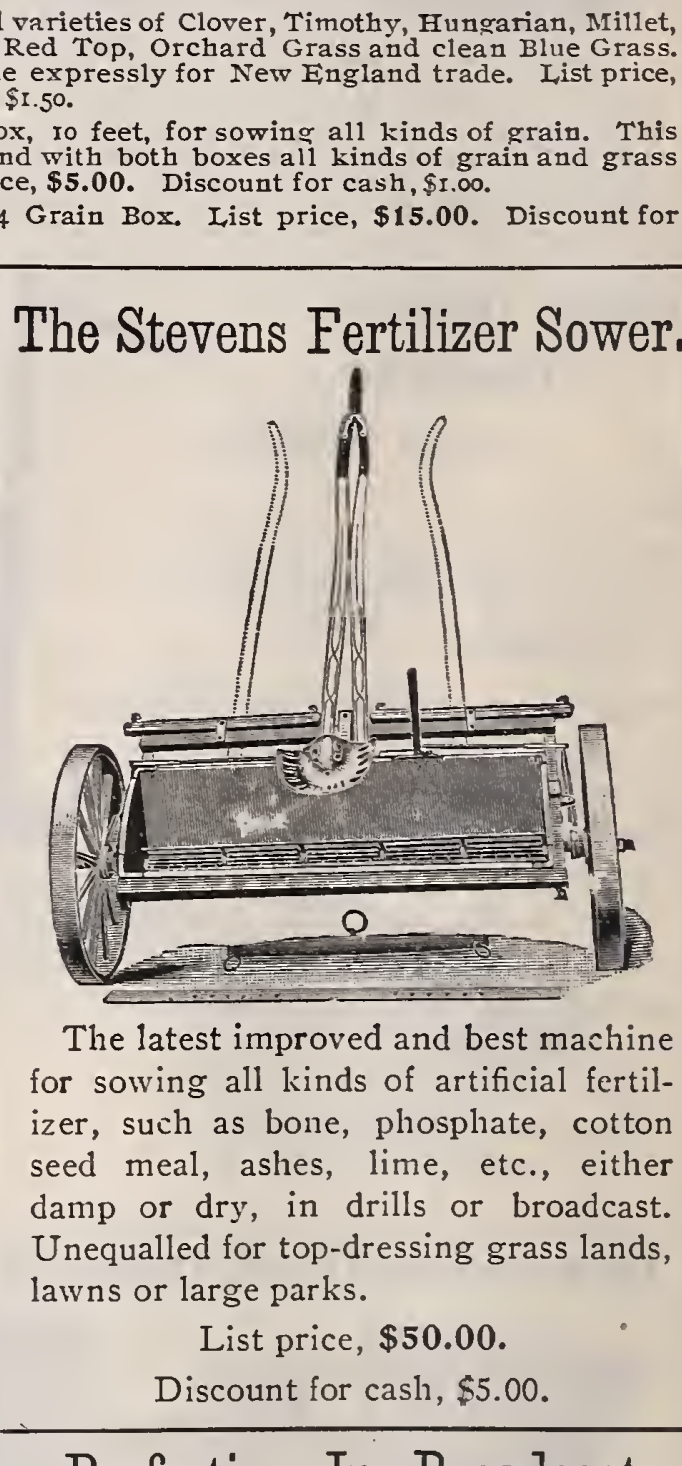

The latest improved and best machine for sowing all kinds of artificial fertilizer, such as bone, phosphate, cotton seed meal, ashes, lime, etc., either damp or dry, in drills or broadcast. Unequalled for top-dressing grass lands, lawns or large parks.

List price, $\$ \mathbf{5 0 . 0 0}$.

Discount for cash, $\$ 5.00$. Perfection Jr, Broadcast

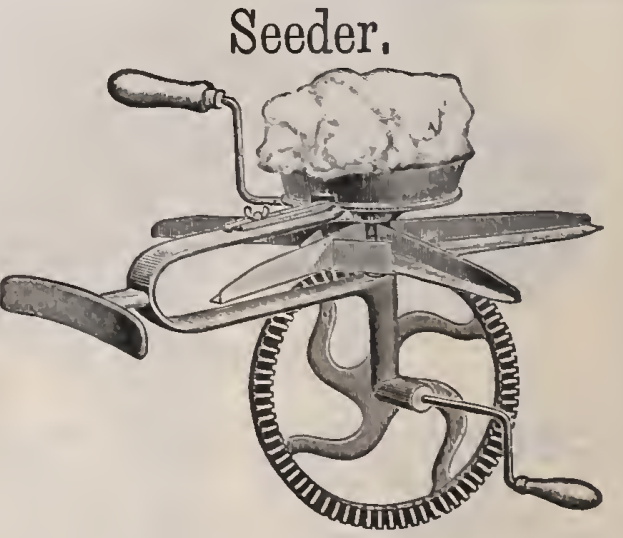

This seeder is similar to the Cyclone, but made very much lighter and cheaper. It is ivell worth the money. Net price, \$1.00. 
The "PLANET JR." No. 4.

Combined Hill Dropping Seeder and Single Wheel Hoe.

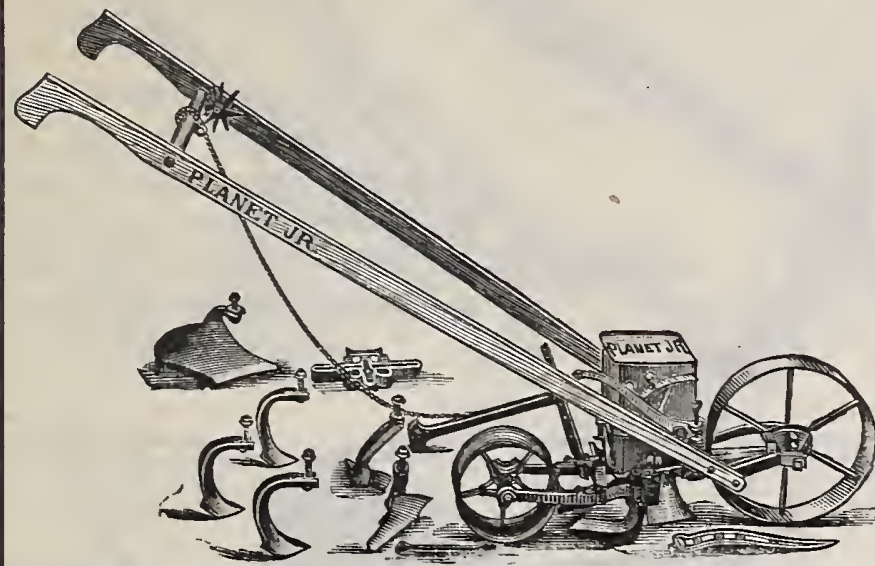

This is exactly the same style No. 5 "Planet Jr." Hill Dropper, only small er in capacity at $4,6,8$, I2 and 24 inches apart, 24 inches apart, thiclness, handling the small est paper of est paper of seed perfcctly. gea r instantly y simply rais ing the handles. The index is ac and easily set.

The drill is detached and the tool frame substituted by moving but one bolt. It then becomes one of the most admirable Single Wheel Hoes. It has a garden plow, two hoes, three cultivating ralies, new form and made to fit 6,9, I 2 I4 and I6-inch rows, three cultivator teeth and a practical leaf guard.

Price, complete, $\$ 10.50$; as a Drill only, $\$ 8.50$.

"PLANET JR." No. 16.

Single Wheel Hoe, Cultivator, Rake and Plow.

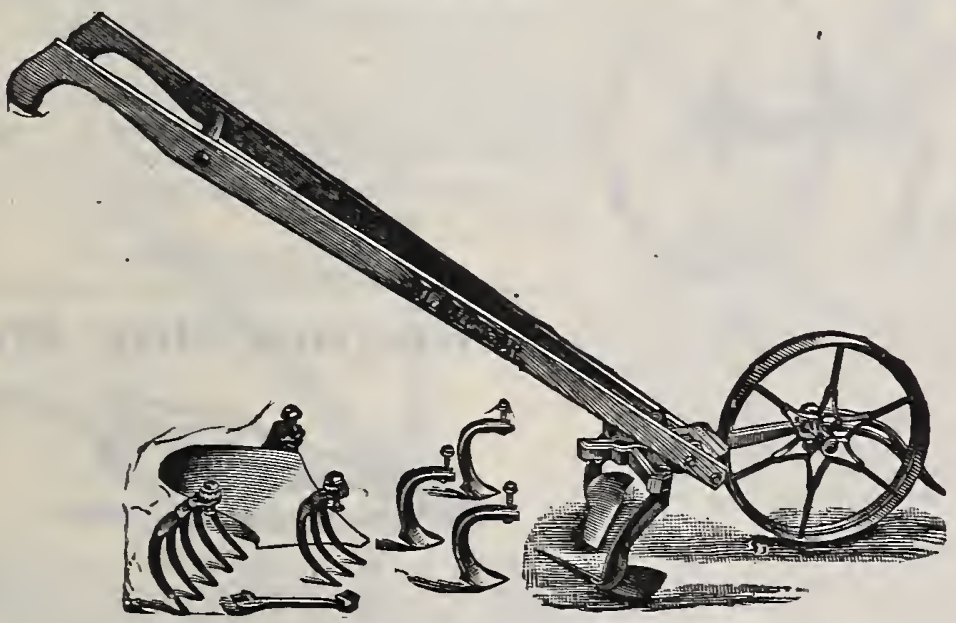

This Wheel Hoe is identical with No. 15, except that it has fewer tools, but the price is proportionately lower, and the remaining tools may all be added as wanted. The equipment is a most useful one and will be found just right for a great variety of work. The frame changes in height, and the wheel to the other side of the frame, to hoe both sides of the row at once.

PRICE, \$5.85.

\section{The "PLANET JR." No. 2 Seed Drill.}

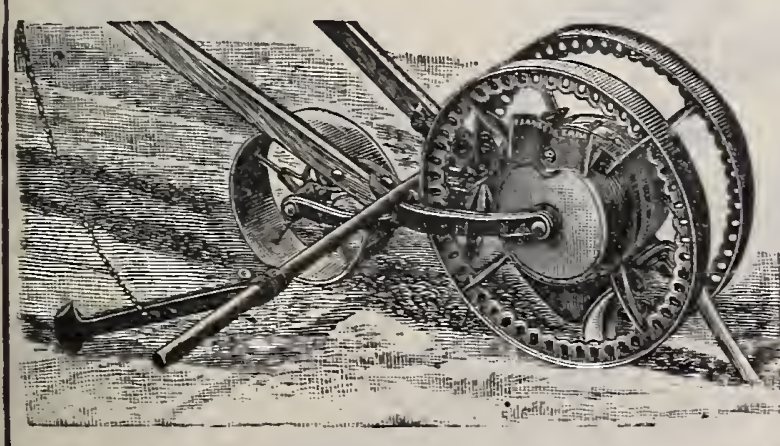

This tool is known the world over, and with the exception of the "Planet Jr." Hill Dropping Drills is the most perfect drill known. It holds two and one-half quarts.

The drill sows in an even, regular stream, whether there is much or little in the hopper. The opening plow, being directly between the wheels, follows all irregularities of the ground, is adjustable, and once set, opens the furrow at a uniform depth, and the seeds are deposited in a very narrow line. The machine is extremely simple; no agitators, belts or gearing.
Planet Jr. No, 25 Combines Hill and Drill Seeder and Double Wheel Hoe. This new combined machin is intended for a class of gardeners who have a large age of crops ior a double wheel loe to be uscd to good advantasc. 21\% quarts (O abolit 5 pounds of onion seed), wheels.

It is almost identical with will so $\mathrm{w}$. drills or liills $4,6,8,12$ or 24 wencs a part a 11 d has the

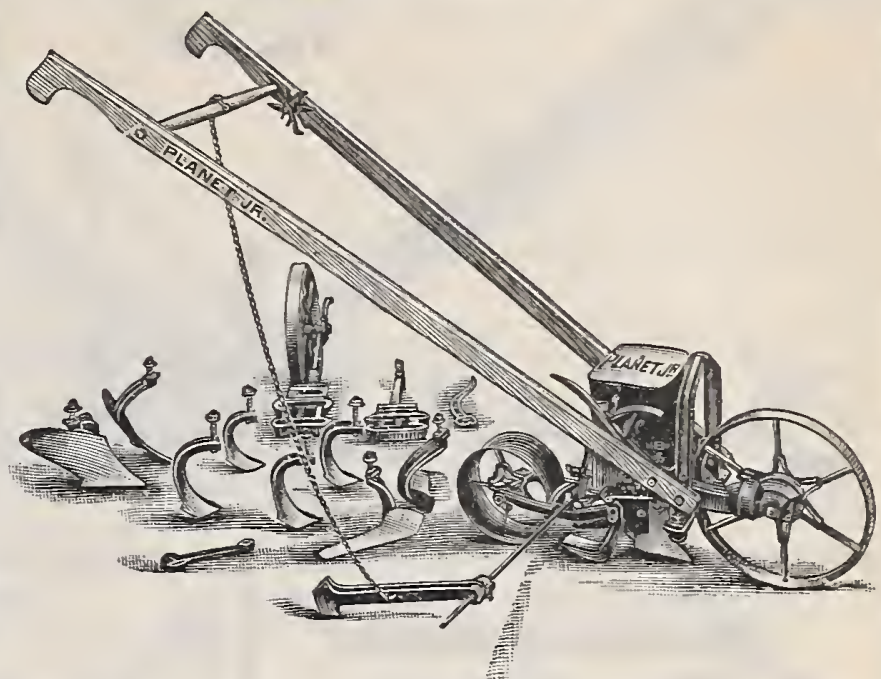

natic device for throwing out of gea

As a wheel hoe it is identical with the No. I 2 double-wheel hoe

ange from drill to wheel hoe takes but a moment, and the entire Net Price, $\$ 13.50$

"PLANET JR." No. 17. Single Wheel Hoe, Cultivator and Plow.

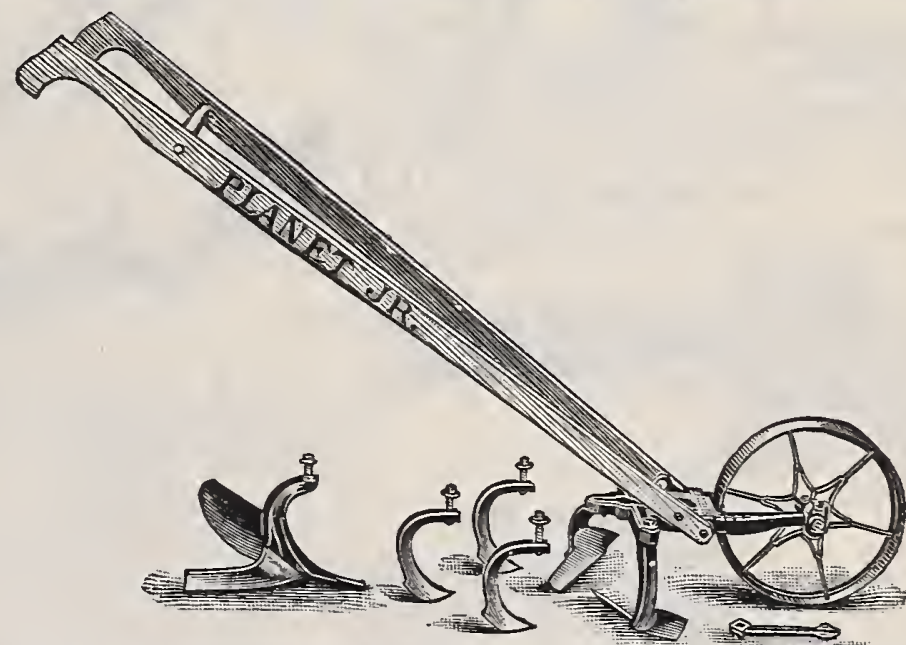

This also has the same frame, handles, etc., as No. 15. but is supplied only with a pair of 6 .inch hoes, a set of cultivator teeth and a plow, a suffi. cient outfit for most gardening work. The others can be added at any time. lhe frame changes in height, and the wheel to the other side of the arm, the working both sides of the row at once.

Price, No. $17, \$ 5.00$; No. $171 / 2, \$ 4.50$; No. $18, \$ 3.50$ No. $17 / 2$ is same as No. 17 , less the plow. No. I8 is same as No. 17 , with hoes only.

"PLANET JR." No. 3. Hill Dropping Seed Drill. A fine Hill Dropping seeder with hosts of friends. This drill will sow in a continuous row, in the ordi-
nary way, with the greatest regularity; but its dislinctive feature is that it iill drop neatly in hills, 24 inches a part. The wheel is 15 inches high, with a broad face. Is changed in a moment from hill dropping to drill work. Sow

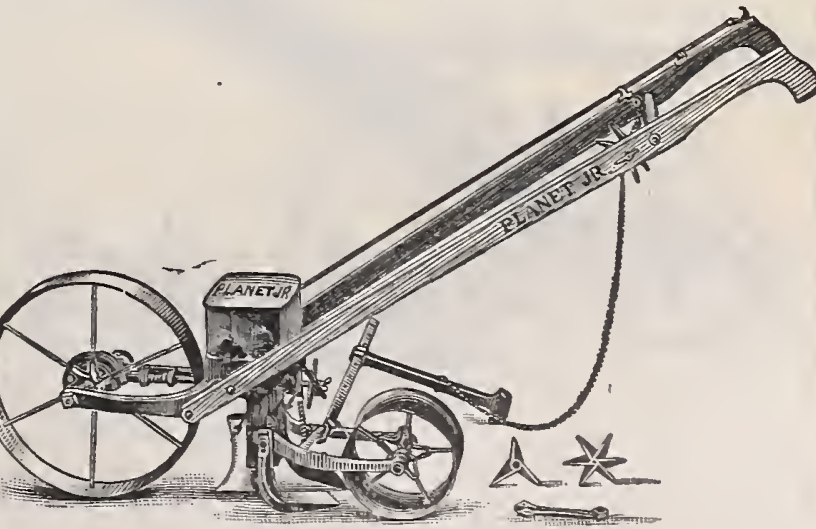
e qua $11 y$ tvell is full or contains only a paper of seed, and will not inwhether the hopper is fas radish, cabbage, etc., which are so often peeled o crushed by imperfect seeders. The plow is adjustable and opens a very narrow furrow which is a great advantage 1 or after cultivation. I 896 was the first year that this machine was sold widely by the manufacturers of the celebrated line of "Planet Jr." goods, but it has since been bought very largely by crre- 


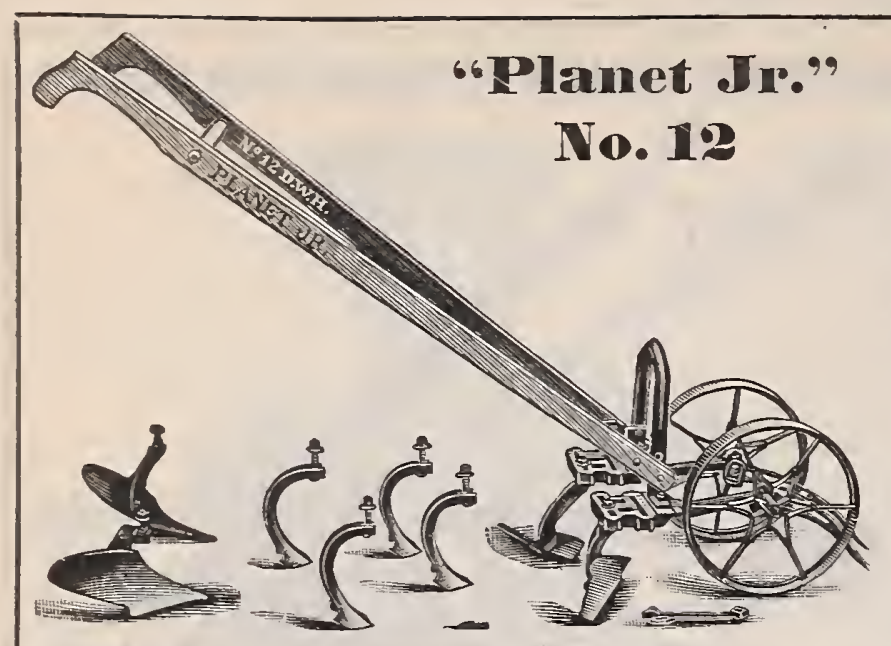

This tool is
identical wit h
No. Ir, except
that it has a less
complete equip-
ment, as shown
in the cut, but at
a corresponding-
ly less price.
The set of tools
with No. I2 is
what gardeners
need most, and
the rest can be
addedas wanted.
Net price, $\$ 7.50$

\section{"Planet Jr." \\ No. 13}

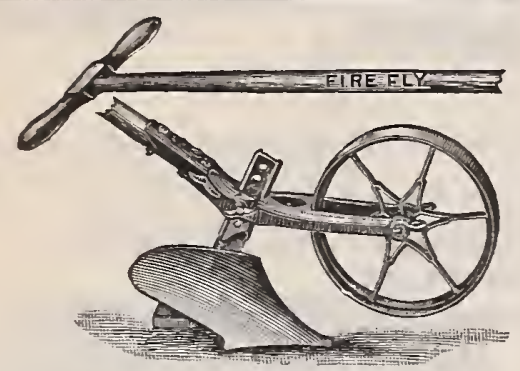

\section{The "Fire-Fly" Plow}

This tool is invaluable for those who have small gardens. The moldboard is tempered and polished steel. The depth may be changed very quickly. The low price brings
it within the reach of all. Very useful to plow up the chicken yards.

Price, \$2.35.

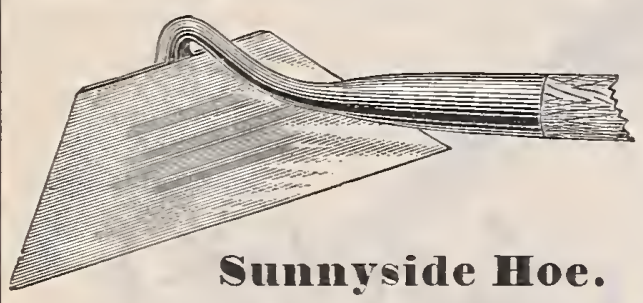

The above cut shows the sunnyside or Strawberry Hoe, invented several years ago by one of our largest strawberry growers fruit growers in the state. It is especially adapted for small fruits and close cultivation.

Price each, 35c.; 3 for $\$ 1.00$.

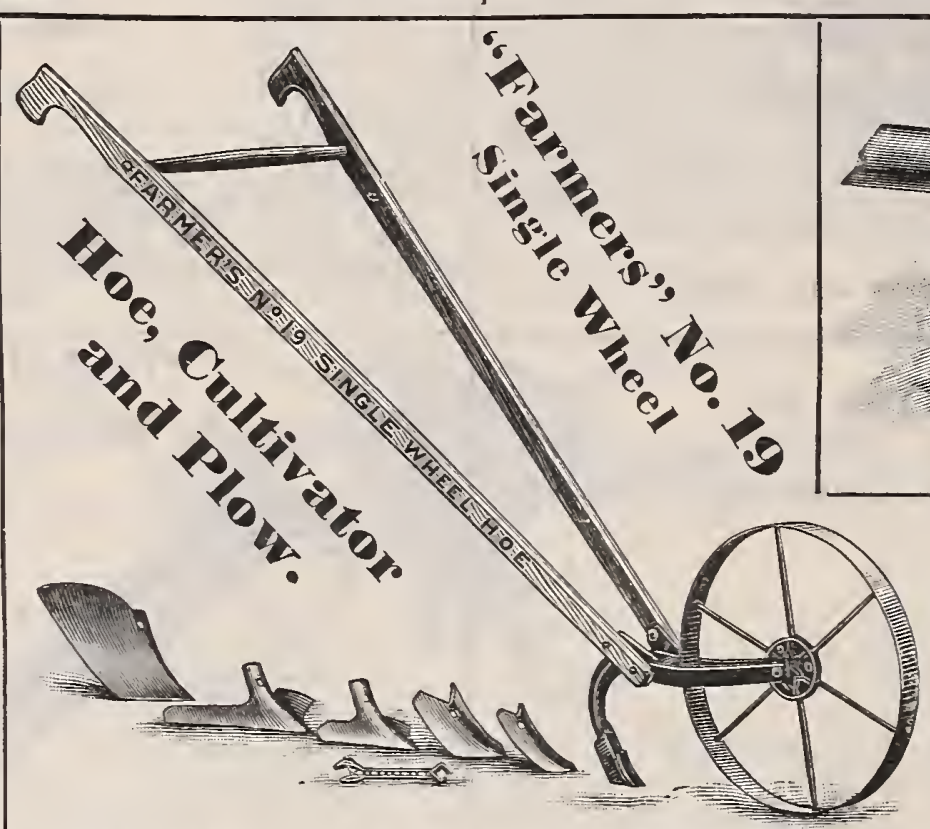

This new and attractive implement is especially designed for the farmer's garden work, though it offers to everyone with either field or garden a cheap and effective tool for all hand The woe operations.

The Wheel is high and is made with stiff steel rim and spokes, and a combination steel and malleable iron hub. The wheel arms are steel and the frame of the tool is attached adjustably to the wheel arms, so that the height of the handles may be readily The Standard is slotted to make regulation of depth easy. The tools are as follows: One Irarge Garden Plow, One Ten Inch Sweep, One Six Inch Sweep, One Four Inch Cultivating Tooth, One Two Inch Cultivator Tooth.

Price, \$3.75. Discount for cash, 25c.
This tool is the No. Ir, with 6 inch hoes only, this pair of tools being most generally used at all seasons. Any or all of the No. II tools may be added at any time, and are sure to fit. Net price, $\$ 4.75$.

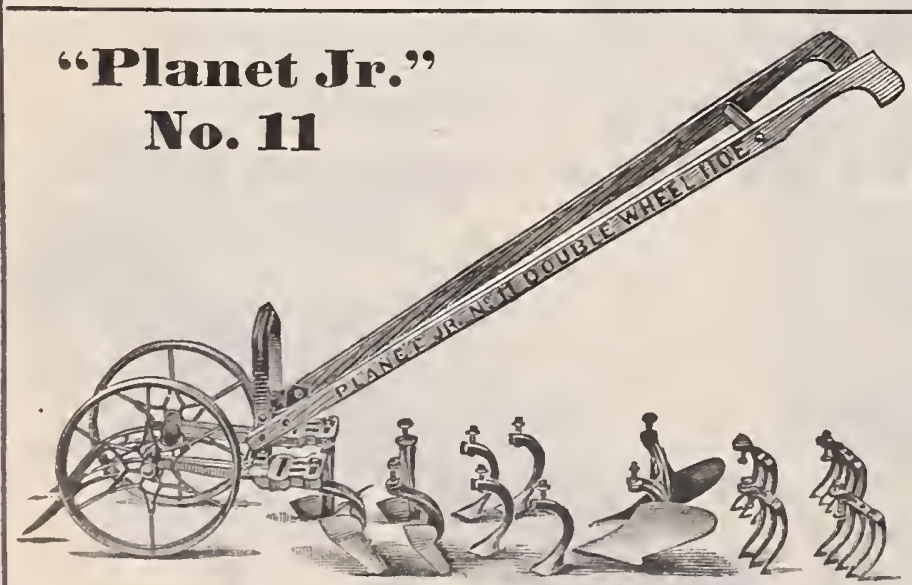

The latest improved double wheel machine, combining all of the merits of the older styles, with several desirable new features. The wheels, Ir inches in diameter, can be set 9 or II $1 / 2$ inches apart for narrow rows, and 4 inches apart when used as a single wheel hoe; the frame is malleable, with a quick change device so the position of the tools may be changed without removing the nuts; the arch is 20 inches high, allowing it to straddle crops when well grown. The outfit of tools comprises the greatest variety and all of the latest designs, covering every possible need.

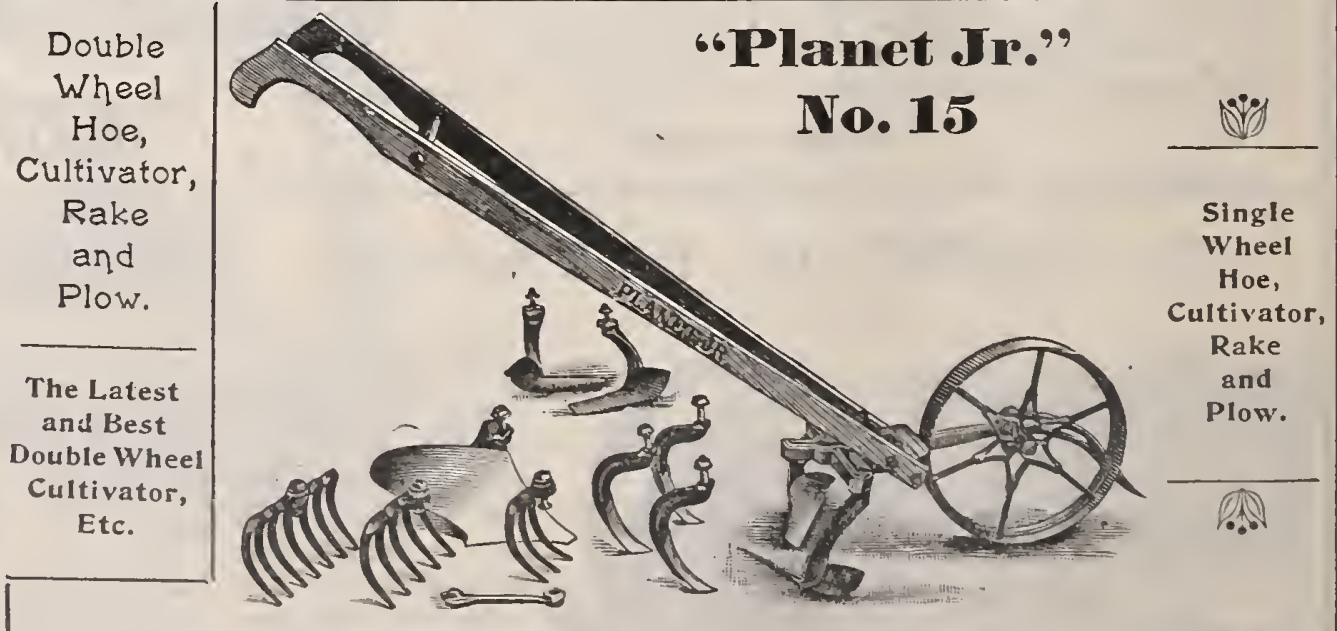

This latest and best Single Wheel Hoe has an II-inch wheel, with broad face, and a convenfound a rranged set of tools, several of them being of a new special design, such as have been frame especially adapted for quick changing of teeth. It is a most perfect Wheel Hoe for narket gardeners or for private places. The tools are a well-shaped plow for plowing, markin out, covering and late cultivation; a pair of neat 4 -inch shield hoes, just right for hoeing a set of three rakes just, right for 6 pair for wider nork; and three cultivator teeth. Also side; the rakes are just the thing for preparing ground for the seed drill. A practical leaf side, the rakes are just the thing for preparing ground for the seed drill. A practical leal guard completes the equipment. The frawe changes ill height, and the wheel to the
side of the frame when both sides of the row can be hoed at oue passage. Price, \$7.00. 


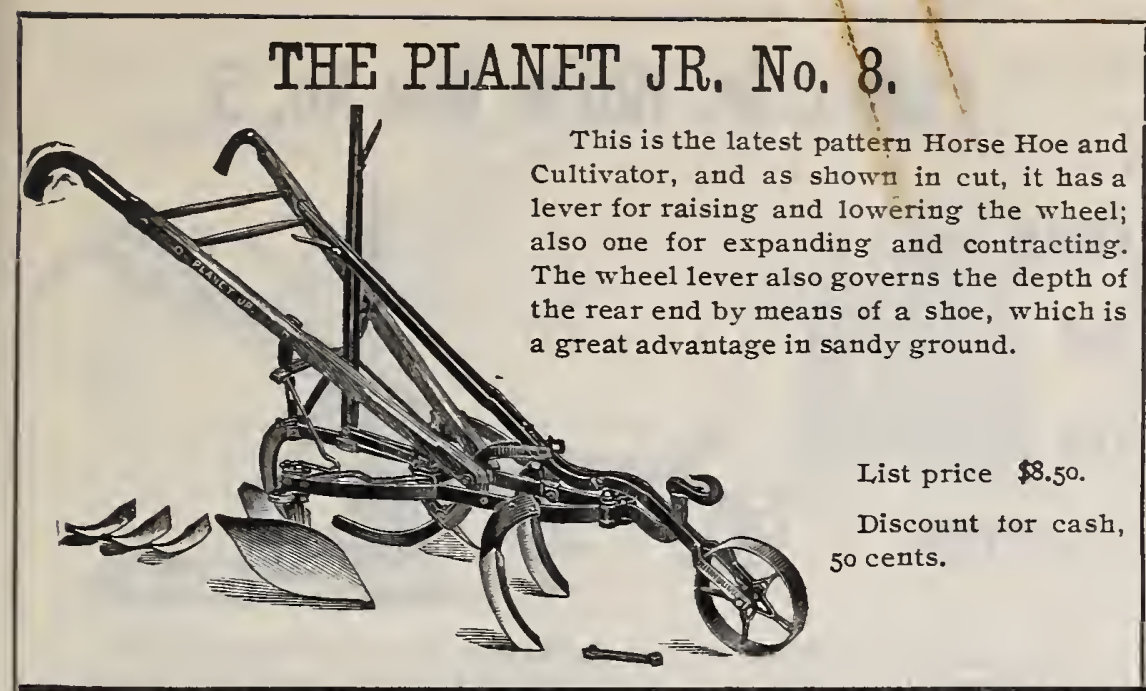

THE PLANET JR. CELERV HILLER.

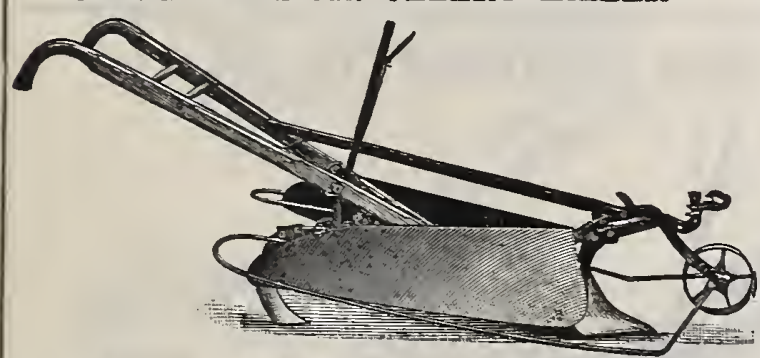

This tool is used largely by celery growers for banking celery in the fall. We can furnish both single or double. The single is used mostly, and will do the work of five men.

List price, double.........\$14.00

Discount for cash, 50 cents.

\section{THE HITCHCOCK POTATO DIGGER And Shovel Plow Combined. \\ ก

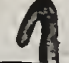 capital work, without throwing earth on small plants, and because the tool is so convenient, durable and strong, the combination of teeth and pulverizer leaving the ground in the finest erator to set the tool, in conjunction with the wheel, to any exact depth desired, making deli- cate work not only possible, but very easy. It is invaluable in narrow rows and delicate work in market gardeus and close work on the farm, and is fine for prous and close work on the farm, and is fine for preparing seed beds. The imple- pander so the depth or pander, so the depth or width can be changed inches, and expands to 32 inches. The handles inches, and expands to 32 inches. The hand \\ List price, with pulverizer as shown, $\$ 8.50$. Less pulverizer, $\$ 6.90$. Discount for cash, $50 \mathrm{c}$.}

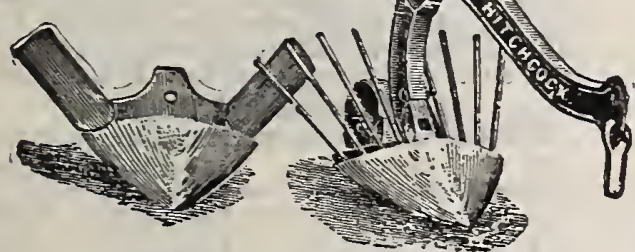

Hitchcock Potato Digger, \$8.00. Hitchcock Potato Digger and Shovel Plow combined, \$ro.5o. Discount for cash, 5o cents.

THE PLANET JR, 12-TOOTH HARROW,

$=$

This thorough working and convenient tool has grown in favor among strawberry growers, is because the twelve chisel-shaped teeth do such is because the twelve chisel-shaped teeth do such

This implement, though rery simple in appear ance, is as near perfect as can be attained and come within the reach of every farmer. By the changing of one bolt it may be converted either into a shovel plow or potato digger. The fingers are adjustable, being held in position by the plow point. Thus, in case of breakage, a new part may be inserted. The fingers, points and wings are made of steel.
THE PLANET JR, No, 7.

Horse Hoe and Cultivator.

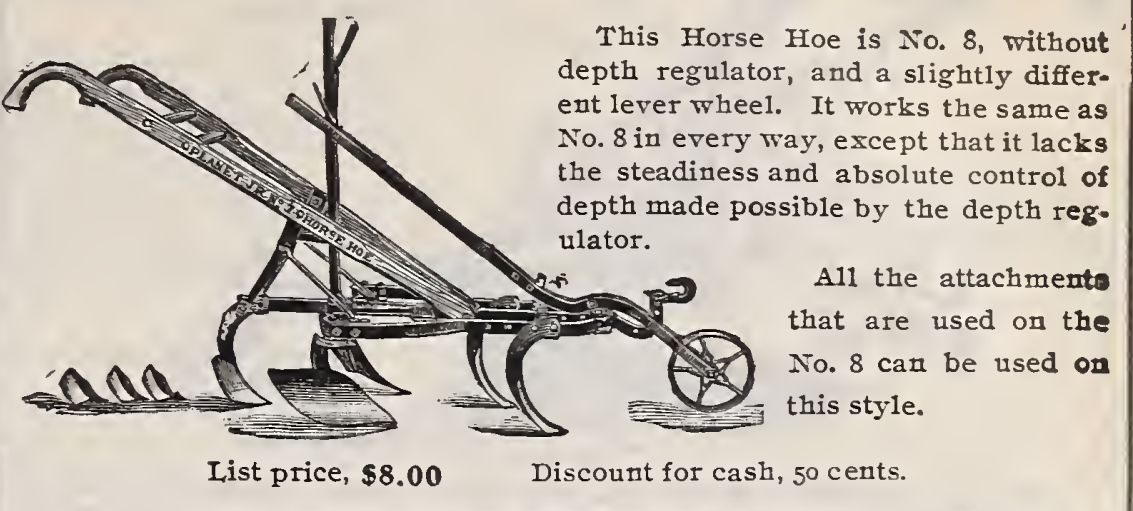

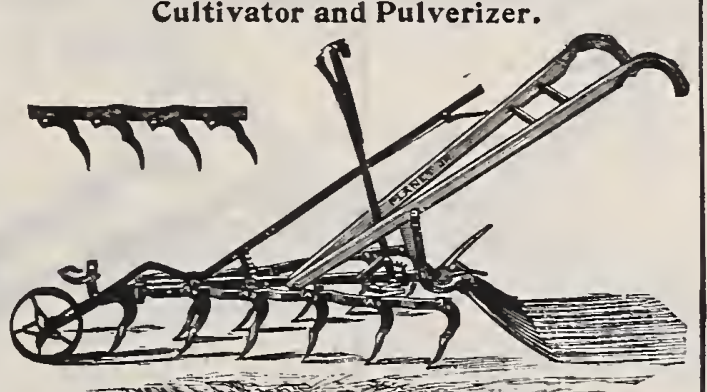

\section{Nera Model Horse Hoe.}

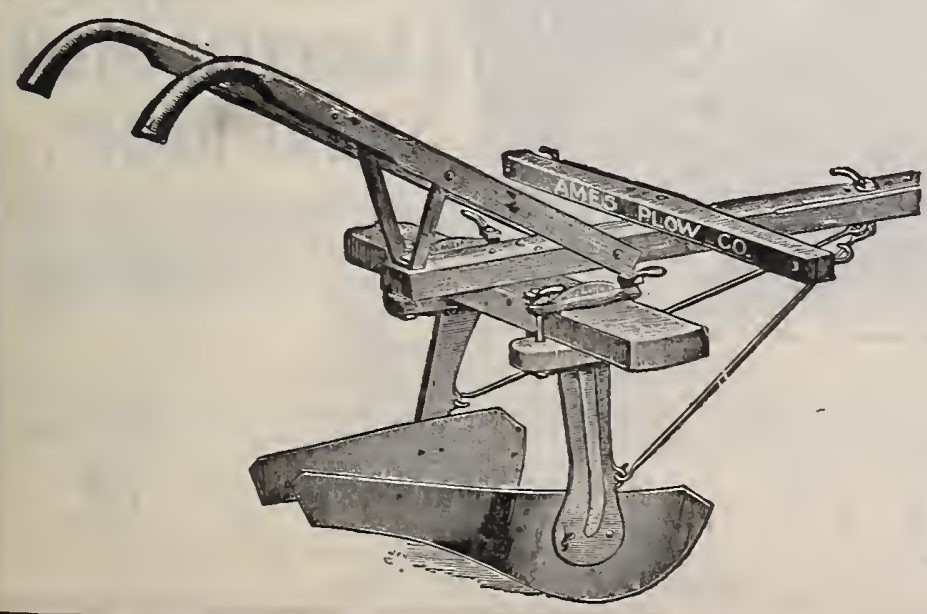

NO. 9 HORSE HOE AND CULTIVATOR.

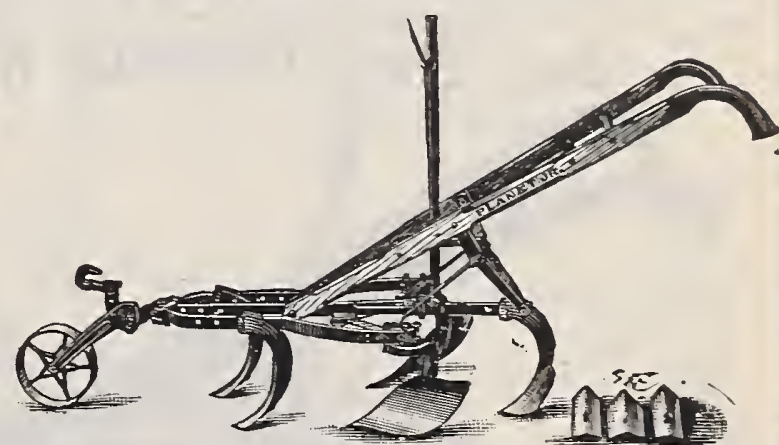

This admirable tool is identical with the No. 8 , ex cept that it has a plain instead of a lever wheel. It has the high frame, patented hollow steel standards, patent lever Star wheel, new lever expander, and new ollow steel wheel arms.

List price, $\$ 7.40$. Discount for cash, 50 cents.

NO. 4 HORSE SHOE AND CULTIVATOR.

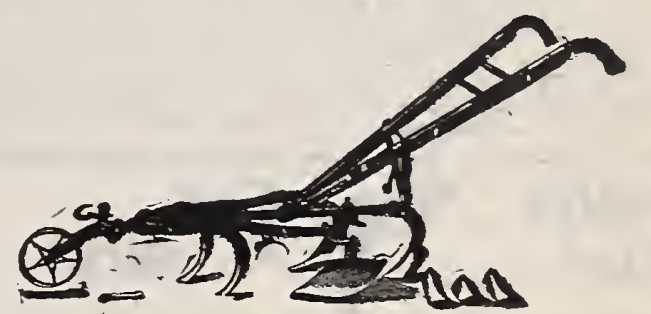

This tool is low in price, strong and simple; it hae the old favorite stirrup clamp and plain expanders: they cost a trifle less than the lever, but are less con venient. List price, $\$ 6.35$. Tiscount for cash, 50 .

PLANET JR. IRISH POTATO DIGGER.

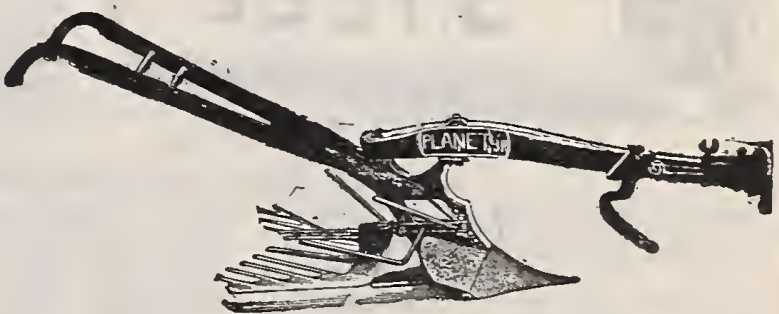

The Planet Jr. Double Moldboard Potato Digger is Cheapest and best twohorse hoe on the market.

Can be used for furrowing out, covering and hilling up. Frame is made of oak, hillers of polished steel. Price $\$ 10.00$. Discount for cash, $\$ 1.00$.

की की की or shakers; the draught is light, and there is nothing to wear out but the shares, and they and the moldboards are hardened steel. The action is that of raising, dividing and turning the row on edge, and then separating the potatoes from the earth by means of steel fingers and lifting them to the surface. The vine

The Planet Jr. Single Moldboard Potato Digger is constructed exactly like the above, except it throws but one way. The double leares the ground has the advantage of leaving the potatoes less scattered.

List price, $\$ 16.00$. Discount for cash, 50 cents. are green, and is of great assistance in weedy patches. 


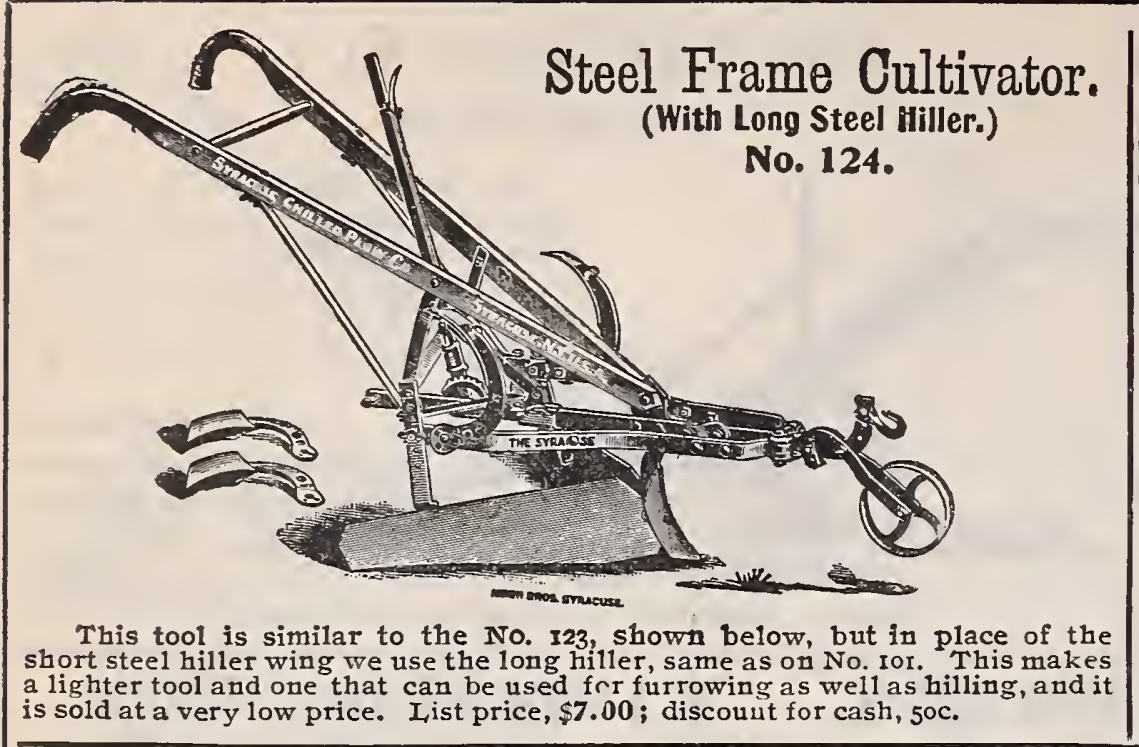

\section{Planet Jr. Horse Hoe No. 5.}

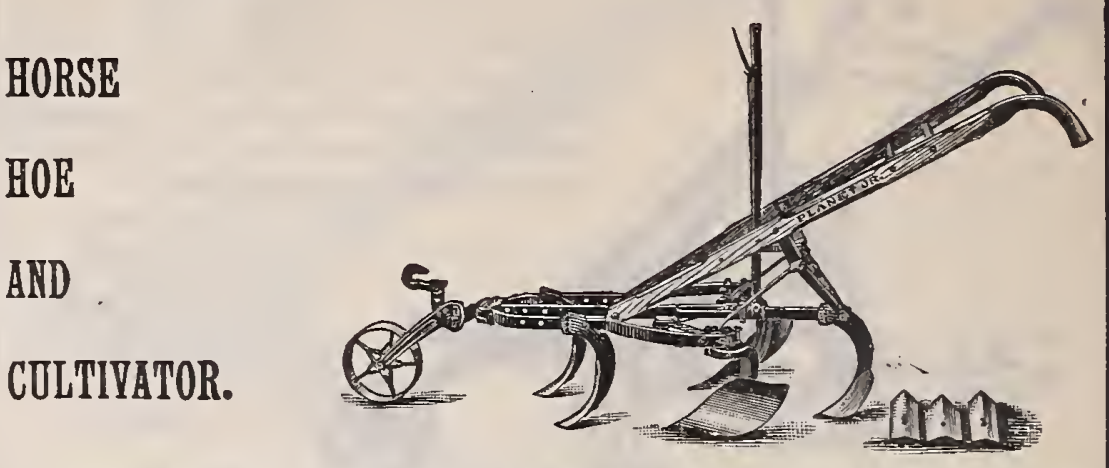

This is similar to No. 9, without the handle brace, and has a cheaper, but good substantial adjusting lever, and is sold at a popular price and is superior
to many that have sold for seven and eight dollars. List price, $\$ 6.50$; dis. to many that have
count for cash, 50 .

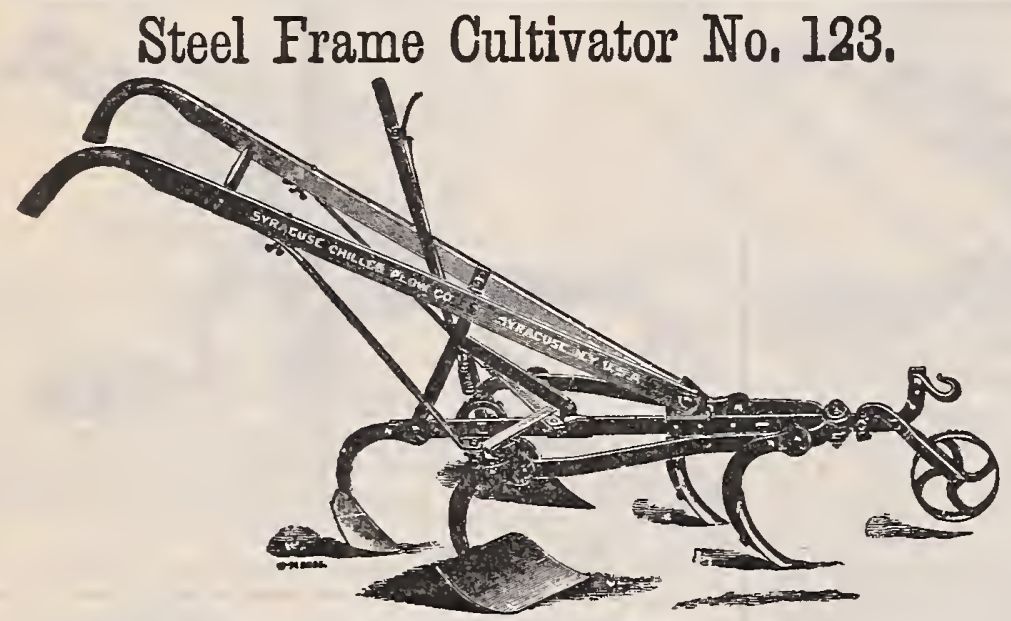

This series of Cultivators meets the demand for a good cultivator at a low price. The points and standards are of the same stock as used in No. ror, but the frame is some what shorter and a trifle lighter. The standards are adjustabie for pitch. The handles can be raised or lowered, or shifted to the right or left.
No. I23 (as shown in cut)-Expanding I,ever, five 3 -inch Points, Wing Points, Shovel Point and Wheel. List price, $\$ 6.00$; discount for cash, $50 \mathrm{cc}$.

No. 121.-Same as above less the horse hoe attachment, 50c. less.

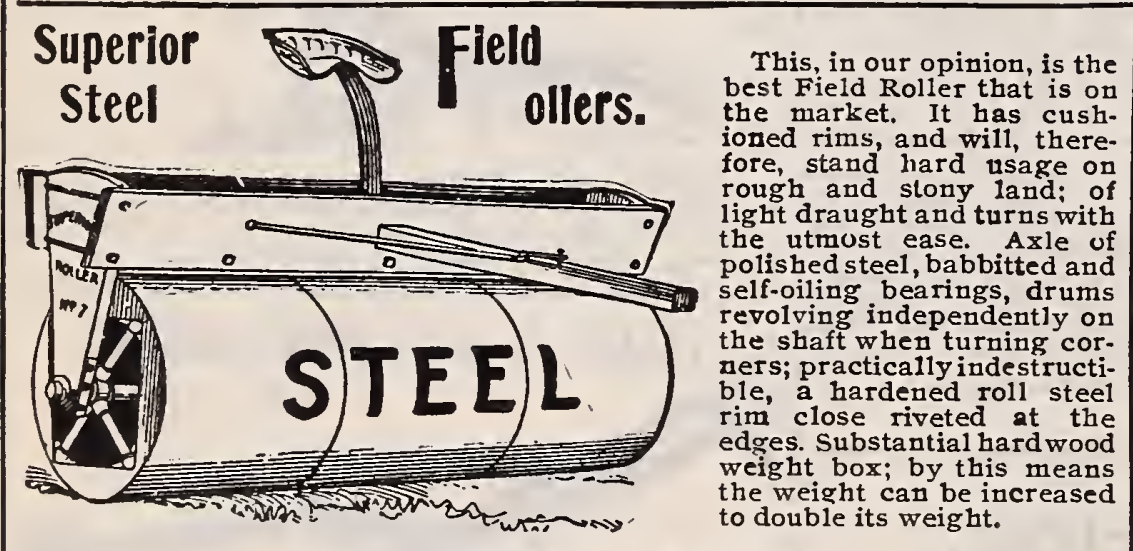
LIST OF SIZES AND WEIGHTS.

\begin{tabular}{|c|c|c|c|c|c|}
\hline & Number. & Length. & Diameter. & Av. Weight. & Price. \\
\hline $\begin{array}{l}3 . \\
7 . \\
4 .\end{array}$ & $\begin{array}{c}\text { Plain Roller. } \\
\text { “" }\end{array}$ & $\begin{array}{l}6 \text { feet. } \\
7 \begin{array}{c}7 \\
8\end{array}\end{array}$ & $\begin{array}{l}24 \text { inches. } \\
24 \\
24\end{array}$ & $\begin{array}{l}550 \text { pounds. } \\
650 \\
750\end{array}$ & $\begin{array}{r}\$ 27.00 \\
29.00 \\
31.00\end{array}$ \\
\hline
\end{tabular}

THE STANDARD FIELD ROLLER, $\begin{gathered}\text { Steel Drum, Steel Angle } \\ \text { BarWeight Boxes. }\end{gathered}$ This Roller has the same steel drum as the Superior, the only difference being in the frame and drum head, the latter is made of cast iron, the former of angle steel.

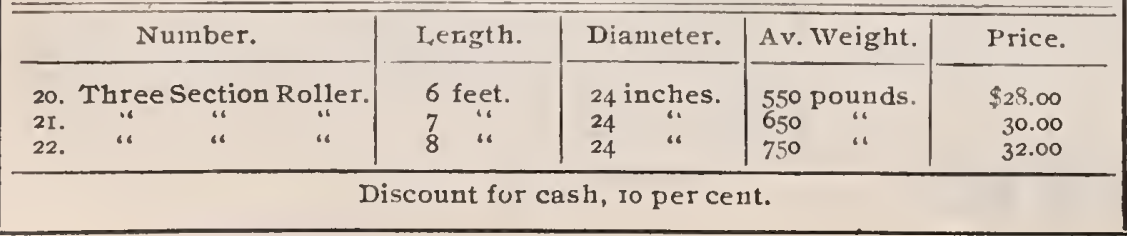

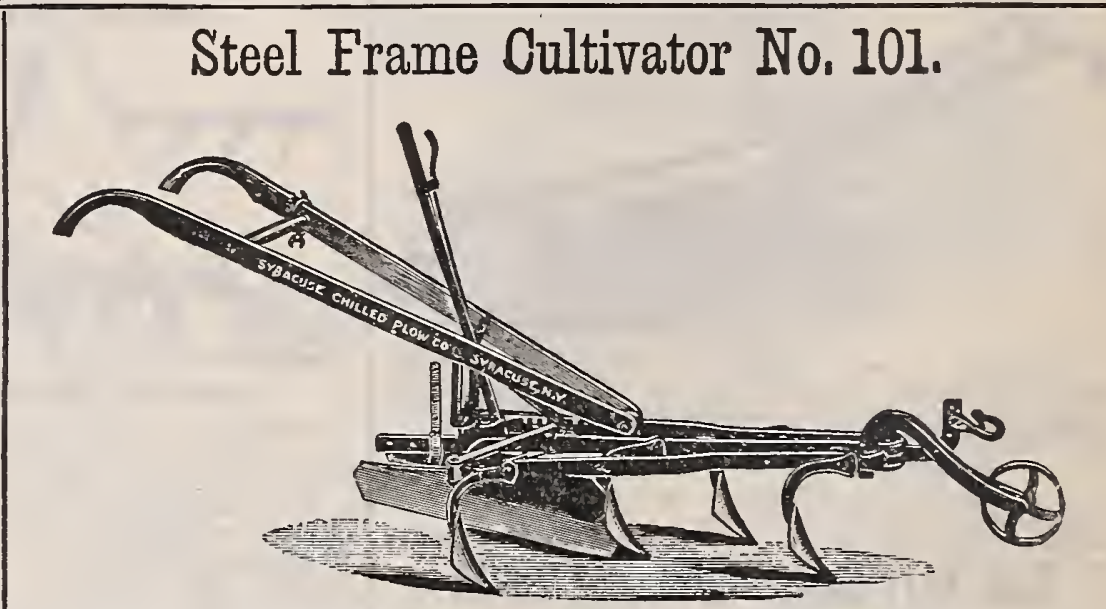

This cultivator is simple, strong and easy to operate. Has no "Dead Centers," and no Loose Joints. The frame and standards of these cultivators are very strong; made of solid steel; the side bars are so curved as to make the teeth run parallel, and also to make all standards interchangeable; square bolt-holes prevent any bother from bolts turning around, and all parts are made with accuracy and nicety of finish. It can be changed to use as a plow, cultivator, horse hoe, coverer and furrowing plow; no extra parts other than those shown in the cut required. Iist price, $\$ 8.00 ;$ discount for cash, $50 c$.

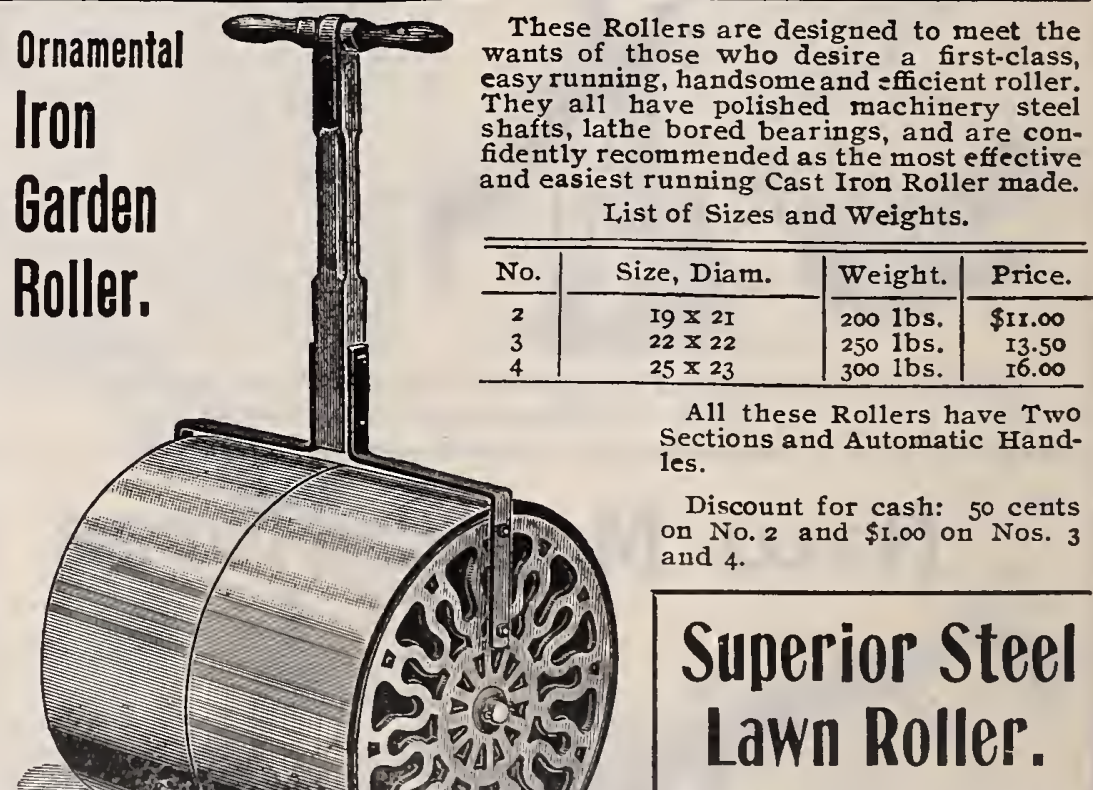

For Latge Lawns, Parks and Golf Links. Fitted with shafts for one horse. Same design as the Superior Field
Roller. HTS.

\begin{tabular}{|c|c|c|c|c|}
\hline Number. & I,ength. & Diameter. & Av. Weight. & Price. \\
\hline $\begin{array}{l}2 \mathrm{~L} . \\
0 \mathrm{I}_{4} \\
3 \mathrm{~L} .\end{array}$ & $\begin{array}{ll}4 & \text { feet. } \\
5 & \text { ". } \\
6 & \end{array}$ & $\begin{array}{l}24 \text { inches. } \\
24 \\
24\end{array}$ & $\begin{array}{l}400 \text { pounds. } \\
550 \\
600\end{array}$ & $\begin{array}{r}\$ 23.00 \\
28.00 \\
31.00\end{array}$ \\
\hline
\end{tabular}




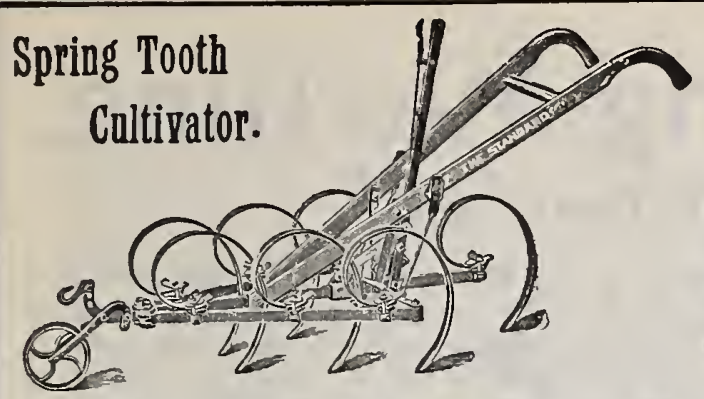

This Cultivator is especially adapted for use in stony ground, The frames are steel, strong, and well put together throughout. The castings are malleable. The teetli are fine oil-tempered springs, and are alike and interchangeable; they are also adjustable for angle and depth. The adjusting levers are of the same form and construction as those used in No. IOI Cultivator.

Expanding Lever, Five Spring Teeth and wheel. List price, $\$ 6.50 ;$ discount for cash, 5o cents.

The Fire-Fly Five-Tooth Cultivator.

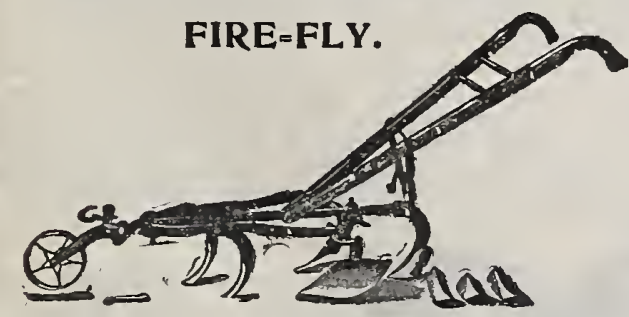

This is a new model 5 -tooth Cultivator and Horse Hoe, with solid frame, stiff handles, adjustable in height, open frame, hollow steel standards. No expanders or hinge. Outside width of frame 18 inches.

List price as shown in cut, $\$ 5.00$.

Discount for cash, 50 cents.

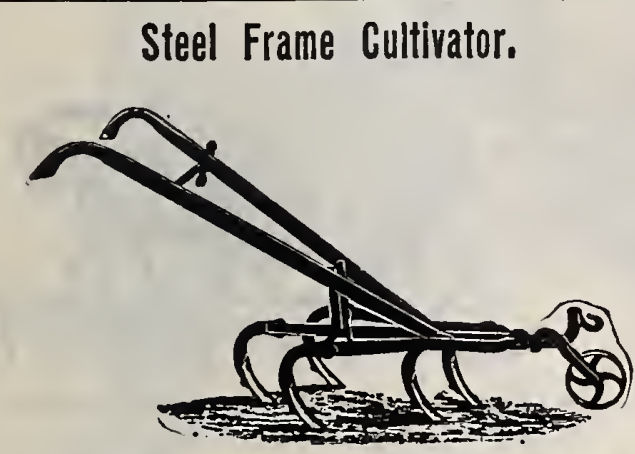

This is a good, well made Cultivator, with steel standards, steel frame and points. Furnished with wheel only.

List price, $\$ 4.50$.

Discount for cash, 50 cents.
Whitman's Hercules Baling Press.

Highest Awards at World's Fair, Chicago, and in Every Other Contest.

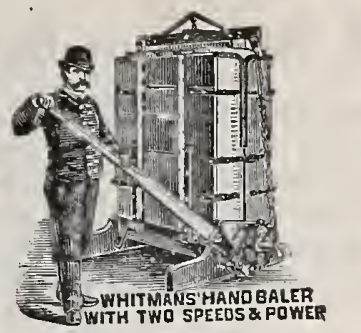

HAND POWER. - For Hay, Straw, Wool, Broom Corn, Pea Vines, Cotton, Rags, Paper, Hair, Moss and Materials requiring Baling.

We guarante this Press to the more rapid and powerful baler of its size in use.

Retail Price List on Car or Boat at St. Louis.

List Price

No. I. Bales $42 \times 18 \times 20$ in........................ \$ 95.00 No. 2. Bales $44 \times 24 \times 22$ in...................... I00.co No. 4. Bales $60 \times 26 \times 24$ in...................... 110.00 Send for Circulars of Power Press.

Keystone Adjustable Weeder.

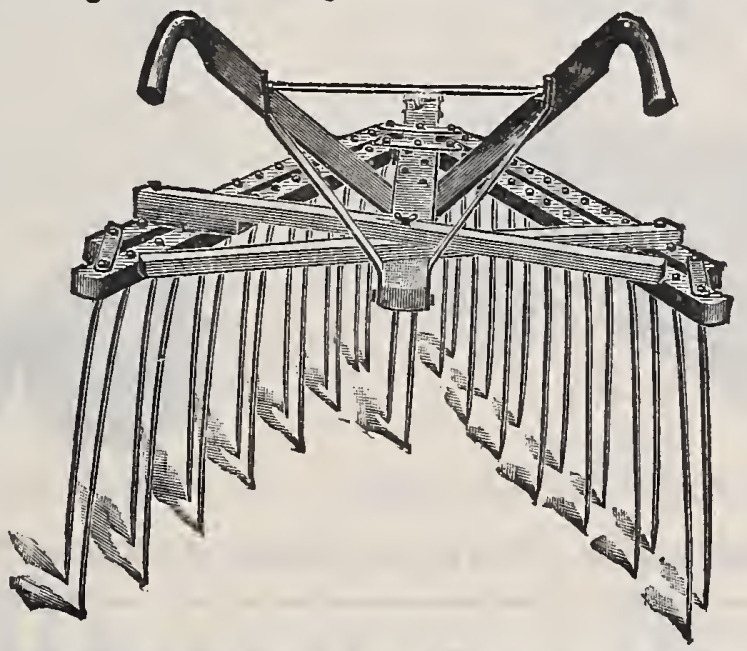

We Guarantee this to be the Best Weeder in the world or Money Refunded. Can expand to $7 / 2$ feet. Can narrow to 30 inches.

"A stitch in time saves nine." Nowhere does this adage apply more surely than in the early and frequent use of the KEYSTONE WEEDER.

the subject of frequent and shat Hove you consider low cultivation? A re culture is endorsed ay the most prominent authorities of ariculture, and has surely come to stay and hallow cultivation has been demonstrated to be a sucable to any depth and width. It can be used as a shallow able to any depth and cultivator working close to the plants between the rows, intil the crops mature-lon arter other weeders are laid aside. It has no shafts that will hinder working close to the fence and prevent turning at the ends. IT WILL Nor CLOG. The long, curved, spring teeth are so placed and shaped that clogging is impossible. It is $V$ shaped, which not only makes it a stronger tool than the straight framed Weeders, but adapts itself much better to uneven surfaces. It keeps the surface fined, to admit the air, and breaks the crust, thereby creating a mulch that absorbs the moisture and retards evaporation. Iist price $\$ 10.00$; discount for cash, $\$ 1.00$.
Spike Tooth Cultivator and Harrow.

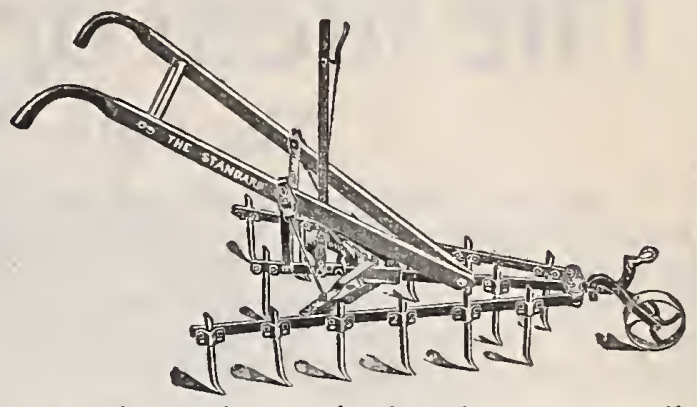

Designed for cultivating between small fruits. Especially adapted to pulverize the soil reversible and the pitch can be quickly changed forward or back by simply loosening one bolt at each tooth. Has is teeth, adjusting lever, and wheel. Iist price, $\$ 6.00$; discount for cash, 50 cents.

\section{SHERWOOD}

\section{STEEL}

HARNESS.

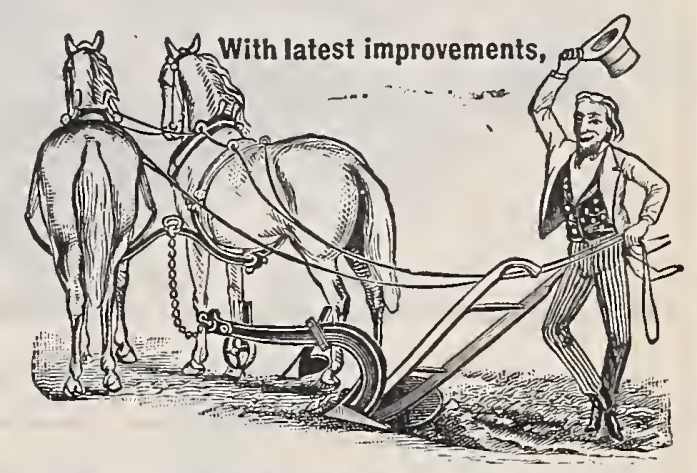

This Harness requires no whiffletrees, no long tugs ; nothing in the way around the horses' heels; nothing to bark the trees; team works better and easier ; less work for man and team. Can be used on plow, scraper or wagon.

List price, $\$ 15.00$.

Discount for cash, $\$ 3.00$.

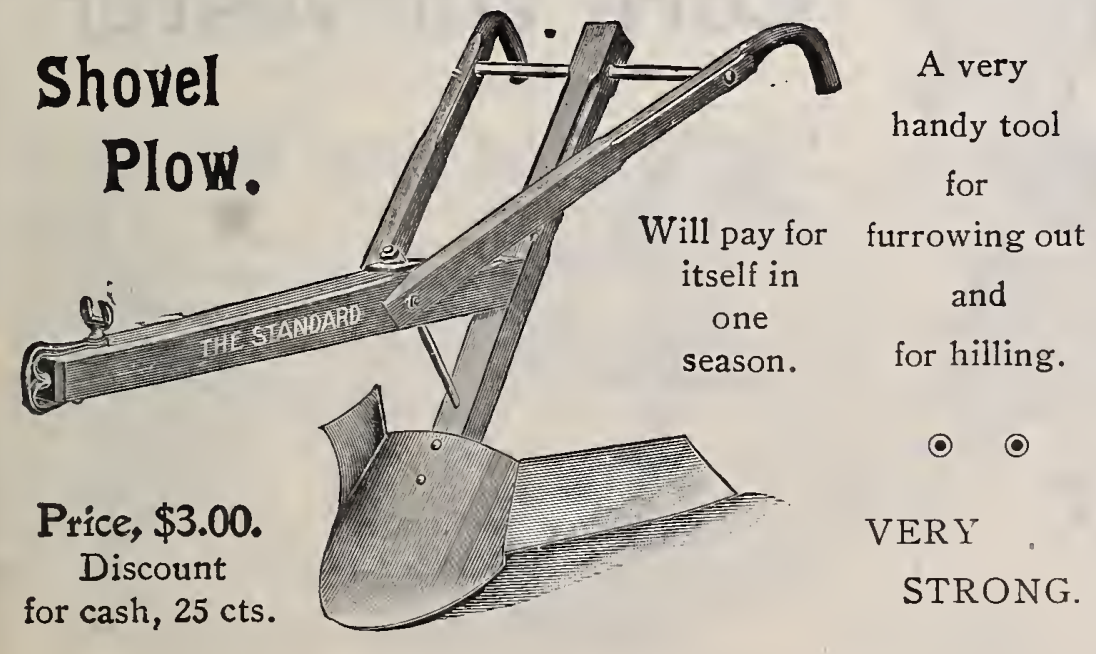

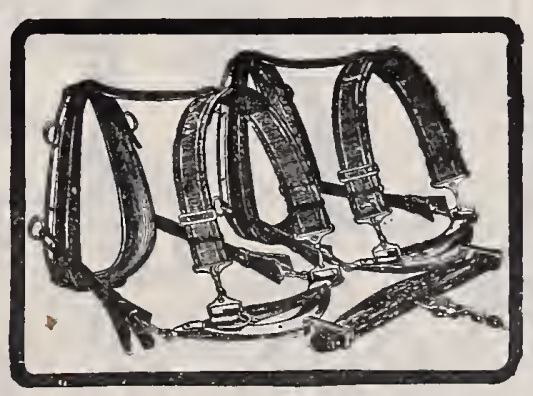

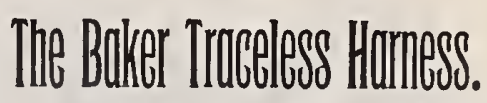

A positive necessity for fruit growers. This harness is particularly adapted for plowing, harrowing, use on scraper, stone boat, etc. It is easy to put on and take off. Each horse is harnessed separately and each is independent of the other. It will pay for itself in one season in orchard work.

Price, with chain, $\$ 15.00$.

This price does not inc'ude Collar or Bridle. 


\section{The Ideal or Bicycle Mowing Machine.}

The Only Machine Made that Runs on Ball Bearings.

This machine runs on ball and roller bearings, the same as the most approved bicycles, and has the same relation to the ordinary mowing machine as the bicycle does to the old velocipede, and we defy anyone to show us one good reason for buying any other machine on account of looks, material, principle or workmanship. The mammoth works of the Deering Harvesting Co., are among the largest in the world, covering 65 acres of ground and employing over 6000 hands, not including the thousands of agents which represent them in all parts of the world. The capacity of these works is one complete machine and thirty miles of twine every minute. It costs money to equip these machines with such bearings, but we are able to offer them at but a few dollars advance above the old style machines.

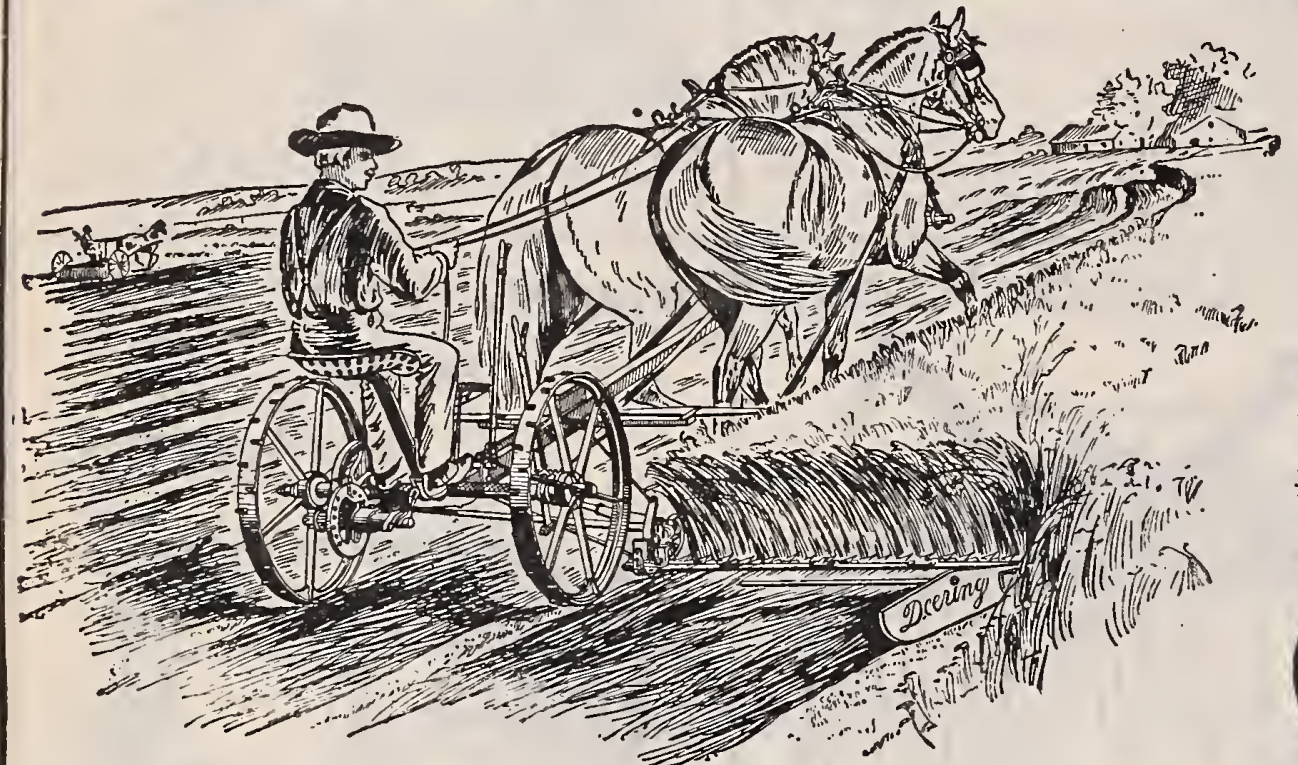

One-Horse, $31=2$ and $4 \mathrm{ft}$. Cutter Bar. Two-Horse, 4 1-2 and $5 \mathrm{ft}$. Cutter Bar. Giant 6 and $7 \mathrm{ft}$. Cutter Bar. All with Ball Bearings.

Price, $4 \frac{1}{2}$ Foot Cutter-Bar, ........\$40.00. Price, 5 Foot Cutter-Bar,.......\$40.00 Price. 6 Foot Cutter-Bar, Giant,...... \$45.00 We carry over 3,000 Dollars Worth of Repairs for these Machines in Stock.

\section{Deering Ideal One-Horse Mower, 32 and 4 Foot Cut.}

The Deering One-Horse Mower is used to cut the finest lawns in Lincoln Park, Chicago.
cretary Bryan of the Board of Commissioners says: "I consider it a perfectly reliable, trustworthy machine.

Many of our best farmers buy two of these oue-horse 4 foot cut machines and thus with one pair of horses cut 8 feet instead of $4 \frac{1}{2}$ or 5 feet with one two horse machine.

Price, $3 \frac{1}{2}$ Foot Cutter Bar,......\$36.00. Price, 4 Foot Cutter Bar,.......\$37.00.

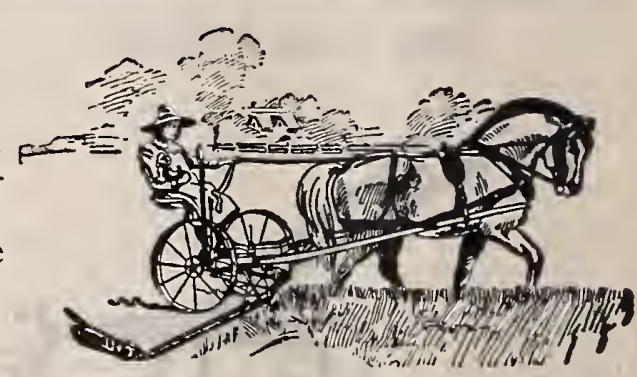

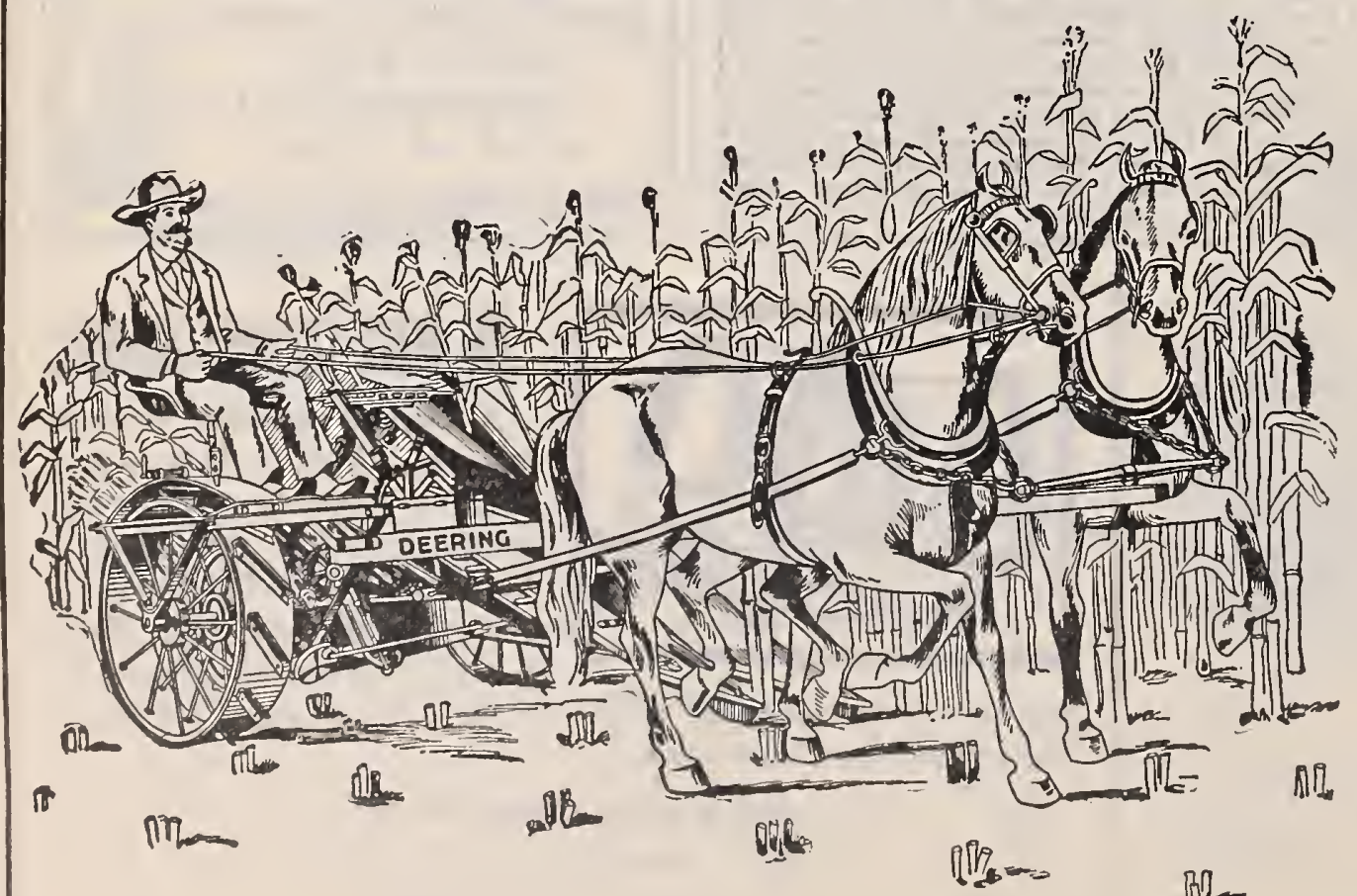

Rn.

\section{Deering Ball=Bearing Corn Harvester.}

Declared by the best informed authorities to be the Only Successful Corn Harvester before the American people. Made on the right principle. The Deering plan of permitting the corn to fall backward on a low horizontal binder deck is superior in every way to the method of holding the top-heavy stalks upright. Lightest in draft, makes a better bundle, and does not break off nearly as many ears as are broken by the vertical machines.

To any farmer who has more than a medium acreage of corn and has any use at all for his fodder, a good corn harvester and binder is a necessity.

Send for handsome illustrated catalogue.

PRICE,

$\$ 125.00$ 
THE MONARCH STEEL HAY TEDDER with Center Chain Drive.

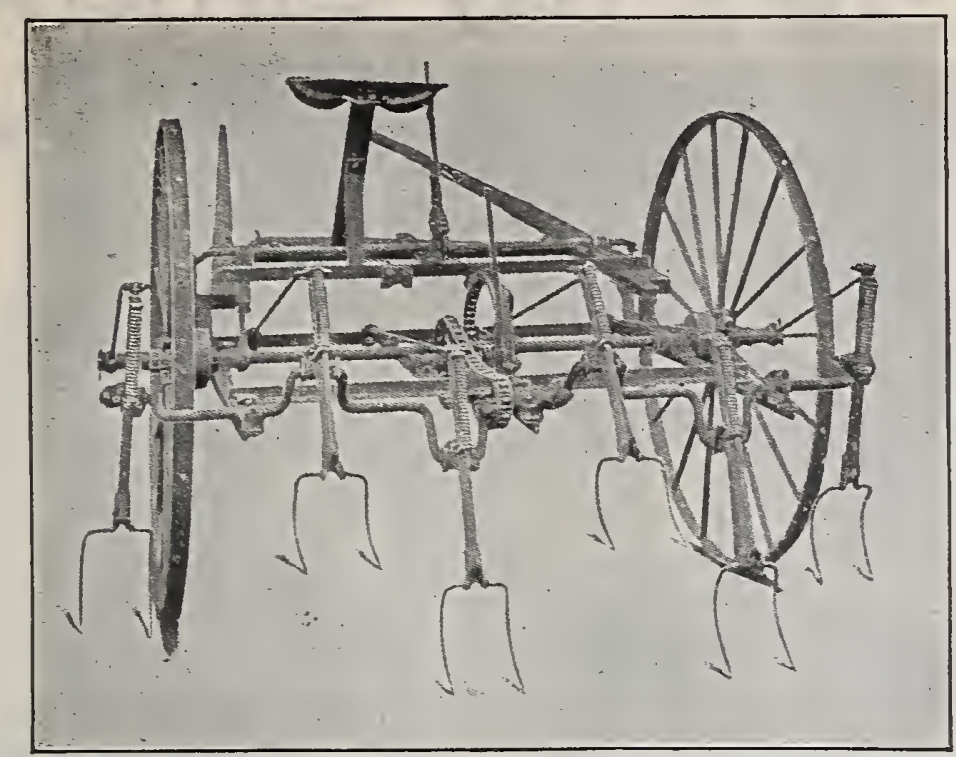

The Monarch Steel Hay Tedder shown abore is the latest thing out for a Chain Driven Tedder. It is made of first-class steel by shilled workment. The Wheels are extra heavy channel tire with staggered steel spokes. The Frame is made of continuous steel angle bars in one solid piece, no spliced corners, no bolts, or rivets to get loose. It has great strength at all points. The Crank Shaft is made of the very best tool steel with turned bearings, and hroad journal boxes. The Fork Arms are made of boiler tube, and relief coil crucible steel spring is provided for each tooth. It has a double seat support and separate levers for throwing in and out of gear and for raising and lowe ring the teeth, to be used with one or two horses. Price, $\$ 32.00$. Discount for cash, $\$ 2.00$.

THE BAY STATE WOOD FRAME HAY TEDOER.
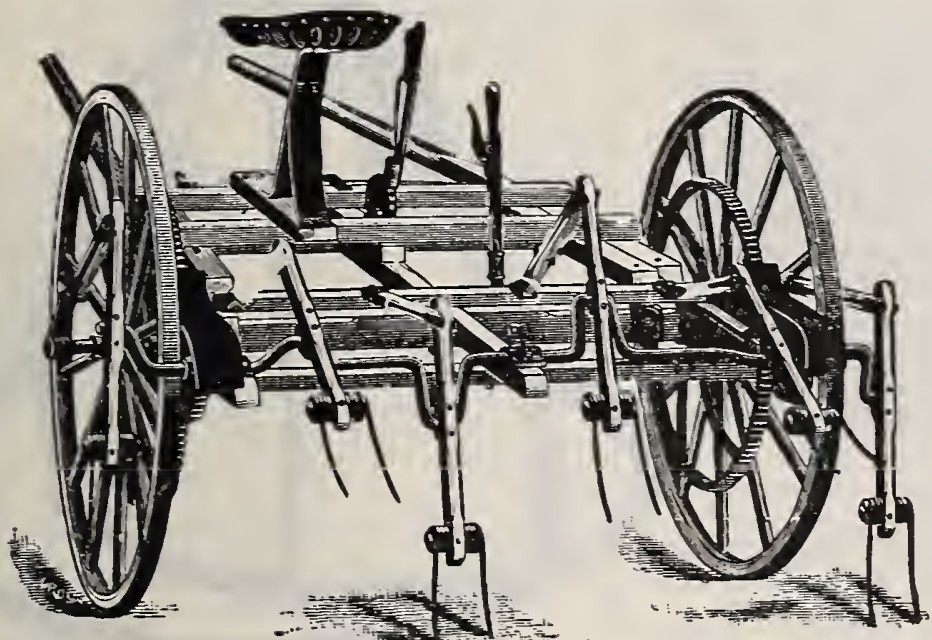

The Bay State Wood Tedder, shown above is, in construction, similar to the Bay State Steel Frame, only wood is used in place of steel. On stony ground, we would recommend this tedder as we believe the frood wheel will wear longer than the steel. The Forks of this tedder are made of crucible steel and the Fork Arms are made of the best hard wood. It has two levers the same as the steel frame. Also has combined pole and shafts, so it can be used for one or two horses. It is the best wood hay tedder there is on the market, and we
do not see how we could jmprove on it, if we charged double the price. We can furnish this tedder with six and eignt forks.

Price, 6 Fork, $\$ 28.00$. 8 Fork, $\$ 30.00$. Discount for cash, \$2.00.

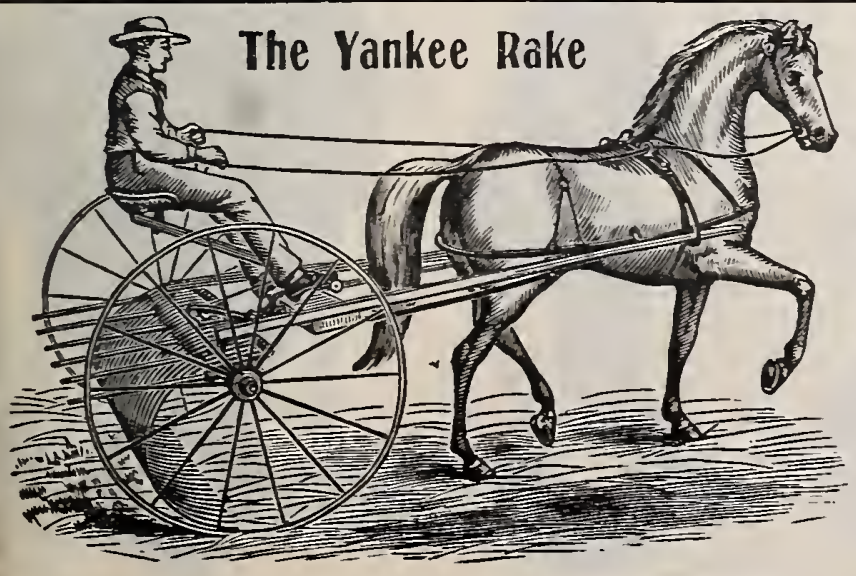

This is the old reliable Yankee, introduction. It is a very eas y rake to operate, each tooth being independent; it 1arge stones without brealing the teeth. It is so easy to operate that a chile it.

List price,

$\$ 22.00$.

Discount for
The Bay State Steel Frame Hay Tedder.

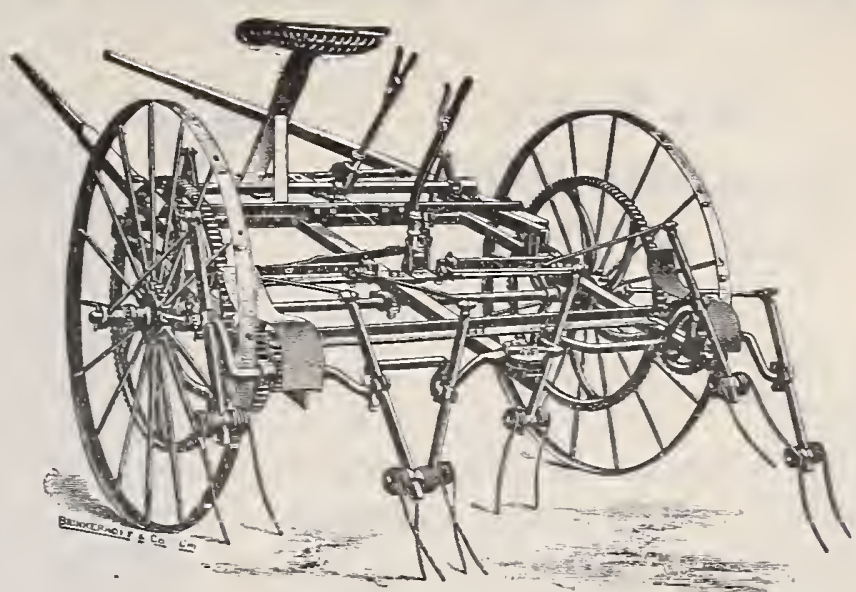

This is the neatest, finest and most substantially mounted steel frame hay tedder on the market. It is mounted upon a substantial steel wheel with a solid steel axle extending from wheel to wheel. It is made of angle steel in one solid piece, no spliced corners, no bolts, or rivets to get loose. The center is built on T steel which gires it great strength in every direction. The Crank Shaft is made of the very best steel with combined bands, also has broad boxes. The Forks and Fork Arms are made of crucible spring steel, it is a1so provided with a very comfortable spring seat; levers for raising and lowering, throwing in and out of gear and are in easy reach of the driver. It has a combined pole and shafts so that it can be used with either one or two horses and the change can be made very quickly. It has.six forks.

Price, $\$ 30.00$. Discount for cash, $\$ 2.00$.

\section{THE TIGER RAKE.}
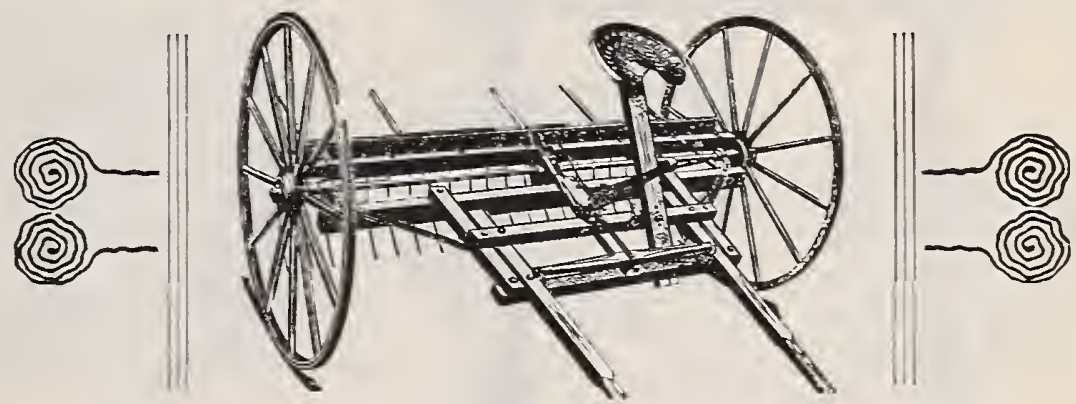

This rake has been sold in New England for the past fifteen years, and has given the best satisfaction probably of any rake on the market. It has a steel axle running the entire length of the rake, and the material used is of large enough to drive a horse, and without doubt the most durable rake ever put on the market. I,ist price, $\$ 22.00$. Discount for cash, $\$ 2.00$.

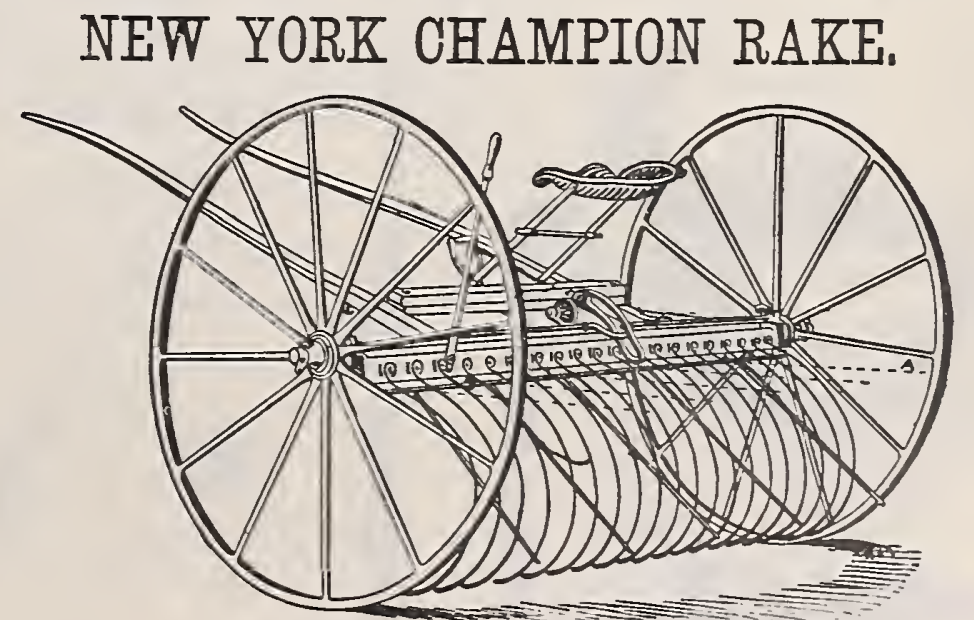

It is impossible to find a11 the guod poists in any one tool, but this rake will properly rake green hay and aftermath better than any other rake. It has the sled runner tooth, is a self-dumping rake, and is easily operated by an Be sure and get the GENuINe. Irist price, $\$ 20.00$. Discount for cash, $\$ 1 . \infty$. 


\section{Myers Reversible Steel Track Hay Carriers.}

\section{No Barn \\ Is Complete Without One of These Rigs.}

The Myers Carriers for rod, wood, or steel track are the most durable and easiest rigs to operate of any on the market. Any one with a hammer and wrench can rig his barn as well as an expert carpenter. We furnish everything necessary for rigging any style of barn. If you will send us the length and height of your barn and style of ridge pole, will name you price for complete job.
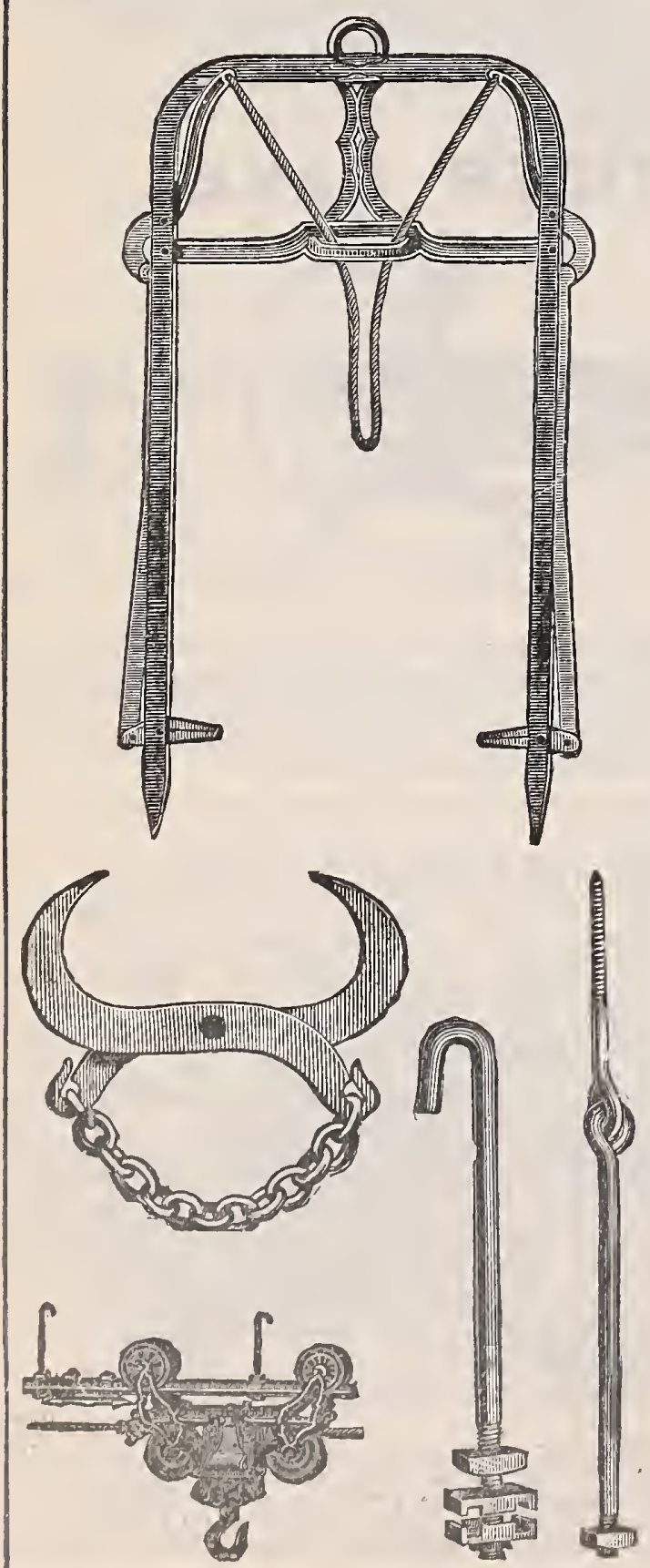

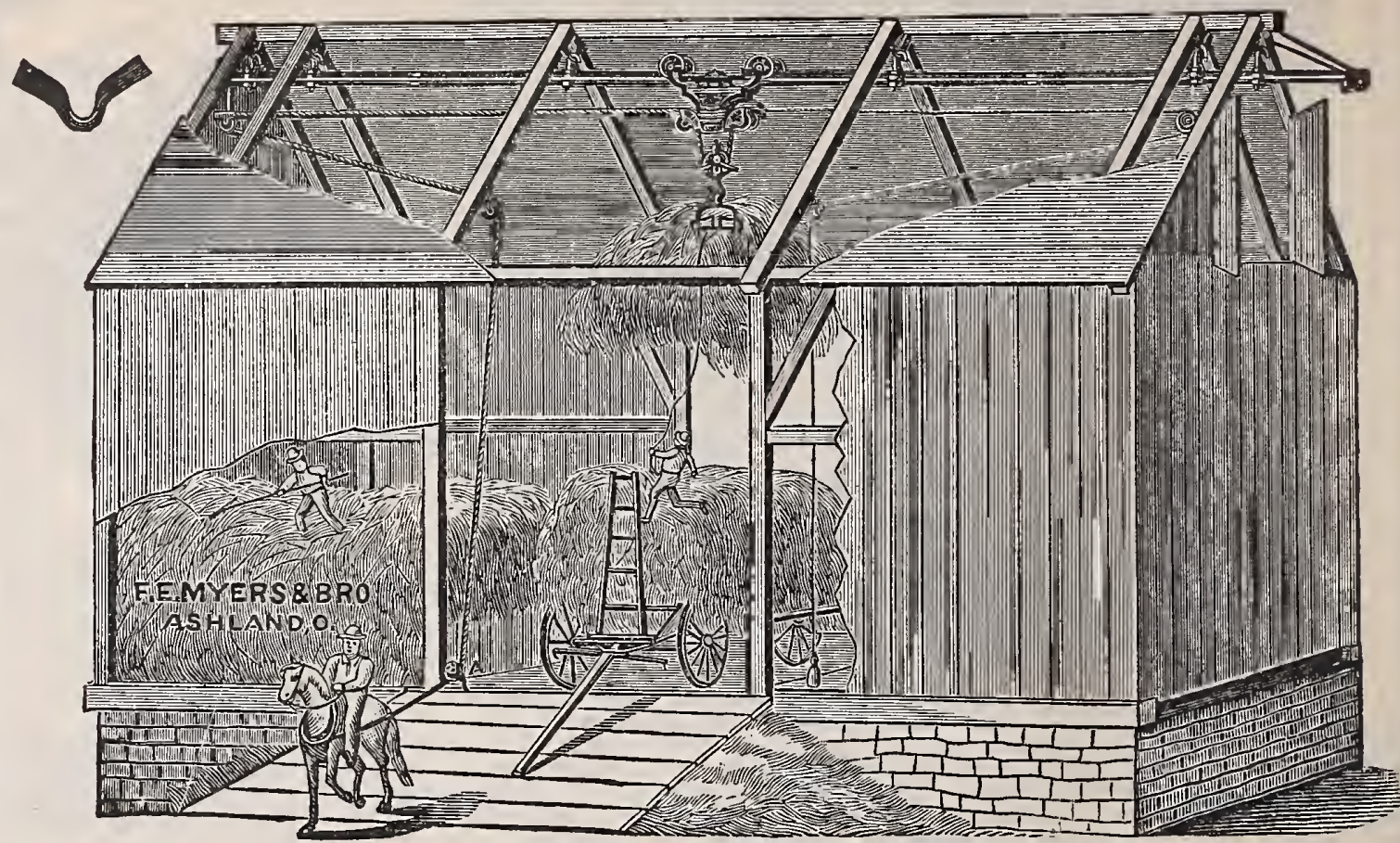

\section{PRICES.}

Reversible Carrier, each, - _ $\quad$ - $\$ 5.00$

One Way Carrier, each, _ $\quad$ - $\quad$ - 4.50

Wood Track Carrier, each, - - $\quad$ - 4.50

Steel Track, per foot, $-\quad$ - $\quad$ - $\quad$ - .13

Steel Hanger Hooks, per dozen, - 1.00

Malleable Iron Rafter Brackets, per doz., $\quad .50$

Jointed Hanger Hooks, per dozen - 1.25

Four Tine Grapple Forks, each,- _ $\quad 4.00$

Six Tine Grapple Forks, each, _ $\quad$ - 5.00

Double Harpoon Forks, each, - $\quad 1.00$

Knot Passing Pulleys, each, - $\quad$ - $\quad .25$

Common Pulleys, each, _ _ $\quad$ _ $\quad .20$

Rope Hitch, each, - $\quad$ - $\quad$ - $\quad$ - $\quad .25$

Floor Hooks, each, - $\quad$ - $\quad$ - $\quad$ - $\quad .10$

Steel Grapple, each, - $\quad$ - $\quad$ - $\quad$ - $\quad .50$

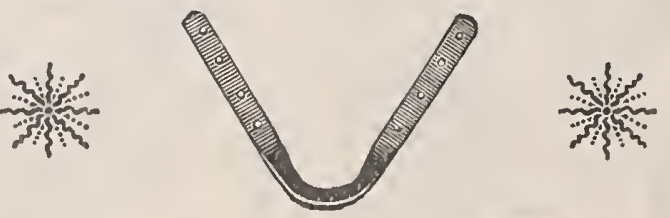

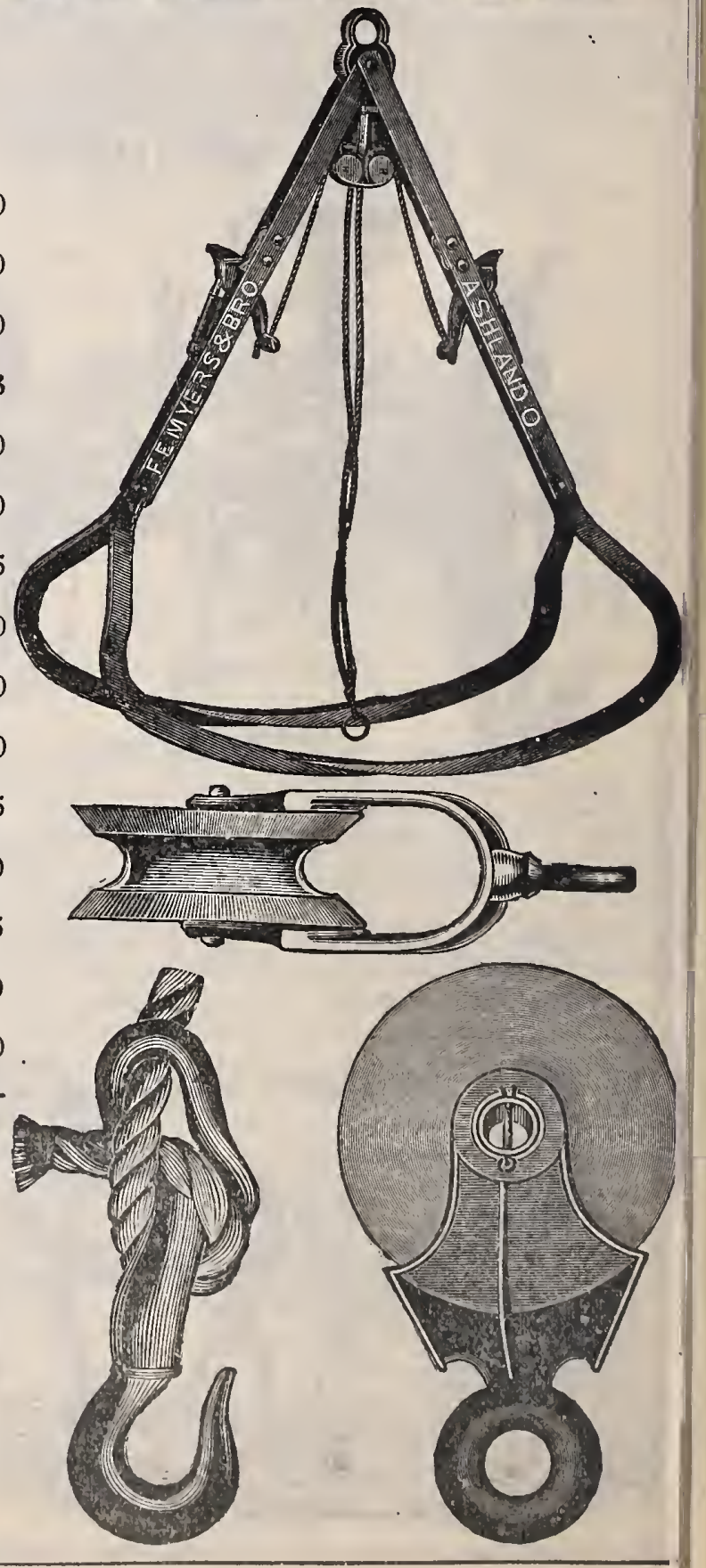


The De Laval "Baby" Gream Separator and other Dairy Goods. The purpose of the Cream Separator is the expeditious and complete Used by all the Leading Agricultural Colleges and Experiment Stations. separation of cream from milk in the most practical manner possible. within and mounted upon a frame provided with a suitable gearing to acquire a high speed with a minimum expenditure of operating power. The whole-milk is fed into this bowl. the separation effected within it, and the cream and skim-nilk are separately discharged from it, the discharge following within half a minute after the

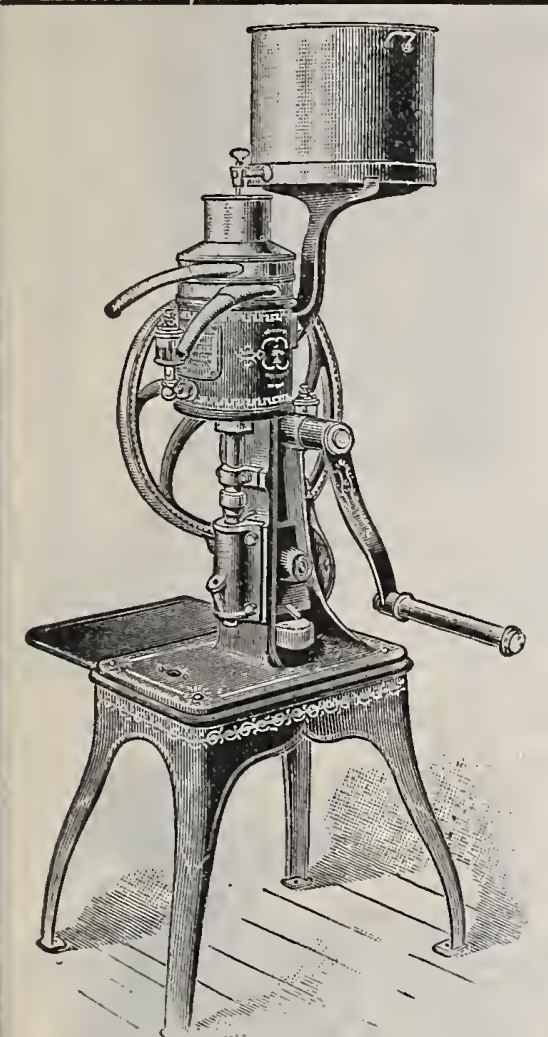

Improved "Baby" No. 1. Iron Stool Style.

De Laval Cream Separator. Capacity, 325 to 350 lbs. per hour.

"Alpha" or "Disc", Bowl

Type.

Price, $\$ 100.00$

Crank Humming Bird.

New Style No. 0.

De Laval Cream Separator.

Capacity, 225 lbs per hour.

Type.

Price, $\$ 65.00$

Improved "Baby" No. 2.

High-Frame Style.

De Laval Cream Separator.

Capacity, 450 to 500 lbs. per hour.

"Alpha" or "Disc" Bowl

We can furnish either style of

We can furnish either style of
tool on Nos. $x$ and 2 . Send for large catalogue.
The R. B. or Round Bottom Milk Bottle.

This Bottle is a great improvement over any other style of bottle made, from the fact that it has no corner for the dirt to stick in. The bottom inside being made round, it cleans very easily. We have them made expressly for us, and every bottle is extra quality glass, and stamped on the side "This bottle to be washed and returned.'

Every bottle has "R. B." on the side, which is a guarantee that it is the best bottle made.

\section{PRICES :}

Two Quart, per doz. $\$ 1.50$; per gross, $\$ 16.00$

One “ “" .75;

Pint,

.60

8.00

One-half Pint, "

50

7.00

5.00

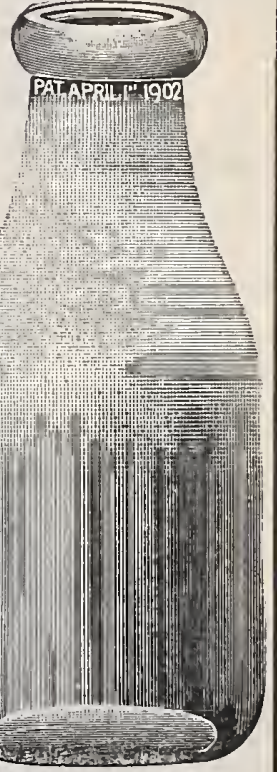

The Health Miik Bottle Caps.

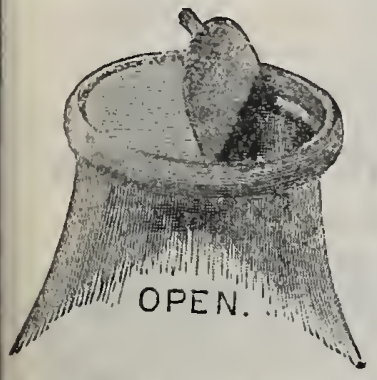
sharp instrument.
All caps, other than the Ilealth Cap must be removed with a fork, knife or som moved cannot be reand finger. When released the old-style cap is a iniost invaria. bly thrown a way, leaving the contents of the bo tle exposed to odors. and in no way meetin and in no way meeting tures of an open receptacle. It costs no more than the ordinary cap. It will fit any standard nilk bottle. It makes sealing and onening of bottles easy. Bott'es can he kept sealed at all times. Keeps mill free from all odors. It is the wost convenient cap on the market.

No knife or fork is needed to remove the Health Cap. Price per 1000, 40 cents; 5000, 35 cents $25,000,33$ cents.

Common Round Caps, 1000, 30 cents ; 5000, 25 cents. 7

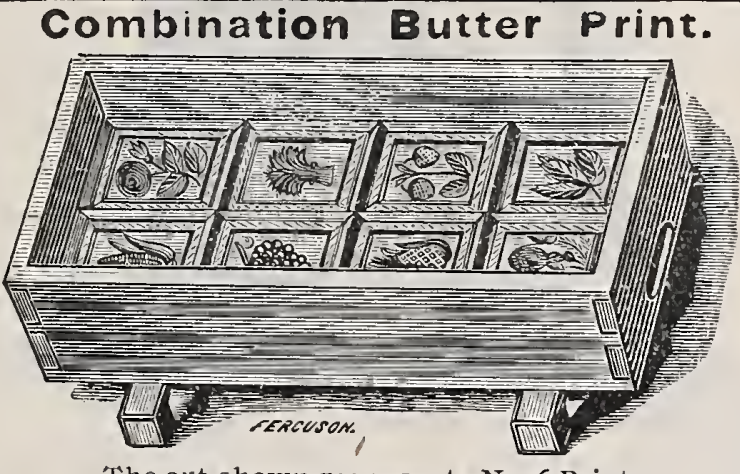

The cut shown represents No. 6 Print. No. of ('apacity Capacity Uimen- DimenCakes at of Dlou!ds of each pression. Pounds, Cake in

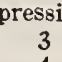

sions of Mould in
inches io $x_{3} 1 / 2$ II $\times 33 / 4 \quad 33 / 4 \times 23$ I2 $x_{3}$ $4 \frac{1}{2} \times$ $10 \times 21 / 2$ $\operatorname{Iox} 3 \frac{1 / 2}{10}$

$3 \frac{1}{2 \times 13 / 4}$

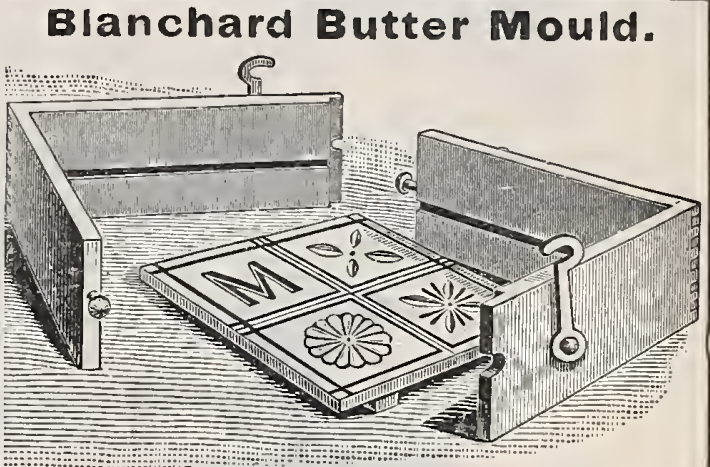

Same size as No. 4 Combination. Initial engraved 25 cents extra.

PRICES :

One-half $1 \mathrm{~b} \ldots \ldots \ldots \ldots \ldots \ldots \ldots \$ . \mathrm{s}_{0}$

1.00

1.25

\section{THE STODDARD CHURN.}

The Stoddard churn is miade by hand in the most thorough manner and of kiln-dried white oak It will last for years. The principle is concussion, not friction-has no float nor paddle inside. It is easily operated, easily cleaned.

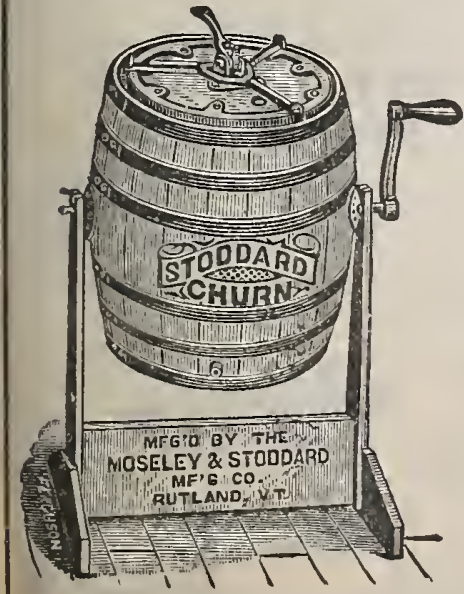

The Hero Barrel Churn.

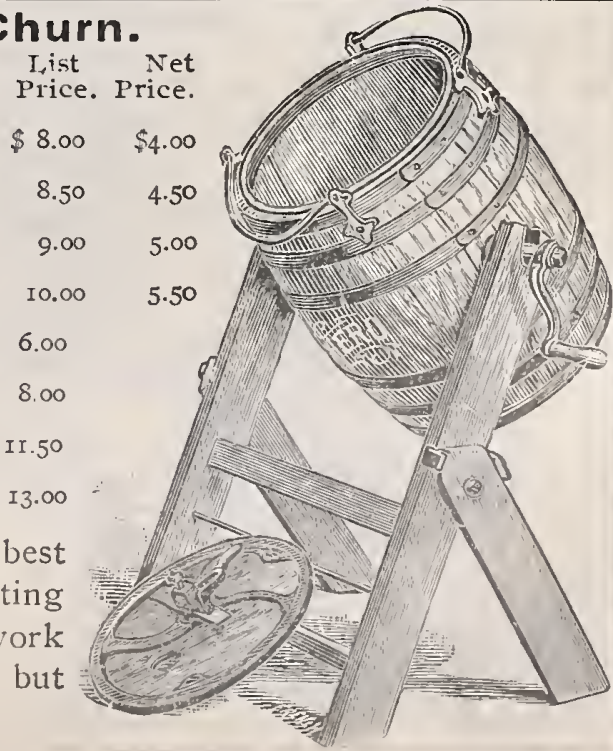




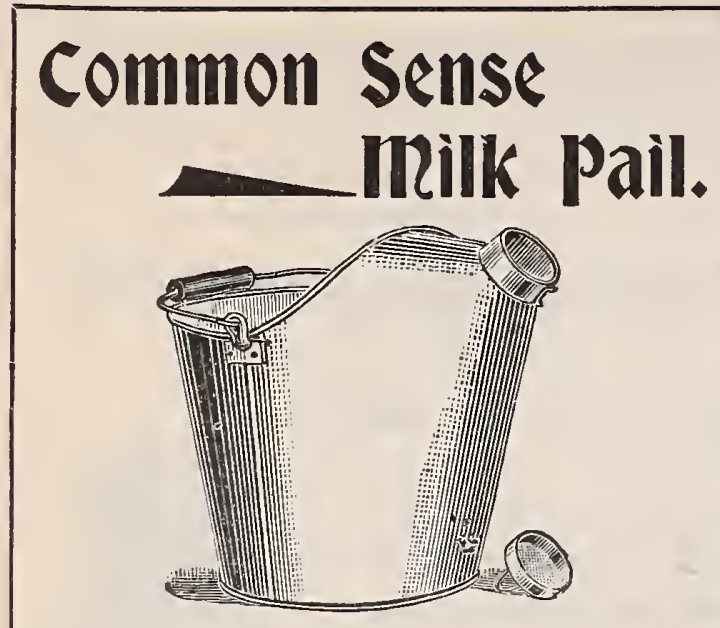

This pail is made of extra heavy tin. The strainer can be removed to clean or repair, and it is the best pail for all purposes made.

Price, $\$ \mathbf{1 . 2 5}$.

Varnished Cylinder Churns.

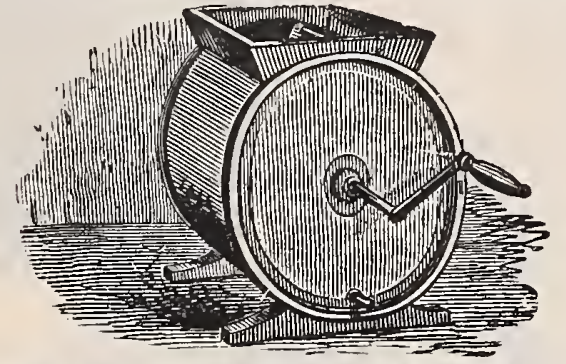

Designed for those having a small dairy. No. I. I.ist price, $\$ 2.50$ Discount for cash, $\$ .75$ No. 2. List price, 3.00 Discount for cash, $\begin{array}{lll}\text { No. 3. List price, 3.50 Discount for cash, } & .75 \\ \text { No. 4. List price, 4.00 Discount for cash, r.oo }\end{array}$ Cedar, same as above, 25 cents extra. They are well worth the difference.

\section{Farmers' Scales.}

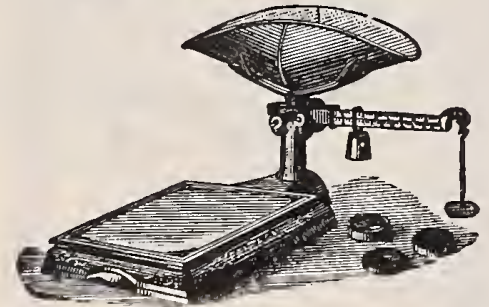

We offer for the use of farmers and dairymen and housekeepers, a convenient and low-priced to 240 pounds. Single Beam, $\$ 4.00$; Double Beam, $\$ 4.50$.

\section{Fairbanks' Dairy Scales.}

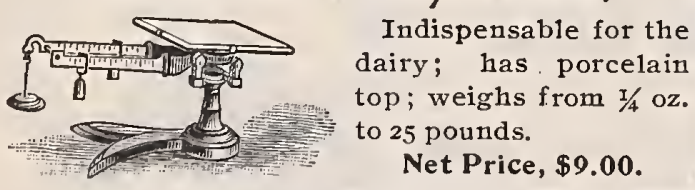

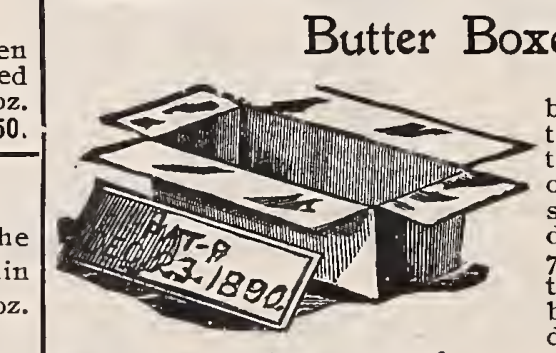

The Gion Combininion Mill Buldetet.

With Removable Strainer.

It has no equal in its simplicity. M a d e of Steel Strainer Frame. The Gem Combination Milk Bucket can be used for milk with cainer, orthe straine cingle turn of the latch and the bucket used for any other purpose. structed of Stee1, with ine Brass Wire Cloth, and can be readily con-

muslin strainer by simply covering the frame with the cloth and inserting the frame in place.

\section{PRICES.}

Io Quarts, each, 6oc. I2 Quarts, each, 70c. I; Quarts, each, 8oc.

\section{The Blanchard Churn.}

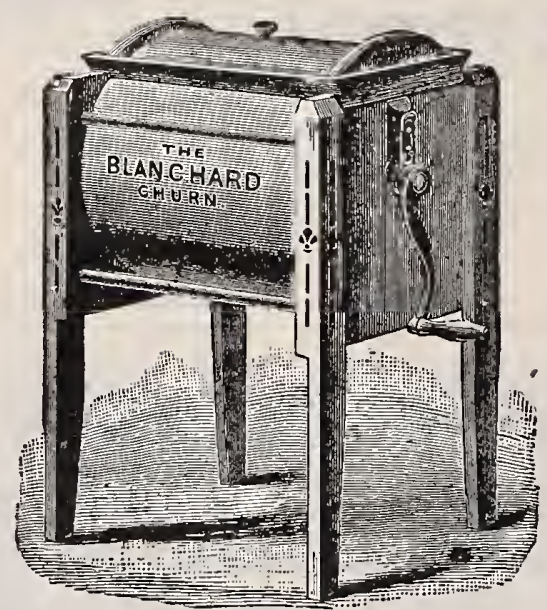

Has retained its reputation for over twenty years as being the best revolving dash churn made for ease of operation and superior butter-ma

No. 3. Churns 2 gal. $\$ 6.00$ No. 6. Churns I2 gal. $\$ 10.00$ No. 4. Churns 4 gal. 7.00 No. 7. Churns 16 gal. 12.00 No. 5. Churns 8 gal. 8.00

\section{Butter Boxes.}

The Dumas square ox holds five pounds: the only box that butof and left in good Phape. Price, per $75 \mathrm{cts}$. We also have the five and ten pound boxes at $60 \mathrm{cts}$. per dozen for five pound,
Iron Clad Milk Pail.

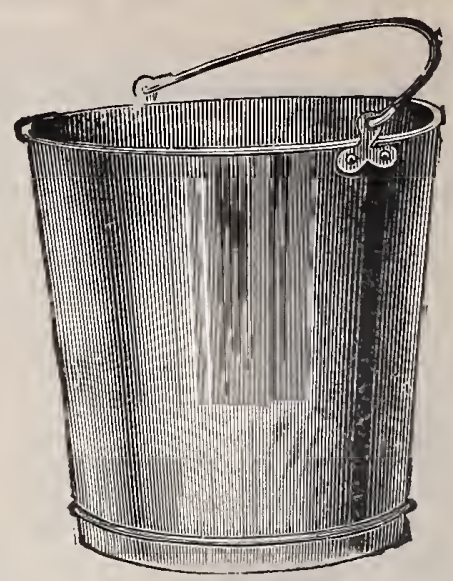

The I. C. Milk Pail is for dairy use. It is a special pattern. The seams are all soldered in. the bottom which serves as a handle in tipping. Price, 14 Quarts, 7oc. 12 Quarts, $60 \mathrm{c}$

The Ideal Milk Cooler. The Ideal Milk Cooler and Aerator does what no other cooler does, namely,thoroughly cools same time aerate it perfectly a it is ready to ship it is ready to ship No time is lost in ctirring morning's inil $\mathrm{k}$ and getting it ready for customers as it is cooled

as, as it is cooled Discount for cash, \$r.oo.

The Blanchard Print Butter Carrier.

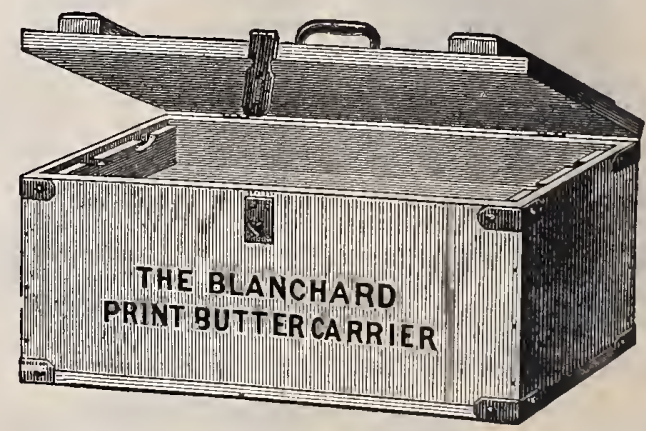

This Carrier is designed for use of dairymen who deliver their butter direct to the consumer. They are also used in shipping butter by express. Blanchard or Conmbination No. 6 Moulds. "They are well made and very strongly iron bound. PRICES. - I6 1b. each, \$I.50; 24 1b., each, \$I.65; $32 \mathrm{lb}$., each, $\$ \mathrm{r} .85 ; 40 \mathrm{1b}$, each, $\$ 2.00$. Fitted with Ice Box, 75 cents extra.
THE DAVIS SWING CHURN.

The principle governing the process of butter-making in the Davis Swin Churn is that the particles of cream come in contact with each other only, and

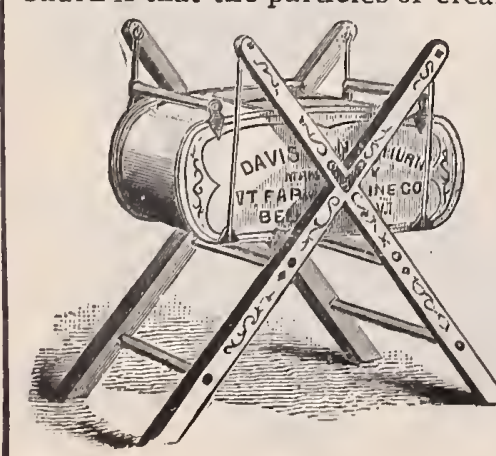

Price List-Complete, with Folding Frame, as shown.

This is the regular frame, and is always sent unless specially ordered otherwise. Eixtra for Tilting Frame, $\$$ r. oo.

Size. Will Churn. - Wgt.1bs. Price. No. I. 4 gal. or less. $55 \quad \$ 7.00$ $\begin{array}{rrrrr}\text { No. } 2 . & 5 & \text {. } & 59 & 8.00 \\ \text { No. } 3 . & 8 & 1 & 73 & 10.00\end{array}$ No. 4 . 10 No. 5 . 13 No. $7 . \quad 30$ No. $9 . \quad 50$

\section{Waters Butter Worker.}

The purpose of working butter is to free it from buttermilk and distribute the salt evenly through it. The Waters differs from nost butter workers principally in the point that the tray, with the butter, moves under a stationary roller instead of the roller travelling over the butter in the tray.

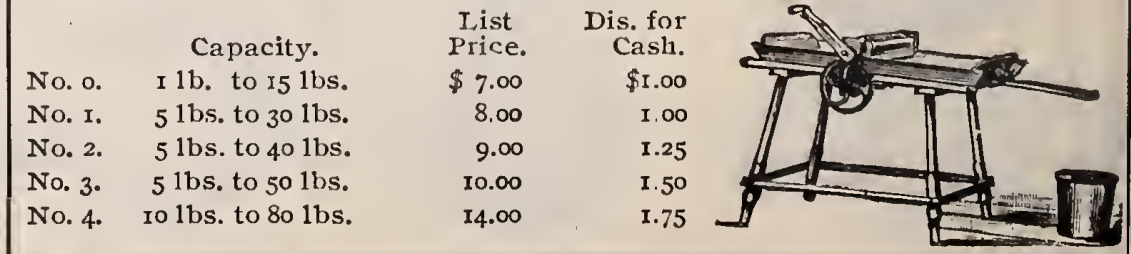



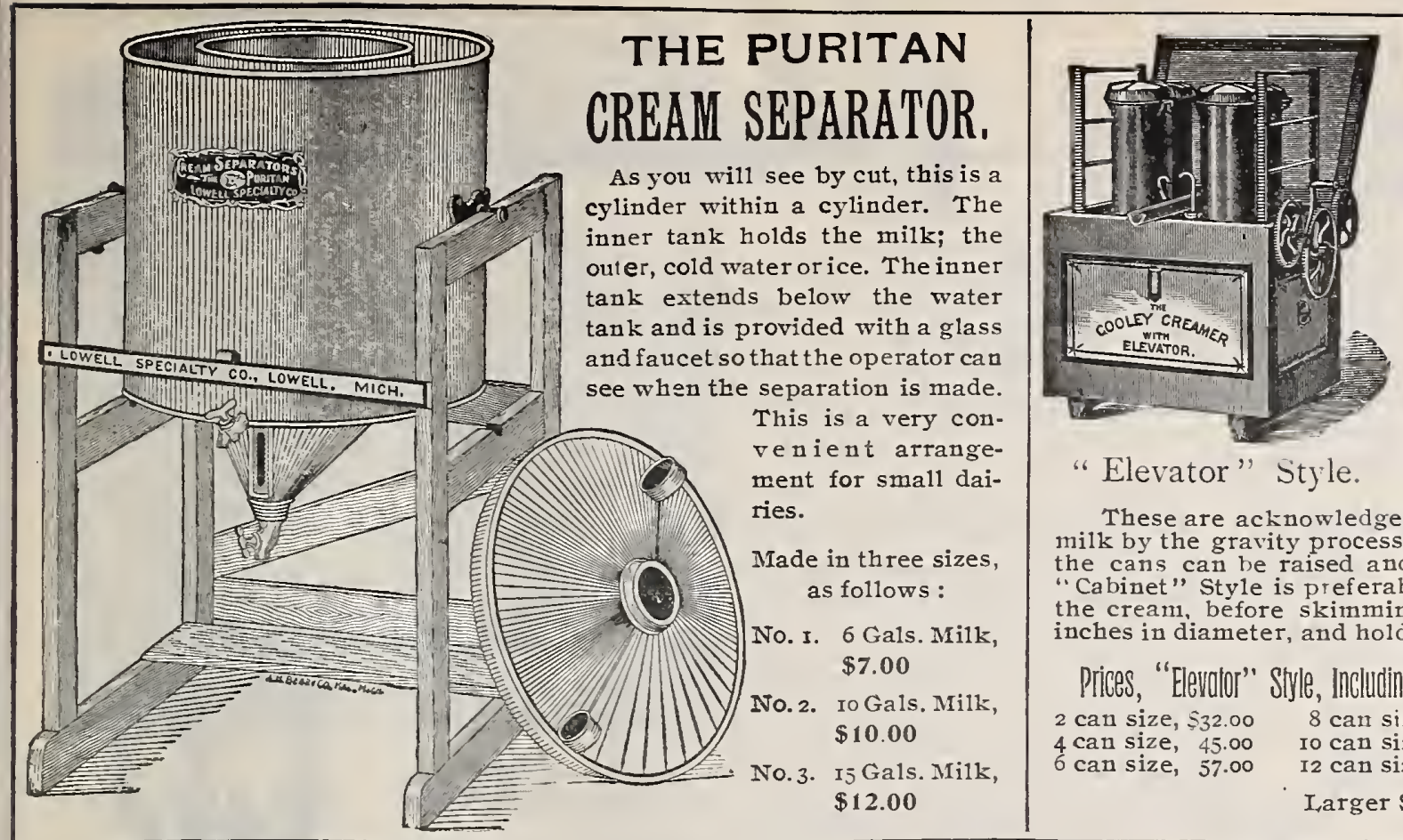

"Elevator" style.

These are acknowledged the best apparatus for separating cream from milk by the gravity process. The "Elevator" Style is the most popular, as "the cans can be raised and lowered into the water by the elevator. The the cream, before skimming. Each can measures Io inches high by $81 / 2$ inches in diameter, and holds I8 quarts, or the milk from two to three cows.

\section{Prices, "Elevalor" Style, Including Cans. I Prices, "Cabine!" Style, Including Cans.}

2 can size, $\$ 32.008$ can size, $\$ 68.00$ I can $\leqslant$ ize, $\$ 20.004$ can size, $\$ 4000$ 6 can size, 57.00 I2 can size, 93.00 3 can size, 33.00 \& can size, 64.00

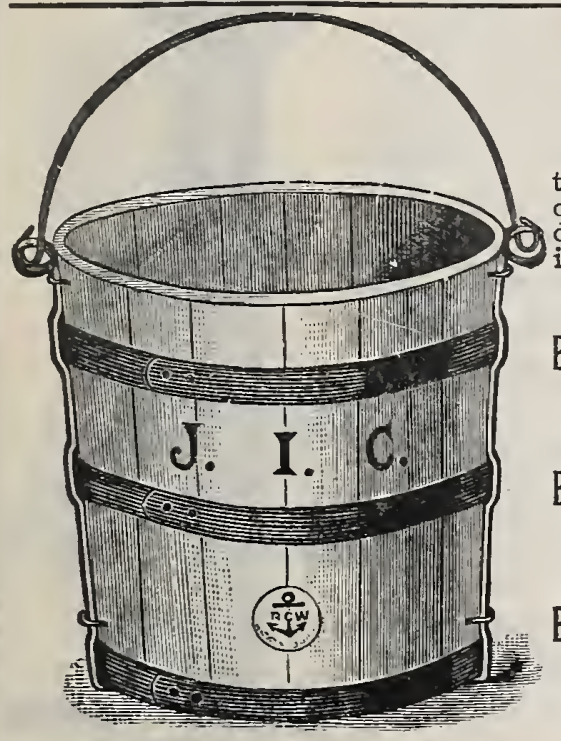

J. I. C. Stable Pail.

The best stable pail on the inarket. Made of best oak, with strap running down the

Price, $50 \mathrm{c}$.

Electric Hrop Barn Pails.

CEDAR. Painted.

Each, 35c.

Electric Hoop Barn Pols.

PINE. Painted.

Each, 30c.

Electric Hoop House Pails.

CEDAR, natural color

Each, 30c.

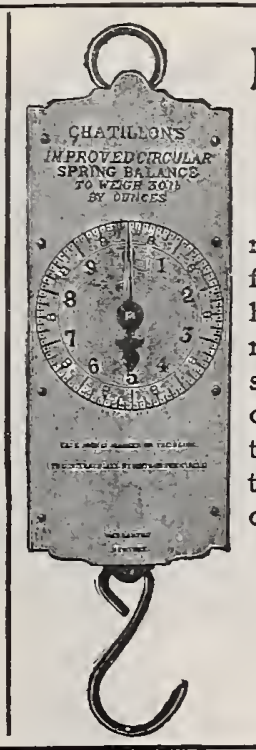

Larger Sizes Quoted on Application.

\section{Dairy} Scale.

This scale is

made especially

for dairy use, and

has an adjust-

ment on the top

sothat the weight

of the pail can be

taken out, giving

the exact weight

of the milk.

Graduated from

$30 \mathrm{lbs}$. to I Oz.

Price, $\$ 3.00$

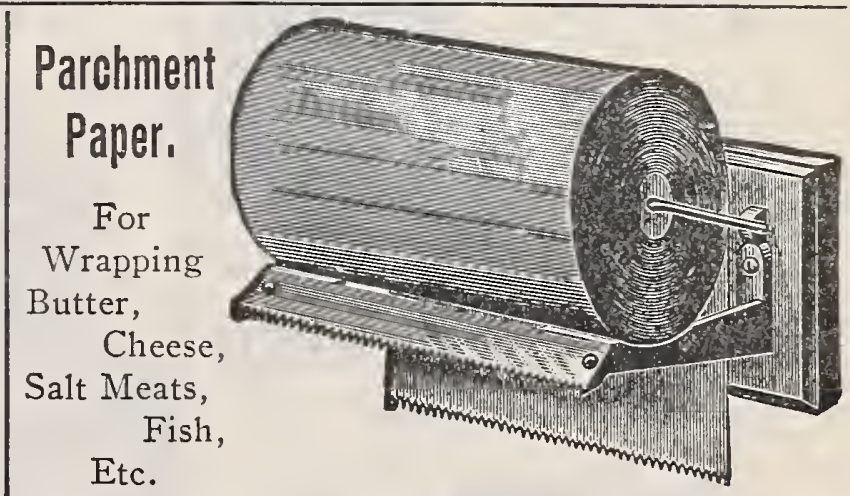

Either in Rolls or Sheets. Parchment paper put up in rolls is very convenient for store keepers. We can furnish sheets in three sizes, as follows: 8 XII, 9 × I2, I2 X I2.

Price per 1b., 20c.; 25 1b. lots, 17c. per 1b

We can also furnish any other sizes to order. nish 9 and 12 inch rolls; weight about 21 bs. We can fur-
WHAT IS LIMITE

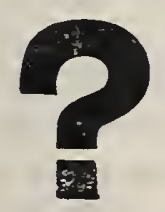

\section{LIMITE}

is manufactured from PURE LUMP LIME, thoroughly hydrated, and possessing all the advantages of quick lime; it will not air-slake when the package is opened, but

WILL KEEP INDEFINITELY,

Being at all times ready for immediate use.

Put up in $1 \mathrm{lb}$. Boxes for $10 \mathrm{cts}$.

$$
\text { and } 2 \text { 1-2 lb. paper for } 20 \mathrm{cts} \text {. }
$$
For Wincoin Glass Pully. For Marking Lawn Tennis Courls.

For a Disiniectant.

For Palching Plaslering.

For Washing Gompound.

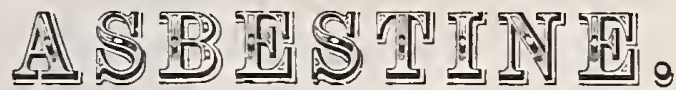

The Original Fireproof and Weatherproof COLD WATER PAINT.

BEWARE OF IMITATIONS.

More Asbestine Sold than all other makes comBordeculux Mixhure lor Fruil Treess.

than all other make
bined.

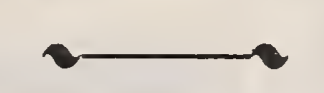

A DRY POWDER.

Add cold Water and you

have a High Class and

Durable Paint.

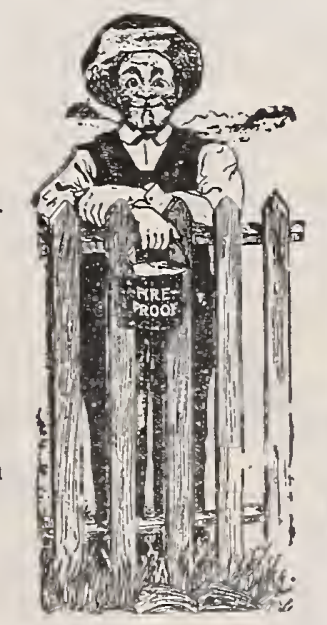

Costs very much less than Asbestine is especially adapted for use outdoors on Barns, Fences, Area Walls, Air Shafts, Freight Sheds, or any surface requiring an economical and durable cnating that will largely resist the action of progress of fire. Ashestine is unexcelled for all sorts of buildings. Send for testimonials. Inside Asbestine is for use on all insille surfaces It gives a whiter and handsomer finish than oil paint. and contains no oil, so will
not turn yellow or change color with age. Send for

ЋETAIL PRICE LIST.

Color Number.

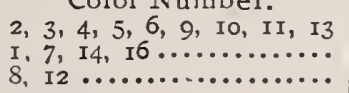
15, $413 \ldots \ldots \ldots \ldots \ldots \ldots . .6$. WHITE...............

\section{Barrel, 400 lbs. I/2 Barrel,}

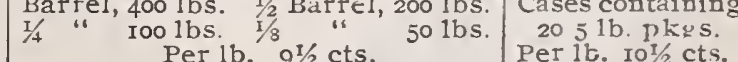

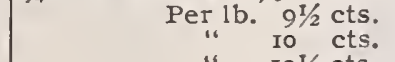

“I II cts.

8 cts.

II $1 / 2$ cts.

I2 $\mathrm{cts}$.

9 cts. Per 1 b. $61 / 2$ cts. Per $1 \mathrm{~b} .7^{1 / 2} \mathrm{cts}$ 

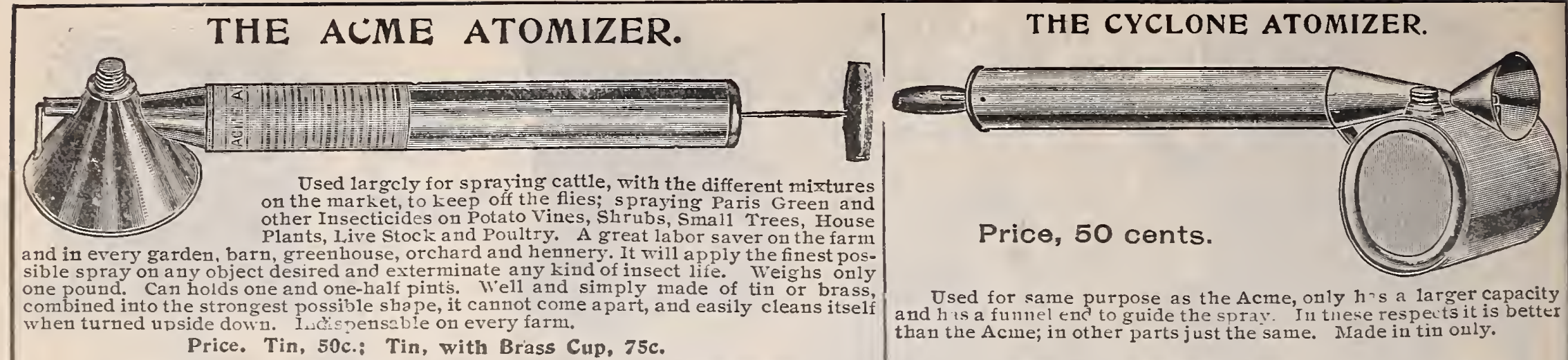

Used for same purpose as the Acme, only h's a larger capacity than the Acme; in other parts just the same. Made in tin only.
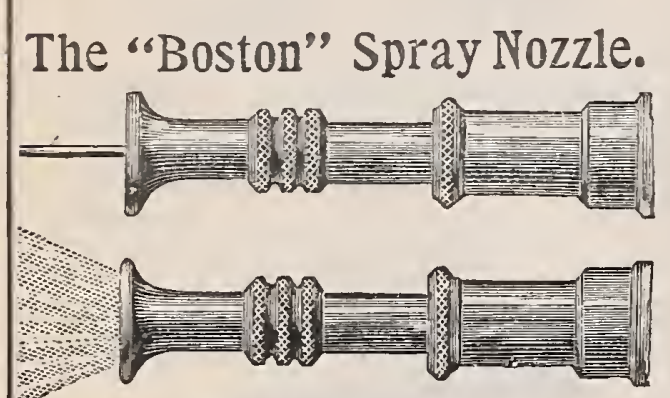

Will throw a coarse or a fine spray, a large or a smail solid stream. The spray can be a rea. These results a re obtained by revolving it part way round.

Price, - 35 cents.

IMPROVED VERMOREL NOZZLE WITH DEGORGER.

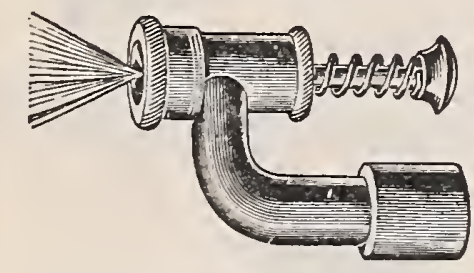

Arranged with stuffing box, so that the liquid will not wet the operator while being used; fitted for 1-2 inch male end or 1-4 inch pipe. Each nozzle is furnished with two caps, with different sized openings, for coarse cr fine spray.

Price, 85 Cents.

\section{MYERS' BRASS SPRAY PUMP.}

This Pump has More Real Advantages than are cono tained in any other pump un the market.

This pump is constructed of material that is notaffected by the poisonous arsenites used in the different formulas for spraying fruit trees, vines and shrubbery. The crlinder and all working parts are brass; has rubber ball valves, and is equipped with our Graduating Spray Nozzle, which will throw a spray as fite as mist. A great

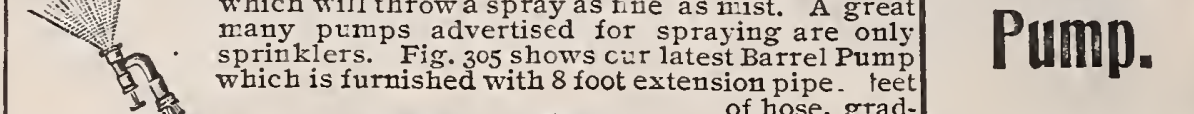

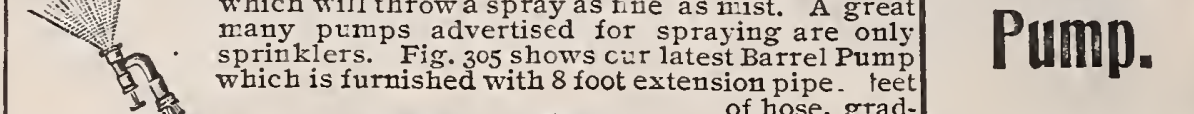

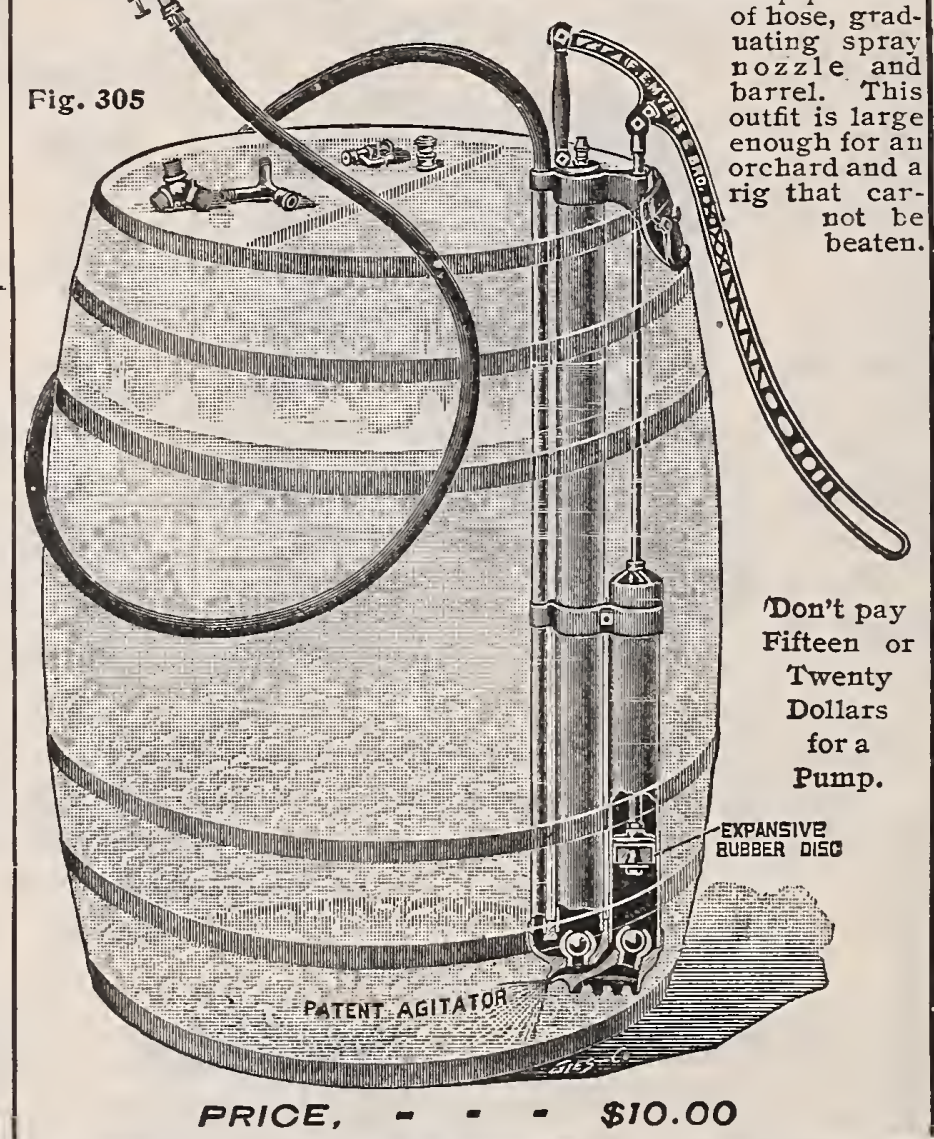

\section{Brass Bucket Spray
Pump.}

This pump is constructed entirely of brass, a metal that is not affected by the poisonous preparations used in spraying. The labor of pumping is all done on the downward stroke of the pump. Has large air chamber, and ball valves. The pressure is held uniformly in the air chamber and on the hose, so that the nozzle

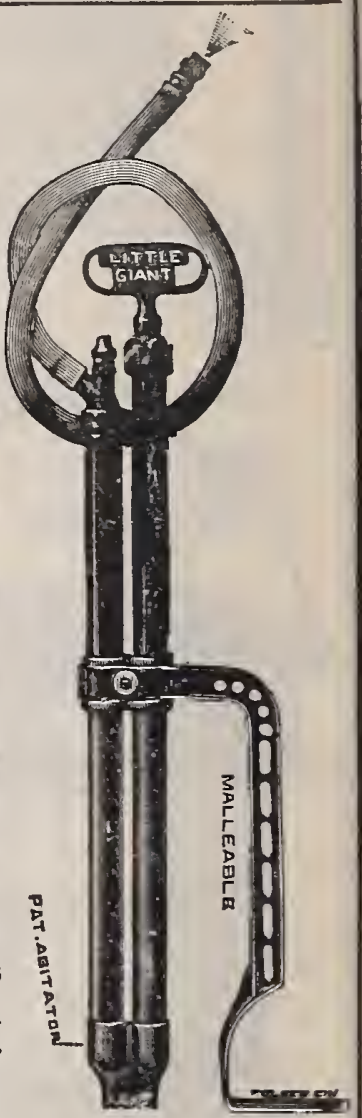

No. $3271 \approx 2$ throws a continuous spray and is not offected by the movement of the plunger. Will throw a solid stream 50 feet. This is the best hand pump we have, and is very handy for washing windows and sprinkling lawns where there is no water pressure. Has foot rest as shown, best hose and spray nozzle. Price, $\$ 4.00$
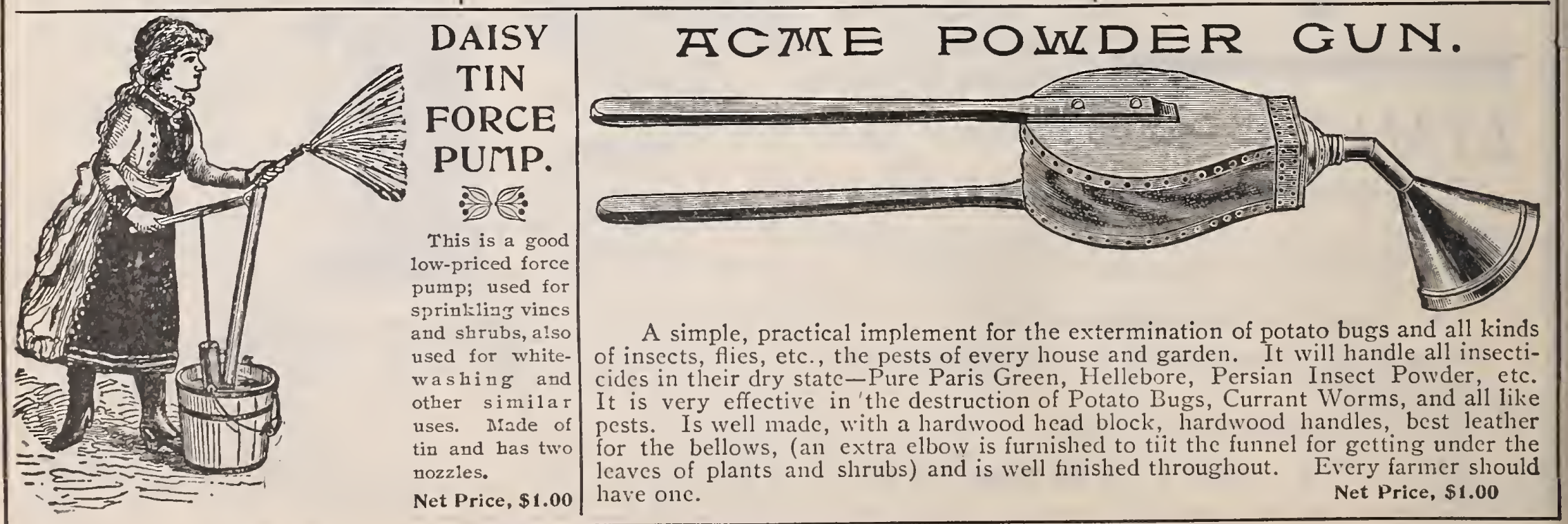


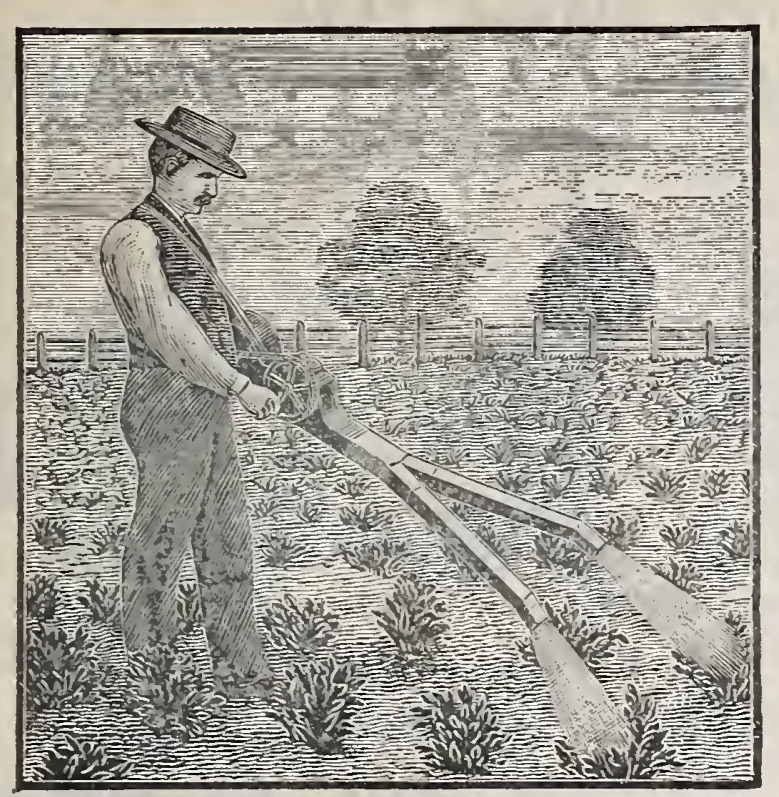

\section{HOTCHKISS DRY POWDER GUN.}

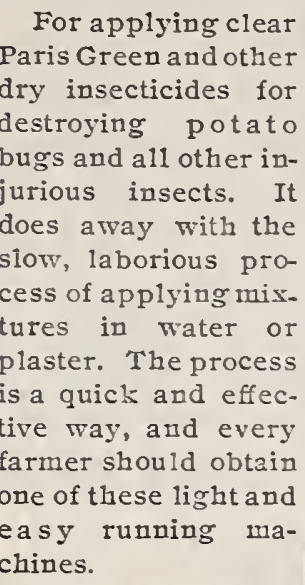

Price, $\$ 5.00$

\section{Champion Paris Green or Dry Powder Gun}

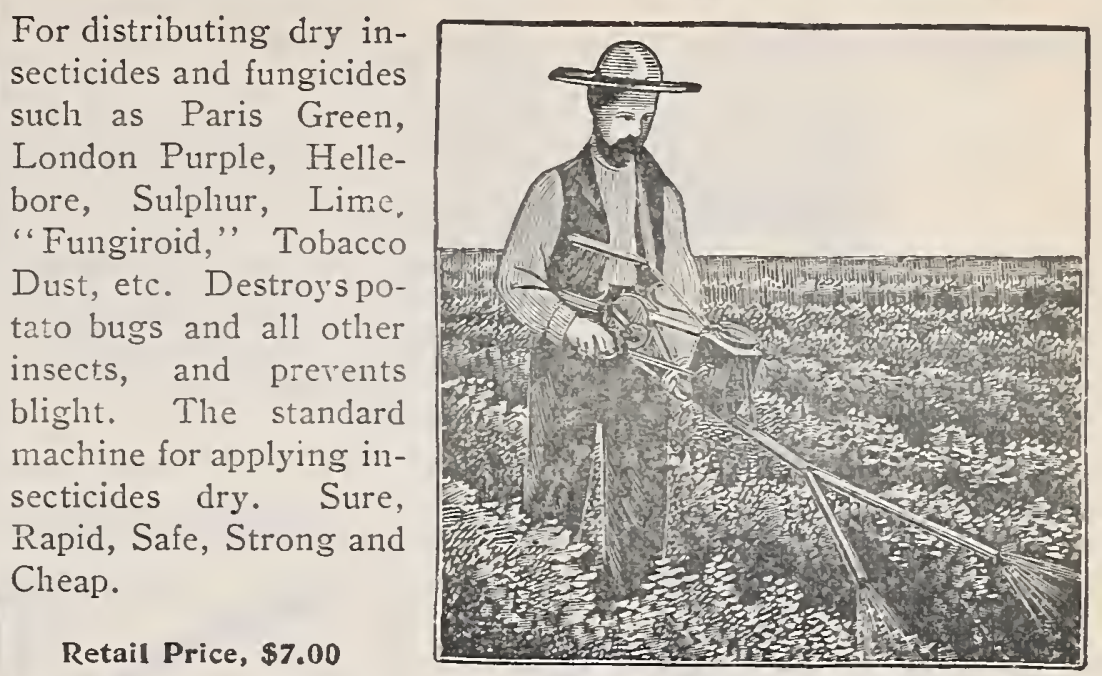

\section{THE LENOX SPRAYER.}

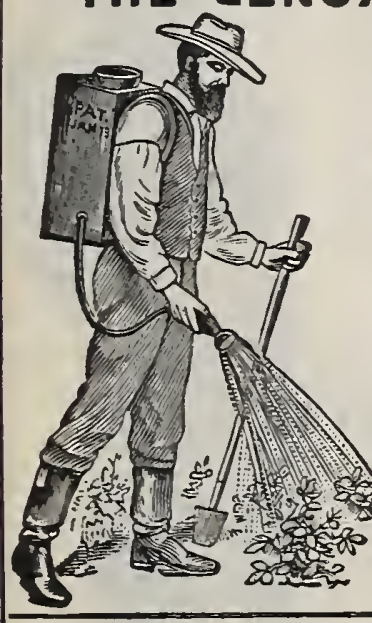

A cheap sprinkler for applying poisonous fluids suchas Paris Greell water, etc., to grape villes, low trees, busles, potatoes, garden vegetables, etc. Can be carried either on the back or by hand, as desired. It is made of galvanized iron, holds five gallons of fluid, wbich Hows through the rubber tube and is forced out in a spray by pressing the rubber bulb heid in the hand; this spray will reach ro to I 2 feet. The I,enox Spray. eris not ada pted forthrowing fungirold, such as spray is not

Price, $\$ 3.25$

The Brownie Duster. FOR GARDEN, VINEYARD AND SMALL

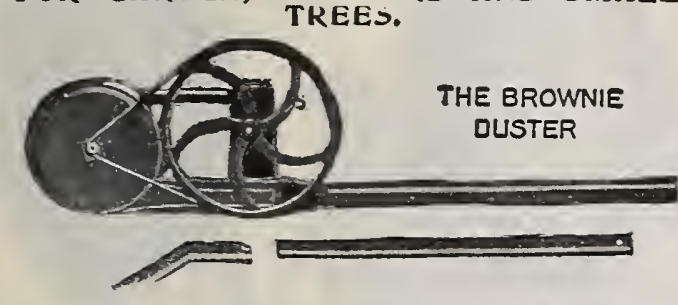

Particularly Useful for In=Door as well as Out-Dour Work, Wherever a Dry Powder is Required.

The crank should be tirned about 80 revolutions a minute.

Two 6 -inch tubes and one bent nozzle furnished with each Duster. Machine weighs complete $3 \frac{1 / 2}{1 b s}$. One packed
Price, $\$ 3.50$.

\section{RUBBER AND COTTON HOSE.}

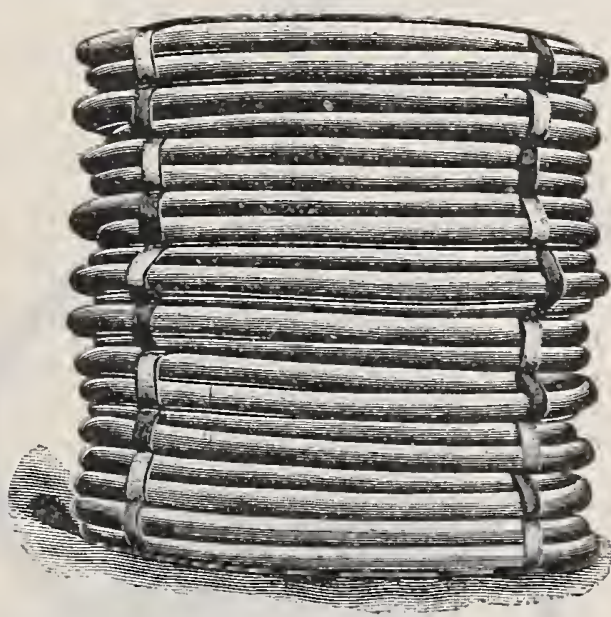

Our Hose is all made expressly for us by the most reliable manufacturer in the state and every piece is warranted, but it is economy to buy the best grade, as it will last several years.

\section{PRICES.}

$\begin{array}{llrrr}\text { Bull Dog, - - } & 7 \text { Ply, } & 12 \text { in. } & 3 / 4 \text { in } \\ \text { Tiger, - - - - } 6 \text { 66 } & 9 & 11 \\ \text { Leader, - - - } & 56 & 8 & 10 \\ \text { Cotton, - - - - } & & 10 & 12\end{array}$

Improved Little Giant Duster.

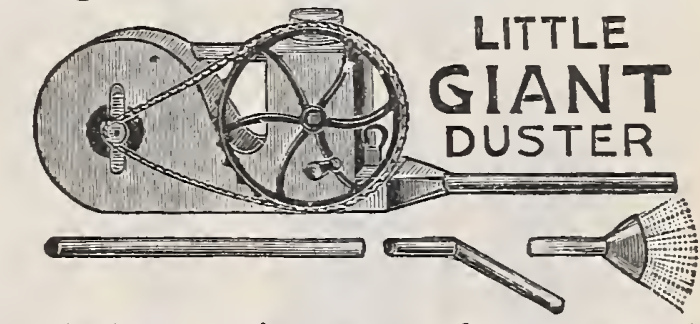

Distributes Paris Green, London Purple, Hellebore, sulphur, Lime, Fungiroid the dry Bordeaux Mixture), Spanish Pink, Pyrethrum Powder, etc. tubes only fve pounds complete. Full length with
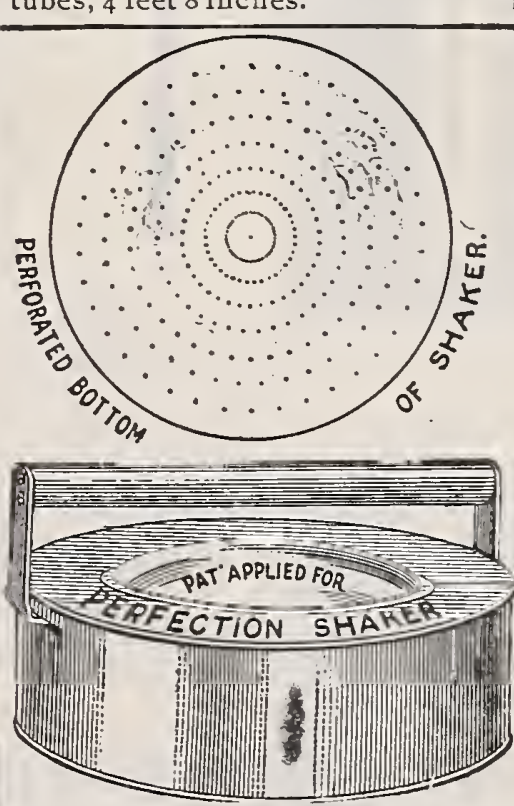

. Thl . Porfpetinn Shaker.

Especially dapted for applying Bug Death, Slug Green, and powPrice, 65c.
THE “COOPER” BRASS HOSE MENDER.

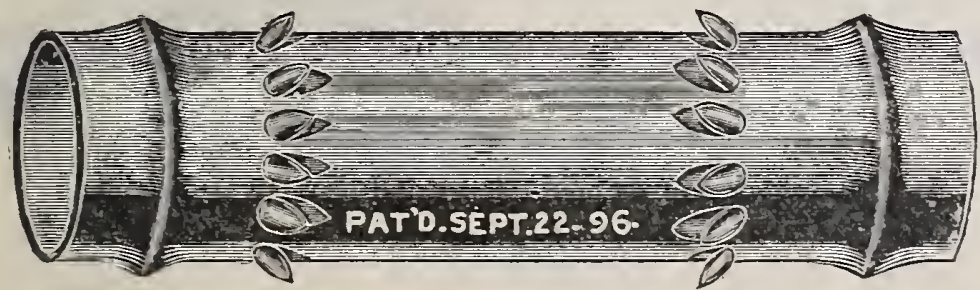

Made of thin brass tubing; will not rust or wear out; scarcely decreases the flow of water. Easily applied by any one; simply cut out your bad piece of hose and force the ends of the good hose over the mender until they meet in the centre. No other fastening is required; the barbs will hold it firm, and no matter what strain is put on the hose it will be as good as new at the point mended, and will not leak.
Price, each, 10 cents; Der dozen, 75 cents.

\section{DICKEY'S Bug Death Shaker.}

Dickey's Bug Death Shaker, shown in cut, is designed for applying any kind of dry powder, and is the best as well as the cheapest shaker on the market. It is provided with a scoop for filling. Order one with your Bug Death.

Price, 25 cents.

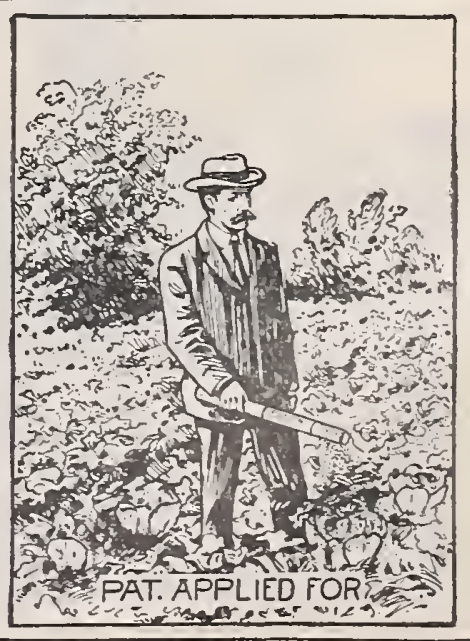




\section{Blizzard High Pressure Sprayer.}

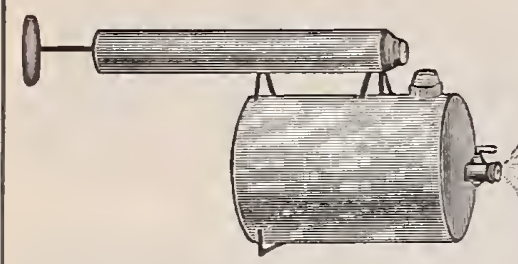

After filling three-fourths full and pumping in about teu mist-like s pray is t h row 1 which will last several min can be sprayed as fast as you can walk, saving a 1 a r ge amount of time and labor. Removing the two pieces of noz thrown direct from the stop cock, which can be varied by slight turm of the key to a coarse spray, 12 to I 5 feet high, or a stream I5 to 20 feet high. The Blizzard is made of galvanized iron. It holds one gallon,
is simple in construction, easy to work, easv to fill and handy to carry. It is light, stroug and neat. A lady can use it. Price, $\$ 2.00$.

\section{THE ROCHESTER SELF-OPERATING SPRAYER.}

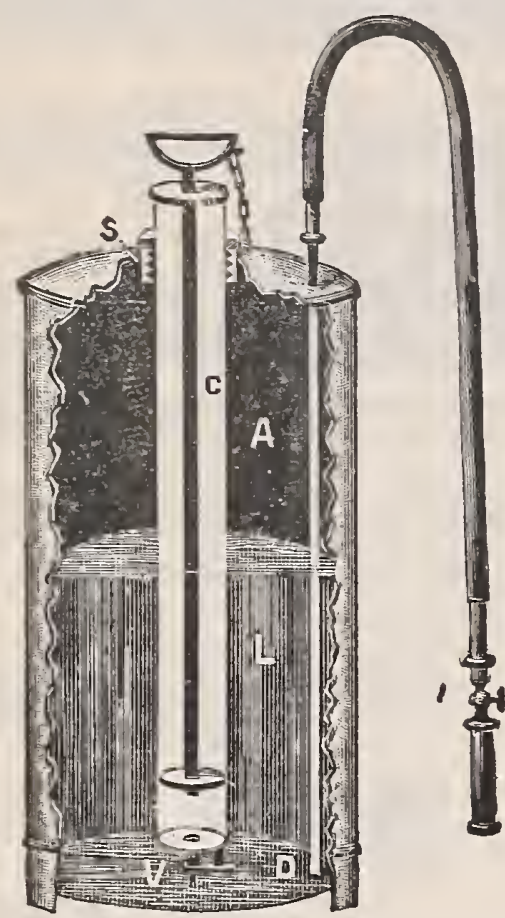

This Sprayer is filled not more than two-thirds full by unscrewing and removing the Brass Air Pump and the machine charged with compressed at bottom of pump, thoroughy agitating and mixing the contents of Sprayer. The compressed out through the outlet pipe, making either a fine spray or a solid continuous stream as desired. This size machine holds from 3 to 4 gallons, ized iron or brass, as desired. Air pump is of brass. Price, Galvanized Iron, $\$ 5,00$; Brass, $\$ 6.50$.

Discount for cash, 50 cents.
Knapsack Spray Pump No. 331.

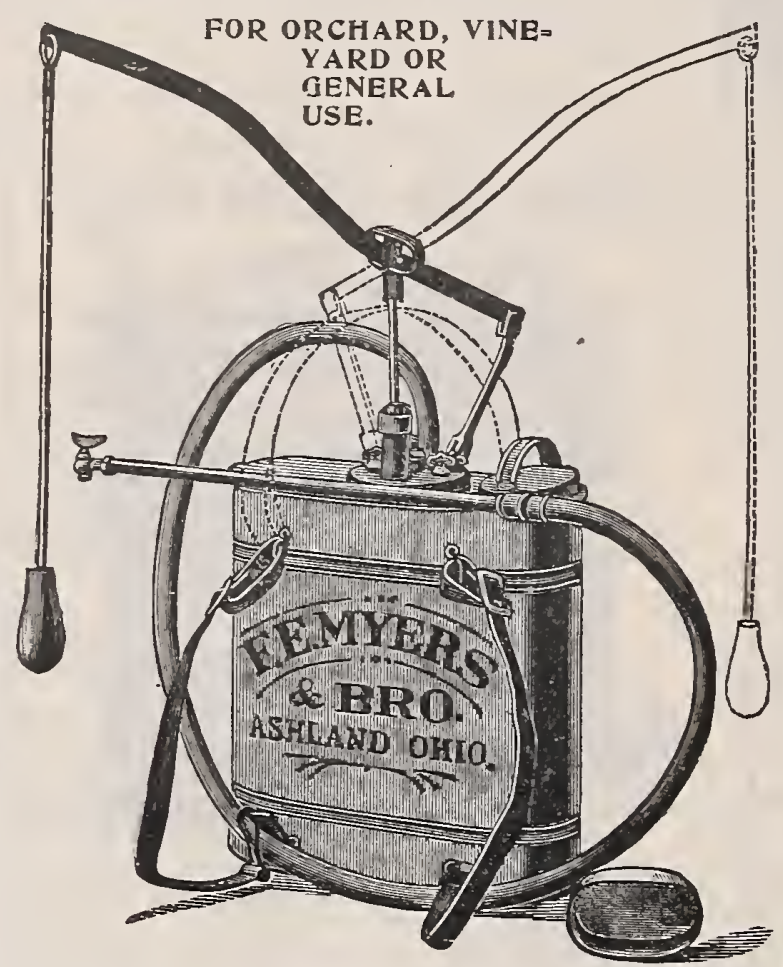

The tank of this pump holds fire gallons, is fitted up with lid and strainer, which can be removed. The pump is our regnlar Copper Tank Spray Pump, with large hamber, ball valres, solid plunger and a gitator. It s so arranged that no water can drip on the operaor. The pump can be removed easily. The pump is 1so fitted with handle. so the operator can use it the ame as a tank with bucket pump, viz.: set the knapack on the ground and work pump wilh handle. Can be carried by hooking snap in strap on the opposite side provided for that purpose, making a neat handle as shown by the dotted lines. The handle lever can be
shifted from right to left shoulder at will.

NET PRICE, - = \$10.00.
Bordeaux Spray and Solid Stream Nozzle.

\section{Use this Nozzle \\ for Whitewashing.}

Will throw a fine fanshaped spray and will should it become clogged, hy turning the cock handie. It will throw a solid stream or may be shut off stream or may be shut off a.together, as desired. It is especially recommendwith the Bordeaux mixture, and all Knapsack spray"ers.

Price, 85 Cents.

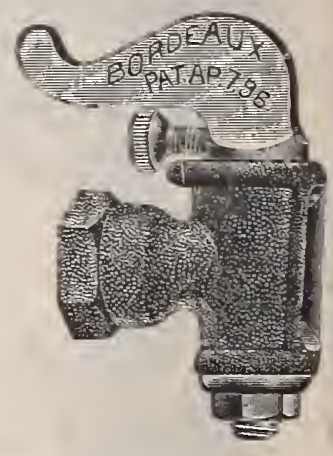

\section{RUBBER ATOMIZERS.}
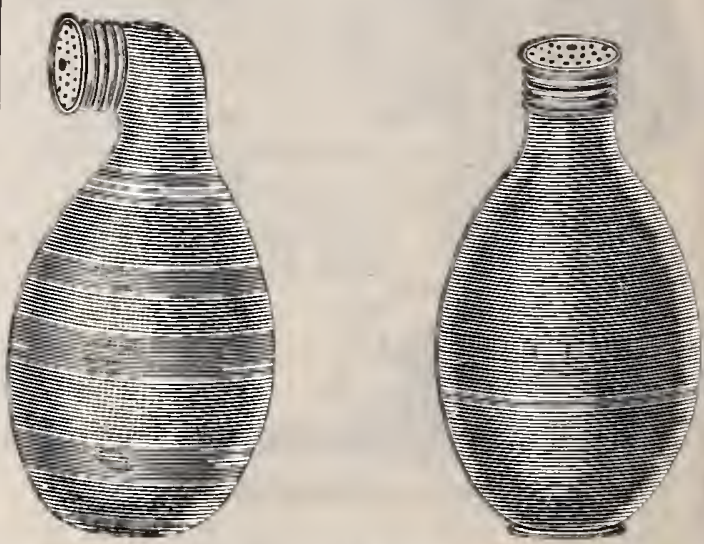

Very useful for sprinkling house plants and also for spraying with hellebore and bug death.

Small Size, 50 cents. Large, $\$ 1.00$. Either style of neck.
The Utica High Pressure Double Cylinder Sprayer. FOUR GALLONS CARRIED EASILY.

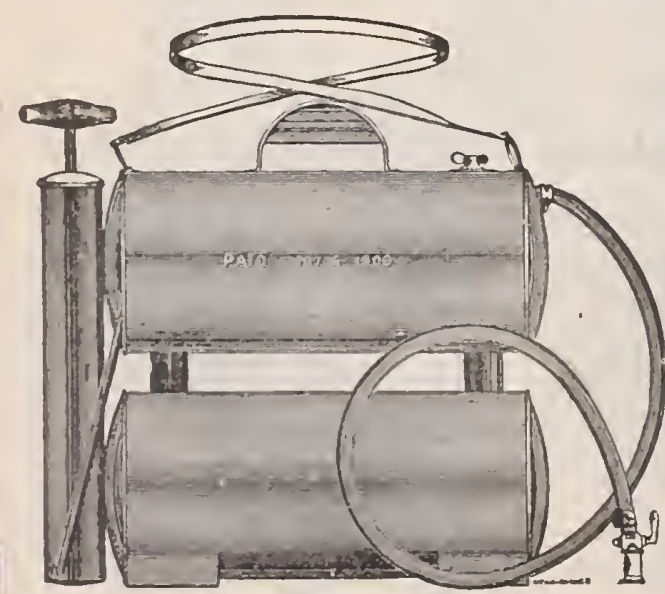

Made of heavy Galvanized iron, strongly braced and reinforced in every part. Heads swelled and double seamed. screw. Strong 2-inch for screw. Strong 2-inch force pump, with heavy rods, best brass spreaders for leathers. Brass ball check valves. The most perfect working sprayer ever inveuted. Adapted for al classes of $\mathrm{s}$ rayillg. This charged, which takes half a minute, will spray continuous$1 y$ for 15 minutes. It is especially fine for large work in potato fields, vineyards, tobacing, whitewashing, $\mathrm{ch}$ ic ke a house spraying and g ree
Newberry Double Acting Powder Gun.

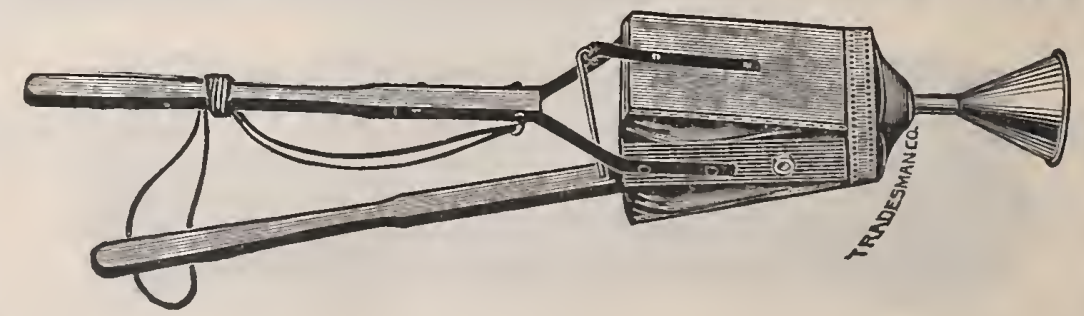

This powder distributor is similat to the Acme distributor shown on preceding page, but is a great improvement where a large amount of work is to be done. It has a double acting, substantial bellows which works when opening and closing, thus throwing a continuous stream. It is provided with a support to hang on the neck of the operator which makes the work very light, and with it a large amount of work may be done in a day. Price, \$1.50. 


\section{Furber Wood Pumps.}

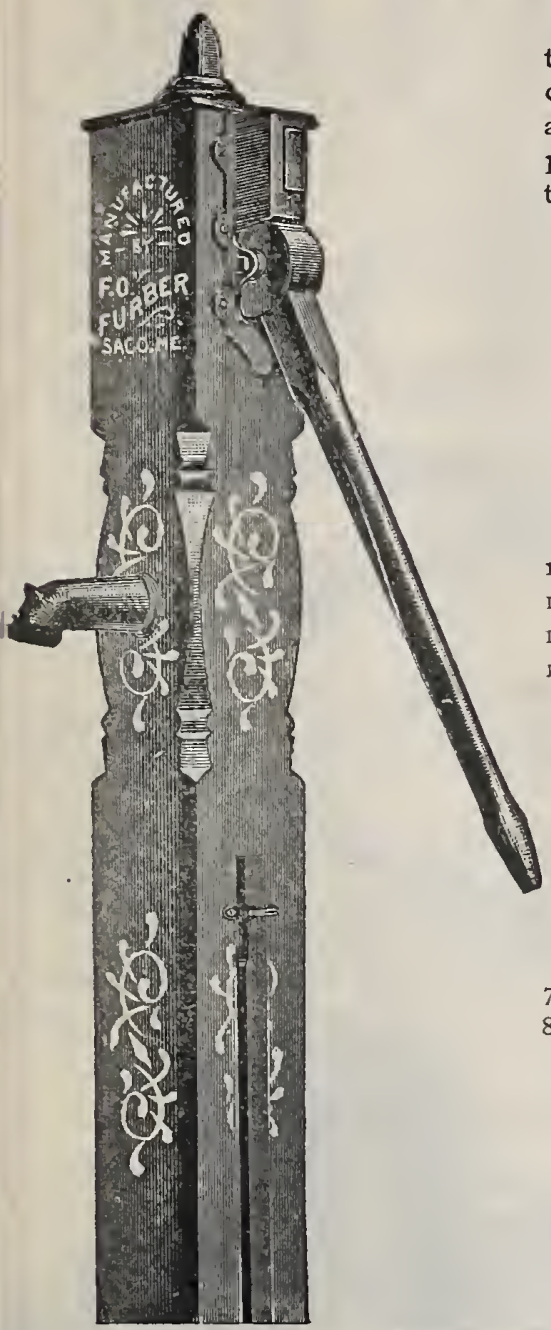

This is the best wood out-door pump that we can buy. It has the patent closed handle bracket, so that stones or any rubbish cannot get into the box; patent let-off to prevent freezing; iron top; lined or unlined.

$6 \times 6$ for house use.

$7 \times 7$ for stock.

$6 \times 6$ Inch Stooks, 3 1-2 Bore, Ior General use.

Porcelain Lined. Unlined. 7 feet long........... \$ $7.50 \quad \$ 6.00$

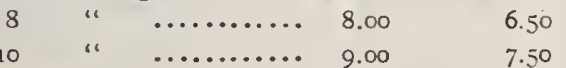
anc.

4 " 4 " $4 \ldots \ldots \ldots \ldots, 11.25$

Use $4 \times 4$ pipe for above pumps, per foot, .18 Couplings and bands for the above each, .50

$7 \times 7$ Inch Stock, 4 Inch Bore. Porcelain
I,iued. Unlined. 7 feet long. .........\$9.50 \$7.75 ".............. 10.00 8.50 Use $4 \frac{1}{2} \times 4 \frac{1}{2}$ inch pipe, per foot, .23 Couplings and bands for the above, each, .60

\section{Retail price,}

25 per cent. off from list.

\section{Drink Pure Water.}

\section{If you Use this Pump you will Enjoy Good Health.}

IT MAKES BAD WATER GOOD AND GOOD WATER BETTER.

We will guarantee to purify any well, no matter how bad the water is, in 5 days, or refund the money.

How IT PUR1F1ES WATER.-Every bucket descends full of air aud ascends full of water. For every gallon of water drawn, a gallon of air (the vital element) is circu. lated through the water, from the bottonn to the top. This agitates, ventilates and puri. fies the water and forces a large surplus of oxygen from the air into the water, which is sufficient to cousume all impurities or organic matter in the foulest well or cistern. It is a fact attested by thousands using it that this purifier is the ouly one invented that will destroy wiggles, water bugs, water lice and germs of disease, and make foul and stagnant well or cistern water pure and sweet, removing all color, bad taste and smell. After a few days' use the old flat ness and insipidity is replaced by a sparkle like that of a mountain spring. A filter purifies, but does not oxygenate; this does

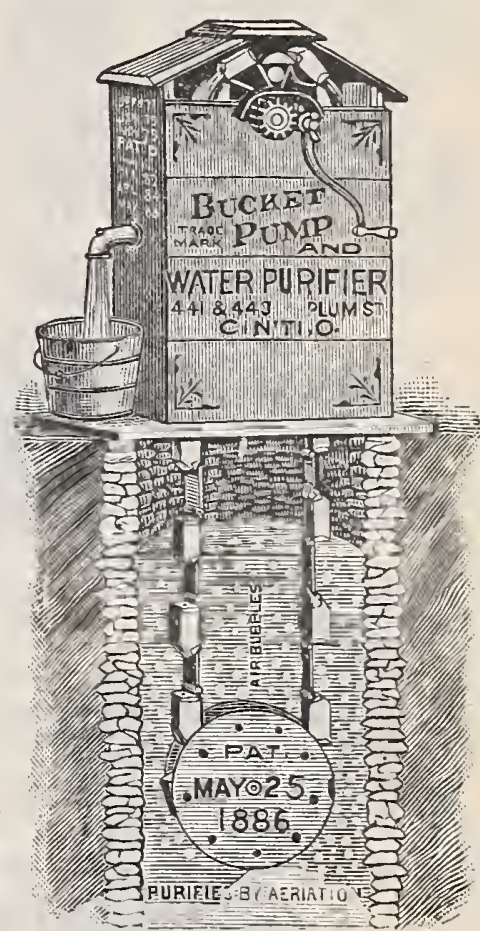

PRTCE，\$10.00 for the first ro feet of well.

Each additional foot of well, 50 cents.

Discount for wells less than 20 feet, 10 per cent.; 20 feet and over, 20 per ent. discount. Cash with order, 5 per cent. extra.

Wells over 40 feet deep require extra heavy fixtures, for which there is an extra charge of $\$$ I.oo.

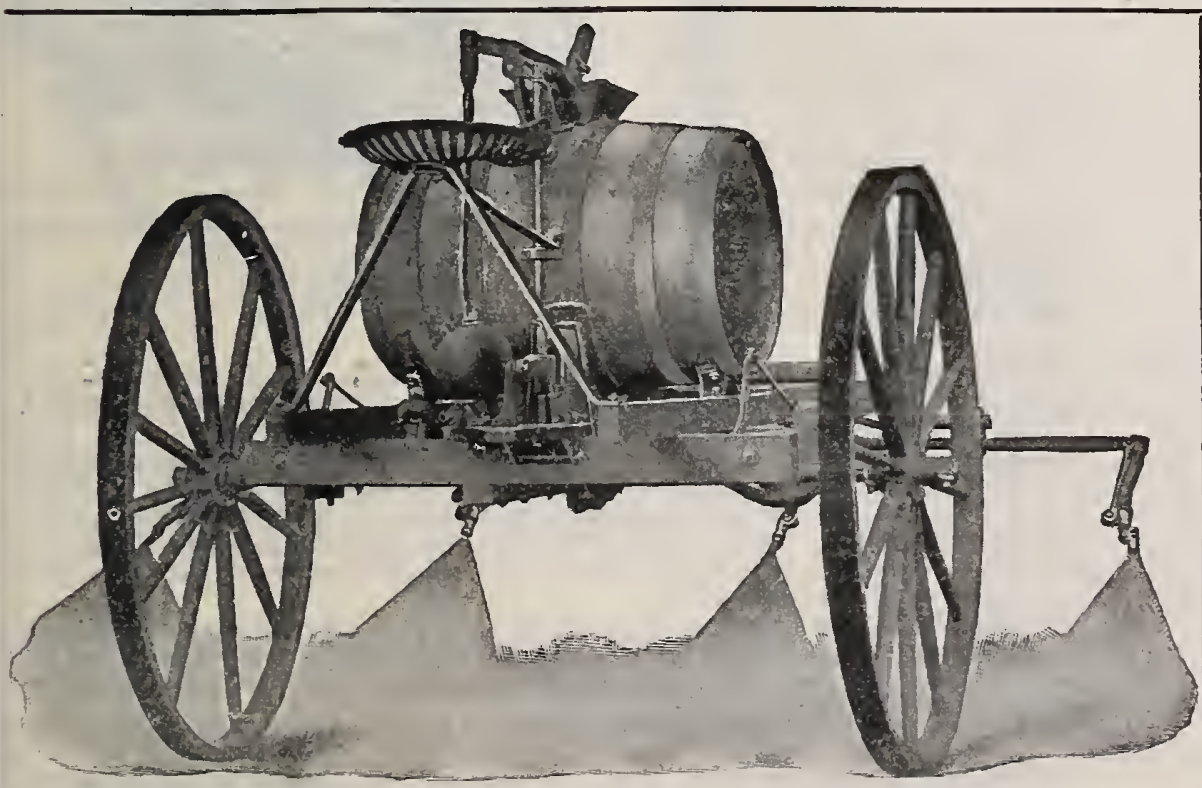

\section{The Aspinwall 4-Row spraver.}

This sprayer is designed for the large potato growers, where the hand machines are too expensive to use. Sprinkling by hand is a thing of the past, and applying insecticides dry is also expensive; but the Aspinwall 4-Row sprayer does the work in a cheap and satisfactory manner, and to anyone planting three or more acres of potatoes we recommend this machine. Conditions now exist that call for the best and most iniproved devises, and we helieve this sprayer meets these requirements. Car loads of these spravers were sold last year, while it was difficult to sell a single machille the year previous. Don't wait until the last day before you order, but send early and have the machine on haud ready when it is needed.

List Price, \$45.00. Discount for cash, $\$ 2.00$.

\section{RUBBER BUCKET CHANN PUMPS.}

They are one of the best cheap pumps.

This is the old reliable Rubber Bucket Chain Pump, and until the BUCKET PUMP (shown above) came into the market, it was used largely in wells where the water was impure, as the coustant motion of the chain and buckets kept the water in motion and prevented sediment.

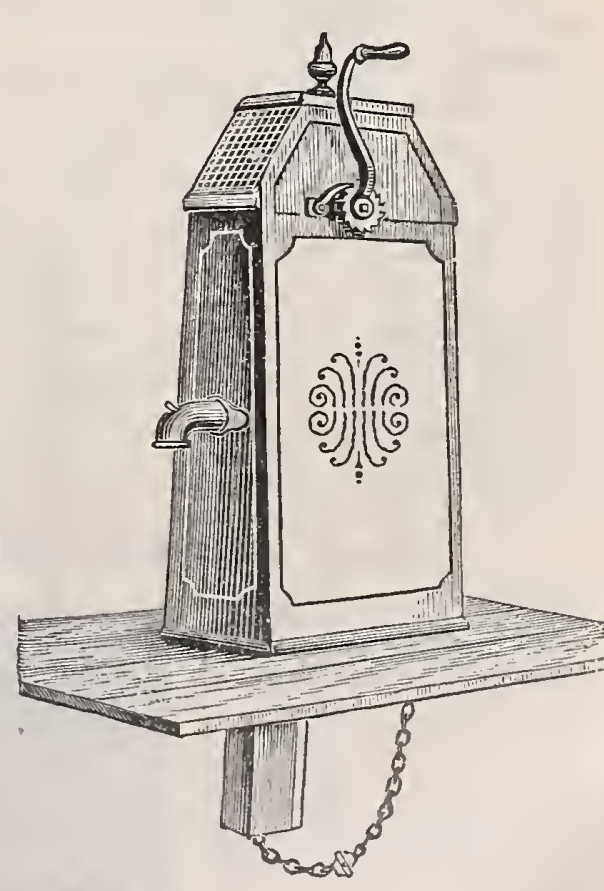

PRICES.

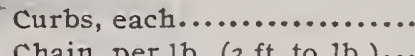

Wood Tubiug, per foot.

Rubber Buckets, each 


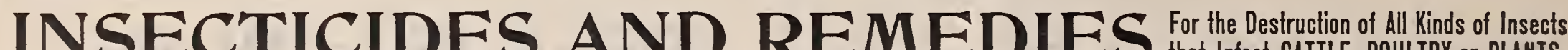

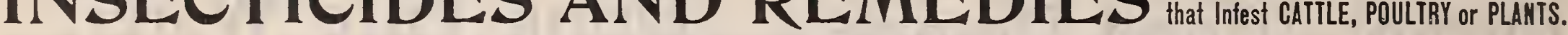

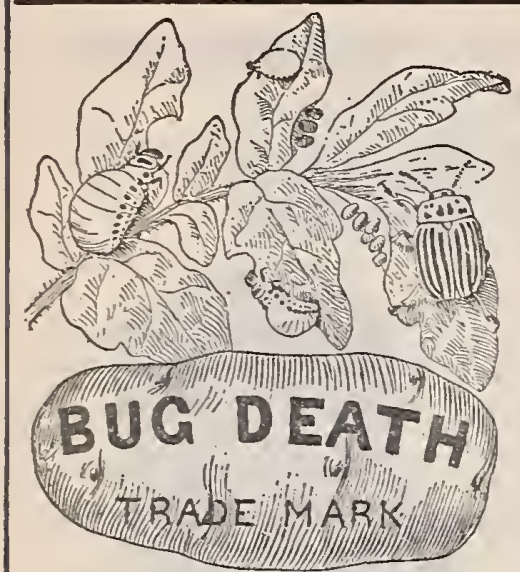

Pat. March I6 and Nov. 9, I897.

Pat. in Canada Nov, 2, 1897 ,

and Jan. 25, 1900

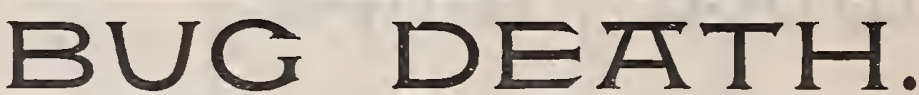

This Insecticide and Plant Food Combined has been on the market for five years and its sales have shown a large increase each year. We can say to our customers that we give Bug Death our fullest endorsement. While the first cost to kill the bugs on an acre of potatoes is rather mote than the arsenical insecticides, the results at harvesting time are entirely satisfactory, and where practical tests have been made the extra yield of marketable potatoes has more than paid the entire expense. It is non=poisonous, which makes it perfectly safe to use on all plants or vines.

Very Beneficial Results are obtained by using Bordeaux Mixture in connection with Bug Death, and they can be mixed and sprayed on the vines at the same time, with any of the spraying machines on the market for that purpose. Bug Death prevents blight.

Reduction in Price. The manufacturers at the request of the trade and many consumers, have added a 100-pound $\mathrm{keg}$, which will be much appreciated by the farmers, as it reduces the cost per pound.

PUT UP IN PACKAGES AS FOLLOWS, WITH TRADE MARK ON EACH PACKAGE:

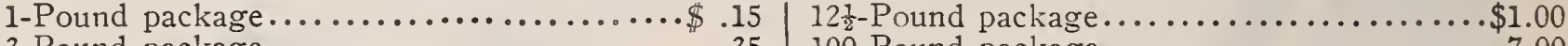

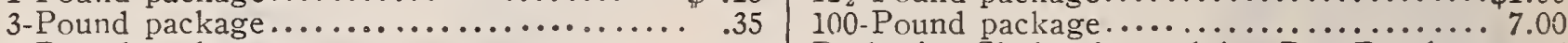
5-Pound package......................50 Perfection Shaker for applying Bug Death... .65

Bug Death may be applied dry with the Perfection Shaker, or with a small bag made from burlap or gunny cloth having the right mesh; also mixed with water and sprayed as above stated.

DANFORTH CHEMICAL Co. Gentlemen: I sprayed a part of my peach and apple orchards the past season with Bug Death alld Burdeaux ilixture, and the results were very much more satisfactory than where Paris Green and Bordeaux Mixture was user the same day on the same variety of trees. The spraying was done but once, and that soon after the blossoms fell. I shall use Bug Death next year and shall try it without Bordeaux Mixture as I believe it spraying was done but once, and that soon after the blossoms fell. I shall use Bug Death next year and shall try
will give excellent results alone. ALDEN DERBY.

WOLFVille, N. S., Sept. I4, Ig02.

Messrs. Bug Death Chemical Co., St. Stephen, N. B. Dear Sirs: I was induced to use Bug Death this season on my apple trees beside Paris Green to test the value of Bug Death. I find that it does not burn the foliage and it kills the canker worm as well as Paris Green. and that it leaves the leaves in a better condition. I think it will be the coming spray for orchards when it is a little better known, as it is NON-POISONOUS which makes it better to handle, and it will kill the worms and won't hurt the foliage. A great many of the farmers will try it next year. Yours truly, $\quad$ J. W. BIGELOW, Fruit Grower.

Pres. Nova Scotia Fruit Growers' Association.

\section{ARSENATE OF LEAD}

Is the best insecticide known for leaf eating insects because it kills quickly. Trees or plants sprayed with Arsenate of Lead and water are quickly freed fom their insect pests. It cannot injure the most delicate pound to ten gallons of water has been us: d on youns, tender leaves without injurious effects. There is absolutely no danger of scorching or burning the leaves. It adheres to the foliage for weeks. Respraying after rains is the varnish-like film, whicl is not affected by dew or rain. One thorough sprayiug will protect the foliage for an entire season.

Ib. Tin Cans, at 20c. per lb.

20 lb. Wooden Pails, at r7c. per $1 \mathrm{~b}$.

5 lb. Wooden Pails, at Inc.

$501 \mathrm{~b}$.
I00 $1 \mathrm{~b}$. Kegs, at $16 c$

Whale Oil soap. For destroying insects ou plants, elc.; iu sinall boxes. Per 1b. I5c.; 5 1bs. $50 \mathrm{c}$

Spunish Pink. Non-poisonous to man or beast; kills cabbage willow or weh worns, caterpillars, rose alll jotato bugs. Excellent for squash,

Paris Green. A poisonous, insoluble powder for preventing the ravages of potato bugs, codliug moth. caterpillars, slugs and bugs. Mix I pound to roo
pounds of plaster, or 200 gallons of water. May be used clear with the Leggett \& Hotch kiss guns. Per 1h. 25c, 5 bs. \$1.00

Dry Bordeaux Powder. For preventing hiight on grapes, potatoes and other crops that are subject to rust, mildew and black rot; applied dry wilh bellows. I lh, 15c, 5 lbs, $75 \mathrm{c}$.

Dry Bordeaux Mixture and Paris Green. It kills potato bugs and all plant-eating pests, prevents bliglit and rust. keeps potato and tomato vine. oxes, per lb $20 \mathrm{c}$

Lion Brand Bordeaux Mixture (Liquid). This mixture is put up in one gallon patent cans. Retail tor $\$ 1$.ro. Une gallon will make 50 gallous by the addition of 49 gallons of water. Gallon caus, $\$ 1.00$.

\section{THE EUREKA FLY KILLER.}

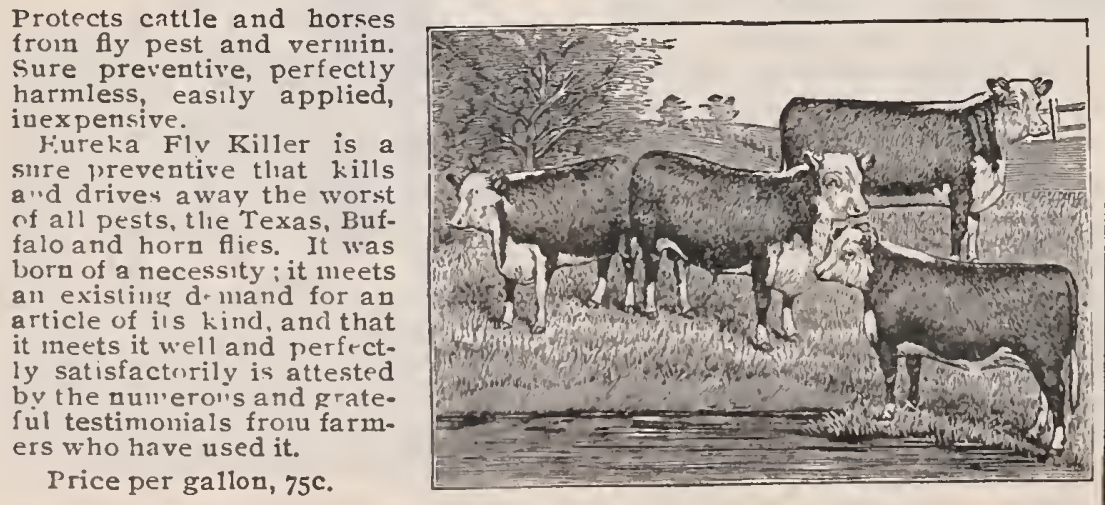

Morrill's Canker Worm

\section{Exterminator.}

A sure protection for fruit trees and Jriamental trees from the ravages of the grub and canher worm. As easily a pplied as paint ba ud of tarred paper six inclies in width, securtly $f$ astened around the tree four feet above the ground, then coveling the paper thoroughly with the exterilinator, using a common paint brush. For $21 \mathrm{lb}$. can, $30 \mathrm{c} ; 3 \mathrm{lb}$. caus, \$I.10: $201 \mathrm{~b}$. cans $\$ 200$.

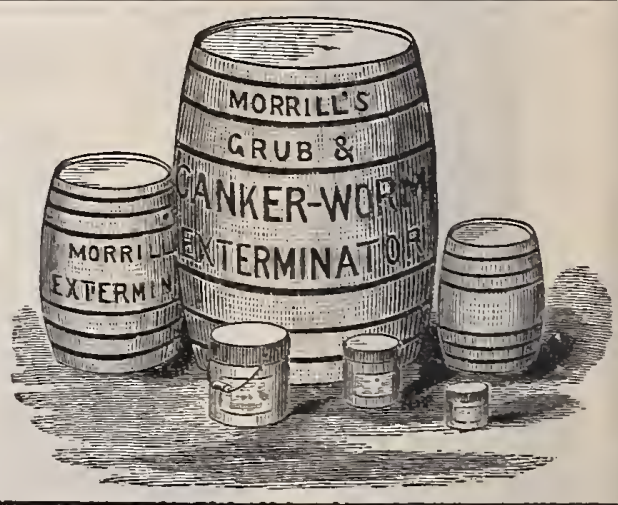

COAL TAR. In quart tin boxes. For tarring corn to prevent crows from pulliugr it. Percan, $25 \mathrm{C}$

LONDON PURPLE. Used by some in place of Paris Green. Per 1b. 25c.

HELLEBORE. Sure death to the currant worm. Per $1 \mathrm{~b} .25 \mathrm{c} ; 1 / 21 \mathrm{~b} .15 \mathrm{c}$;

TOBACCO AND WHALE OIL SOAP. Something new to prevent scale green and black fil, mealy bug and red spider on greenhouse plants, and hills lice ou dogs a ud poultry. P1ice, 25c.

TOBACᄂO STEMS. Indispensable for fumigating greenhouses and conervatcries; for destroyiug aphis, should be dampened before using, and use small handlul on some dry shavings, and light it. Price per roo lbs., \$I, 5

TOBACCO DUST. Kills green and black fly, etc., if dusted on when the plants are moist. Also good to mix in the soil to destroy ground insects. Gillall size, roc, for roo $1 \mathrm{bs}$. $\$ 2.00$.

CONKEY'S RUUP CURE is the only remedy that will positively cure roup in all its forms. It is simply put in drinking water and the chicken takes its own medicine. It prevents

(iKEELEY'S KOUP CURE. The result of twenty-five years' experience. sure cure if nsed in season. Price, 25 cents.

LAMBERT'S DEATH TO LICE. As its name implies, it is sure death to ice on hens and chickens. It is harmless to huntan and aninal life. Should used on setting hens; it will not injure the eggs or harm the youngest lick. Large size, 50 cents ; snall size, 25 cents.

LEE'S LICE KILLER is a liquid preparation; comes in tin cans; highly

DR. HESS' HEALING POWDER. A great antiseptic powder. Cures galls nd open wounds. $4^{-0 z}$. box, $25 \mathrm{c}$.

\section{DR. HESS' INSTANT LOUSE KILLER.} KILLS LICE.

Put up in round can with perforated top ready for use in one and three pound packages. The large size is the cheaper. You get three pounds for 60 cents and with the handle it is just as convenient as the smaller size. Large size, $60 \mathrm{c}$; small size, $25 \mathrm{c}$.

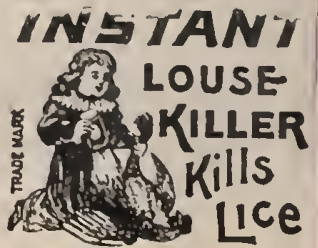



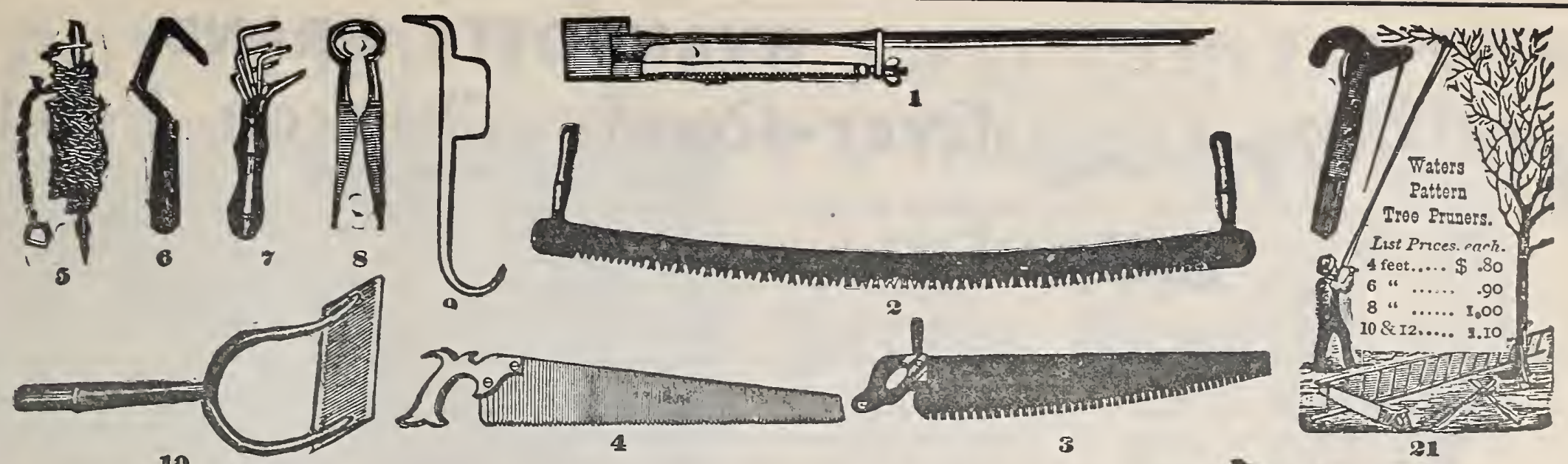

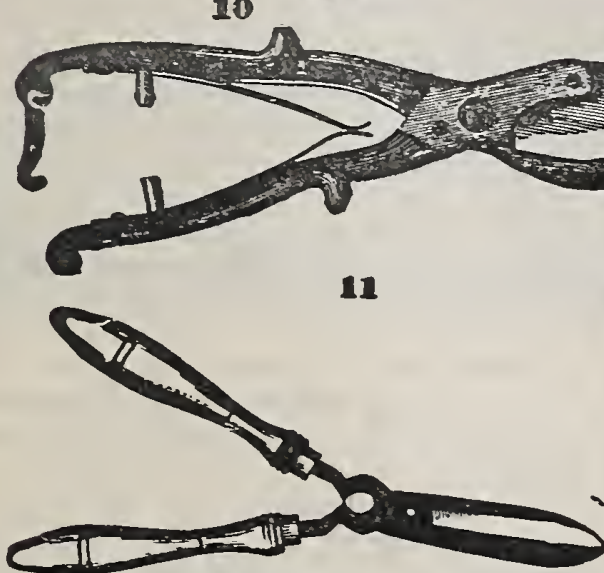

13

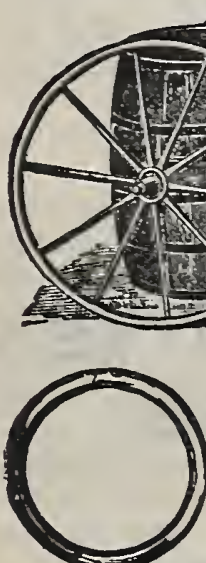

BULL RINGS. 15

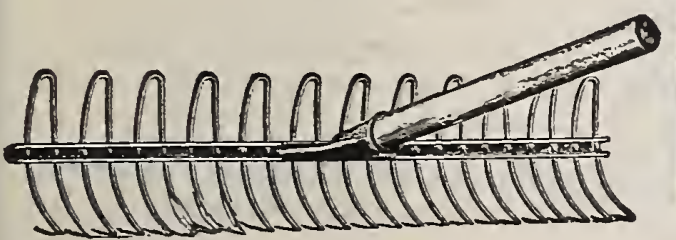

20

Hedge Shears, Border Knives, Scuffle Hoe, Weeders, Etc.

Pruning Saw and Chisel, (Fig. I) .. ................. $\$ 2.00 ; 4 \frac{1}{2} \mathrm{ft} ., \$ 2.25$.

Narrow Tree Saw, (Fig. 2) with handles, $4 \mathrm{~T} / 2 \mathrm{ft}$., $\$$ I.I5; $5 \mathrm{ft}$., \$I $25 ; 5 \mathrm{~T} / 2 \mathrm{ft}$., \$r.40; $6 \mathrm{ft}$., \$r. 50 .

Pruning Saw, (Fig. 4) 6oc.; Double Eidged, Fine and Coarse Teeth, Straight Blade, I6 in, 50c.; I8 in. 60c.; Curred Blade, 16 inch, 50 cents; i 8 inch, 60 cents.

Tethering Chain, (Fig. 5) with Stake, $20 \mathrm{ft}$. \$1.65; $30 \mathrm{ft.}$, $\$ 2.00$.

Werder.-Hazelton's, (Fig. 6)........................

Weeder.-Secor, (Fig. 7) ...........................

Seep Shears, (Fig. 8), used for grass, 25 cents; polished, 60 cents.

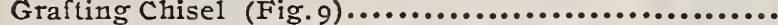

Scuffle Hoe, (Fig. Io), 6 inch, 45 cents; 7 inch, 50 cents; 8 inch, 55 cents ; 9 inch, 60 cents.

Pruning Sliears. (Fig. II) 25, $30,35,50$ and $\$$ I.00.

Garden Sy:inge, Brass, (Fig. I2) No. A, I2 inch barrel, $\$ 2.00$; No. I2, 14 inch, $\$ 3.00$; No. 2 , I4 $1 / 2$ inch, $\$ 4.00$.

Hedge Shears, (Fig. I3) No. I00, 9 inch, \$r.50; No. IOI, notch in blacle for large limbs, $\$$ I. 75 .

Water Barrel Truck, (Fig. I4) without barre1, including

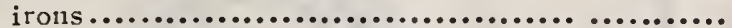

Bul1 Rings, (Fig. I5) Copper, 2 I/2 inch, 25 cents; 3 inch 30 cents.

Post Ho:e Digger, (Fig. I6) Gibbs patent............... Lawn Rake-The Queen,(Fig.20) Wire, tinned, 60 cents; The Parason Wire, wood head, 40 cents.

Animal Tether-Wright's patent, (Fig. 22) animals cannot get entangled................................

Calf Feeder, Small's, (Fig. 23) \$2.00; extra nipples, $25 \mathrm{C}$. Wood measures, Oak, (Fig. 24) Full set, sealed, \$r.25; I qt., ro cents ; 2 qt. I5 cents ; 4 qt., 25 cents; 8 qt., 30 cents, $1 / 2$ bushel, 50 cents.

Corn Tie, Holdfast, (Fig. 25) per hundred \$1.50

Carver's, per hundred, 60 cents; per thonsand ............................ Malleable Iron, I2 teeth, 25c; I4 teeth, $30 \mathrm{c}$; 6 teeth, 35 cents.

Cast Steel Rake, I2 teeth, $45 \mathrm{C}$; I 4 teeth, $50 \mathrm{O}$; I6 t eth................................

Wood Lawn Rake, 24 teeth, 50 cents ; 22 teeth.................... Iron Hitch Post, (Fig. 26) with Chain........................... Wood Hitch Post, Iron Cap....................................... Feed Bags (Fig. 27) Iroquois, 85 ccnts; Whitaker, 75 cents; B. O., 60 cents; Brave, 60 ce nts ; Modock........................

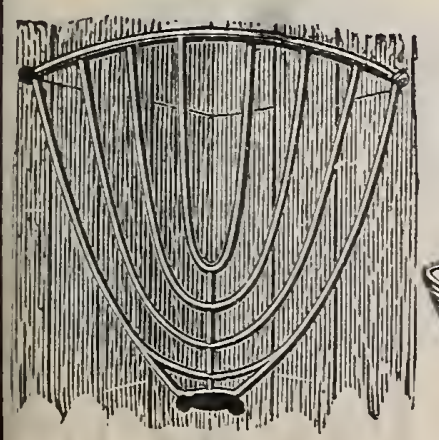

30
Corner Hay Racks, (Fig. 30) cast.............................

\section{$\$ 1.00$}

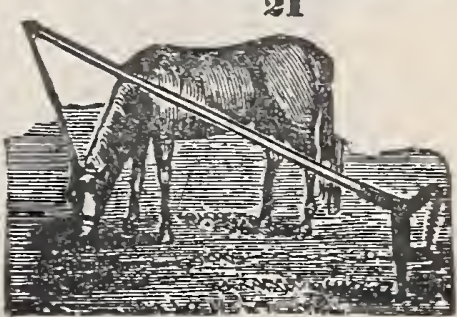

22

.25

.10

.50

6.00

1.50

2.75
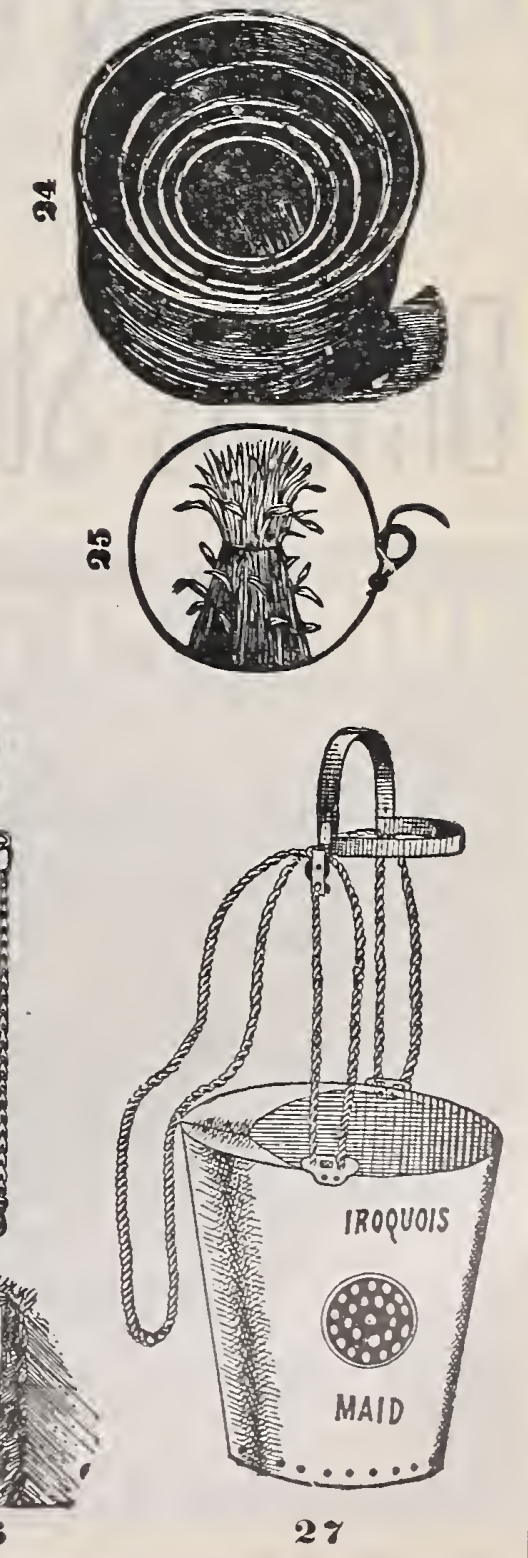


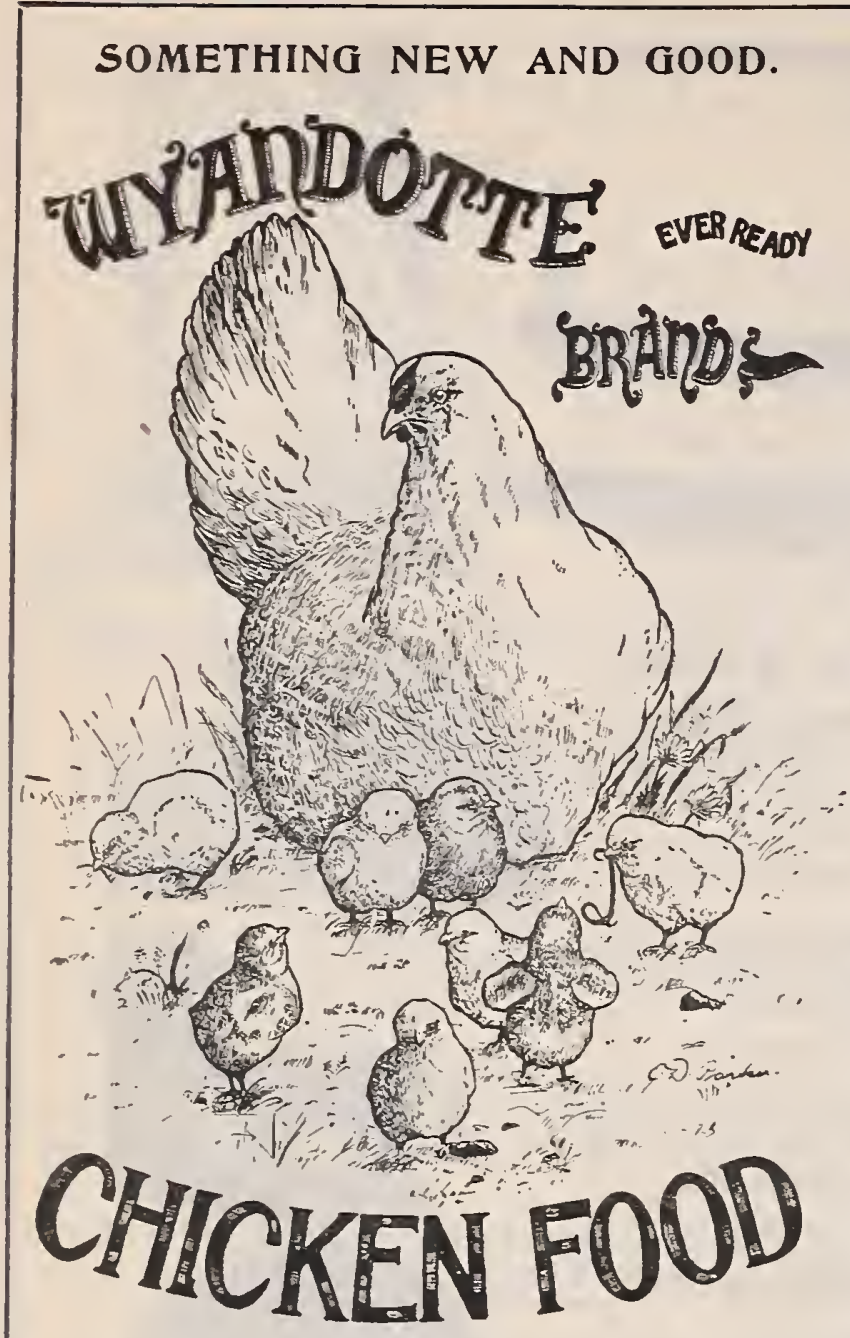

WYANDOTTE BRAND

Ever $=$ Ready Chicken Food.

COR a number of years past we have felt the need of a Chicken Food that could $\checkmark$ be fed to young chickens just out of the shell, that would be much better than the common grain usually fed and be a safe and nutritious food, and something that could be sold at a medium price, so that any one raising chickens, no matter how few or many, could afford to feed it. Thousands of young chicks are lost annually by feeding wet food when first hatched. This food is given dry and will take the place of all kinds of grain. Wet or even moist food of any kind should never be fed to young chicks, if you expect to raise them.

For the first 24 or 36 hours, hard boiled eggs should be fed. Those tested out as not being fertile will answer that purpose. After that, feed nothing but Wyandotte Food until they are large enough to to eat whole grain. Feed this often and give them plenty of fresh water within handy reach.

Wyandotte Food is not an experiment and is not put up in fancy packages or sold at drug-store prices, but is something we mix ourselves, and there is nothing used that cannot be fed alone with perfect safety, and much less when mixed together. In preparing the food our aim has been to get a safe and nutritious food that would be a balanced ration without the use of any other kind of feed.

It contains the choicest imported Bird Millets, fine cracked charcoal, free from dust and thoroughly dried cracked corn and wheat. To this we add a small amount of fine oyster shells and grit, as these two articles are as important as the first named. The sale of the food has been wonderful in the short time we have had it on the market. We ask you to give it a trial and we are confident that we shall have you as a permanent customer. Where we expected to sell tons last season we sold carloads, and we could print testimonials by the yard from parties who have used it and many of them have tested it carefully beside all other kinds of feed.

There never was a time when the outlook for raising Broilers and Poultry was as promising as at the present time, but success can only be had by knowing how to feed to get the best results for the money expended. Order a trial bag and if you have not tested it before, try it with other foods and note the results. Wyandotte Food is put up in 25, 50 and $100 \mathrm{lb}$. bags, and if you cannot get it in your town write us and we will mail you a sample free, if you will give us the name of your local grain dealer.

Trade Mark Registered $\quad$ Retail price $25 \mathrm{lb}$. Bags, 75 cents. $50 \mathrm{lb}$. Bags, $\$ 1.35 . \quad 100 \mathrm{lb}$. Bags, $\$ 2.50$. Grain and Feed Dealers write for wholesale prices.
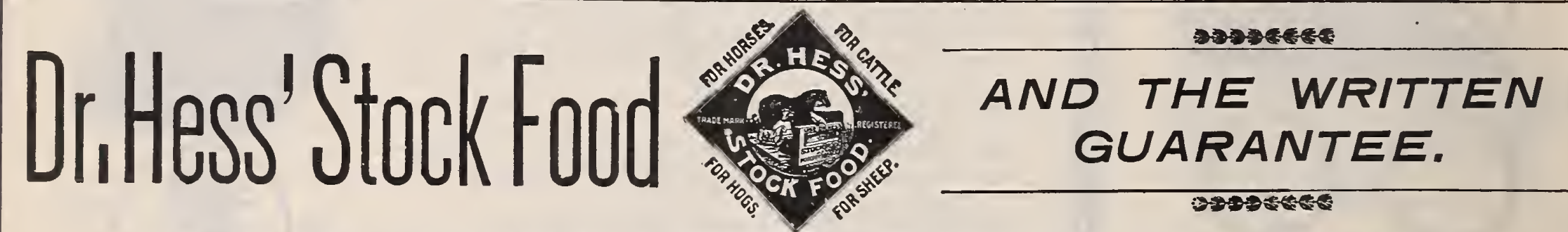

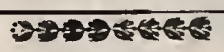

Two Mighty Principles Combined for the security of the Farmer.

\section{The Written Guarantee compels us to refund your money if it fails to fulfill every claim.}

Dr. Hess' Stock Food is the great stock tonic and milk producer. By so strengthening and improving the digestion the animal is enabled to appropriate every particle of nutrition from the food fed, thereby saving feed and compelling the quicker formation of fat, bone, muscle and milk, shortening the feeding period of the average animal at least thirty days.

$7 \mathrm{lb}$. Package Dr. Hess' Stock Food............... \$.50 25 lb. Pail Dr. Hess' Stock Food.................. \$1.60

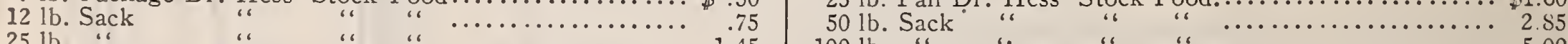

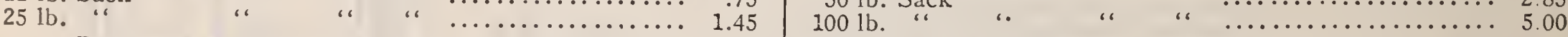

Dr. Hess' Stock Food is recommended by eminent scientists as the logical preventive for diseases and epidemics which frequently attack a communit

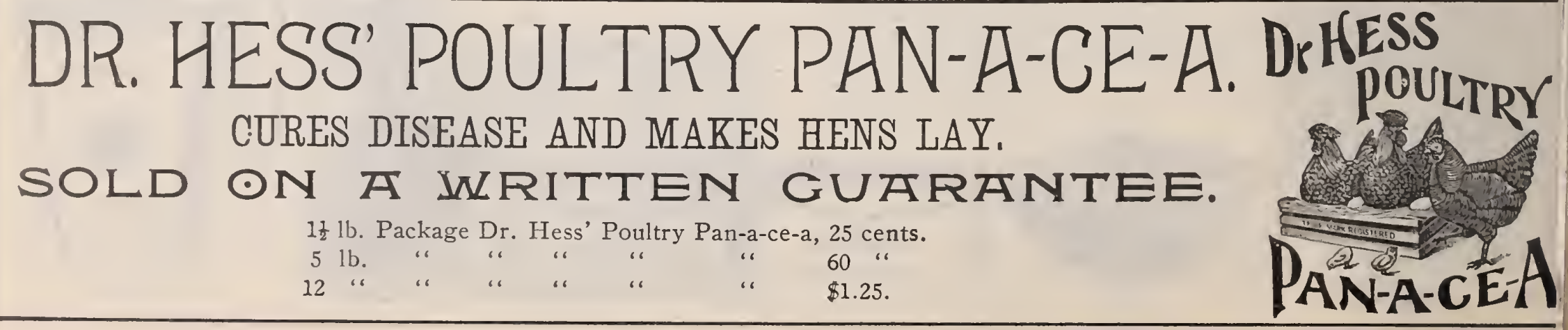




\section{POULTRY FOODS AND CONDITION \\ POWDERS of ALL KINDS.}

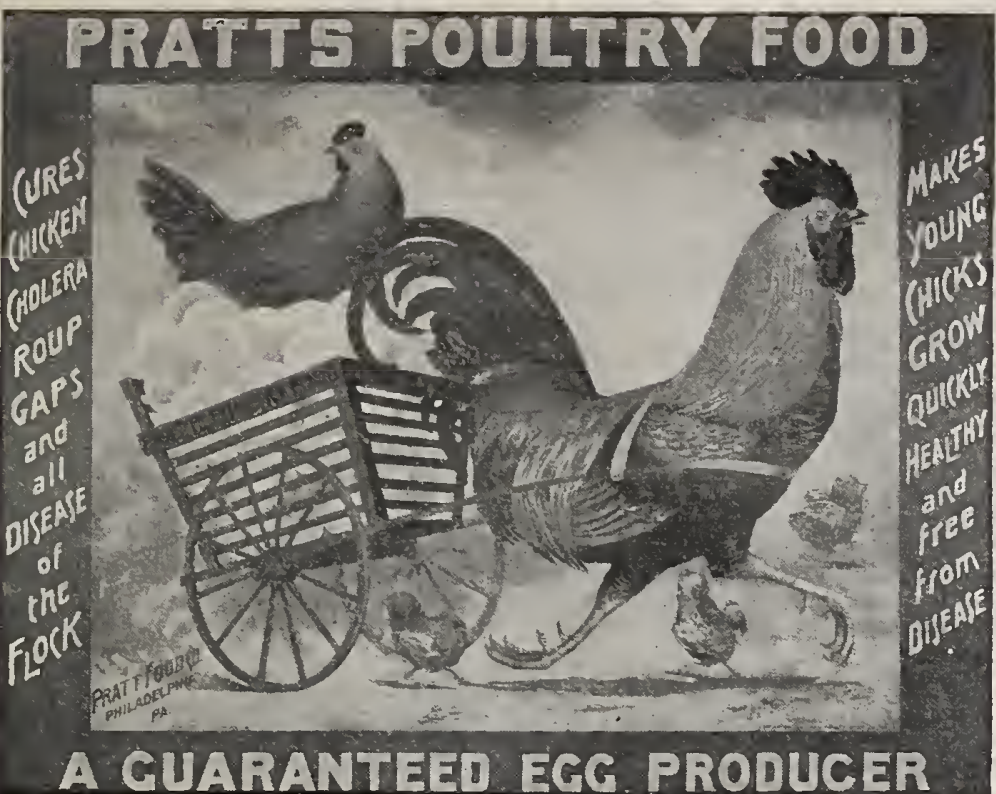

We Handle Poultry Supplies in Large Quantities, and We Have a Large Assortment of the Reliable Brands to Choose From.

\section{Mratts

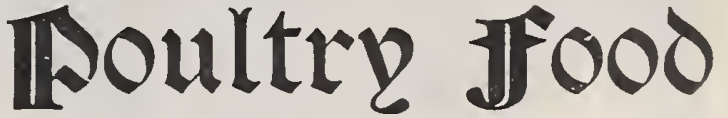

is the Standard. We have sold it for nearly ten years and our trade is constantly increasing. To obtain the best results it should be fed regularly. It keeps the poultry in a good, healthy condition, which is necessary to egg production.

P R I C E S.

Poultry Food, large size, each.......................\$.60

Poultry Food, small size, each...................... . . 25

Poultry Food, 12 lb. bags, each ..................... 1.25

Poultry Food, 25 lb. bags, each ..................... 2.50

Old Fashioned Beef Scraps. These Scraps are ground fresh for us, and do not contain any oyster shell or tankage, but are good fresh bone and meat. Per 100 lbs., $\$ 2.25$.

Cracked Bone. Fresh cracked bone, without any meat, will keep for any length of time. Should always be kept in a box where the hens can get to it. Per $100 \mathrm{lbs.,} \$ 2.00$.

Ground Oyster Shells. We buy shells direct from Baltimore in one hundred ton lots, and handle nothing but the best grade, free from dust. Per 100 lbs., 60 cents.

Granite Grit. This is the best Milford Grit, crushed to just the right size for poultry or pigeons. Per 100 lbs., 75 cents.

Clover Meal. This is the latest and best food for all kinds of poultry. It is clover as near pure as can be had, finely ground, and is mixed with other kinds of feed, and being light, it makes a very nutritious food and is also an egg producer. Per 100 lbs., $\$ 2.00$.

Cut Clover. This is same as above, only cut about one-quarter of an inch long, and is either fed dry or mixed with feed. Per 100 lbs., $\$ 2.00$.

Sea Shells. This is similar to common oyster shells, only they are very small shell and are fed whole, and as they contain a large amount of meat, are a grand egg producer. Per barrel of about 150 lbs., $\$ 1.75$.

Sheridan's Condition Powders. These goods are known in every town and need no recommendation from us. Large size, regular $\$ 1.00$ size, our price, 80 cents; small, 20 cents.

Dole's Horse, Cattle and Poultry Food. This is one of the best foods for either of the above. Once tried, always used. Large box, 75 cents.

Meat Meal. Is finely ground meat and blood, and is preferred by many to Beef Scraps, as it may be mixed with wet feed and prevents waste. Per 100 lbs., $\$ 2.00$.

Desecated or Dry Ground Fish for poultry. This is a great egg producer and takes the place of beef scraps, which are so hard to get at the present time. The price is also much lower than scrap. Per 100 lbs. $\$ 2.00$.

Glass Nest Eggs. Each, 5 cents. Dozen, 30 cents.

Kaffir Corn. This is probably one of the best, as well as the cheapest, food for hens, chickens or pigeons. It is about the size of a very small pea, and is fast taking the place of other grains for poultry food. Try it. Per $100 \mathrm{lbs}$., $\$ 1.75$.

\section{PRATTS HORSE, CATTLE AND HOG FOOD, WHAT PRATT'S FOOD WILL DO FOR HOGS.}

Hog cholera is positively unknown where Pratts Food is fed. Pratts Food positively prevents and cures hog cholera in its early stages. We have cured many cases of hog cholera when the animal has been too weak to stand and given up to die. It is to be remembered that Pratts Food is to be fed to prevent cholera as well as to cure it. The above is also true of cattle. The constant feeding of Pratts Food, which is the best animal regulator known, will enable the cattle to receive full benefit from their food.

Hog and Cattle Food, 12 lb. bags, each 75 cents. 25 lb. bags, each $\$ 1.50$.

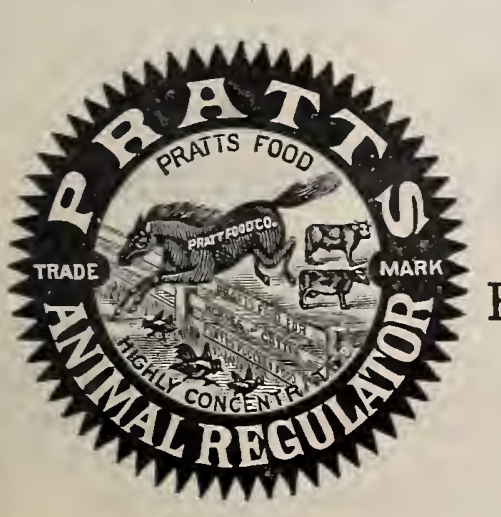

PRATT'S BOOK.

SHORT TALKS.

Every Owner of a Horse, Cow, Sheep, Hog or Hen Should Have One.

MAILED FREE: SEND FOR IT.

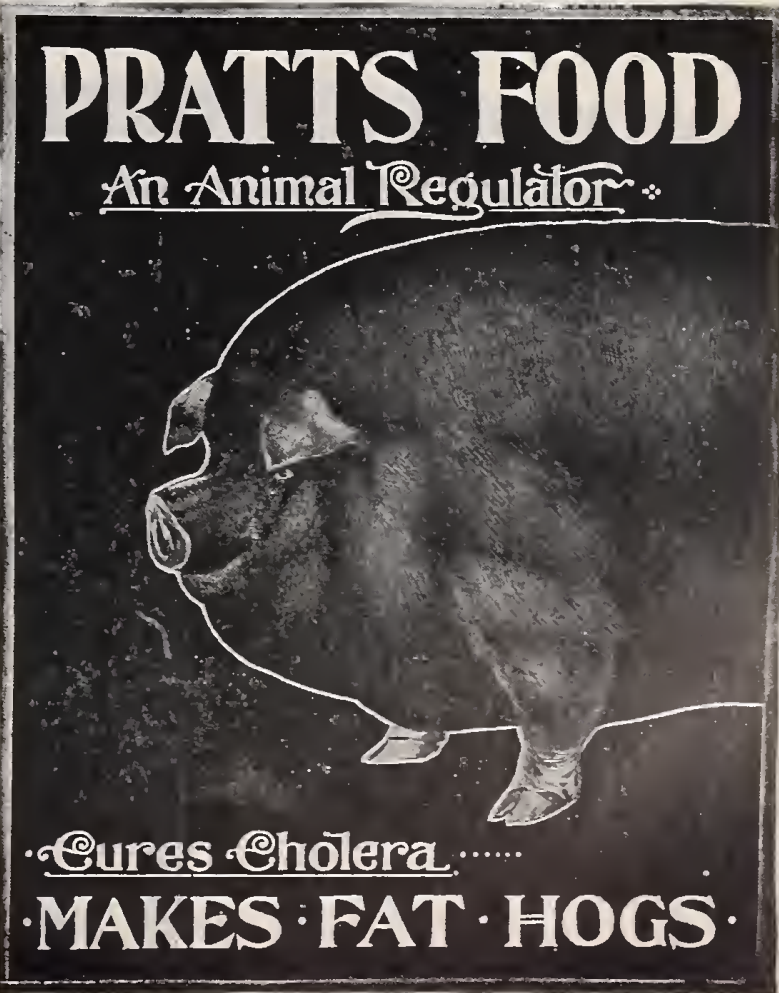




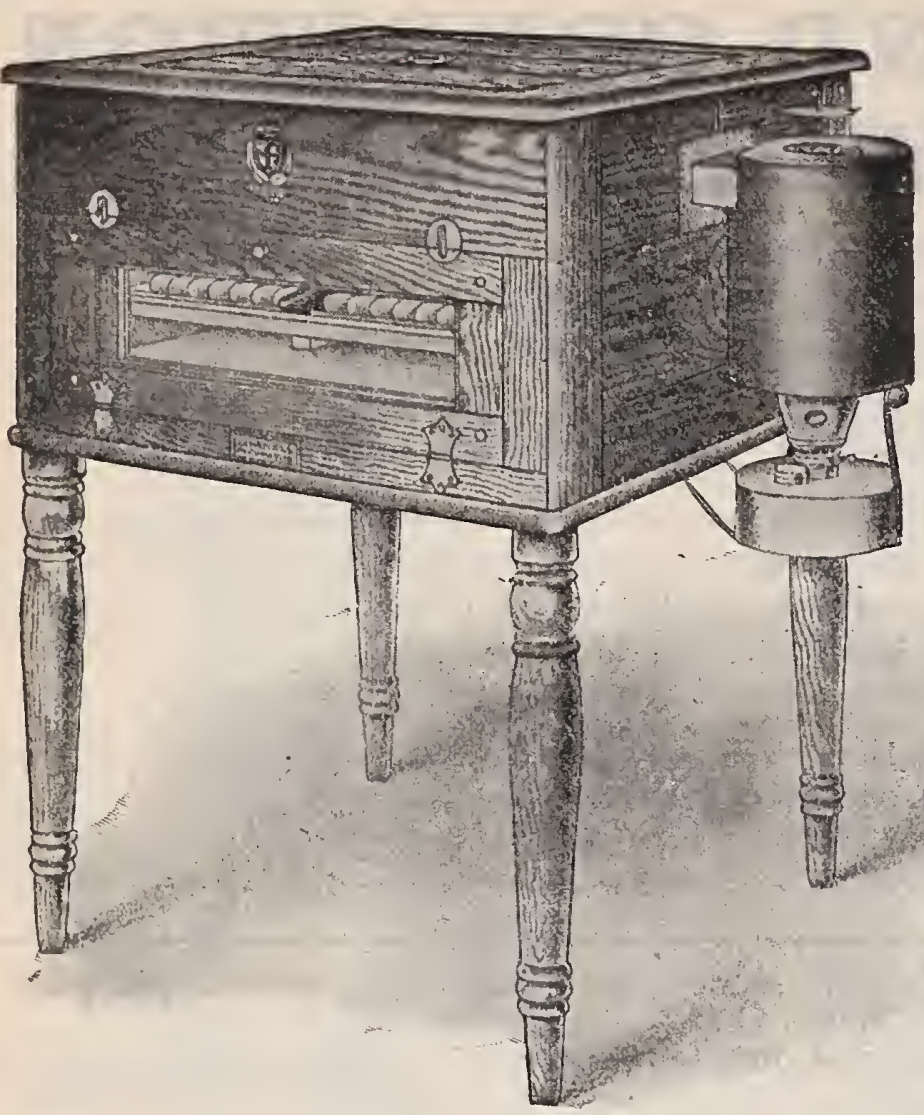

INCUBATORS and BROODERS

It is impossible in the small amount of space at our disposal to give any lengthy desciption of this important line, but we will null a complete catalogue showing the CORNELL INCUBATORS and PEEP O' DAY BKOODERS on request. We head our list of incubators with the Cornell, for we believe after carefully investigating that as it is made for 1904 , it is superior to any other make on the market. We mention only a few of its good points.

THE TABLE TOP. This to our mind is one of the most important imorovements on any incubator made, and is alone worth the difference in price that you have to pay on other makes. The regulator, as will be ser by the cut, is inside, and out of danger, and leaves the top free to use in turning and testing eggs. Many hatches have been spoiled by a cat, or p'ssibly a rat hitting or lying against the regulator during the night when the machine is left to itself. With the cornell such accidents are impossible.

THE DOOR on the Cornell Incubator is entirely original, and is found on no other make. It is practically two doors in one without that inconvenience; it being opened as one door. Fach section is insulated with felt, making it a positive fit and practically air tight.

The Cornell Incubator is the finest finished machine on the market. The Cornell Incubator is the finest fisised machine on the market. Only the best materials are used. In short, the Cornell Incubator has shown itself in the hands of numerous poultrymen to be the most successful Pan-American Exposition it took the Gold Medal as being the best incubator Pan-American Exposition it took the Gold Medal as being the best incubator there. We will gularantee every incubator to be as represented, wise, the amount paid for it will be refunded provided it is in good condition.

\section{Peep 0' Day Brooders.}

No matter how good an incubator you have, it is important that you have a safe and reliable brooder of some make. The Peep O' Day is so well known that it needs no word of praise from us. We can show here only one style, but they make several sizes and different styles, all of which are illustrated in their catalogue, which will be mailed free. When buying a brooder, be sure and get one large enough, or better still, have a greater number of only a few dollats saved in the first cost, in crowding the chicks into too close only a few doll Day Brooders are made for all conditions and all kinds of quarters. Peep O' Day Brooders are made for all conditions and all kinds of work. They are the best brooders on the narket at the present time. If you water or milk, with plenty of rcom, the results will be salisfactory iu the end.

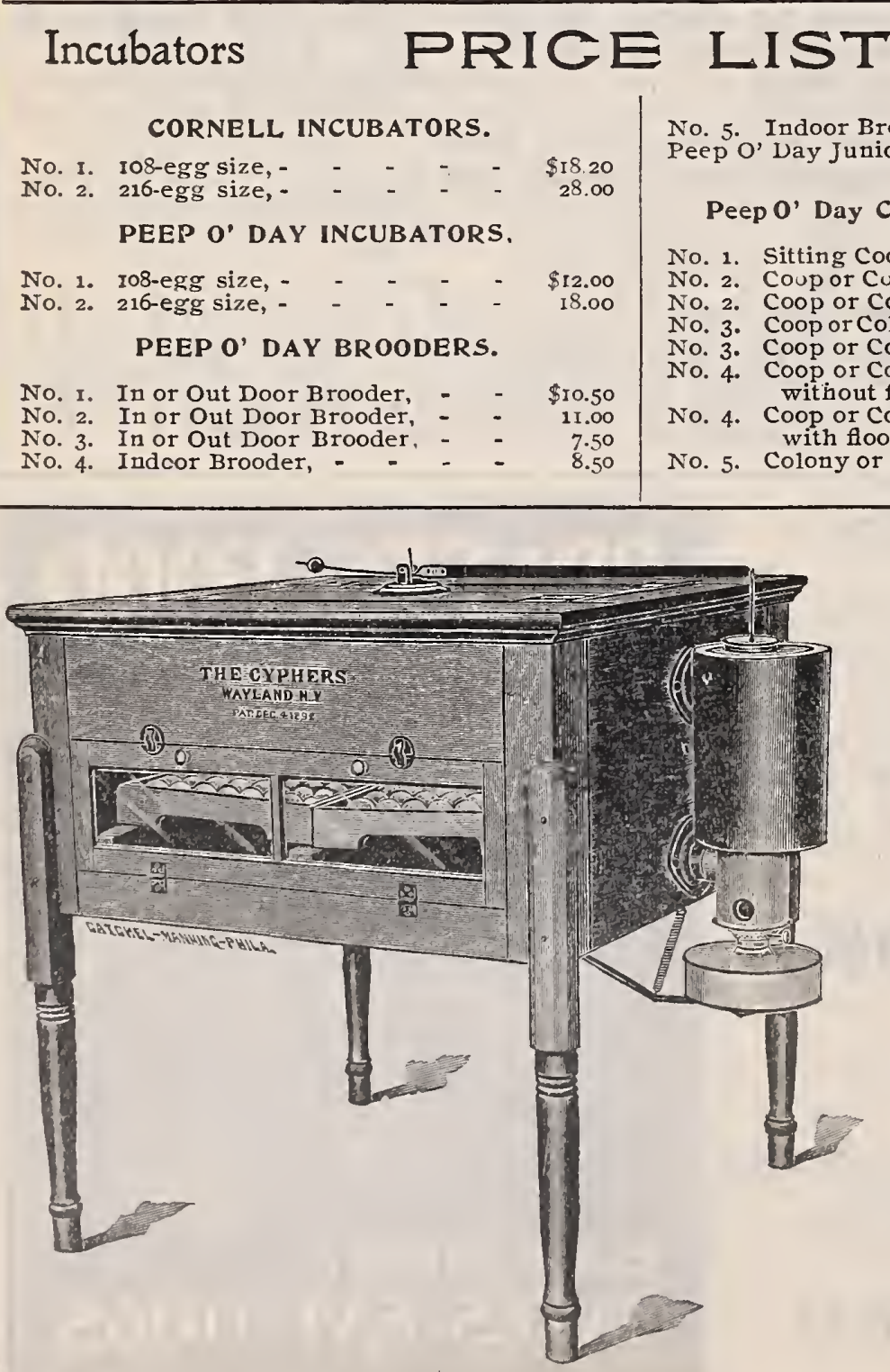

Brooders

CORNELL INCUBATORS

PEEP O' DAY INCUBATORS

No. I. In or Out Door Brooder,

No. 2. In or Out Door Brooder,
No. 3. In or Out Door Brooder

No. 4. Indcor Brooder, -
No. 5. Indoor Brooder, -
Peep O' Day Junior Brooder,

Peep 0' Day Coops and Colony Houses.

No. 1. Sitting Coop,

No 2. Coup or Culony House, without floor, $\$ 2.00$

2. Coop or Colony House, with floor, 6.00

No. 2. Coop or Colony House, without floor, 5 .00

No. 3. Coop or Colony House, with floor, 6.00

No. 4. Coop or Colony House, with run,

No. 4. Coop or Colony House, with run,

with floor,

6.00

7.00

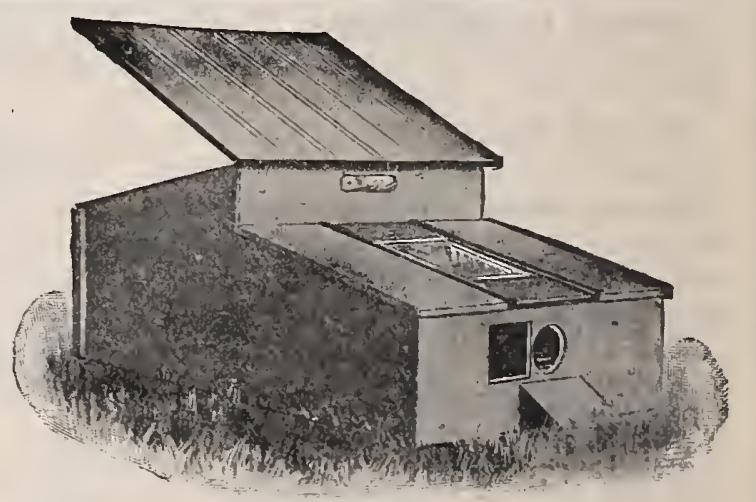

Peep $0^{\prime}$ Day Brooder No. 3, Price $\$ 7.50$

\section{Cyphers Incubators}

While we have had some complaint in the past with these machines, we believe the manufacturers are sending out a better incubator this season than ever before, and as we have bought a large lot of the latest pattern machines, we are in a position to fill orders promptly, and at the prices named, we will prepay the freight to any railroad station east of the Mississippi River. The Cyphers Incubators are too well known to need any description, and next to the Cornell, we consider them the best on the market.

\section{鿟 察 淙 \\ Price List of Cyphers Incubators.}

No. 0. 60 Hen Eggs, 48 Duck Eggs, - _ _ _ - _ $\quad \$ 14.00$

No. 1. 120 Hen Eggs, 100 Duck Eggs,

20.00

No. 2. 220 Hen Eggs, 190 Duck Eggs,

29.00

No. 3. 360 Hen Eggs, 190 Duck Eggs, _ $\quad$ - $\quad$ - $\quad$ - 37.00

No. 2. Double Decker, 440 Eggs,

58.00

No. 3. Double Decker, 720 Eggs,

74.00

Freight paid at above Prices to Any Freight Depot east of the Mississippi River. 


\section{The $=$ - \\ Old Homestead Brooder.}

THIS BROODER is built on a very different principle from most other makes. The heat is all from overhead, and there is positively no chance for the young chicks to crowd and trample on each other. It has no legs, and chicks three days old can run out and in as well as they can three weeks old. There are no pipes inside or other obstructions, and every inch of room is available. The top lifts up, which shows every chick. It has no dark corners or traps to kill the young chicks.

\section{Built in Two Sizes.}

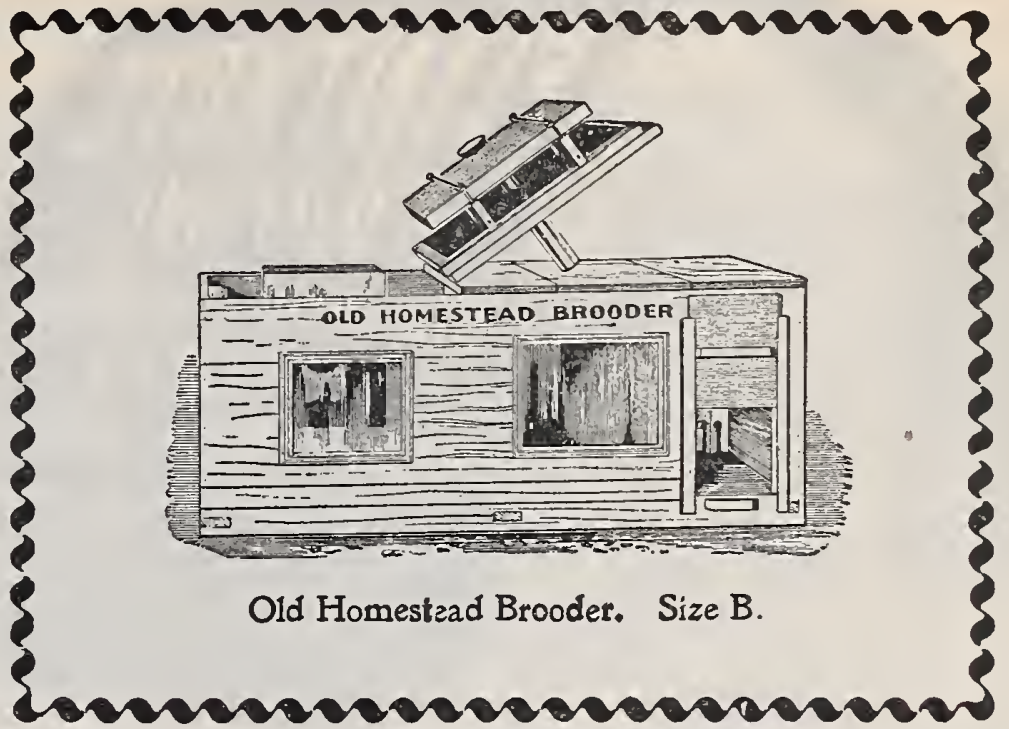

Style D, for 100 Chicks, Indoor, $\$ 12.00$ Style B, for 50 Chicks, Indoor, $\$ 9.00$

We can furnish a waterproof top and extra cover for the lamp box to the Style $D$, so it can be used as an outdoor brooder. Price for both, $\$ 1.50$ extra.

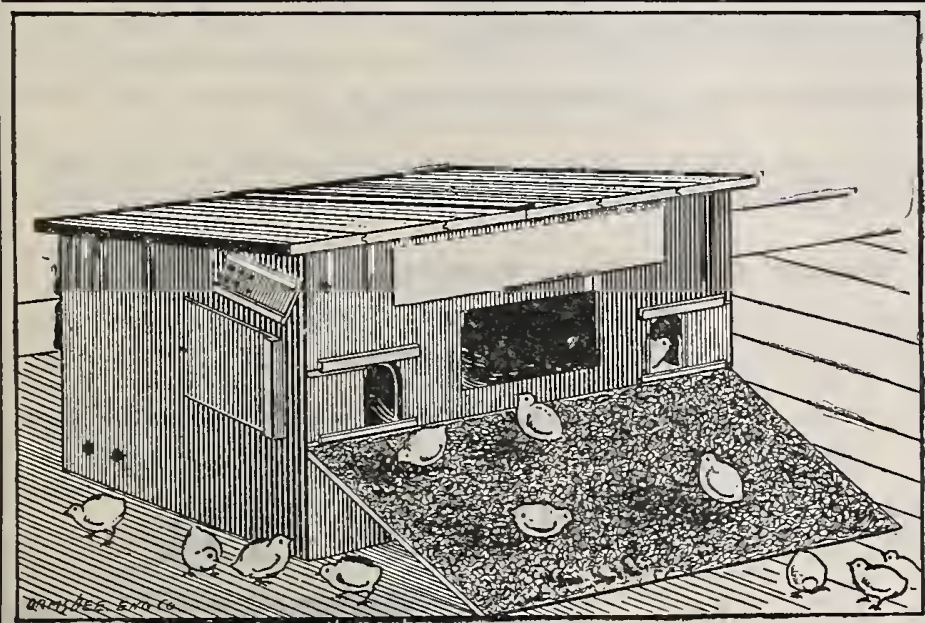

\section{PRIZE BROODER.}

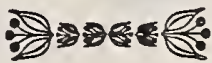

This is the best cheap brooder on the market; it is built to set close to the ground, and there is no open space for the cold to get in. The lamp is very easy of access, the floor being raised up from the ground. There is no danger of water, and for beginners who do not want to buy a high-priced Brooder we can commend this one. We have sold a lot of them and they give perfect satisfaction. Run shown in cut not included at price quoted.

Net Cash Price, $\$ \mathbf{5 . 0 0}$.

$\$ 5.00$ Outdoor Prize Brooder.

\section{Mann's New Open Cylinder Bone Cutters.}

Practical Poultrymen are for the most part concerned with facts. They want eggs when eggs are worth most, and they want to produce them at the least cost. They want to maintain the health of their flocks and promote growth. And every year more of them are demonstrating to their own satisfaction that raw bone, meat and gristle do these things.

The Fowl Demands Raw Animal Food. Every one knows how eagerly a fowl will chase clear across a half-acre lot to gobble up a bug or a worm.

When Hens Get Such Food in abundance they lay in abundance. When they are deprived of such food they do not lay so abundantly. It is the poultryman's business to see to it that they get raw animal food in some form. He can not attain the best success if he neglects it.

Properly Cut Green Bone, with meat and gristle attached, supplies this food in the most available manner. And the MANN'S provides the easiest and quickest way of preparing it. TRY IT AND SEE.

\section{NET CASH PRICE LIST.}

No Diseount from these prices.

No. 5 C, (with Crank Handle).................\$ 6.00 No. 5 B, (with Balance Wheel)................ 8.00 No. $5 \mathrm{BM}$, (with Balance Wheel and Iron Stand) 10.40 No. 7, (with Balance Wheel) ................. 12.00 No. 9, (Standard Bone Cutter, Iron Stand)..... 18.40 No. II, (Combination Power Cutter)........... 26.00 No. I2, (Small Power Cutter)................ 30.00 No. I5, (Large Powtr Cutter)................. 60.00
No. I4, (Large Power Cutter) $\ldots \ldots \ldots \ldots \ldots \ldots \ldots \ldots . \ldots 76.00$ No. I6, (Made to Order).....................225.00 Clover Cutter, (with Balance Wheel)............ $\quad 8.00$ Clover Cutter, (with Balance, Wheel \& Iron Stand) 10.00 Mortar (Perforated, Cast Iron).................. $\quad 3.00$ Swinging Feed Tray, (IS inches long)........... 1.00 Swinging Feed Tray, (27 inches long)........... 1.25 Swinging Feed Tray, ( 36 inches long).......... 1.50

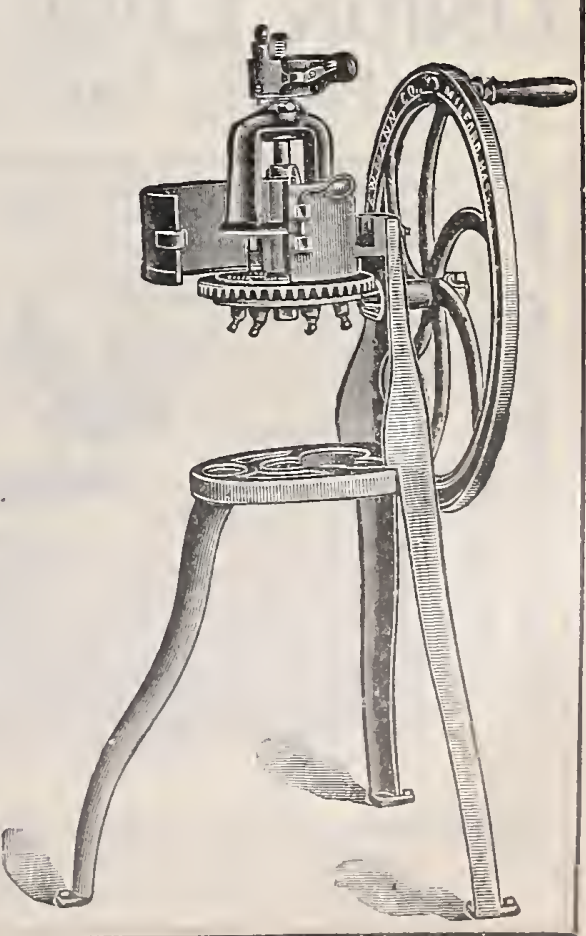




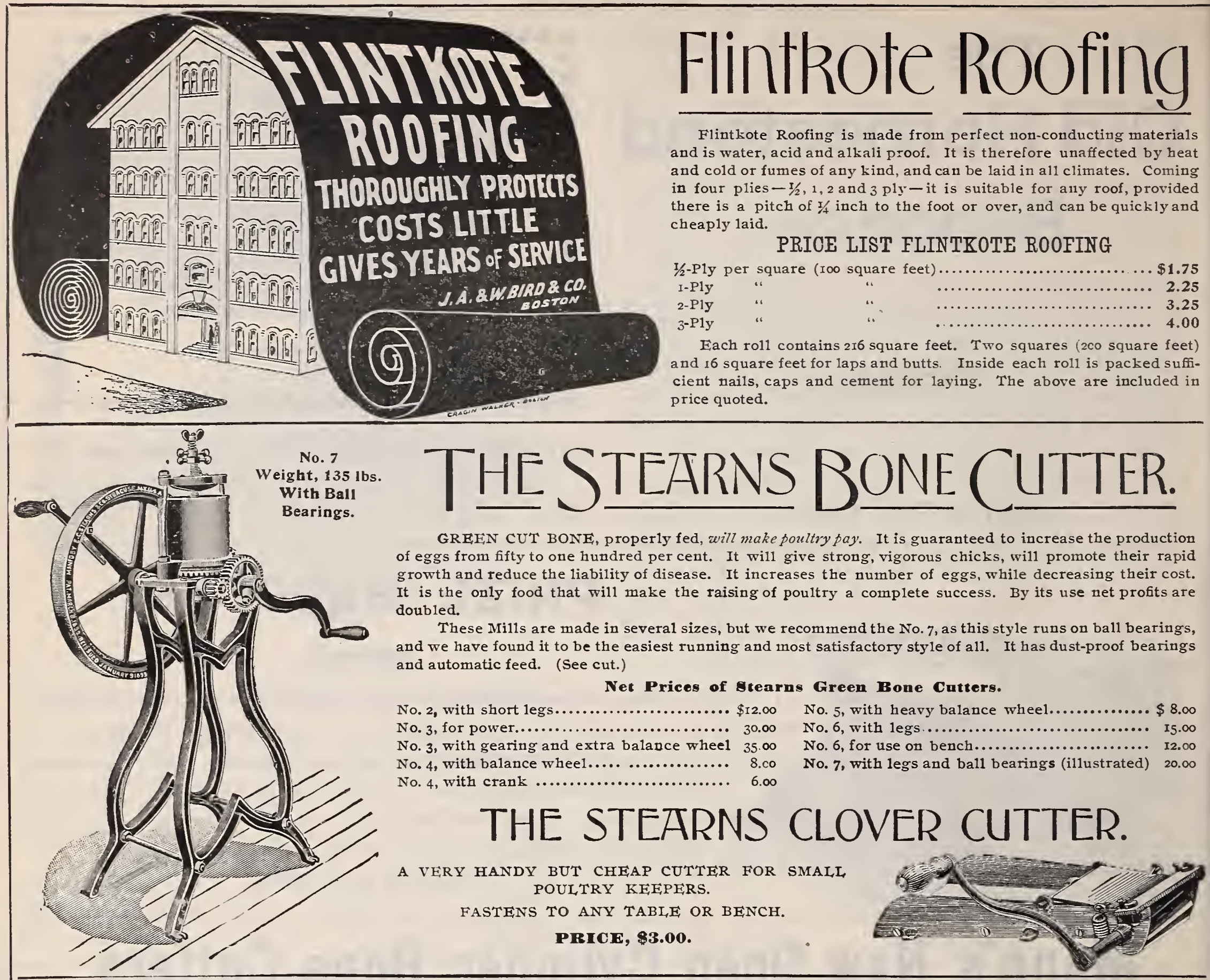

UNION LoCK POUlTRY FENCE. For Poultry, Rabbits, Orchards, Gardens, etc.

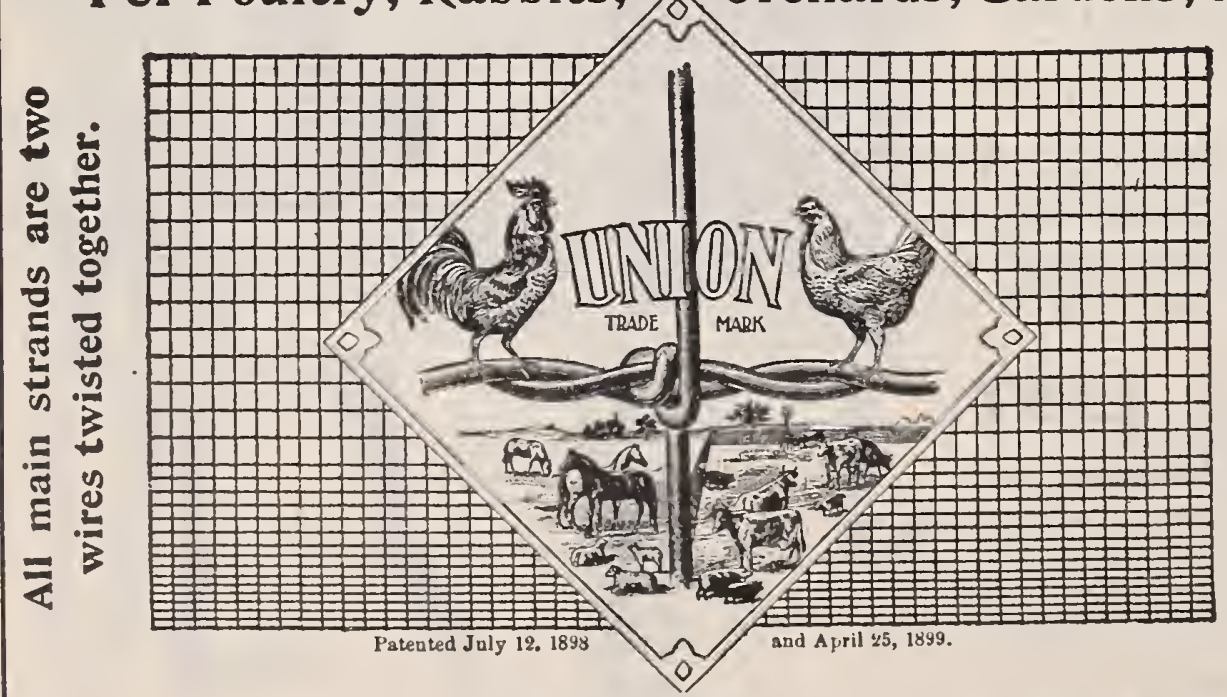

In comparing prices with ordinary poultry netting remember these bales are, 15 feet longer. We don't sell less than full rolls.
The horizontal lines of this fence are all composed of two No. 20 galvanized steel wires twisted together.

Beginning at the bottom the first seven cables are II/4 inches apart, the next three cables are $I / 2$ inches apart, then six cables 2 inches a part, and all above that 4 inches a part. - This gives a mesh of $1 / 1 / 4 \times 3$ inches at the bottom where it is $\frac{0}{x}$ only reach when on the wing, the mesh is $3 \times 4$ inches.

를

On account of the picket being at right angles to the cables, this fence will fit any unevenness of the ground without cutting, which is an advantage not possessed by any diamond mesh netting or diagonal inesh fencing.

As all of the cables are of the sane length and run the whole length of the fabric every part can be stretched perfectly. The fence is allply strong, as the breaking strain of a No. 20 two-wire cable is 192 pounds, and there are ten cables in the first foot of fence.

Because of its strength and construction this fence requires no top or bottom rail.

\section{NET RETAIL PRICE LIST.}

10 Rod Rolls (165 feet).

$24 \mathrm{in.}$ wide..\$2.80 $36 \mathrm{in}$. wide.. $\$ 3.50 \quad 45 \mathrm{in}$. wide.. $\$ 4.00$ 60 in. wide. $\$ 4.75 \quad 72$ in. wide.. $\$ 5.40$ 


\section{American Field and Hog Fences. $\overbrace{}^{\circ}$ made of galvanized woven steel wire.}

The strength and durability of the AMERICAN FENCES, together with their low cost, combine to give them a wonderful popularity.

Construction. - The main structural features are: Large and strong wires throughout; top and bottom bars No. 9 galvanized wire; intermediate bars No. 11 galvanized wire; stays No. 12 galvanized wire; stays 12 or 6 inches apart, as desired; Hinge Joints at every intersection of stay and bar; Tension Curve at every intersection of stay and bar and at proper intervals between stays.

AMERICAN FIELD AND HOG FENOING.
It is the Strongest Fence Made because of the good quality and amount of material properly distributed
throughout its entire consiruction. No. 9, No. 11, No. 12 wire as used in the AMERICAN FENCE are sufficiently heavy and strong to meet all requirements, and with them the AMERICAN FENCE is practically
everlasting, with reserve strength enough to meet every possible contingency or special use to which this fence may be subjected.

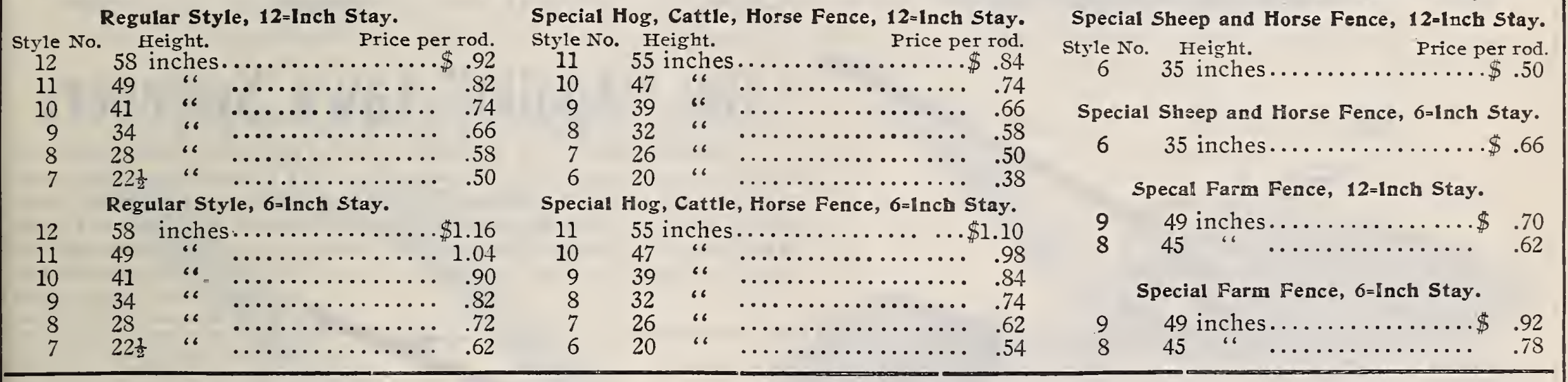

\section{Galvanized Special Twist Poultry Netting.}

A Very Popular Fence for poultry yards, or for any purpose, where a heavy stock fence is not required. This fence is woven and afterwards galvanized, which makes it very durable. We can furnish it in all widths, from one to six feet, and in one and two-inch mesh. We handle this in very large quantities, and are, therefore, in position to make very low prices, as you will see below. Parties wanting five or more rolls will do well to write us for special prices. Please take notice that the prices quoted are for rolls of 150 feet in length and not per 100 feet.

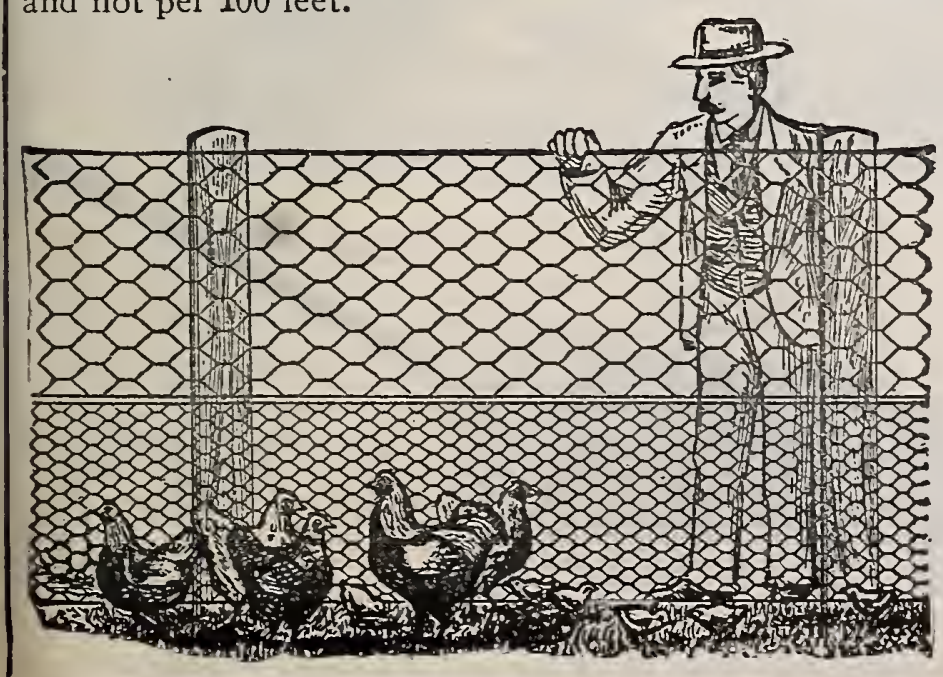

Price Per Roll of 150 Running Feet.

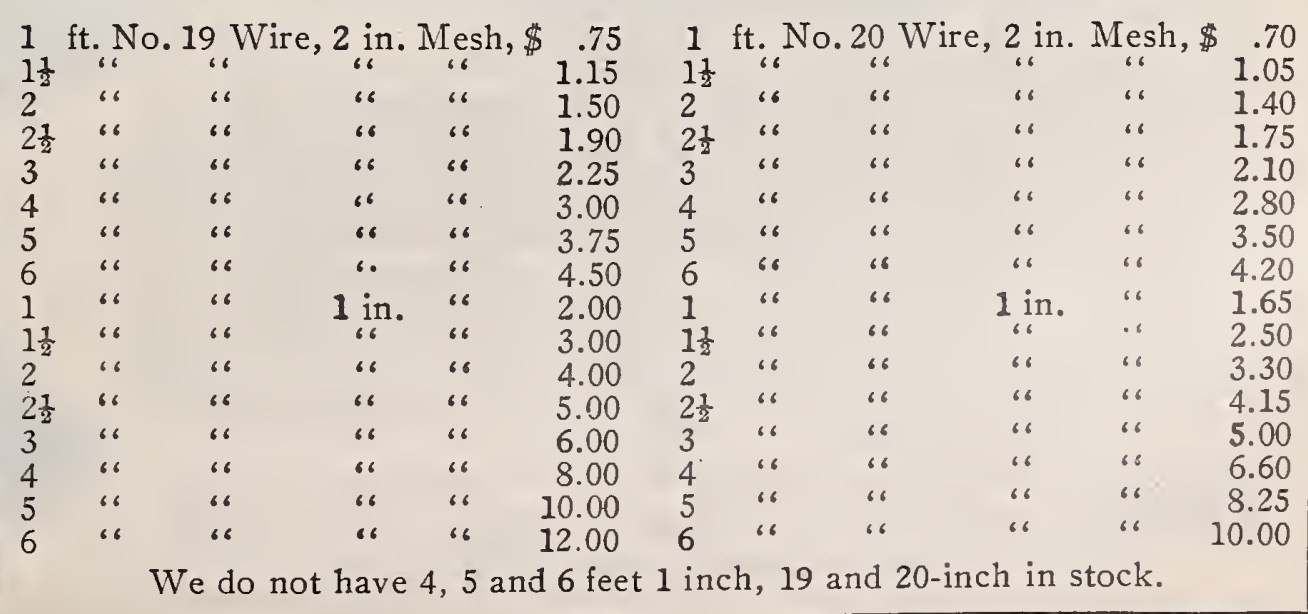




\section{* LAWN GOODS OF ALL KINDS *}

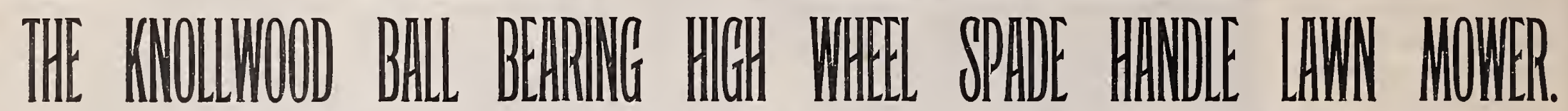

\section{A MACHINE THAT POSSESSES ALL THE GOOD QUALITIES OF OTHER STYLES.}

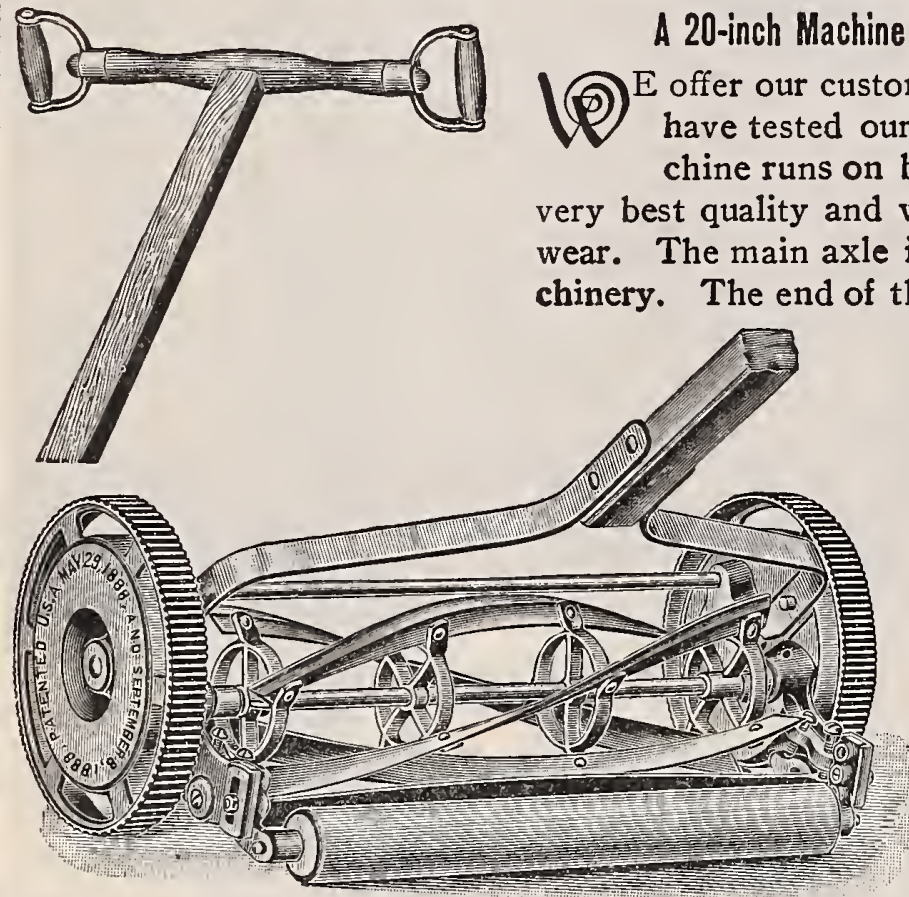

A 20-inch Machine of this make runs as easy as a 12-inch of the old style, and a Handle made to fit your hands.

themers machine not as an experiment, but as a guaranteed article, one that we

have tested ourselves during the past season, and know what we are talking about. This machine runs on ball bearings (and all first-class machines ought to). The balls used are of the very best quality and will last for years. They are enclosed in steel cups, which protect them from wear. The main axle is steel and lathe fitted and is adjusted as nice as any high priced piece of machinery. The end of the axle where it comes in contact with the balls is cone-shaped, and any possible wear can be easily taken up. The machine has a nine-inch wheel, four knives of the best quality of steel and, last but not least, a handle that is made to fit your hand. (See the spade handle in cut.) After giving you the best mower it is possible for us to get, we have put on to it a handle we have all been looking for. With this Spade Handle the operator has perfect control over the machine and can handle it perfectly on a side hill or on narrow borders. We shall make this our leading machine, and therefore shall offer it at a popular price, which is within the reach of all. We guarantee to take back every machine that is not satisfactory, after a fair trial. While this machine is the best one on the market for private homes, it is especially adapted for parks, cemeteries and large lawns, and to that class of buyers we will make special prices in quantities.
14-inch........\$6.85
18-inch.
$\$ 7.35$
16 -inch ......... 7.10
20-inch.
7.60

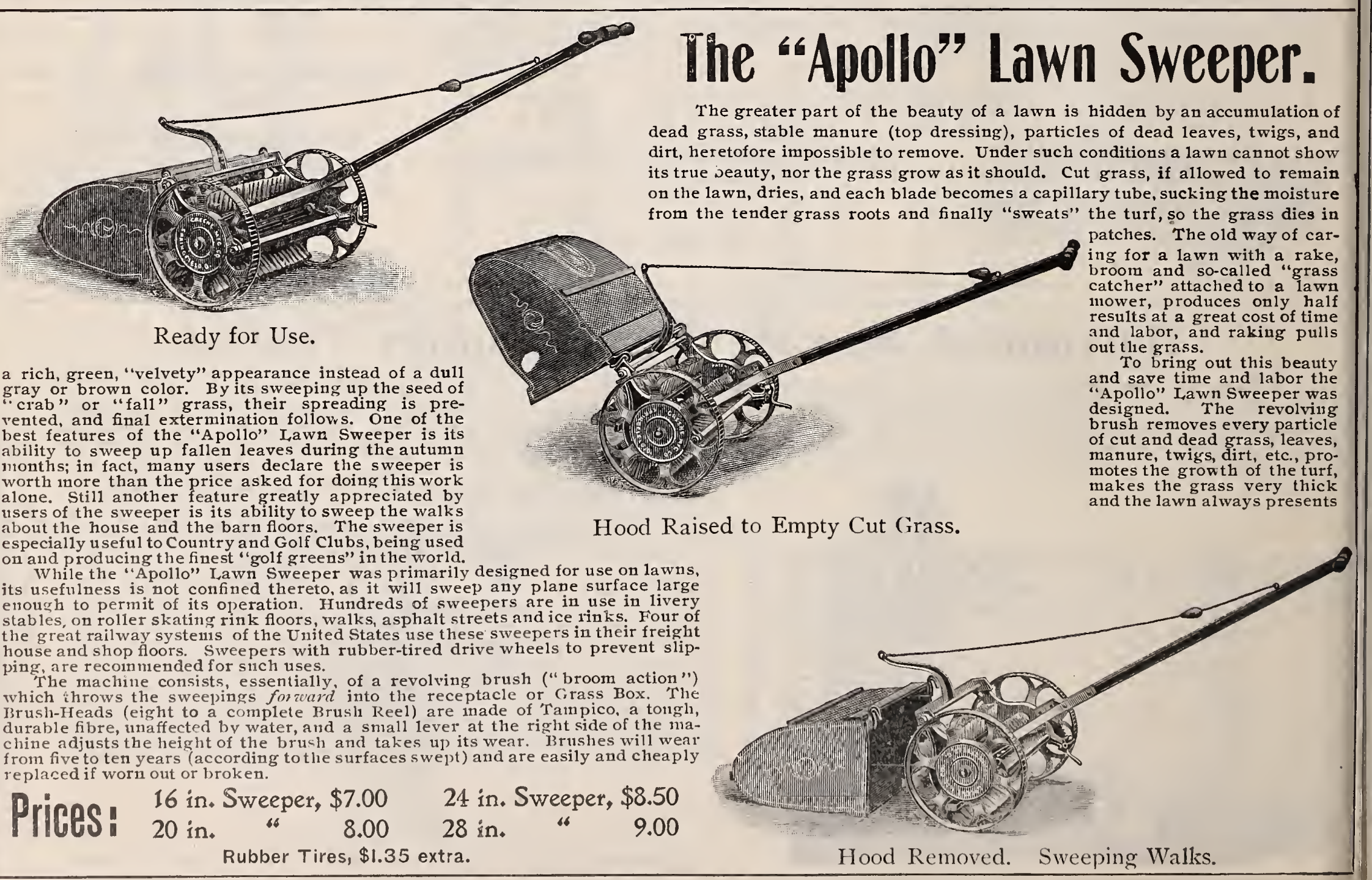




\section{The Cpcle slibower.}

Ibigh talbeel. $=$ JBall JBearings.

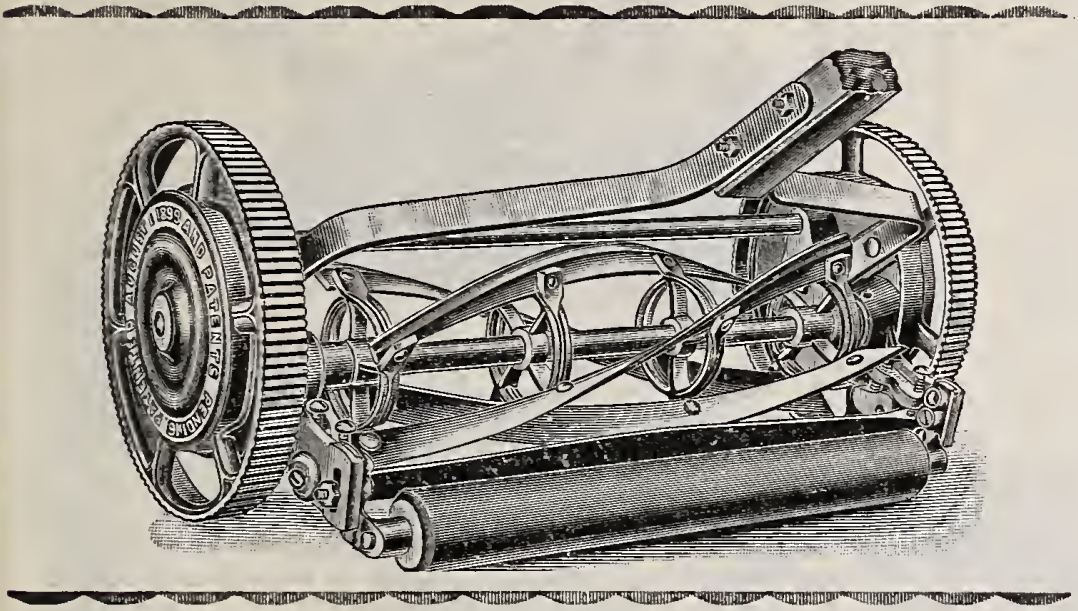

This machine, as its name implies, is built like a cycle. The ball-bearings are the best it is possible to make. It has four knives, a 10-inch open wheel, which makes it light but very strong and durable. This is our next best machine, and equals in every way the $K$ nollwood excepting the handle.

14 inch...\$7.00. 16 inch...\$8.00. 18 inch...\$9.00. 20 inch......\$10.00.

\section{The Charley TRoss Inawner.}

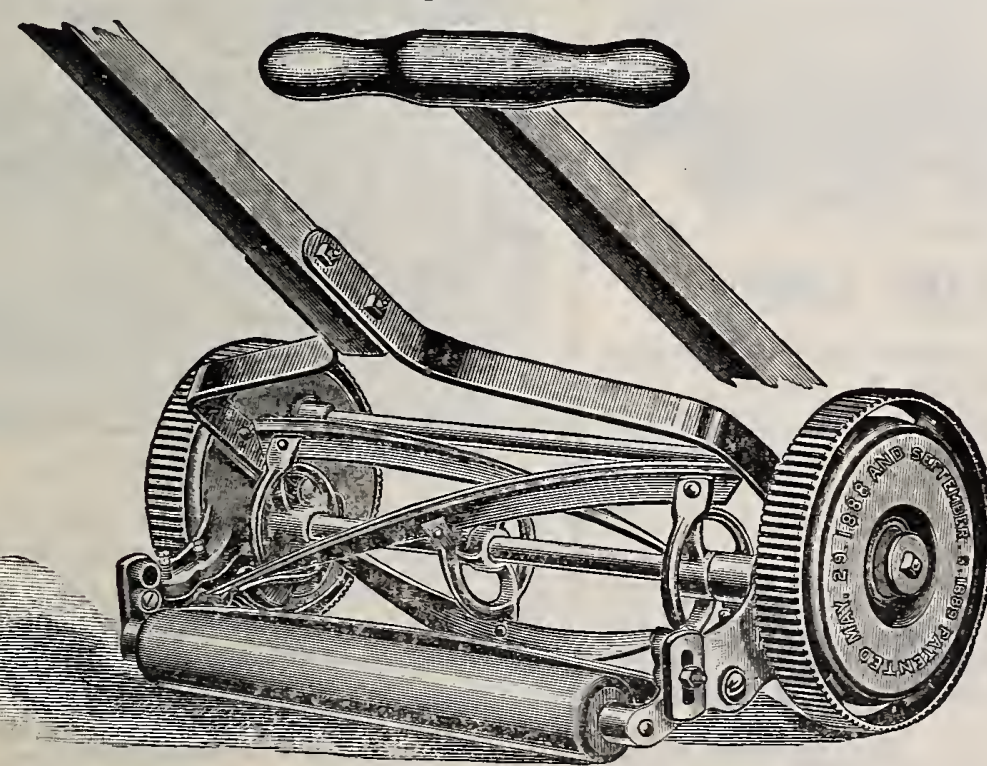

Next to the Rossmoyne we recommend this mower, which is made for us by the most reliable manufacturers in the country. It is a strictly high-grade machine in every particular and the extra rim on the wheel makes it nearly equal to our Rossmoyne high wheel. If you are looking for a three-knife machine at a medium price try this one. $8 \mathrm{in}$. wheel.

This machine has Ball-Bearings and Three Knives.

12 inch...\$4.50. 14 inch...\$4.75. 16 inch...\$5.00. 18 inch ....\$5.25. 20 inch ...\$5.50.

\section{TRossmonne ILawn IIIDower.}

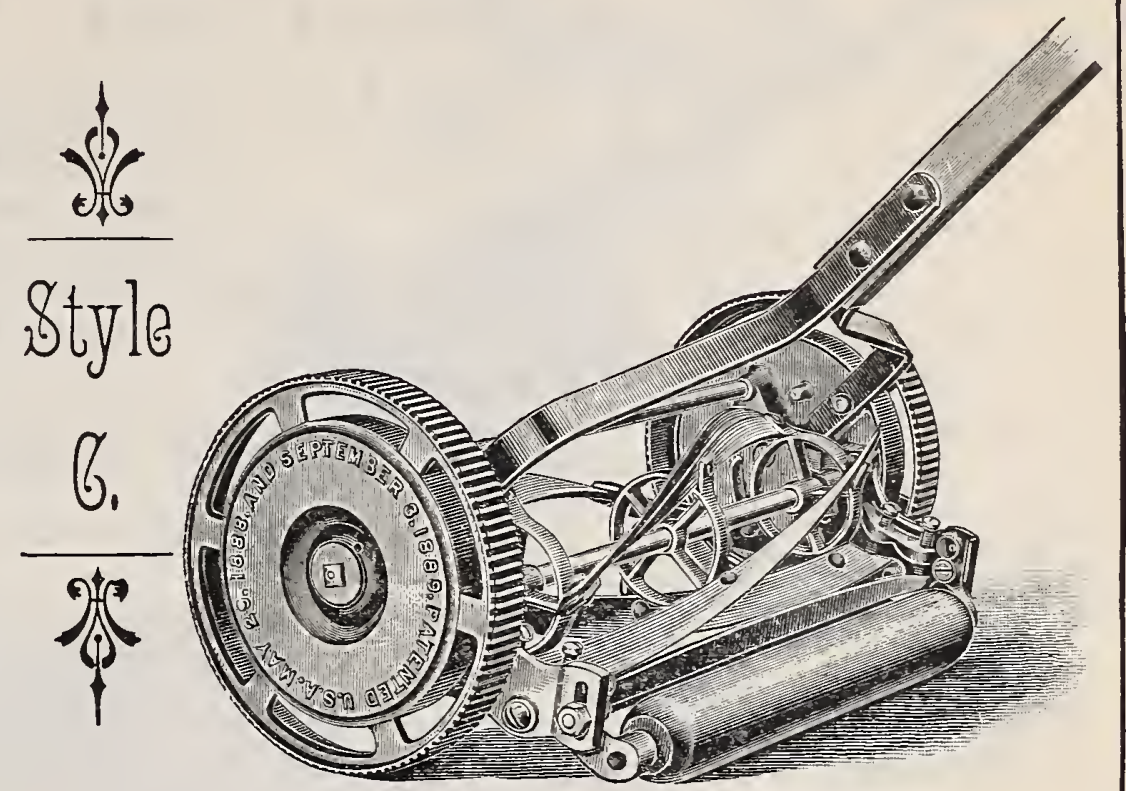

This machine has four knives, high wheels, and is of same grade as the Charley Ross, with the extra knife and high wheel. It runs on ball-bearings of the same quality as those used on other machines. It is a first-class, medium-price mower. All the parts are fitted on a lathe, and we warrant every machine we sell. For a medium-price machine, you will make no mistake in buying this one.

12 inch $\ldots . \$ 5.00$. 14 inch $\ldots . \$ 5.25$. 16 inch....\$5.50. 18 inch...\$5.75. 20 inch...\$6.00.

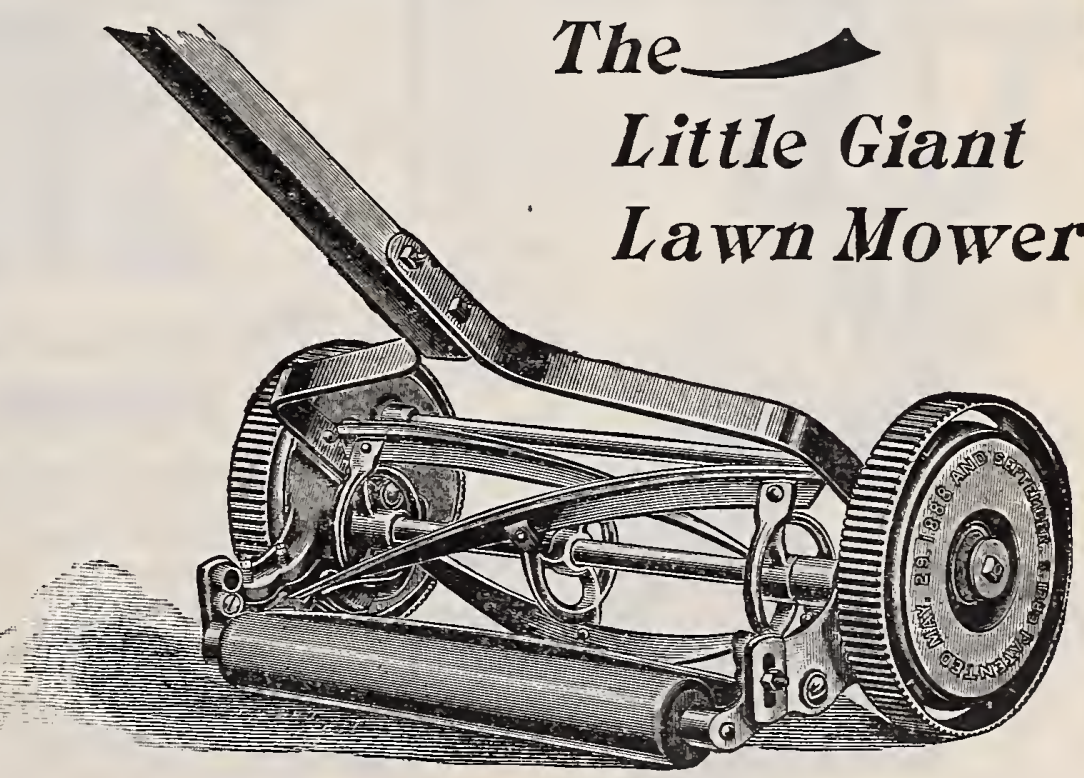

For the benefit of those who want a low-priced mower or those who have but a small amount of grass to cut, we offer this machine, and we think we are safe when we state that it is as good as one-half of the mowers sold as a high-grade machine, and, being a light-running mower, is preferred by many to the higher grade styles. We warrant every machine and have never had to replace one. $8 \mathrm{in}$. wheel.

\section{-NET PRICES.-}

12 inch..\$2.75. 14 inch..\$3.00. 16 inch..\$3.25. 18 inch.. \$3.50.

All the machines shown on this page have the Flexible Lower Knife and may be adjusted by a child. 


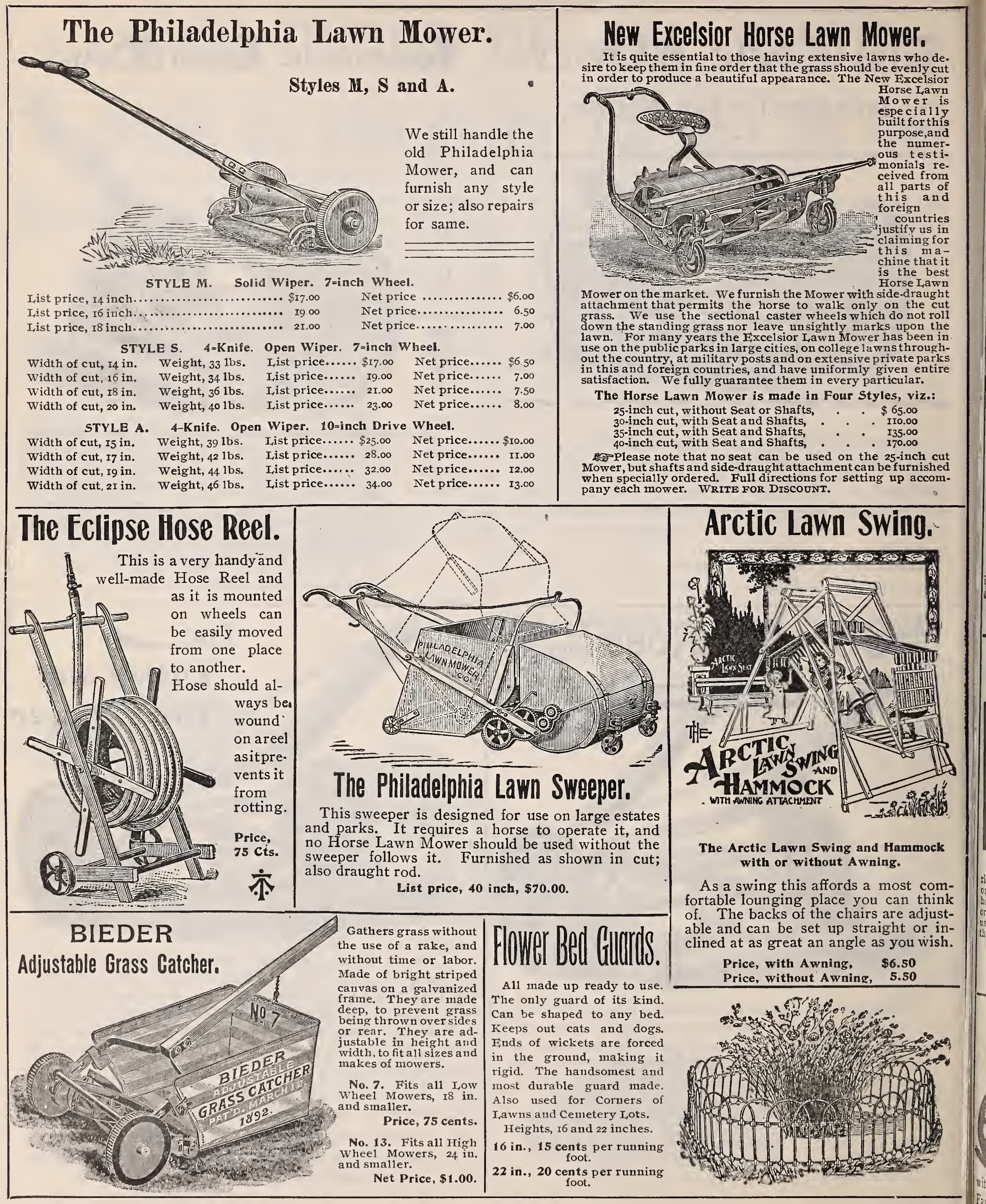




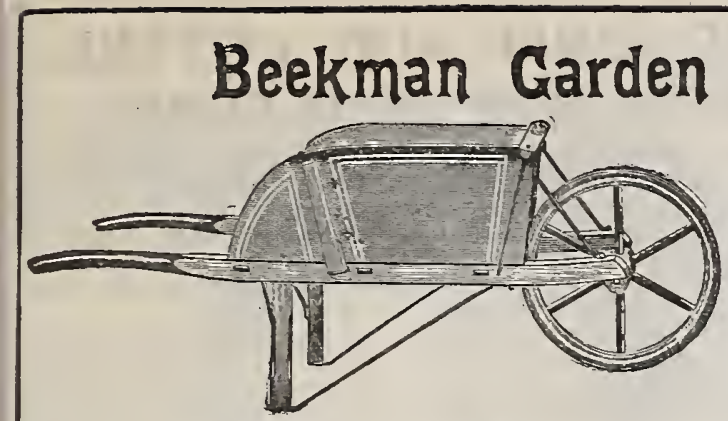

Barrow.

This barrow is made of hardwood but not alloak; it is well made, all parts being bolted or screwed. Our best seller. PRICES.

No. 2. Boys' Size, $\$ 2.75$ No. 4. Medium Size, for garden,................ 3.00

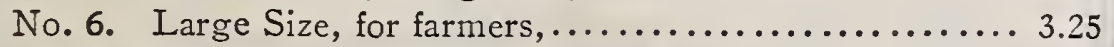

\section{Klondyke Steel Tray Barrow.}

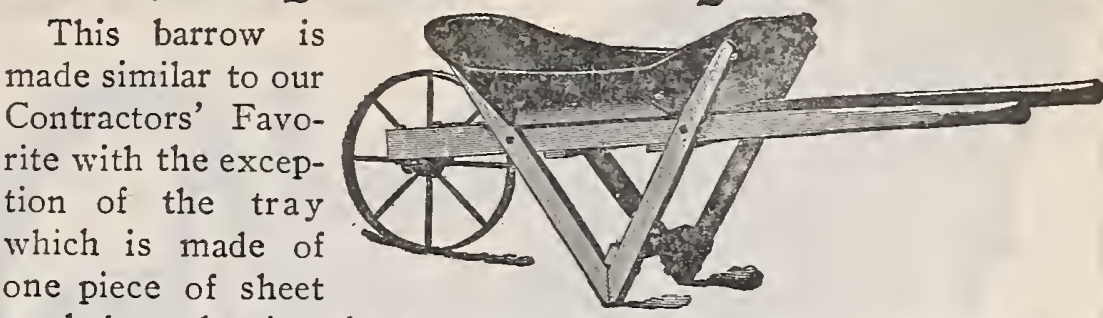

steel about the size of a wood tray. Trays are painted one heavy coat of paint.

Price, each, $\$ 2.75$

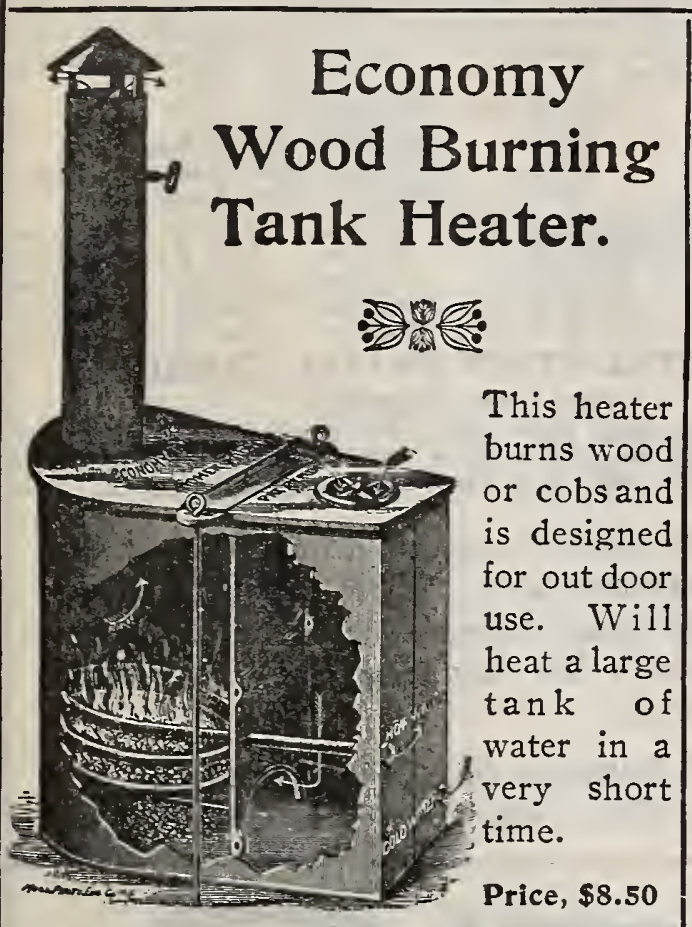

THE UNION SPRING STEEL WIRE CUSHION.

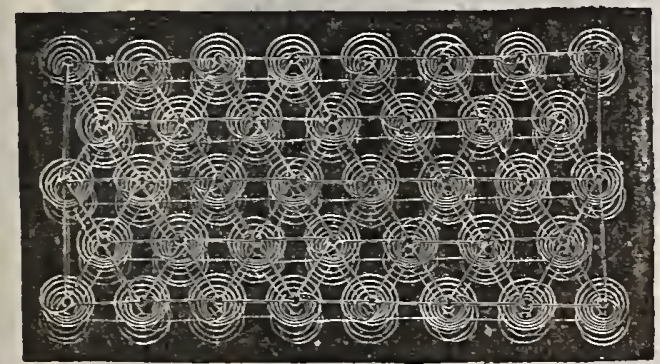

The best in the market for wagons, carriages, barges, etc. Made any size in length or width. Can be used either side up, and are order. They are placed on the seat and are used with only a thin cushion or a blanket on them, and in wet weather can be used alone. PRICES.

I4-Inch, \$I.25; I8-Inch, \$I.50; 42-Inch, \$3.00 Other Sizes Made to Order.

\section{Lawn or Garden Wheelbarrow.} CUSTOM MADE.

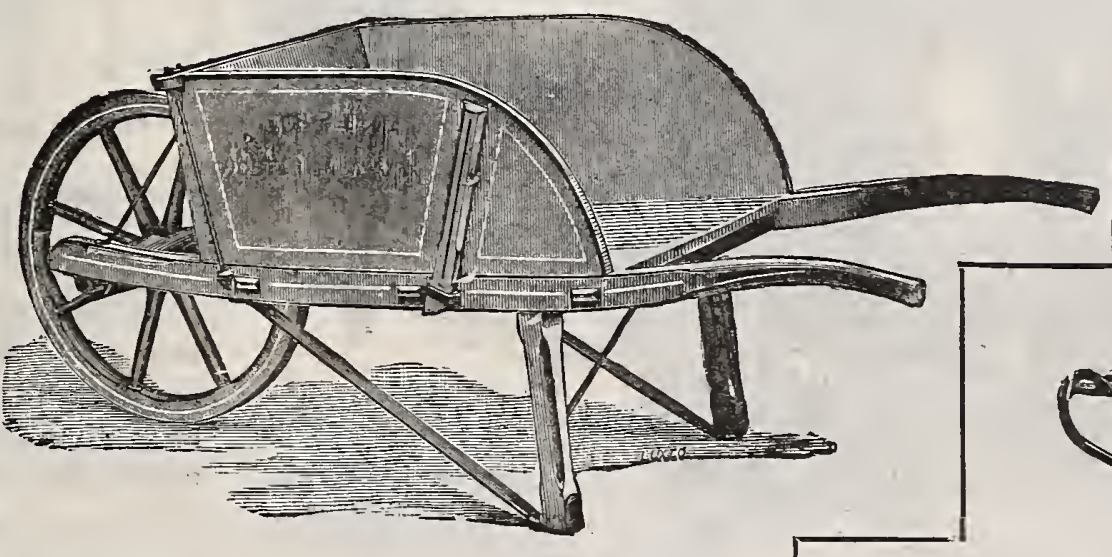

This barrow we have made for us and is especially designed for our retail trade. It is made entirely of oak, is handsomely painted and varnished, and is put together with bolt $\mathrm{s}$ and screws. Has a high wheel with eight spokes. It is an ornament to any garden. One size only.

No. 4. Price, $\$ 4.00$
TOOL RACK.
Designed for Store or Stable. Made in three styles for Shovels, Hnes or Forks. Combination Racks for stores can be used for all.

Price, each, 50 cents. Dozen, $\$ 5.00$.

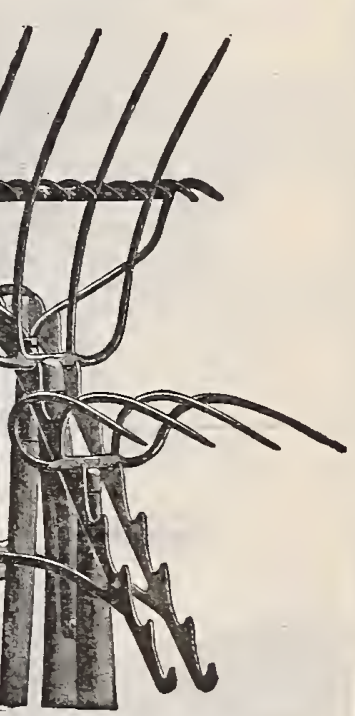

\section{FARTMERS' OVAL SLIDE VISES.}

Made of best quality of stock with hardened steel jaws and proportioned for strength and durability.

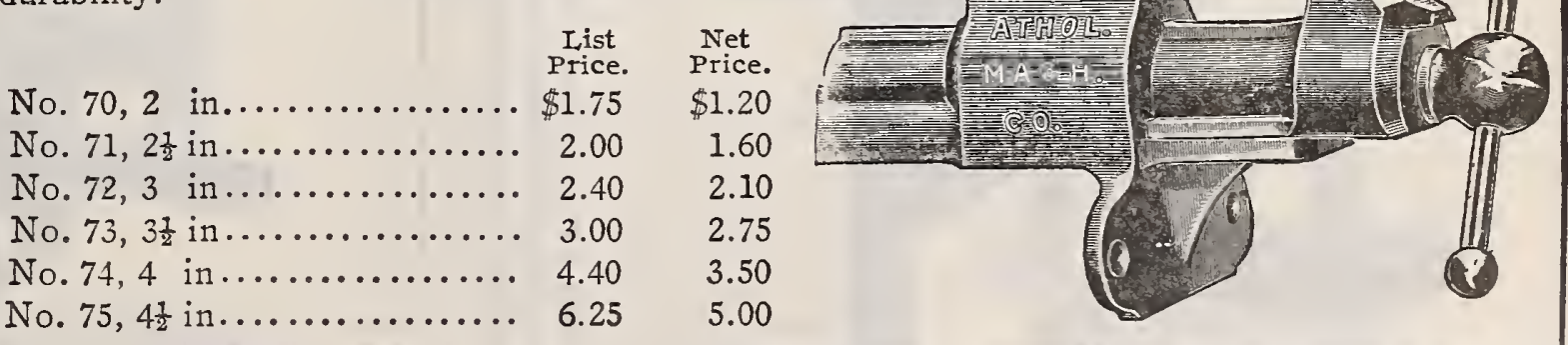

\section{Common Bolted Dump Barrow.}

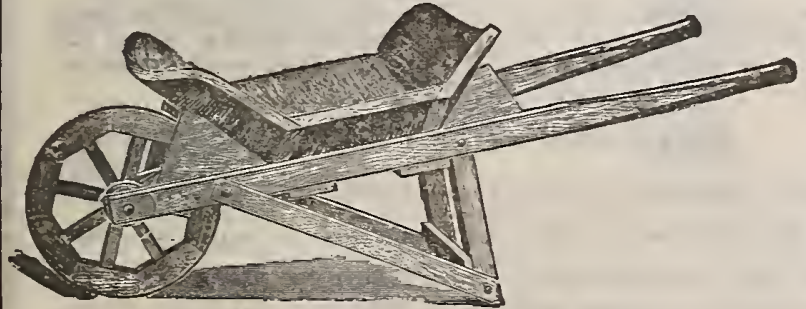

\footnotetext{
This is a much better made barrow for the price than is usually sold. The legs and braces are bolted, has a good wood wheel
} with iron bound hub, and with the exception of our Contractors' Favorite is the best dump made. Price, each, \$1.60; per dozen, $\$ 18.00$

\section{Dump, or Contractors' Barrow.} The Contractors' Favorite Dump Larrow is without doubt the strongest and most durable dump barrow notice the Iron shoe, which is unlite any other barrow. The

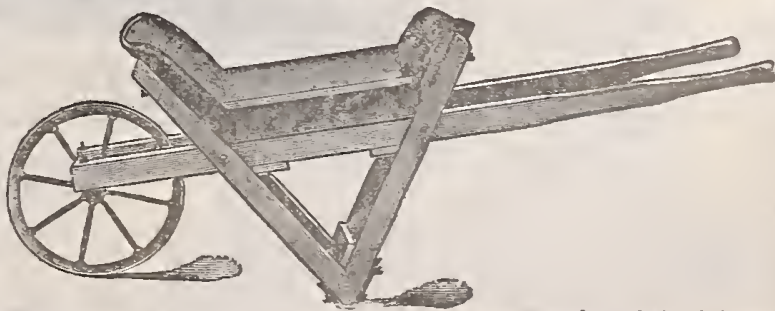
stock used is the very best, and it is bolted throughout. We can furnish either wood or steel wheel.

Price, each, Wood Wheel, $\$ 1.75$, doz. $\$ 20.00$; Steel Wheel, $\$ 2.00$, doz. $\$ 23.00$ 


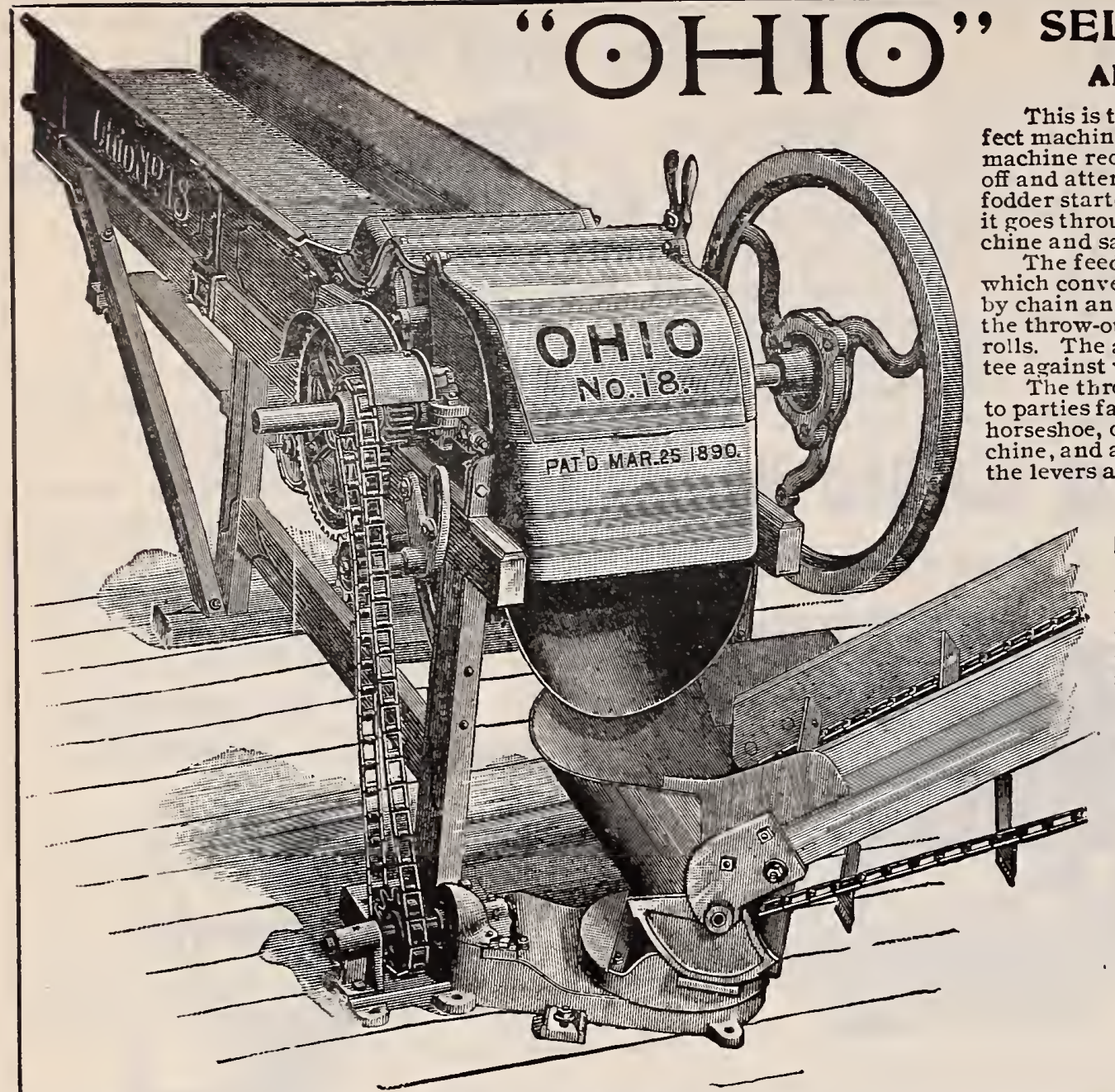

SELF=FEED ENSILAGE CUTTER,

AND NEW METAL STRIP SWIVEL CARRIER.

This is the "Ohio" Ensilage cutter with travelling feed table. It is a per(this requires one man to throw off the wagon, one man to belp throw attend to the machine. One or two men constantly pushing to get the

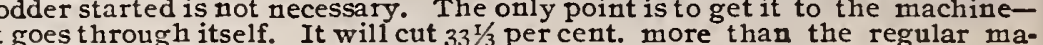
.

The feed table is supplied with a continuous travelling chain or belt apron

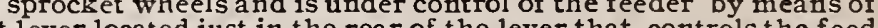
. The apron travels on five pairs of sprocket wheels, which is a guaranainst wear. 位 horseshoe, or some other foreign substance mysteriously strays into the machine, and about the time it reaches the knives the feeder has only to catch SIZES AND PRICES.

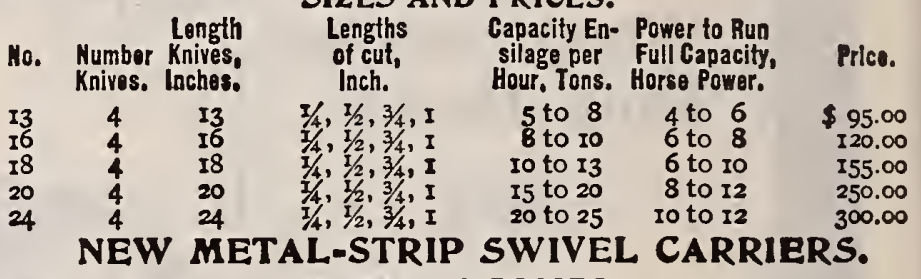
For SIZES AND PRICES.

No. 13 Cutter, $12 \mathrm{ft}$. long, $\$ 45.00$ Over I2 ft. long, extra per $\mathrm{ft}$, $\$ 1.70$ No. I8 Cutter, I2 ft. long, 45.00 Over I2 ft. long, extra per ft.; r.70

We also carry in stock the No. 11 and No. 13 Cutters with Standard table. These are both Power Cutters and are equal in every way to the above only they do not have the travelling table but list at a much lower price.

No. 11 Cutter, 4 knife. List, $\$ \mathbf{\$ 5 . 0 0}$

No. 13 Cutter, 4 knife. List, $\mathbf{6 5 . 0 0}$
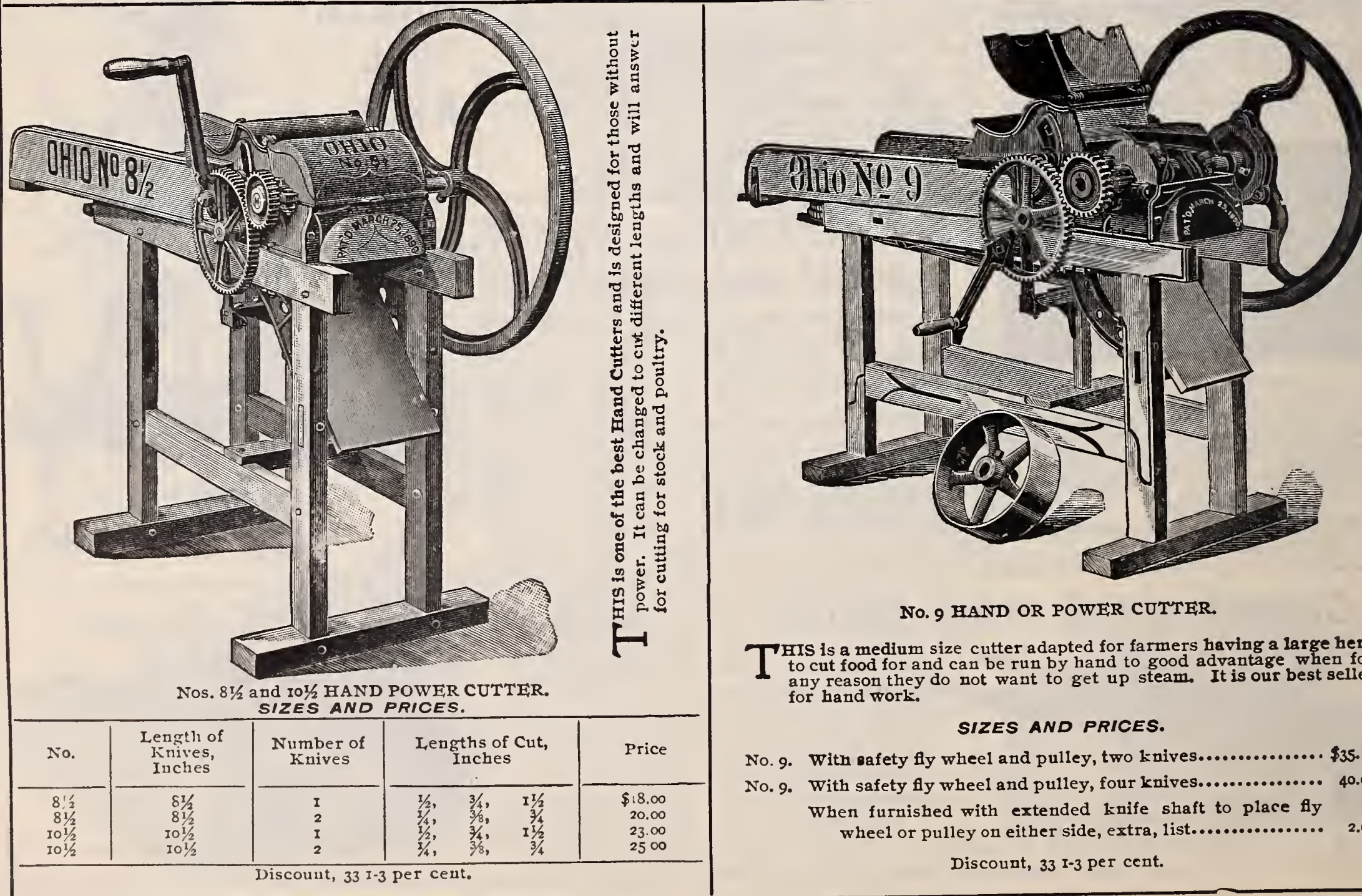

No. 9 HAND OR POWER CUTTER.

THS is a medium size cutter adapted for farmers having a large herd to cut food for and can be run by hand to good advantage when for to get up steam. It is our best selle for hand work

\section{SIZES AND PRICES.}

No. 9. With eafety fly wheel and pulley, two knives................ \$35. 05

No. 9. With safety fly wheel and pulley, four knives............... 40.00 When furnished with extended knife shaft to place fly wheel or pulley on either side, extra, list............... 2.00 Discount, 33 I-3 per cent. 


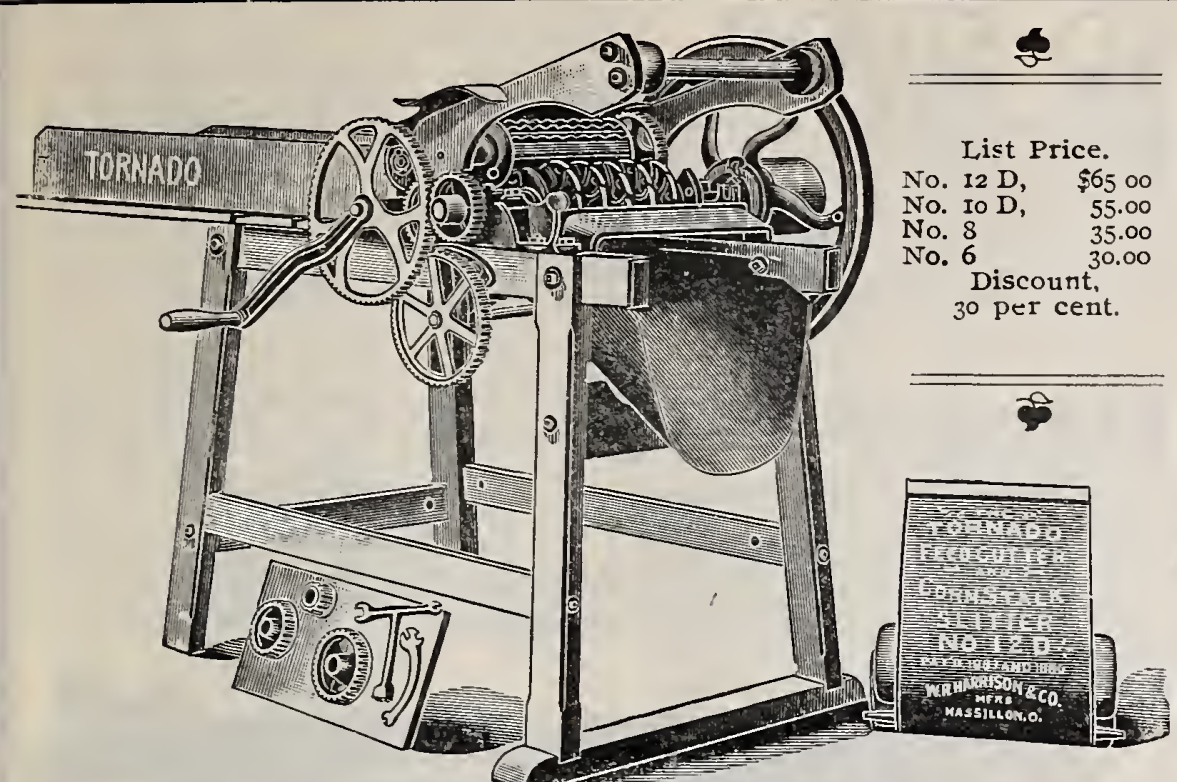

Flat Feed Tables will be furnished with above cutters instead of feed troughs when so ordered.

\section{CORN FODDER.}

Its Value, and How to Handle and Feed It to the Best Advantage and Greatest Profit to the Farmer.

CORN FODDER is taking such a prominent place among rough feeds that the greatest effort should be put forth in trying to discover and bring into general use the best modes of handling and the most economical was paid to this matter, but since the hay crop has become so uncertain almost every farmer has learned that it is one of the best rough feeds for horses, cattle and sheep. It has been accurately determined by expericare of and utilized, is as great as a acre of hay.

The VALUE of the Corn Fodder is not in the blades nor in the husks, BUT IN THE STALK, as has been proven by so many of our farmers and by our different State experimental stations. It is, therefore, necessary to same time. This the TORNADO CUTTER will do.

Improved Nos. $10 \mathrm{C}$ and $12 \mathrm{D}$ Combined Hand and Power Cutters.

These machines, as here shown, are built for both Hand and Power use, are of nedium size, rapid sellers, and adapted to ordinery farm or dairy use. Both are arranged to cut $1 / 2,3 / 4, \mathrm{I}$ and $\mathrm{I} / /$ inches, and when run by power should be given a speed of 1,000 to $I, 200$ revolutions of the cutting cylinder per minute, and in no instance when power is used should the use.

In the construction of this machine are found all the good features of the Improved Baldwin Feed and Ensilage Cutter, which have made that well-known machine so popular. The Gale-Baldwin is a strong feeder, and cuts with great ease and ra pidity. The Beecher's Patent Rotary Cutter Head is used exclusively on this machine, and its long use on the power Baldwin machine has prored its superiority over
for ease of adjusting the knives and durability.

\section{DESCRIPTION OF SIZES.}

No. 16.-Capacity for ensilage, 21/2 to 5 tons per hour. Povrer required, one to two-horse engine. Speed, 500 to 600 revolutions per minute. Cut, $1 / 4,1 / 2,3 / 4$ or $I$ inch. Pulleys and wheels interchangeable.

Price of Cutter without Carrier....................\$\$60.00

Price of Cutter withery Carrier, feet long or under....... 24.00 Angle Delivery Carrier, I2 feet long or under, with New

Spout Carrier................................... 32.00

Over I2 feet, extra per foot.................... 1.50

Safety Treadle Lever... . ...................... $\mathbf{5 . 0 0}$

No. 18.-Ca pacity for ensilage,50 to roo tons per day. Powe requinute. Cuts $\frac{3}{16}, 3 / 8,3 / 4$ or I inch. Gear also furnished to cut $1 / 2$ inch if ordered.

Price of Cutter.............\$100.00

Price of Cutter.....................................\$100.00

Angle Delivery Carrier, in feet long or under.......

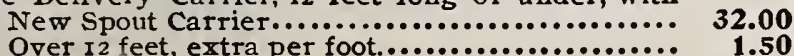

Safety Treadle I ever...... $\mathbf{5 . 0 0}$

No. 22 is a very large and heavy cutter, of great capacity. Power required, five to ten-horse engine. Length of cut same as No. 18. Price of machine, $\$ \mathbf{1 5 0 . 0 0}$. Straight Delivery Carrier, I2 ft. long or under.\$30.00. Over $12 \mathrm{ft}$., per foot, \$2.00. Safety Treadle Lever, $\$ 6.00$.

Discount on Cutters, 30 Per cent. On Carriers, 20 Per cent $\sigma^{\circ}$ Gale-Baldwin Ensilage and Feed Cutter.

Length of Knives in inches same as Number of Machine.

Each Size made with TWO KNIVES.

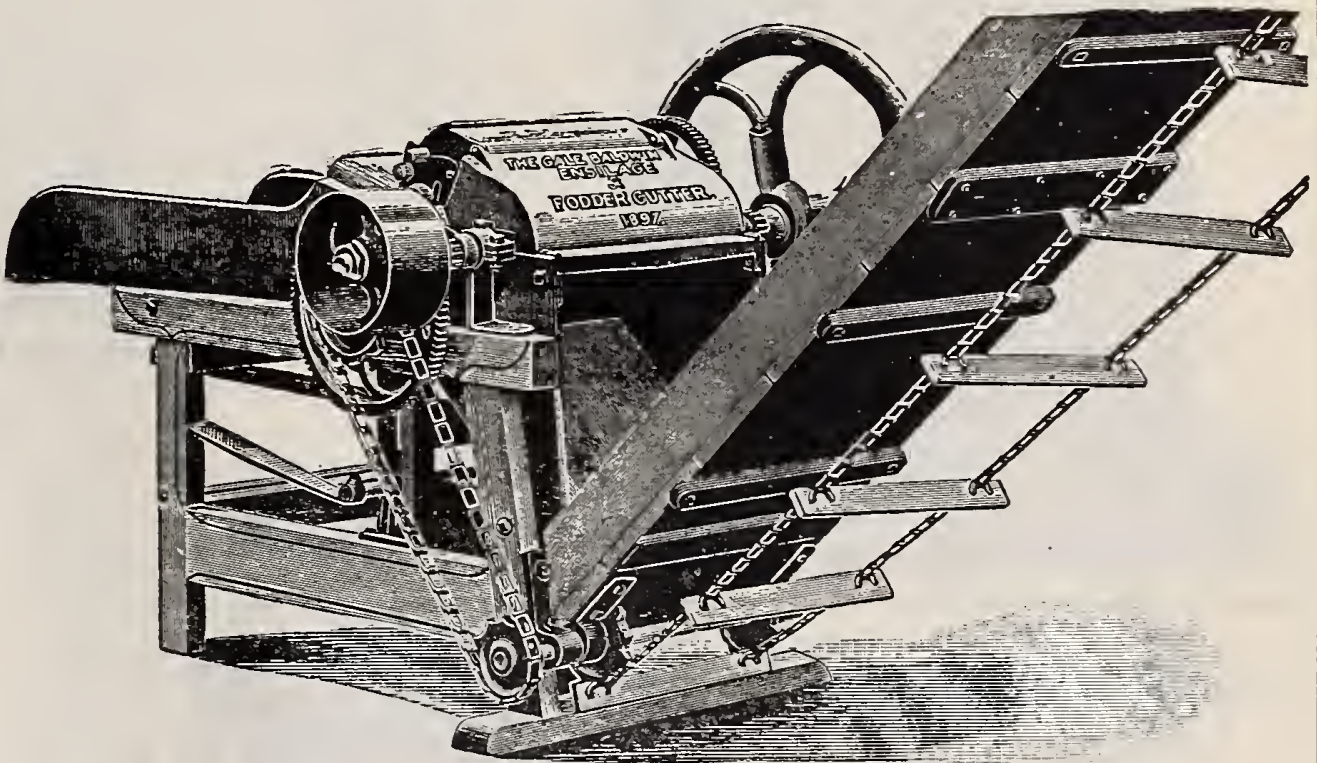

\section{Freeman Ensilage Cutters}

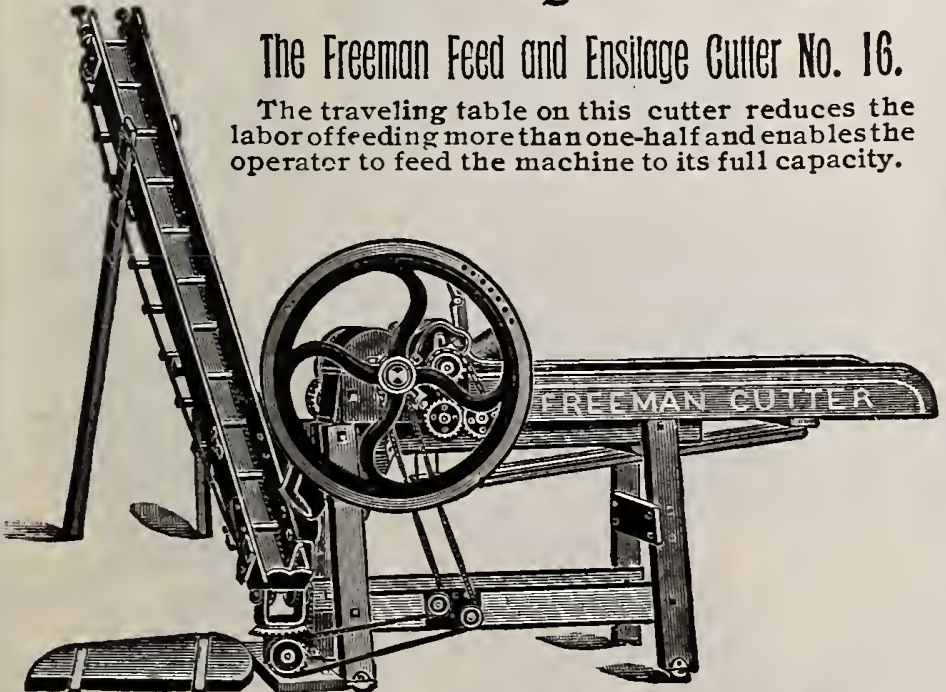

We can furnish 13,16, 20 or 24 Inch Cutter with Travoling Tablo.

This cutter is fitted with four knives, each 16 inches $100 \mathrm{~g}$ and will cut either $1 / 4$-inch, $1 / 2$-inch or $3 / 4$-inch long. Weight, $6001 \mathrm{bs}$.

List price, with Traveling Table, $\$ \mathbf{\$ 1 2 0 . 0 0}$ List price, with common Table, $\quad \mathbf{9 0 . 0 0}$

Discount, 40 per cent. on all sizes of Cutters.

Send for Catalogue of other sizes.

\section{The KELLY DuPLeX GRINDing MILLS}

The Kelly Duplex Grinding or Feed Mill is in very general use throughout the whole country. The one reason why the Kelly Duplex is so popular, and why it attracted such a large number of buyers, is that it is superior to any other mill. By superior, we mean that it is capable, in the hands of ordinary operators, of doing a great deal more than any other mill, and doing it better and easier, requiring less power and producing a better grade of feed.

Why This Is The Best Iron Mill Made.

Because it is provided with a double set of grinders or burrs. for which reason it salled the "Duplex."

It is the only mill manufactured which has double or duplex grinders.

It can do as much work as any other mill of double its size.

It will grind a ny kind of grain, or corn and cob, equally well, and will produce meal of any desired quality, coarse, medium or fine.

\section{PRICE}

\begin{tabular}{c|c|c|c|}
\hline No. 1 & No. 2 & No. 3 & No. 4 \\
\hline$\$ 35.00$ & $\$ 4500$ & $\$ 50.00$ & $\$ 65.00$ \\
\hline
\end{tabular}
send for Circular.

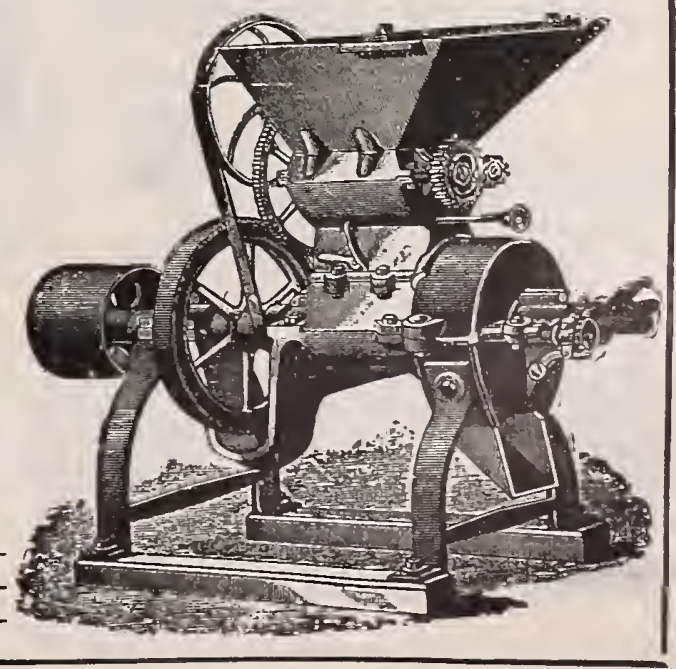




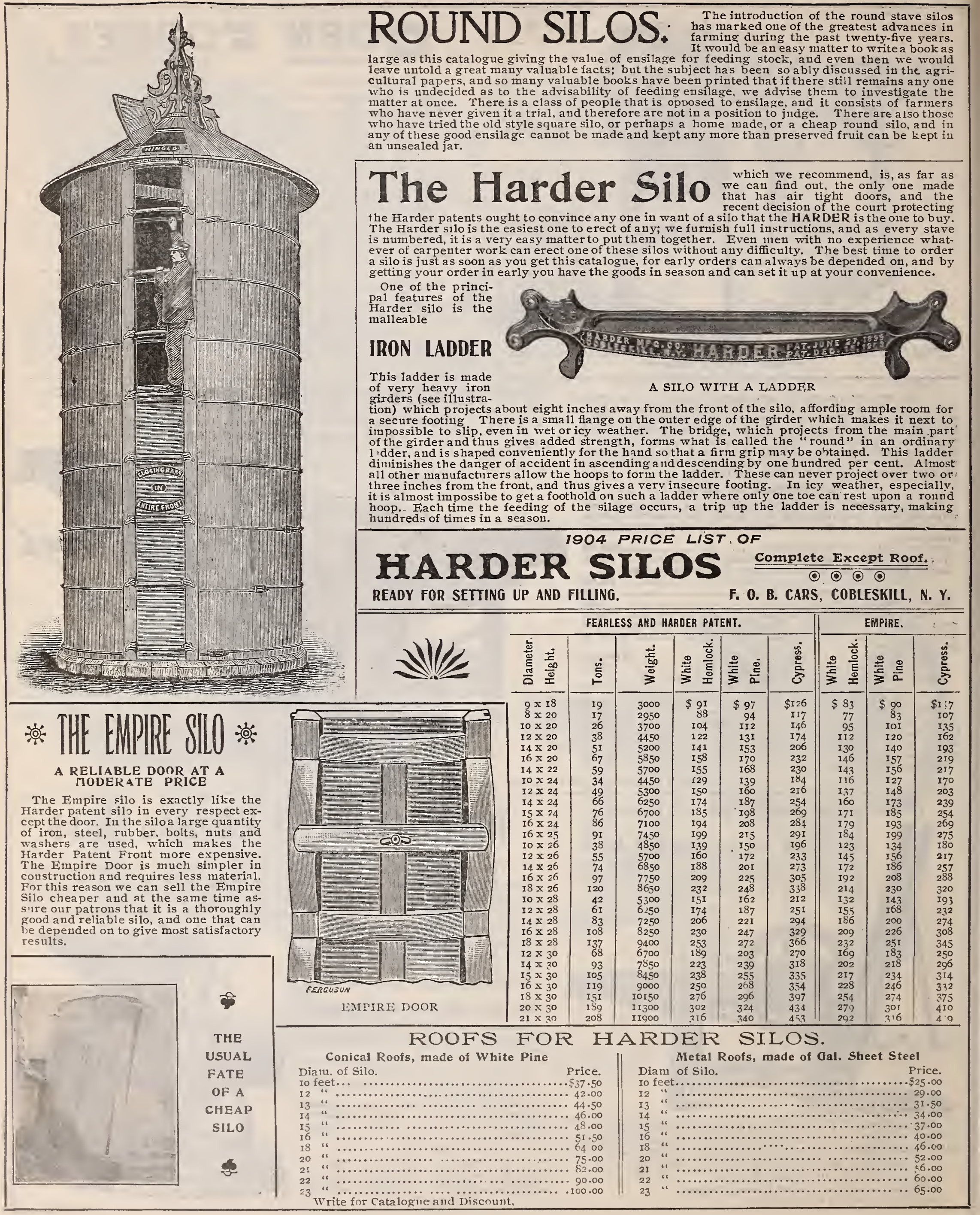




\section{Wine

There seems to be no one kind of power that is adapted to all kinds of work. Some farmers require power only for pumping water, and the windmill is as cheap and as durable and perhaps, all things considered, the for cutting food and such work as can be done in the stable. For that use the tread porrer for either one or two horses is adapted. For all purposes

where it is either impossible on account of danger or other reasons to use steam power, the Gasoline Engine can be used, and this style of power has a great many advantages over any other kin

In bur very little more.

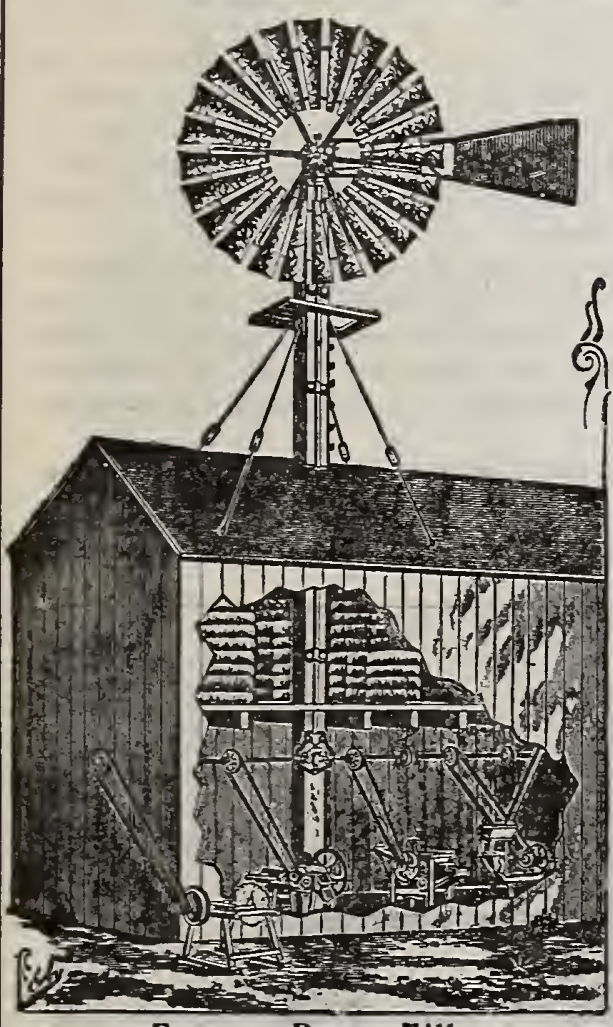

Freeman Power Mill.

\section{(2)-The Freeman Steel raindmill- (a)}

It is impossible in the small space we can devote for that purpose to give anything like a complete description of this mill, but we will mail to anyone upon request, a complete catalog describing it in full, and showing wherein it is superior to any other. The price quoted is f.o.b. cars at Racine, Wis. We do not set up any mills. We prefer to sell them on the same margin of profit that we doother goods, and let the customer set them up. We have no plumbers and can not charge their price, but it is an easy matter for any one to erect a mill. We think you will find it much cheaper to buy a mill of us aud erect it cheap, but we guarantee every mill to be first class in every way.

\section{Write for complete catalog.}

List Price of Steel Pumping Mills and Towers.

$\begin{array}{ccc}\text { Diameter } & \text { Painted } & \text { Galvanized } \\ \text { of Wheels. } & \text { Weights: } & \text { List Prices. }\end{array}$

8 feet

Io feet

$3301 \mathrm{bs}$.

$3701 \mathrm{bs}$.
$4201 \mathrm{bs}$.

537.50

$\$ 42.50$

I2 feet

$760 \_1 \mathrm{bs}$

40.00

45.00

$\$ 42.50$
47.50

STEEL POWER MILLS

Diameter
of Wheels.
I2 feet
I4 feet

Weights.
$8001 \mathrm{bs}$.

II 50 lbs.

Painted
List Prices.

$16001 \mathrm{bs}$

List Price
$\$ 87.50$
I 20.00

I 20.00
200.00

FOUR=POST ANGLE STEEL TOWERS

Height.

20 feet

40 feet

50 feet

60 feet

8o feet

Weights.

$35^{\circ} 1 \mathrm{bs}$.

$5351 \mathrm{bs}$.

910 lbs.

$1485.1 \mathrm{bs}$
$-800 \mathrm{lbs}$

Painted
List Pric
$\$ 25.00$
36.00
47.5
60.00
75.00
925

9250
I1 0.00

Discount, 40 per cent. from Iist. 5 per cent. extra for cash with order.

\section{Greendale Gas Engine.}

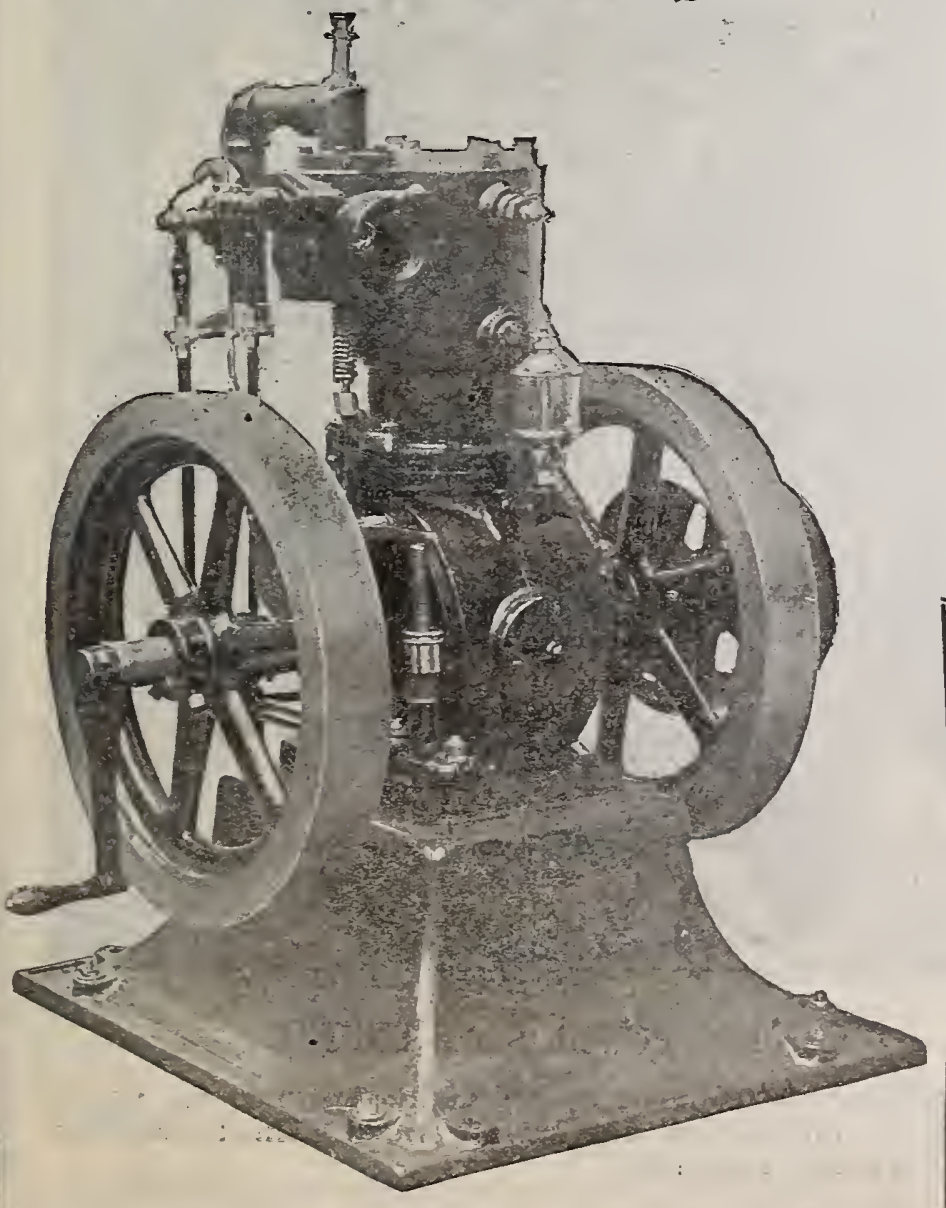

Since Gas Engines have been on the market we have been looking for one that we could recommend with perfect confidence to our customers as being a first-class machine. The Greendale is made here in Wolcester and the manufacturers are thoroughly reliable parties, and it has been tested by several of our leading farmers in this county. We could print several testimonials which would convince any one in want of a Gas Engine that they were taking no chances in buying this one. It may be economy in sonve lines of tools anit under certain circumstances to buy cheap or low priced goods, but on an engine the liest is none too good. Where your life is endangered, never take any chances by buying simply because you can save a few dollars. Youmay be able to save $\$ 50$ 00 or $\$ 75.00$ buying some other inake, but it is liable to

This engine has the simplest and most eff active self

It starts int wear out arid always ready for use. It also has an automatic and substantially made. With this pulley, the engine is free to start but takes up the load gradually. There has been one size added since year last, a fifteen horse power. List price
5 horse, $\$ 250.00$. discount for cash $\$ 2500$. 7 horse list $\$ 300.00$ or discount for cash $\$ 30.00$. 15 horse list $\$ 445.00$, discount for cash $\$ 45.00$. At these prices we furnish a man to set up and start them.

\section{St. Albans Horse Powers.}

We claim for this HorsePower an adaptahility for farmers' use never equalled by any other powerinthe market. The study should meet all their wants, and be easily adjusted to any and every use. particular ting hay and straw, saring wood, and cuthorses It hos of late been f illy demoti strated that the farmer makes a largesaving by cutting his hav, straw. stalks or small portion of meal; and that he also gains very largely in the better condition
of his stock. One-Horse Power, with Speed Regulator
$\$ 70.00$. Two-Horse Power, witli Speed Regulator, $\$ 90.00$. Discount for casl, $5 \%$

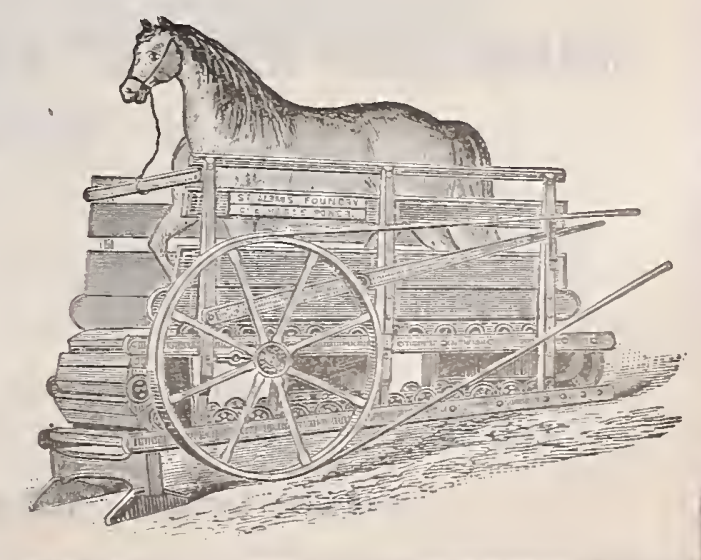




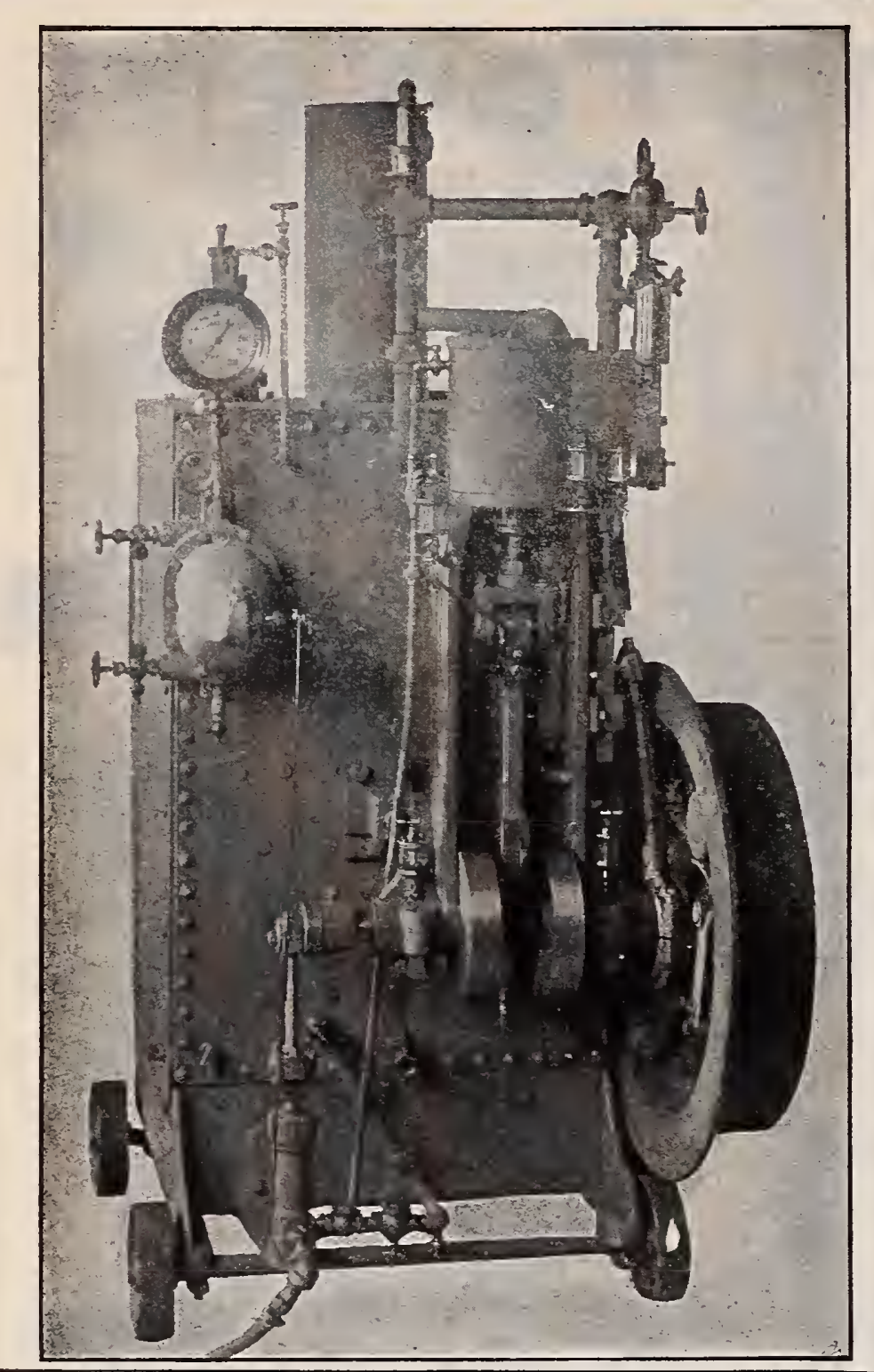

Heating Houses and Stores. These boilers make the best kind of heat for houses, stores and shops. The draft being controlled automatically, the temperature of the room may be controlled as desired.

Fuel. Hard or soft coal or wood, such as old rails, knots, limb wood, auything that will burn and is not fit to burn in the house or to sell, will make all the steam wanted. The fire bux will take wood 20 in. long. We guarantee a saving of at least one-half the fuel over any common ball governor engine made. The boilers are made of the best flange steel and extra charcoal-iron lap-welded boiler tubes and are tested to $250 \mathrm{lbs}$. pressure per sq. in. They are supplied with an automatic feed water regulator. This is an excellent device to save time and attention.

Full directions for setting $n \mathrm{p}$ and operating these engines will be furnished to every customer, also instructions in regard to cleaning, oiling and caring for them.

$$
\circ 00
$$

\section{PRICES OF SAFETY ENGINES AND BOLLERS COMPLETE.}

$\begin{array}{rrcc} & & \text { List Price. } & \text { Net Cash Price. } \\ 3 \text { horse } & \$ 230.00 & \$ 210.00 \\ 4 & \text { “ } & 300.00 & 270.00 \\ 5 & \text { “ } & 310.00 & 280.00 \\ 6 & \text { \# } & 370.00 & 335.00 \\ 3 & \text {. } & 415.00 & 385.00 \\ 10 & 520.00 & 480.00 \\ 12 & \text {. } & 55000 & 500.00\end{array}$

Send for complete catalogue.

\section{THE SAFE ENGINES AND BOILERS 0000000}

In presenting this line of engine to our customers, we desire to call your attention to a few of their merits which we think are possessed by no other make. The boilers are made of the very best material and the work is done in the most careful manner. It occupies the least amount of space of any boiler made of the same capacity. It is small and not liable to explode and uses about one-half the fuel usually required to dothe same amount of work and this is the only engine where with an armf ul of wood. steam can be raised to from 60 to 80 lbs. within from Io to 15 minutes' time. These engines are made in all sizes and are adapted for all purposes, but for farmers' use we cannot recommend them too highly. Safety plugs are put in all of the boilers, but should the boiler by carelessness become overheated and leak around the tubes, it is not necessary to send for a boiler maker, but the leak can be repaired with a common monkey wrench. The engine is built for hard work and with the new oilers, it can be oiled whlle the engine is running.

This engine has been greatly improved since last season and we are pleased to say that it is now being manufactured by parties who can fill orders promptly, as during the past three years, it has been next to impossible for us to get the engines when they were wanted the most and through the negligence of the old manufacturers and the New England agent, we have been obliged to disappoint a gieat many customers.

The speed of the engine can be changed from two to five hundred revolutions per minute, as the circumstances require.

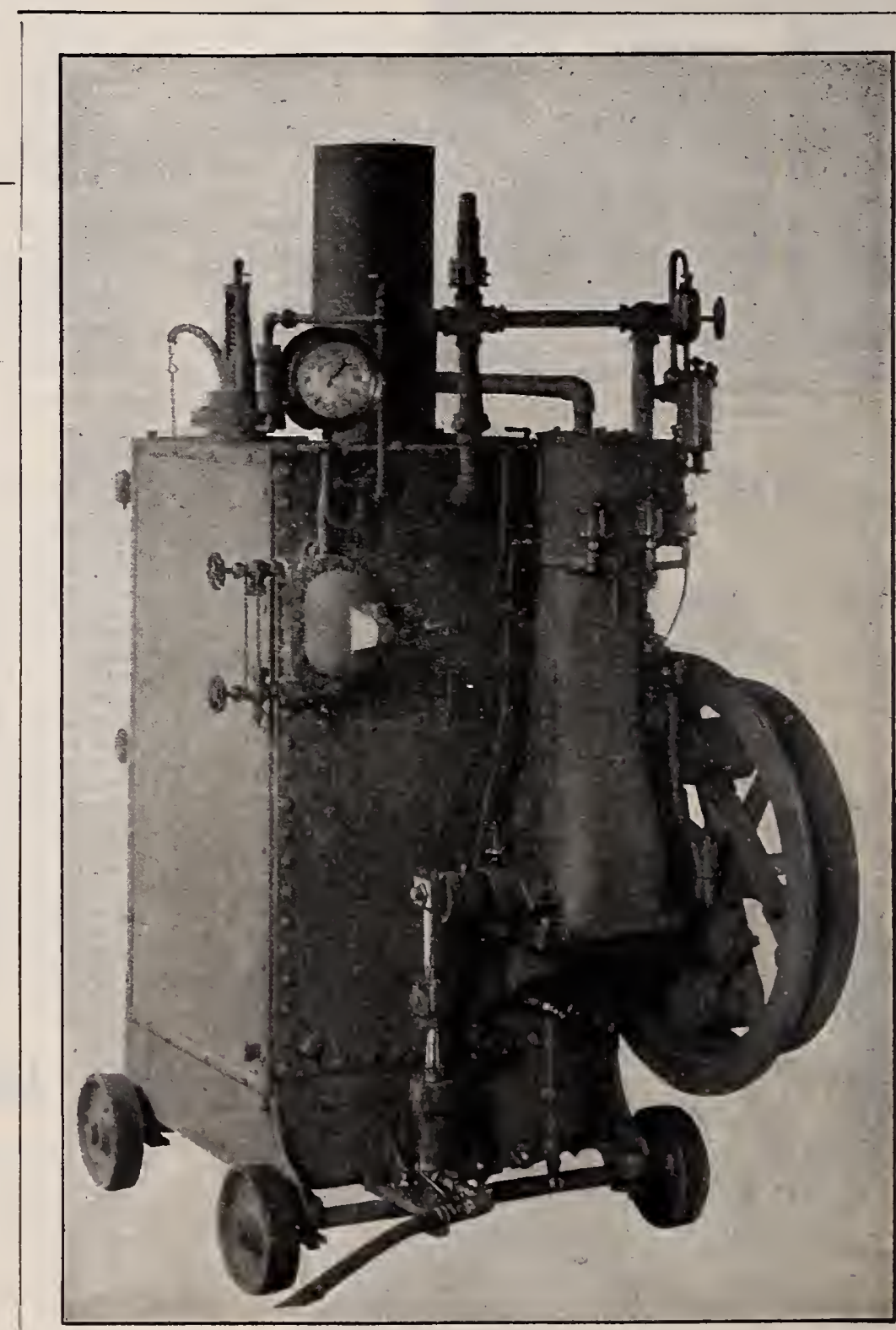

\section{5-HORSE POWER SAFE ENGINE}

With working parts inclosed; especially designed for people going about filling silos and sawing wood. This is our best seller for general farm use. 


\section{$*$ ROSS Pole and Wood Sarus and Frames $\circledast$}

All wood saws are made to drop the wood on the right hand side, unless otherwise ordered. We carry only the best selling sizes in stock; other sizes will be shipped direct from the factory. Discount on sizes in stock, 40 per cent.; when shipped from factory, 40 and 5 per cent. The extra 5 per cent. will nearly pay freight.

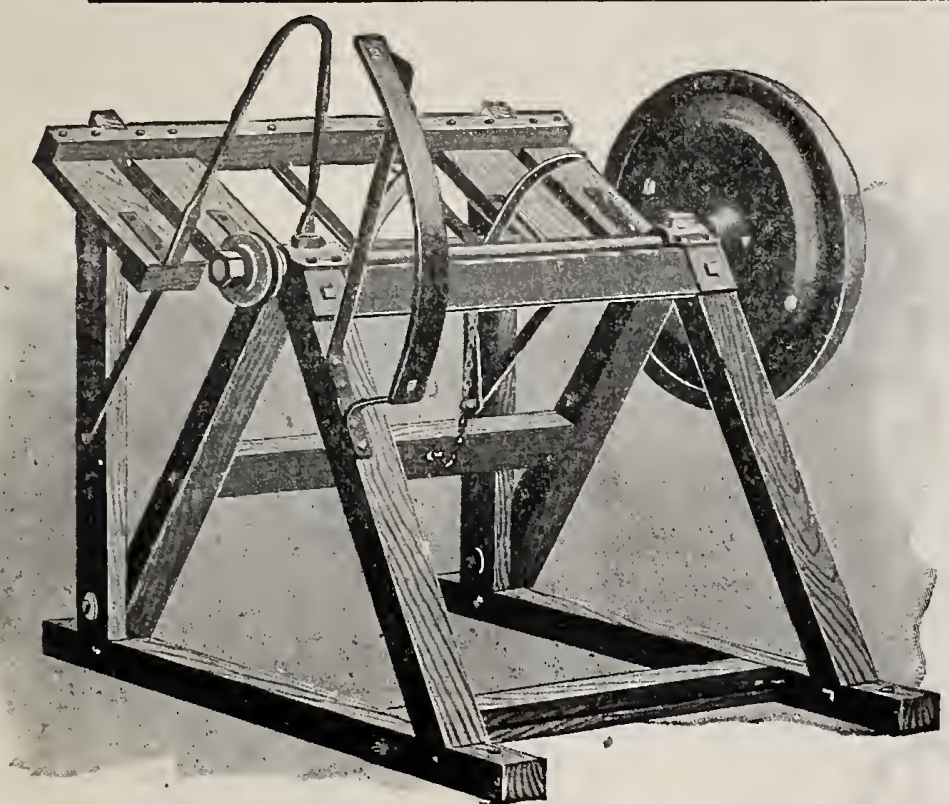

TILTING TABLE WOOD SAW.

The above will give you an excellent idea of the high type of these saws. They are made of good material throughout, and are built in a thoroughly workmanlike manner in every respect. The arbors are of steel, the bearings long and well babbitted. The balance wheels are heavy and well balanced. This machine is finished in an attractive manner. It has a tilting table pivoted so that it balances perfectly, and is therefore a great favorite with the sawyer.

PRICES, TILTING TABLE WOOD SAWS:

20 in. $\$ 40.00 ; \quad 22$ in. $\$ 42.50 ; \quad 24$ in. $\$ 45.00 ; \quad 26$ in. $\$ 47.50$; 28 in. $\$ 50.00$

Discount 40 per cent.; 5 per cent. cash with order.

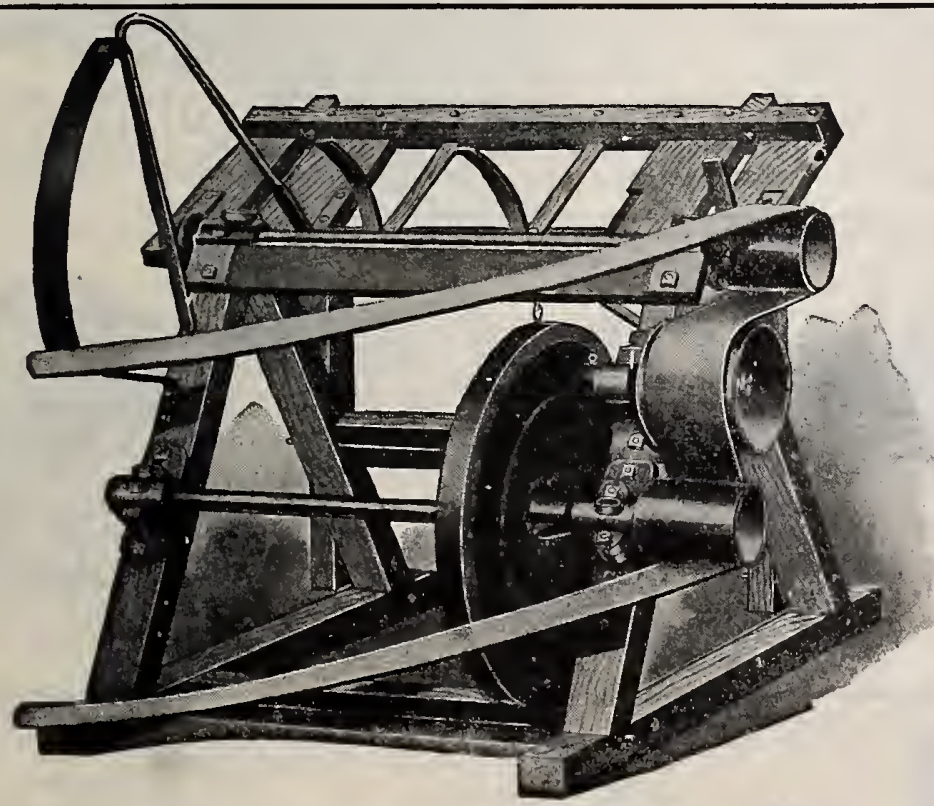

TILTING TABLE POLE SAW.

Great care has been used in the construction of our pole saws. They are built just as substantially as any of our wood saws except that the balance wheel is on a scparate shaft and entirely out of the way, so that long poles may be sawed as well as wood. The power is fed direct to the saw. The belt passes around an idler pulley to the balance wheel shaft, giving a steady, well balanced motion to the saw.

PRICES, TILTING TABLE POLE SAWS.

20 in. $\$ 47.50$; 22 in. $\$ 50.00 ; \quad 24$ in. $\$ 52.50$; 26 in. $\$ 55.00$; 28 in. $\$ 57.50$

Discount 40 per cent.; 5 per cent. cash with order.

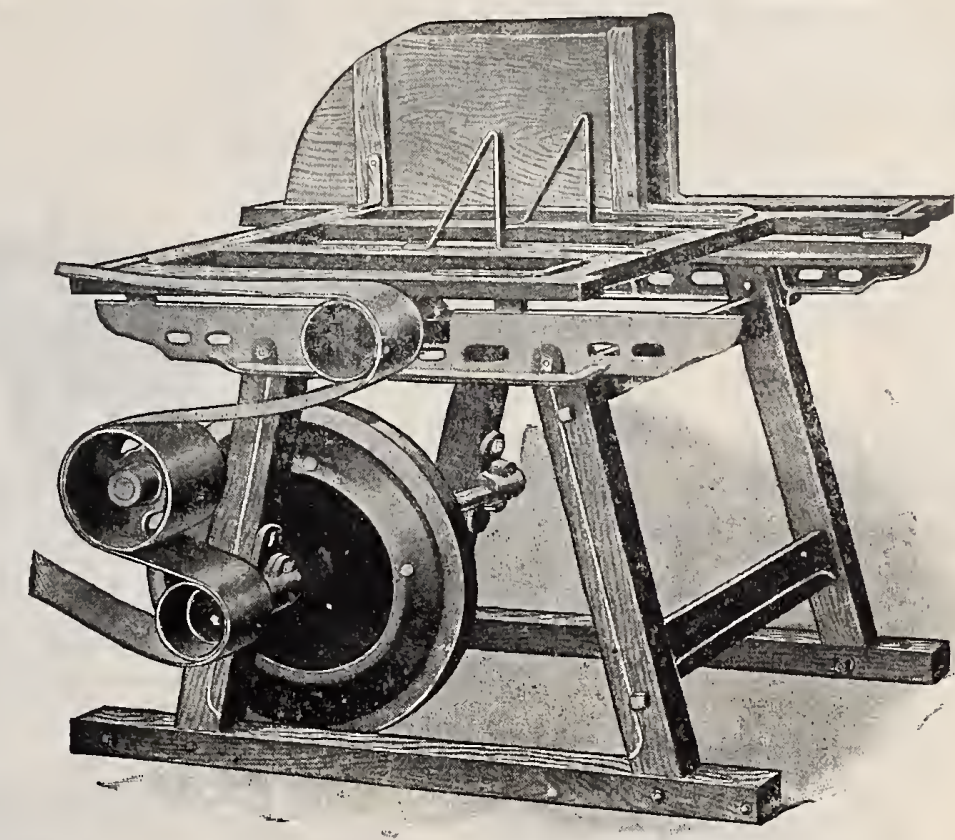

\section{SLIDING TABLE POLE SAW.}

This machine has been carefully designed and all parts are well made. The above clearly illustrates it. It is built with a sliding table, and the balance wheel is on a separate shaft entirely out of the way. Long poles can be sawed as well as wood. Power is taken in the same manner as tilting table pole saw. All our wood saws are made right hand unless otherwise ordered. PRICES, SLIDING TABLE POLE SAWS.

20 in. $\$ 50.00 ; \quad 22$ in. $\$ 52.50 ; \quad 24$ in. $\$ 55.00 ; 26$ in. $\$ 57.50$; 28 in. $\$ 60.00$.

Discount 40 per cent.; 5 per cent. cash with order.

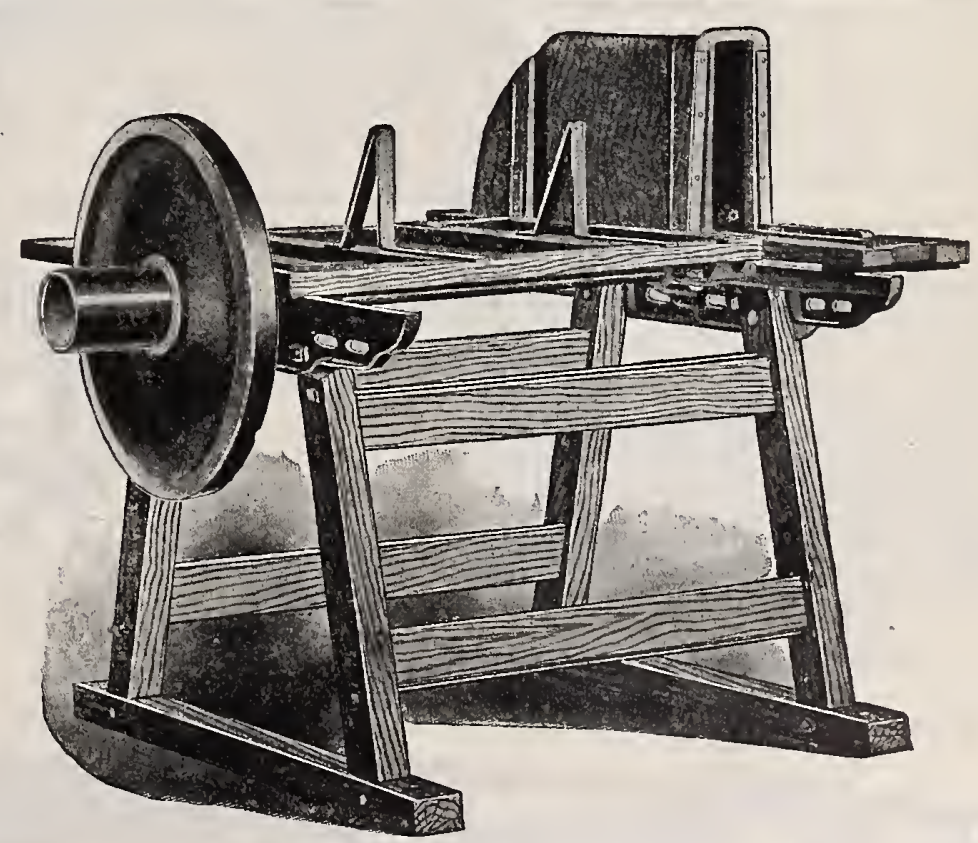

\section{SLIDING TABLE WOOD SAW.}

This sliding table wood saw, as jllustrated, is mounted on roller bearings which run on the table guides, and is consequently easy to operate. It is a very substantial and strong machine throughout.

PRICES, SLIDING TABLE WOOD SAWS.

20 in. $\$ 42.50 ; \quad 22$ in. $\$ 45.00 ; \quad 24$ in. $\$ 47.50 ; \quad 26$ in. $\$ 50.00$; 28 in. $\$ 52.50$.

Discount 40 per cent.; 5 per cent. casi with order. 


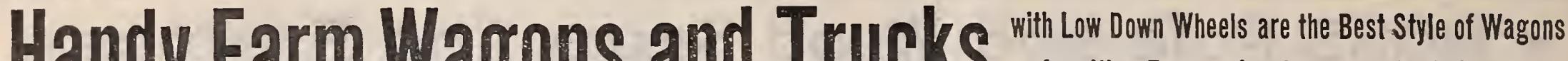

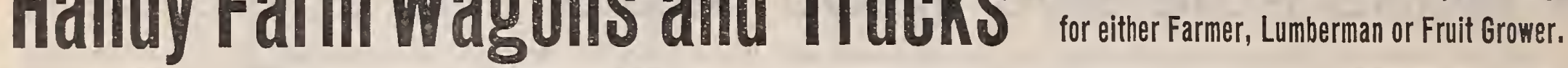

METAL WHEELS VS. WOODEN WHEELS.

There was a time not long ago when wooden wheels were used exclusively, but as iron has superseded other material in so many places so it has in wheels. Metal wheels have been found superior to wooden wheels in almost every way. They will stand the weather. If the paint gets off they are not ruined in a short time - that is they do not shrink in dry weather and have to have the tires reset: the spokes do not get loose (excepting in the cheap metal wheels): in fact they will stand much harder treatment in every way than wooden wheels. Metal wheels with wide tires are lighter in proportion to the load they will carry, than wooden wheels.

\section{Our No. 1 Gear.}

Good hounds in rear, double braced in front, hollow stakes for extension, good axles and good wheels. Made by experienced workmen, from good seasoned lumber, well painted and ironed. Good to carry 4,000 to 5,000 pounds.

List price, complete, with wheels 30 and 34 inch, tire $5 \times \frac{3}{8}$ inch, $\$ 35.00$.

Less discount for cash, $\$ 2.00$.
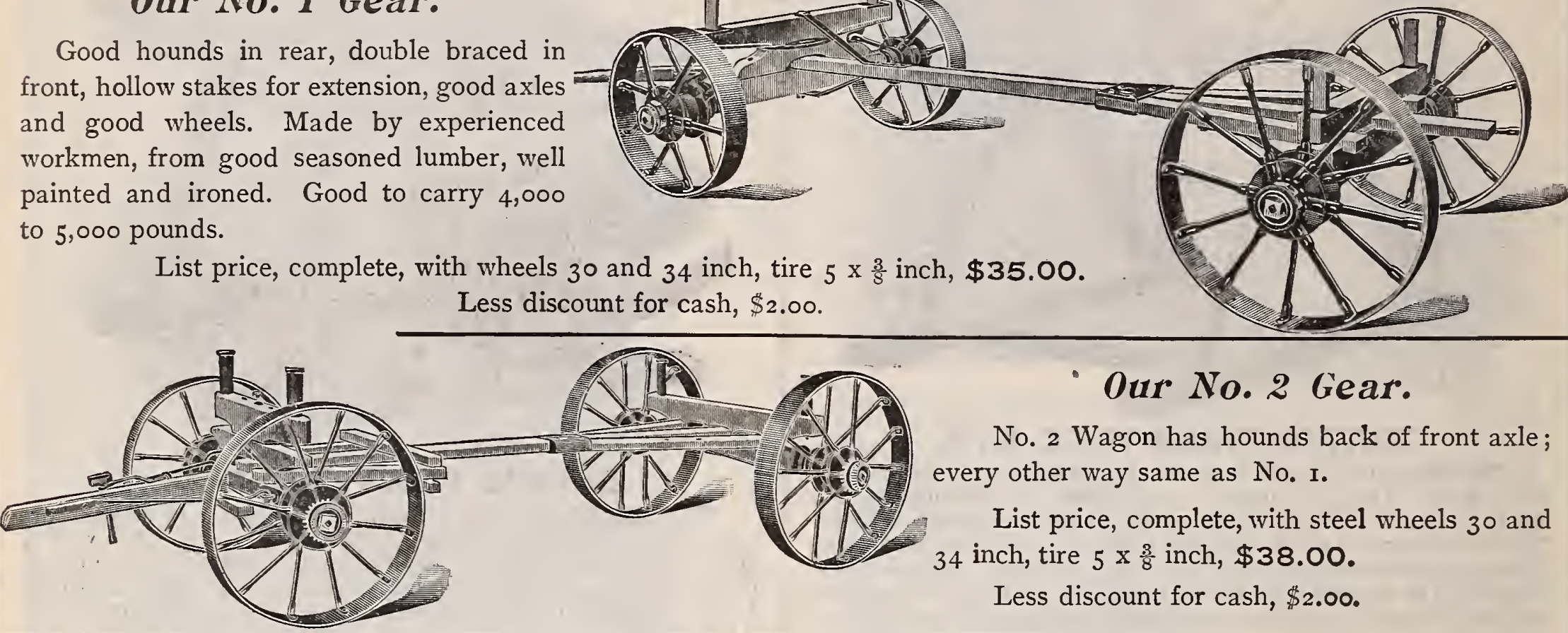

\section{Our No. 2 Gear.}

No. 2 Wagon has hounds back of front axle; every other way same as No. I.

List price, complete, with steel wheels 30 and 34 inch, tire $5 \times \frac{3}{8}$ inch, $\$ 38.00$.

Less discount for cash, $\$ 2.00$.

\section{BROAD TIRES VS. NARROW TIRES.}

It has been repeatedly demonstrated that a load can be drawn much more easily on wheels with wide tires than on those with narrow tires, on any kind of roadway. Broad tires a re greatly preferred on the fields and farm roads, as they do not sink so deeply into the soft earth and do not draw so hard. The following is taken from the Fourth Anqual Report of the Commissioner of Public Roads of New Jersey:-

"On a good, hard, sandy road you can haul 500 pounds more on four-inch tires than ynu can on one and one-half inch tires, or on level gravel roads 475 pounds more. It has been shown by experiment that a team can haul a load over the different kinds of roadway by exerting the following pull per ton: Earth road in fair condition, 130 to $160 \mathrm{lbs}$. Gravel or hard ea rth. 60 to $100 \mathrm{lbs}$. Macadam in good order. 40 to $601 \mathrm{hs}$.

Brick pavement, good 20 to 30 lhs. Anite blocks, smooth, 25 to 40 lbs.
"So it will be sphalt pavement, good, 5 to 25 . the resistance. Therefore, if the roadway is soft, there must be more surface of tire to prevent sinking where an inch and a half tire would sink six inches it is safe to say that a six inch tire would not sink an inch and a half with the same load, and on sod ground it would he even less. Broad tires are road makers. Narrow tires are road destroyers. The first does the work of a roller, the second that of a pick. Thus you see that broad tires save both your horses and your roads."

\section{Our No. 3 Gear.}

No. 3 Wagon has full hounds and pole, same as the make of lumber wagons.

List price, complete, with wheels 30 and 34 inch, tire $5 \times \frac{3}{8}$ inch, $\$ 42.00$.

Less discount for cash, $\$ 2.00$.
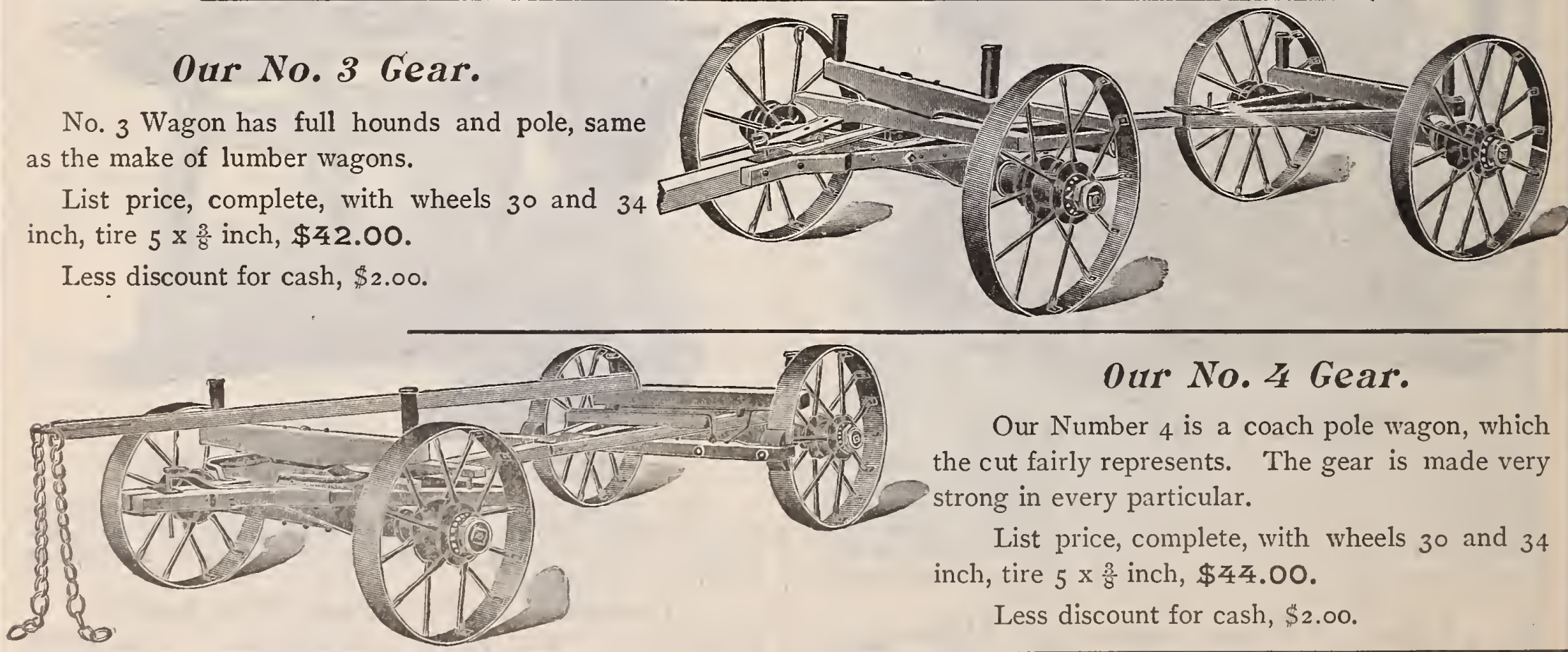

The above prices are Free on Board Cars at Geneva, Ohio. The Purchaser Pays the Freight. Other Sizes of Wheels can be Furnished if Desired. 


\section{LOW DOWn Far'm Wagrons with Solid or steel Wheces, tor Los- LOW DOW II Fal'II Wag'OHS ging or Farm work; 1 or, 2 Horse.}

What we have said on the preceding page in regard to Low Down Wagons and Wide Tires will apply to this line of wagons also; and for logging we

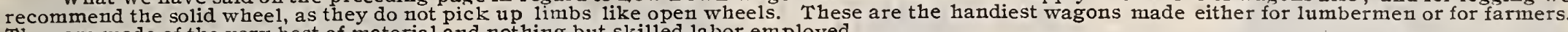
They are made of the very best of material and nothing but skilled labor employed.

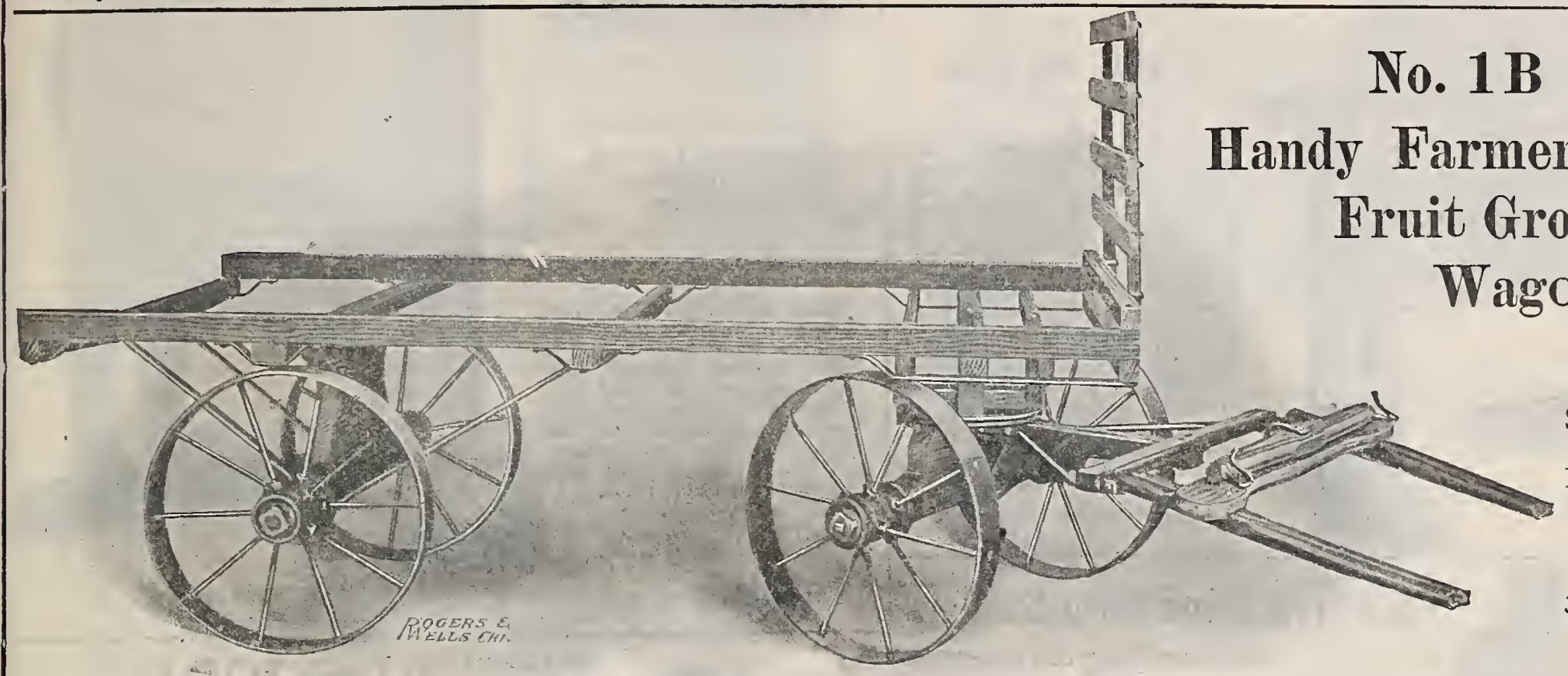

With

Steel Wheels.

Furnished in

one track

only

3 feet 2 inches to center of

tires.

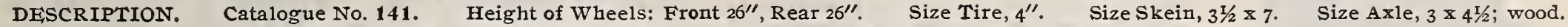
Weight, $65^{\circ}$ 1bs. $\quad$ Capacity, 3000 lbs. List price, $\$ 35.50$.

Write for Special Circulars.

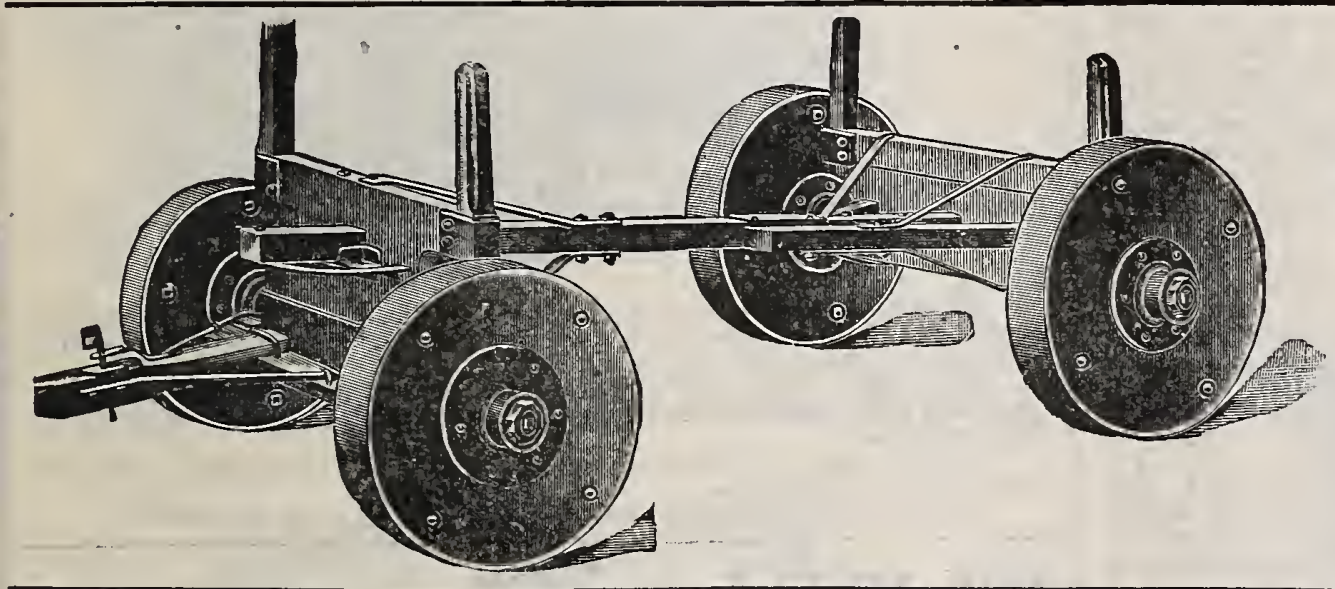

\section{No. 9 Handy Wagon.}

Two-horse, short turn style; wheels turn under load. Standard track-narrow, 4 feet 8 inches; wide, 5 feet center to center of tires on ground. Bolsters, $38 \mathrm{~T} / 2$ inches between stakes on narrow track; 42 inches on wide track.

Prices include pole and wrench only.

DESCRIPTION.

Catalog Wheels. Size Size Size List

No. Front. Rear. Tires. Skein. Axle. Capacity. Price,

$101 \quad 24^{\prime \prime} \quad 28^{\prime \prime} \quad 6 \quad 3 \frac{1 / 2 \times 7}{3 \times 41 / 2} \quad 4000 \quad \$ 27.00$

$102 \quad 26^{\prime \prime} \quad 30^{\prime \prime} \quad 6 \quad 3 \frac{3}{1 / 2 \times 7} \quad 3 \times 4 \frac{1}{2} \quad 4000 \quad 28.00$

$10328^{\prime \prime} \quad 3^{\prime \prime} \quad 6 \quad 3 \frac{1 / 2 \times 7}{3 \times 4 / 2} \quad 4000 \quad 29.00$

Write for Special Circulars.
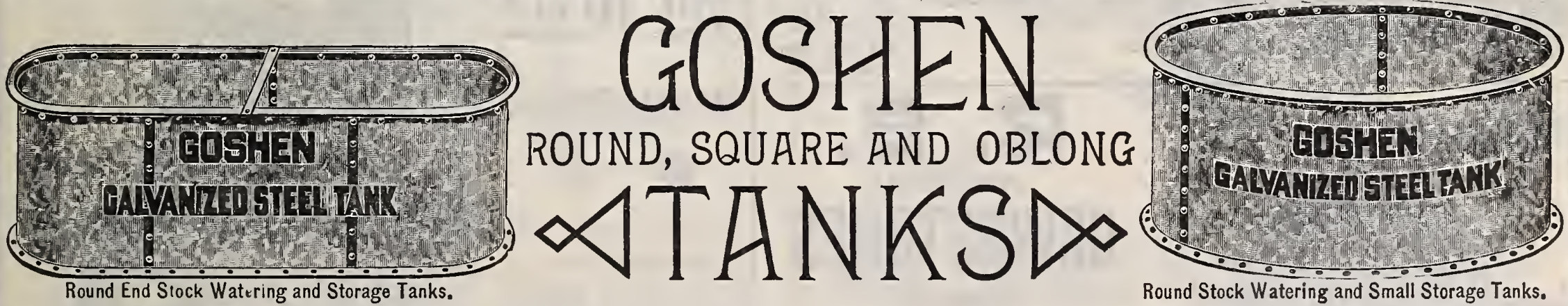

Round End Stock Watering and Storage Tanks,

Round Stock Watering and Small Storage Tanks.

FOR STOCK OR TOWERS. Send for complete price list. Steel tanks are far superior to wood.

\begin{tabular}{|c|c|c|c|c|c|}
\hline $\begin{array}{l}\text { No. } \\
101\end{array}$ & $\begin{array}{l}\text { Width. } \\
2 \mathrm{ft} .\end{array}$ & $\begin{array}{l}\text { Height. } \\
2 \mathrm{ft} \text {. }\end{array}$ & $\begin{array}{c}\text { Length. } \\
{ }_{4} \mathrm{ft} .\end{array}$ & $\begin{array}{l}\text { Capacity. } \\
33 / 4 \text { bbls. }\end{array}$ & $\begin{array}{l}\text { Price. } \\
\$ \mathbf{7 . 0 0}\end{array}$ \\
\hline 102 & $2 \mathrm{ft}$. & $2 \mathrm{ft}$ & $5 \mathrm{ft}$ & $43 / 4$ bbls. & 8.70 \\
\hline 103 & ft. & $\mathrm{ft}$. & $6 \mathrm{ft}$. & $53 / 4 \mathrm{bbls}$. & 10.25 \\
\hline 104 & ft. & ft. & $7 \mathrm{ft}$. & $61 / 2 \mathrm{bbls}$. & 11.25 \\
\hline 105 & $2 \mathrm{ft}$. & $\mathrm{ft}$. & $8 \mathrm{ft}$. & $7 \mathrm{I} / 2 \mathrm{bbls}$. & 12.25 \\
\hline 106 & $2 \mathrm{ft}$. & $2 \mathrm{ft}$. & Io ft. & $9 \mathrm{I} / 2 \mathrm{bbls}$. & 15.00 \\
\hline 107 & $2 \mathrm{ft}$. & $2 \mathrm{I} / 2 \mathrm{ft}$. & $8 \mathrm{ft}$. & $9 \frac{1}{2} \mathrm{bbls}$. & 14.00 \\
\hline 108 & $2 \mathrm{I} / 2 \mathrm{ft}$. & $2 \mathrm{ft}$. & $8 \mathrm{ft}$. & $9^{1 / 2} \mathrm{bbls}$. & 13.00 \\
\hline 109 & $2 \mathrm{I} / 2 \mathrm{ft}$. & $2 \mathrm{ft}$. & Io $\mathrm{ft}$. & I2 bbls. & 16.80 \\
\hline 110 & $21 / 2 \mathrm{ft}$. & $21 / 2 \mathrm{ft}$. & $8 \mathrm{ft}$. & I2 bbls. & 15.00 \\
\hline 111 & $3 \mathrm{ft}$. & $2 \mathrm{ft}$. & $8 \mathrm{ft}$. & II $1 / 2 \mathrm{bb} 1 \mathrm{~s}$. & 14.00 \\
\hline 112 & $\mathrm{ft}$. & ft. & Io $\mathrm{ft}$. & I4 $\mathrm{bbls}$. & 17.50 \\
\hline
\end{tabular}

GOSHEN TANKS are made of No. 20 Galvanevery way. The measurements are outside covers. 2 Can be furnished at about 20 cents per square foot. There are so many sizes made, and as all tanks are shipped set up, we do not carry them in stock, but can guarantee prompt shipment from factory, and we offer a liberal discount which will cover freight charges to nearly any freight station in New Eng land. We can also furnish any size or style of tank either set up or flat.

Send for complete list with discount.

\begin{tabular}{|c|c|c|c|c|c|}
\hline No. & Diameter. & Height. & Cape & acity. & Price. \\
\hline $\begin{array}{l}1 \\
2\end{array}$ & $\begin{array}{l}3 \mathrm{ft} . \\
4 \mathrm{ft} .\end{array}$ & $\begin{array}{ll}2 & \mathrm{ft} . \\
2 & \mathrm{ft} .\end{array}$ & $\begin{array}{l}31 / 2 \\
6\end{array}$ & $\begin{array}{l}\text { bbls. } \\
\text { bbls. }\end{array}$ & $\begin{array}{r}\$ 8.00 \\
9.50\end{array}$ \\
\hline 3 & $4 \mathrm{ft}$ & $2 \mathrm{t} / 2 \mathrm{ft}$. & 7 & bbls. & 10.75 \\
\hline 4 & $4 \mathrm{ft}$. & $3 \mathrm{ft}$. & 9 & bbls. & 12.75 \\
\hline 5 & $4 \mathrm{ft}$. & ft. & 12 & bbls. & 1600 \\
\hline 6 & $4 \mathrm{ft}$. & $\mathrm{ft}$. & 14 & bbls. & 19.00 \\
\hline 7 & $4 \mathrm{ft}$. & ft. & I 8 & bbls. & $23.7 j$ \\
\hline 8 & $4 \mathrm{ft}$. & ft. & 24 & bbls. & 2600 \\
\hline 9 & $5 \mathrm{ft}$. & $2 \mathrm{ft}$. & $9^{1 / 2}$ & bbls. & 13.00 \\
\hline 10 & $5 \mathrm{ft}$. & $21 / 2 \mathrm{ft}$. & 12 & bbls. & 14.50 \\
\hline 11 & $5 \mathrm{ft}$. & $3 \mathrm{ft}$. & I4 & bbls. & 15.50 \\
\hline 12 & $5 \mathrm{ft}$. & ft. & 19 & bbls. & 21.00 \\
\hline
\end{tabular}




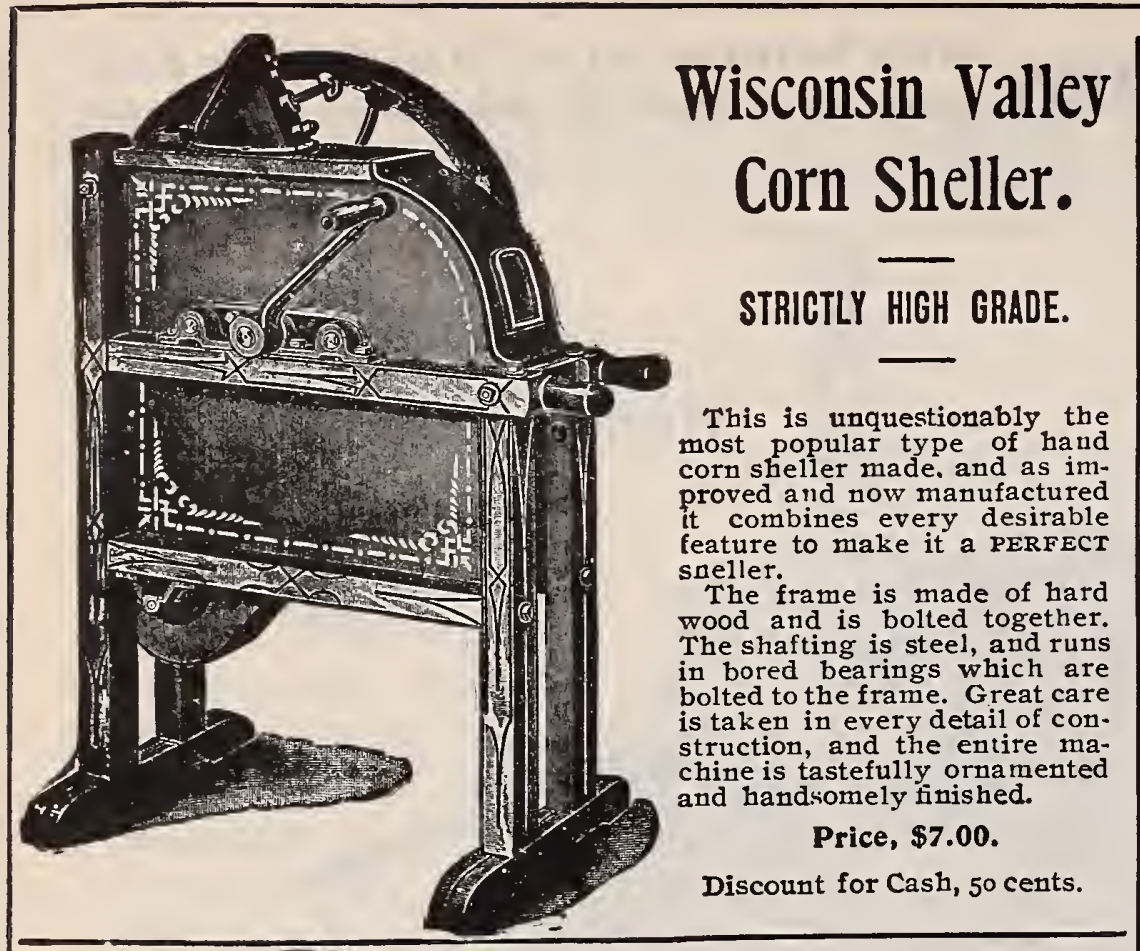

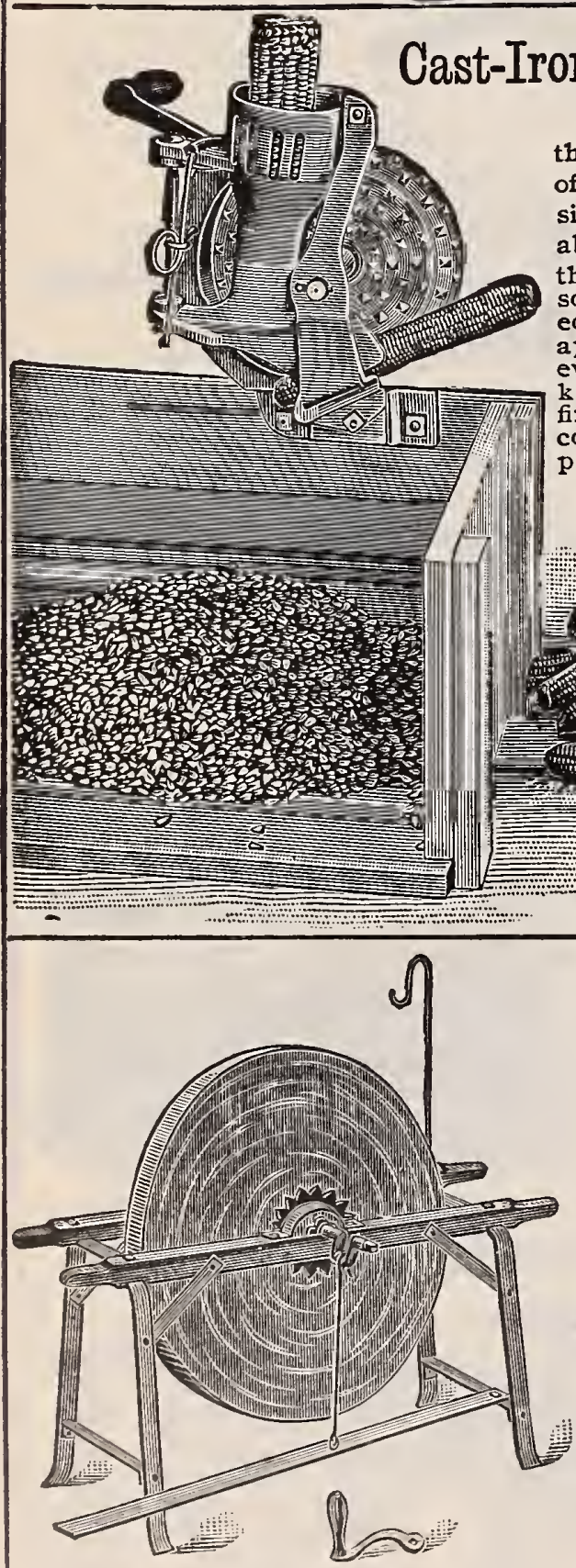

No. 1. Stone weighs about 1001
For convenience and general utility his little corn sheller will be found one of the handiest tools imaginable. It is so simple that there is absolutely nothing about it to get out of order, and so strong that it will not break. Can be adjusted so as to shell small or large ears with equally good results. Its value will be appreciated most in the cold winter vernings, when it can be taken into the kitchen beside a warm and comfortable tre. Can be used to shell pop corn, seed purpose, and can be operated by a child. The adjusting shell is hela against the ear spring, the tension of $w h_{2}$ ch is easily \& quicklyadjusted. This shell forces the ear of corn shelling wheel and causes the ear to revolveso that the corn is shelled fro

\section{Not Cash Price only $\$ 1.50$. GRINDSTONES}

This is the best low-priced grindstone on the market. The stone is best Berea Grit (Ohio) the legs are iron, which will not rot if left out during haying, the woodsidepieces arepainted bright vermilion, and the hangings made nterchangable. It is a very handy stone to move from one place to another.

$\$ 5.00$

No. 2.

lbs........

4.50

$60 \mathrm{lbs}$

4.00
LION

CORN
SHELLER

Is a Rapid, Easy Working and Smooth Running Sheller, shelling all

kinds of Corn.

Made with a heavy Balance Wheel, Steel Shafts. Adjustable Iron Hopper with steel Springs. Solid Side Bearings, which hold the shaft.s firmly in position. Gearing all inside, and so made that the corn cannot our Improved separator.

Retail Price, $\$ 12.00$.

Discount for Cash, $\$ 2.00$.

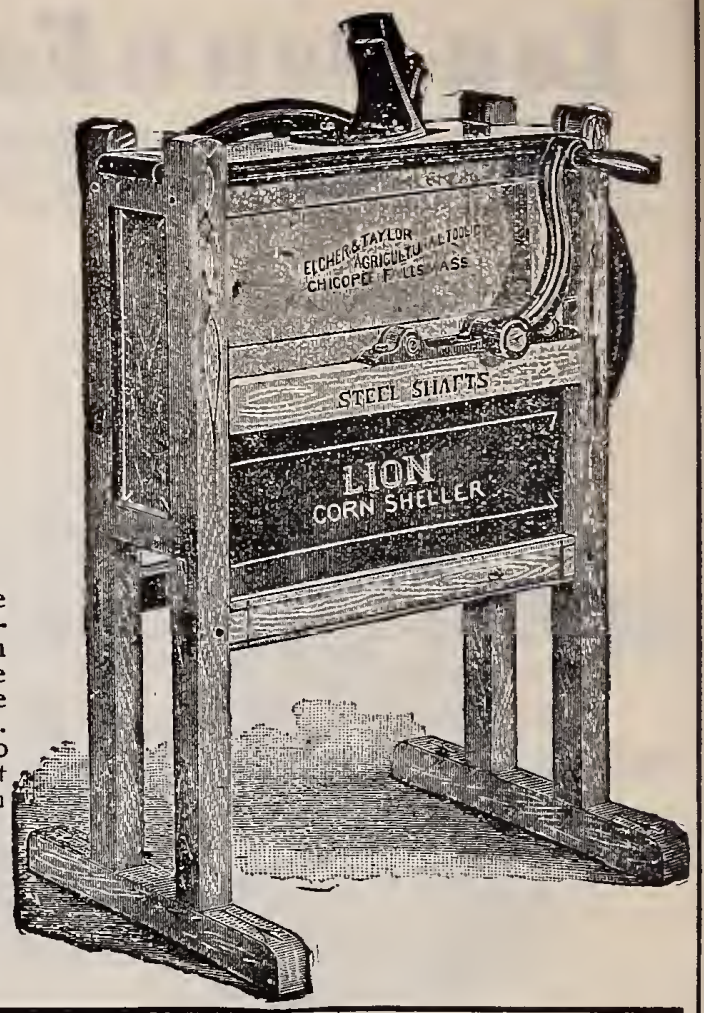

U. S. STANDARD COAL, HAY AND FARM SCALES.

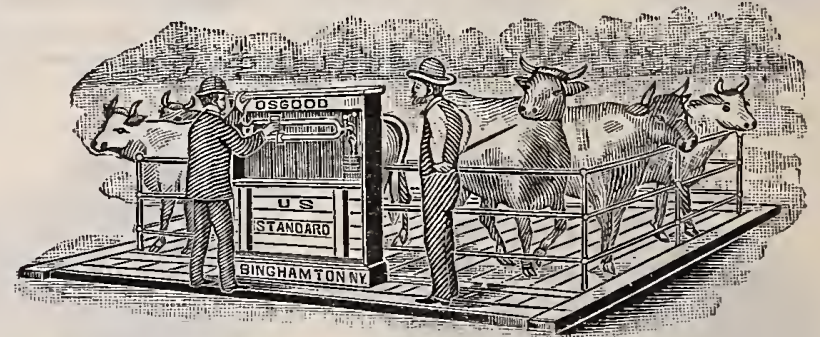

There is no better scale on the market than the OSGOOD. We have had one of them in constant use in our seed roon for fifteen years, and it is as good, apparently. as when new.

to be an accurate United States standard scale, and to last as long as any other scale of like capacity in ike location.

Beams (single, double or combination), of extra heavy polished

brass with sliding poise.
Send for free Catalogue and Descriptive Sheet, and Discount.

\section{THE HECLA} OAK FRAME GRINDSTONE

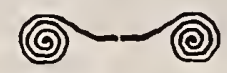

This stone we have made for us, and it is as good a stone as money will buy. It is furnished with a best Nova Scotia stone, the frame is very strong and made of oak, has both crank and foot treadle, with trough and protector.

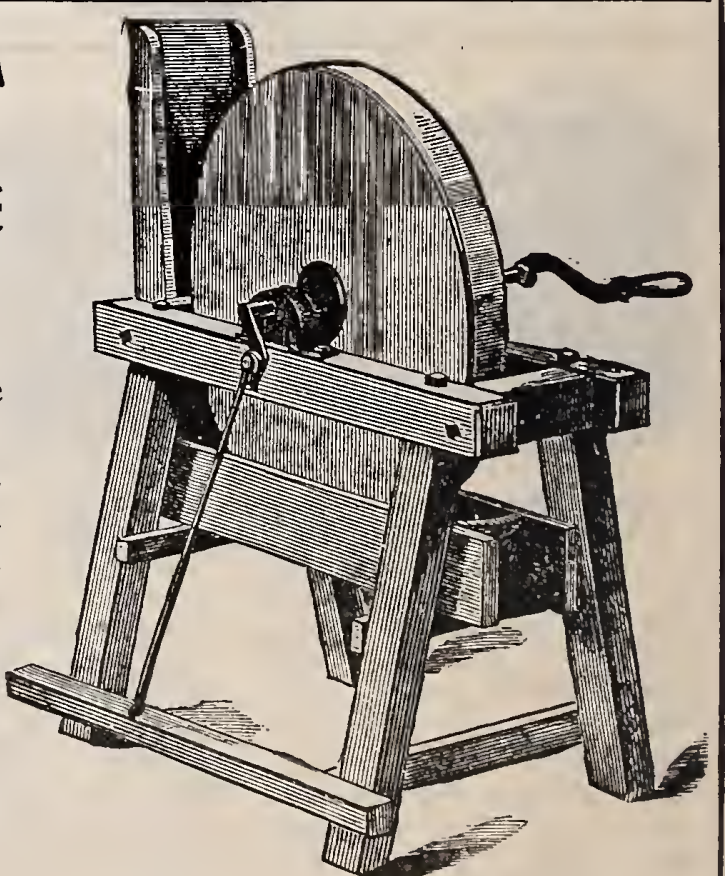

size. 22 in..... Iist Price, $\$ 7.25$. Net Price, $\$ 6.00$

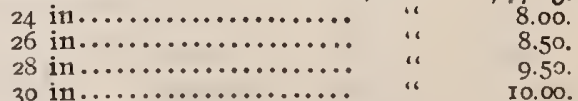
8.00 


\section{The Banner Root Yegetable Cutter.}

The "Banner" Root Cutter is, without question, the best ever invented. It contains features found in no other machine. It has a self-feeder; separates the dirt from the cut feed, and leaves the cut ford in such condition that the stock cannot choke. The pieces ate cut in long half-round slices, and are not crushed, ground or torn; even young lambs can safely be fed with roots cut with the "Banner" Cutter.

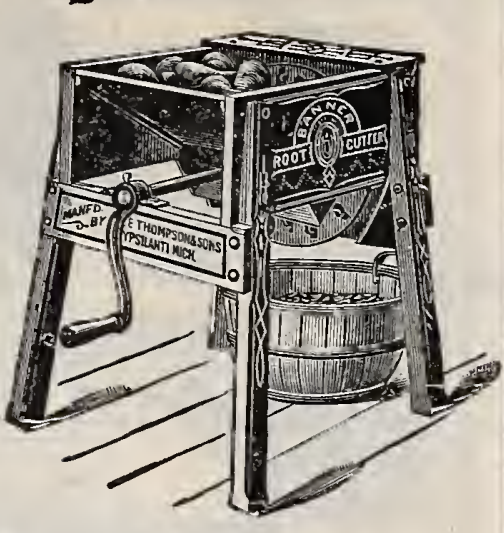

PRICES.

No. 20. Hand power, capacity 30 to 50 bushels an

No. 15. The above fitted with pulley power, capacity 60 to 80 bushels an hour,

$\$ 11.00$

No. 16. Power cutter, capacity 120 to 180 bushels an hour,

Discount for cash, $\$ 1.00$.

13.00

18.00

\section{The Centennial Fanning Mill.}

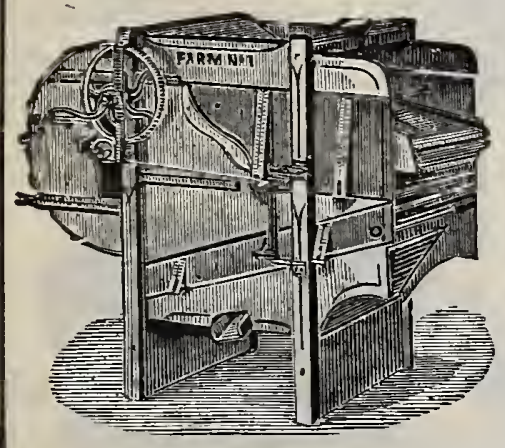

The Most Perfect Cleaner, Grader and Separator of all Grain and Seeds.

The Centennial is an excellent chaffer, having plenty of wind and shake. Having two shoes it carries more screens than any other mill in the market. It will separate oats and all seeds, such as pigeon grass, wild buckwheat, cockle, cheat, and other wild seeds from wheat at one operation. The best mill for all purposes in the market.

List Price, \$20; discount for Cash, \$4.

\section{White Mountain Ice Cream Freezer.}
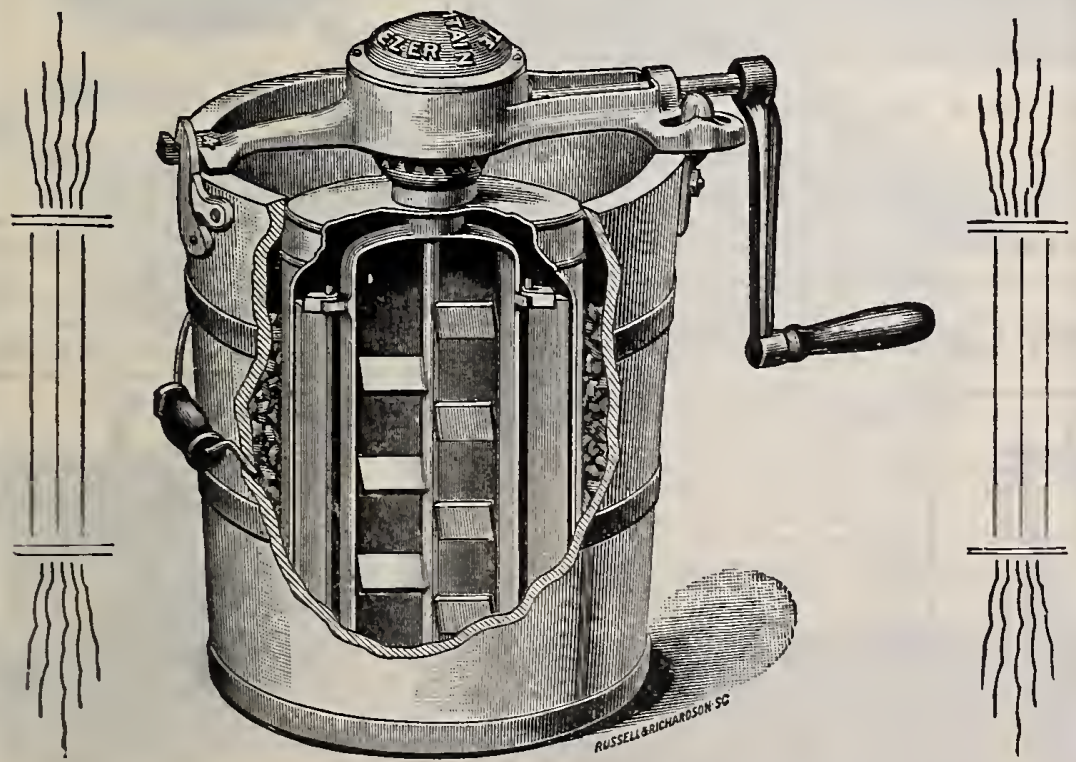

These Freezers are imitated, but not equalled. There are cheaper freezers in price than the White Mountain, but not so good.

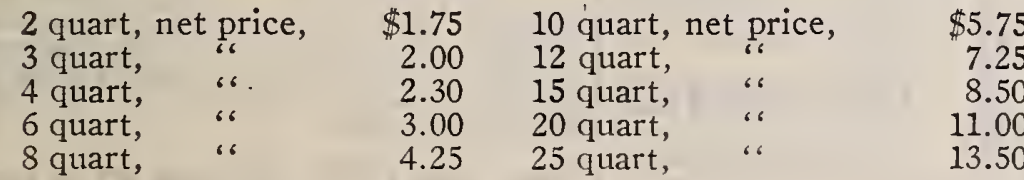

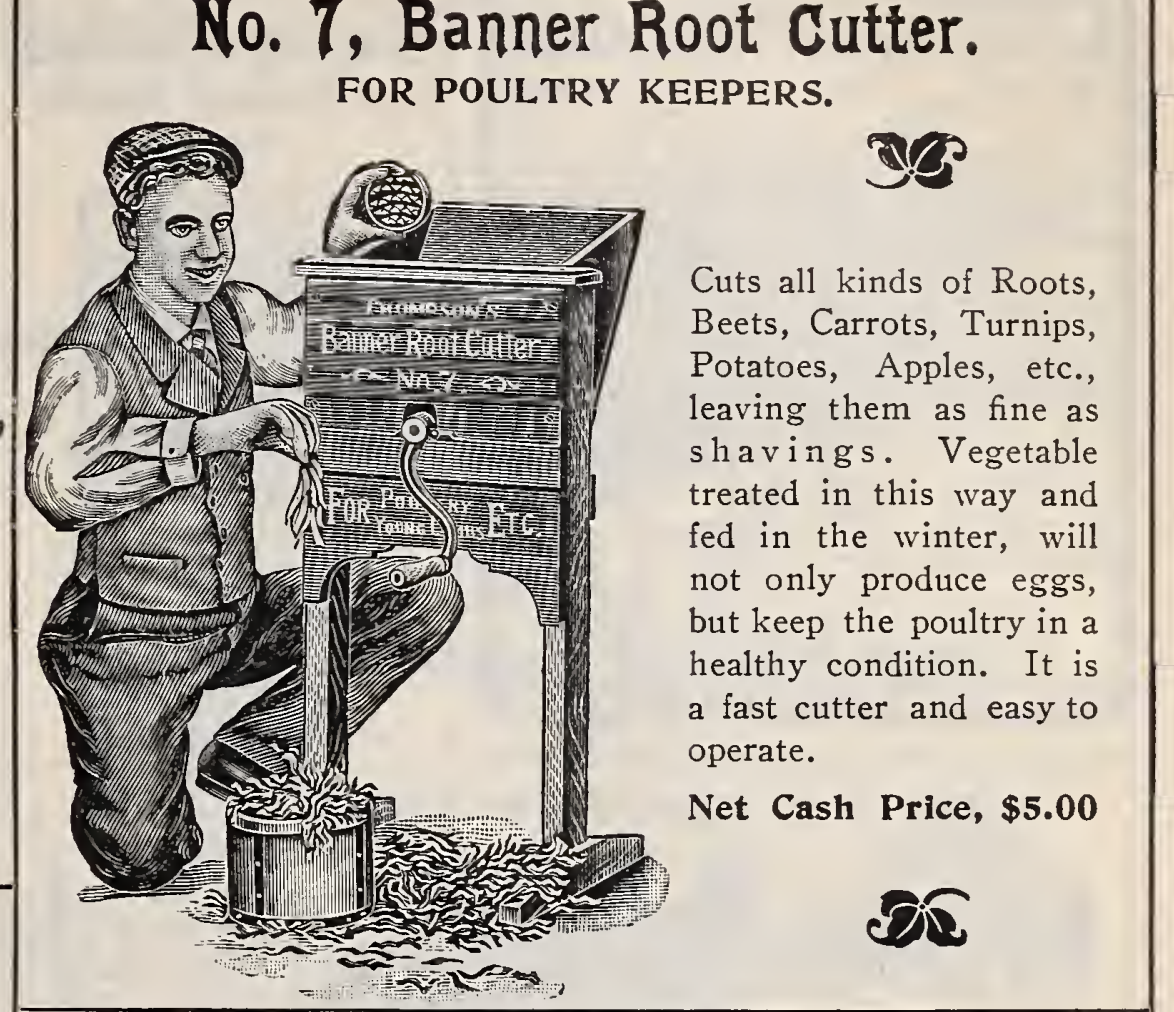

\section{The Rich Lever Cutter.}

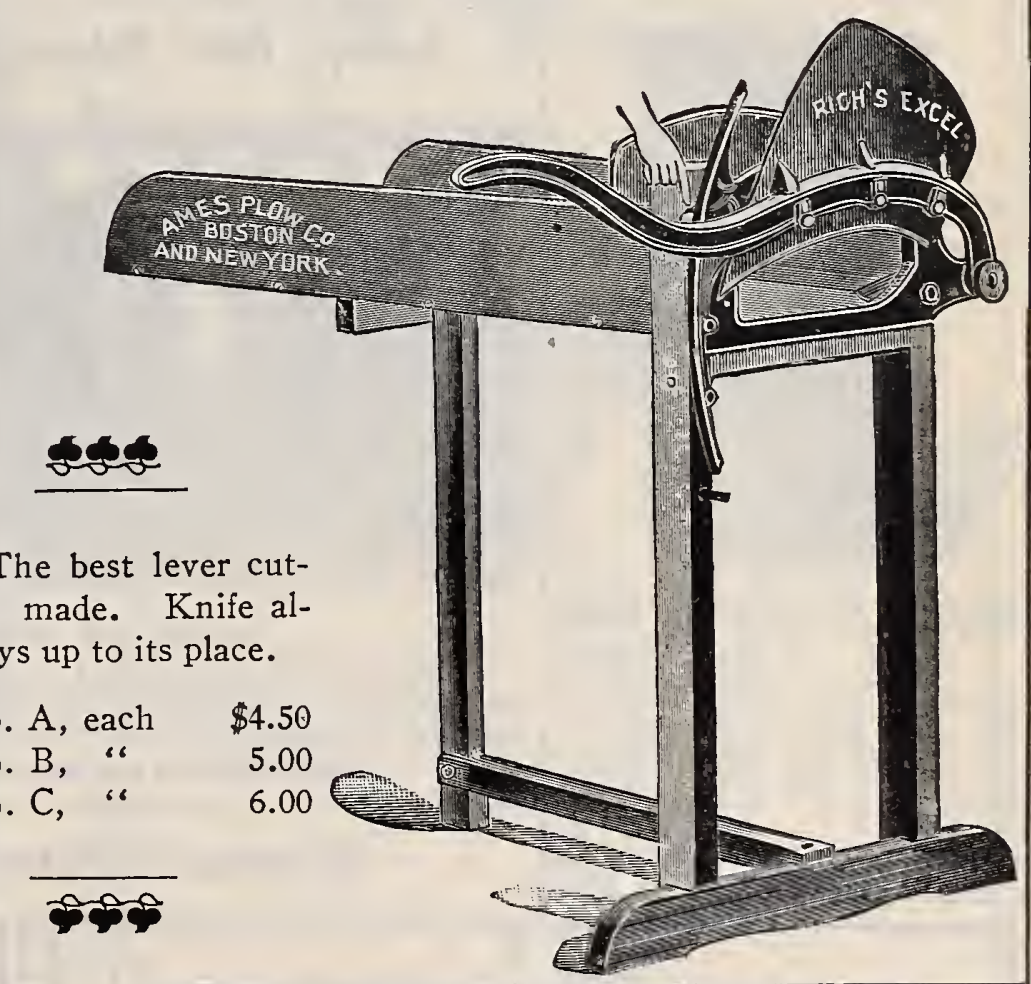

\section{New England Vegetable Cutter}
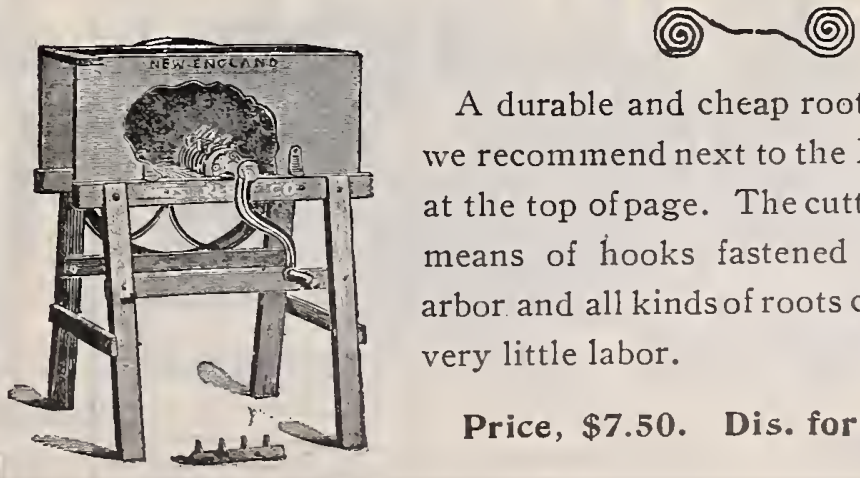

A durable and cheap root cutter, which we recommend next to the Banner shown at the top of page. The cutting is done by means of hooks fastened to the main arbor and all kinds of roots can be cut with very little labor.

Price, \$7.50. Dis. for Cash 50c. 

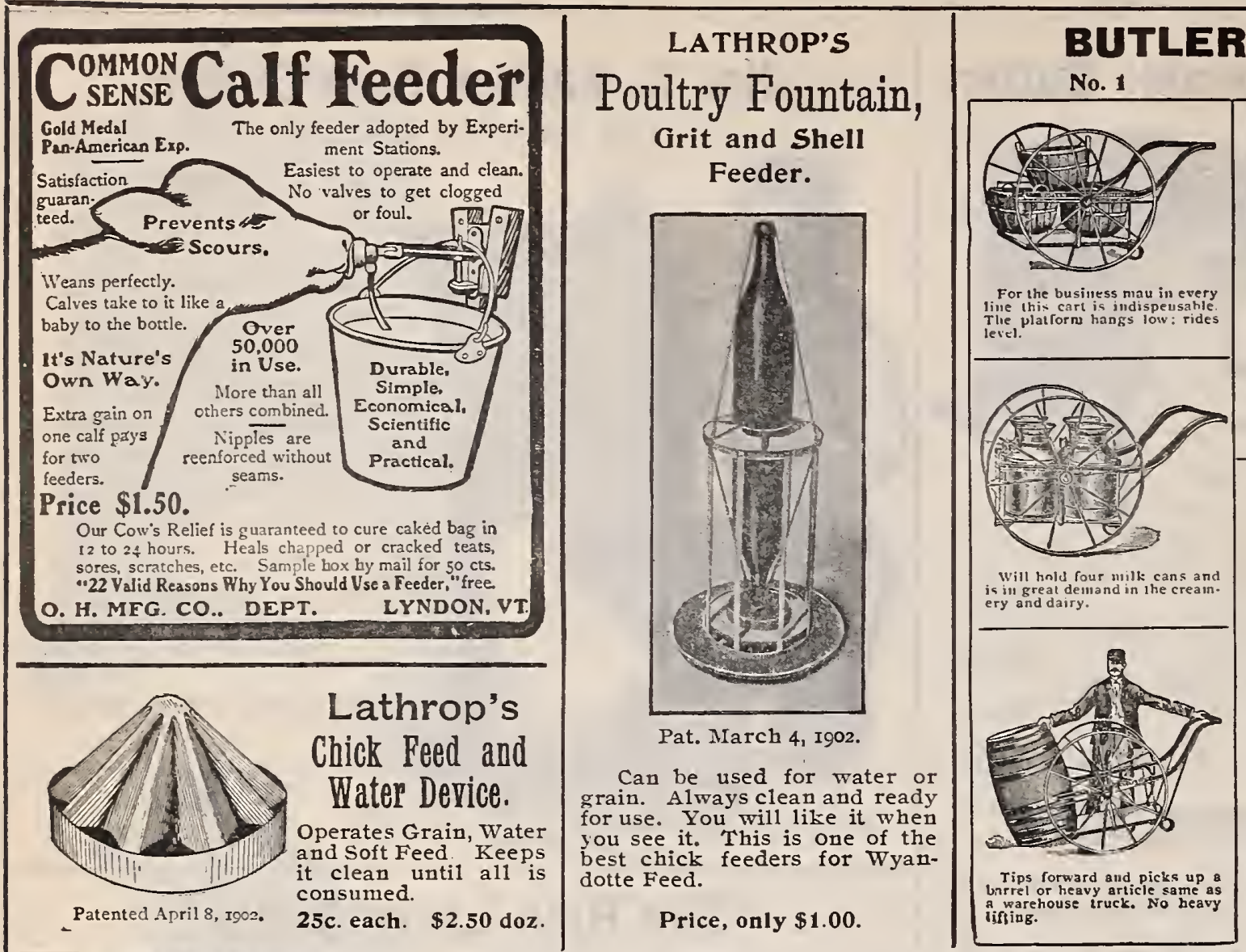

\section{STEEL HAND GART. \\ No. 2 \\ No. 3}

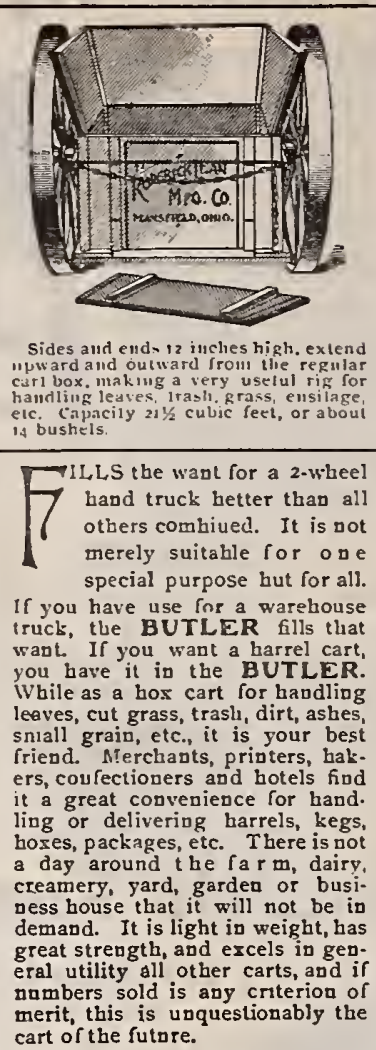

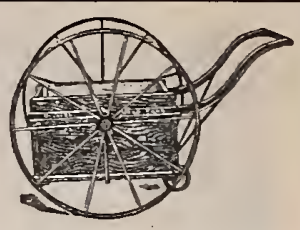

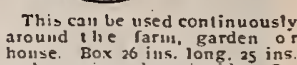

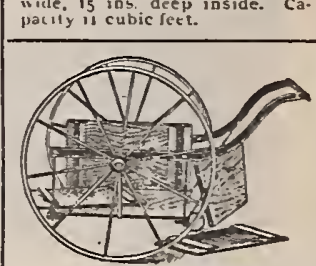

The side and end boards can be
quickly delached. Easily loadcd
as a wheeelbarrov.

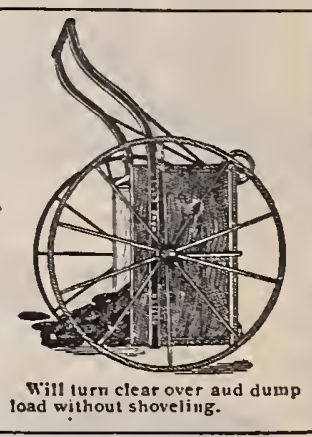

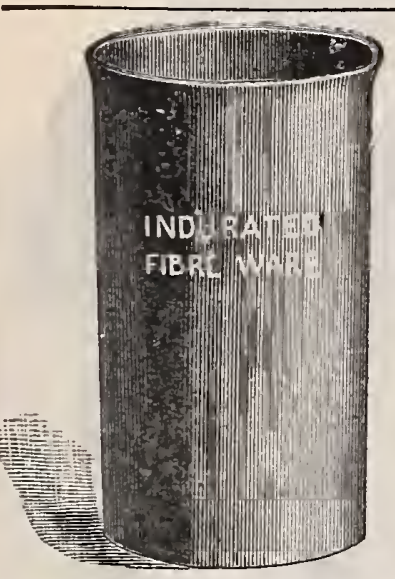

Indurated Fibre Florists' Vases

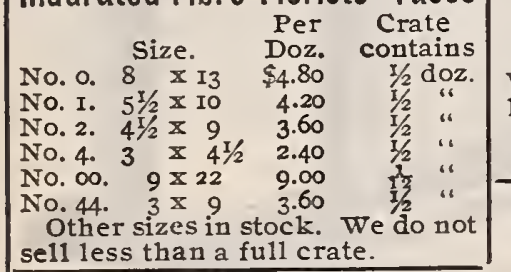

sell less than a full crate.
Buckley's Patent Watering Device For Watering Stock In Stables.

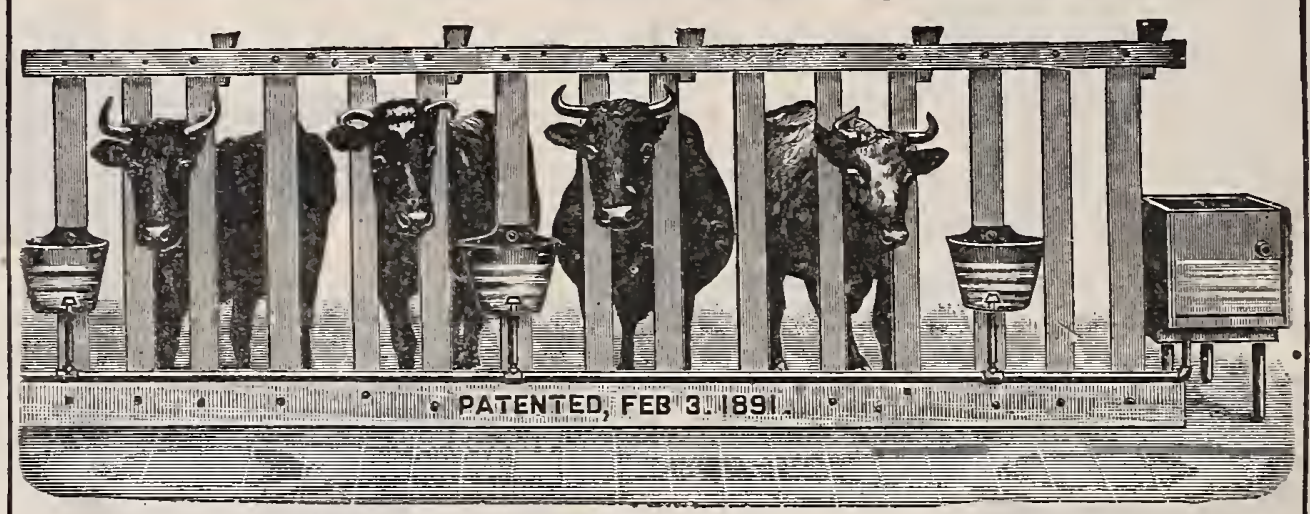

WATER IN THE STABLE IS A NECESSITY.

It has come to be regarded as a matter of necessity for the proper caring of stock, while in the stable, that they should have constant access to the water of suitable te
perature. The Buckley process shown above is the most practical method of having it.

Plain, each, \$1.00; doz., \$11.00. With valve, \$1.25; doz., \$14.00.

Warriner's Patent Chain Cattle Stanchions.

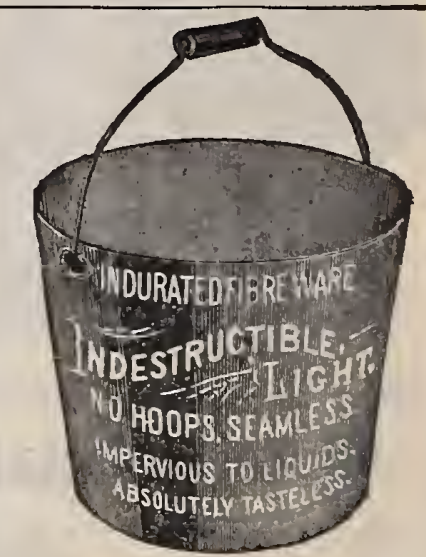

Indurated Fibre Pails.

Star, I2-quart, each, 30 cts. Stable, I4-quart, each, 40 cts. Stable, I6-quart, each, 50 cts. Pine Stable Pails, 3-hoop, 25 cts. Cedar Stable Pails, 3 -hoop, 35 cts. J. I. C. Stable Oak Pails hisoop, 50 cts. Io qt. $25 \mathrm{c}$.; I2 qt. $35 \mathrm{C}$.; I4 qt. $40 \mathrm{C}$.
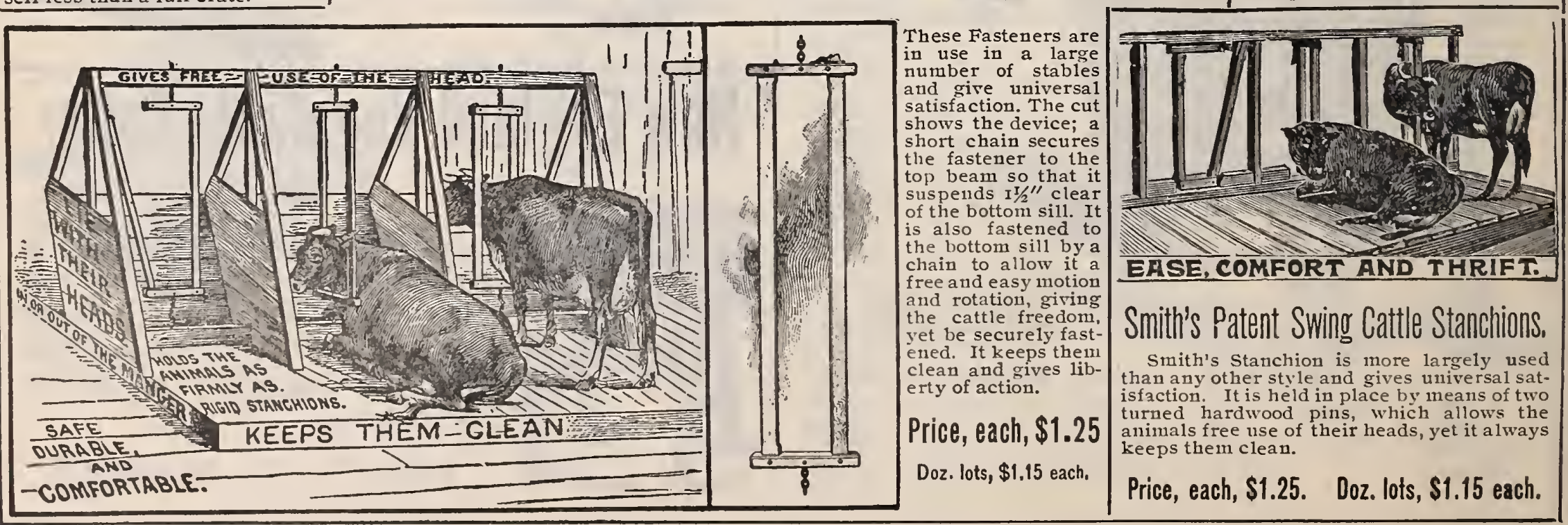

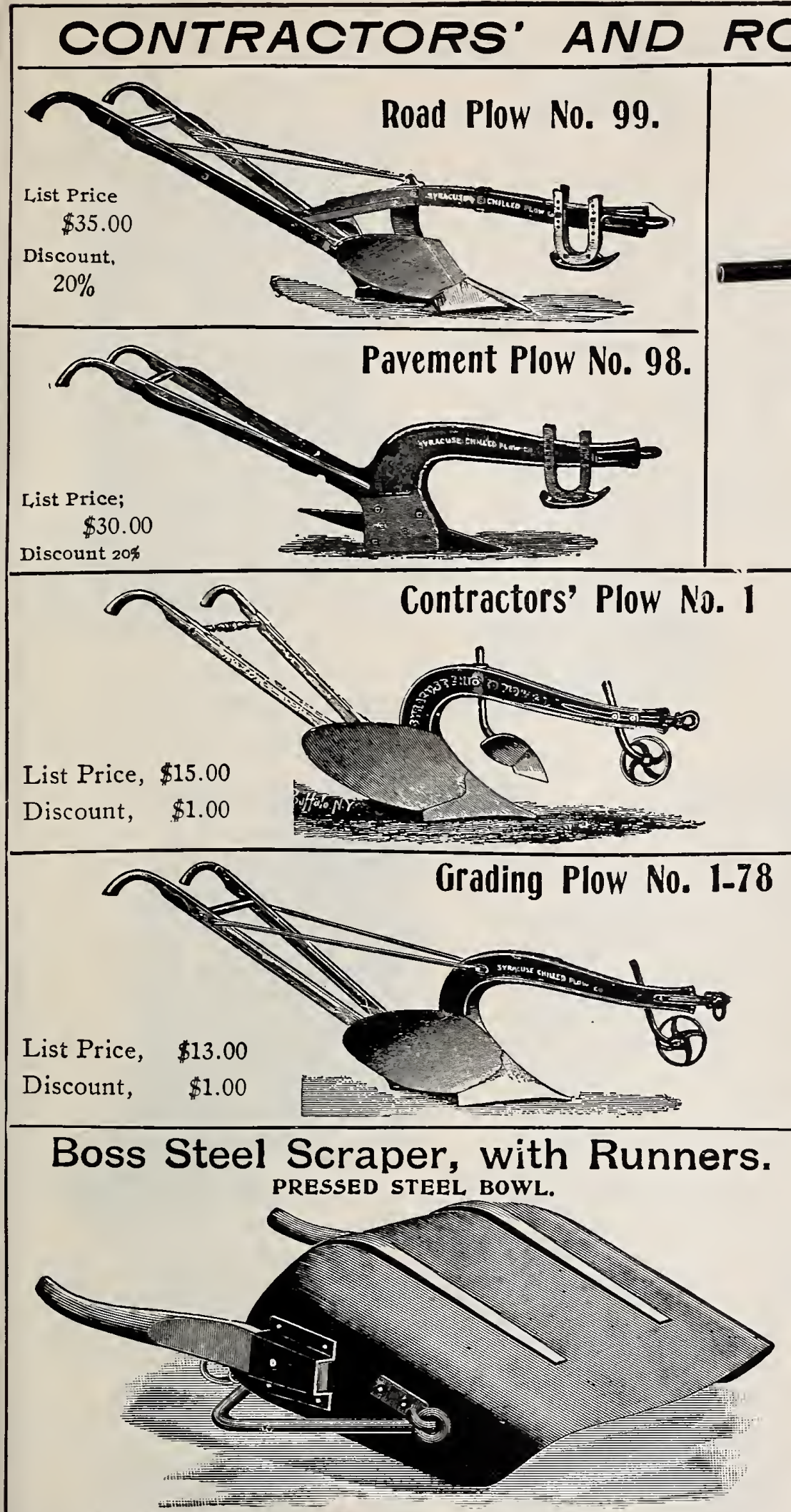

\begin{tabular}{ll|l} 
No. o, carries Io feet of earth, \$II.00 No. 3, carries 3 feet of earth, $\$ 6.00$
\end{tabular} \begin{tabular}{llll|ll} 
No. I, " 7 " & " & 7.00 & No. 0 , Riveted Bowl, & 10.00
\end{tabular} Shovels Following are all Ames' Make.

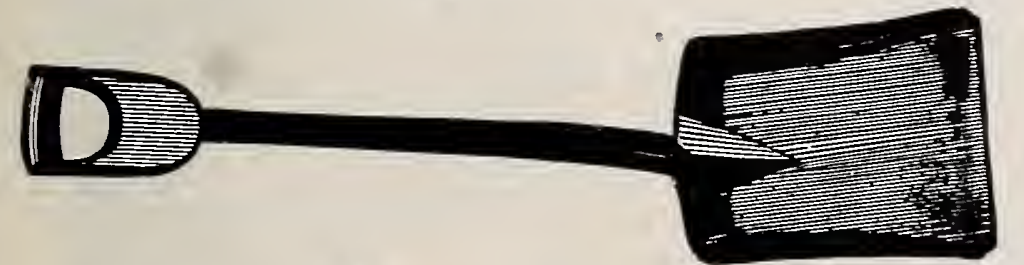

No. 2, Ames' Special, D. H., Each. Doz. $\mid$ No. 2, Sunnyside, D. H., sq. $\$$ Each. Doz.

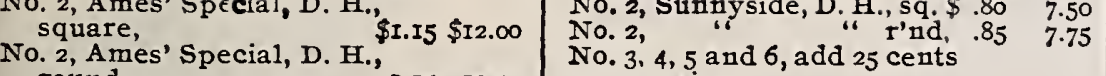

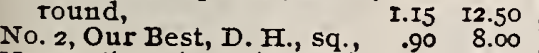

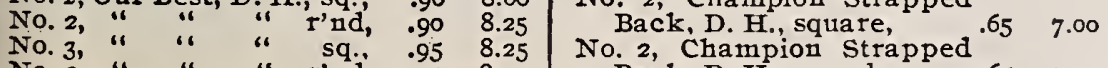
Black finish 25 cts, per doz. .958 .50 \begin{tabular}{ll|ll} 
No. $3.4,5$ and 6 , add 25 cents & 7.75 & 6 lb., & $60 \mathrm{c}$ \\
7 lb., & $65 \mathrm{c}$
\end{tabular} No. 2, Champion Strapped Mattocks.

$\begin{array}{ll}\text { Back, D. H., square, } & .65 \quad 7.00 \quad \text { Axe, } \quad 75 \mathrm{C} \\ \text { No. 2, Champion Strapped }\end{array}$ \begin{tabular}{lll|l} 
Back, D. H., round, & .65 & 7.00 & $\begin{array}{l}\text { Pick, } \\
\text { Bog Hoes, }\end{array}, \begin{array}{l}75 \mathrm{C} \\
\text { 50 }\end{array}$
\end{tabular}
Tubular Steel Barrow with Pressed Steel Bowl.

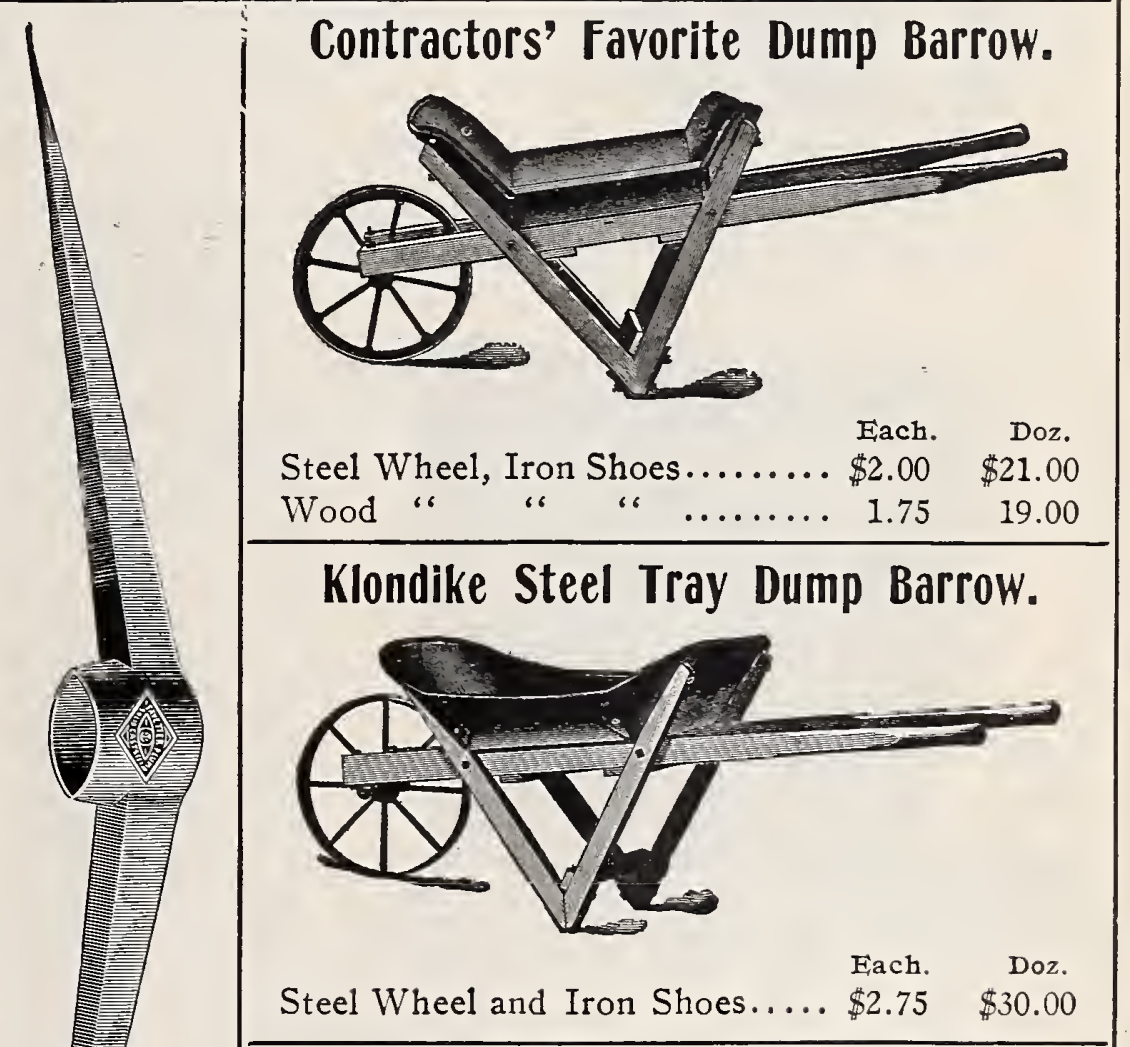

Stump Puller and Rock Lifter.

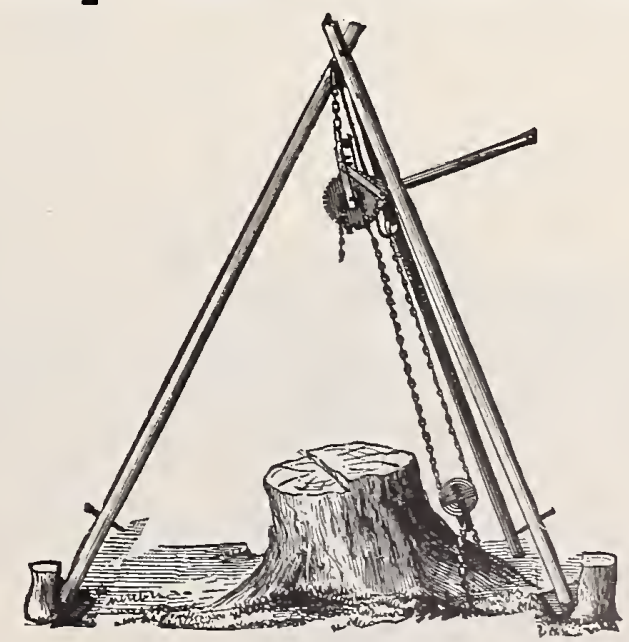

Simplest and most efficient device ever invented for pulling stumps and lifting stones or handling heavy bodies.

Price complete with Tripod........ \$28.00

Without Tripod .............. 25.00 


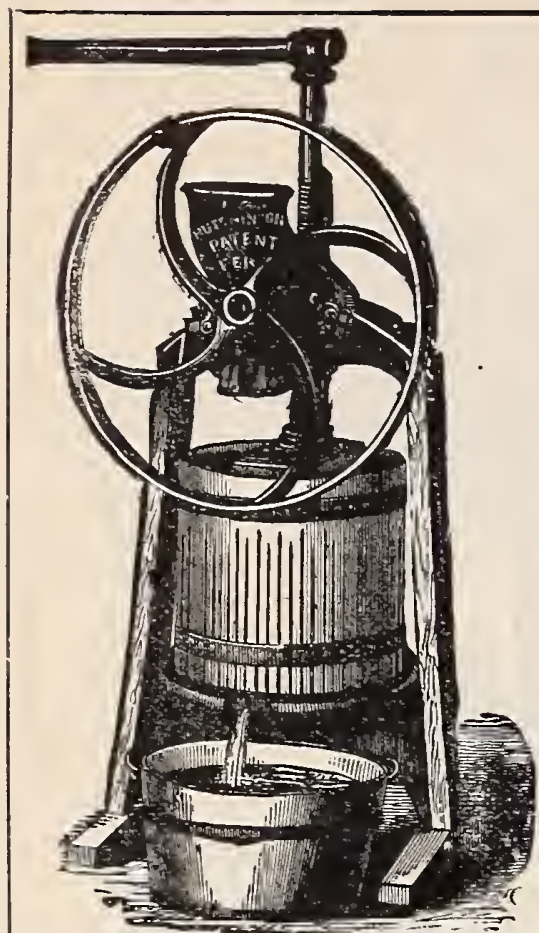

\section{The Hutchinson \\ Family Cider and Wine Mill.}

For those who only make limited quantities of cider or wine, this old favorite machine is unexcelled. It will grind from eight to ten bushels of apples, and from ten to twelve bushels of grapes, currants, etc., per hour. The curb (or press) will contain the pomace of one bushel or more of apples. One man can make with it from two to three barrels of cider, or from one hundred to one hundred and fifty gallons of wine per day, while it is always ready to make a pitcher or bucket of cider in a few minutes. No. 0. List, $\$ 10.00$. Net, $\$ 7.50$ No. 1. List, 12.00 . Net, 8.50

\section{NATIONAL CIDER YILL, FAMILY PAMLY}

This mill is especially adapted for family use, beinglight, strong and convenient. It is exactly the same in principle as the farmers' mill shown below, only of smaller size and sold at a less price. This mill will pay for itself in one season by gathering the windfalls and making them into cider for vinegar and for the market; this is just the size for that purpose.

Two Curbs, $\begin{array}{cc}\text { List } \\ \text { Price. }\end{array} \quad \begin{gathered}\text { Net } \\ \text { Price. }\end{gathered}$

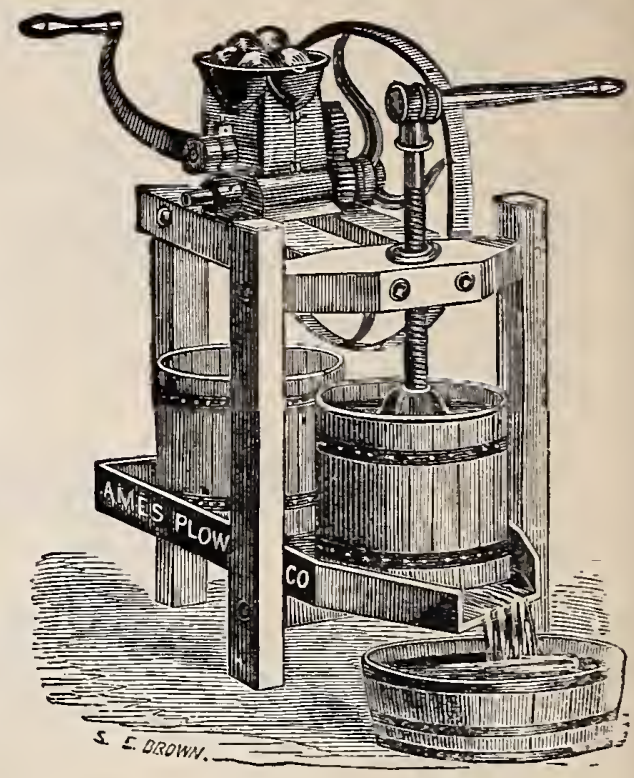

\section{Peekham's Furnaces}

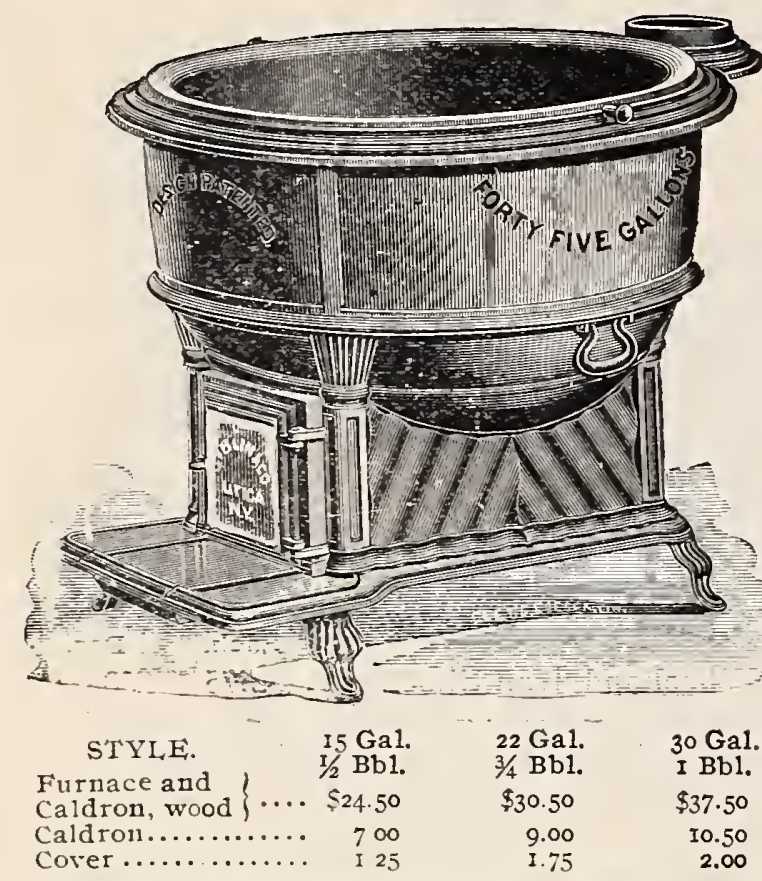

\section{and faldrons}

Made in seven sizes, from 15 to 120 gallons. These furnaces are arranged to burn either hard or soft coal, or wood. The flues are so constructed that instead of going direct to the smoke outlet, the heat is directed evenly against all sides of the caldron. This construction secures the use of all the heat generated and very little heat is wasted. The furnaces are shipped with legs and provided with handles so they can be set almost anywhere. They can be used out-of-doors and are instantly ready for use when the smoke pipe is attached. The fire boxes in the furnaces of the respective sizes are made for suitable lengths of wood. Coal furnaces are provided with coal grate and heavy firebrick.

\begin{tabular}{|c|c|c|c|}
\hline $\begin{array}{l}45 \mathrm{Gal} \text {. } \\
\mathrm{I}^{1} / 2 \mathrm{Bbl}\end{array}$ & $\begin{array}{l}60 \text { Gal. } \\
2 \text { Bbl. }\end{array}$ & $\begin{array}{l}90 \mathrm{Gal} . \\
3 \mathrm{Bbl} .\end{array}$ & $\begin{array}{c}\text { I20 Gal. } \\
4 \text { Bbl. }\end{array}$ \\
\hline$\$ 435^{\circ}$ & $\$ 50.00$ & $\$ 88.00$ & $\$ 115.00$ \\
\hline & 16.00 & 30.00 & \\
\hline
\end{tabular}

NATIONAL CIDER MILL. FARMERS' SIZE.

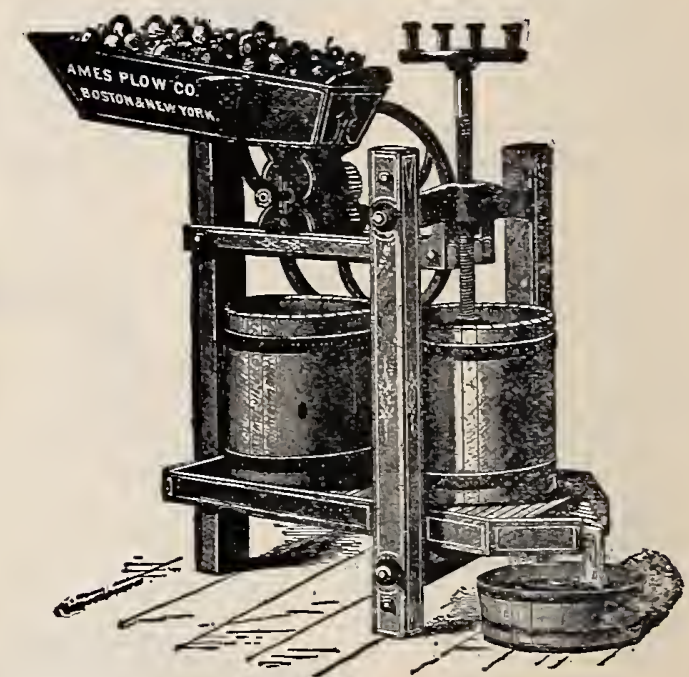

This mill is constructed upon new principles, avoiding the defects in all other mills. The grinding arrangement works in such a manner that the cells of the fruit are all broken and fine pomace produced; a larger per centage of juice is obtaince making more cider from a given quantity of ap-

Capacity is six to eight barrels per day.

List Price, \$28.00. Net Price. \$23.00.

\section{Economy Boilers.}

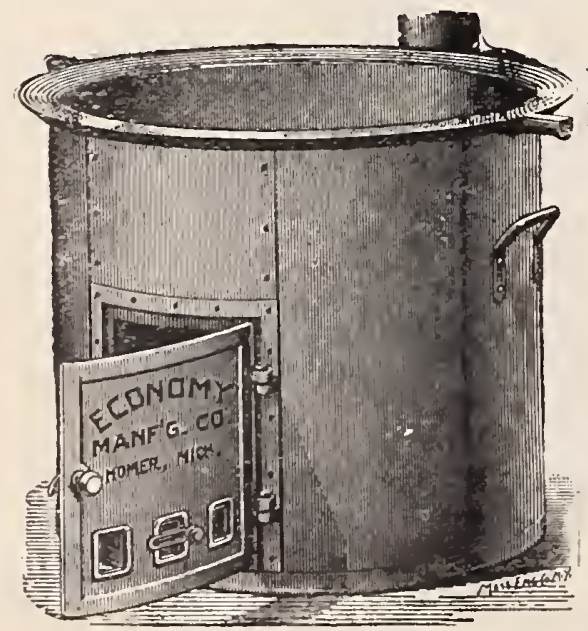

No Farmer can afford to be without a farm boiler or large kettle of some kind. The Economy, shown in cut, is the cheapest of any on the market.

For out-door use only.

\section{PRICES}

$33 \mathrm{Gal}$. List, $\$ 14.00 \$ 9.25$

$48 \mathrm{Gal}$. " $\quad 16.00 \quad 10.50$

$65 \mathrm{Gal}$.

$$
\text { " } 20.00 \quad 13.00
$$

Other sizes furnished if desired.
"Grunille stole" Waler Henler.

For Butchers and Milkmen.

Boilers of galvanized steel; furnace of gray iron castings and sheet steel; sides of double thickness of steel with hot air space between.

\section{PRICES.}

25 gal. $\$ 15.00 \quad 50$ gal. $\$ 21.00$ 30 gal. 16.5065 gal. 22.50 40 gal. 19.5075 gal. 24.00 100 gal. $\$ 27.00$

Discount for cash, 10 per cent.

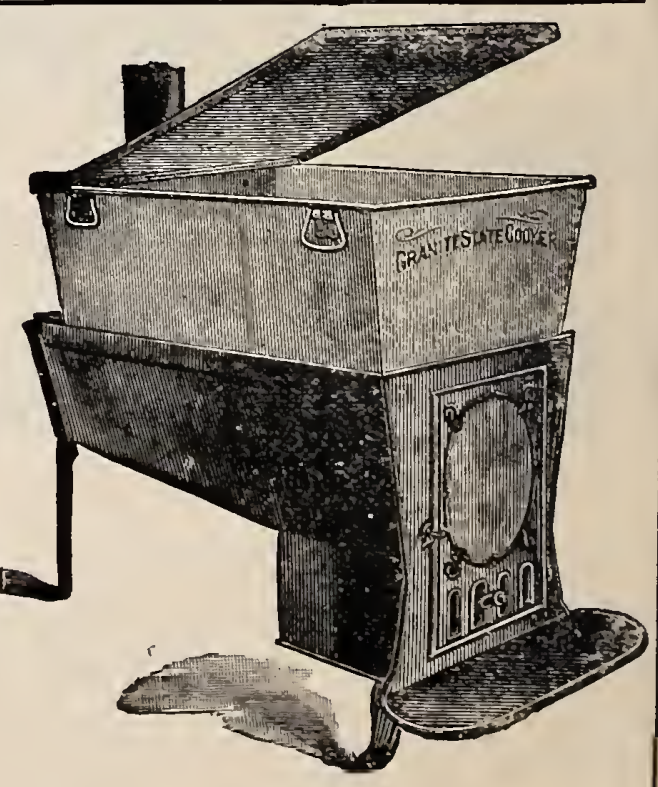




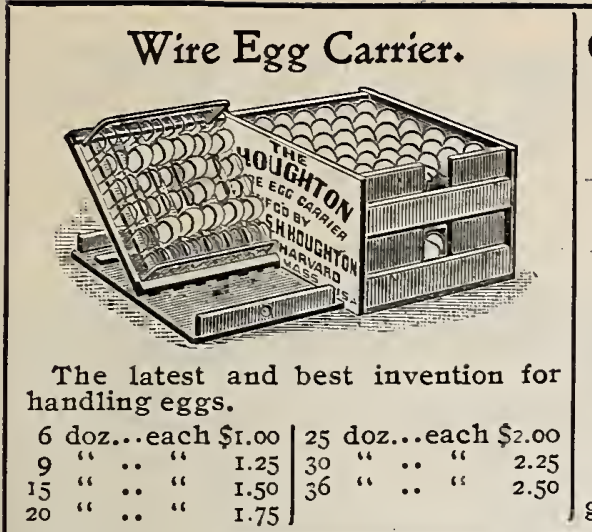

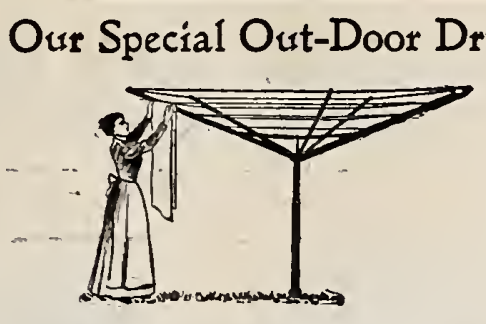

Made of Best Stock; Cotton Line. I Io Foot I, ine............. \$4.00 I50 " " Above includes box to go into the ground.

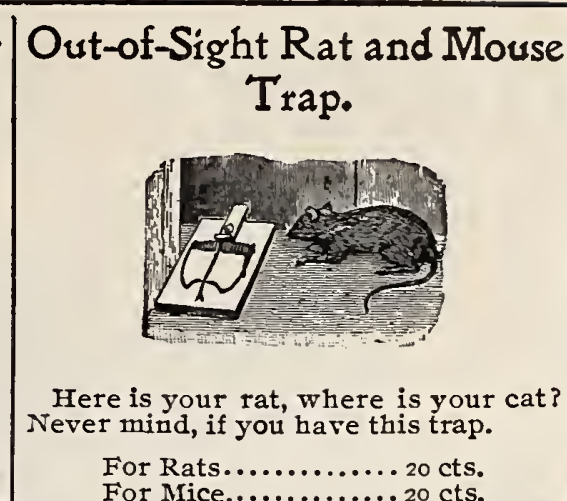

Hill's Balcony Dryer.

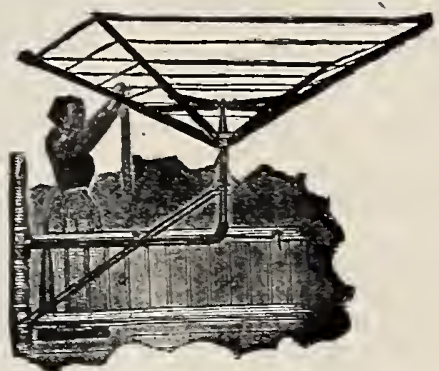

The best Dryer made for balconies. Endorsed by all the leading architects. List Price, $\$ 12.00$. Disc. for cash, $\$ 1.00$.

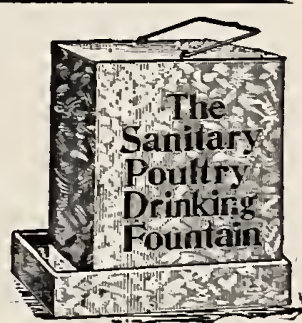

Can be thoroughly and easily cleaned and filled in a minute. Will go into any brooder. No danger from drowning. Is not injured by freezing. Hangs upon a nail out of the dirt.

One Gallon.............. 50 cts. Two Gallon............... 85 cts.
Fruit Pickers.

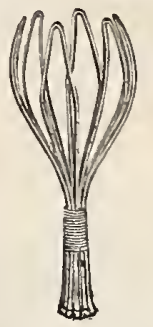

The Peerless. Very handy for gathering apples, pears or plums.

Price, Peerless.........25 cts. Price, Young's.......... $20 \mathrm{cts}$.
Three spaces. Made of heavy galvanized iron; will last a life time; saves waste; hangs on a nail; holds four quarts; soon pays for itself. Price........ 50 cts.

"Sanitary" Self Feeding Box Called Grit Box for short.
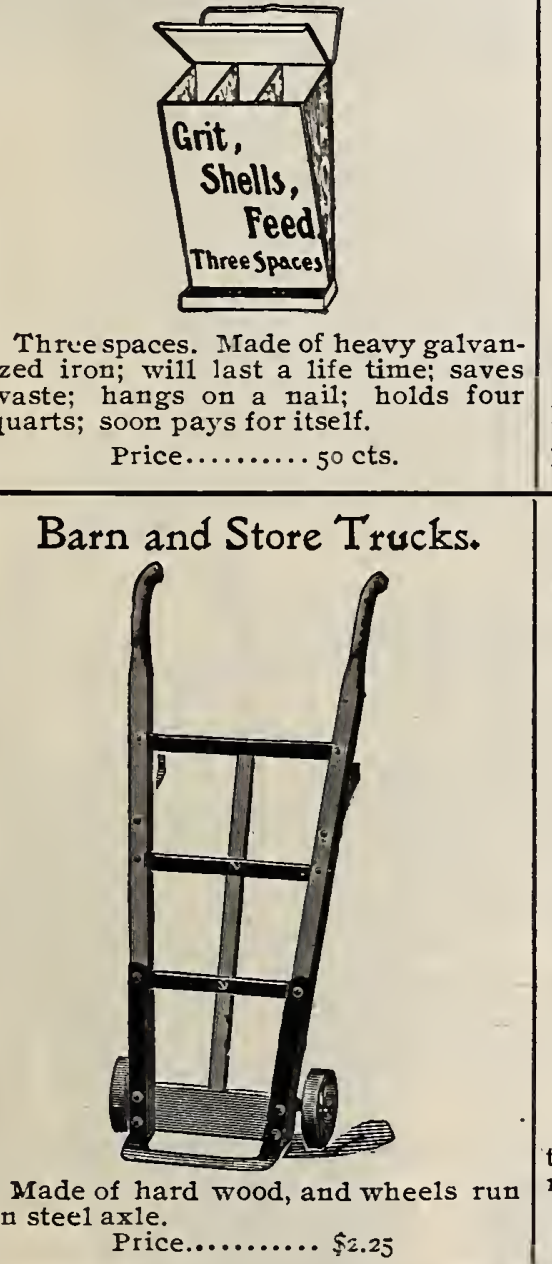

\section{W. R. Poultry Fountain.}

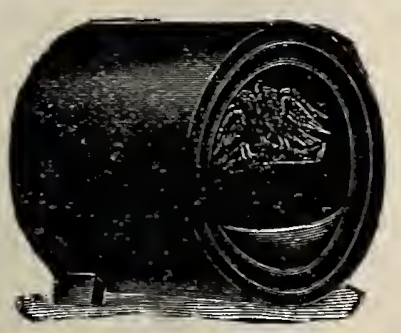

Very handy and convenient. 2 qts. 20c.; 4 qts. $30 \mathrm{c}$; 8 qts. $40 \mathrm{oc}$.

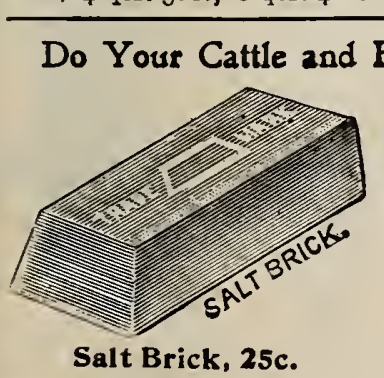

Salt Brick, 25c.

\section{Deering Machine Oil.}

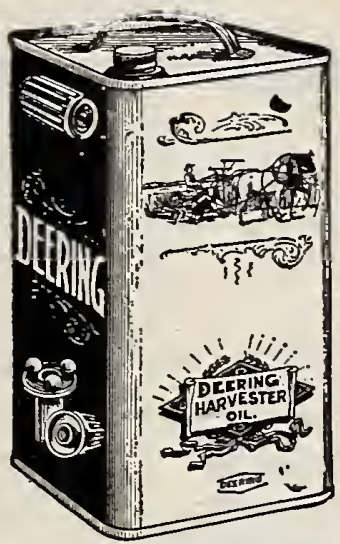

Never use cheap oil; the best is none too good. If you buy Deering Oil your too good. If you buy De

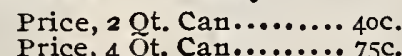

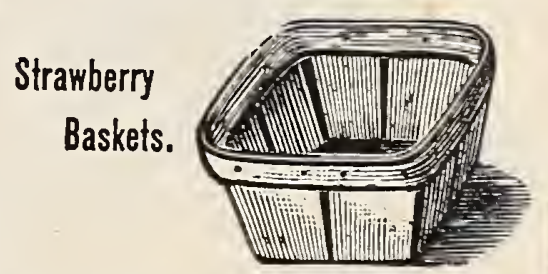

Fruit put up in a neat package a. ways commands a better price than that shipped in cheap baskets.

Order early; do not delay until the goods are wanted, and then expect them the next day.

Prices-No. I, all White Stock, wire tacked. I00, 50c.; 1000, \$3.50.

leberry basSpecial price on 10

Lawn and Flower Bed Wickets

Mowing Machine Sections.

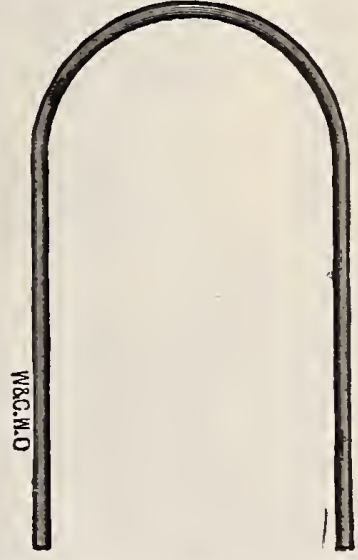

Protect flower beds from dogs, cats or children; very ornamental; painted green.

Per Dozen............. $\$ .65$
Per roo............. 5.00

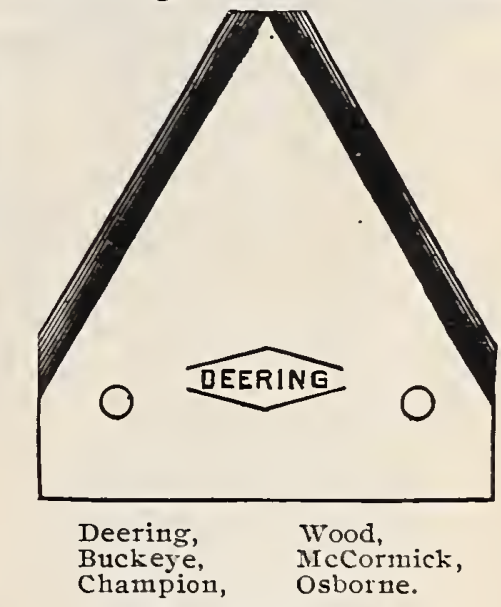

Each, 6c.; per 100, $\$ 5.00$

Give size of section, or send old one for pattern.

\section{E. H. M. Poultry Fountain.}

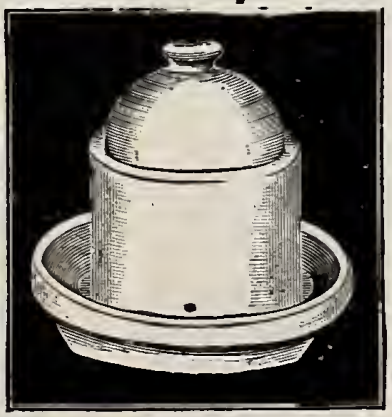
Easiest fountain to clean ever made.
I qt. 25 c, 2 qts. $30 c, 4$ qts. 35 c, 8 qts. $50 c$.
This method of feeding pure salt to stock has been adopted in the largest stables and grows in favor daily. All first-class stables should have it.

Salt Brick Holder, 25c.

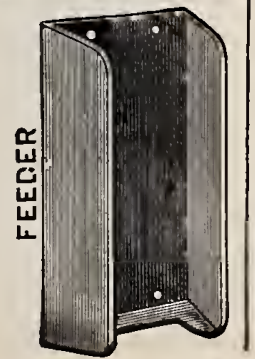

Deering Binder Twine.

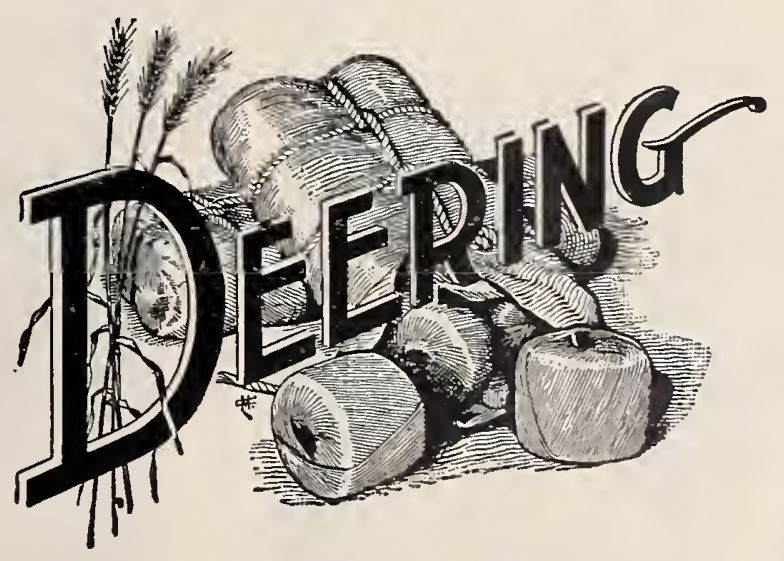

Manila or Sisal Binder Twine, for grain reapers or corn harvesters. This is also used for tying vegetables for the market; is much cheaper than raffia, and not as much work to tie. It is put up in 5 pound balls, a very convenient size. 


\section{VETERINARY INSTRUMENTS}

EVERYTHING SHOWN ON THIS PAGE WILL BE SENT POSTPAID ON RECEIPT OF PRINTED PRICE

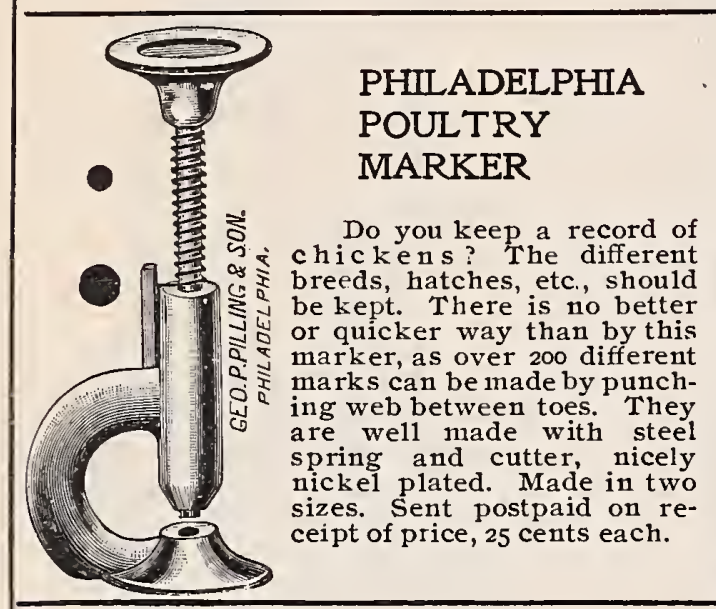

STRICTURE INSTRUMENTS

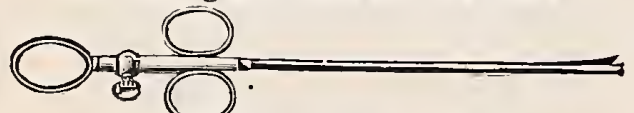

Pilling's Three-Ring Stricture Cutter.

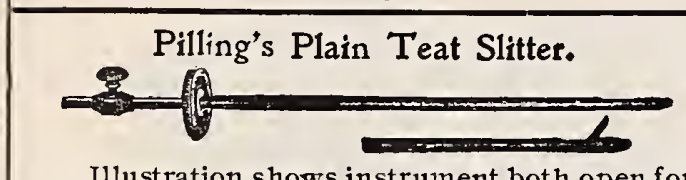

cutting and closed for inserting. Plated $\$ 50$

French Poultry Killing Knife.

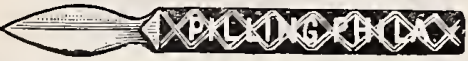

Every poultry raiser should have one of our tempered instrument steel, with nickeled tempered illstrument steel, with nickeled
handle ; will last a life time. It will be one of the best investments you ever made. Sent postpaid on receipt of 50 cents.

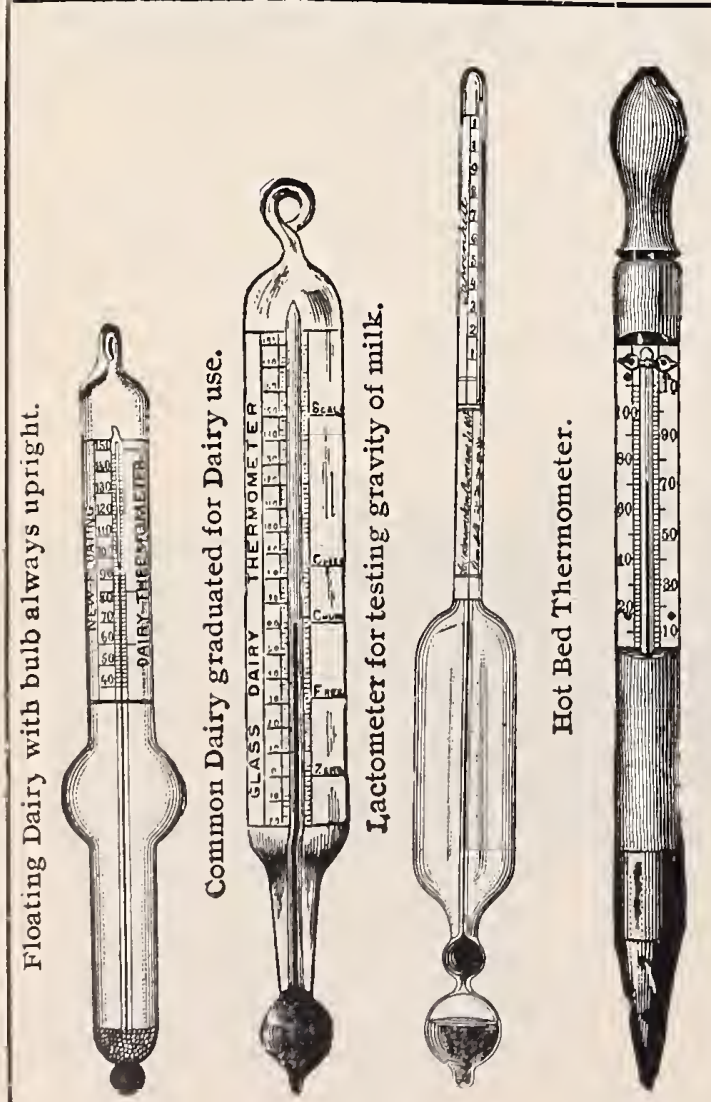

Price 50c. Price 25c. Price 65C. Price $\$ 1.50$

PILLING'S CAPONIZING TOOLS.

Poultrymen can double their profits by Caponizing their chicks. The operation is very simplebe able to perform the operation. The demand for Capons far exceeds the supply, the price per pound being twice as much as for ordinary chicks. 'The object of Caponizing is to largely increase the weight of the fowl, causing them in many cases, to grow as large as turkeys and weighing from ro to I5 pounds, to make the meat a finer and sweeter I5 pounds, to make the meat a frer and sweeter worth \$r.00 to $\$$ I.50 more than cocks not Caponized. Whey are very much quieter in disposition.

Complete with instructions, \$2.50. In Velvet-

lined case as per Engraving, $\$ 2.75$. We send book,

"Complete Guide for Ca ponizing," with every set.

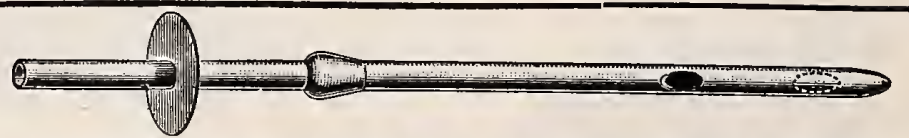

MILKING TUBES for Sore and Obstructed Teats and Hard Milking Cows.

DIRECTIONS.-The long rounded end of the tube is inserted in the orifice of teat, when the milk will flow without the use the hands. It is best to wet the Tube with a drop of milk or water before using. Remove tube when milk ceases to flow. If in some cases, the obstruction is further up the teat than can be for all purposes. German Silver plated, $2 \frac{1}{2}$ in., $25 \mathrm{c}$.; 3 in., $35 \mathrm{c}$.; $3^{1 / 2}$ in., $45 \mathrm{c}$. Common White Metal, $2^{1 / 2}$ in. 20c.; 3 in., 3 oc.; $3^{T / 4}$ in., $40 \mathrm{oc}$.

Aluminum Tag Bonds. Made of one piece; two sizes;
lose. In ordering give breed. Price, postpaid, doz. 20c.

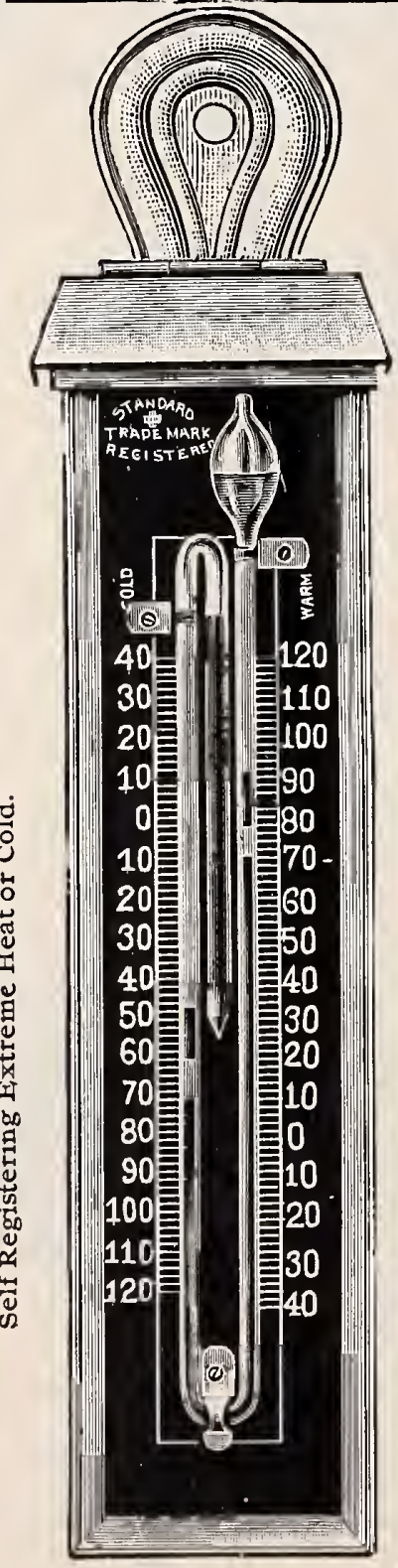

Price $\$ 2.00$
Pilling's Improved Instrument for Opening Obstructed Teats.

$\longrightarrow$
The above instrument for opening obstructed (cows) teats. There has been a demand for some simple remedy for this purpose, which we think is now filled by this little instrment, being highly endorsed by some of the best Veterinary surgeons of the Country for its very successfu1, and at the same time harmless and simple use, so that any person of average intelligence can use it with per- fect safety. We send it securely packed in neat box, with full instructions, postpaid, on receipt of price. 75 cents.
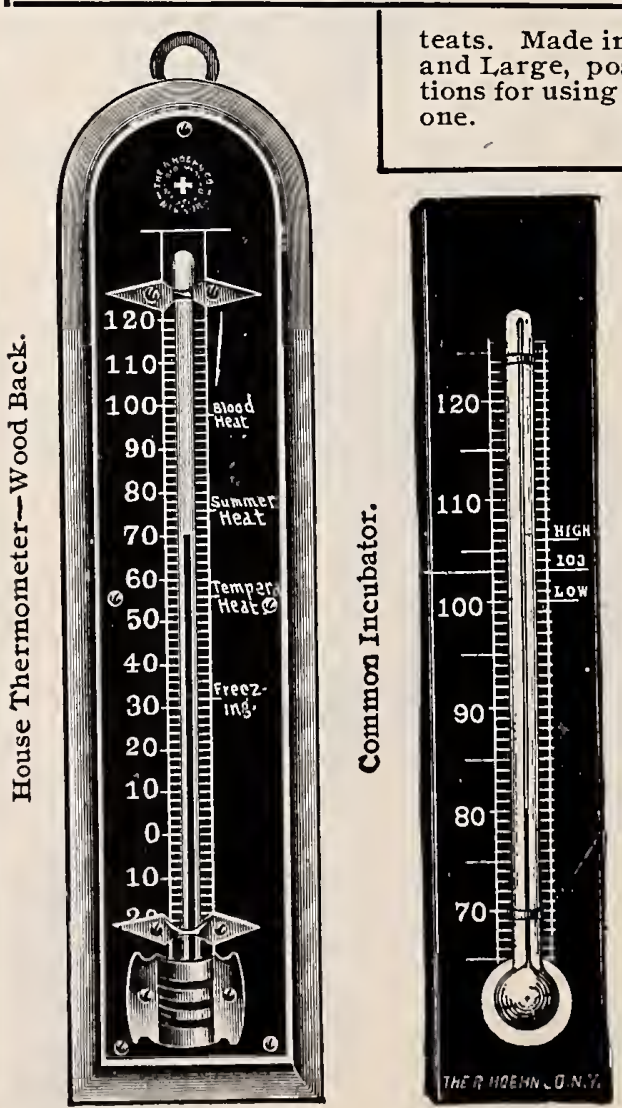

three sizes: ce, postpaid, doz. $20 c$

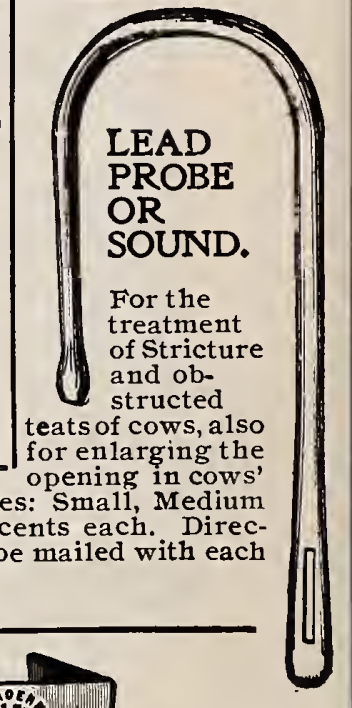

Price 85€.
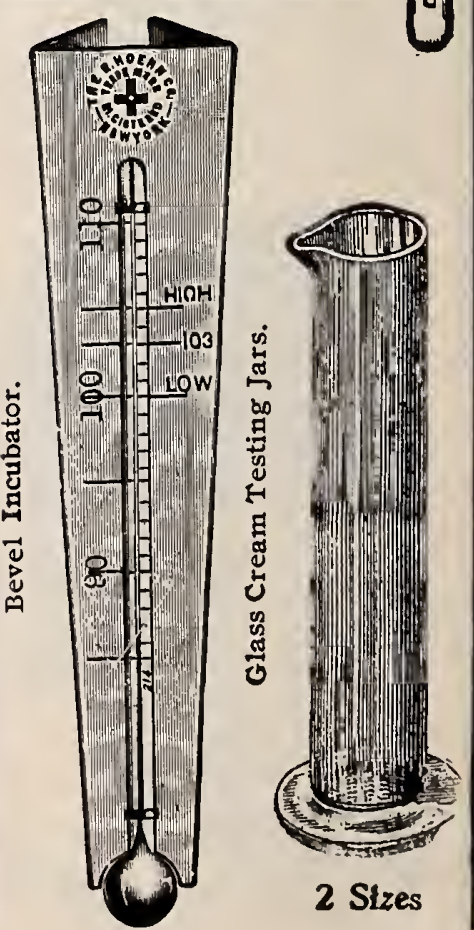

Price 50C.

Price $60 \& 75 C$.
Price 50C. 


\section{PRICE LIST OF A. H. HEWES STANDARD FLOWER POTS}

If You Buy STANDARD POTS You Will Not Be Disappointed-As They Always Give Perfect Satisfaction.

\section{STANDARD POTS.}

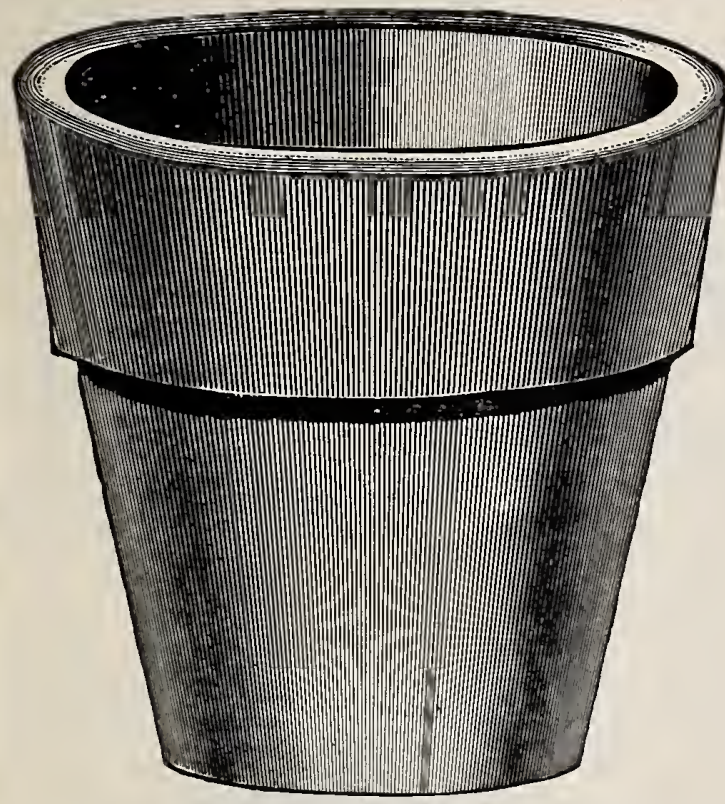

2 1-4 inch.

Price per M,

\section{Neponset Flower Pots}

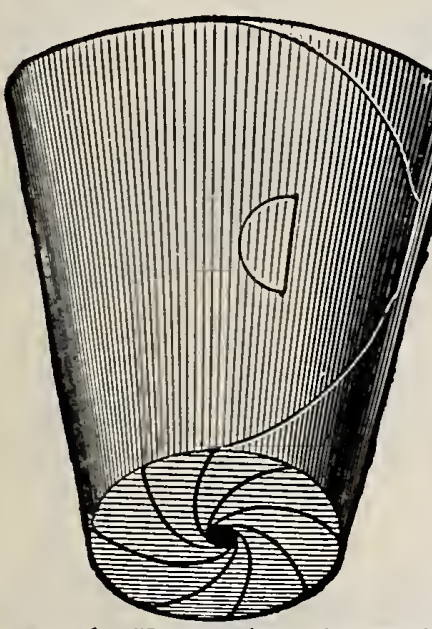

Every florist knows that plants and cuttings packed for shipment in paper. by the ordinary method, are ofte in transportation. No transportation. more cheaper and mode of protecting plants in transit is plants in transit is of the NEPONSE' FLOWER POTS. They are the cheapest pots on the market. Made from the well knowu NEPONSET WATERPROOF FABRIC, and for lightness cleanliness, and cheapness have no equal. You ought to know that for many purposes they are far superior to clay pots, as, being water proof, they retain the moisture, so that the plants do not require watering as often.

Weights and Net Prices.

These pots nest closely for shipment and are so light that one thousand 3 -in. only weigh as much as I lo clay pots, same size. The freight is, therefore, a mere fraction.

\section{WEIGHT}

Packed for Shipment.

No. Size Weight Per 100 Per 1000

$10002 \mathrm{I} / \mathrm{inch}$ Pots 20 pounds. $\$ 0.25 \$ 2.20$

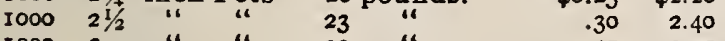

1000 3 31 “. “

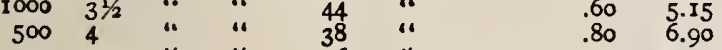

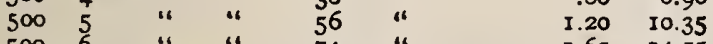

Not less than original crates rooo rate. SAMPLES BY MAIL.

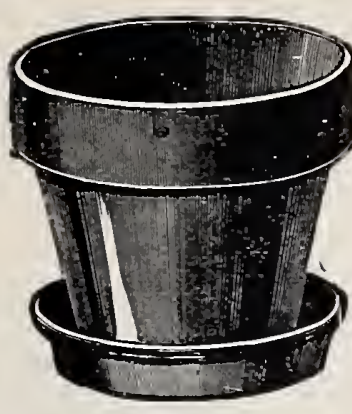

Size.

$1 \frac{8}{4}$ in.

2 in.

$\$ 7.00$

8.00

Size.

4 in. per hund.

5 in. 66

6 in. 7 in. 6

7 in. 8 in.

8 in.

9 in.

11 in.

12 in.

13 in.

14 in. each

15 in. 66

16 in. 6

18 in.

\section{CALLA LILY POTS.}

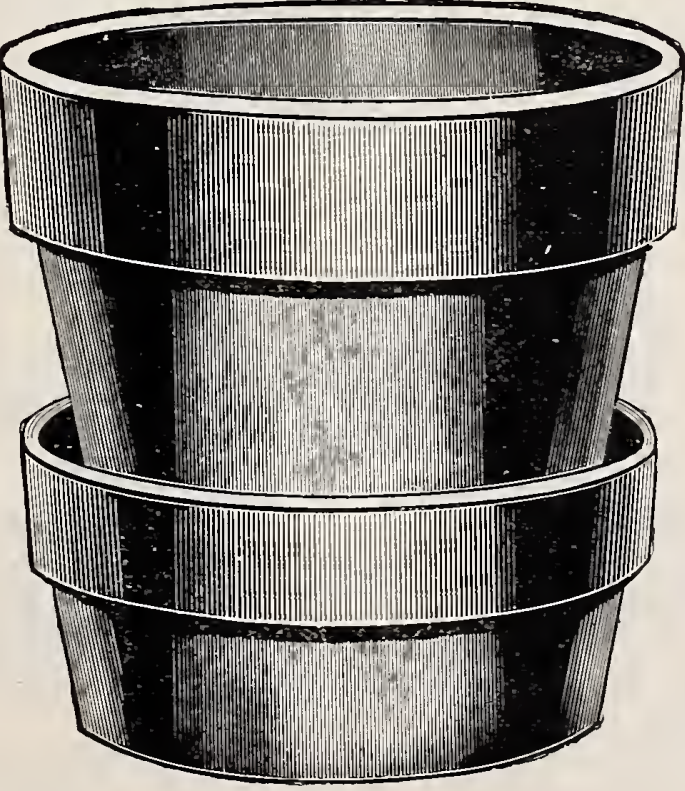

No. 304.-UNPaINTED.

8 in., each,

10 in., each,

No. 305.-Painted Red.

8 in., each,

10 in., each.,
FLOWER

POTS

SAUCERS.

STANDARD.

WITH RIMS.

Inside measurement,
width and depth equal.

Size. Per M.

$2 \frac{1}{2}$ in $\$ 11.00$

$2 \frac{8}{4}$ in. $\quad 12.50$

Pots. Saucers. P.\&S.

$\$ 2.20 \$ 1.80 \$ 4.00$

$4.00 \quad 2.25 \quad 6.25$

$\begin{array}{rrr}6.00 & 3.00 & 9.00 \\ 10.00 & 4.00 & 14.00\end{array}$

$\begin{array}{lll}14.00 & 6.00 & 20.00\end{array}$

$\begin{array}{lll}20.00 & 8.00 & 28.00\end{array}$

$\begin{array}{lll}27.00 & 10.00 \quad 37.00\end{array}$

$\begin{array}{lll}36.00 & 12.00 \quad 48.00\end{array}$

$\begin{array}{rrr}75.00 & 20.00 & 95.00 \\ 1.00 & .25 & 1.25\end{array}$

$\begin{array}{lll}1.00 & .25 & 1.25\end{array}$

$\begin{array}{lll}1.50 & .30 & 1.80 \\ 2.00 & 35 & 2.35\end{array}$

$\begin{array}{lll}3.00 & .50 \quad 3.50\end{array}$

round seed pans.

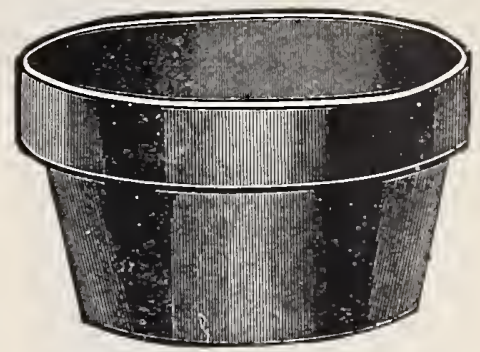

No. 309.

6 in. Round, per hund., $\$ 6.00$

7 in. "6 " 8 " 8.00

8 in " ، ،

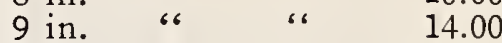

10 in. 6 " 6 618.00

12 in. "6 " " 625.00

14 in. " ،

HANGING VASE.

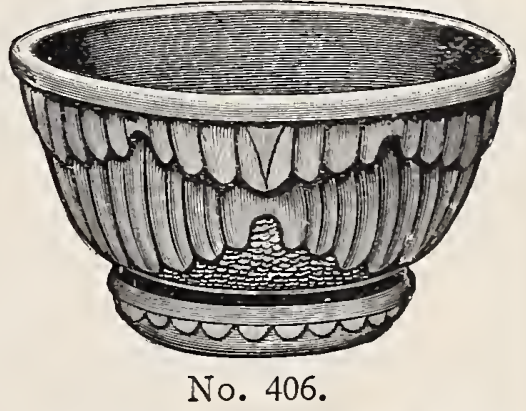

7 in., each, 20c. Doz., \$2.00

8 in., each, 25c. Doz., 2.50

9 in., each, 30c. Doz., 3.00

\section{HANGING VASE.}

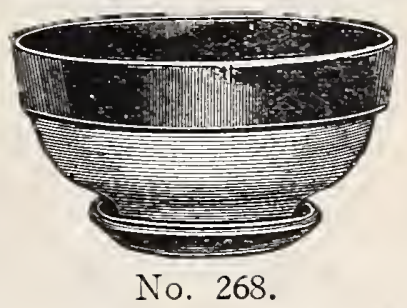

C $\frac{1}{2}$ in., each, 15c. Doz., $\$ 1.50$

HANGING VASE.

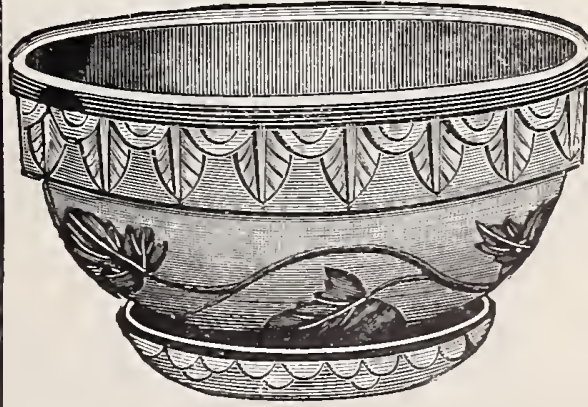

No. 373

7 in., each, 20c. Per dozen, $\$ 2.00$ 8 in., each, 25c. Per dozcu, 2.50 9 in., each, 30c. Per dozen, 3.00

Discount on Standard Pots and Seed Pans, 20 Per Cent for any Quantity Less than 100-Lots of 100 or Over 25 Per Cent-500 and Over 40 Per Cent-Larger Lots Ask for Price.-Hanging Vases and Calla Pots are Net. 


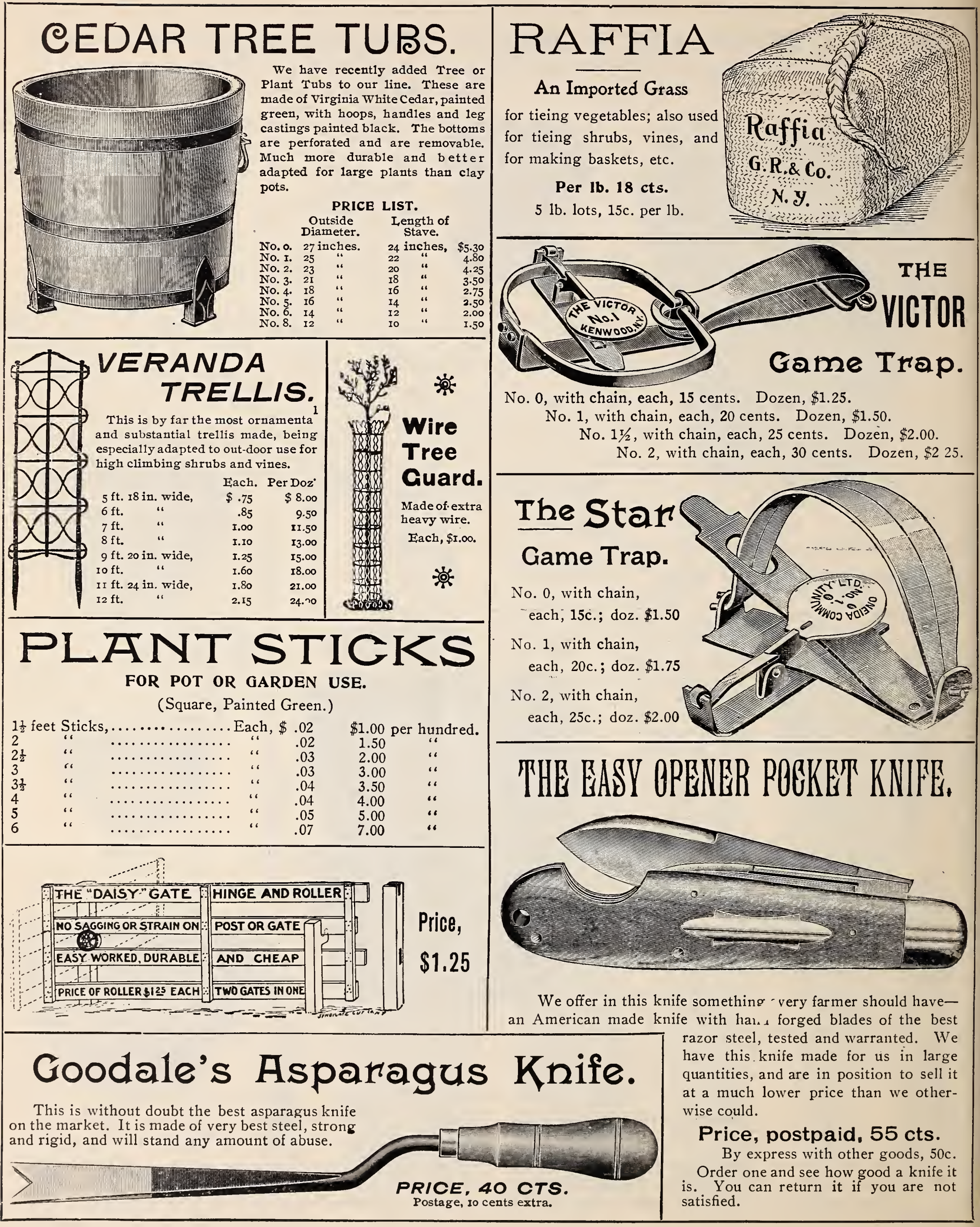




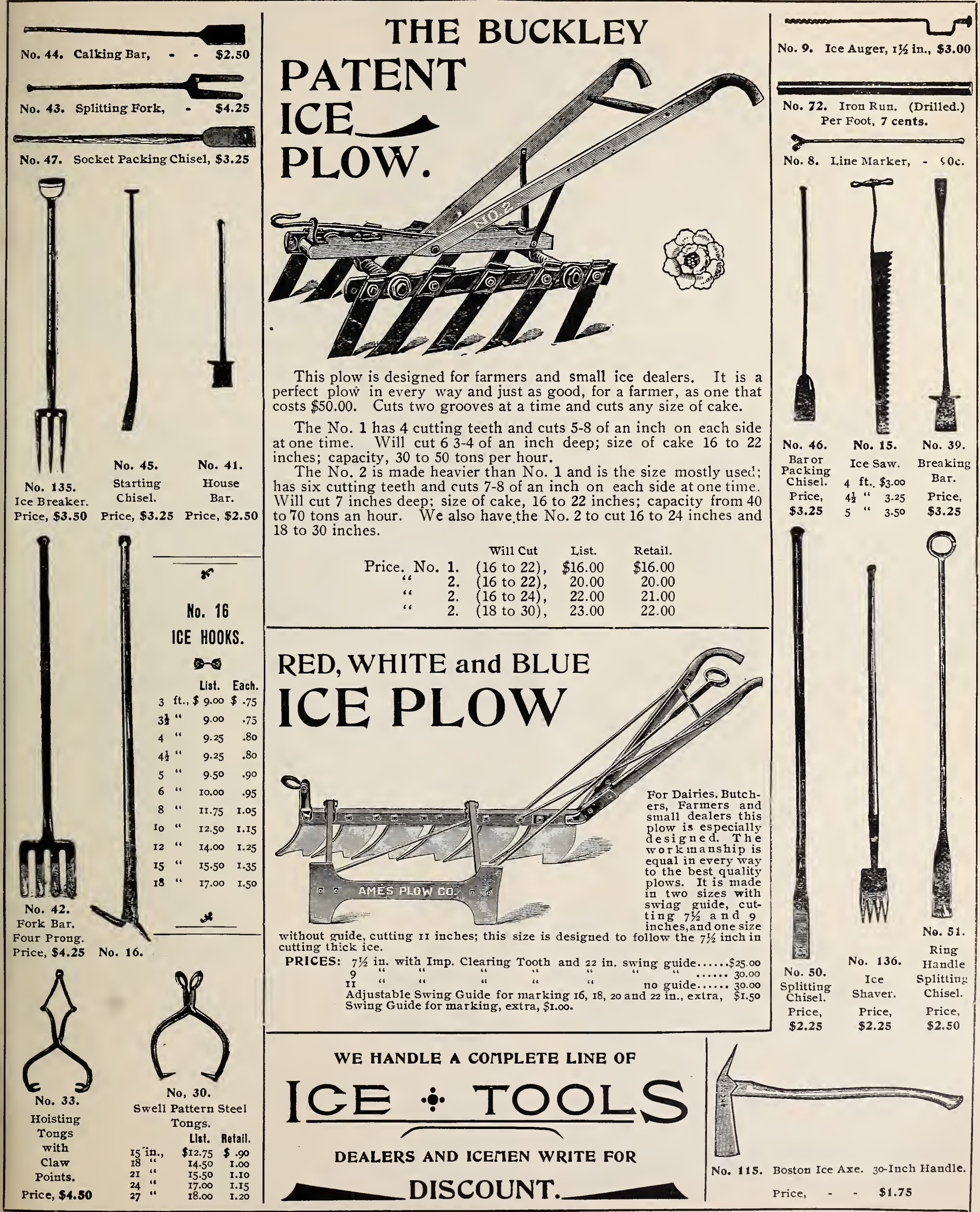




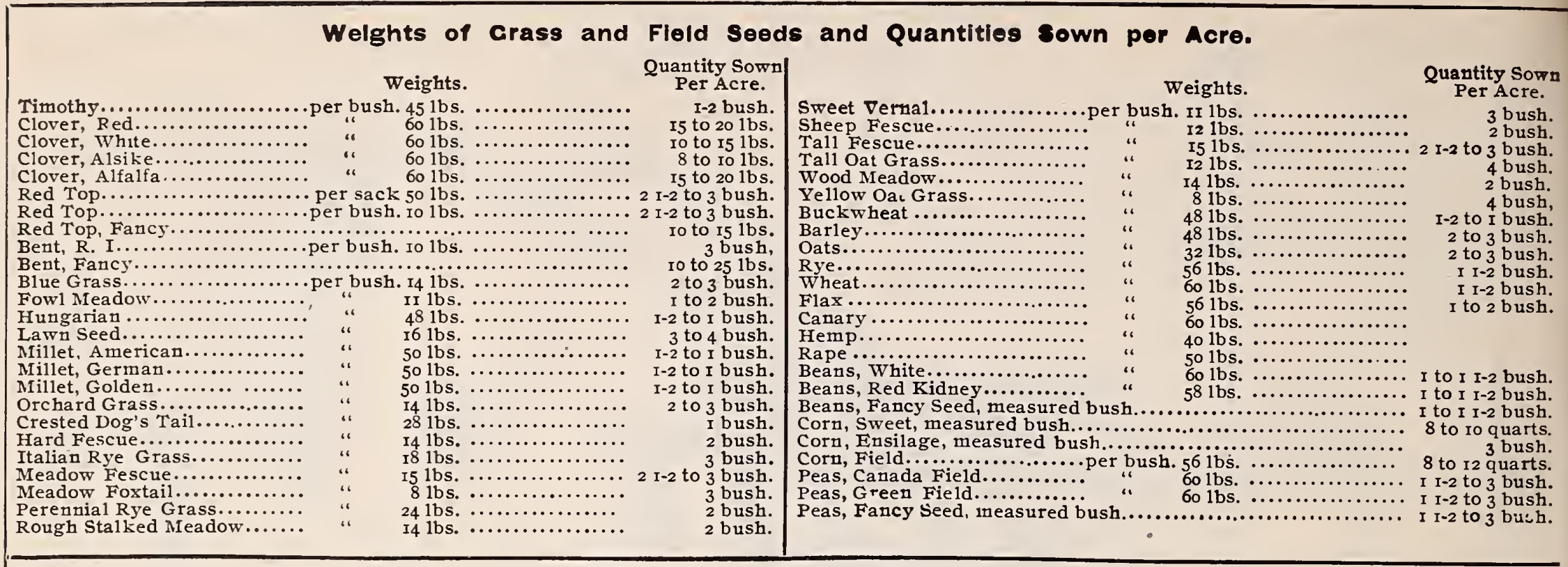

Quantity of Seed Required to Sow an Acre of Cround.

Quantity
Per Acre.

Artichoke, I 07. to 500 plants.....

Asparagus, I oz. to 200 plants.

Beans, dwarf, I quart to 150 feet of drill...

Beans, Pole, 2 quarts to 200 hills......

Beet, Garden, I oz, to roo feet of drilli........

Bet, Mangel, I oz. to I5o feet
Broccoli, I oz. to 3,000 plants.

Broom Corn

Brussells Sprouts, I oz. to 3,000 plants

Cabbage, r oz. to 3.000 plants...

Carrot, I oz. to r5o teet of drill.....
Caulifiower, I oz. to 3,000 plants

Cauliflower, I oz. to 3,000 plan
Celery, I oz. to ro,ooo plants.......

Celery, I oz. to Io, ooo plants...
Collards, I oz. to 2,500 plants.

Corn, sweet, I quart to 500 hilis

Cress, I oz. to r5o feet of drill...
Cucumber, I oz. to 80 hills...

Egg Plant, I oz. to 2,000 plants ...

Endive, $r$ oz. to 300 feet of drill

Flax, broadcast.............

Kale, I oz. to 3,000 plants.................
Kohl-Rabi, I oz. to 200 feet of dril

Leek, I oz. to 250 feet of drill..............

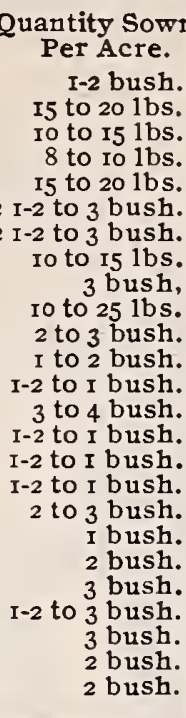

Quantity Sown 3 bush. bush. 4 bush.

I I bush. I I-2 bush. to 2 bush.

to I I-2 bush.

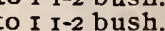
quarts. I I -2 to 3 bush.

-

I I-4

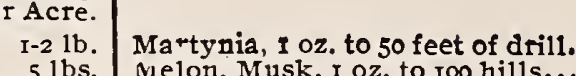

4 bush. Melon, Water, I oz. to Ioo hills.....

$1-2$ bush. Nasturtium, I oz, to 50 feet of drili.........

ro lbs. Okra, I oz. to 50 feet of drill.

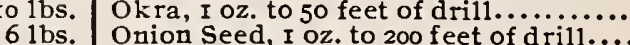

$5 \mathrm{oz}$. Onion Seed for Sets...

ro lbs. Onion Sets, I qt. to 20 feet of d rili................

$5 \mathrm{oz}$. Parsuip, I oz. to 250 feet of drill

$\begin{aligned} 5 \text { oz. } & \text { Parsley, I oz. to } 250 \text { feet of drill............... } \\ \text { z-2 1bs. } & \text { Peas, Garden, I qt. to I5o feet of dril }\end{aligned}$

5 oz. Pepper, I Oz. to I, 500 plants

4 oz.
6 oz.

8 qts.

8 1bs.

$\mathrm{r}-41 \mathrm{bs}$.

3 lbs.

$4 \mathrm{oz}$

4 1bs

Pumpkins, I quart to 300 hills.
Radish, I oz. to I5o feet of drill...

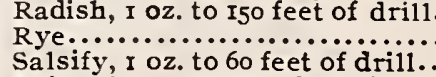

Salsify, I oz. to 60 feet of drill...

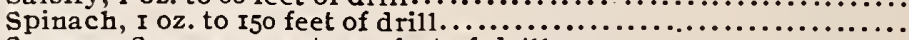

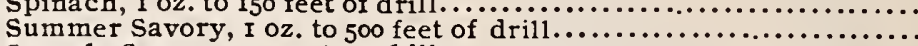

Squash, Summer, I oz. to 40 hills

Squash, winter. I oz. to ro hills..

Tomato, I oz. to 3,000 plants.....

Turnip, I oz. to 250 feet of drill.
Quantity

Per Acre.

ro 1 bs.

I $3-41 \mathrm{bs}$.
I I -2 lbs.

Io $1 \mathrm{bs}$

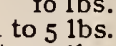

30 to $50 \mathrm{lbs}$.

8 bush
5 lbs.

$51 \mathrm{bs}$.

I I-2 bush.

8 bush.

4 qts.
8 ibs.

I I-2 bush.

$81 \mathrm{bs}$.
Io $1 \mathrm{bs}$.

$21 \mathrm{bs}$.

$21 \mathrm{bs}$.

3 lbs.

$3 \mathrm{oz}$.
$2 \mathrm{oz}$.

I I-2 lbs.

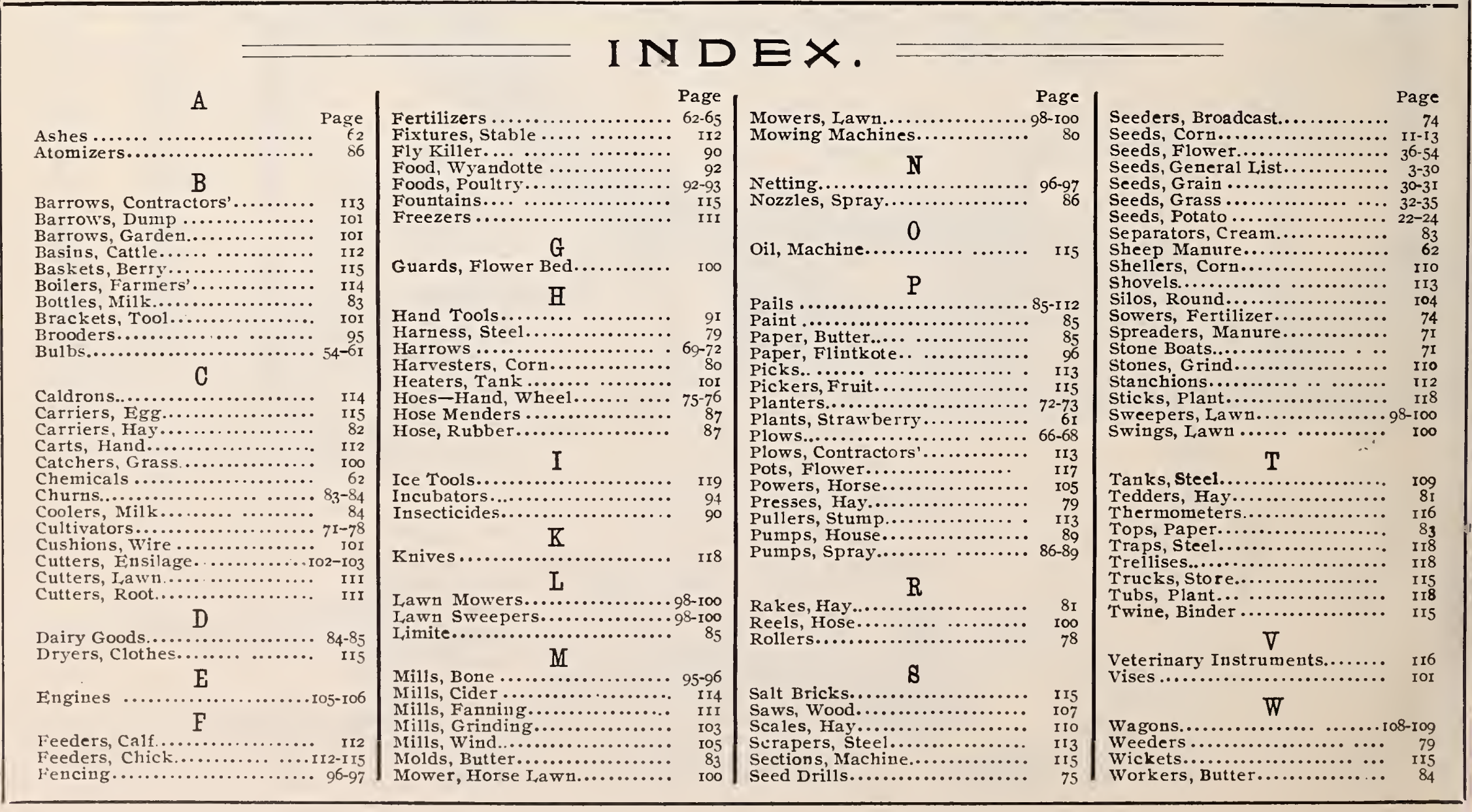




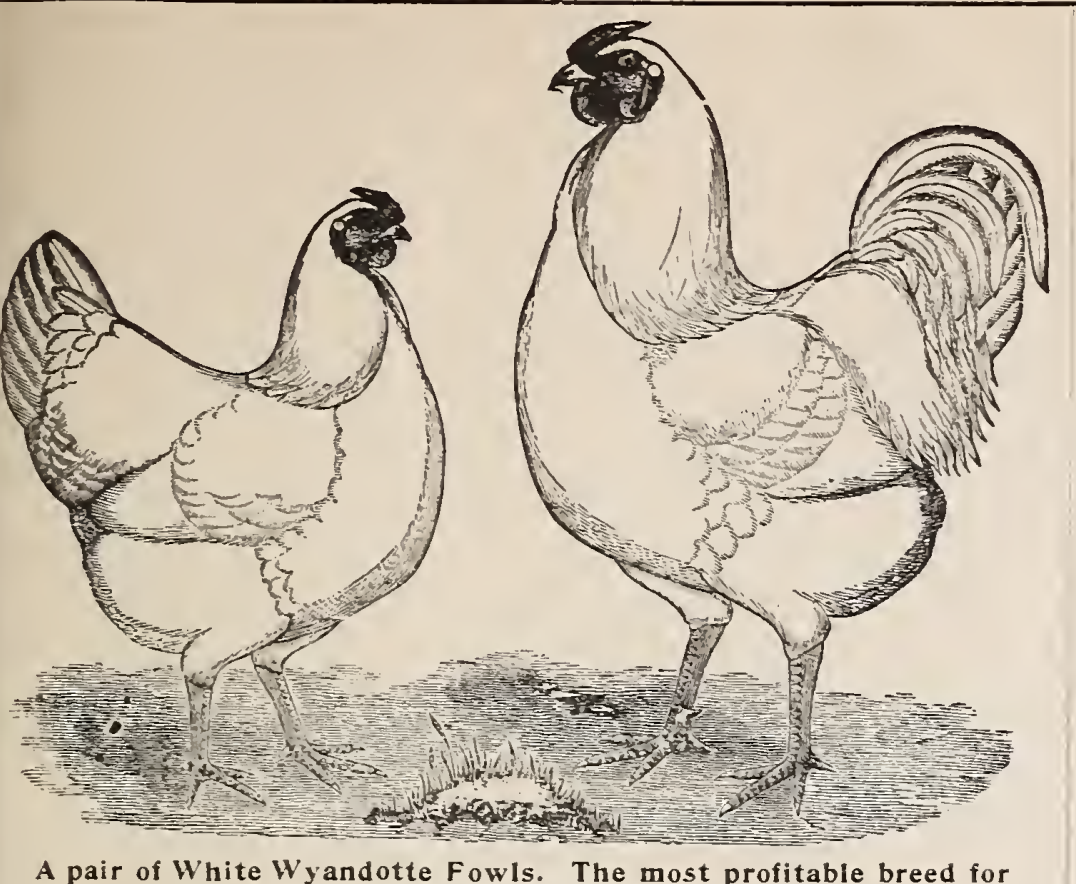

A pair of White Wyandotte Fowls. The most profitable breed for general purposes.

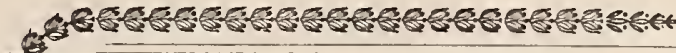 From Thoroughbred
POULTRY.

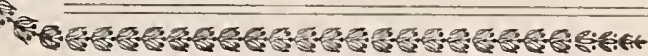

There is no one branch of Farming that pays a better profit or gives more satisfaction than Poultry.

With the increased price of poultry, caused by the beef combine, no farmer can. afford to neglect this most important branch of farming, for with the present demand for both poultry and eggs and the better facilities for proutucing both, the outlook was never letter than at the present time. With the use of an Incubator and Brooder and our IVyandotte Chick Food the cost of raising a flock of chicks is reduced about one-half, and thoroughbred poultry can be had at the present time about as low as common mixed breeds. We have as good a stock of the four leading kinds as it is possible to get, and we are in position to furnish

Eǵgs either by the hundred or in smaller lots of the following breeds:

\section{Valuable Poultry Books Cheap.}

We believe that everyone interested in Poultry should have some reliable book for reference, and we have therefore made arrangements with the publishers to furnish the following books, all sent postpaid at price quoted.

Artificial Incubating.

and Brooding.

A practical work contributed by the most experienced operator of incubators in America. $140 \mathrm{pp}$. $7 \times 10 ; 100$ illustrations; 8 full page designs. It contains full and complete instructions on the use and abuse of incubators.

Price, only 50 cents.

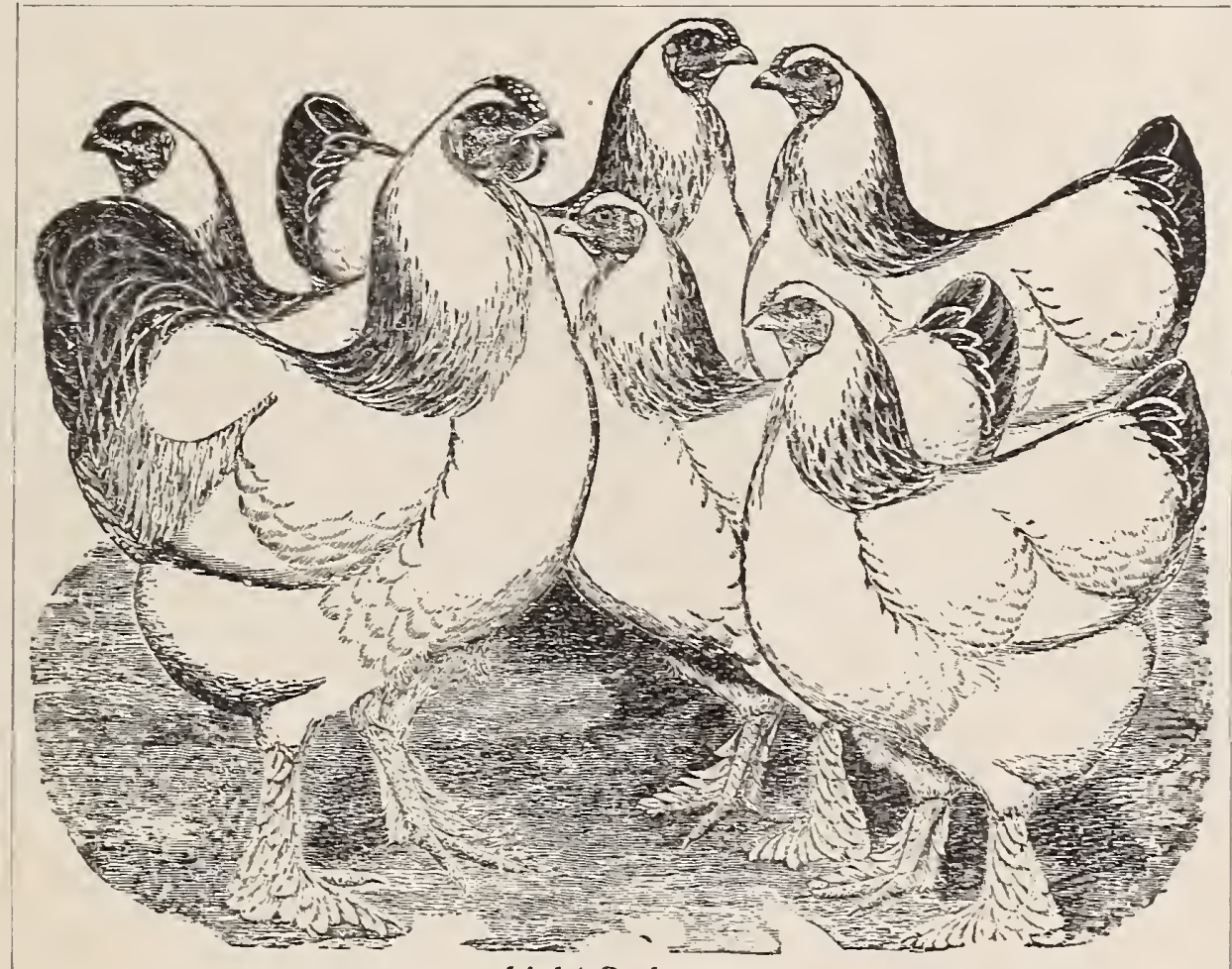

Light Brahmas

\section{Prices of Eggs.}

White Wyandotte,

$13, \$ 1.50 ; ; 26, \$ 2.50$.

Buff Wyandottes,

$13, \$ 2.00 ; 26, \$ 3.00$.

Barred Plymouth Rock,

$13, \$ 1.50 ; 26, \$ 2.50$.

Light Brahmas,

$13, \$ 2.00 ; 26, \$ 3.50$.

White IVyandotte and

Barred Plymouth Rock,

Per $100, \$ 6.00$.

Send for Free Sample of

Wyandotte

Chick Food

\section{Eggs and Egg Farms.}

The mainstay of the poultry business. The bonk you have been looking for. Contans a large collection of facts. Covers the ground you will have to travel if you are startiug in the poultry business. Eighty pages. Price, only 50 cents.

\section{Poultry Houses and Fixtures.}

32 pages, $9 \times 12$. Contains up-to-date designs of practical poultry building and special fixtures. Shows you how to build a cheap or a good house or coop. Beginners should have this book. Price, 25 cents.

Other books that we have not room to describe:

Ducks and Geese.

Plymouth Rocks-Barred, White and Buff.

Price, 50 r.ents Price, 50 cents Wyandottes_White, Buff, Golden, Silver and Black. Price, 50 cents The Leghorns-Brown, White, Black and Buff.

The Bantam Fowl.

Turkeys_All Varieties.

The American Standard of Perfection.

Price, 50 cents

Price, 50 cents

Price, 50 cents

Price, $\$ 1.00$

All of the above postpaid, and money refunded if not satisfactory.

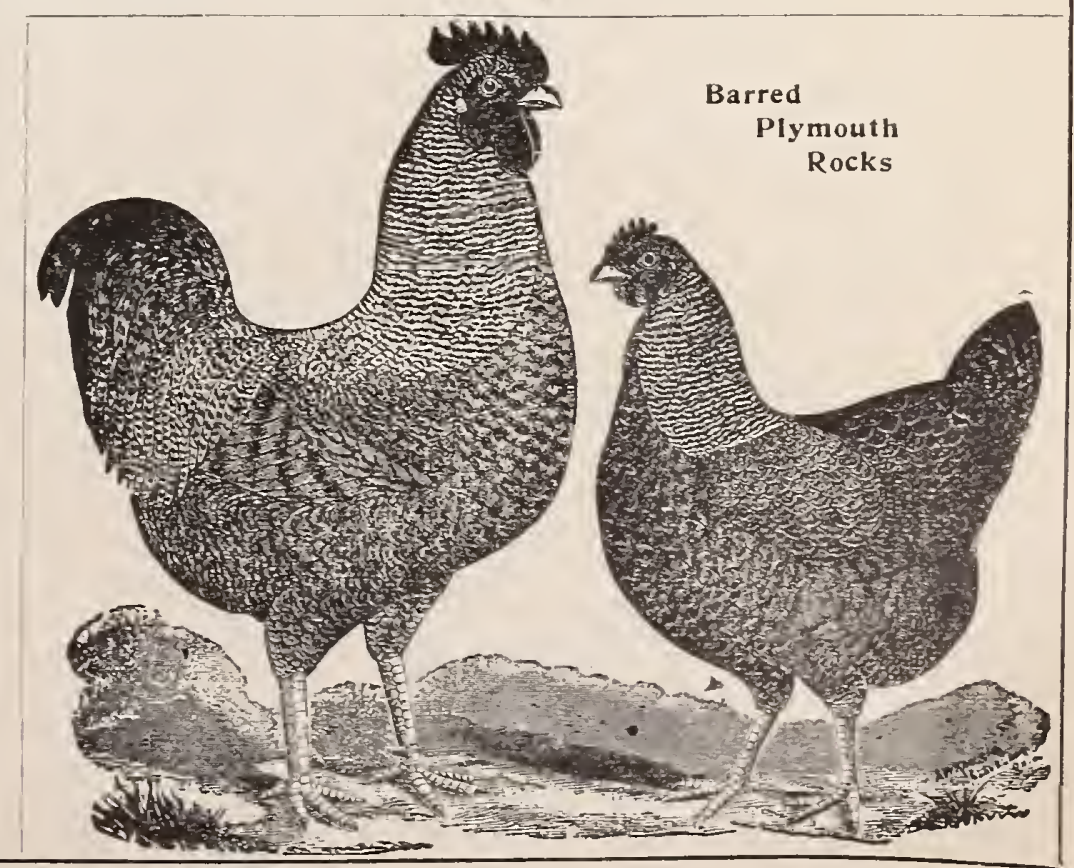


